bepwonth 



\section{ALFRED I. DUPONT}

The Family Rebel 




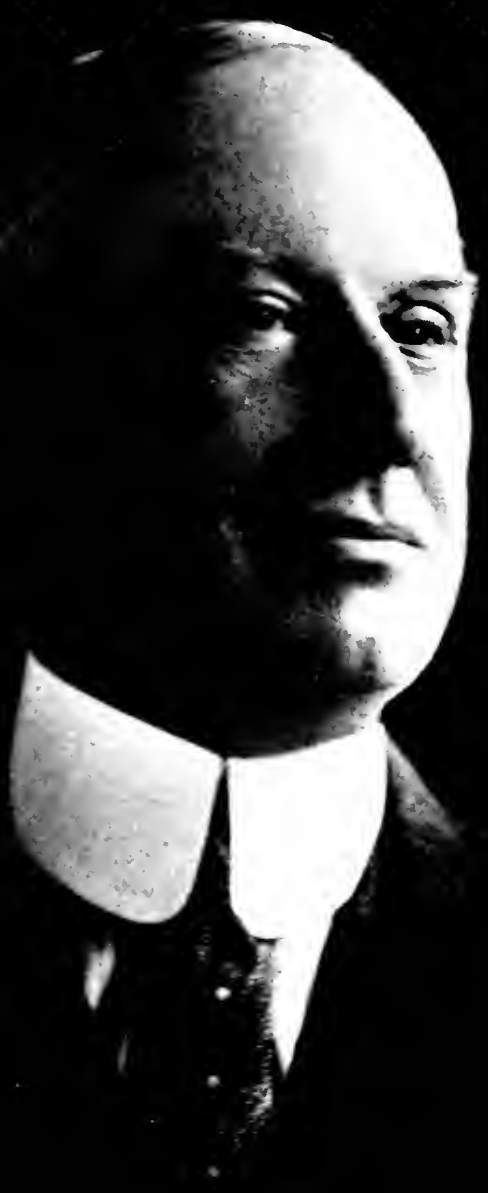

(C) Bachrach

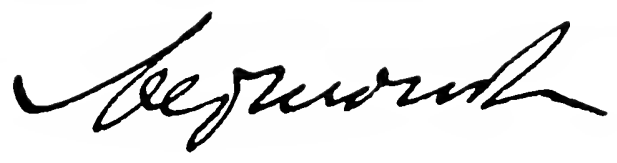




\title{
ALFRED I.
}

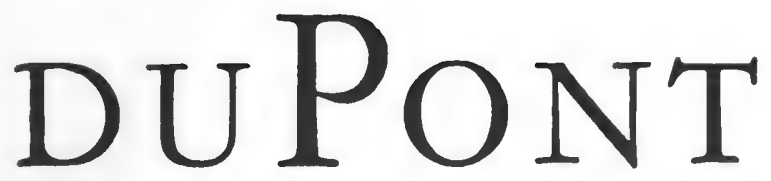

\section{The Family Rebel}

\author{
by \\ MARQUIS JAMES \\ Author of The Raven: \\ A Biography of Sam Houston \\ and \\ The Lipe of Andrew Jackson
}

ILLUSTRATED

THE BOBBS-MERRILL COMPANY

Publishers

INDIANAPOLIS

NEW YORK

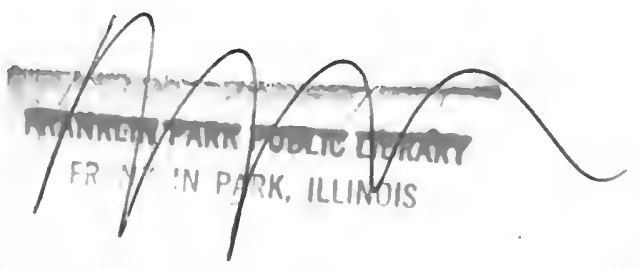


COPYRIGHT, I94I, BY MARQUIS JAMES

PRINTED IN THE UNITED STATES OF AMERICA

\section{EIRST EDITION}

PRINTEd AND BOUND BY THE haddon CRAFTIIMEN, INC. 


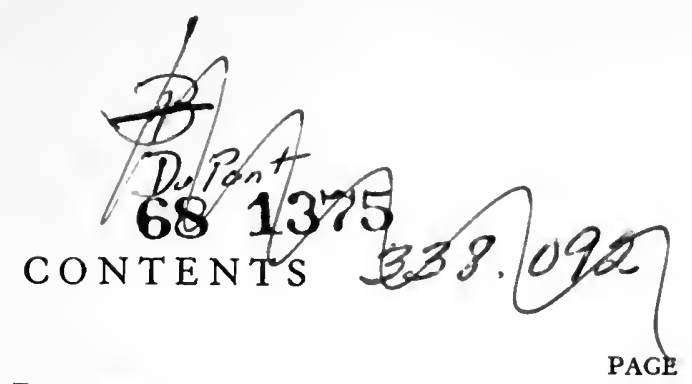

CHAPTER

Part One: Boyhood on the Brandywine

I The Five Orphans of Swamp Hall . . . . . 13

II The Down-the-Creek Gang . . . . . . . 28

III An Education in School and Out . . . . . . 39

Part Two: Powder Maker

IV Breaking in on the Powder Line . . . . . . 6i

V A Partner in the Firm . . . . . . . . . . 79

VI Small Clouds . • . . . . . . . . . . . 93

VII Discord in Swamp Hall . . . . . . . . .

VIII The Spirit of '98 . . . . . . . . . . . . 122

IX The Debacle. . • • . • . . . . . . . . 137

Part Three: The Three Cousins

$\mathrm{X}$ DuPont Back in the Saddle . . . . . . . 157

XI A Dream Fulfilled . . • . • . . . . I75

XII A Surprise for the Family . . . . . . . . I84

XIII The Wars of the Roses . . . . . . . . 201

Part Four: Expelled fRom the Company

XIV A Farewell to the Brandywine . . . . . . 223

XV An Important Meeting at the White House • • 240

XVI Coleman Sells Out . . . . . . . . . 254

XVII The Case of DuPont Versus DuPont . • . 277

XVIII EAGLES OF VICTORY . . . . . . . . . . 297 


\section{CONTENTS-Continued}

Part Five: An Anxious InterLude

XIX Light and Shadow . . . . . . . . . 313

XX His Back to the Wall . . . . . . . 331

XXI A Crisis Left Behind . . . . . . . . 345

Part Six: Climax of a Career

XXII A Life Expands . . . . . . . . . 365

XXIII Dawn of an EXPeriment . . . . . . 392

XXiv The Old-Age Pension Campaign . . . . 407

XXV Building a Chatn of Banks . . . . . . . 429

XXVI Florida's "Strong Man" . . . . . . . . . 449

XXVII The CRISIS of 1933. . . . . . . . . . . . 470

XXVIII Mr. duPont and the New Deal. . . . . 495

XXIX Evening on the Brandywine. . . . . . 5 II

XXX A Life is Ended, Its Work Not . . . . . 522

Notes . . . . . . . . . . 545

BibliogRAPHY . . . . . . . 57

Personal Acknowledgments . . . . . . 577 


\section{ILLUSTRATIONS}

Alfred I. duPont

Parents of Alfred I. duPont

DuPont genealogical chart

Alfred I. duPont at the age of eight

Swamp Hall

The young ladies of Swamp Hall

Powder wagon and team

Five tough customers

Alfred I. duPont at 18

Student at Massachusetts Institute of Technology

The budding scientist

Locomotion on the Brandywine

Bessie Gardner duPont

"Al's Band"

An unsung hero of the Spanish American War

Roughing it

Savior of the DuPont Company

One of A. I. duPont's many inventions

DuPont as a composer

Belles of Balls Neck

Madie and Bep

Boy and Vicky

In South Dakota, Igo6
Frontispiece

FACING PAGE

BETWEEN PAGES

I6-I7

FACING PAGE

26

30

$3^{6}$

40

$4^{6}$

52

56

68

76

94

I 20

I32

I46

160

I 82

I 86

I 88

190

I98

206 
Alicia Bradford duPont

FACING PAGE

The mansion house at Nemours

218

A tribute to the boss

Mother and daughter

A portrait, 1913

A 1916 Campaign Cartoon

Commodore duPont

Denise duPont, aged 3

Jessie Dew Ball

A rare photograph

Mrs. Alfred I. duPont

Mr. duPont and young friends

Mr. duPont's daughters

Alfred Victor duPont

In Miami, 1926

A tea party at Epping Forest

The yacht Nenemoosha

An old powdermen's reunion

An airplane view of Nemours

A family wedding, Nemours

Mr. \& Mrs. duPont, Palm Beach, I928 508 An intimate group at Epping Forest 518

New Year's Eve, I931, in Rome 528 
ALFRED I. DUPONT

The Family Rebel 



\section{PART ONE}

BOYHOOD ON THE BRANDYWINE 


\section{CHAPTER I \\ The Five Orphans of Swamp Hall}

When the new edifice of Christ Church in Christiana Hundred was building in 1856 , stonemasons employed by the DuPont Company in the perpetual work of repair and improvement of the powder mills carried their tools up from the gorge of the Brandywine to work on the walls. Alexis duPont, ${ }^{*}$ a partner in the firm and a grandson of the founder of the family in America, periodically inspected the work. He was a tall, slender, sinewy man with the big Roman nose and clefted chin that were hall-marks of DuPont blood. Dark whiskers rimmed his long face. Expressionless gray eyes and thin lips gave an aspect of sternness which was more apparent than real. On one of his visits to the unfinished church Alexis saw a party of masons pass a whisky bottle and then tuck it among the stones in the middle of the wall they were raising. Without a word to indicate that he suspected anything out of the way, Mr. duPont confined his supervision to the labors of his dramming artisans until their hidden bottle had been sealed with a course of gray Brandywine granite. ${ }^{1}$

DuPont masons were good masons. The buttressed three-foot walls of the powder mills were built to last; and they did last in the face of all but the more calamitous explosions which every so

* Down the generations the DuPonts have written their name variously: "Dupont"; "DuPont"; "Du Pont"; "duPont"; "du Pont." To avoid possible confusion no attempt has been made in this volume to follow the different preferences. Referring to individuals, I have spelled the name as the subject of this biography spelled it: "Alfred I. duPont." When the name designates the family firm, however, I have used the prevailing form of "DuPont Company"-with a large "D." Also a large " $D$ " has been employed to denote collective use of the name: "the DuPont family"; "the DuPonts." In later years when Alf red formed his own business which was independent of the family firm, I have followed his choice of the small " $d$ " and called it "the duPont organization," meaning always Alfred I.'s organization and not the older DuPont corporation. 
often for half a century had shaken the Brandywine countryside. The church, too, was constructed to resist these man-made earthquakes, for it stood well within the zone of danger. On that account the DuPonts had chosen Christ Church as their own place of worship, in return endowing it solidly and without any show. This prospering, prolific and insular family liked the things with which it had to do-whether pertaining to this life or the nextclose at hand, convenient to their solid, roomy homes and to their powder yards on the banks of the tumbling Brandywine.

Christ Church received its first bad shaking before it had stood a year. This occurred on a Saturday evening. Alexis duPont had gone to the Hagley Yard to inspect a graining mill which needed repairs to the masonry. Seeing that the mixing box had not been removed, Mr. duPont summoned five men to help him take it out so the masons could begin work the first thing on Monday morning. It would have been dangerous for them to work in the presence of the great iron vessel encrusted with powder which a spark from a trowel or a stone hammer might ignite. It was all the six men could do to lift the box, which they handled carefully. All metal is carefully dealt with in a powder mill, for fear of striking a spark. The soles of powdermen's shoes were fastened on with wooden pegs instead of tacks.

Mr. duPont and his helpers had got one end of the unwieldy mixing box through the door when a side of it brushed the masonry, striking fire. The powder in the box ignited. The men let go and tried to beat out the fire with their hands. Powder grains on the floor carried a train of fire to a tub of waste which blew up. The explosion killed three of the six outright. A fourth, the foreman, was blown thirty feet. In a daze he got up and started walking home. He barely lived to get there. Mr. duPont was blown thirty feet and his clothing set on fire. Leaping into the mill race to extinguish the flames, he saw that the graining mill had been wrecked and a flaming fragment thrown upon the roof of a press room near by. A full charge of powder was in the press. Clambering out of the race Mr. duPont started on a run toward the press room to snatch away the burning brand.

The building blew up in his face. Terribly wounded, Alexis 
duPont directed his seventeen-year-old son, Eugene, to tie a gallus around a mangled leg and check the bleeding. Carried home on a window shutter, the dying powder maker calmly took leave of his wife, his children and a number of workmen who flocked to the house. ${ }^{2} \mathrm{He}$ was the first DuPont to be buried from Christ Church.

Thus it was that the little rural church, with a bottle of whisky aging in its Gothic walls, became the scene of DuPont devotions, christenings, confirmations, weddings and funerals. As the generations passed this was to prove a quality of patronage a cathedral might envy.

Under a cloudy sky on Wednesday afternoon, September I9, I877, Christ Church was opened for the funeral of Eleuthère Irénée duPont II. The deceased was a member of the firm and a great grandson of the founder of the American family. At forty-eight he had died of consumption, fatally aggravated by exposure in the powder yards. The service over, a line of carriages and buggies conveyed the mourning relatives to the private burying ground a half mile away. The graveyard formed a clearing in Sand Hole Woods on the farm of the original DuPont to settle on these shores. Farm and cemetery topped a bluff overlooking the Brandywine from whence, day and night excepting the twenty-four hours of the Sabbath, rose the gentle sound of wheels turning in the powder mills.

Eleuthère Irénée II's was the forty-fifth grave to be made in the clearing among the oak, beech and hickory trees. The first grave was that of the first head of the American family, covered by a slab of white sandstone bearing this legend:

"Sacred to the memory of Pierre Samuel Du Pont de Nemours Knight of the order of Vasa, of the Legion of Honor and of the order du Lis; Counsellor of State, member of the first Constituent Assembly, President of the Council of Ancients 
and member of the Institute of France.

Born in Paris, December, A. D. 1739

Died at the Eleutherian Mills

August 17, A. D. 1817"

This brief biography does not overstate the case for one of whom Thomas Jefferson wrote: "I always considered him the ablest man in France."3 DuPont de Nemours was a watchmaker's apprentice who became a liberal philosopher, economist and statesman, raising himself to the lesser nobility for his part in France's collaboration on the side of the Colonies during the American Revolution. He was 'Turgot's right-hand man during the thwarted effort of that financier to balance the budget of the reckless monarchy; he consorted with Voltaire, with the elder Mirabeau and with Lafayette; he won the intellectual respect of Franklin and of Jefferson. When France's revolution came duPont de Nemours' liberal sentiments protected him until the advent of Robespierre and the Terror. Escaping the guillotine by the skin of his teeth, he sailed for America in 1799 with the grandiose object of planting in western Virginia a colony called Pontiana which should realize his enlightened social aspirations. ${ }^{4}$ The scheme fell through and funds were running low when the philosopher's son came to the rescue. Eleuthère Irénée duPont-he dropped the de Nemours-had learned gunpowder-making under the French chemist, Lavoisier. Perceiving the demand for powder in a frontier country and the poor quality manufactured here, he built the Eleutherian Mills on the Brandywine, four miles from the village of Wilmington, in 1802. Soon his Eagle Brand powder was first in the esteem of the leather-shirted pioneers, pushing our borders westward before the muzzles of their long rifles.

The company assembled on the overcast September day in 1877 to see Eleuthère Irénée duPont's grandson and namesake laid to rest afforded proof of the fecundity of the transplanted family. Old and young, sixty persons must have been present-nearly all of them DuPonts or DuPont in-laws.

There was Henry duPont, tall, masterful-looking, erect, with red whiskers fringing his square, clefted chin, a silk hat and, in 



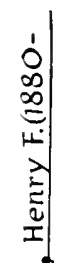

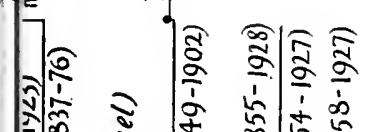

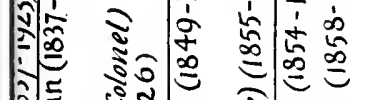

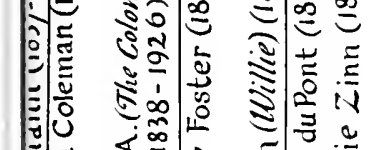

:

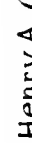

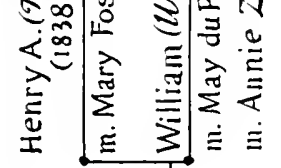

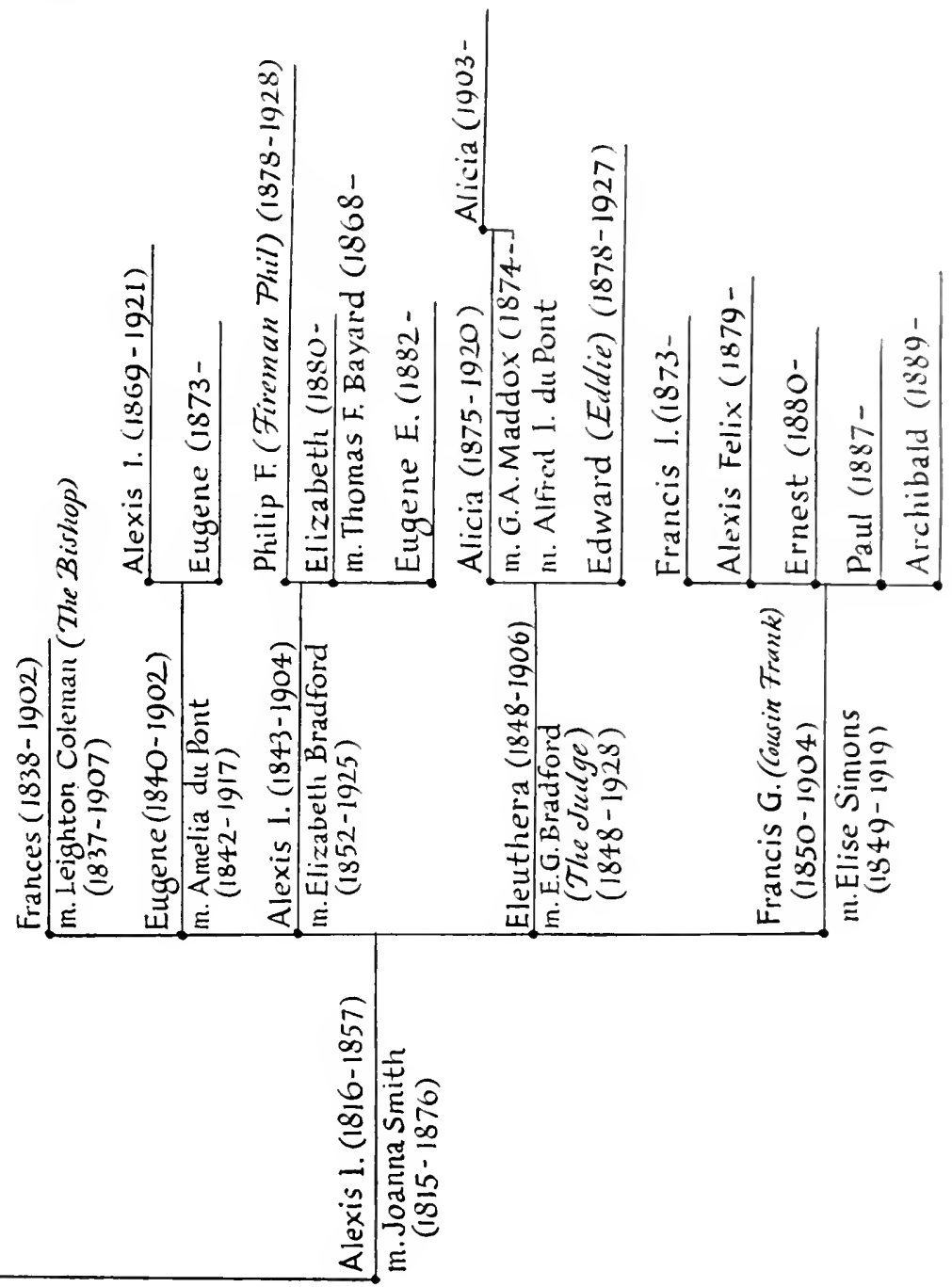

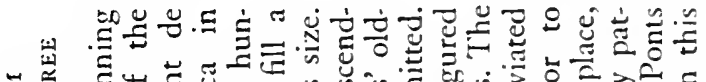

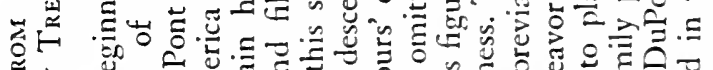

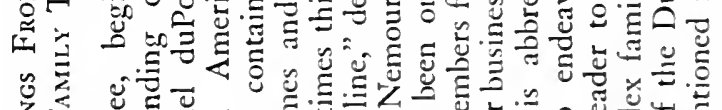

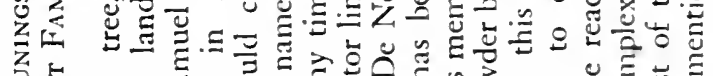

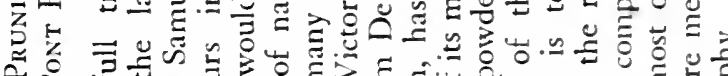

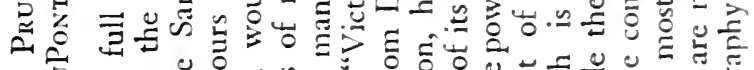

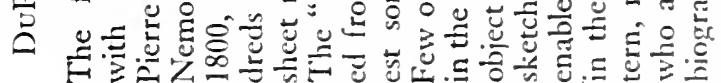


$=$ e 
deference to the occasion, trouser-legs outside his boots instead of stuffed in them as usual. Henry was the ruling partner of the powder firm and the actual, if not the titular, head of the family.

The titular head was, of course, the oldest son of the oldest son of Pierre Samuel. But the second son, Eleuthère Irénée, and not his older brother Victor, had founded the business which rescued the family from an uncertain future in 1802 and which continued to keep it in comfort. Members of the "Victor line" of the family continued to be buried on the right hand of Pierre Samuel's grave and members of the "Irénée line" on the left; but this rule of precedence gained little for the Victor people who remained above ground. The reason was that the Victor men showed little talent for the powder business. Though most of them had worked in the yards, none had risen to the responsibilities of a partner. Redbearded Henry, governing partner since 1850 , governed the firm with a tighter rein than any of his predecessors. His control of the clan revenues carried into the purely domestic family councils an authority with which no amount of seniority of descent on the part of the Victor line could cope. These councils sat, French fashion, to advise on fireside emergencies and on such questions as the schooling, marriage and establishment in life of the ever-increasing crop of young DuPonts.

Control of the family was rendered easier for Henry because the present titular head took slight interest in such matters. This man-named Victor-was a non-conforming DuPont in more ways than one. In the first place he had attained success in life without working a day in the powder yards. The best-known lawyer in Delaware, Victor duPont charged fat fees for his services to corporations. Poor persons caught in the law's nets were represented with equal zeal and charged nothing. Although a director of banks and insurance companies, he was the only political liberal among the DuPonts of his generation. An active Democrat (the rest of the family being Republicans), he had refused his party's nomination for United States Senator when it would have been almost tantamout to election.

At the burial of Eleuthère Irénée II were also Henry's three remaining co-partners: brilliant, kindly Lammot duPont, a brother 
of the deceased-very tall and slender, bespectacled and beardedpersons had remarked his likeness in appearance to Abraham Lincoln; Eugene duPont, son of the late Alexis, chin-whiskered, reserved and mild of countenance; keen and lean-faced Francis G. duPont, who would succeed his deceased cousin as superintendent of the yards.

Present also was Colonel Henry Algernon duPont, trim and military-looking, with the blue rosette of the Congressional Medal of Honor on his lapel. Colonel Henry waxed his mustaches and wore the air of a man of the world. Two years before, however, he had forsaken that world at the bidding of his father, the ruling partner, and had joined the company. It had been hard for Henry Algernon to give up the profession of arms, in which he had distinguished himself, but family and firm came first. It had probably been hard for the red-bearded father to make this request of his son, for old Henry himself had, in his own time, made a similar sacrifice. An honor graduate of West Point's class of 1833, the old gentleman had served only a year in the army when an emergency in the firm had called him away. On the other hand the son had got to serve fourteen years, including all through the Civil War. Now he was to be advanced to the partnership made vacant by the death of Eleuthère Irénée II. Such was the reward for DuPonts who were able and who yielded to family discipline.

Present also at the burial was another DuPont who had not conformed. Neither had he failed in life, though one could not have deduced this from his looks. Alfred Victor duPont was an own brother of the deceased. His tall, rangy figure was clad in illfitting black. Alfred Victor had come from Louisville. He belonged to the "Kentucky branch" of the family, which had not only cut away from the powder company, but had committed the additional indiscretion of deserting the ancestral acres by the Brandywine. Alfred's big-nosed, vital face was thoughtful. He had promised his dying brother to look after his children: quite an undertaking for a bachelor-residing in distant Kentucky.

Beneath the wind-rustled trees that ringed the little cemetery stood a knot of men in workingmen's clothes-powder-mill hands from the yards below, paying their respects to their late superin- 
tendent. Among them were descendants of men who had helped to raise the first mill in 1802 . A paternalistic tie united the DuPonts and their workmen. The DuPont they were seeing buried this day had demanded no risk of his men which he, himself, would not take. He had asked them to perform no task which he, himself, could not perform: for Eleuthère Irénée duPont II had begun his apprenticeship in the manufacture of powder as a laborer in the yards.

But neither powdermen, partners, head of family nor head of firm were the principal mourners of the departed Eleuthère Irénée. Five children, the oldest a girl, seventeen, the youngest a boy, nine, stood holding hands and weeping beside their father's grave. This was the second visit the children had made to the graveyard in four weeks. Just a month before their mother had been buried. She had died in a hospital in Philadelphia. The father was then too ill to be told of his wife's passing. He had breathed his last without knowing that the children who were to look to their Kentucky uncle for guidance were orphans.

The rector of Christ Church intoned the concluding lines of the Episcopal burial service. The northeast wind had stiffened and rain-bearing clouds scudded lower. With apprehensive glances at the sky the company at the graveside divided and departed-the DuPont elders to a family council to determine the future of the orphans; the orphans themselves to Swamp Hall, the rambling half-stone, half-frame homestead on Breck's Lane in which they had been born. Horses felt the flick of whips as all hastened for shelter in advance of the downpour.

Alfred Irénée duPont, born May 12, 1864, was thirteen, the oldest boy of the orphans. He remembered his father best for two things: his humor and his fondness for machinery. The name of the family residence, Swamp Hall, was an example of the humor. Most of the DuPont residences bore names, as the custom had been in France. Sycamore Lodge was the original title of the house on Breck's Lane, deriving from the handsome trees that shaded the 
circular carriage drive. Eleuthère Irénée II had substituted Swamp Hall, usually shortened to The Swamp, though the house stood on a well-drained slope with no swamp in miles. The incongruity of this name always appealed to Alfred.

A spirit of independence, not easy to assert in the rule-bound clan, was another thing Eleuthère Irénée II had passed on to his son, who of all the DuPonts in the history of the family's first century-and-a-third in America was to make the most of it. In the councils of the firm Eleuthère had had the temerity on occasions to resist the authority of the ruling partner himself. In the councils of the family he had, at one time, proved a dissenter in the matter of attending Christ Church because he disliked the current rector. His oldest child was christened at Christ's, but the others, including Alfred, were christened at St. James Church, at Stanton, Delaware.

Moreover, the boy shared his father's liking for machinery. The year before his death Eleuthère Irénée II had taken his oldest son to the Centennial Exhibition at Philadelphia where they had reveled together in the mechanistic marvels on display. Returning home, he had bought the boy a Porter-Allen stationary steam engine which was not a toy but a serviceable slide-valve horizontal engine with a twenty-horsepower boiler. Alfred set up the engine in a shed near the barn and, with the most mechanical-minded of his youthful cronies, Walker ("Gilly") and Francis Mathewson and Albert ("Yaba") Buchanan, he began to explore its mysteries. The Mathewson brothers and Yaba Buchanan were the sons of powdermen who lived across Breck's Lane not a hundred yards away in shock-proof little stone houses such as the firm built for its employees. The four boys got so they could take down the engine and reassemble it almost in the dark.

In the engine shed was a workbench at which $\mathrm{Al}$ duPont and his fellow-craftsmen made miniature water wheels, modeled after the big ones which drove the mills in the yards, and set them to be turned by the waters of Thundergust Run, rushing to meet the Brandywine. They also made muskrat traps and fireworks. In preparation for the observance of the preceding Fourth of July, they had undertaken the largest fireworks project yet: pinwheels, 
flowerpots, Roman candles and bombs. Wangling from the storehouse foreman of the Upper Yard a keg of Neal's Saltpeter, a special powder made for the Paine fireworks people, the boys mixed two dozen Roman-candle balls and laid them on a board to dry. One of the balls rolled off into the ashpit of the steam engine. Flaring up, it threw the other balls into the hot coals.

Boys who have spent their lives around powder know what to do. Two of them dived through the shed's only window. Two others went through the doorway, the door itself following immediately as the detonation of the keg of powder tore it from the hinges. The shed was pretty badly used, but with sighs of relief the boys learned that their steam engine had survived injury. Carrying lumber and paint three miles from the yard carpenter shop, they repaired the damage to the building. ${ }^{5}$

Alfred's memories of his mother were less vivid than those of his father. This was perhaps as well, for her story was a touching one. In I858 Eleuthère Irénée II had married and carried from her Virginia home beautiful and sensitive Charlotte Shepard Henderson. At Swamp Hall the bride found life different from that in the Old Dominion. Though Delaware was a slavery state, the only slaves ever held by a DuPont had been a Negro woman and her child whom one of the DuPont wives two generations before had bought out of sympathy. The secession question divided the State, the DuPonts being intensely pro-Union. Henry duPont, the ruling partner, notified Virginia that a large order of powder placed by that State would be delivered only if Virginia stood by the Union. Virginia seceded and got no DuPont powder; Delaware did not secede.

In the war that followed, the colors were served conspicuously by two DuPonts-Rear Admiral Samuel Francis and the ruling partner's son Colonel Henry Algernon. One of Colonel Henry Algernon's most gallant acts was the disobedience of an order to shell undefended historic buildings in Lexington, Virginia. The head of the firm himself was made a major general of home guards. He would have been at the front had not the War Department preferred him on the Brandywine making powder.

With her Virginia menfolk fighting for the Confederacy, Char- 
lotte Henderson duPont felt herself a prisoner in the camp of the enemy. Eleuthère's mother attempted a bossy attitude toward her Southern daughter-in-law. Eleuthère stood by his wife, beginning an estrangement which never ended, the son refusing to see his mother when on his deathbed. The four nightmarish years of war undermined Charlotte's delicate nerves for life. In search of health she spent a year abroad. When Alfred was ten or eleven she went to Europe for another long sojourn. The five children were left at Swamp Hall in charge of an Alsatian nurse, Emma. Emma beat the three little boys black and blue and starved all her charges, lining her own purse with the money embezzled from the household funds. The mother returned, apparently restored to health. Beaming and happy, she distributed presents among the household. The two oldest boys got toy pistols, which amused Alfred who was no longer in the toy-pistol stage. Annie, the oldest girl, told about Emma. Welts on the back of Alfred were exhibited in substantiation of her story. In a stormy scene Charlotte discharged the cruel nurse. The five youngsters illuminated the path of the departing Emma by burning her effigy and shooting off Roman candles the boys had made in the shed.

The joy of the emancipated children was short-lived. The strain of the Emma incident had been too much for their sensitive mother. She collapsed and was taken to a Philadelphia sanitarium, dying on August 19, 1877, twenty-nine days before her husband. ${ }^{6}$

The events of the last twelve months of their parents' lives had matured beyond their years the youthful inhabitants of Swamp Hall, kneading into a compact little social unit five brothers and sisters. To be sure, this unit was only a component of the DuPont family hierarchy whose elders were now in consultation to determine the future of The Swamp and its residents. These knowing orphans were aware of the authority carried by family councils. Possibly they learned by grapevine telegraph, or perhaps they merely shrewdly surmised, that the decision in their case would be to break up The Swamp household, parceling out the children among their relatives. In that event Swamp Hall would be turned 


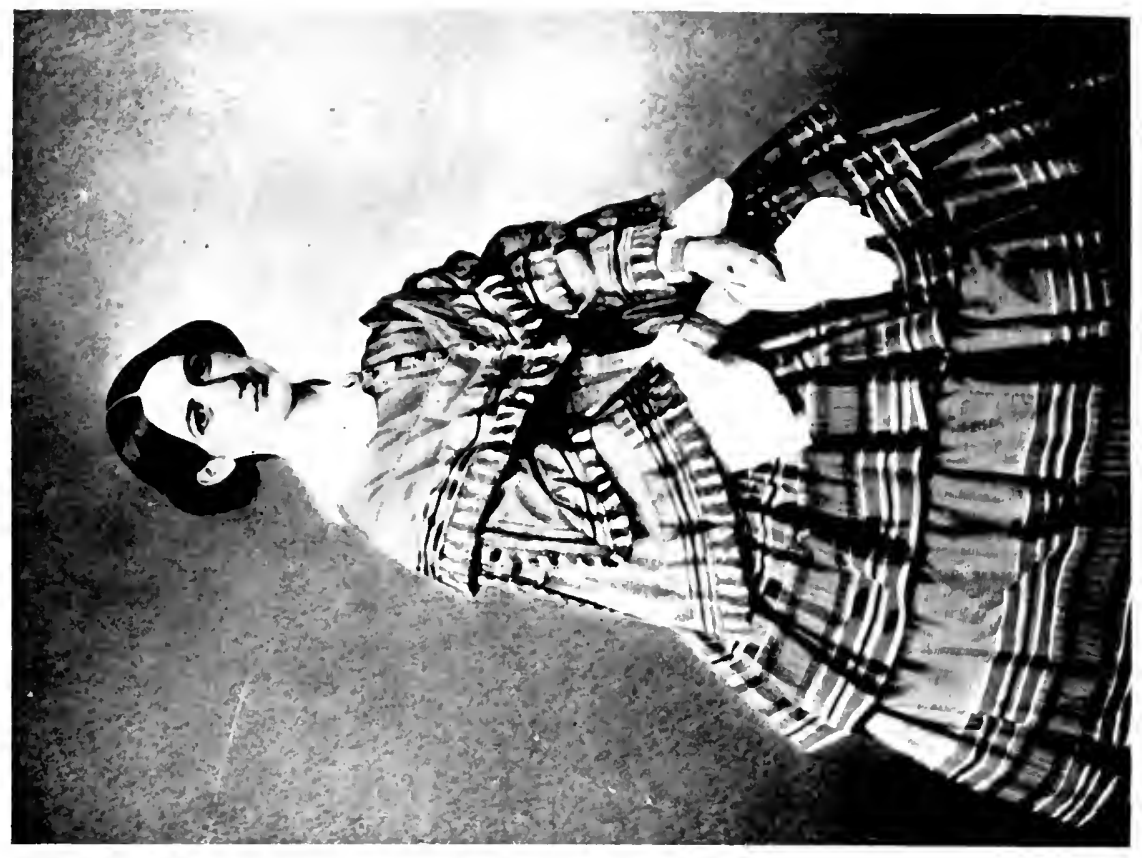

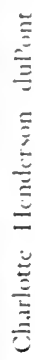

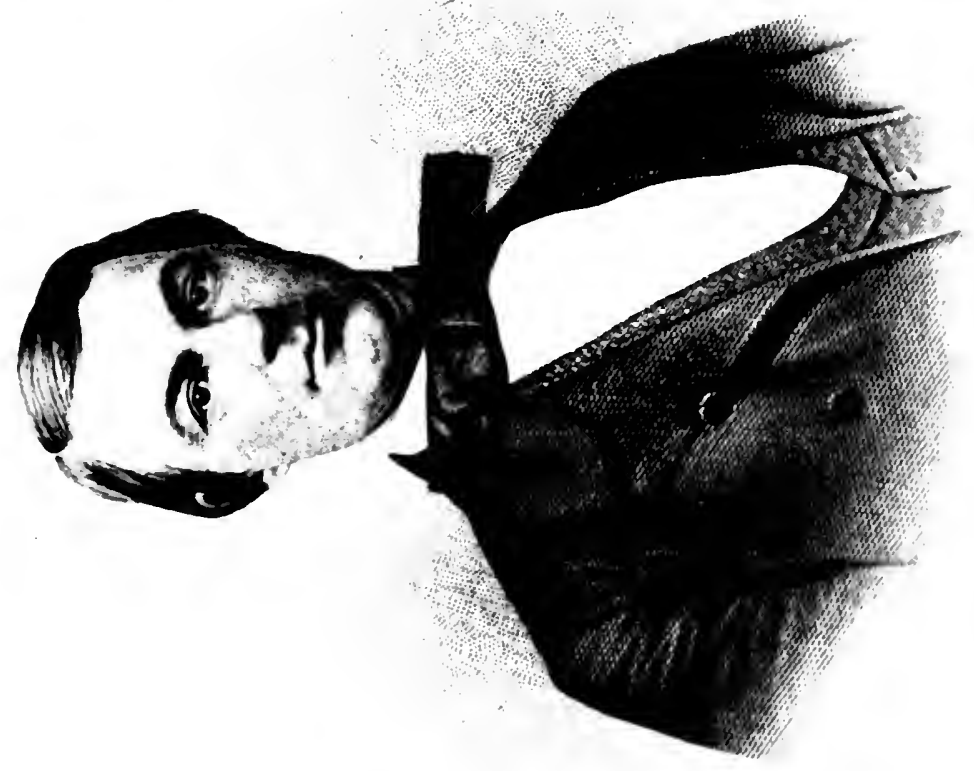

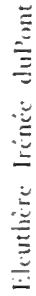


$=$ 
over to another DuPont needing or desiring a residence with ten bedrooms.

Though the late Eleuthère Irénée duPont II left an estate appraised at $\$ 498,87$ I.4I, Swamp Hall had not been his to pass on to his children. Under the form of communal life practiced by the hierarchy, an individual DuPont did not own the home in which he may have been born and from which he may have been buried. Titles to the DuPont residences were held by the firm. When a DuPont married he got a house to live in and possibly a saddle horse and a cow. The livestock was a gift, the house a loan. Should a DuPont prove useful to the firm he would, as his children came on, receive the use of a larger house or permission to add a wing to the original. From his own funds he might buy a carriage. In that way Swamp Hall had grown from a small house to a large one. When their father died, in addition to a half million dollars, the five orphans found themselves possessed of four carriages, a sleigh, three horses, a cow and a heifer; but no home.

Already young DuPonts of marrying ages were beginning to grumble over this state of affairs. They wanted to be homeowners, not tenants. Against this the masterful head of the firm, Henry duPont, had set his hand squarely. Henry was a land-hungry man. As the firm's cash surplus mounted he added thousands of acres, on both sides of the Brandywine, to the already large DuPont holdings. Moreover Henry duPont was power-hungry and naturally disinclined to surrender a source of power. He ruled the firm as no other principal partner ever ruled it. Therefore, so long as the firm should own the roofs over the heads of virtually all the DuPonts in Delaware, Henry would have the deciding voice in the family's concerns.

Of course the orphans did not sketch the problem in this detail. Furthermore they rather liked their Great-Uncle Henry who stood in higher favor with the children of the clan than with its elders. One often saw him, on his rides about the DuPont domain, waylaid by a squealing bevy of youngsters clinging to his stirrups until he bought his freedom with sticks of horehound candy which he carried for that purpose. But this much the orphans did learn or surmise: that the decision of the family council would be to dismember the Swamp Hall household. 
Whereupon the Swamp Hall household held a council of its own, brown-eyed, capable Annie (christened Anna) Cazenove duPont, aged seventeen, presiding. Around her gathered spirited Marguerite, fifteen; rough-and-tumble Alfred Irénée, thirteen; Maurice, eleven, and little Louis Cazenove, nine. With a formality which they imagined a correct imitation of their elders, the proposal was made and unanimously ratified that the brothers and sisters stand together and refuse to be separated.

By effective scouting the orphans learned when the elders' council broke up and a representative dispatched to Swamp Hall to convey the decision. The representative was Uncle Fred (Alfred Victor), from Louisville. The children met him on the front porch, demanded and received the verdict without a waste of words. It was what they had expected. Annie picked up an ax, Marguerite a rolling pin, Alfred his new twelve-gauge shotgun, Maurice a flint-lock pistol and Louis a bow and arrow. Alfred, as the oldest boy, said the children would not submit to the dictate of the council and would defend their home.

Uncle Fred asked for a parley. Weapons were laid aside and Annie stated the case for the brothers and sisters. She was a quiet, sensible girl. She said she.knew how to run the house, having had full charge of it since the last collapse of her mother. The servants were trustworthy and devoted. Annie promised to finish her own schooling and to see that her sister and brothers finished theirs. She would welcome the counsel of her older relations, but she would not desert her sister and brothers, would not permit them to be taken from her, and would not give up The Swamp. ${ }^{7}$

Uncle Fred gravely took his hat and departed. The band of brothers and sisters, who had learned solidarity against the tyranny of Emma, awaited the issue of their defiance.

It was victory: no separation; no dispossession. Great-Uncle Henry had yielded.

In point of fact it seems that the red-bearded old gentleman had liked the youngsters' spunk. Probably this was due in part to the 
tactful and sympathetic way their Uncle Fred had placed the cause of his wards before the clan's chieftain. Fred duPont and Lawyer Victor, titular head of the family, had been named cxecutors and trustees of the estate by the terms of the will of the late Eleuthère Irénée. They had argued the children's right to their birthplace, Annie's competence to manage the house. They had promised an active supervision until the girls should be married off and the boys settled in their careers.

Concerning careers it was too early to plan: but might not young Alfred's kink for machinery prove significant? Indeed, even so embryonic a possibility may already have occurred to Great-Uncle Henry whose steady eyes looked far ahead, missing little that might concern the welfare of the firm. With manufacturing methods changing, an inventive mind for mechanics would not be amiss in the yards. Young Alfred's father had introduced metal kegs of his own design for packing powder and had built an improved horizontal graining mill.

This Fred duPont, the children's friend at court, was a singular and superior personage: no mediocrity could have swayed old Henry. Like most DuPont men Fred was raw-boned and slender. His strong face was clean-shaven except for a tuft of chin whiskers, his gray eyes secretive. He dressed poorly, even by comparison with the Delaware DuPonts who, with the exception of Colonel Henry Algernon, were no molds of fashion. In Louisville he lived in one room in the Galt Hotel. He was the founder and the brains of a paper manufacturing company and of a horsecar line in Louisville which were making the Kentucky DuPonts rich; but the president of these concerns was Bidermann DuPont, a brother of Fred. Bidermann was a man of imposing presence, with meager ability behind it. A presence, however, was all that was required of him, Fred duPont supplying the rest.

The lonely bachelor loved children and already was a second father to Bidermann's brood in Louisville. It warmed his heart to see how his first move in behalf of the Swamp Hall orphans had drawn his new charges to him. The house question settled, Uncle Fred sat down in the gaunt old parlor of The Swamp to explain to the children the terms of their father's will. The fortune was left 
in trust to Uncle Fred and Cousin Victor to be divided equally among the children, each receiving his share on reaching the age of twenty-one. ${ }^{8}$ Meantime from the income the children would be educated and Swamp Hall maintained. The details of the holdings of the late Eleuthère Irénée II, after the payment of outstanding bills, show the extent to which DuPonts kept their money at home. The first item represents the deceased's stake in the firm of E. I. duPont de Nemours \& Company which, despite its title, was a simple partnership, not a corporation.

"Due from surviving partners of the firm, who, according to family custom, had purchased the dead partner's share

"Notes and mortgages

"Thirty-three shares Delaware Railroad stock

"Lehigh Coal \& Navigation Company bonds

$\$ 491,559.53$

II,I75

"Furnishings of Swamp Hall, horses, carriages, etc.

"Cash in Union Bank of Wilmington

825

460

847

90

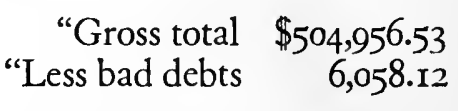

"Net value of estate $\$ 498,87 \mathrm{r} \cdot 4 \mathrm{r}$ ",

This sum in the hands of an investor as competent as Uncle Fred would bring at least 5 per cent or in round figures $\$ 25,000$ a year. But Uncle Fred had no intention that his wards should spend their income to the hilt. He was not a man to go in for lavish living, nor had his nieces and nephews been brought up to expect it. Making allowance for the understatement characteristic of DuPonts, barnlike old Swamp Hall, which the children had fought with clenched fists to keep, could have been no more of a palace on the inside than on the out. The valuation of the furniture for fourteen rooms, submitted for court record, was $\$ 567$. The guardian who lived in one hotel room and had refused to permit the management, during a periodical renovation, to change the carpet on his floor, doubtless thought The Swamp well-enough appointed. The household budget, over which Annie had charge, was proportioned accord- 


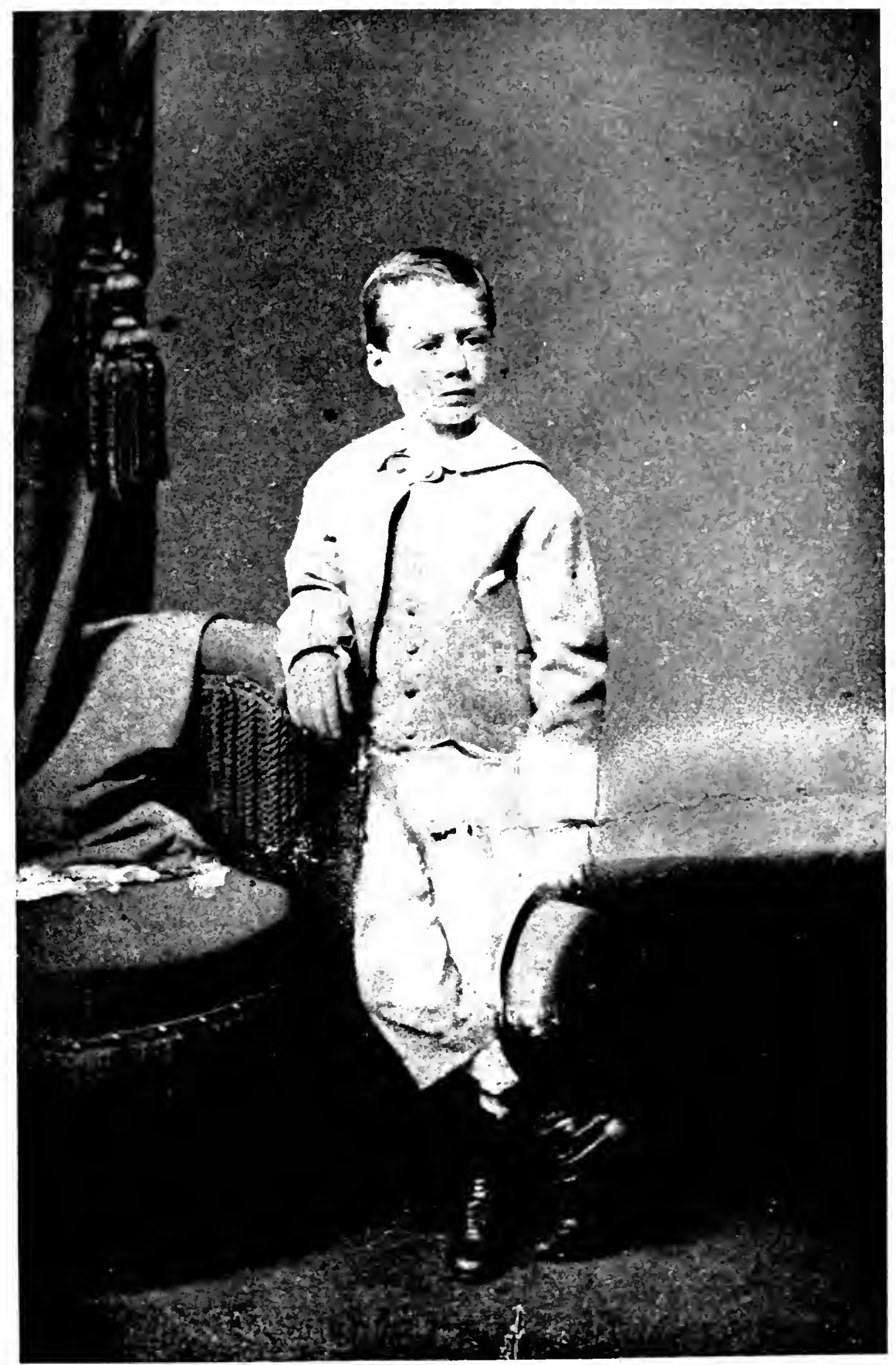

Alfred I. de Pont at the Ari af Finolit 
ingly. It provided, however, for the retention of the four old servants and a carriage.

These arrangements made, Uncle Fred took a train to Louisville, promising to be back before long to see how things were going. Annie and Marguerite returned to their classes at a girls' school in Wilmington, the coachman, Lytle, driving them to and fro. The two younger boys went to a small private school near Philadelphia. Tearing himself away from the Porter-Allen engine and from his Breck's Lane chums, Alfred Irénée reluctantly resumed his place in the Reverend James G. Shinn's small and strict academy for boys at Waterford, New Jersey. What Alfred liked best about Parson Shinn's school were the extra-curricular activities. On certain Saturdays he fired a wood-burning switch engine in the railroad yard. Another time he buried a dead cow for 25 cents. 


\section{CHAPTER II}

\section{The Down-the-Creek Gang}

I

A FEw days before Christmas, 1877 , Alfred stamped the snow of Doctor Shinn's campus from his boots. The resolute five at Swamp Hall were reunited and, with $\mathrm{Al}$ duPont back, the Down-theCreek boys' gang was made complete. Days were never long enough to get through all there was to do: skates to sharpen; a sled runner to repair; a snow fort to build; the Porter-Allen to steam up; Al's shotgun to clean of its laying-away coat of grease; twelve-gauge shells to load, for what would be the fun of shooting "store" ammunition?

Breck's Lane was a fine place for coasting if one did not mind a thrill at the end of the ride. The grade was steep enough to start a sled at the tollgate guarding the junction of the Lane with the Kennett Pike which one had to pay to use. The incline increased so that a sled would be flying before it had gone a quarter of a mile, passing the Swamp Hall grounds on one side and the line of powdermen's houses on the other. Then came the test of nerve and skill. Two hundred yards farther Breck's Lane met at a right angle the Creek Road-pronounced Crick Road-bordering the Brandywine. The steersman had to bank for the sharp turn, watching out for traffic on the Creek Road, which was used by the sixmule teams drawing covered powder wagons. Failing to make the turn, one had the options of a spill, of butting the stone wall which separated the Creek Road from the creek, or, if the snow were deep enough to cover this barrier, of shooting over it and down an almost straight bank to the surface of the frozen Brandywine fifteen feet below.

Marguerite was almost the only girl with courage to try that turn 28 
on a sled going full tilt. Moreover, she could skate more gracefully than any boy and nearly as fast. Of course some limit had to be imposed on a girl who might have become an embarrassing rival, so the Down-the-Creek-pronounced Crick-gang made a law: no girls for ice hockey-too rough. Left to her figure eights and to the disquieting realization that she had been born into a man's world, Marguerite could only look on while George, Gilly and Frank Mathewson, Sam, Johnny and Yaba Buchanan, Mike Foster, Matchie McMahon and her brother Alfred fought it out with the Up-the-Creek boys at hockey.

The personnel of the rival Brandywine bands ranged in ages from thirteen to seventeen, making $\mathrm{Al}$ duPont a junior member, which in boyhood's scheme of things is not a position of authority. Al was the only boy of the DuPont name in either gang, the others being the sons of powdermen in the yards. The DuPont name got $\mathrm{Al}$ no privileges and perhaps a little more hazing than usual. Any standing he enjoyed was won by his skill at games, his daring, and his generosity with his possessions. Once when $\mathrm{Al}$ and Matchie McMahon got into a fist fight, the older boys stood judicially by letting them slug it out for a while. Then they pulled them apart, calling the scrap a draw and telling the scrappers to save their strength for use against the Up-the-Creekers.

Christmas vacation was not all fun, however. On Sunday mornings Alfred and his brothers had to scrub themselves, put on their best clothes and pass inspection under the eyes of Annie. Down the center aisle of Christ Church the five would march to the Swamp Hall pew, well in front. After the service they would be surrounded by relatives whose clucking solicitude made Alfred uncomfortable. There was, of course, a shoal of young cousins, among whom Annie and Marguerite had their particular friends. Maurice and Louis might find relief in boy's talk with Cousin Pierre for these three were near enough of an age to play together sometimes. But Alfred had no chum among the DuPont boys of his years, and casual acquaintance requires a degree of formality difficult for lads of thirteen to manage. Moreover, Alfred held the private opinion that most of his young kinsmen were sissies. The church ordeal over, he would dive into old clothes and with a 
whoop burst from The Swamp in search of his Down-the-Creek companions, a familiar world regained.

Annie's preoccupations with the large house gave her little time for the out-of-doors. She did not complain, for managing a domestic establishment seemed her forte. The older DuPont women who had viewed Annie's undertaking with skepticism at first were frank in their praises of the capable girl who kept The Swamp as neat as a pin, was a veritable mother to the two younger boys and sometimes knew more of the unorthodox goings on of Alfred and his particular set than that young man suspected. On New Year's Day she received her reward. Since the DuPont clan had landed in America on January 1,1800 , the New Year's custom of every male head of a DuPont household had been to call on every female head and give her a present. January I, 1878 , the DuPont men, from Great-Uncle Henry down, called on Annie. When the gas lamps were lighted their yellow rays fell upon a huge pile of boxes filled with chocolate drops and sugared fruit. It had been a great day for the young mistress of Swamp Hall. ${ }^{1}$

When summer vacation came Alfred showed up with a classmate, a Cuban boy named Nick. Nick's Latin politeness pleased Annie, and his more rugged qualities passed muster with the Down-the-Creekers. The Mathewson boys kept pigeons and a pigeon shoot was decided upon in the ten-acre lot next to the Mathewson house, where the Swamp Hall cow was pastured. The young marksmen got several birds and one window pane in the Mathewson house. Annie deducted the cost of a new pane from Alfred's minute allowance, and there was no more small-arms practice in the cow-lot.

To satisfy their appetites between meals the boys would rob the. Swamp Hall garden. The raids were elaborately planned. While the gardener was chasing off one party of miscreants, another would fill their caps with strawberries. A loaf of bread and a can of molasses snitched from the Buchanan kitchen would complete the wherewithal for a feast down in the reeds by Thundergust Run. 


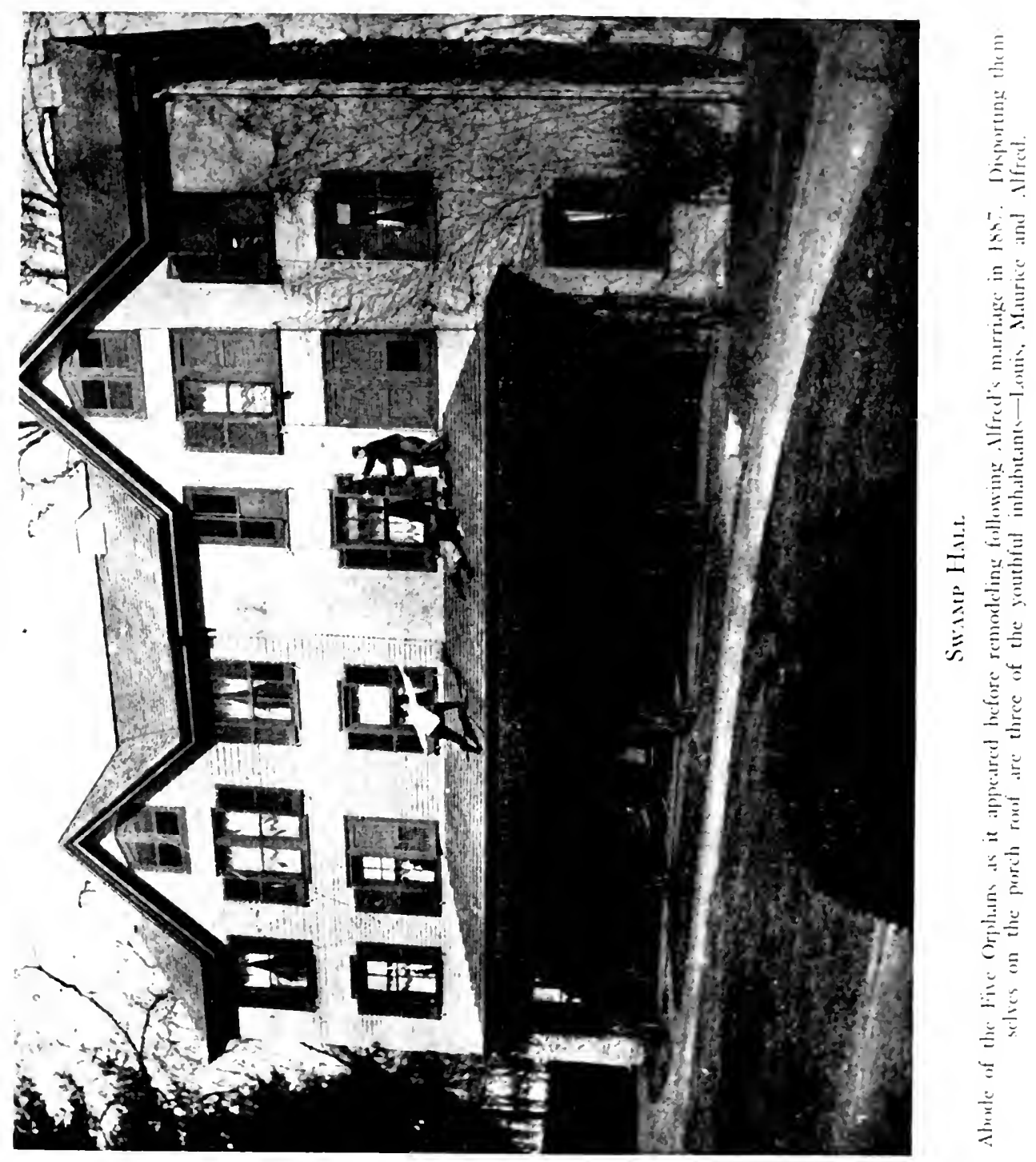


$=$ 
A suspicious odor in Alfred's clothes closet prompted Annie to make an investgiation. She found a bag of smoking tobacco in her brother's pocket. A little observation produced other incriminating evidence, and Annie asked Alfred if he didn't think smoking cigarettes behind the barn a bad example to set his younger brothers.

Suspecting Nick as the mastermind behind the smoking episode, Annie bundled the young señor off to Cuba. Alfred could not protest too strongly. To excite Annie's curiosity as to what else Nick might have taught the Brandywine innocents would have been unwise. The fact is that in the Cuban they had met their first acknowledged man of the world. Nick swore in two languages and had a fund of sophisticated anecdote that capped anything ever heard in juvenile circles along the Creek. Nick could not shoot very well; no matter, he said, a knife, which did its work silently, was the weapon of a Cuban gentleman. At the bench in the engine shed, $\mathrm{Al}$ and his friends had turned a whole set of files into daggers while the superior Nick blew smoke rings and discoursed on the particular virtues of each blade.

Perhaps Nick left too soon; at any rate young Down-the-Creek gentlemen continued to arbitrate otherwise irreconcilable differences with their fists. Al licked Mike Foster and he licked Matchie McMahon. Five minutes after the fights late adversaries were swimming in the Brandywine together as if nothing had happened. While diving $\mathrm{Al}$ struck a submerged stone, breaking his nose. Sam Buchanan pulled the stunned boy out of the water. Twenty years later when Mr. duPont began to get hard of hearing, a specialist attributed the difficulty to the broken nose which had been permitted to heal without benefit of surgery.

Baseball was about the only sport known to the Brandywine at which $\mathrm{Al}$ duPont did not excel. Matchie McMahon was the best ballplayer. In games of One Old Cat, he would strike out $\mathrm{Al}$ ingloriously. When some of the Breck's Lane crowd tried out for a Brandywine boys' baseball club called the Never Fails, Matchie was taken as pitcher whereas Al failed to make the team. Thereafter young duPont's interest in baseball declined. He seemed too much of a perfectionist to stick to a thing he could not do well.

Besides the normal diversions of a Down-the-Creek boy, Alfred's chief interest was music. Having begun piano lessons as a child 
and always enjoyed them, he did not have to be nagged to practice, though smudged scores and piano keys often suggested a transfer of attention from the Porter-Allen engine to the arts without pausing at the wash basin. At fifteen he read ordinary music at sight, played with a budding feeling for theme and, on his own, had begun to pick up the violin, bass viol and the flute. ${ }^{2}$

In the fall of 1879 , Alfred entered Phillips Academy, at Andover, Massachusetts, taking along his flute. The change may have been made on the advice of Uncle Fred, who was interested in the subject of education and was to build the City of Louisville a high school and to help devise a curriculum for boys who wished to prepare for scientific courses in college. Uncle Fred had been faithful in the discharge of his responsibilities as guardian of the Swamp Hall minors, and his frequent visits were always welcomed.

After the longest journey he had ever made alone, Alfred appeared at the famous old preparatory school, for the first time in his life utterly among strangers-a tall, stand-offish, carelessly dressed boy of fifteen with blue eyes and a mop of fine light hair. Negligence in the matter of attire suggests a deliberate affectation copied from Uncle Fred, of whom a woman cousin had said: "I'll declare, he goes around looking as if he didn't have a five-cent piece in his pocket."

The head of the English Department was benign "Papa" Merrill, the best-liked instructor in the school. His classroom was so short of blackboard space that each board was chalked into three parts to enable three students to do their exercises at a time. This did not give a boy much room. At the beginning of the term the boys were told to go to the boards and, to facilitate acquaintance, each write his full name. Frowning at the small space before him Alfred took up his chalk and wrote boldly:

"Alfred Irénée duPont de Nemours."

The name extended the width of the board.

Papa Merrill smiled indulgently; Alfred had matriculated under the name of duPont. The old instructor asked the pupil if he could 
not condense it so as to stay within the limitations of his portion of the blackboard.

"No, sir," said the boy; "that would be highly improper."

Nevertheless "de Nemours" did not appear on the blackboard again and the new boy became "Dupie" to his fellows.

During his early days at the strange school, Alfred would sit by his bedroom window and play his flute, perhaps from loneliness. Innovations were not tolerated at tradition-bound Phillips, particularly on the part of new boys. Dupie's music was resented, but the greater the resentment the louder Dupie tooted. When the resenters learned that the new boy could back up with his fists his devotion to music, the issue seems to have solved itself, both the objectors and the flutist becoming less insistent on their particular points of view. Phillips gradually discerned in Dupie the qualities which had marked him on the Brandywine. The school's mischiefmakers, recognizing a fellow-spirit, initiated him into their secrets. During his three years at Phillips Alfred ran with this crowd, becoming a ringleader.

The headmaster, the celebrated Doctor Bancroft, wore a silk hat which was a target the boys could not resist in snowballing time. Once Alfred caught the hat squarely with a hard ball and virtually demolished it.

"DuPont, come here," summoned the headmaster.

Alfred approached, all apologies. He had, he said, "made a regrettable mistake."

"That mistake, duPont," said Doctor Bancroft, gazing at the wreck of his hat, "will cost you just $\$ 5$."

New headgear for the headmaster took Alfred's spending money for a month.

A midnight party in a room on the Latin Commons was interrupted by the sound of a teacher's tread on the stairs. Dupie leaped from a second-story window and might have been hurt had he not landed on top of a policeman patrolling his beat. The officer re. covered from the shock in time to seize Dupie and march him off in the direction of the town lockup. Young duPont professed to be contrite. He was getting what he deserved. He talked on so pleasantly that the policeman relaxed his grip on the prisoner's arm. As 
they approached the station house duPont suddenly thrust his foot between his escort's legs, tripping the bluecoat flat on his face. An instant later Alfred was out of the sight and the reach of the law.

The last year he was at Andover, Alfred was president of the Bicycle Club. Bicycles of those days had a front wheel five feet in diameter and a small wheel in the rear. They were hard to ride. A favorite excursion was to Lawrence-favored, perhaps, because Lawrence was out of bounds to Phillips students. One day when the club had planned to ride to Lawrence an instructor who owned a wheel invited himself along. Dupie fixed the rendezvous for the club members, saying he would join them-without the instructor. Then Alfred went to meet his guest. They started down a sidewalk, Alfred leading. Between the walk and the street was a deep ditch, crossed at intervals by narrow planks. Pedaling up to a good speed Alfred suddenly turned and crossed one of the planks into the street. The instructor turned, but his wheel struck the ditch instead of the plank.

Alfred sang tenor in the Glee Club and was chosen to carry the air in the boy's choir in church. Though not a good student, he stood above average in all classes except English and chemistry. In those he stood near the top. He seemed to have a natural ear for correct and rather felicitous language. His English compositions almost invariably earned good marks and he had a gift for dashing off jingles.

The boy had a contempt for mere marks, however, and occasionally showed it. An instructor commented on an examination paper of Alfred's:

"DuPont, you made 75-a bare passing grade."

"Yes, sir; and if a bare passing grade were 85 I would have made exactly that."3

At Christmas and Easter and during the summer vacations, Alfred found it good to be back on the Brandywine; good, and a little exciting to discover the results of Time's altering hand on the familiar scenes. 
Older boys-Sam Buchanan, George Mathewson-were dropping out of juvenile affairs to begin their apprenticeships in the yards. When the bell at six in the evening announced the changing of the shifts, they trudged home carrying dinner pails, speaking a strange adult tongue and too weary for much frolicking. Matchie McMahon had not followed his father into the DuPont employ. $\mathrm{He}$ was earning more than any apprentice by pitching a baseball game twice a week for the Blue Rose club, a semi-professional nine which played up and down the Brandywine. Youngsters not dry behind the ears a couple of years before pushed up to take the vacated places in the Down-the-Creek gang; thus Maurice and Louis had become full-fledged members.

Al stepped into a position of leader, for which he possessed much native gift. He proved his supremacy in fights with his standing rivals, Matchie McMahon and Mike Foster. Men are still living who witnessed Al's last fight with Mike. Both boys were about seventeen and they punched each other for an hour. It was the bloodiest "friendly" battle remembered on the Brandywine.

By this time Alfred was able to discern good points in some of his cousins, not all of whom could be dismissed from consideration as sissies, because they combed their hair and wore neckties. They were 'Lex and 'Gene duPont, grandsons of the Alexis who had lost his life in an explosion. There was also a visiting first cousin from Kentucky who was anything but a sissy. This was Coleman duPont, a son of Bidermann, whom Uncle Fred used to bring on his trips from Louisville. Five months Alfred's senior, Coly was a handsome, dashing, strapping fellow, six feet four inches tall when he was eighteen, and the only youth on the Brandywine that $\mathrm{Al}$, five feet eleven, could not outdo in feats of daring. ${ }^{4}$

Uncle Fred duPont gazed fondly at those attractive striplings and liked to regard them as his particular protégés. The favor of Uncle Fred was not a boon to be regarded lightly, though his eccentricities increased with his wealth. He built a mansion in Central Park, Louisville, only to find himself unable to desert Room 422 in the Galt Hotel with the same threadbare carpet on the floor. So the palace was turned over to Bidermann duPont, the father of Coly. Fred duPont dressed more seedily than ever, though 
his horsecar line had grown until Uncle Fred was the master of public utilities, which made him a behind-the-scenes power in the Ohio Valley. The middle-aged bachelor gave much of his money anonymously to charities. Another thing he liked was to place ambitious young men in jobs with futures and watch their progress. ${ }^{5}$

\section{5}

Annie and Marguerite were young ladies and had just returned from a sojourn abroad. The Swamp was filling up with beauxespecially when the lively Marguerite was at home. Alfred occasionally took a girl to a dance, and Coly, who had a way with the fair, caused many a heart to flutter during his visits to the Brandywine. One summer the two swains found their fancy tending in the same direction-toward Alice duPont (for some reason called Elsie in the family), a distant cousin who belonged to the Victor line. She was a pretty, pert little thing whose blonde head hardly came to the shoulder of either of her tall squires. Such an attachment was bound to raise a buzz of speculation over the teacups of a clan whose genealogical chart was replete with cousin marriages. In the main these interlacing ties were encouraged because they drew the family closer together.

Consciousness of the proud family structure and of his place in it began to bear upon Alfred while he was still a schoolboy, three parts Breck's Lane hooligan. He was the male head of Swamp Hall-the youngest male head-of-house in the DuPont hierarchy. On New Year's day he would mount his saddle horse-or bicycle if the weather were good-and, laden with candy in holiday wrappings, call upon all the female heads of families.

But whatever the satisfaction flowing from a privilege which placed him a cut above other DuPont lads of his years, Alfred Irénée's true domain remained out-of-doors. Boy and youth, he had learned every foot of the powder yards and every acre of the miles of contiguous countryside in which Great-Uncle Henry was sinking so much of the profits of the firm as well as his own money. The freemasonry of a boyhood spent with powdermen's sons had ac- 


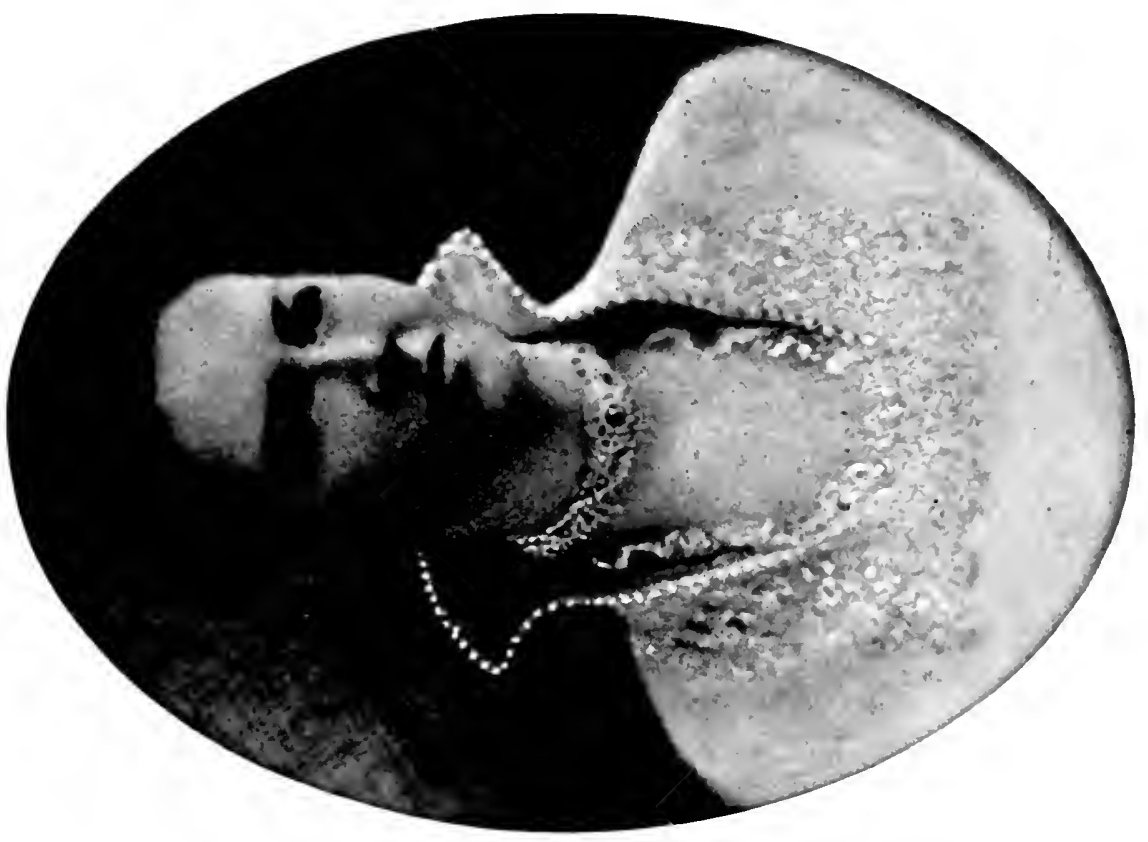

俈

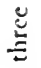

岇

แै

Е

$\stackrel{\mathscr{\Xi}}{\Xi}$

ส

苞

ᄃ

艺

능

元

结电

岕总悉

ठั 气气

嘴

ลิ

Ф

$0 \%$

5

$\therefore$ 응

敬

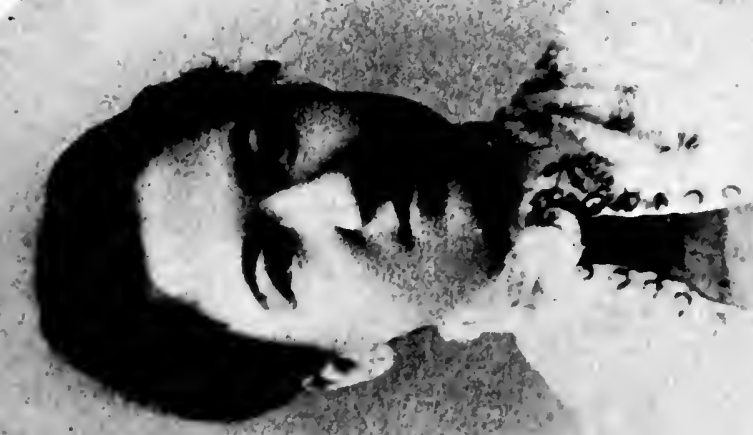

$E$

岁鞄

$\cong$

$\because$

$\stackrel{2}{\geqslant}$

䒿

气

ป

؛ 

quainted him with a powderman's view of Brandywine affairs perhaps before it occured to him that a DuPont's view might be something different.

He learned to think of his great-uncle as "Boss Henry" and "The Red Fellow"-from the hue of his beard. Those were workingmen's private terms for the head of the firm whom they addressed, to his face, as "Mr. Henry." Perhaps also by this time Alfred knew something of the family's restiveness under the tight rein Boss Henry held over their concerns: the firm's ownership of dwelling houses; the unequal division of profits among the partners, Henry taking as much as his fellow-partners put together; Henry's sequestration in lands of so great a part of the profits and, not content with that, putting an expensive stone fence around every new field or woods. There was a resentful family saying that Henry would build a $\$ 4000$ fence around a $\$ 2000$ pasture; another family saying that he took most of the distributable profits unto himself to keep the other partners in the paths of virtue, money being the root of all evil.

None can deny Henry's passion for stone fences; he seemed to like the handiwork of masons about him. But there was method in his "folly" of keeping a crew of masons available at all times. When a blast sprung a wall or wrecked a mill, or when a new mill was needed, artisans trained to powder-yard work were at hand to begin work on the hour. A badly damaged mill might be running again in four days, a saving of time which would pay for miles of field fences when there was nothing else for the crew to do. The masons themselves profited by this system-so much so that they were known among powdermen as "the never-sweats." The truth is that they did build farm walls very leisurely. Boss Henry's daily constitutional was a horseback ride. He would whistle up his two big greyhounds and set out, usually on a country road leading in the direction where the masons were supposed to be at work. For these visits the never-sweats would prepare by assigning one of their number as a lookout to signal the approach of The Red Fellow. Alfred and his cronies learned of this stratagem early in their lives. If well-behaved they might be allowed to stand sentinel while the 
regular lookout had a snooze. To betray the never-sweats no more occurred to Alfred than did any other act of black treason to his playmates or to their fathers.

In his office Boss Henry had a collection of relics picked up on the field of the Revolutionary Battle of the Brandywine. For years Down-the-Creek boys had kept a batch of "Revolutionary" bullets, of their own manufacture, aging beneath the ground. When properly antique in appearance a ball would be exhumed and added to Mr. Henry's small museum, in exchange for io cents. ${ }^{6}$ 


\section{CHAPTER III}

\section{An Education in School and Out}

THE powder yards strung a good three miles along the Brandywine. Farthest upstream was the Upper Yard, the original Eleutherian Mills, whose first buildings were erected in 1802. Then came a safety zone, so that an explosion in one yard would confine itself to that yard, and would not, in the powderman's idiom, "blow" a mill in another yard. Below the safety zone was Hagley Yard, a "double set of works," in other words two yards in one. They were built in 1812 and in 1828 , on the sloping shelf that runs back conveniently from seventy to eighty yards from the water's edge before the sharp ascent begins. After Hagley came another safety zone, and on the opposite, or east, side of the creek stood the Lower Yard, built in 1836 . Excepting sheds and odd buildings all structures, more than a hundred in number, were of Brandywine granite. They looked like forts. Nevertheless, some of them had been blown to atoms and rebuilt a half-dozen times. Most of them at one time or another had been virtually wrecked. Excepting the very new structures, there was not one which had not been damaged by a blast.

This reach of the Brandywine is a boulder-strewn stream about forty yards across except where the mill dams, one for each powder yard, spread it into little lakes which were capital for swimming. For the most part the banks are better than a hundred feet high and very steep. Originally they were heavily wooded, but as the yards grew the trees were cleared until only the east bank across from the Hagley slope was left with a stand of trees.

Surmounting the west bluff, so close to the works that they had been damaged many times, stood the pioneer DuPont residences. 
Most pretentious of these and nearest the seat of danger was the home of Boss Henry. On its spacious lawn was a solid stone structure of five rooms. This was the office from which Henry duPont, seated in a plain chair before a plain flat desk, since 1850 had directed the affairs of E. I. duPont de Nemours \& Company so ably that now he controlled the destinies of the powder industry in America. Four clerks and a boy, a teamster's son, comprised the office force. Clerks were permitted oil lamps and steel pens, but Mr. Henry's desk was illuminated by three candles. He wrote his letters-sometimes twenty in a day-with a quill, blotting the pages with sand. Copies were laboriously transcribed, longhand, in a letter book. Vainly Edward Collison, the veteran chief clerk, contended for consent to take a typewriter on trial.

Mr. Henry was not behindhand in other matters, though. His yards were fitted with the most modern powder-making machinery in the world, much of it improved by DuPont inventions. The electric telegraph was perfected in 1844 . Before the beginning of the Crimean War in 1853 , the DuPont Company had a private line from the office to Wilmington where it connected with the wires of the Western Union. Liberal use of the telegraph more than once had given the DuPonts the jump on their rivals in the race for war orders from across the sea. The telephone was invented in 1876 . Three years later a private exchange connected the office, the three yards and the houses of the partners. In I884 this system was joined to the exchange in Wilmington. In his boyhood ramblings the only features about the office which interested Alfred were the telephone and the telegraph instruments. The only details of the clerk's work which engaged him were sending and receiving Morse messages, for each clerk was a telegraph operator. The secrets of their letter books and ledgers attracted the prying boy not at all. The worst fate he could imagine was to be stuck on a high stool in an office. ${ }^{1}$

But to drive a six-mule team hauling a powder-laden Conestoga wagon as far as middle Pennsylvania-that would be something like it. Fascinated and a little fearful, people turned aside to let the wagons pass while, bestride the tongue mule, sat the swearing driver like a nonchalant prince. On a street in Wilmington three 


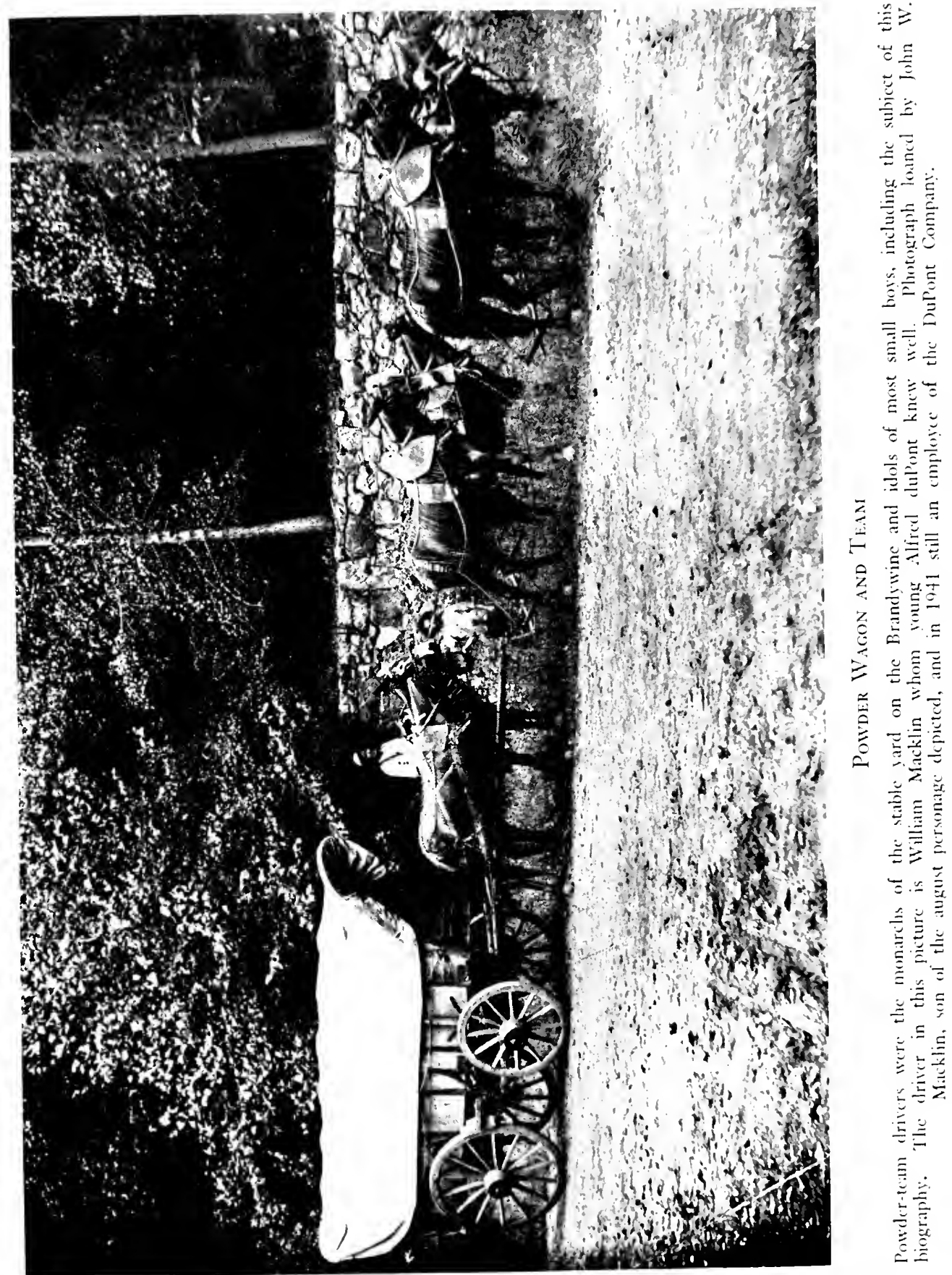


wagons had blown up, killing the drivers, two passers-by and twelve mules. A city block was wrecked. The DuPonts rebuilt it, and thereafter the powder wagons had avoided towns.

Mules were kept in the Big Stables near the office, where every morning the drivers came up from their tenements in Wagoners' Row. Drivers were the aristocrats of the stable-yard as well as of the road. They did not have to care for or even to harness their mules. There was rivalry among these aristocrats, particularly between the drivers of powder and of limestone teams. Bill Connor, powderteam driver, found a limestone wagon stuck. He pulled it out, exacting from the beneficiary the fancy hames and bells with which he had adorned his mules. Boss Henry chuckled over the incident, but, as the decorative gear had been the personal property of the limestone driver, he told Connor to give it back.

Bill Connor liked his bottle and would come to the stable a bit unsteady on his legs. But as he had trained his tongue mule to get down on its knees Bill could mount without difficulty. Boss Henry told the stablemen to substitute an untrained tongue mule. A few days later Bill called Alfred Lecarpentier, the paymaster, to the door of the office.

"Look here," he said, tapping the new mule on the legs.

The animal got down on its knees and Connor stepped into the stirrups. Another tap and the mule got up.

"Now tell the Boss if he has any more green mules I'll train 'em."

DuPonts used to say that Uncle Henry took more from his workmen than he did from his own flesh and blood. In some ways this was true. Nor would it be surprising to discover evidence that the tolerant old autocrat knew more than he let on of the secrets of the never-sweats and of the youthful counterfeiters of Revolutionary relics.

\section{2}

Homes the firm had built for their hands extended from Squirrel Run above the northern gate of the Upper Yard to the Lower Yard on the other side of the Brandywine. They lined the shelf or perched in clusters on the rocks part way up the irregular bluff in the safety zones between the yards. They dotted Barley Mill Road, 
Breck's Lane and Rising Sun Lane leading from the Kennett Pike to the creek, and the Creek Road which bordered the stream between the Hagley and the Lower Yards.

Counting old and young this made a community of about a thousand persons living with the sound of the powder mills in its ears-a sound which a north wind brought clearly to Swamp Hall. It was not a formidable or even a disturbing noise. Only the dull clank of shafting gears distinguished it from the ordinary sounds of nature: the Brandywine purring over gray boulders and over the dam spillways; the swish of water on the water wheels that ran the mills. The community had its post office, named for that good Whig, Henry Clay, its stores, its saloons, a dance hall and a Roman Catholic Church. Two of the saloons were locally famousthe Blazing Rag, on Rising Sun Lane, Tim ("The Lord") McCarthy proprietor; the William Penn, on the Creek Road, Tom Toy proprietor. McCarthy was a retired powderman, Toy the son of a powderman killed in the yards. The William Penn was the unofficial Democratic political headquarters for Christiana Hundred and Tom Toy the party boss.

Excepting Victor, DuPonts voted the Republican ticket and in France they had been Protestants since the year 1555, suffering confiscation of property and many indignities for their devotion to their faith. Their first workmen on the Brandywine had been largely French, but Catholics. These were succeded by Irish who were Catholics and Democrats. A powderman stood in need of the assurances and his family of the consolations that religion could offer. For these offices the direct and practical tenets of the Catholic creed were ideal. In $184 \mathrm{I}$ DuPont stonemasons, on company time, had erected the thick walls of the Church of St. Joseph's-on-the Brandywine. The edifice was built well back from Barley Mill Road with an acre in front for a burying ground where many a powder-blast victim, or as much of him as could be found, was laid to rest, a DuPont always attending the service. St. Joe's-the Irish get on such intimate terms with their saints-was a great center and red-faced, jovial Father Kelly a countryside personage. When youthful Down-the-Creekers encountered him, Alfred would raise his cap respectfully with the rest. 
Francis Gurney duPont, who had succeeded Alfred's father as superintendent of the yards, kept a narrative record of explosions compiled from his own experiences and from those of other survivors. By interviewing old workingmen he gathered as much data as possible on disasters prior to his own time, going back as far as 1815. To the year 1880 this record, admittedly incomplete in its earlier parts, mentions 54 accidents in which 154 persons lost their lives.

The firm of DuPont provided more than spiritual comfort for the hazards endured by their laborers. It provided a degree of economic security rare for the times, antedating by ninety years the earliest workmen's compensation law in the United States. A DuPont job was not only lifetime employment for the reasonably faithful; it was a legacy to be handed down. Examples of three generations of a family in DuPont employ could be found in 188 o. The maimed and sometimes the superannuated were kept on the pay roll at easy tasks. A family bereft of the sole breadwinner was taken care of according to its needs: there was always a house; possibly a pension of ten dollars a month for the widow; possibly milk from a DuPont cow and vegetables from a DuPont garden; always work for the boys as soon as they grew old enough. Powdermen's daughters might find employment in the DuPont households, and there were powdermen's sons galore among whom to take husbands. Hanna Deery, the chambermaid at Swamp Hall, was the daughter of a Hagley Yard foreman.

\section{3}

Such was the community, closely knit after the fashion of the family which had brought it into being, that the boy Alfred knew inside and out. From the days when Emma used to starve him he had eaten snacks in powdermen's kitchens. In the shops attached to the yards he learned to develop his manual skill and his dexterity with tools watching the machinists, wheelwrights, millwrights, blacksmiths and metalworkers. A number of these were superior men who, afforded the opportunities for technical educations common a generation later, might have left their marks as engineers. 
Alfred looked up to these craftsmen. He learned much from them and never wearied of hearing their personal histories.

Pierre Gentieu had many a good tale to tell. Born in France, he had emigrated to New Orleans as a youth in 1860 , and for companionship joined a militia company. When Louisiana seceded, the company commander drew a line on the floor and asked those who did not care to follow the State out of the Union to step across it. Pierre alone stepped across. Making his way North, he joined a Federal artillery regiment which happened to be commanded by Henry Algernon duPont.

In Alfred's boyhood Pierre Gentieu was the foremost amateur photographer on the Brandywine, and for twenty years the only person allowed in the yards with a camera. Alfred used to follow Gentieu around and eventually he acquired for himself a secondhand camera. A darkroom was established in the basement of Swamp Hall where Alfred did his developing and printing, his fingers seldom free from acid stains. Later on, when about nineteen, Alfred designed and, with Gilly Mathewson, made a camera which took excellent photographs on plates about eight by ten inches in size.

It is possible that Alfred remembered Jonas Miller, who was killed in 1873 , leaving grandchildren about Alfred's age. Certain it is that the ears-open boy heard much of this remarkable foreman under whom half a dozen DuPonts served their apprenticeships in the yards. Whenever two powdermen fell to reminiscing sooner or later something would come out concerning Jonas Miller. Francis G. duPont's manuscript tells of Miller's first day's work for the company. It was March 19, 1818. With his possessions in a parcel, the lad had set out to seek his fortune and was standing on the east bank of the Brandywine looking across at the powder works when three gentlemen arrived in a carriage. One of their number signaled to the DuPonts' private ferry and seeing young Miller offered him a place on the boat. In the middle of the Brandywine a rush of air nearly knocked the four passengers overboard. Then came an orange-colored flash and a mighty roar. Other flashes and roars followed, one after another, as every mill in the Upper Yard blew up. 
Landing amid an inferno of destruction, the boat passengers fell to with axes, liberating from the debris the injured and the bodies of the dead. Jonas Miller's traveling companions turned out to be Victor duPont, the Marquis de Grouchy, late Marshal of Napoleon Bonaparte, and Grouchy's son. Exiles since Waterloo, the Frenchmen were passing through Wilmington where Victor had gone to fetch them to his home for a visit. Thirty-four were killed in that explosion. Many of the bodies were never reassembled, bits of them being thrown as far as the flower gardens surrounding the DuPont residences on the bluff.

Alfred had had his hair cut at Mick the Barber's in Long Row on the Creek Road-an excellent place to absorb the folklore of the yards. Mick (Michael Dougherty) worked part time as a powderman, part time as a barber, and he had a standing arrangement for laying out the dead at company expense, a task which sometimes called for a considerable knowledge of anatomy. ${ }^{3}$ Of this work Mick had not had as much to do as formerly, for the number and the seriousness of explosions were being reduced. In the summer of 1876 when Alfred was twelve, a press room at Hagley blew, killing the crew of three and a rolling-mill man who was unloading a charge for the next run. In January, '77, one man was killed while Alfred was absent at school. After that there was no fatal accident for six and a half years.

It was often difficult to determine the cause of an explosion, the evidence and the witnesses having been destroyed. But the DuPonts, particularly Lammot and Francis G., worked on the problem with encouraging results. The tires of a cart backed against the masonry of a glazing mill struck the spark that set off one blast. Metal, such as an old nail, in the mixture at the wheel mills was a constant menace. Other common dangers were the careless handling of tools and the failure to sweep a mill clean before carpenters or masons came to make repairs. One man was supposed to have deliberately blown a mill to commit suicide. Another was discharged on the suspicion of having blown a mill to settle a grudge with two men who were working in it. The two escaped injury. ${ }^{4}$

At Mick the Barber's Alfred heard speculations that carried 
matters beyond the researches of Lammot and Francis G., into the sphere of the supernatural. For two generations the story had been told of the night crew which had come off watch with the tale of a warning apparition: two young girls dressed in flowing white, tripping among the boulders in the Brandywine. Next night the mill blew, killing nine. More recent was the warning vouchsafed Mickey Mullin. Mickey had received a letter from his mother in the Old Country, begging him to return before she died. Pondering the matter, Mickey had returned from work one morning and said to Mrs. Pierre Boissou, widow of a powderman with whom he boarded: "You know, last night I heard me mother cryin'." "Where?" asked the landlady. "Out on the rocks," said Mickey. "It was only an owl," said Mrs. Boissou. "Just the same," said Mickey, "I'm going to Ireland soon." That night his rolling mill blew and Mickey went "across the Crick" instead."

"Across the Crick" was a powderman's euphemism for Kingdom Come. Three sides of a DuPont mill were constructed of granite, one side and the roof of wood. The roof and the wooden wall opposed trivial resistance to the force of an explosion, giving it an easy exit and often leaving the stone walls standing. This facilitated the task of reconstruction. The wooden sides faced the Brandywine and so were blown, along with the human victims, across the stream. In Alfred's boyhood the scarred trunk of a tree on the east bank marked the place where the bones of a rolling-mill hand had been chopped out for reburial at St. Joe's.

Young Alfred was irresistibly drawn to those powder yards and to the mystery-breeding danger of them which had done so much to isolate from the rest of the world the proprietary family and the community in its employ. Fred and Bidermann duPont had gone to Kentucky in 1854 because the firm was too closed a corporationtoo few parternerships available for the number of DuPonts on hand. The success of their ventures there was attracting other members of the family to Louisville where Fred duPont strove to make a young man's path to fortune easy whereas on the Brandywine 


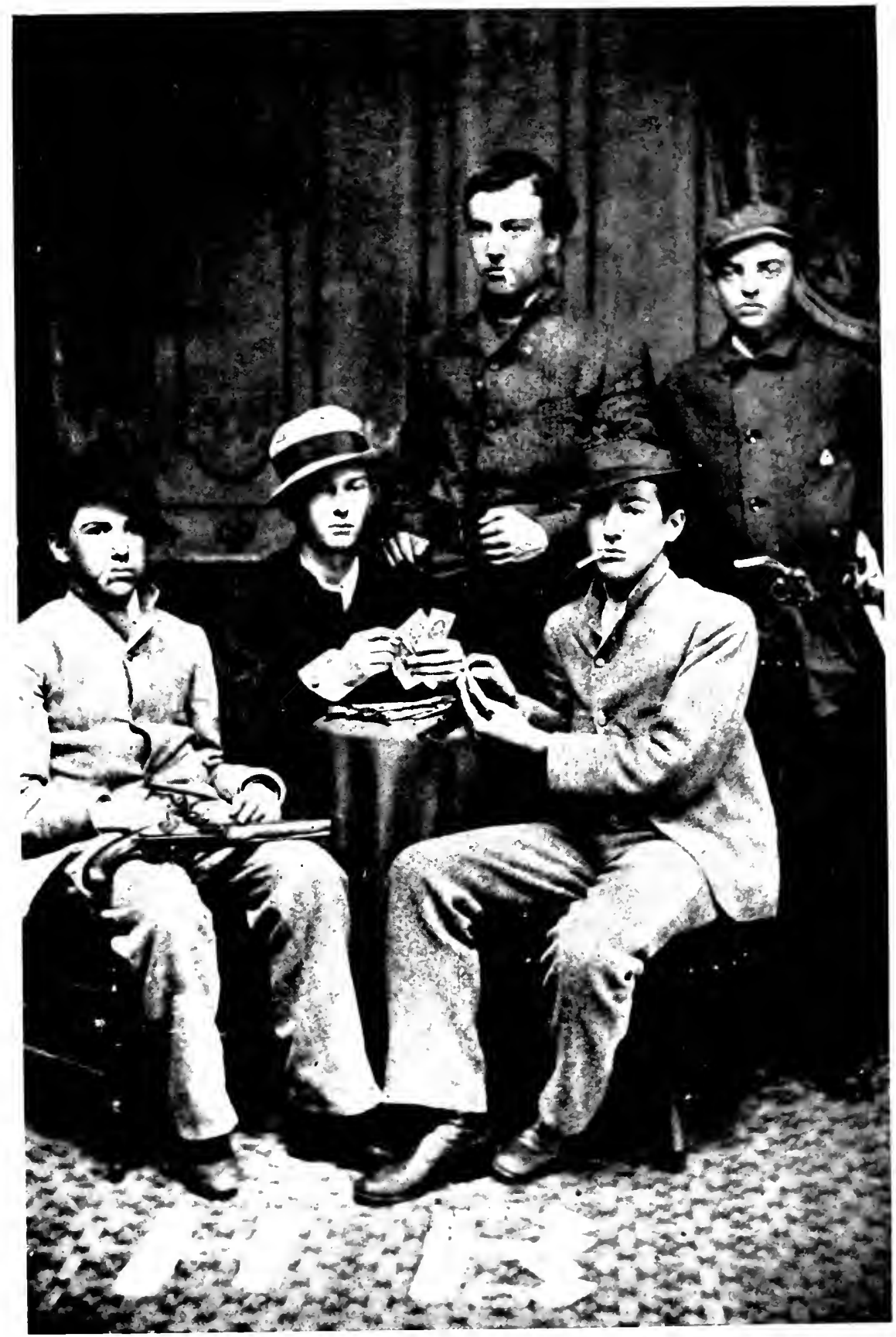

Five Tough Customers

Alfred I. duPont (standing, left) and his brothers, Louis (seated, left), and Maurice (seated, right) with two other nembers of a secret and sinister socicty known as the Holy brotherhool. Note the initials made with playing cards in the foreground. This photo-

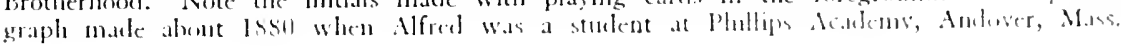


$=$ 
Henry duPont seemed to strive to make it hard. Bountiful opportunities in the West were Alfred's for the asking as the holdings of Uncle Fred spread from paper manufacturing into street railways and thence into coal mines. Had Alfred's success at English composition, which brought him good marks in school, imparted a yearning for journalism, Uncle Fred could have placed him under no less a master than Henry Watterson of the Louisville CourierJournal. Fred duPont held Marse Henry's notes and did not press for payment.

When he thought of the future, Alfred was satisfied to take the hard way, not because it was hard, but because he felt a kinship with the banks of the Brandywine that he felt with no place else. In later years Alfred told the story of a talk he had had with his father on his deathbed.

"Son," Eleuthère Irénée had said, "I am not going to be with you long. I doubt if your mother will. [The dying man did not know that the boy's mother was already dead.] You must get an education and then come back, take off your coat and go ask your Uncle Henry for a job. I think the old company may need you sometime. I just have that feeling."

It seems a reasonable surmise that the disquieting feeling was caused by the supremely autocratic precedent of rule set by old Henry which in the hands of a weaker man might invite disaster.

At eighteen, had Alfred felt himself free to choose a career apart from the powder yards he would have chosen music. By then the violin was his favorite instrument, and he had made some attempts at musical composition. But he played any instrument, string or wind. He could pick up a powderman's banjo and twang out a jig or a reel that would set Irish feet tapping. He attended the workingmen's hilarious dances, usually taking a place with his fiddle in the little band of musicians.

Something more than an aptitude for mechanics and for chemistry directed Alfred's destiny toward the yards. Something more than boyish impertinence had guided the hand that had chalked on Papa Merrill's blackboard: "Alfred Irénée duPont de Nemours." In the last years of his life, with many illusions concerning family and firm gone forever, Alfred I. duPont said in response to a ques- 
tion touching the almost incredible latter-day success of the company: "A lot of blood is down the line."7

At eighteen everything on the Brandywine conspired to strengthen the dynastic feeling in Alfred: the teeming yards; the family councils; the ritual of New Year's Day visits; his father's deathbed admonition; the ancestral tombs in Sand Hole WoodsDuPonts in life and in death. After a career in Europe that had taken him into the presence of kings, Pierre Samuel duPont de Nemours had gone to his grave, at seventy-seven, from overexertion fighting a fire in the powder works. Young Alfred Irénée was the eldest son of the eldest son of the eldest son of the founder of those works. Prime considerations, these, for an imaginative boy struggling with the yeasty turmoils of a creative spirit. At times Alfred was convulsed with religious emotion. He would put his whole being into the responses he made in Christ Church on Sunday. ${ }^{8}$

Changes were coming faster, childish things left behind. In I88 $\mathrm{I}$ the first of the five orphans quit the home nest. At eighteen lively Marguerite was married to Cazenove G. Lee, a Virginia-born lawyer, practicing in Washington. The bride and the groom were third cousins on Marguerite's mother's side, and he a Lee of the family which had produced Richard Henry, Lighthorse Harry and Robert E. Seventeen-year-old Alfred made a grand thing of his sister's wedding. At Christ Church he gave the bride away and that evening donned his first suit of dress clothes for the reception at Swamp Hall.

In the spring of $\mathrm{I} 882$ the boy finished his studies at Phillips Academy and that fall he entered the Massachusetts Institute of Technology.

\section{5}

Though more compact, M.I.T. was as utilitarian as the Brandywine Yards and about as attractive to the aesthetic eye. One shabby building in Boylston Street, a block from the Public Gardens, housed the classrooms and the laboratories. A low annex contained the clanging shops. In Essex Street, three blocks toward Back Bay, stood the gymnasium on whose floor were held the military drills 
compulsory for the budding engineers. The busy life of Boston flowed all around. Just emerging from a somber struggle to avert bankruptcy, with no campus, no dormitories and little organized college folderol, Tech constituted an educational institution differing materially from that which clustered about Harvard Yard across the Charles River. Of the 368 students only thirty-odd belonged to Greek-letter fraternities. By joining the Sigma Chi, Alfred became one of this gay minority. In his second year he helped to organize the school's first orchestra.

Confronting the sterner aspect of life at Tech, Alfred brushed aside the regular curriculum and matriculated as a special student. This permitted latitude in the choice of subjects, for which he forfeited the hope of obtaining a degree. In his first semester Alfred took mathematics, chemistry, mechanical drawing, German and forging. The student could read French. German was probably continued to enable him to use the excellent scientific books issued in that language. In the second semester, however, he dropped everything except chemistry and shop work, to which lathe and pattern work were added. Fifty years later an officer of the Institute, looking over Alfred's selection of subjects, called it the mark of a man who knew "what he wanted to do and did it."

A suspicion of the infallible wisdom of hindsight colors this estimate. At the time Alfred did not impress his classmates as a serious student bent on realizing the most of his potentialities. A constitutional indifference to marks and a similar desire to have a good time do not afford the best foundation for a shining academic record, and Alfred did not shine. Except in shop he seldom ranked above the middle of a class.

In his cousin Coleman, Alfred had a roommate who was no deterrent to the enjoyment of the lighter side of Boston life. Coly duPont was spending his second year at M.I.T. He knew the town. Knowing Boston, in an undergraduate sense, required money. With an indulgent father at the end of the supplying line, Coly had Alfred at a disadvantage in this respect. Uncle Fred doled out an allowance of $\$ 30$ a month, deaf to his ward's appeals for a raise. The first snowfall remedied this situation, however. Alfred could make $\$ 3$ a day cleaning sidewalks and still put in an appear- 
ance at classes. A little later he was able to earn his spending money more congenially by playing in a theater orchestra.

This opened to exploration the enchanting world that dwells behind the footlights. It captivated Alfred's imagination to such a degree that he would pay for the privilege of "suping" during the grand opera season at the Boston Theater. Still, he kept his bearings sufficiently to resent the hauteur with which some of the stars regarded the supers. Once while helping to carry a supercilious tenor about the stage in a sedan chair Alfred "accidentally" tripped, spilling the star from his seat. ${ }^{10}$

Alfred bridged the gap which separated the home of grand opera from the home of burlesque, and at Howard's Atheneum made the acquaintance of John L. Sullivan. The champion pugilist was in the first flush of his heyday as a national idol. He had restored to Boston a prestige equal in popular eyes to that of the days of Emerson and of Lowell. Returning from his victorious title bout with Paddy Ryan, the homecoming hero was accorded a reception at the Dudley Street Opera House which evoked comparisons with that given Daniel Webster after the debate with Hayne. Already a legendary figure, John L. was followed wherever he went by luminaries of the sporting world, the underworld, and by politicians big and little. Nightly he appeared at Howard's Atheneum which had posted $\$$ Iooo in cash, available to anyone who could stay four rounds with the champion.

Although he gave a good account of himself with the gloves at Tech's gymnasium, Alfred did not try for the $\$$ rooo. He was content to cultivate the champion's spacious social side. There was no dearth of contenders for the prize money, however. One came all the way from New Zealand and lasted three rounds. Though he tore into an opponent like a man avenging a personal grievance, Sullivan could be magnanimous in victory. He would lift a comatose adversary from the floor and invite him out to have a drink. Trailed by a whooping crowd, the fighters would pile into a barroom, Sullivan roaring:

"I can lick any man in this place. John L. Sullivan, that's me."

No takers appearing, the champion would offer to drink twice as much whisky as any person present, the loser to pay for the refreshment. ${ }^{11}$ 
In return for the patrons he could bring in, Sullivan was given a partnership in a saloon on Washington Street, not far from M.I.T. Alfred won the champion's esteem, however, without trying to drink him under the table, which was about as hard to do as to knock him under. The fact is that the young man's only tipple was beer, a rather surprising circumstance considering the company he kept and his headlong enthusiasm for life generally. Possibly the basis of the friendship was a discerning appeal to the prize fighter's appreciation of higher learning. In a day when most pugilists could little more than sign their names, Sullivan was proud of the week or so he had spent at Boston College in pursuance of a brief parental hope that John might ornament the priesthood. The champion liked to punctuate his conversation with sesquipedalian words, often correctly used.

Whatever it was that brought them together, Alfred had quickly become an undisputed favorite of the great man. Blond, good-looking and sober, the student would puff a formidable cigar and sun himself in the reflected glory of the roistering champion, grandly introducing his schoolmates. Presentation of the sophisticated Coleman, who so shortly before had indulgently regarded his Brandywine cousin as an untutored rustic, must have been a source of particular satisfaction.

During the summer Alfred visited his roommate in Kentucky and seems to have been absent from the Brandywine when an Upper Yard press room blew up, killing Powdermen Patrick Haley and Thomas Pearl, whom Alfred knew well, and breaking every window in the residences of Boss Henry and of Eugene duPont.

In Louisville Alfred found much to interest him in the shops in which repairs were made to Uncle Fred's horsecars. The shops stood on the bank of the Ohio River which furnished the motive power. Adjoining was Fred duPont's sparingly furnished office. One warm day Alfred asked Uncle Fred why he did not make himself comfortable with a mechanical fan. The old bachelor was horrified.

"Too much money," he said. 
Fred duPont had first attracted favorable public notice to his streetcars by the sleek appearance of the horses in a day when most horsecar animals were bags of bones. But he counted every penny spent on himself.

Alfred told his uncle to give him the run of the machine shop and he would install a mechanical fan without the expenditure of a cent.

Fred duPont pulled at his thin chin beard. "Young fellow, you're going to get me into money."

But Alfred won his point and at a lathe turned out a woodenbladed fan and made all the gear necessary to transmitting power to Uncle Fred's office. The fan worked first-rate.

"Alfred," said the boy's guardian, enjoying the breeze, "you've got some sense. This is the first time I ever knew a man to eat his cake and have it, too."12

Meanwhile an epochal thing had happened on the Brandywine. For the first time in his life Great-Uncle Henry was demonstrated to have made a serious error of judgment.

In 1862 the Swedish chemist Alfred Nobel had put to practical use an explosive called nitroglycerin, which was many times more powerful than powder. Henry duPont had made light of "blasting oil," as he dubbed the new product, calling it too dangerous to handle. News of an explosion in California confirmed him in this view. "We think that will be the end of Nitro-Glycerin in this continent," he wrote. He seemed borne out when Nobel's own plant in Sweden blew up, and Belgium and England forbade the importation of nitroglycerin. A few months later Nobel introduced nitroglycerin in an altered form called "dynamite." Mr. Henry still scoffed. Dynamite, said he, would suffer the fate of its predecessor. He campaigned against the product which several companies had begun to manufacture somewhat crudely in this country, warning the Pennsylvania Railroad against its transportation. ${ }^{13}$

Lammot duPont approached the situation with a more open mind. Lammot was the inventor of "soda powder," in which soda was substituted for the much more expensive saltpeter. This product had revolutionized the blasting-powder business. Its originator was not so sure that ultimately dynamite might not bring 


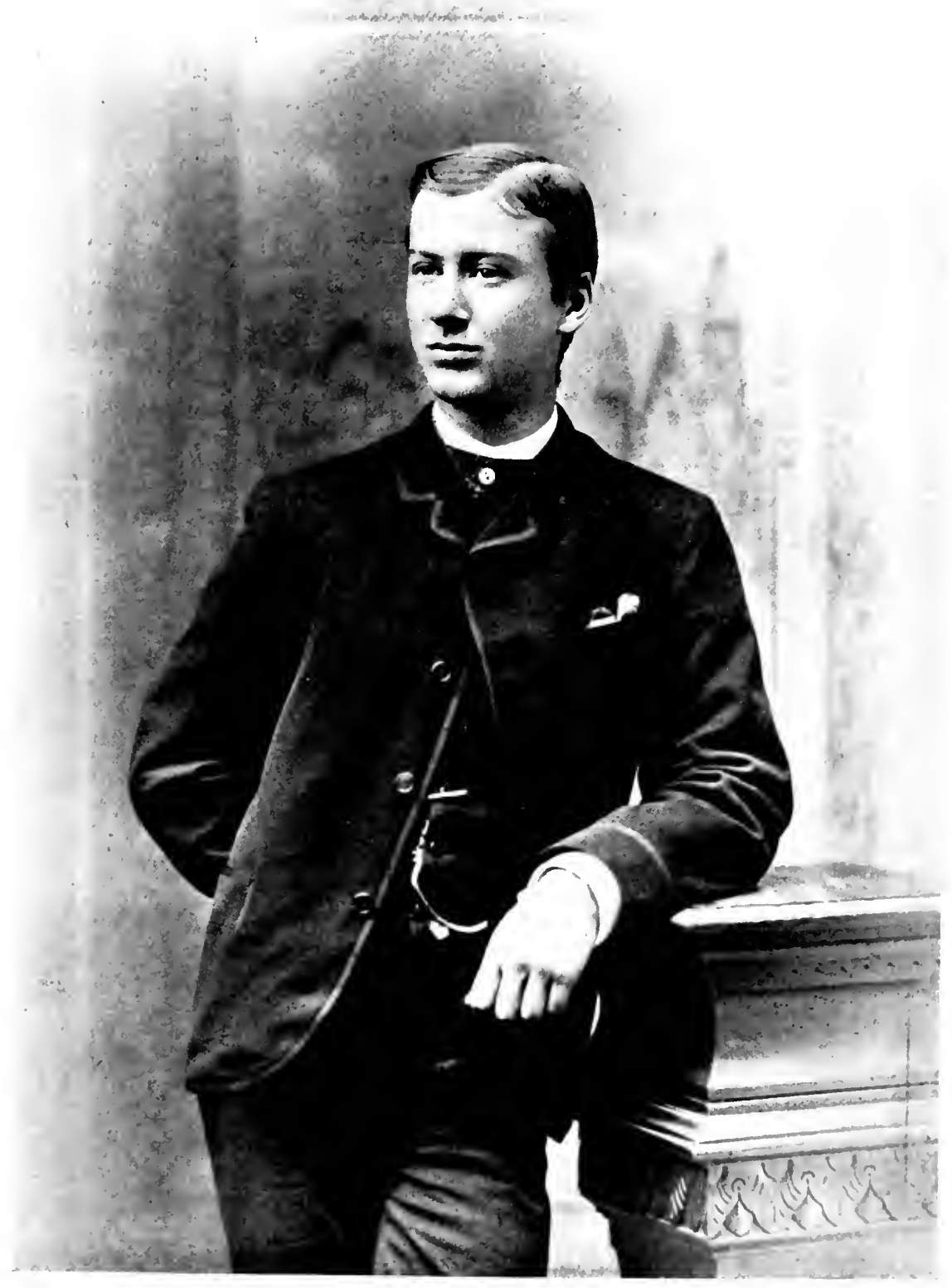

Alfred I. duPont at 18

Taken about the time of his graduation from Phillips Academy in 1882. Ilis chicf interests were music, machinery, athletics and English composition. 
$$
=
$$ 
changes just as great. He began to experiment with the product his superior would have none of. Convinced of its advantages over powder in many blasting operations, and of the possibility of rendering it safe for use, he urged his uncle to add dynamite to his line of explosives. Henry duPont refused, and at length the quiet Lammot announced his intention to withdraw from the firm and make dynamite on his own. This and the pressure of younger partners, notably old Henry's son William, brought the head of the firm around. He capitulated to the extent of taking a third interest in Lammot's venture which started business under the name of the Repauno Chemical Company with a plant on the New Jersey bank of the Delaware, about mid-distance between Wilmington and Philadelphia. Lammot would have preferred it nearer home, but Henry said that would be too dangerous.

Repauno began operation in 1880 . In a year it was an assured success. In 1883 its success was so great that Henry consented to purchase, in the firm's name, an additional third interest in Repauno. The shares were bought from Lammot personally. Lammot's courage in opposing the will of his uncle had made him the richest of DuPonts, saving only Uncle Henry himself. The important thing, however, was that he had placed the old firm in a commanding position in the vigorous and growing high-explosives industry, without which old Henry most likely would have been defeated in his grim aspiration to maintain the whip hand over the explosive business in America.

In 1883 Alfred returned alone to Boston, Coleman dropping out of school to take a job in a Kentucky soft-coal mine owned by his father and uncle. Alfred signed up for a light schedule-German, chemistry and shop-but increased his outside activities which, owing to the lack of official sponsorship, were largely a matter of individual preference and initiative. Alfred often visited at neighboring Wellesley College his mother's cousin, Mrs. Paulina Durant, who with her husband had founded that school for young women which Alfred's sister Marguerite had attended for a year. 
He saw more, however, of John L. Sullivan. The champion had married Annie Bates, a chorus girl, thus providing Alfred with his first intimate view of tempestuous domestic waters. Instead of settling him down, matrimony seemed to have the opposite effect on John. He "trained" on whiskey, answering Annie's remonstrances with a caress which sometimes took the form of an uppercut. Annie would watch her chance to even the rounds. One night Alfred and the newlyweds were sitting in the Sullivan apartment, the champ rather the worse for wear. From across the room Annie aimed a beer bottle at her husband's head and let it fly. Her aim was so good that, if Alfred had not caught the bottle, John L. Sullivan might have experienced his first knockout nine years before Gentleman Jim Corbett came along.

In and out of the Sullivan family circle, young duPont absorbed so many pointers on boxing that opponents became hard to find at M.I.T.'s gymnasium. Thereupon, according to an attractive tradition surviving in the DuPont family and among some of Alfred's contemporaries at Tech, the student sought stiffer competition. The fact that Uncle Fred had not increased the $\$ 30$ allowance may also have had something to do with it. In any event much of the boxing of the day was done in rings roped off in the rears of low saloons and dance halls. These were about the only places an obscure beginner could find an opportunity to show his talents or a thirdrate veteran to keep in meal tickets. Purses ran from $\$_{3}$ to $\$$ ro, the winner usually taking all.

Under John L.'s coaching, and an assumed name, Alfred I. duPont is supposed to have made a few such professional appearances. ${ }^{14}$

On March 30, 1884, headlines in the Boston newspapers brought the carefree student to earth. A terrific explosion at the works of the Repauno Chemical Company had killed Lammot duPont and five others. Lammot perished in the preservation of the DuPont tradition that in an emergency the post of greatest danger goes to a member of the family. Among the dross from the manufacture of nitroglycerin were certain acids which polluted the waters of the Delaware, bringing complaints from the shad fishermen. To save the fish, and also the acids with the possibility of their commercial 
use in view, Lammot had conducted laboratory experiments by which the spent acids could be separated from the nitroglycerin and saved. For the first time the experiment was being conducted on a manufacturing scale when something went wrong. Lammot hastened to the nitroglycerin house. Finding the situation critical, he ordered all others away. Next moment the blast came. ${ }^{15}$

Lammot duPont left a widow and nine children of whom Pierre S., twelve, was the oldest son. Fred duPont of Louisville assumed the guardianship of this brood. With three Swamp Hall minors still in his charge, this raised the number of the bachelor's wards to an even dozen.

As a child Alfred and all the Swamp Hall children had loved "Uncle Big Man" as they called the kindly Lammot. Growing older, Alfred had come to regard Lammot as the ablest DuPont of his generation, clearly perceiving what he had done by prodding Great-Uncle Henry into the manufacture of dynamite. Six weeks after Lammot's death Alfred threw up M.I.T., his school days over. Any connection between these events is conjectural but the fact remains that Alfred believed the firm bereft of its most distinguished intelligence. In this circumstance it would seem out of character with the impetuous self-confidence of a gifted youth, who knew himself to be gifted beyond any sign visible to others, not to have recalled, as he often did in the years to come, the prophecy of his father: "The old company may need you sometime."

Though Alfred chucked school about the time of his twentieth birthday in May, 1884 , he did not enter the employ of the company until the succeeding autumn. Possibly Great-Uncle Henry, who was given to that sort of thing, wished the young man to take time for his impulses to cool; or, just as likely, the delay was Alfred's own doing. For he had become interested to the point of obsession in electricity.

It is hard to say whether this interest was a result of Alfred's somewhat light-hearted career at Tech. The chances are it was not. A primitive course in electrical en ineering-hardly at that junc- 
ture a teachable profession-had been introduced at M.I.T. in 1882, when Alfred enrolled. Alfred did not take it. Any formal instruction in electricity he may have obtained as a part of his schoolwork must have been in his second year shop courses. Yet, by the time he left Boston, he had progressed, especially in the science of incandescent lighting, beyond anything likely to have been taught in a school. Certainly for the most part, if not altogether, Alfred had taught himself.

One of the wonders which had thrilled twelve-year-old Alfred duPont on his visit to the Centennial Exhibition at Philadelphia in 1876 had been the electric arc lamp. A dazzling light was made by an electrical flame passing in the form of a bow or arc between two sticks of carbon. By 1884 the arc lamp was replacing gas for street lighting. A move was on foot to install a plant in Wilmington. The arc lamp was not suited for indoor illumination, however. The light was too bright, it gave off a hissing sound and the flame, burning in an open globe, fouled the air.

In 1879 after a year of intensive work, snatching sleep in his laboratory, Thomas A. Edison had produced an incandescent lamp, giving light from a superheated filament in the hermetically sealed glass bulb. Sixteen hundred experiments were conducted to determine the best substance for the filament, carbon being the final selection. Hard and long as he had worked on it, the invention of the incandescent lamp gave Edison only a link, though a vital link, in his system of indoor electric lighting. Something could be learned from arc lighting, though not as much as a layman might suppose. A new type of generator had to be invented, a new system of distribution devised for carrying current long distances without danger and without wastage. A control had to be set up to prevent the first lamp on the line from absorbing more than its share of the current and burning too brightly while others burned too dimly. Switches, lamp-sockets, service boxes, fuses and other devices for wiring houses had to be invented.

In less than three years this work was done and on September 4, 1882, Edison opened his Pearl Street electrical station in New York, which lighted a number of near-by business houses, with no charge for service. The experiment was successful. The superiority to gas- 


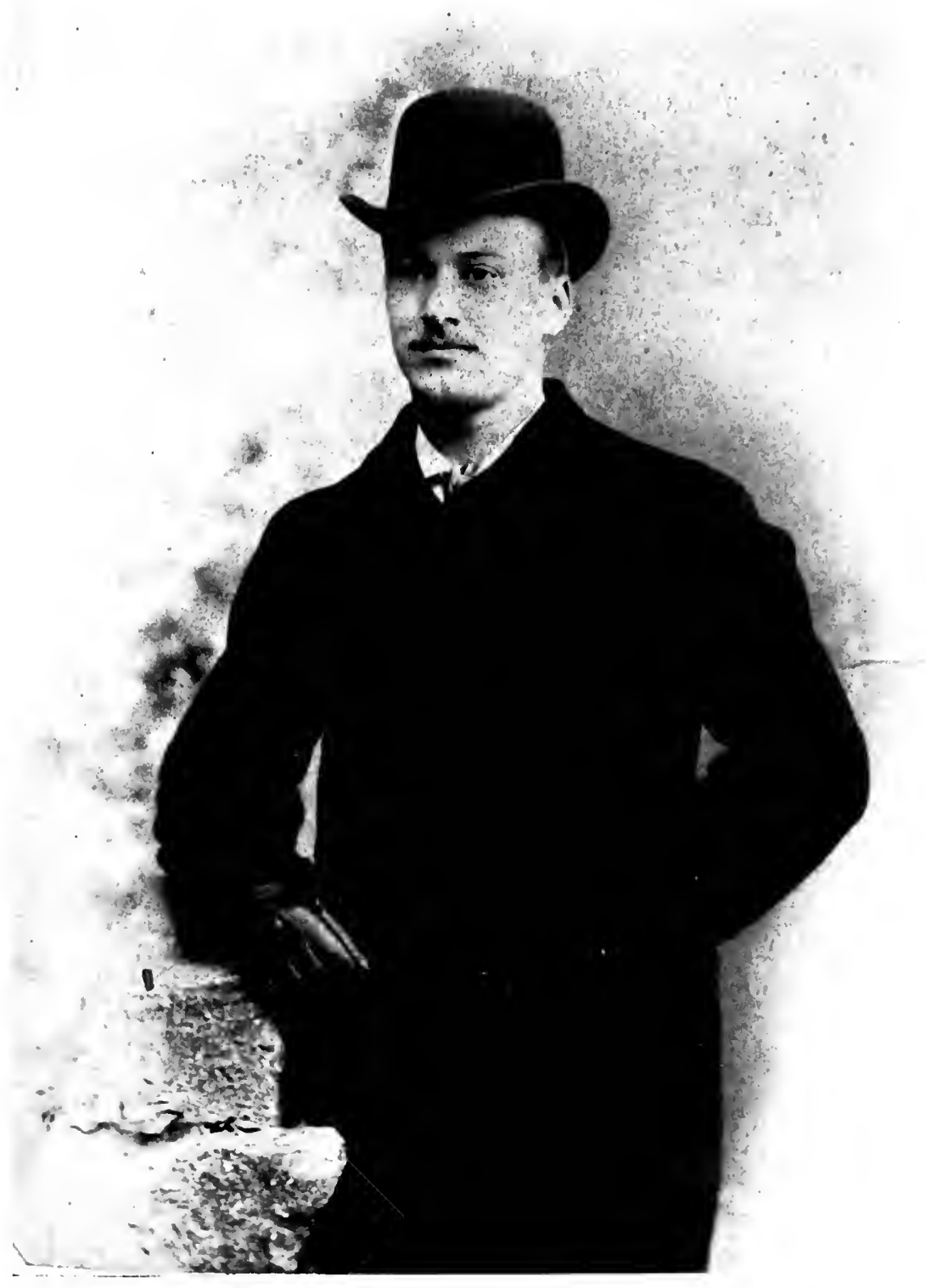

\section{Student at Massachusetts Institute of Technology}

To picce out his allowance of thirty dollars a month, Alfred duPont played in a theater orchestra and, using an assumed name, is supposed to have fought a few professional prize fights under the tutelage of John L. Sullivan. Academically his standing at M.I.T. was only fair and he left there in 1884 without a diploma to work in the powder yards. 
$=$ 
lighting was demonstrated. Within three months Edison was lighting 193 buildings. In January, I883, he began sending out bills for current. On his trips through New York Alfred had visited the Pearl Street station and was fascinated by it. In December, I882, the first electric lights in Boston were introduced in the Bijou Theater-incidentally the first playhouse in the world to be illuminated in the new way. The performance was Gilbert and Sullivan's lolanthe, and it would be difficult to say which Alfred had enjoyed more, for he was almost as much of an admirer of Gilbert and Sullivan's light operas as of Thomas A. Edison's lights.

Leaving school in May, 1884, Alfred stopped over in Philadelphia to explore an exhibition of incandescent lighting devices which included all the latest Edison and foreign apparatus. He bought a German-made Gerard dynamo, and a kerosene burning Shipman steam engine to run it. With the help of Gilly and Frank Mathewson, dynamo and engine were set up in a building on the Swamp Hall grounds formerly used as an icehouse. Alfred began to teach the Mathewson brothers what he knew about incandescent lighting. They were apt pupils. Soon the three experimenters had a string of about twenty lights going in the icehouse.

The nearest place electrical equipment could be purchased was Queen's, an engineers' supply house on Chestnut Street in Philadelphia. One day Mr. Richardson, who had charge of the electrical department at Queen's, introduced Alfred to Thomas A. Edison. Surprised at the young man's knowledge of electricity and by the torrent of intelligent questions he asked, the inventor invited duPont to visit the Edison laboratory at Menlo Park, New Jersey. The invitation was a great compliment and a priceless opportunity. Alfred made several trips to Menlo Park during the summer, each time bringing back a batch of ideas to work on with the Mathewsons. One of these resulted in an electric rattrap which was entirely successful. ${ }^{16}$ 



\title{
PART TWO
}

\author{
Powder Maker
}





\section{CHAPTER IV}

\section{Breaking in on the Powder Line}

I

Alfred duPont Lecarpentier was the son of a powderman, one of the old French strain, who had admired his employer. Entering the office of the firm as a boy, Lecarpentier, fils, had risen to the multiple responsibilities of stock clerk, shipping clerk, paymaster and cashier. Standing before his high desk he inscribed a new name on the pay roll for October, $188_{4}$ :

"DuPont, Alfred I., $\$ 83 . " 1$

The earning of that wage cut drastically into the time available to Alfred for his electrical hobby. At six-fifty o'clock in the morning, he reported in overalls at the lower gate of Hagley Yard. Perhaps at first he jokingly showed his worker's pass, though this would hardly have been necessary, for it must have been all over the yards that another DuPont, young Mr. Alfred this time, was breaking in. Powder-yard gatekeepers were men who had been unfitted by injuries or by age for harder work. They did not often call for passes. A DuPont man's face was usually his pass.

At seven Alfred took a team from the Big Stables and, riding one of the horses, guided it down the hill to the car shed on a spur of the narrow-gauge railroad track. Hitching the team to a car, he piloted it along the siding to the packing house. There he helped the packing-house men load the car with three thousand pounds of powder in kegs. This load he hauled to the magazine, for safety's sake isolated at the upper end of the Upper Yard a mile and a half away.

Then setting the proper switches, he conducted his empty car to the soda house for a load to carry to the refinery. There he helped to unload the soda and to take on a load of saltpeter. Shuttling 
back on the "main" line of the narrow-gauge track, Alfred carried the saltpeter down to Hagley and distributed it among the rolling mills. All this time Alfred's had been only one of a number of horsecars coming and going over the maze of tracks which threaded the busy yards.

The saltpeter disposed of, he might be called on to repeat the trip to the Upper Yard, this time to bring down soda, sulphur or charcoal to the composition house-and that was a dirty job, handling sulphur and charcoal. Or it might be his car's turn to carry a charge of unfinished powder from a graining mill to a glazing mill, or from a glazing mill to the packing house.

At noon Alfred fed his team, ate his dinner from a pail with a group of other laborers and stretched out for a rest. After ten hours' work the day shift knocked off at six. Alfred returned his team to the stables, rode his bicycle home and changed his clothes for supper.

Not all the cars on the DuPonts' miniature railroad were drawn by horses. Some were pushed by gangs of four to six men. Alfred got his turn with the push cars. This was harder work and it had to do with stages of the powder-making process which horsecar work skipped. The push cars were smaller than the horsecars, carrying only a ton for a full load. They transported "black dust" and soda from the composition houses to the rolling mills; carried the finished charges from the rolling mills to the press rooms; carried the broken "presscake" from the press rooms to the graining mills.

Work on the horse and the push cars took a man to every corner of the yards, and put him in touch with every step in the fabrication of powder. Having observed them from childhood, Alfred had been somewhat familiar with those steps before he went on the pay roll. But this was the way a laborer in the yards was broken in, and the way a DuPont who aspired to take his place in the company was broken in. On duty Alfred was as liable as any workman to the orders of the foremen. The only difference was that they addressed him as "Mr. Alfred." All DuPonts were addressed by their first names prefixed by "Mister." "Mr. duPont" would not have done because there were so many of them. Foremen had a way of hazing beginners a little. Old powdermen still chuckle when they 
tell of the time Mr. Alfred showed up too sprucely dressed to suit one of the foremen. He sent Alfred to relieve a man in the 'coal house, where wood was burned to charcoal. At the end of the shift Alfred looked like a Negro. ${ }^{2}$

Only on paydays was a distinction apparent between Alfred and the other common laborers. Some months Alfred drew $\$ 83$ and some months $\$ 84$, so as to round out $\$ 1000$ a year without going into odd cents. This was slightly more than two and one-half times the $\$ 34$ a month which other unskilled hands received. Powdermen drew $\$ 40$ a month; teamsters $\$ 42$; millwrights, wheelwrights and mechanics $\$ 45$ to $\$ 60$; powder foremen $\$ 60$; boss millwrights, wheelwrights and mechanics $\$ 90,{ }^{3}$ in addition to houses for all the married men.

Alfred alternated between the day and the night shifts and, in the fullness of time, Cousin Frank promoted him to apprentice powderman, with no increase in pay. Cousin Frank was Francis G. duPont, the superintendent of the Hagley and the Lower Yards. As an apprentice powderman Alfred worked by turn at every step in the conversion of the raw materials into the finished product. These ingredients were few and simple: sulphur, charcoal and saltpeter or soda. Soda powder, invented by Lammot duPont, though used only for blasting, was the firm's biggest money-maker, the demand for it exceeding the demand for all other powders by four to one. Hagley, the biggest of the yards, made soda powder almost exclusively. Sporting and military powders were made with saltpeter which was much more costly than soda.

The primary steps in manufacture had to do with the preparation of materials. Saltpeter was produced at the refinery by boiling soda and potash, charcoal at the 'coal house by carbonizing wood. Willow was used for sporting and military powders, almost any other wood for blasting or soda powder. The 'coal house and the refinery, requiring open fires, were situated far up the bank in the Upper Yard, a proper distance from anything a spark from a stack might explode. 
Next came the preparation of black dust at the composition house by grinding and-mixing in fixed proportions charcoal and sulphur. Except during very high or low stages of the creek, the composition house and all other mills with moving machinery were run by water power. Paralleling the Brandywine flowed a race, with sides of masonry, from which flumes carried the current to the water wheels. By means of shafting, set on piers about three feet above the ground, one water wheel might supply power to a number of mills. The grinding of the gears where this shafting changed direction was the loudest and most persistent sound in the yards. To avoid interruption of work during exceptionally high or low water, Francis G. duPont had prevailed on his Uncle Henry to install a steam plant in Hagley Yard. It was built far up on the side of the hill and operated only at the rare times when water power failed.

From the composition house Alfred was transferred to a rolling mill for the first dangerous operation in powder-making. In Hagley Yard were twenty rolling mills, each quite small so that should one blow the blast would be less liable to set off other mills. As additional safeguards the rolling mills were constructed on the very brink of the Brandywine, with their one frame side pointing across the creek like the muzzles of cannon. In a rolling mill saltpeter or soda, according to the kind of powder being "run," was added to the coarse black dust from the composition house. These ingredients were further pulverized and thoroughly mixed by two slowly revolving ten-ton iron wheels. The old name for a rolling mill was "wheel mill" and, when Alfred broke in, veterans still called it that.

A run of blasting powder required an hour, of gunpowder three to four hours. A spark struck by the mishandling of a tool, by a stray piece of metal in the mixture, or by a wheel scraping the bedplate meant an explosion. Powdermen entered a rolling mill only to start or to stop the machinery at the beginning or the end of a run, or to add water to the composition about once an hour. Thus rolling-mill work, though exacting, was not arduous. Crews spent their time while charges were being run in a rude clubhouse called 
the night shanty. There were bunks for those who wanted to sleep and benches for those content to gossip and chew tobacco. As they could not smoke in the yards most powdermen chewed tobacco. Though Alfred never chewed, he is said to have been the only DuPont to make a habit of sharing the bantering camaraderie of the night shanty.

After a tour of duty in the rolling mills, Alfred went to a press room. There the fine dust from the rolling mills was pressed into slabs about two feet square by one inch thick under a weight of three thousand pounds to the square inch. Next these slabs were broken by a cutting machine into pieces that looked like lumps of coal. This, too, was dangerous work, a press-room explosion being more serious that a rolling-mill blast because of the greater quantity of powder on hand. Consequently, as a protection to neighboring buildings press rooms were built into the side of the hill.

The broken presscake went to a graining mill there to be crushed between corrugated rollers into grains of desired sizes. In fiftypound bags the grains went to the glazing mills where they were emptied into glazing barrels and graphite added. Glazing barrels were revolving hollow cylinders. This process smoothed the grains, polished them and filled their pores with graphite. The operation took from eight to fourteen hours, and it was dangerous.

The finished powder then went to the packing house to be sealed in kegs, branded and stored in the magazine in the Upper Yard for shipment.

Alfred served in every class of mill in the yard, and at every job in every mill until first a foreman and then Cousin Frank had pronounced him a first-rate hand. Though a precise man, Francis duPont was no martinet. No mill of his had blown since July, I883, and he wanted to extend the record. Along with others, sometimes Alfred grumbled, though not very seriously for he knew the meaning of Cousin Frank's exactions. Moreover, he liked his work, took pride in the skill of his powder-grimed hands, and applied himself more diligently than ever he had in schools. After twenty-one months in overalls, he was promoted to assistant superintendent and his pay raised to $\$ 1500$ a year. ${ }^{4}$ 
From the date of his start in the yards at $\$ 83$ a month, Alfred had not been required to live on his wages. When the young man had left school Uncle Fred had raised the allowance from his patrimony from $\$ 30$ to $\$ 40$ a month, payable quarterly. Contrasted with college days this was a fancy income, and Alfred kept a daily record of its disbursement. The money went pretty fast and before the end of a month the young man was sometimes obliged to draw in advance on his salary. His principal extravagances were electrical equipment and tools, chemicals, and machinery necessary to the pursuit of his hobbies. On these things he spent much more than he did on clothes. Theater tickets were other frequent items. Expenditures for beer, cigars, and cigarettes were frankly recorded; also a loss of 87 cents to Louis at poker. This was the only entry suggesting involvement in a game of chance. Gambling had never interested Alfred. Six dollars and fifty-five cents covered a trip to Philadelphia with Annie to hear Adelina Patti, and again he laid out $\$ 6$ to buy his oldest sister flowers on her birthday. ${ }^{5}$

Celebrating his own twenty-first birthday on May 12, 1885, Alfred became a wealthy young man in his own right when Uncle Fred turned over his nephew's legacy. The exact amount seems unascertainable, though it must have been above $\$ 100,000$. In 1877 , when his father died, Alfred's share of the estate had been just under that figure. He did not disturb the investments his uncle had made for him.

But he began to use more of the income, and the pattern of his life expanded. The daily ledger, accounting for every dollar spent, was dropped. Though a bicycle remained his favorite means of getting about, Alfred acquired a smart-looking horse and gig which was more suitable for taking young ladies for rides on Sundays. Once when a girl cousin married, Alfred borrowed a patrol wagon from the Wilmington police, filled it with wedding guests and went charging up to the residence of the bride-to-be.

His love for the theater continued and he was a steady patron of the Wilmington Opera House. Sometimes he took a girl, some- 
times a party of fellow-workmen from the yards. Often he went alone. He journeyed to Philadelphia to hear the Symphony Orchestra and to New York for plays and prize fights, keeping in touch with John L. Sullivan and through him extending his acquaintance in Marquis-of-Queensbury circles. The familiarity gained in Boston with the attractive world backstage was kept green. After a performance, he might frequently go behind the curtains to congratulate a player he knew and to invite some of the company to supper-a thing he would have liked to do in Boston but could not afford on his allowance.

Supper with the theatrical crowd in Union Square might last until dawn, which would give Alfred a chance, before turning in, to visit Edison's lighting station in Pearl Street. This was still a rendezvous for the curious, for scientific dabblers and for serious students of electricity. It had grown. Eleven Jumbo dynamos were in operation and Edison's underground wires were spreading over lower Manhattan. Smart people were putting electric lights in their houses. The latest devices for interior installation were on attractive exhibition at the Edison Illuminating. Company's offices in the old Bishop mansion at 65 Fifth Avenue. Edison was a salesman. He had selected the Fifth Avenue location to attract the fashionable; and his Jumbo dynamo was named for Barnum's elephant.

Sometimes the inventor showed himself in the display room at "Number Sixty-Five." He looked older than his thirty-seven years -a graying, absorbed figure in a wrinkled frock coat and a stiff shirt with a handkerchief knotted about the neck in place of a collar and cravat. Frequently he needed a shave and he was suspected of using his deafness as a pretext to avoid conversations that bored him.

Young duPont continued his visits to the Edison laboratories and shops at Menlo Park, where he was one of the few of a great company of worshipers of the electrical genius who occasionally got to exchange a word with him. ${ }^{6}$

In all there were some glorious week ends for the young powderman who at six-fifty on Monday morning would be back at the 
lower gate of Hagley Yard, sleepy, perhaps, but otherwise fit for a ten-hour day.

In the old icehouse at Swamp Hall Alfred still fussed with his electric lights. He strung a wire into the main house, hanging one bulb from the gaslight fixture in the downstairs hall and another from the fixture in his bedroom. As these lights could be turned on and off only by starting or stopping the kerosene-burning engine in the icehouse, Alfred devised a way so as to undress without resorting to the gaslight. He installed a valve in the pipe that fed fuel to the engine, and a trap to work the lever that closed the valve. A wire running to a window of his bedroom would spring the trap. When ready to retire he would cut off the oil supply, leaving enough in the pipe to keep the engine going and the lights burning for five minutes.

Alfred's next enterprise was to wire Swamp Hall for electricity. This required so much equipment that first he built, back of the house, a machine shop about twenty by forty feet in dimensions, equipping it with power lathes, a drill press and benches supplied with good tools. There Alfred designed and, with Gilly and Frank Mathewson, made most of the contraptions for wiring The Swamp. It was a surface-wiring job, completed in the spring of 1886 , with bulbs dangling from the gas fixtures throughout the big house. Switches for turning on and off individual lights were made by altering the twist-catch mechanism of doorbells. The Swamp was the first house lighted by electricity in Delaware and possibly the first house in the United States successfully wired by amateurs. The second house to be wired was the Mathewson cottage across Breck's Lane.

For the system to work properly, it was necessary to keep someone in the engine room at all times with his eyes glued on the voltmeter. If the voltage got too low the lights burned dimly and if it got too high they burned out. More current was necessary for twenty lights than for ten or for one, and the supply of current had to be regulated constantly by hand. Otherwise, with twenty lights burning, if ten were turned off the remaining ten lights would be 


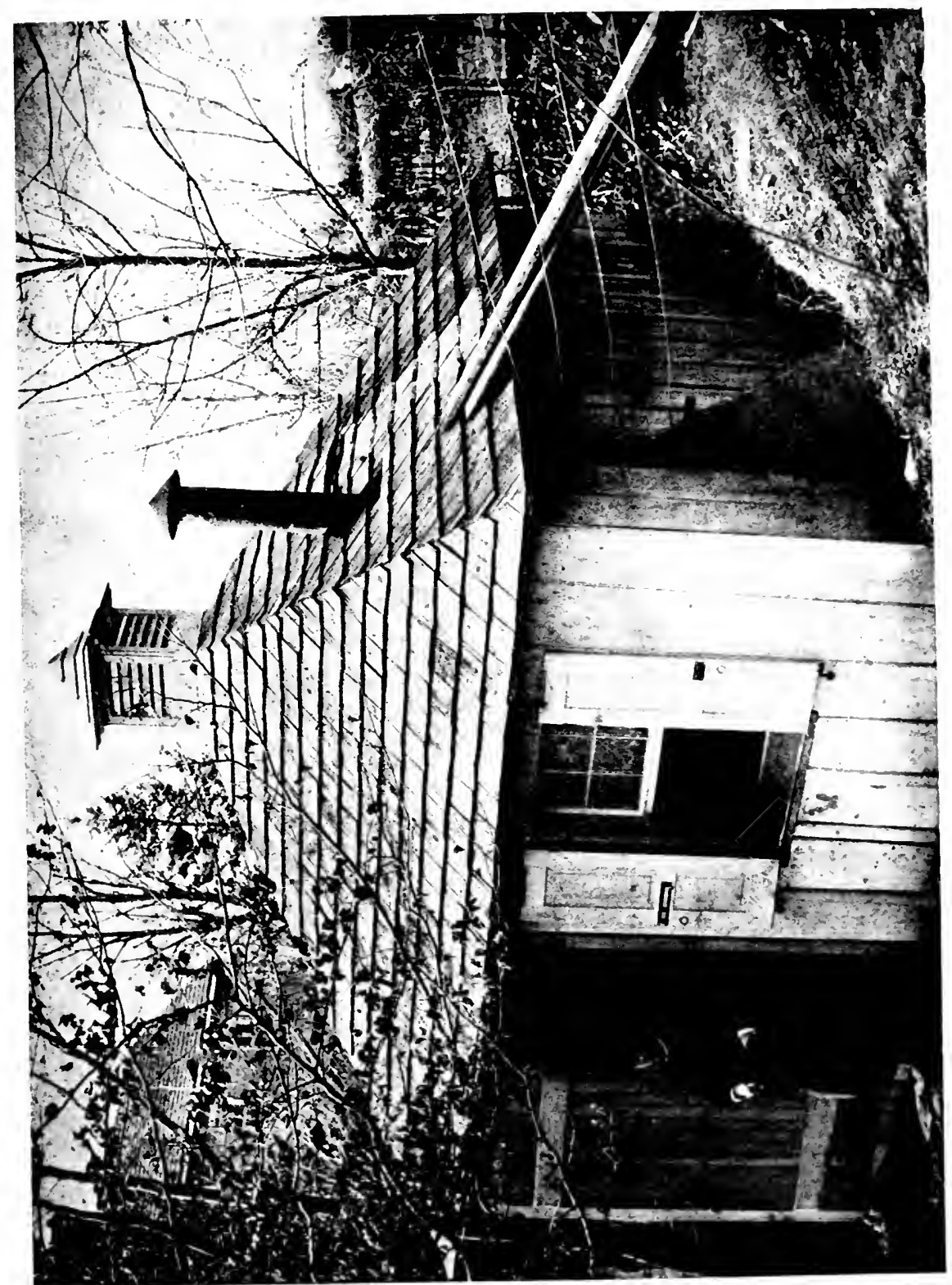

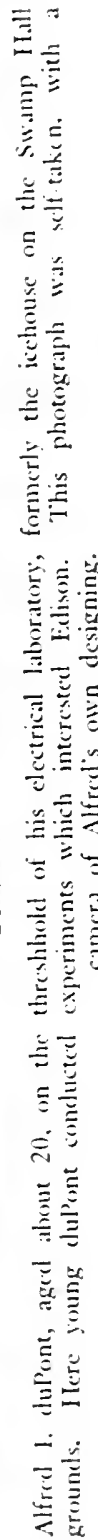


$=$ 
burned out by the excess of current. Frank Mathewson was hired to watch the voltmeter and regulate the current according to the indications of the meter. At length Alfred obviated this by designing a self-actuating rheostat which the Mathewson brothers made in the machine shop. This device, believed to have been the first in use in a private house, automatically diminished or increased the flow of current according to the number of lamps in service.

The electrically lighted houses became show places. Every evening carriages from Wilmington passed along Breck's Lane so that the occupants could gaze at the sight. Visitors desiring a closer look were shown the generating plant and given an instructive lecture by one of the Mathewsons or by Alfred himself. ${ }^{7}$

Music continued to be the other great avocation of the master of Swamp Hall. He had three teachers: for the violin, Gustav Hille of Philadelphia, former concertmaster of the Berlin Philharmonic Orchestra, and Tom Bird, champion square-dance fiddler on the Brandywine; for the guitar, "Professor" Skimmerhorn, a Negro employed by the Western Union Telegraph Company in Wilmington. Alfred organized an orchestra named the Tankopanicum Musical Club and called "Al's band" for short. Tankopanicum is an Indian name associated with the Brandywine.

Al's band rehearsed in the machine shop unless a piano player was present. Then the musicians moved into the Swamp Hall parlor. Some of the early members of the band were Samuel Parr, superintendent of a neighboring cotton mill, first violin; Louis Greenleaf, son of the Swamp Hall family doctor, second violin; George Mathewson, millwright's apprentice, second violin; Mike Maloney, blacksmith's helper, second violin; Sam Buchanan, laborer, bass violin; Henry Kane, laborer, first cornet; Gilly Mathewson, machinist, second cornet; Jack Hern, clerk in a hardware store, piccolo; Hamilton Stewart, contractor, trombone; Alfred duPont, leader, playing, as need arose, first violin, clarinet, cornet or piano. Although he never mastered it, Alfred loved to fool with a bass violin, which he called "shaking hands with a bull fiddle."

The leader bought better instruments for, and staked to private lessons, those who could not afford them. Playing for its own amusement at first, soon Al's band was furnishing music for the 
powdermen's dances and for entertainments at Christ's and at St. Joseph's churches. ${ }^{8}$

\section{5}

Not a great deal of authority went with Alfred's title of assistant superintendent because Cousin Frank was not one to delegate much authority.

Francis duPont was a silent man and deeply religious. An amateur astronomer of note, in the residence he occupied, Montchanin, he had a twelve-inch reflecting telescope and was one of the first men in the United States to use such an instrument in astronomical photography. His other diversion was trapshooting. This was a diversion only in part, for when shooting, Mr. Frank kept a record of the comparative performances of the different brands of DuPont and of other powders. The workmen never gave him a nickname. A DuPont pensioner has confided to the writer:

"Mr. Frank held himself aloft [the speaker meant aloof] from those who worked for him. In six months Mr. Alfred knew the workmen better than Mr. Frank did after twenty-five years as our boss."

And Alfred was nicknamed at once. He became "The Young Fellow" and "Short Pants" because of his fondness for cycling knickerbockers.

It was Alfred's relationship with the workmen after the quittingbell rang that determined the depth of their esteem for him.

As one veteran has put it:

"If Mr. Alfred knew you in Hagley he knew you on Market Street."

Market Street is the main thoroughfare of Wilmington.

"Yes," said another old-timer to whom the statement foregoing was repeated. "And if he knew you in Wilmington he knew you in Philadelphia or New York."

Catching this remark, the veteran's wife paused in her housework.

"My father, Michael Gordon, was on the powder line," she volunteered, with the merest trace of a brogue, "and he lived to be 
eighty-one. I knew Mr. Alfred when I was a girl growing up, and I want to say that he was a gentleman. He liked fun with the best of them and used to tease us about our fellows until we blushed like anything. But he did it like a gentleman and not like some of your rich young men, all too ready and willing to take advantage of a poor girl's ignorance or her love of a little finery."

It is possible that Francis duPont found it hard to delegate authority because the authority he possessed had been so dearly won from Uncle Henry, the head of the firm. In 1886 the old gentleman was seventy-four, and he had been head of the firm for thirty-six years. His famous red beard was a little gray. He had exchanged his saddle horse for a top buggy, and when entering his private office would jack off his heavy boots and put on carpet slippers. But the boots had left their mark; in the thick planks beneath the flat desk was worn a place which Willie Macklem, the office boy, said looked like a cobbler's seat.

At this desk Boss Henry still scratched out, with quill pens, three thousand letters a year-letters which more than the communications of any other man shaped the current destinies of the explosive industry in America. After a spell of writing the Boss might take the air in his buggy. If he met a powderman's child returning from school, he would give him a ride. Spying a stick of willow wood fallen from a wagon, he would pick it up and deliver it to the shed by the 'coal house. He still wore silk hats, an old one on weekdays, a new one on Sundays; still made unscheduled night inspections of the yards, lighting his steps with a square lantern holding a tallow dip. One night he heard a suspicious sound in the Upper Yard. It was traced to a glazing mill where an overheated shaft was shooting sparks that might cause an explosion at any second. While Foreman Thomas Kane stopped the mill, Boss Henry carried water from the race in his high hat and cooled the shaft. ${ }^{11}$

Yet for all his attention to small things, the only big thing on which he had been wrong was dynamite; and the late Lammot duPont's successful rebellion had saved the company from the consequences of that. Judged by his work as a whole, Henry duPont towered above rivals in the industry. He had been the only 
powder executive to bring his firm through the chaotic period following the Civil War without getting into financial hot water.

Insular as he was, Henry had been the first DuPont to extend the firm's manufacturing activities outside of Delaware, in 1858 opening a plant in the coal-mining district on Wapwallopen Creek, a tributary of the Susquehanna in Luzerne County, Pennsylvania. During the Civil War, with the established companies occupied in filling military orders, small powder plants had sprung up almost everywhere to supply local needs. The war over, some of these plants closed down and kept their profits. Others had struggled on, many of them making poor grades of powder and cutting prices to keep going. The Government complicated the situation by throwing an enormous surplus of war powder on the market. Some of this was good powder, some of it dangerously bad, and all sold for less than the cost of manufacture. Scrambled railroad rates, with drawbacks and rebates openly given, added the final straw to the manufacturer's load of woe.

DuPont's three closest competitors-Hazard, Smith \& Rand and Laflin-were soon in difficulties. Though Henry duPont felt the pinch, he had carefully husbanded his abnormal wartime profits. He bought up some of the Government's surplus and reworked it. In 1869 with his competitors feverishly shortening sail-Smith \& Rand and Laflin consolidated in that year-Henry had the money for some hard-times bargains. He bought out one sizable concern and five smaller mills in the Pennsylvania coal fields where the use of powder in the mines was increasing.

In 1872 the time had come to deal systematically with cutthroat conditions. Mr. Henry made one of his rare trips to New York. In the DuPont office at 70 Wall Street he met representatives of the Hazard, Laflin \& Rand (formerly the Smith \& Rand and Laflin companies) and three other powder concerns. The consultation led to the formation of the Gunpowder Trade Association-the Powder Trust-with Lammot duPont as president. In the councils of the Trust the three big companies-DuPont, Laflin \& Rand and Hazard-had ten votes each. The Oriental Powder Mills had six votes; the Austin, American and Miami companies four votes apiece. 
The Trust fixed powder prices and laid out trade territories. With competition virtually eliminated among the kingpins, the lesser fry were easier to handle. Some were driven to the wall, some bought up, some disciplined and brought to terms. One independent in northern New York and two in the Ohio Valley gave the Trust its stiffest fight. Before the fight was over the Association had cut, in the recalcitrants' territory, prices on rifle powder from $\$ 6.25$ to $\$ 2.25$ a keg, and on blasting powder from $\$ 2.75$ to 80 cents. Two of the rebels sold out to the Trust's Big Three-DuPont, Laflin \& Rand and Hazard. The other adopted the Association price schedule and kept to the markets assigned it.

From this strife the DuPont Company came out as it had gone in-top dog-with a "stabilized" industry to lord it over. In 1876 the secret acquisition of a majority interest in the Hazard Company gave Mr. Henry twenty votes in the ruling council of the Trust. Next DuPont, Hazard and Laflin \& Rand clubbed together to take over Oriental Mills, an ailing fellow-member of the Association, which gave the Red Fellow on the Brandywine control of twenty-six of the forty-eight votes. Actually he ruled the powder business by a larger margin than that. In addition to companies controlled in conjunction with other components of the Association, the DuPont firm bought into two other strategic concerns. These were the Sycamore Mills, near Nashville, Tennessee, and the California Powder Works which so dominated the Pacific Coast that the Trust had been obliged to abandon that territory.

Aside from the California company, the one powder concern in North America Henry duPont did not completely overshadow or control was Laflin \& Rand, which represented a union of the only powder families on the continent older in the business than the DuPonts. A Laflin had made powder in Massachusetts during the Revolution and a Rand had set up a wheel mill in Connecticut about 1800 . Their descendants were in the modern company. Yet as the Gunpowder Trade Association's scheme of control had worked out, Laflin \& Rand and DuPont were collaborating so intimately that competition between them was unthinkable-cspecially by Laflin \& Rand, because the DuPont resources were greatly superior. ${ }^{12}$ 
The only organization more dominant in its field was John D. Rockefeller's Standard Oil Trust, which gave the name "trust" to business combinations powerful enough to smother competition. The original Standard Oil Company was an Ohio corporation with no legal existence outside that State. Control of properties elsewhere was through the Standard Oil Trust by which Rockefeller and his principal partners held, as trustees, the controlling shares of companies they swallowed up. The DuPont Company being an unincorporated partnership with legal existence anywhere did not have to resort to this fiction. The partnership could own outright shares of other concerns anywhere, just as an individual could have owned them. Nevertheless, the word "trust" affixed itself to Boss Henry's Gunpowder Trade Association.

\section{6}

If Alfred tried to take a bird's-eye view of the vast industrial organism of which he was a cellular part, it was a hazy picture that rewarded his effort, for Great-Uncle Henry did not blab the secrets of his Powder Trust. Since the death of Lammot, it is doubtful if any one partner knew the true extent of the firm's grip on the industry, or the whole story of the means by which it was maintained. Certainly Alfred knew no more than enough to keep him from being too puffed up over the promotion to assistant superintendent. He was under no illusion of being more than a small potato at the bottom of a very tall pile.

This did not discourage him. He was free with suggestions for improvements in the yards-too free and too abrupt in his manner, Cousin Frank often thought. Change was a thing the DuPonts approached with caution-far too much caution, thought Alfred. His work in electricity, which was no respecter of precedent, encouraged this state of mind. Arc lights had appeared on the streets of Wilmington. Alfred studied them carefully, reducing to mathematical formulas their points of superiority over the kerosene lamps which dimly illuminated the roads in and about the powder yards. $\mathrm{He}$ worked out a project for dismantling the steam plant in Hagley, harnessing its Corliss engine to dynamos to illuminate the 
yards with arcs and to provide better and cheaper power for the mills when the Brandywine was too high or too low to turn the water wheels.

This he took to Cousin Frank who, though not untouched by DuPont conservatism, had a good scientific mind. Frank duPont was impressed. He called in his older brother Eugene, who had a considerable influence with Boss Henry. Eugene was impressed. This was progress: Alfred working harmoniously with two important members of the firm on a revolutionary innovation. A little plot was hatched to impress Mr. Henry with the virtues of electricity.

Francis and Eugene duPont asked the old gentleman to make an inspection of young Alfred's private electrical plant. He consented, and one night they took him down to The Swamp. Alfred had everything tuned up first-rate and the demonstration went off without a hitch, Alfred delivering a running commentary on the advantages of electricity as a source of light and power. The old man had always liked Alfred. Noting his qualities of leadership and his energy, Henry had put his great-nephew down in his will for a $\$ 25,000$ legacy. Of course it was still too soon to say what Alfred's talents might mean to the firm. That was paramount: the welfare of the firm. Conceivably a DuPont might become a successful lawyer, doctor, musician or electrician. Uncle Henry would be gratified because of the satisfaction any success meant to the individual and because of the luster it shed on the family. But when a DuPont became a good powderman-ah, that was something desirable in the first degree: it helped the firm.

Without so provincial an outlook as his great-uncle, young Alfred also was sincerely, even passionately, attached to the firm. His electrical demonstration was aimed solely to show how this new agent might minister to the greater glory of E. I. duPont de Nemours \& Company. When he had finished, the four men adjourned to the Swamp Hall parlor. Mr. Henry lighted a cigar and smoothed his beard, obviously in a pleased frame of mind. He complimented his great-nephew on his hobby. It was good to see a young member of the family spending his spare time at something so novel, so fraught with possibilities of service to the old 
firm. The day might well come, he added, when electric lights and electric power would be practicable in a powder yard. But for the time being he was sure that kerosene, candles and water would answer these purposes satisfactorily.

With that the old gentleman shook hands warmly with his great-nephew, thanked him again for his trouble and said a hearty good night. The three visitors departed, leaving their youthful host alone with the realization of dreams reduced to ashes by a word from the old czar from whose decisions there was no appeal. ${ }^{13}$

Curiously, however, about this very time, Frank Haley, the correspondence clerk in the company's office, fared better as an innovator. Several times Mr. Henry had refused to buy a typewriter. Finally Haley hired a typewriter for a month, took it home and learned to use it. Then Willie Macklem, who had risen from office boy to clerk, carried the machine to his home and mastered the keyboard. One morning Haley laid on Mr. Henry's desk a few typed letters. The old man signed them and told the clerks they could purchase the typewriter. He remained adamant, however, in his refusal to dictate to a stenographer. His twenty letters a day were still scratched out roughly in longhand for Haley or Macklem to type. ${ }^{14}$

\section{7}

In May of 1886 invitations to the wedding of Annie Lee, a Virginia connection on their mother's side, were a signal for a homecoming of the Swamp Hall tribe. Maurice arrived from Boston where he had entered Massachusetts Tech in 1884 , the autumn after Alfred had left. Louis came down from Yale. Another guest from New Haven, by Louis' invitation, was Bessie Gardner, a cousin of the bride-to-be and therefore a cousin of the residents of The Swamp. She was a daughter of Dorsey Gardner, a man of letters, at that time collaborating with President Porter, of Yale, on a new edition of Webster's Dictionary.

Though the discovery of a new cousin was no great event for Alfred, the meeting with Bessie Gardner proved an exception to 

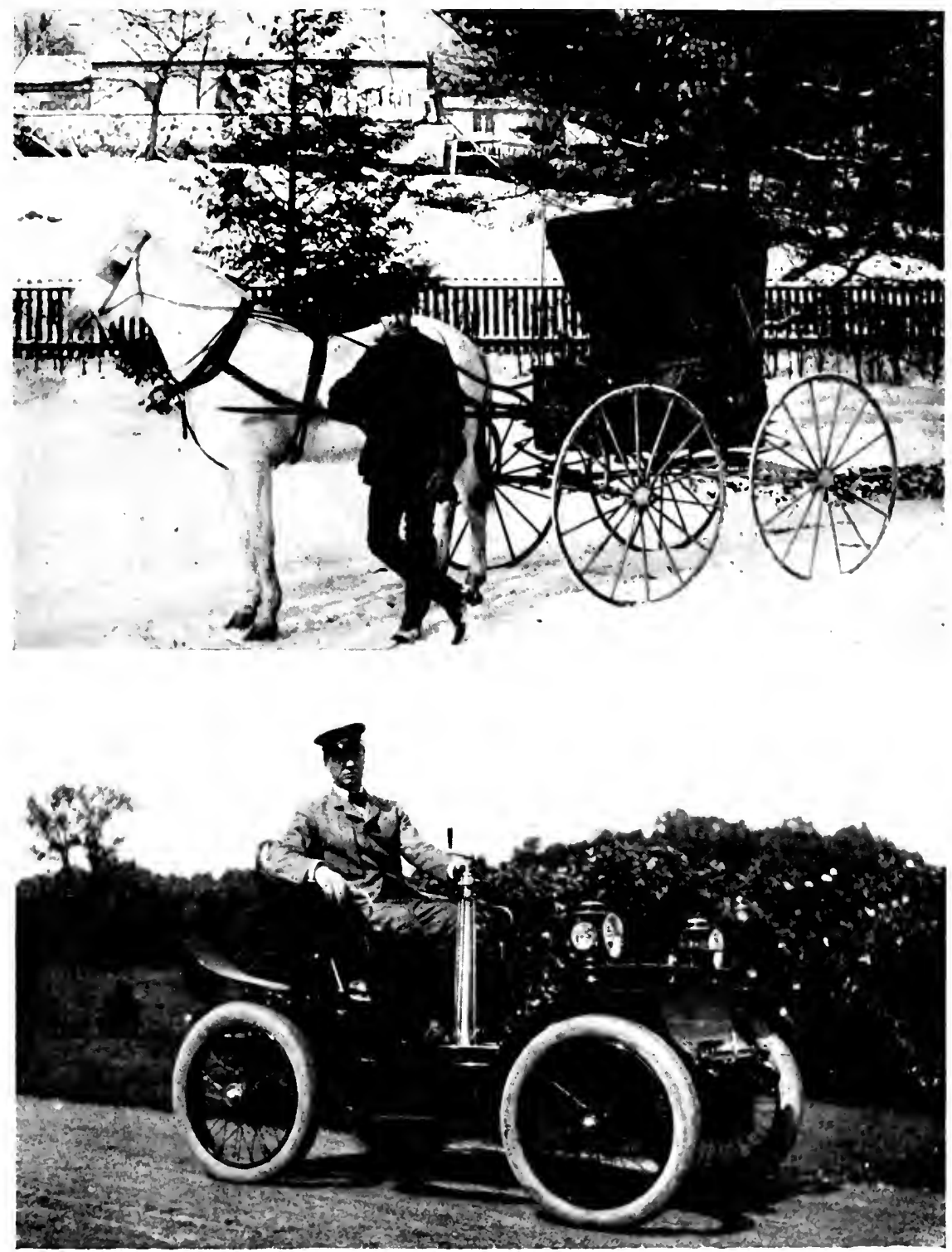

Locomotion on the Brandiwine

1884: Alfred I. dul'ont, puwderman's apprentice, his driving mare $\mathrm{X}$.ll and crersilw buggy. For Sunday engagements with the young lidies Alfred hitched $x \mathrm{dl}$ to 1 swankicr-looking trap.

About 1900: A. I. duPont and horseless carriage. Mr. duPont owned the second automobile in Delaware and once thought of leaving the family firm to huilat moturcars. 
this rule. She was twenty-one, or four months younger than Alfred, blonde, attractive, intelligent and gay. Familiarity with a cultured world had imparted an air that made the Brandywine and the Kentucky girl cousins he knew seem countrified by contrast. Louis and Bessie had met in undergraduate circles at Yale, and obviously Louis was impressed by her charms. So was Alfred, who set out to reduce the advantages of a prior acquaintance enjoyed by his brother.

In all it was a congenial party that headed south. As the wedding was near Alexandria, across the Potomac from Washington, the Swamp Hall residents and their pleasant guest put up at Marguerite's house on New Hampshire Avenue in the capital. Bessie returned to New Haven, and Alfred wrote her a letter, which began a regular correspondence. When Louis resumed his classes at Yale in the fall, Alfred lost no time manufacturing an excuse to visit him. Of course he saw Bessie Gardner. Thereafter Alfred's trips to New Haven were frequent. Before Christmas he told Louis that he and Bessie were engaged. The younger brother looked very puzzled.

"You are not," he asked slowly, "going to marry Bessie Gardner?"

Alfred said that he was, indeed. Nevertheless, he rode back to Wilmington vaguely depressed. A close bond existed between the brothers. Alfred was surprised and pained that Louis should take it so hard.

The assistant superintendent of Hagley Yard was not the only one to involve Swamp Hall in the coils of romance that autumn. While Alfred was bringing his swift courtship of Bessie to a successful termination, victory crowned the protracted campaign of Absalom Waller to win the hand of Annie. Alfred greeted the news joyfully. The couple were married in Christ Church on December 22, 1886, and Alfred gave them a reception at The Swamp, with music by his orchestra.

The old house did not long remain a bachelors' hall. On January 4, 1887, Bessie and Alfred exchanged their vows in St. James's Church in Philadelphia where the bride had relatives. While they were honeymooning in Bermuda, Gilly and Frank Mathewson fell 
upon Swamp Hall, tearing out the exposed electric wires. They ripped up floors and bored through walls, installing concealed wires and wiring the old gas fixtures for electricity. This compliment to the bride was executed according to plans Alfred had worked out in minute detail after having consulted no less an authority than Edison himself. ${ }^{15}$ 


\section{CHAPTER V}

\section{A Partner in the Firm}

The Tankopanicum Musical Club serenaded the returning honeymooners, powdermen crowded around to offer congratulations and a big time was had by all. Bessie duly admired the electric lights, though secretly she would have preferred some book cases. She had had her books sent down from New Haven. They stood about in packing boxes because there was no place to put them. Though he had inherited something of a library from his father, Alfred's personal book collection consisted of a set of encyclopedias and a few shelves of scientific works. Accommodations for Bessie's books were quickly provided.

Bessie was not interested in music. Yet she would take a book and sit on the stoop of the machine shop and read while Alfred rehearsed his orchestra. After rehearsals there would be a social get-together in the parlor. Bessie, too, brought her friends into that parlor, which she had tastefully refurnished, her proud husband applauding every acquisition. Bessie's friends were literary, professional and artistic people the like of whom had rarely, if ever, been seen before in a DuPont household. Alfred also had his theatrical friends, but apparently it had not occurred to him to invite them to The Swamp. But Bessie invited them, and invited stage acquaintances of her own, among whom were such particular friends as Mary Mannering, Kathryn Kidder and James K. Hackett. Louis brought his chums from Yale and Maurice his from Johns Hopkins, to which university he had transferred his attentions after spending two and a half years at M.I.T. One seldom sat down to dinner without guests; and "dinner" became the meal served at the end of the day, not the middle, as heretofore. Other 
DuPont households continued to serve dinner at noon and supper in the evening. Some of the older members of those households raised their eyebrows when The Swamp was mentioned. They were correct in saying that the Brandywine had seen nothing the equal of the innovating breezes Bessie had brought with her.

Alfred liked the change of atmosphere, and laughed at the misgivings of the "old women," by which he meant kinfolk of both sexes. In October, I887, Bessie gave birth to a baby girl, Madeleine - called Madie-and the happiness of the young couple seemed complete. Alfred's state of mind was reflected in the zeal he threw into his work, which three months after Madie's arrival brought a \$500 raise in pay from Great-Uncle Henry, making the assistant superintendent's salary $\$ 2000$ a year. More noteworthy, however, was the ruler of the firm's tacit approval of Alfred's innovating wife. This took the form of permission to remodel Swamp Hall at company expense. The alterations were rather extensive. Four baths were installed and a billiard room added which, because it contained a piano, became a rendezvous for Alfred's musical friends. The front porch was given more pleasing lines. When Bessie had finished redecorating, the old house, though falling short of pretentiousness, presented, inside and out, the spacious aspect of a homey country place. To live up to the refurbished Swamp probably cost Alfred, for the first time in his life, nearly all his income, including salary and the earnings of his inheritance.

January I, I889, Alfred's pay was raised to $\$ 2400$ and GreatUncle Henry entrusted to him a mission which proved the strength of the old dictator's confidence in his energetic young subaltern. ${ }^{1}$

Six years earlier, at the request of the Navy, the DuPont Company had begun the experimental manufacture of brown prismatic, or "cocoa," powder-so-called from its color and the shape of the grains. The new product took its name from the brown or underburned charcoal which was used instead of ordinary hard black charcoal. It was for large-calibered guns and gave better results than black powder. Gradually DuPont improved processes 
and product of which they were the only makers in the United States and which by agreement they sold only to the Government. Meantime, however, our military attachés abroad reported that the French army's brown prismatic powder was superior to ours and moreover that the French had a new powder, called smokeless, which was superior to their brown powder.

Since I804 DuPont had made powder for the United States. Their relations with the Government had been close and frequently confidential. They stood well with officialdom and deserved to do so. In the present instance the Navy asked DuPont if it could ascertain whether the information received concerning the French powders was correct, and if so whether DuPont would get the scientific data necessary to bring its powders up to the foreign standards. In the course of his apprenticeship in the yards, Alfred I. had learned as much about the manufacture of brown powder as anyone in America. Mr. Henry selected him for this delicate and technically difficult task.

On March 20, I889, Alfred sailed with Bessie, little Madie and a nurse. Ten days later he registered at the Hôtel des Deux Mondes, Avenue de l'Opéra, Paris. In striped trousers and gloves and swinging a stick, the visitor looked startlingly French. He spoke the language of the country, though with an Alsatian accent that was a legacy from Emma.

Without loss of time he went to work. A letter of introduction from Secretary of State James G. Blaine to the United States Minister to France enlisted the co-operation of that official. This diplomat had the honor to apprise the Ministry of War of the presence in France of the distinguished M. duPont whose "house is a most honorable one.... Any condition imposed upon them will be most carefully respected." Writing in French, Alfred himself gave the Ministry of War a tactfully incomplete account of the occasion of his visit. In reply the Minister of War had the honor to inform M. duPont that he would be received by the Director of Powders and Saltpeters. A pass to the Ministry of War was enclosed. M. duPont was invited, somewhat vaguely, to present the pass on a day after Tuesday of the following week at any time from two to five in the afternoon. 
The Director of Powders and Saltpeters turned out to be all courtesy. In response to Alfred's precise questions, the figures he gave on the performance of the brown powder indicated that it was in no way superior to that manufactured on the Brandywine. Alfred requested permission to visit the works at which the powder was made. After some delay a very brief inspection was permitted. Nevertheless the sharp eye of Alfred noted that the machinery and the fabrication processes were much behind those on the Brandywine, which seemed to explain the figures he had obtained on performance.

The visitor mentioned smokeless powder. The French officials were politeness embodied, but absolutely powerless, they regretted to say, to utter a syllable on the subject of smokeless powder. After a little research Alfred learned the reason. So closely was guarded the secret of smokeless powder that the different processes in its manufacture were carried on in four distant parts of France, the director of each process being ignorant of the methods employed elsewhere. Notwithstanding, DuPont's envoy succeeded in learning something of the performance of smokeless powder. This record was astonishing. Two and a half grams of smokeless powder would put a bullet through a target which five grams of black powder could only dent. No comparison of the respective performances of smokeless and of brown powder would have had any meaning, however, because smokeless powder was used only in small arms and brown powder only in cannon.

Meantime Alfred had received from the Brandywine a request the United States Navy had made of DuPont to investigate a brown powder manufactured by the Chilworth Powder Company in England. Abandoning his bootless efforts to penetrate the mystery of the composition of smokeless powder, Alfred and family crossed the Channel. There he learned that Chilworth was an offshoot of the Rhenish Westphalian Powder Company of Cologne, which was contemplating erecting a mill in the United States. Its powder, however, was no better than the French. But to head off the threatened American invasion, Alfred got tentative terms for the manufacture of Westphalian powder by DuPont on a royalty basis. 
Again picking up the smokeless-powder scent, Alfred went to Belgium, where both smokeless and brown powder were made by Coopal \& Company. There Alfred put up at a monastery at Wetteren, drank wine with the monks and played the bass viol for them. They provided the powder scout with a laborer's clothing, in which Alfred was able to mingle among the Coopal workmen. Despite this stratagem Alfred seems to have learned little, if anything, about the smokeless-powder formula; but he did learn that the results obtained by Coopal smokeless were virtually identical with those of the French smokeless. He learned also that the Belgian brown prismatic powder was superior to that kind of French powder.

With these facts in hand Alfred donned his striped trousers and top hat and called on the Coopal officials. He was able to get tentative contracts for the manufacture of both these powders by DuPont on a royalty basis on terms better than those he had obtained in London for brown powder.

In his enthusiasm over this stroke Alfred exceeded his powers. Taking for granted the ratification of the Coopal agreement, he contracted options on Belgian brown-powder machinery to be transported to Delaware. In high spirits he sailed for home the middle of June. ${ }^{2}$

One of the last letters Alfred had received from the head of the firm had probably been written late in the night after Frank Haley had covered his typewriter and gone home. In any event it was written in the old man's own strong clear hand. After dealing with the subject of Chilworth powder it concluded:

"All well; hoping you are the same, I am

"Your Aff. Uncle

"Henry duPont"

Arriving on the Brandywine, filled to the ears with ardor and with plans, Alfred found all far from well. One tremendous fact 
tumbled his smokeless-brown-powder projects into eclipse: GreatUncle Henry's rugged health, as taken for granted as the gray boulders that pebbled the Brandywine, had broken. The old warrior desperately ill, his partners had their hands full trying to mind the multitude of unfamiliar irons their senior already had in the fire, instead of heating the new one Alfred brought from overseas.

This furry among the partners was understandable. Unmindful of encroaching years, the old man had continued to bludgeon ahead, piling responsibility upon responsibility, running everything himself and keeping many important details his own secret, as if he should live forever. The company had bought control of the Hercules Powder Company, the Hecla Powder Company, the Hercules Torpedo Company. It had bought into a spunky independent, the Marcellus Powder Company, and-most notably-it had bought into the only remaining concern which by any stretch of imagination could be called a rival, Laflin \& Rand. To tighten its grip on the Mississippi Valley market, it was building, near Keokuk, Iowa, the Mooar Mills, destined to be the largest blastingpowder works in the country.

Moreover the Gunpowder Trade Association had been revamped with a membership of twelve companies making $921 / 2$ per cent of the powder output of the United States. Sales territories and sales quotas were rigidly redrawn and prices fixed, retaining for DuPont definite control of the powder empire.

The independents yelled lustily. Now and again, in Congress or in a State Legislature, a public servant had risen in his place to denounce the Trust. An agent for the DuPont products in Texas had made so bold as to write the company that popular sentiment against corporation control of industry was mounting. Mr. Henry himself answered that letter, as he answered every letter which came to his desk to his last day in the office.

"We are a partnership [he wrote]. We are not an incorporated company. We manage our own business in every particular, and allow no trusts or combinations to rule or dictate what we shall do or what we shall not do. We make our own powder, and we make our own prices, here, there and everywhere in the world it is for 
sale. We are every day dictating to agents as to prices, terms and conditions; but we do not allow anybody to dictate to us. We do our own dictating."3

What the old dictator omitted to say was that the prices he fixed for "our own" powder were also, by necessity, the prices fixed by every other powder maker who wished to enjoy the privilege of doing business.

Henry duPont wrote that letter in April, 1889. On August 8, which was his seventy-seventh birthday, he died. This verse from the Psalms was carved on his tombstone:

"Mark the perfect man and behold the upright; for the end of that man is Peace."

The peace that had come to the perfect man in the graveyard in Sand Hole Woods did not envelop his surviving partners of the unincorporated company. Eugene duPont, the older brother of Francis G. and nephew therefore of the departed Boss Henry, was chosen head of the firm-a distinction for which no member of the family envied him. Frankly appalled by the weight of his burdens, Eugene effected a reorganization distributing to some extent the responsibilities his uncle had carried singlehanded. In the last weeks of his life, old Henry had plumed himself on the fact that his selling organization followed the pattern introduced in 1802 - direct one-man control of hundreds of agents scattered over the country. Eugene set up regional districts, giving the men in charge considerable authority. A new partner, Doctor Alexis I. duPont, a proven executive though without powder experience, was brought in. This addition was a gift to the shaken old firm from Cousin Fred duPont of Louisville. Educated in medicine, Alexis had, however, gone to work for Fred's street railroads in the West, and, learning the business, had risen to a position of responsibility in tramcar management in New York City. A new office building, five times the size of the old one, was also begun, and on its completion in I89I was filled with a corps of clerks, secretaries and stenographers. 
Other quaint touches of the old order vanished. The mule teams were done away with and all powder hauled by railroad. The never-sweats never got back to their wall-building. At the time of Boss Henry's death, they were working on a new refinery to replace the one which had burned a few weeks previously. That finished, they were chopped from the pay roll. Those who had not drifted away were rehired when work on the new offices began. When that was done they were dropped for good.

Alfred's salary was more than doubled: $\$ 6000$ a year. His title of assistant superintendent of the Hagley and the Lower Yards was invested with real authority while Cousin Frank took on a burden of administrative work. The healthy pay increase was probably not made without strong representations on the part of the beneficiary. And still Alfred was not satisfied. He demanded a partnership, and was joined in this request by Charles I. duPont, five years Alfred's senior, and assistant superintendent of the Upper Yard. At first Cousin Eugene refused, then compromised with an offer of 5 per cent interest for Alfred. The five existing partners, including the newly admitted Alexis, held 20 per cent apiece. Alfred refused the 5 per cent and became an aggressive advocate of his and of Charley's cause, saying the least they would take was a 20 per cent interest split between them.

William duPont, old Henry's son, simplified matters by resigning his partnership. Perhaps William did this to help the young men; perhaps he did it because, with the presidency of the Repauno Chemical Company and a measure of family trouble, he had enough on his hands. However it was, Alfred and Charles I. were offered io per cent shares for $\$ 225,000$ each. Charley borrowed from William duPont the money to take up his share. Alfred raised the purchase price by applying the $\$ 25$,000 legacy from Great-Uncle Henry, \$100,000 from his personal fortune and $\$ 100,000$ borrowed from Cousin Fred of Louisville at 7 per cent interest. ${ }^{4}$

Thus, at twenty-five, Alfred attained the cherished goal of every DuPont who had entered the company's service: a partnership. In the history of the firm only four partners had been younger, and they served in days when the company's affairs were small and its 
problems simple by comparison with the situation on the death of Boss Henry. None had reached the council table as a result of so forthright a campaign in his own behalf. Such behavior violated the traditions of family and of firm. Cousins Eugene and Frank were ruffled. They decided to take the ambitious young man down a peg. When the partners met to discuss company affairs the elders treated Alfred as if he were not present."

This, of course, was not so rude as might appear. It was the way of running things introduced by Boss Henry before whom Eugene and Francis, as young partners, had sat mute. The salient factor in the present situation was that Boss Henry's mantle happened to be somewhat oversized for the shoulders of Eugene duPont.

When the time came to consider it, Alfred's work abroad did not get a very cordial reception from his fellow-partners. They saw no use in buying a formula for brown prismatic which was at best only slightly better in performance than their own. As to smokeless powder, they took the position that it was in the experimental stage.

The United States Government viewed the matter differently. It suggested that contracts for smokeless and for brown powder be made on the terms negotiated by Alfred, the Government paying the royalties. The elder DuPonts objected. The Government insisted and had its way; the contracts were made ${ }^{6}$ and the machinery Alfred had engaged for was shipped over. Eugene and Frank did not think much of this machinery and were pretty severe on Alfred about it. In setting up the machinery Alfred overcame some of the objections with improvements and began to make brown powder for the Navy according to the Belgian formula. These peacetime orders were, of course, very small-a drop in the bucket by comparison with the total production of the yards.

Nothing was done with the smokeless-powder formula, which was admittedly unsatisfactory. The problem challenged the excellent scientific mind of Francis duPont. Busy as he was with matters of administrative readjustment, Cousin Frank set up`a 
small laboratory near his home and began an independent investigation of the possibilities of evolving a smokeless powder.

On the question of electricity Alfred got along better with his kinsmen who controlled the firm. Cousins Eugene and Frank decided they wanted their residences lighted like Swamp Hall. Under Alfred's supervision Gilly and Frank Mathewson wired the houses. Alfred's IIo-volt direct-current dynamo was moved into the steam plant in Hagley Yard, another similar dynamo purchased, and both connected to the Corliss engine. These installations were no more than completed when Alfred's Aunt Mary and-surprisingly-his Great-Aunt Louisa intimated that they would like the bright new lights in their houses, too. Aunt Mary was the widow of Lammot duPont and had always kept up with the times. But Aunt Louisa was the seventy-four-year-old relict of the late Boss Henry who would never have anything except candles in his home.

Alfred teased his Cousin Mary, who lived in an old stone house just up the hill from The Swamp, into joining the movement. This dumpy old spinster was a character, who, in the early days of the five orphans' occupancy of Swamp Hall, had proved a good friend to them. She used to waddle down nearly every day to see how Annie was coming on with her charges, particularly Alfred, who more than once received a first-rate dressing down from the old lady's sharp tongue. Miss Mary duPont consenting to have electricity in every room except her bedroom, Alfred saw to the installations in the three houses, taking the precaution to get Cousin Mary away on a visit. Otherwise he knew she would never permit the depredations to her beloved house that were necessary to lay the wires. On her return Cousin Mary liked the lights so well that she told Alfred he might as well place a lamp in her sleeping room. When Frank Mathewson began to tear up the floor to put in the wires, Miss Mary was aghast. "Why didn't that Alfred tell me he was going to pull the house down? I wouldn't have stood it for a minute!"

Colonel Henry Algernon duPont, Doctor Alexis duPont and Mrs. Antoine L. Foster, a sister of Colonel Henry A., were the next applicants for service. Their homes were too far away to connect 
with the direct-current system serving the other houses. In those days an alternating current carried with less wastage. Therefore Alfred designed and Gilly Mathewson built an alternating-current dynamo of a thousand volts and strung the wires to the three houses. At the same time he achieved his ambition to light the yards with arc lamps and to wire the new office building which was under construction. For the yards he designed and Mathewson built an arc dynamo which, of necessity, operated on a principle different from dynamos making power for incandescent lights.

The next building wired was the DuPont place of worship, Christ Church. This done, Alfred suggested that the firm wire the church which most of its workmen attended-St. Joseph's Roman Catholic. Accordingly DuPont electricity was conveyed not alone to St. Joseph's Church but also to the rectory, the convent and the school on its shaded grounds.

\section{5}

Such were some of the pleasant events of 1890 , doubly welcome because on the whole the year proved one of the most distressing in the company's long history. With the readjustments forced by Boss Henry's death, and heavy expenditures for construction, the partners had prepared for a hard year; but not for a year as hard as they got.

On the day after Christmas, I889, Frank duPont reached home after dark about five-forty in the evening, and turned his horse over to James Horty, the stableman, with the remark that it was getting cold. After washing the powder from his hands, he played a while with his children, the youngest a baby eleven months old, and then went into his study to write a letter before supper. An instant later Horty appeared saying that he smelled burning straw. From a window the two men saw a thin trail of smoke issuing from a large barn which stood near the stable. A strong west wind carried the smoke directly toward Hagley Yard. The men dashed out. A quick look showed the loft of the barn to be on fire.

"Do the best you can!" duPont shouted to Horty. "I'm going to Hagley." 
He called men from the cottages as he ran down the bluff. Hoses were rigged and soon playing on the two glazing mills and the lower press room as a precaution against flying sparks. By this time a glow on the bluff told of the progress of the flames. Then came a cloud of sparks, borne by the heavy wind. They began to fall upon a line of rolling mills, on the outside of which a charge of unfinished powder was standing. "I expected them to blow any minute," Francis duPont wrote in his formal report. Nevertheless, he led a crew of men to the mills. The exposed explosive was got inside, doors closed and roofs wetted down. Danger past in the yards, Frank duPont climbed the hill to see how his home had fared.

The huge barn was reduced to embers. One side of the stable had burned. But the house was intact, and still dripping from the water that had been poured on the shingle roof. Frank duPont's satisfaction was the greater when he learned that his oldest boy, Francis Irénée, seventeen, had courageously directed the effort by which the stable fire had been extinguished and the house saved from destruction.

The next step was to ascertain the cause of the fire. The developments were alarming. Though nothing could be proved, suspicions pointed to incendiarism. Motive seemed to be supplied in the resentment of certain incompetent or negligent employees who had been dismissed during the shake-up since the death of Boss Henry. The doing away with the powder teams and the new policy which threatened the Elysium of the pampered stonemasons had caused a good deal of grumbling.

A few weeks later another stable on one of the DuPont farms went up in smoke, destroying nineteen head of cattle. Then a large barn near the late Boss Henry's residence burned. This fire raged not more than five hundred feet from powder-laden buildings in the Upper Yard. Only a prompt general alarm and energetic preventive measures averted an explosion. ${ }^{8}$

Nothing, however, could avert the tensest anxiety the DuPonts had known during their three generations in the powder business. To live in a powder works which vengeful firebugs are trying to blow up is not a tonic for the nerves. Yet an aspect of surface calm- 
ness was maintained. Only the partners and a few others knew the truth or the identity of a number of green hands who appeared in the yards and on the surrounding DuPont farms. The green hands were private detectives.

When six months passed without another untoward incident, the powder partners breathed a little easier. On October 7, I 890 , Alfred went to Philadelphia to be the guest of honor at a luncheon at the Devon Inn, a place on the outskirts of the city popular with visitors to the Horse Show. Mr. duPont had installed electric lights in the inn. The luncheon was a gesture of appreciation.

The celebration over, Alfred had returned to the heart of the city expecting to take an evening train to Wilmington, when the ground shook and there was a distant rumble. People rushed from their houses, thinking an earthquake had struck Philadelphia. Alfred duPont knew it was no earthquake. He dashed to the Broad Street Station and before he could catch a train home he heard that the whole DuPont works had blown up, killing a hundred people.

Fortunately Alfred knew that first reports of powder explosions seldom minimized the facts. Arriving at Wilmington, however, he observed that the truth must be bad enough. Windows had been broken all over the city, a thing that had not happened in forty years. It was dusk when he reached the Brandywine. Rain drizzled down and the acrid smell of burnt powder stung the nostrils. All the blasts had been in the Upper Yard, which was virtually a ruin. After learning that his family was safe, Alfred spent the night with a lantern working among the debris. By dawn it was possible to sketch roughly what had happened.

The first explosion had been in the magazine containing thirtyfive tons of powder where two tinsmiths were soldering metal boxes filled with brown prismatic powder. This explosion had "blown" the cannister house and next the mixing house where forty-five tons of the highest grade sporting powder made a terrific blast. Next had gone a drying house, then a packing house with 
nineteen tons of explosive, then a press room with fifty tons. Lastly, a brand from the press room had blown the graining mill.

Seven jagged craters disfigured the earth where seven buildings had been. Nearly every other structure in the Upper Yard was damaged. A number of workmen's cottages were stove in or their roofs blown off.

Considering the force of the detonations which Frank duPont, the last man to exaggerate, called the greatest "that ever happened I will say in the world," the loss of life was happily small. The dead: two tinsmiths in the magazine; one man in the mixing house, "blown to small pieces"; two press-room hands-"nothing much found of these men," noted Frank duPont; one man who had been near the press room; four in the graining mill; a woman and a baby crushed in the ruins of a cottage: in all, twelve. DuPont partners visited every bereaved household and attended each of the funerals.

The investigation to determine the cause of the Great Explosion, as it became known, lasted for three years. The obliteration of evidence made definite proof of anything impossible. The first thought was, of course, incendiarism. For a time this theory had strong adherents, among whom was Alfred. It was never entirely abandoned, though Frank duPont gave as his final conclusion that an accident in the magazine had been responsible.

Two more barn fires followed the Great Explosion. On evidence supplied by the detectives, a discharged carpenter, a teamster and his wife were sent to prison for setting them. Their conviction stopped the suspicious fires. 


\title{
CHAPTER VI
}

\author{
Small Clouds
}

I

Meantime the domestic scene at Swamp Hall had flowed on, punctuated by the events big and little which imperceptibly crystallize the pattern of a household's history.

The month of October, 1889, was significant for two events, happening three thousand miles apart: the birth of Bessie's and Alfred's second daughter, and the marriage of Alfred's brother Maurice in Cork, Ireland. Christened for her mother, the new baby became Bep to the family, just as her sister Madeleine had become Madie.

Judged by the repercussions it created, the arrival of Bep was the lesser of the two events of October, '89. This was in the nature of things, DuPont homesteads being noisy with babies whereas marriage was a matter in no way regarded so casually. Prospective matches were talked over, French fashion, by the elders of the tribe. The time was not far gone when these talks had meant something, and some of the fading generation liked to pretend, as they went through the motions, that such was still the case.

Imagine, then, the outraged state of their sensibilities on receiving the first particulars of Maurice's nuptials via the press. The DuPonts regarded the press as an instrument of unwarranted intrusion on their privacy. They kept their names out of print whenever possible. In Wilmington this was nearly always possible, the family having become sufficiently rich and powerful to find means of impressing its wishes upon the local gazettes with the single exception of the Evening Journal. When occasion presented, this breezy sheet retained the habit of treating the Brandywine barons, their scions and connections as a source of good copy. Maurice's 
marriage came under this head, the Journal calling it "the sensation of two continents," which was merely an echo of what the yellow press of New York was saying in greater detail.

The facts upon which this Sunday-supplement field-day were based appear to be these. Maurice had lasted only a year at Johns Hopkins University. In possession of his inheritance of about \$105,000 he was traveling abroad when in Queenstown, Ireland, he met Margery May Fitz-Gerald. That meeting sealed his fate. The newspapers described Margery May Fitz-Gerald as a barmaid and Maurice duPont as an heir to the powder millions. One description was about as accurate as the other. Margery was descended from a proud Irish family which had run out of money. When Maurice met her she was working in a hotel in some sort of minor managerial capacity. The engagement was announced and Maurice returned home. Some months later he crossed the ocean again and they were married. A cruising American foreign correspondent heard an attractive story of the romance and in his dispatch improved the tale immensely. "He Married a Barmaid," the headline proclaimed. "Story of Maurice duPont's Romantic Match. . . . Beauty and Virtue Her Only Dowry." The result was what the Journal conservatively called a sensation of two continents.

The fury of the elder DuPonts, deriving more from the newspaper notice the marriage had received than from the marriage itself, was not a circumstance calculated to align Alfred against his brother. If anything it worked the other way. A cordial message went to Ireland, welcoming Margery and Maurice to Swamp Hall.

Though they took their time returning, the couple's arrival on these shores was a signal for the New York papers to warm up the exhilarating story. Wilmington was on the qui vive and the DuPont clan in a lather. Tart of tongue, good-looking and witty, Margery captivated The Swamp household. Alfred and Bessie turned their hands to the work of pacification and a few of the DuPont women called on their new in-law. They liked her. The calls were returned and the family ruckus subsided considerably. Nevertheless Maurice declined invitations to enter the employ of the company-at the bottom, as his brother had done. He had enough money to live modestly without working. So after a few 


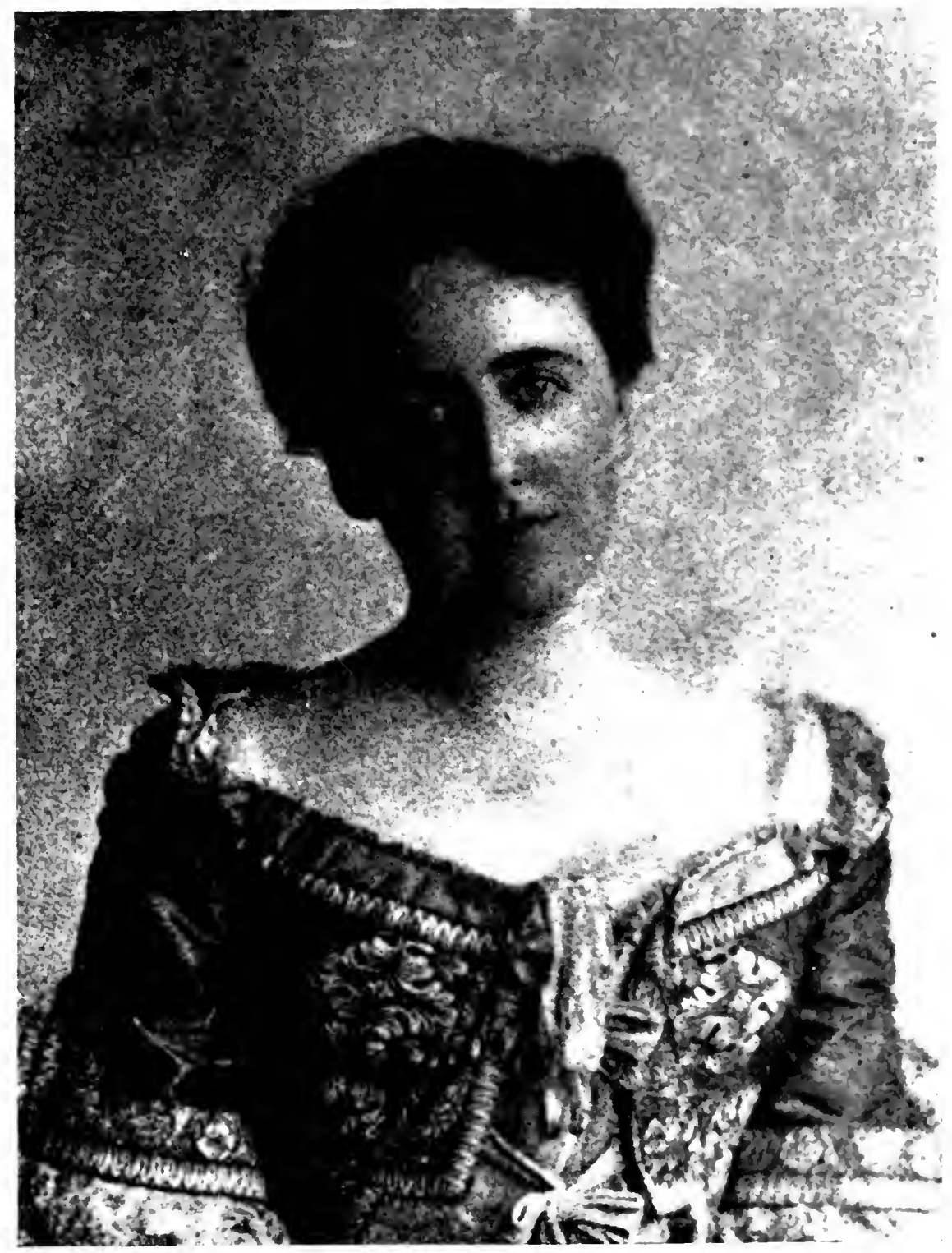

Bessie GardNer dePont

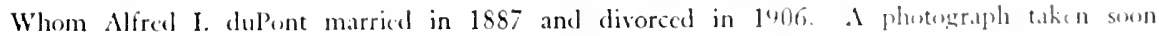
after their marriage. 

months he and Margery resumed their travels, sojourning where fancy struck them, an occupation at which they have been destined to spend a good part of their lives. ${ }^{2}$

Alfred's orchestra grew in numbers, excellence and popularity. Moreover, his inspiration had brought into being two other musical organizations: the DuPont Club Brass Band and the Brandywine Fife and Drum Corps. The DuPont Club, which gave its name to the band, was an organization of employees to which the company had turned over the late Boss Henry's fine residence as a clubhouse. The bandsmen had uniforms consisting of red coats, blue pants and caps bearing tall red plumes. George Mathewson, the millwright, was leader. Alfred played a cornet or a clarinet, and, in Mathewson's absence, occasionally acted as leader. The band marched in Memorial Day and Fourth of July parades. It played at political rallies, Republican and Democratic. The fife and drum corps was made up of boys as a preparatory school for talent for the orchestra and for the band.

Two DuPonts joined the orchestra: Felix, a young son of Cousin Frank, who played a cornet, and Pierre S., a son of the late Lammot, who played the piano. Pierre-Peerie to the old Down-theCreek boys-had finished Massachusetts Tech with honors in chemistry and was working in the company laboratory in the yards. In his effort at impartiality at rehearsals Alfred leaned backward, being more critical of his cousins' playing than of the other members'. Peerie's talent for music was a natural one; he had never taken a lesson in his life. The result was sometimes a spotty performance. At a concert at the Green Hill Presbyterian Church, he bungled his part in a medley of Southern airs.

At midnight the musicians were walking home in silence, the weight of Pierre's blunder heavy upon them. At length Alfred spoke:

"You know, Pierre, tonight I wished I had had a baseball bat in my hand instead of this little stick."

"Alfred," said Pierre, "I can easily understand it." 
That seemed to break the ice and the contretemps was laughed off.

Alfred made headway as a composer, writing and orchestrating several waltzes and marches. The orchestra played them from manuscript scores which Alfred wrote out for each instrument. Without deserting the powdermen's rollicking square dances, the orchestra began to accept invitations to play at dances given by members of the DuPont family-where different numbers were rendered, with a good deal less abandon. The significant change in the history of the orchestra, however, was the relinquishment of Alfred's attempt to integrate it with the life at Swamp Hall. Definitely Bessie did not care for music. After a year or so she gave up pretending to and ceased to sit on the stoop of the machine shop during rehearsals. Alfred transferred his rehearsals to the second floor of a deserted mill at the foot of Breck's Lane. With money earned playing at DuPont family dances and other revenueproducing affairs, the place was fixed up in fine style.

Every winter Alfred took his musicians on an excursion to Philadelphia to hear Sousa's band. Alfred was a warm friend of the great bandmaster who once in Atlantic City permitted duPont to direct his musicians. In New York Alfred liked to take an after-theater party to the Imperial Hotel where the orchestra leader would always surrender his baton for a number. ${ }^{3}$

Despite the departure of the orchestra, Swamp Hall remained a lively household and, to surface appearances, a happy one. Both Bessie and Alfred enjoyed amateur theatricals. They joined a club in Wilmington and shone in its performances. Professionals of the theater continued to be regular guests at The Swamp, and Alfred, in amiable seriousness, undertook the impossible task of keeping James K. Hackett sober. When her father failed in business in Louisville, Ellen LaMotte, a seventeen-year-old cousin of Alfred, came to Swamp Hall to live. She liked Bessie and was a long time learning that all between the mistress and master of The Swamp was not as congenial as it appeared to be. 
Others less favorably situated for close observation attached no importance to the fact that Alfred devoted more and more time to avocations in which his wife had no interest. In his cellar he built an electrically operated ice plant; he designed a boilerhouse to heat The Swamp with steam; he designed and had Gilly Mathewson make a machine to knit the wool stockings he wore with the cycling knickerbockers which had given him the powder-yard nickname of Short Pants. Alfred's inventiveness extended to the field of music. For his Montagnana violin (Montagnana was a pupil of Stradivarius) he designed an adjustable bridge, now widely used.

He bought a hunting hideaway called Cherry Island, in the Little Choptank River, an estuary indenting the eastern shore of the Chesapeake, ten miles from Cambridge, Maryland. One reached the isolated place by way of the Choptank River Line which operated from Baltimore two little old side-wheel freight steamers, called the Joppa and the Louise. When the line was about to discontinue on account of slack times Alfred bought the two boats, reorganized the business, and sold it at a profit to the Pennsylvania Railroad. This was done not primarily to make money but to preserve a communication with the Choptank. With Cherry Island had gone its two inhabitants, Jim and Araminta Cook, slaveryborn darkies. They occupied three of the four rooms of a shack that stood on the place. The other contained accommodations for Alfred and his guests-six or eight cots, a plain board table to eat on, and a rack of guns and fishing tackle. "Aunt Middy" did the cooking, except for the coffee which, with the air of a connoisseur, Alfred percolated over an oil lamp.

A typical week-end party at Cherry Island would include "Cap" (Theodore) LaMotte, a cousin whose military title derived from the militia; Wallis Huidekoper, a young Philadelphian; Gilly and Frank Mathewson, and "Caz" (Cazenove) Gardner, Bessie's likable brother who was always ready for anything except work. Alfred had given him a couple of jobs in the yards, but he would not keep them. To navigate the waters about Cherry Island, Alfred, in consultation with Edison, built the Jim Cook, said to have been the first boat operated by electricity. The source of power was 
chlorine cells. The Jim Cook was succeeded by a craft driven by storage batteries, which a friend of Alfred's ran to Philadelphia where it created quite a stir in boating circles. ${ }^{4}$

Like Caz Gardner, Louis duPont drank too much on occasions. This worried Alfred. Louis' intellectual gifts had engendered high hopes in the breast of the older brother. Though much had occurred to dim these expectations, Alfred clung to the belief that Louis would outgrow his foolishness.

The month that Alfred and Bessie were married Louis had attained his majority. Collecting his legacy, he began, according to the saucy Wilmington Journal, to achieve a reputation as "the only swell in the DuPont family." One visible effect of this behavior was on Louis' career at Yale. Originally in the class of '89, he dropped back into the class of ' 90 and then into the class of ' 9 I.' Louis' third successive senior year at New Haven was sketchy. The young man's sense of balance seemed gone. After a succession of brilliant recitations he would disappear for two or three weeks. Like a pendulum he swung between periods of high spirits, attended by displays of sparkling wit, and intervals of uncommunicative moroseness. Failing to graduate in I89I, Louis attended the Harvard Law School for a year, after which the pretense of study was given up. Louis passed much of his time in gay company in New York. Late in November, 1892, he turned up at The Swamp in time to attend an assembly of the smart Wilmington Club. In a lively mood that night, he seemed to enjoy himself immensely.

At three-thirty on the afternoon of December 2 he entered the club. Young Willard Porter spoke to him about the next forthcoming dance. Louis said that he could be of no help, that he was going "a long distance away." Half an hour later a shot was heard in the club library. A colored servant found Louis slumped in a chair in front of a writing table. A pistol was on the floor beside him, a bullet in his head. The nearest doctor was called. He pronounced the young man dead.

Thus the last of the orphans, save Alfred, took his leave of 
Swamp Hall. A mystery was made of Louis' death which survives in legend today. It was said that a Negro servant of the club shot him. It was said that he took his own life because he knew too much about the enigmatic end of a Wilmington working girl who had been found shot in a lane near the city. It was said that he was hopelessly involved in a love affair with a married woman of Wilmington, and, just before shooting himself, had written Alfred about it and that this letter had been intercepted by an attorney who was a part of the social milieu at Swamp Hall.

The first surmise is impossible and the second unlikely-as is the detail of the suicide note in the third surmise. Willard Saulsbury, who had received his legal training in the office of Victor duPont, represented the family at the coroner's inquiry. It seems clear that the only writing of Louis' found in the Wilmington Club was an unfinished note to a friend, possibly a schoolmate, and had no bearing on the problems which had driven the young man to selfdestruction. ${ }^{5}$

As in the case of Maurice's marriage, the smug elements of the DuPont family resented the public notice poor Louis had brought upon their name. Loyal to the memory of his brother, Alfred resented this resentment.

Before another year was out the tenderly guarded amour-propre of the clan received another wound. This time the principal actor was no erratic schoolboy. William duPont, the president of Repauno, went to South Dakota and divorced his wife, May duPont, who was also a cousin. This was the first divorce in the history of the DuPont family. Then William married fetching Annie Rogers Zinn, a divorcee of near-by New Castle, Delaware, with whom his name had been associated in gossip. Next, May duPont married Attorney Willard Saulsbury who had acted for her in William's divorce proceedings. William duPont was placed under a family sentence of excommunication. He resigned from Repauno and with his new wife took up the life of a country squire in Virginia. Alfred did not forget that it was William duPont who had made possible his attainment of a partnership in the firm. He called the family ostracism unjust and contended that his cousin's private life was his own affair. ${ }^{6}$ 
While William's and May's domestic drama was unfolding, word came from Louisville of the sudden death of Alfred Victor duPont-Uncle Fred, late guardian and steadfast friend of the Swamp Hall orphans. Louisville mourned the loss of its richest and most public-spirited citizen. In solid pages of type the local newspapers recounted the virtues and the quaint eccentricities of the deceased, whose body was brought to the Brandywine for burial. Here was a DuPont-respectable, respected, rich and frugal -whom the proud feudal family could truly honor. The luster his freshly recapitulated merits shed upon the name did something to obscure the memory of recent disagreeable family occurrencesuntil the Cincinnati Enquirer appeared with a three-column article giving the true history of the honored man's passing.

It appeared that Fred duPont had not died in the palatial home of his brother, Bidermann, as a result of an unexpected seizure, but had been shot in the fashionable fancy house of one Maggie Payne. Louisville papers, including Henry Watterson's CourierJournal, indignantly disputed the Enquirer, though that journal's account was clear, detailed and convincing. Copies sold for $\$ 5$ each on the streets of Louisville.

Alfred had not had to depend on the Enquirer for the truth. Coleman duPont, who came on for the funeral, had played an important role in trying to cover up the murder. Ostensibly, neither the family nor the Kentucky authorities ever abandoned the story of a natural death. There was no arrest or attempt at prosecution. According to the accounts related years later by older members of the family, Uncle Fred was shot by a woman in the heat of a quarrel over a financial settlement for the benefit of their child. If that is true Fred duPont's mistress displayed an imperfection of judgment. Though he believed that the young should be taught the value of a dollar, we have the testimony of Alfred, Pierre and other of his wards, that Fred duPont was one of the wisest counselors youth could find.

The busy yards were Alfred's principal refuge from these vexations and from the increasing friction of his own domestic life at 
Swamp Hall which, in his pride, he managed to conceal from all but the sharpest observers. He was often at the works at six in the morning, to spend an hour or so before returning home to eat breakfast and tumble on the nursery floor with his little daughters until the shouts of father and babies rang through the house.

Then to the yards again, where the stream of tasks and problems flowed as unceasingly as the waters of the Brandywine. A day's inattention, and problems would back up and accumulate as the Brandywine's waters backed up when the dam gates were closed. By unremitting labor the losses from disaster during the calamitous year of 1890 were made good.

The company had bought a large tract of land at Carney's Point on the Delaware opposite Wilmington and begun the erection of a guncotton plant for the manufacture of torpedoes for the Navy. The idea was that this site should also serve for the making of smokeless powder whenever the DuPonts found a satisfactory formula-either as a result of their own inventive efforts or by purchase. The formula was found by their own efforts. Frank duPont drew his young cousin Pierre into collaboration in the experiments he had begun in the laboratory on the grounds of his home and in 1892 they took out a patent on their process. A plant and a laboratory for continued experimentation were erected at Carney's Point and in 1894 DuPont put the first American-made smokeless powder on the market, for use in shotguns. Pierre left the Brandywine yards for Carney's Point, under Cousin Frank, to devote all his time to the improvement of the new product. The result was a smokeless powder which in 1895 the Army found fairly satisfactory for artillery and, with further refinements, for infantry rifles. Though still short of what the Army desired, this smokeless powder excelled the French and the Belgian products, opening the way to the greatest advance in the powder-making art since Pierre's father had invented soda blasting powder in 1857 .

The development of smokeless powder for the Navy followed another course. On the Navy's insistence in 1889 DuPont had acquired the Belgian formula which produced a product so inferior that it was never used. During the next few years the Navy had depended more on its own devices for the development of a satis- 
factory smokeless powder than on private industry. The experiments were conducted at its Torpedo Station at Newport, Rhode Island, where small quantities of the explosive were made and tested. Progress was slow and for regular service use the Navy employed brown prismatic powder, in the manufacture of which Alfred duPont had achieved great success. This achievement surpassed the expectations of Cousins Eugene and Frank who had opposed the acquisition of the Belgian formula, even with the Navy paying the royalties. Alfred's accomplishment was largely due to the improvements he, himself, had wrought in brown-powder machinery. These included the invention of a new type of press. This machine was later adapted for use in making black powder. It was regarded as the safest press ever devised. Old powdermen say there is not a case on record of one blowing up.

With the retirement of William duPont from the presidency of the Repauno Chemical Company, management of the DuPonts' high-explosive business passed into the hands of two exceptional men, J. Amory Haskell and Hamilton M. Barksdale, with a consequent improvement of earnings.

In these ways the disasters of 1890 were further repaired and expenditures incident to launching Carney's Point and to the modernization of the company's administrative structure were discharged with amazing promptness. Profits rolled in faster than ever before. The bulk of them came from black powder, the production of which on the Brandywine became Alfred's particular responsibility. When Cousin Frank took charge of Carney's Point, he retained the title of superintendent of the Hagley and the Lower Brandywine Yards, but gave over to Alfred most of the authority for their actual operation. Cousin Frank would meet Alfred and the foremen at seven in the morning, check the work in hand and leave for Carney's Point. What happened after that was largely up to Alfred.

He succeeded brilliantly. Though improvements had been made in the course of the reconstruction after the Great Explosion, the Brandywine yards no longer could be called up-to-date. They rep- 
resented the slow growth of ninety years rather than a first-rate engineer's starting-from-scratch conception of what an efficient powder plant should be. Particularly was this true of the Hagley and the Lower Yards which were under Alfred. There was too much crosshauling of materials. Instead of moving in a straight line, beginning with the assembly and preparation of raw ingredients and ending with the finished product, the manufacturing process zigzagged and backtracked, resulting in a great waste of effort. Sulphur, soda, saltpeter and charcoal were carried from the far end of the Upper Yard to Hagley Yard to be worked, then hauled back for storage in the form of powder. The Upper Yard contained only two grinding mills, which was far short of needs. The narrow Brandywine shelf afforded room for no more. Consequently most of the Upper Yard's black dust was hauled in the horsecars to Hagley for grinding and then taken back for the other processes.

Under these conditions Alfred turned out as good powder in the same time and at no more cost than was produced in up-to-date plants, including those owned by DuPont elsewhere. The secret was in his skill as a powderman, his incessant energy and above all his mastery of the variable human equation. An up-to-date yard indifferently manned can turn out no more work than an out-ofdate yard expertly manned. Alfred fired the Brandywine working force, competent to begin with, with an esprit de corps which generated a positive enthusiasm for its tasks and for its boss.

The new office building on the hill contained a room for Alfred. He was seldom in it, and the clothes he wore would have been out of place there. Alfred's real office was a room containing a chair and a rough board table in a little stone building near the Hagley Yard machine shop. He did not spend much time there either. Short Pants did not run his yards from a desk. In a rough shirt open at the throat and dirty cycling knickers, he was everywhere in the works every day, keeping green the belief that he could take over on the instant any job in the yard and do it better than the man assigned to it. Yaba Buchanan had charge of the Corliss engine which turned the dynamos. Alfred would take a shovel from an inexperienced fireman and show him the particular twist to give 
the handle to distribute the coals evenly over the fire. "Slick as grease, ain't he?" Yaba would say admiringly after his old playmate had departed.

The superintendent's manner with his men was businesslike and sometimes brisk to the point of abruptness. New men mistaking this for harshness soon learned better. Alfred encouraged directness on the part of the men in their dealings with him. He could spot servility in a minute. He listened attentively to dissenting opinions from foremen, then made a ruling which might or might not have been influenced by what a subordinate had said. But whatever the ruling, it was to be obeyed to the letter, Alfred assuming all responsibility. It went without saying that when a new mechanical contrivance was tested with explosive ingredients or a mill restarted after an overhauling, Alfred followed family tradition by taking the post of greatest danger.

The character of the yards' personnel was changing a little. A trickle of Italians was filtering in. The Irish resented them. Alfred studied these Italians closely. He learned their broken dialect and, in his intercourse with them, used it without cracking a smile. $\mathrm{He}$ began to incline to the opinion that Italians might prove temperamentally better suited for powder-yard labor than the Irish. This judgment showed a scientist's disregard of personal preferences. In boyhood Alfred had developed a sentimental attachment for the Irish which lasted to the end of his days.

The Italians were fatalists and, like the Irish, Roman Catholics. Alfred believed the Catholic religion ideal for a powderman. Unlike the Irish, Italians drank wine and rarely turned up with Monday morning hangovers.

"Moreover, an Italian will do what he is told," Alfred reported to his partners, "whereas an Irishman is apt to get to "thunkin" of some way to do it better. When an Irishman on a powder line gets to 'thunkin' 'it's time to begin to look for him on the other side of the creek."

Alfred would have liked to talk to his partners of other things affecting the larger aspects of the company. He would have even 
been willing to use the neat office provided for him on the hill had he been given anything to do there. And Alfred imagined there were many things he could have done. Much as the administrative setup of the company had been changed since Boss Henry's passing, Alfred believed further decentralization possible and desirable. To this the senior partners would not listen. They ran the company as it had always been run, with the elders in control. Alfred's business was to make good black powder as cheaply as possible, and to leave other company affairs alone. Was not his io per cent share of the profits making him a rich young man? It was: especially since in the settlement of the late Uncle Fred's estate Alfred's \$100,000 debt had been forgiven-the 7 per cent note on which he had punctually kept up the interest canceled without payment. Cousins Eugene and Frank took the position that young Alfred was doing well enough and that the company was doing well enough as matters stood. Alfred could not help but reflect that, if he treated his foremen as the senior partners treated him, he would have no working force in the yards worth the name. His words having no weight at the council table, Alfred ceased attending the formal meetings of the partners.

He used to air his complaints to Pierre who admitted the justice of them, but thought that his cousin helped the situation none by continuing to rub the fur of his elders the wrong way. Though Pierre chafed under restraints similar to those which irritated Alfred, he seldom made a fuss about them. Pierre duPont had a great deal of tact; Alfred almost none. Both young men watched with certain heartburnings the rise of their Cousin Coleman in the West. In the extensive holdings of the late Uncle Fred, Coly had fallen heir to a world of enticing opportunities for a young engineer. He was making the most of them: advancing fast on his merits, there being no hidebound family elders to frustrate or to hold him back.

Alfred thought the policy of his Cousin Eugene shortsighted and stupid. Who should run the company of the future-and the nottoo-distant future, Alfred thought-if the young men were not given a chance to show what they were made of? Often Alfred thought of going on his own-as his guardian, Uncle Fred, had 
done-and showing up the whole Brandywine bunch. But the very things that made his life miserable with the company kept him working for it. He had been born within the sound of the Brandywine yards' turning wheels. His heart was there, and somehow he felt that one day his chance with the old company would come. Restless, impatient and increasingly unhappy-the unhappiness not arising from business perplexities solely-he stayed on. 


\section{CHAPTER VII}

Discord in Swamp Hall

IN THE spring of 1897, "John J. Brown,"1 construction engineer, was seated in his office in New York City when the telephone rang.

"This is Alfred I. duPont," abruptly announced a voice. "May I come and see you?"

Mr. "Brown" was not acquainted with the DuPonts, but he had heard plenty of them-who had not?-as a result of the fantastic political warfare between Colonel Henry Algernon duPont and John Edward O'Sullivan Addicks over a seat in the United States Senate. Neither did "Brown" know Addicks, although he was building a gas plant for him, and hoped for other work. It was profitable employment, and "Brown" was a young man just starting out. He particularly did not wish to become tangled in Addicks' political battles. The engineer asked Mr. duPont the object of his proposed call.

"What difference does that make?" said Alfred.

This increased "Brown's" suspicions. It might make considerable difference, he said. For example, he was not interested in Delaware politics and did not care to discuss them.

Alfred replied that he had not come to New York to talk politics. "This is an engineering matter." With some misgivings "Brown" consented to an interview at his office.

The Addicks-duPont affair had become the biggest show in national politics. "Gas" Addicks' introduction to public life had been as a ward heeler for the Republican machine in Philadelphia, Tammany Hall's only rival for corruption in municipal politics. When Addicks got in the illuminating-gas business, his apprentice- 
ship served him well in the matter of obtaining franchises from city governments. Gas plants which the ex-ward heeler built in Boston, Brooklyn, Jersey City and Chicago brought him millions, and also the conviction that a judicious expenditure of money would gain any prize within the gift of politicians. Addicks decided, in his case, the gift should be a seat in the Senate from Delaware. Then a resident of Boston, the gas magnate qualified as a citizen of Delaware by boarding periodically with a good-looking widow in the hamlet of Claymont, near the Pennsylvania line.

In 1888 the Republicans had won control of the Delaware Legislature, which meant that they would send to Washington the first Republican Senator in the State's history. A hubbub of speculation awakened the drowsy colonial village of Dover when the Legislature convened there to make its choice. Wearing a silk hat, a flashing stone in his cravat and a fur-collared overcoat, Addicks descended upon this scene attended by three professional fixers who handled his political matters in Boston and in Philadelphia. But despite this practiced company, the Legislature elected Anthony Higgins to the Senate. Addicks immediately began preparations for 1895 when the Senator's term should expire. In the election of 1892 the aspirant spent \$roo,00o and virtually got control of the Republican organizations in two of Delaware's three counties. In I894 he spent \$140,000, and nineteen Republicans were elected to the Legislature, leaving the Democrats with only eleven seats. Sixteen votes would make Addicks a Senator. However, when the Legislature convened only six of the nineteen Republicans came out for Addicks. Ten were for the re-election of Higgins.

Addicks felt that this was enough to try one's faith in human nature. He had bought the Republicans their victory and now they wouldn't deliver the goods. But the ambitious office seeker meant to have that senatorship, no matter what the cost. Ten thousand dollars apiece was offered for the needed votes. The offers were declined. Addicks' pay-off men scratched their heads. "Damned queer," said one. "In Boston Mr. Addicks can get all the men he needs for \$5000 a throw."

Addicks thereupon changed his strategy, deciding to hold his six in line and deadlock the Legislature. "Me or nobody" was his 
defiant slogan. After four months of battle, Senator Higgins said he would withdraw in favor of a compromise candidate, but Addicks refused all offers of accommodation. "Me or nobody." The psychology of the situation called for a switch to a brand-new man to oppose Addicks-a man of unexceptionable character and reputation; if possible, a figure new to politics, with no partisan obligations. Higgins believed he had hit upon just such a candidate when he announced that Colonel Henry Algernon duPont had been persuaded as a public duty to permit his name to go before the Legislature.

It had not taken a great deal of persuading. Twenty years before, Colonel Henry had entered the powder firm from a sense of family loyalty, though preferring the prestige of the profession of arms. He had proven an energetic, forward-looking and reasonably able partner who had the courage to oppose some of the arbitrary notions of his father, Boss Henry, and latterly to support the attempted innovations of young Alfred I. But as a man of business the old artilleryman had never been happy. The chance to defeat the outrageous pretensions of Addicks and to enter the United States Senate at one swoop came as a welcome release and surprise.

The Colonel journeyed straightway to Dover to take nominal command of the forces of righteousness. He was a fighter who looked the part. At fifty-five, his carefully trimmed imperial was touched with gray. His bearing was erect and distinguished, his manner formal without coldness, his glance forthright and fearless: comprising, for all of twenty years of civilian life, an engaging likeness of a weathered old soldier.

The effect of the Colonel's appearance in Dover was salutary. Two of the six deserted Addicks' standard, and the vote stood: duPont 15; Addicks 4; Democrats 1 r. One vote more for duPont or one vote less for Addicks or for the Democrats would carry the Colonel in. It seemed that this had come about when the Governor of the State died and William T. Watson, Democratic Speaker of the Senate, succeeded to the executive chair. The lineup was: duPont I5; opposition I4. But before the legislators could assemble and register that vote, Addicks got Governor Watson to return to the legislative chamber and cast his ballot with the opposition. 
After the resulting tie had endured for thirty-five ballots Governor Watson, acting also as Speaker of the Senate, adjourned that body sine die. Whereupon the DuPont forces got the Speaker of the House to rule out Watson's ballot and to declare the Colonel elected Senator.

Addicks carried the battle to Washington. When Colonel duPont presented his certificate of election to the Senate, it was challenged. Skilfully exploiting the division in Republican ranks over the question of Free Silver, the gas man maneuvered the Senate into a refusal to seat duPont by a vote of 31 to 30 . The "me-ornobody" banner had triumphed. One of Delaware's seats in the chamber of the United States Senate remained vacant.

The old soldier whose lapel bore a rosette of the Congressional Medal of Honor was not the man to take lying down a defeat of that stamp. Declaring he would seek vindication at the polls from the hands of the people of Delaware, Colonel duPont plunged into the practical work of party organization. Addicks did the same. Crisp currency from the gas magnate's Boston bank appeared like a shower of leaves in autumn. Not since the days when it had taken a thousand dollars in Continental scrip to buy a pair of boots had Delaware seen so much money in motion. ${ }^{2}$

This was the state of affairs in 1897 when "John J. Brown," the New York engineer, sat dubiously awaiting the arrival of Alfred I. duPont who had introduced himself over the telephone. He need not have been uneasy. His caller turned out to be an affable, attractive man, who quickly effaced the impression of brusqueness left by his telephone conversation. The engineer got a start, however, when after the pleasantries of introduction were over, Alfred duPont asked:

"Do you believe in God?"

"Well," replied "Brown," "if it is pertinent to our conversation I'll ease your mind by saying 'Yes.'"

Without another word Alfred plunged into the subject of his visit. He wished, he said, to build a house-a home for his family. 
He had some ideas of his own, he said-the type of house he wanted, and the kind of grounds-landscaping, planting and so on. But he wanted to go over the whole subject with someone else and see what their joint consideration might produce. Alfred talked of his two daughters and "Brown" gathered that his affection for them had a good deal to do with his plans for an estate. Alfred was in a talkative mood that day, or perhaps the presence of an imaginative young man like himself inspired his reflections. Suddenly he left off the discussion of plans for a successor to The Swamp to speak of the DuPont Company. They should double the size of the laboratory, he said, and fill it with a corps of alert chemists who would set to work exploring the mysteries and the potentialities of chemicals that were thrown away as waste in the manufacture of explosives. Moreover, he thought they ought to look into the possibility of extracting nitrates from the air, thus freeing the powder industry from dependence on Chilean nitrates. This, said duPont, might one day be a factor vital to the security of the country in time of war.

An hour passed quickly. Young "Brown" was thrilled. In Alfred I. duPont he was sure that he had met an exceptional personage: a practical man of science living in advance of his time and exhibiting the temperamental vagaries of genius; a man whom he hoped to see more of.

When Alfred returned to the subject of a house, "Brown" readily accepted an invitation to run down to Wilmington and inspect sites.

A fortnight later the two met again as old acquaintances. Alfred was in high spirits. Driving out the Kennett Pike, which had been bought up by the DuPont Company, Alfred had a bantering jest for the tender of the tollgate who nodded him past the barrier. They stopped at Hagley Yard.

"Got a match ?" duPont suddenly asked his visitor.

"Brown" said that he had.

"Then let's get the hell out of here. This is no place for a man with matches."

Crossing the old covered bridge which spanned the Brandywine at the foot of Rising Sun Lane, they entered the rolling, sightly 
farming country east of the stream. Three farm properties were looked over. Each site Alfred had in mind for a residence consisted of an elevation, far from a main road, giving a view of the surrounding country. In one case an adjoining farmhouse marred the view.

"I could put a bank of trees in front of that," said duPont.

Driving from place to place, Alfred talked again of the company and of his ambitions for utilizing wood-tar waste.

"But first," he said, "we must have that laboratory to find out what can be done with wood tar."

At the property last visited duPont stood for a long time on the spot he had chosen for a house, surveying the pleasing panorama of woods and fields. In the distance the hills marking the western shore of the Brandywine were dotted with the homes of other DuPonts.

"I'm talking about this," said Alfred in the abstracted way of a man thinking aloud, "as if it would all come to pass and bring me what I want. It would cost a lot of money. I have the money; plenty of money. But will it buy happiness?" The speaker turned to his companion. " 'Brown,' I'm not a happy man," he said. "My home life is not happy." Alfred fixed his keen blue eyes on the engineer. They looked lonely and sad. After a pause he spoke briskly: "Ever have any trouble like that?"

The astonished "Brown" said no, that he was a single man:

On the drive back to Wilmington Alfred's high spirits had ebbed.

"I can't make up my mind which property to build on. I'll think about it some more and let you know."3

Many of us have had the restoring experience of confiding to a virtual stranger things we would withhold from friends. On no other basis can one explain Alfred duPont's singular revelation of a spirit tormented by domestic infelicity to a man he had seen only once before in his life. Though Alfred said nothing to the men 
he had known from childhood, the rift that had come between the master and mistress of Swamp Hall was no longer a secret on the Brandywine. Secrets of that nature were hard to keep in so compact a community. In the powdermen's stone cottages the fact that Alfred's brother and sisters did not come to stay at The Swamp was noted and remarked upon, with a correct diagnosis, in general terms, of the cause.

About the time that Bep was born, Marguerite had journeyed from Washington to spend a week. The spirited girl had grown into a spirited woman. Having come for a week, Marguerite remained a week, after which she said that her sister-in-law's behavior had been so rude that she would never go back. Nor did she. Marguerite related the experience to Annie. Annie, who had been mistress of Swamp Hall at seventeen, declared that she would never go there to stay again. Of all the Swamp Hall orphans Maurice was the most even-tempered and easy-going. His wife, Margie, said she had never seen him angry except at Bessie's conduct toward Alfred. This ended Margie's and Maurice's sojourns at The Swamp, though when visiting Wilmington Margie, after much persuasion on the part of her peace-loving husband, consented to drive out for short calls.

Ellen LaMotte, the young cousin to whom Alfred had opened his home, had changed the favorable opinion she had first entertained of Bessie. Later she was to testify that "frequently" she had seen Alfred "leave his own table to save a scene and escape the direst humiliation." Distressed by the way things were going, Ellen remonstrated to Bessie over the "mental anguish" her "studied" behavior caused her husband. These overtures failing, Ellen packed her belongings and left. ${ }^{4}$

Proud and sensitive, Alfred felt the weight of this isolation. He knew the Brandywine community well enough to realize that his family troubles provided tittle-tattle for every cottage under the hill. He grasped at a straw.

A new home on a distant slope across the creek might mean a fresh start, recapturing the felicity of his and Bessie's early life 
together and restoring, by some magic, harmony to a home in which daughters were becoming of an age to take account of things. At any rate it would remove from under the eyes of the men with whom he had to work every day the spectacle of a house divided.

The men with whom he worked were weaving the saga which has made Alfred I. duPont a legendary figure to their children and their grandchildren.

John Thompson, a rawboned, Dublin-born six-feet-twoer with a sandy beard, stoked a charcoal furnace. He was Alfred's expert on turning dry wood into brown charcoal for brown powder-a job that had to be done just so.

"Know what I seen Short Pants do?" said John Thompson, spitting reflectively. "Well, he comes on to a pushcar with its truck off the rails. There was a light load-a ton of sulphur aboard, I'd say; and four or five men who had been straining to get her back on the track had given up and one of them had gone to fetch a length of shafting to make a lever.

"'What's the matter?' says Mr. Alfred. 'You don't need no leever.'

"Just then Mike Maloney comes along. Mike Maloney was a blacksmith and he beat the bass drum in Mr. Alfred's brass band. 'Maloney,' says the boss, 'I want a man, just one good man; and you're it.'

"Him and Mike shifts the load in the car a little, so as to set up a sort of counterweight. Then they puts their shoulders under the bed of the car. 'Heave-o,' grunts Mr. Alfred, 'heave-o an' heave,' and that truck was back on the rails.

"Yes, sir, that was Mr. Alfred in the old days at Hagley."

Yaba Buchanan speaking:

"I come on Mr. Alfred when he was jawing with Mr. CharleyMr. Charley who was Mr. Victor duPont's son, and who was boss of the Upper Yard like Mr. Alfred was of Hagley and the Lower. They were testing the brown powder in a six-inch gun up in the meadow on the hill near Boss Henry's old house. 
“' 'Trouble with you, Charley,' Mr. Alfred was saying, 'was your bringing up. You didn't have to hold your own with a gang of tough kids like I did when I was a boy.'

"Then Mr. Alfred looks at me and says, 'I held my own, didn't I, Buchanan?'

"'I know one time it took about all you had to hold your own,' says I.

" 'Who was that with?' says Mr. Alfred.

" 'McMahon,' says I.

" 'You're right, Buchanan,' says he. 'Toughest fight I ever had.' ", Matchie McMahon visited his old stamping ground every winter to reap rewards of a renown which rested not alone on his reputation for having held his own with fists against $\mathrm{Al}$ duPont. Matchie played baseball with John McGraw's famous Baltimore Orioles. Nine years a professional, he was still one of the best pitchers in the game and the idol of the American boy. His record for 1890 had landed Matchie among the mound's immortals. For the Philadelphia Athletics he pitched fifty-six games that season, winning forty-three.

John W. (Willie) Macklem, pioneer typist for the DuPont Company, still knows his keyboard. The ensuing incident is presented as he tapped it out:

"Repairs were necessary at the Refinery Engine Room. A mechanic from Wilmington was doing the work. Mr. Alfred came along, hands and face more or less black with powder dust. He was dressed in a corduroy suit of Norfolk style, belt hanging loose, and red stockings. Peering in at the workman, he stated:

" 'That's not right.'

"The workman, losing his temper somewhat (he did not know Mr. duPont), crawled out from under the job and asked:

" "What in the hell do you know about it?"

"Mr. Alfred responded: 'Fourteen hours and two meals per day,' and kept on going."

The two meals a day is a piece of accurate reporting on the part of Mr. Macklem. Mr. duPont went on periodical diets-sometimes to keep down his weight, sometimes as a matter of self discipline. "Never form a habit, good or bad," he told a young cousin, 
Victor duPont. "The fact is, Vic, there isn't such a thing as a good habit. All habit impairs will, initiative and free agency."

William F. Lynch, boss steam fitter and plumber:

"Mr. duPont-I think I was the only man in the yards who called him Mr. duPont-Mr. duPont liked a man who would speak up and give his opinions but when a thing was settled and decided on he wanted it done according to orders. He was strict about that and if it turned out wrong he would take the blame and not try to pass it off on one of the hands like many a boss that every workingman knows of.

"Mr. duPont come to me and says, 'Lynch, can I get water in my house for bathing?'

" 'You got water,' I says.

“ 'Got mud,' says Mr. duPont, 'got mud.'

"He was referring to the water from the Brandywine which was pumped into a big tank on the hill for fire protection. It also supplied Miss Mary duPont's house and The Swamp.

"He says he wants artesian wells. We look things over and decide where to put the wells and where to put a thousand-gallon tank on the roof of his house. Then Mr. duPont goes on a trip. I drive eight wells but when I got to put up the tank I see the rafters won't stand it. So instead of one thousand-gallon tank I puts two five-hundred-gallon tanks where the stone walls will take the weight.

"When Mr. duPont comes back and sees them he just blows up. Orders is orders. In a fury he goes to work and refigures the stress on the rafters. Pretty soon he comes back, mild as milk.

" 'Lynch,' he says, 'where did you go to college?"

" 'Not at Boston Tech,' says I, feeling pretty good."

And so runs the legend of Alfred I. duPont.

The banks of the Brandywine were alive with the children of powder workers. One encountered them playing even in the yards after they had carried dinner pails to their fathers. Before entering a yard gate a youngster submitted his shoes for examination, and 
no footgear with nails in the soles was admitted. Beside the lower gate to Hagley was always a row of scuffed little shoes whose owners were inside, barefoot.

All the children knew Mr. Alfred, who could call most of them by name. His trousers' pockets jingled with pennies which found their way via small hands to the counter of Peggy Dad's little store at the foot of Breck's Lane where a striped stick of candy could be had for one cent and a dish of ice cream for two. Another delicious tidbit was half-smokes, a sausage about the size of a hot dog. A butcher sold them from a cart. Once Mr. Alfred bought the vendor's entire supply and distributed them among a squealing mob of children.

On his bicycle, on horseback or on foot, the superintendent passed along the Creek Road several times a day going from Hagley to the Upper Yard or to the Lower. There was always time to tarry a moment to watch the boys swimming in the Brandywine and to offer criticisms on the form of their strokes and dives; to referee a fair fight; to cheer the current Down-the-Creek hockey team in its perennial tournaments with the Up-the-Creekers; to join hilariously in a snowball battle.

Frank duPont had built a school at the corner of Breck's Lane and the Kennett Pike, donating it to the school district of Christiana Hundred. One day Alfred saw Yaba Buchanan's small boy, Bill, and another lad rolling in the dust of the Lane, fighting for dear life. John Conly, stonemason boss and a member of the Christiana Hundred School Board, was passing on his way to work.

"Conly," said Alfred, "isn't there a kindergarten in that school?" Conly said not.

"Then there's a job for you," said Alfred. "Start one."

Alfred footed the bill. ${ }^{9}$

When the epidemic of typhoid swept through DuPont School, Alfred took charge of the situation. Engaging two physicians he told them to spare nothing to save the children. To the little patients went ice from the ice machine in The Swamp's cellar and delicacies from its larder. The whistle in Hagley Yard was stopped from blowing. During anxious days and nights many a candle was 
lighted in St. Joseph's Church and many a prayer said in which Alfred duPont was remembered for his good deeds.

The children all recovered. One of them has related to this writer:

"It came so that in times of trouble there was a saying in our house, 'Send for the priest and Mr. Alfred. "'10

This circumstance afforded the rector of St. Joseph's and the yard superintendent a chance to become well acquainted. Father William J. Berminham was a credit to his exalted calling. After a summons to an abode of affliction, the priest and the powder maker would often walk away together, deep in earnest talk. The bond between them grew. Brandywine Catholics in overalls and in calico looked on approvingly, proud in the hope that the consolations of the true Church (with its unrivaled institution of the confessional) might sooth the distressed spirit of their friend and benefactor. ${ }^{11}$

Two survivors of the typhoid epidemic were Madeleine and Bessie Deery, named for Mr. Alfred's little girls. Their father, Charley Deery, had gone to work in the yards as a boy when his father had had the sight of his eyes destroyed by an explosion. When the children were all well, two women cousins of Alfred started a sewing class for the workers' girls which met on Saturday mornings in the Green Hill Presbyterian Church. One Saturday Charley Deery was running a charge in a glazing mill when Alfred said in a solemn tone:

"Deery, I'll have to speak to Father Berminham. A pretty note, your turning Presbyterian."

Then he walked off.

At noon Charley Deery rushed home to his wife.

"Kate," he said, "that sewing circle-l'll have no turncoats in this house."

Kate wanted to know what in heaven's name her husband was talking about.

"I said no good would come of Madeleine and Bessie going inside a Presbyterian Church. Now see what's happened: Mr. Alfred's heard about it."

That evening when the superintendent emerged from Hagley Yard, Kate Deery was at the gate. In plain speech the Irishwoman 
vouched for the safety of the souls of her daughters: they were going to the Presbyterian Church only to learn to stitch. Mr. duPont said he was much relieved. He promised to allay Charley's fears and to see that the girls' needlework was not interrupted. ${ }^{12}$

Alfred had not outgrown his love for fireworks. Each Fourth of July was made memorable by a display, primarily for the entertainment of his daughters, which all the Brandywine and a good many sightseers from Wilmington would gather to see. The exhibition was staged on the east bank of the Brandywine and for a quarter of a mile the bluff on the western bank was peopled with onlookers.

On Halloween he paid a fancy ransom to protect The Swamp from depredations. The hall downstairs was loaded with candy and cakes. On a table sat a bowl filled with small coins. Any child could come in and help himself.

But the surpassing event was the annual party on the night before Christmas Eve. The preparations extended over a fortnight. Mrs. duPont sent out the invitations in the names of Madeleine and Bessie. She bought a hundred children's gifts at Schwarz's in Philadelphia. The orchestra's hall in the old mill at the foot of Breck's Lane was tricked out in festal array. Colored electric bulbs made the great Christmas tree a sight worth going far to see.

Powder wagons, scrubbed clean, brought the guests to the hall. In boots, beard and furs Mr. Alfred played the role of Santa Claus. There was a present for every boy and girl; a basket holding a Christmas dinner for the family of each workman in Alfred's yards; cigars and good plug tobacco for the men; buckets of candy standing around for all to dip into. The evening ended with music and a Punch and Judy show which Santa Claus would witness, half buried under the believing little ones who climbed on his lap. ${ }^{13}$

It seemed that Alfred could bring happiness into almost every household on the Brandywine except his own. And yet another trial to his spirit was in the making.

\section{6}

Mrs. Lammot duPont gave a masquerade party at which Alfred appeared as an Indian brave. Before entering the house he an- 
nounced his presence by tapping on windows, brandishing a tomahawk and uttering war whoops. The whoops changed to gales of laughter when Alfred caught sight of Victor duPont and a Mr. Morris. These gentlemen weighed three hundred pounds each. They represented Tweedledum and Tweedledee. Alfred sat in the snow beneath the window and laughed.

Next day he was in bed with a cold. The attack left him with a congestion in the head which so impaired his hearing that he could not distinguish tones sufficiently to conduct the orchestra at practice. A physician said that Alfred's nose, broken when he was a boy, would always give him trouble with his ears. This seemed borne out when a Philadelphia specialist failed to restore $\mathrm{Mr}$. duPont's hearing, though he improved it. ${ }^{14}$

This was a blow, for music had come to mean much to Alfred. On business trips he sometimes carried a violin with him and, muting the strings, would play alone in hotel rooms between conferences on black powder. He delighted in his daughters' aptitude for music. Madeleine played the piano, Bessie the violin. Nearly every evening when he was at home, father and daughters made a musical trio in the billiard room.

When his hearing failed to return to a point where Alfred felt he could do his orchestra justice, he hired James L. Dashiell to spell him as leader, Alfred taking his place in the violin section. Jimmy Dashiell was chief clerk in the Wilmington office of the Pennsylvania Railroad. He had played in the Philadelphia Symphony Orchestra. Dashiell also gave violin lessons to Bessie and to several children of powder workmen, the children paying 25 cents a lesson and Alfred, on the quiet, making up the balance. He thought the youngsters would work harder if they had to pay something out of their own pockets. ${ }^{15}$

On a trip to New York Alfred ran on to "John Brown." The engineer asked if he had come to a decision about a site for his new house.

Alfred's face clouded under a look of sadness. "No, not yet; not yet." With visible effort he shook off the mood mention of the house had precipitated. " 'Brown,'” he said briskly, "we're going to have war." 

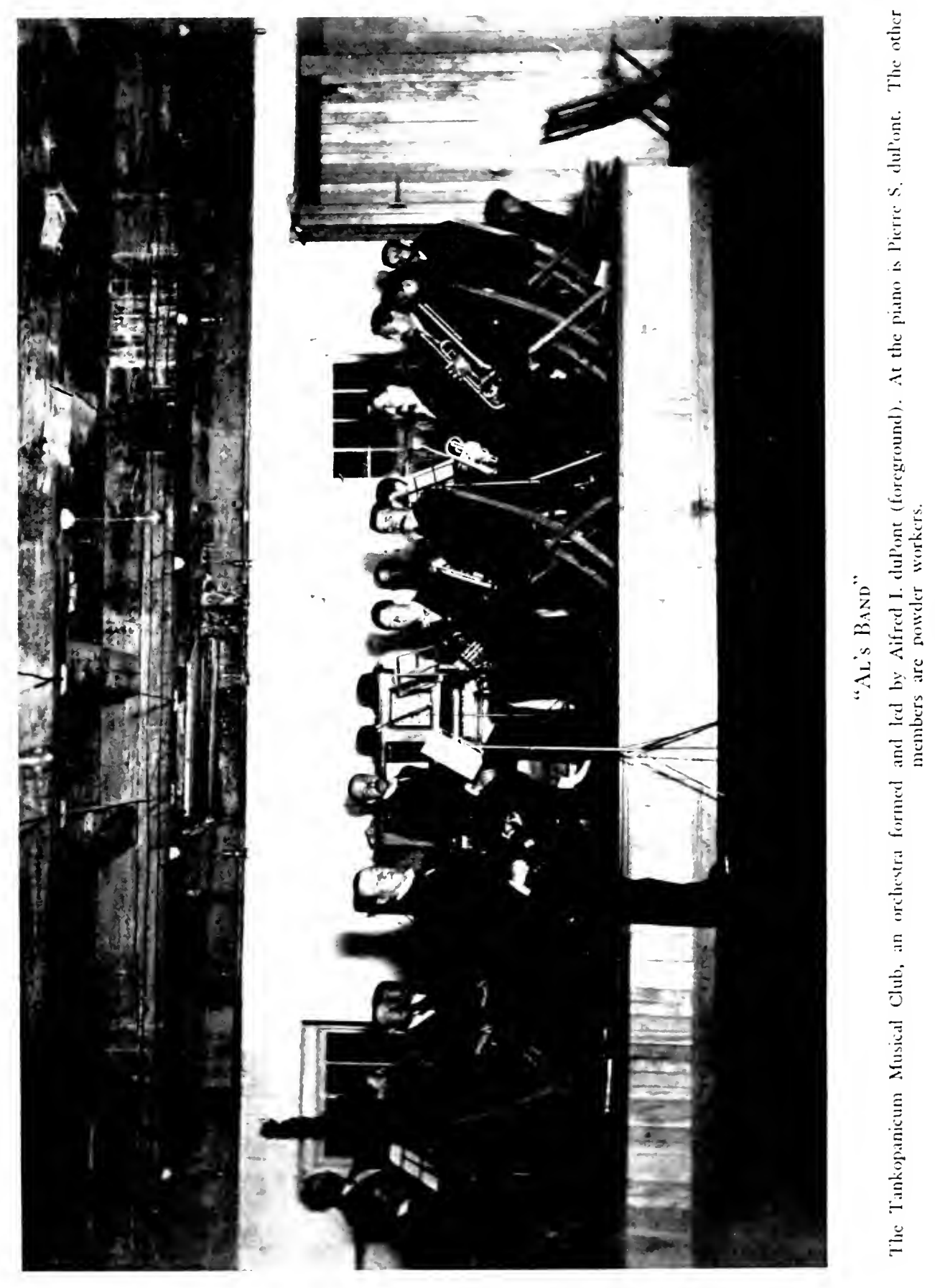

The engineer did not think so. There were too many sensible people in the country.

"Makes no difference," said duPont. "They can't stop it. The newspapers will start this war." 16

Newspapers were, indeed, doing their best. The bellwethers of jingoism, Hearst and Pulitzer, had locked horns in a battle for supremacy in circulation. They found that advocacy of intervention in Cuba's struggle for independence made good "copy." A large share of the lesser press took up the cry, painting star-spangled pictures of an American empire on which the sun should never set. 


\title{
CHAPTER VIII
}

\author{
The SPIRIT of ' 98
}

Believing hostilities near, Alfred called on the Secretary of War and volunteered his services for the field. He came away with the promise of a commission as major in the Corps of Engineers. That was how much the muddling old politician who headed the War Department knew of the state of his powder stores and lines of supply in January, 1898 .

On February 15, the battleship Maine was blown up in Havana harbor with a loss of 260 lives. Captain Sigbee cabled that "public opinion should be suspended." Although a naval commission was unable to fix responsibility, the sensational press whipped up the popular imagination with stories of Spanish treachery. While street crowds yelled, "Remember the Maine!" we declared war in April. With bands blaring Alfred's friend Sousa's "Stars and Stripes Forever," tens of thousands of young men swarmed upon the recruiting stations.

In no such exuberant mood Army and Navy ordnance officers converged upon the Brandywine to closet themselves with Messrs. Eugene and Frank duPont. The United States has always been unprepared for war. In 1898 this unreadiness constituted an especial danger. Our Regular Army, though competent, was far too small; and the Navy, the modern creation of the past fifteen years, was inadequate for the extensive coast line it had to guard. But what was concealed from the shining eyes of the masses who had hurrahed us into the conflict was the lack of powder for all heavy weapons, land or sea. There was ammunition only for infantry rifles, and not an abundance of that.

Smokeless powder had just been brought to a point where it could be satisfactorily used as the standard ammunition for big guns. 
As yet facilities for the manufacture of smokeless on a wartime scale were in the drafting-table stage. Both the Army and Navy were still discussing the large orders they contemplated placing. Meantime they were using up their surpluses of brown prismatic powder, nearly all of which had been produced in the Brandywine yard by Alfred. The only other maker of prismatic was a small mill of the California Powder Works, limited in output and located awkwardly distant from the war scene. Orders for the brown powder having been discontinued, Alfred was preparing to dismantle his machinery.

The worried ordnance officers addressed Frank duPont, head of the company's smokeless-powder works at Carney's Point. Could he make smokeless powder in quantity-ten, twenty, and thirty thousand pounds a day-and start deliveries at once? He said he could not. It would take six months to get his plant ready. After that the powder would have to dry for six months before it could be packed.

From Laflin \& Rand, from the Dittmar Powder Company, from the Giant Powder Company and from the California Powder Works came similar replies: plant facilities could not be improvised overnight.

The only alternative was to fight the war with brown powder, of which there was hardly a pound in reserve.

"You will have to supply us," the Goverment men told Frank duPont. "Alfred I. duPont is the best brown-powderman in the country."

"True," Frank replied, "but Alfred has been promised a commission in the Army. He has given us notice."

Smeared with powder, Alfred came up from the yards. Readily surrendering his military ambitions, he said he had volunteered only because he believed some member of the family should be in uniform. ${ }^{1}$

\section{2}

With its brown-prismatic-powder supply dependent largely on one man, the Government took steps to protect his plant. This proved a disappointment to the soldiers of a Pennsylvania regiment 
whose path to glory ended at the Brandywine. They spent the war walking a picket line around the DuPont works while comrades more fortunate charged the trenches on San Juan Hill and comrades more numerous, though less fortunate, died of ptomaine poisoning after eating tinned beef in Southern training camps.

The thirty-three-year-old powder superintendent flew at his task. He loved the work and gloried in the responsibility, which tapped inner reservoirs of strength and of ingenuity. He was happier than he had been in years.

Fear of a raid by Spanish sea power on the Atlantic Coast had our eastern seaboard in a state of nerves, though not as bad a state of nerves as would have been the case had the public known the amount of powder on hand to serve our coast artillery. The Navy Department divided the Atlantic fleet, sending half to blockade Havana and retaining half at Hampton Roads to protect our coast. This was a gamble. Should the Spanish navy prove as strong on the water as it seemed on paper, our strategy courted disaster.

The Government asked for 20,000 pounds of powder a day. The brown-powder capacity of the Brandywine yards was 3000 pounds. Alfred promised to run this up to 20,000 within sixty days. No one thought he could do it.

Alfred demanded from Cousins Eugene and Frank an absolutely free hand in the yards. He got it, which in itself was a notable triumph. In addition to an imperative duty to his country, Alfred's task took on a personal aspect of a labor of self-vindication. At last he could work his will in those old Brandywine yards into which the blood and sweat of DuPonts and of DuPont workmen had gone for ninety-six years. He had a free hand to show Cousins Eugene and Frank what he could do; and to show them with brown powder. That would make victory doubly sweet. Eugene and Frank had always been critical of and impatient with Alfred's attention to brown powder, which they had never wanted to make in the first place.

Success, therefore, would be a wonderful thing for Alfred duPont, as well as for the United States of America-especially in the event this war into which we had plunged so blithely should last very long. 
But failure?

It seems a sober fact that that possibility occurred to Alfred no more than to the boys who marched away singing "Good-by, Dolly Gray."

Commercial powder production suspended, everything was given over to the making of brown powder, fit for nothing but cannon. New buildings were erected and filled with machinery which outside shops worked night and day to deliver. A faster type of press, the invention of Alfred, was installed.

The young superintendent virtually lived in the yards, snatching half an hour's sleep where he could get it-tilted back in a chair in his rude yards' office or on a bunk in the night shanty. Powderman George Seitz used to tell of the time he and Mr. Alfred stretched out together on top of a row of powder kegs in the storehouse and knocked off forty winks.

Eight-year-old Bep would set her alarm clock for dawn so she could slip down to the kitchen and get her father's breakfast, hours before another person was stirring in the house. Bep carried her dad's dinner (i.e., lunch) to the yards. One day there was a new soldier on duty at the lower gate.

"You can't go in there, little girl," he said.

"But I have to," said Bep, going right ahead.

The soldier barred the way with his rifle, which had a bayonet on it.

"My dad has to have his lunch," said Bep, trying to push the weapon aside.

The soldier said his orders were to shoot people who resisted a sentry. Bep started to cry. She didn't want to be shot, but she knew her father expected his lunch and she mustn't be late. Just then an old powderman came along.

"Why, that's Mr. Alfred's little girl," said he, which made everything all right.

Bep used to bring her dolls to Hagley Yard and play with them on the steps of the rolling mills. Someone asked Alfred if he did not think that an awfully dangerous place for a child to be.

"Not awfully dangerous, no," said Alfred. "And besides: my men work there." 
Alfred bought Bep a new violin and let her keep it in the closet he had equipped with a thermostat of his own design to maintain the temperature at what he thought the proper level for violins. Sometimes of an evening when he could get home for an hour, Alfred and the children would go to the billiard room and make a little music-Madeleine playing the piano, Bep and Dad violins. As long as the war lasted this seems to have been Alfred's only recreation.

The superintendent drove his men nearly as hard as he drove himself. The production schedule was mercilessly boosted up and up: 500 to Iooo pounds more powder every day than on the day before until it seemed that neither machines nor men could stand the strain.

Take Long John Thompson, the charcoal burner. Stripped to the waist and black as a Negro, this bearded giant was working eighteen hours a day-and still Alfred demanded more charcoal today than yesterday. Thompson had always made the charcoal for brown powder. He was a specialist on it. In the old days when the military powder production was small, brown charcoal comprised a small fraction of the daily grist of the 'coal house. Now it was everything. Alfred insisted that Thompson do the work. No one else had the knack, and Alfred refused to run the risk of sacrificing quality by breaking in new hands.

"Cocoa" charcoal was produced differently from black charcoal, which an old hand like Thompson could burn by instinct-at any rate merely by watching the color of the smoke. Brown charcoal, made from wood which had gone through a week's drying process, was carbonized on a Fairbanks scale with superheated steam. Five hundred pounds of wood went in at a firing, and 300 pounds of charcoal came out. That was theoretical perfection. In the parlance of the 'coal house, Alfred gave Thompson "I per cent to come and go on." That is, the five to three ratio must be maintained within I per cent. From 500 pounds of wood must come not more that 303 or less than 297 pounds of charcoal. Overburned 'coal was too 
light and underburned too heavy. Either affected the muzzle velocity of the powder.

Thompson's pay was 18 cents an hour. An eighteen-hour day meant eight hours of overtime at 18 cents, this being before the day of time-and-a-half for overtime. Thompson's extra wages ran into what was to him a nice little nest egg. But like 500 others in the yards, John Thompson was not working for money or for remembrance of the Maine.

He was working for Mr. Alfred. The Gov'ment had been caught short. Billy McKinley had ast Mr. Alfred for powder to fight them Spaniards. Mr. Alfred had said to count on him. He figgered the hands would back him up; and, by God, he figgered right.

That was the Spirit of ' 98 on the Brandywine; workin' for Mr. Alfred.

"Thompson," said Alfred, "you look like you'd been dragged through a knothole. You're dead on your feet. I'm sending you two helpers. Make 'em take some of the load off you, but remember: I per cent to come and go on."

The strain affected men in different ways. Sam Buchanan, who had once saved Alfred from drowning, was a rolling-mill boss. Always a taciturn man, the poison of physical fatigue made Sam moody. He would not have a dog about his mill.

"When I go across the Crick I don't want no houn's bones mixed up with mine."

\section{4}

The outmoded mills throbbed with activity. From a daily production of 3000 pounds, Alfred flailingly pushed up the schedule until the "impossible" requirement of 20,000 pounds was reached and surpassed. Within sixty days every twenty-four hours saw more than eight hundred square, zinc-lined boxes, holding twentyfive pounds of powder each, delivered at the Wilmington \& Northern Railroad siding which years before, over the protest of his father, Boss Henry, Henry Algernon duPont had brought into the Upper Yard.

The feat, to which public notice has not hitherto been directed, 
shines by contrast with the general conduct of a war begun on an Olympian note of mismanagement-no powder reserve-and continued in that vein to the end: cavalry without horses; horses without saddles; infantry without shoes; vile rations; similar sanitation, thirteen men dying of disease for every one killed in action; regiments sent one place, tents and blankets another; troops poured into Cuba's steaming tropical summer clad in woolen uniforms. Had Alfred duPont produced 5000 pounds of prismatic powder a day instead of 20,000 , it could be said, in mitigation, that his performance did not fall below the average of those charged with the administration of the war.

Fortunately for our national self-esteem, notice was diverted from these dismal scenes by the word pictures of the most glamorous corps of war correspondents in our military history. The newspapers which had started this fray did not let their public down. The exhilarating most was made of Dewey at Manila Bay ("You may fire when ready, Gridley"); Lieutenant Rowan winning through with the message to Garcia; Hobson scuttling the Merrimac under a rain of Spanish shells; Teddy Roosevelt's Rough Riders at San Juan Hill (minus their horses but attended by Richard Harding Davis); the destruction of Cervera's fleet in its quixotic dash from Santiago harbor (Captain Jack Phillips of the Texas: "Don't cheer, boys, the poor fellows are dying").

Only because Spanish bungling exceeded our own was it over so soon. With nearly 200,000 troops in Cuba, 13,000 of whom were in Santiago, not more than r7oo Spaniards were got into position to face 15,000 Americans in the brisk little battle of Las Guasimas, El Caney and San Juan which put us in possession of the ridge commanding the city. The fact that those r700 were furnished with smokeless powder, which did not give their positions away, enabled the Spanish to resist longer than otherwise would have been the case. With brown powder for artillery and black powder for small arms, our forces could be spotted every time they fired. The heights about Santiago in our hands, on July 3 Cervera made his brave sally and our brown powder did terrible work. Eleven days later Santiago surrendered. August I2 a protocol ended hostilities pending a final settlement of issues at a peace conference. 
The Brandywine yards slowed down and Alfred's force got a chance to slack off and rest. In four months' time he had delivered 2,200,000 pounds of powder, and had increased the capacity of his plant nearly ninefold. With the exception of a very small quantity of smokeless powder bought in England for a few guns which would take no other, Alfred duPont had made nearly all the biggun powder used in that war.

He had spent forty hours at a stretch in the yards. He had evoked from his men a loyalty that drove them to deeds beyond their strength. He had felt the buoying force of the ambition that fires a slighted subordinate who means to show his superiors that he can do what they think no man can do. Much as these things count for any undertaking, they do not wholly explain the achievement which, so far as the record discloses, remains unequaled in the annals of the powder industry in America. Without ability of the highest order, Alfred duPont could not have done what he did regardless of long hours, co-operative help, or impulse to vindication.

The feat passed unnoticed except in the powder fraternity and by a few ordnance officers. When hostilities ended so abruptly, a vast amount of smokeless powder, whose superiority in action had been decisively demonstrated, was nearing the end of the sixmonths drying period. Enlarged plants would insure an adequate supply in event of a renewal of military operations. The Navy asked the DuPont Company to cancel an order for $1,000,000$ pounds of brown prismatic and to substitute a similar amount of smokeless powder "at a price which will compensate you for the expense to which you have been put in increasing your output of Brown Prismatic."

\section{Eugene duPont replied:}

"For the last four months we have devoted the whole output of our mills to the [Navy Ordnance] Bureau and the [Army] Ordnance Department. Our customers who have been with us for years have been scantily supplied. We have jeopardized our business to a great extent. As to compensation, we fully believe that our business will be benefited to a much greater extent by turning our mills onto the regular manufacture. We, therefore, think that no 
compensation is required for the money expended in increasing the output of Brown Prismatic powder."5

Alfred received his recognition, however, and in a manner that afforded satisfaction. It came about unspectacularly, as did most things in the family firm which had to do with the personal equation. Many had been the short words Alfred had exchanged on the subject of brown powder with Eugene and Frank duPont. Now these two came to their cousin and told him that they had been mistaken, had judged too hastily, and that Alfred's brown-powder work had reflected credit on the old company. ${ }^{6}$

From a senior partner to a junior, especially one as outspoken as Alfred, that was extravagant praise.

The treaty of peace, recognizing the independence of Cuba and transferring Puerto Rico and the Philippines to the United States, was signed in Paris on December 10, 1898. By that time the regiment guarding the Brandywine mills had long since gone home. To the Government's great relief Eugene duPont had canceled all brown-powder contracts without compensation. Wartime machinery not adaptable to black-powder uses had been scrapped. The works had dropped back into what Eugene called "useful, orderly business"- the routine of peace.

Feverishly made wartime additions had complicated further the crazy pattern of the quaint old yards, already suffering from nearly a century of Topsy-like growth. What was called the Upper Press Room in Hagley was in reality the middle of three press rooms, counting either up or down stream. At one time it had been the upper of two press rooms, and, DuPont-like, the name had not been changed. This Upper Press Room had been built for safety's sake, into the side of the steep bank, two hundred and sixty feet from the creek, and directly behind a string of six rolling mills which, like all the rolling mills, were at the water's edge. The race, supplying water to turn the wheels which turned the rolling-mill machinery, ran between these mills and the press room.

At ten-five o'clock in the morning of December 9 , when officially 
the war had twenty-fours to go, one of the presses in the Upper Press Room was running a charge of black sporting powder. Two charges of blasting powder had just been finished, and the presscake was standing in the tubs on the floor, waiting for a horsecar to haul it to the graining mill. The car drawn along the narrowgauge track by two horses in tandem was on its way from the rolling mills by the creek's edge with six bags of dust, for which the presses were waiting. This delivered, the car would take away the finished presscake. John Mulhearn was driving the team. Beside him, in the front of the car, were Sam Stewart and Tom Knox. In the rear of the car were John Moore and Thomas McCann.

The car was in the middle of a bridge over the race when Sam Frizzle, driving a grocery wagon, passed it. The lead horse shied, threatening to pull the car off the rails. Mulhearn leaped from his perch and dashed to grasp the bridle of the frightened animal. He never reached it. The car careened, a bag of the highly explosive dust toppled off and the four men on the car jumped. John Murphy, walking along the road beside the race, saw it all. Before the men who had jumped could touch the ground the explosion came, erupting men, horses, pieces of car and pieces of bridge in all directions.

Murphy saw Robert McIlhenny and John Wright standing on the press-room porch, with the door open to receive the car's load. He saw them about as long as a man could count ten. Then a rush of air took the breath out of Murphy. Where McIlhenny and Wright had been, a column of flame and smoke belched out for two hundred feet: the press room had blown. Then like firecrackers on a string went the six rolling mills below, spewing their contents against the opposite bank of the creek.

Alfred was in his buggy on the Creek Road in front of the shop of his boyhood friend, Mick the Barber, in Long Row. Reaching the lower gate at a gallop, he found the gateman barring the way to one of Yaba Buchanan's boys who was yelling with tears streaming down his face:

"I don't care just so it ain't my father!"

Alfred put his arms around the little fellow and sent him home in the buggy. 
In the yard Alfred passed John Mulhearn, burned and dazed, being walked home between two men. Moore and McCann were being stripped in the night shanty. A look told Alfred they were dying. But no need to send for Father Berminham: he would be there without sending. Stewart also was beyond human aid.

A flaming brand had set fire to a composition house, the contents of which, though inflammable, were not explosive. Alfred turned his attention to a glazing mill upon which sparks from the composition house were showering. The glazing mill contained tons of powder. Already two men were mounting the roof with a hose. Going up after them, Alfred recognized the veterans Charley Deery and Benny Watson.

"Mr. Alfred, get down!" shouted Deery. "This is no place for you."

"What do you figure to do, Deery?" demanded the superintendent. "Push me off this roof?"

What remained of McIlhenny and Wright, press-room hands, was found on top of the bluff on the opposite side of the Brandywine, six hundred feet away. These victims brought the fatalities to five. In the wrecking of the six rolling mills not a man had been injured. The explosions had occured when the mills were empty of hands, as they were most of the time when charges were being run. ${ }^{7}$

Shortly after that experience Charley Deery went on the retired list. Alfred set him up selling bicycles in Wilmington.

This was the only accident in Alfred's yards during the war period, and privately Alfred always disclaimed responsibility for it. With the end of the emergency his wartime authority had been taken from him and his dictatorship over his beloved yards ended. Without avail he had objected to restoring to Frizzle his pre-war privilege of driving his grocery wagon through Hagley Yard. ${ }^{\mathbf{a}}$

In the matter of accidents Frank duPont, at Carney's Point, was less fortunate, though in this connection it should be borne in mind that Frank was pioneering with smokeless powder, a more dangerous product. Moreover, Frank's health was giving way from the strain of overwork while Alfred's seemed to thrive on it. Cousin Frank had saddled himself with too many kinds of duties. He was 


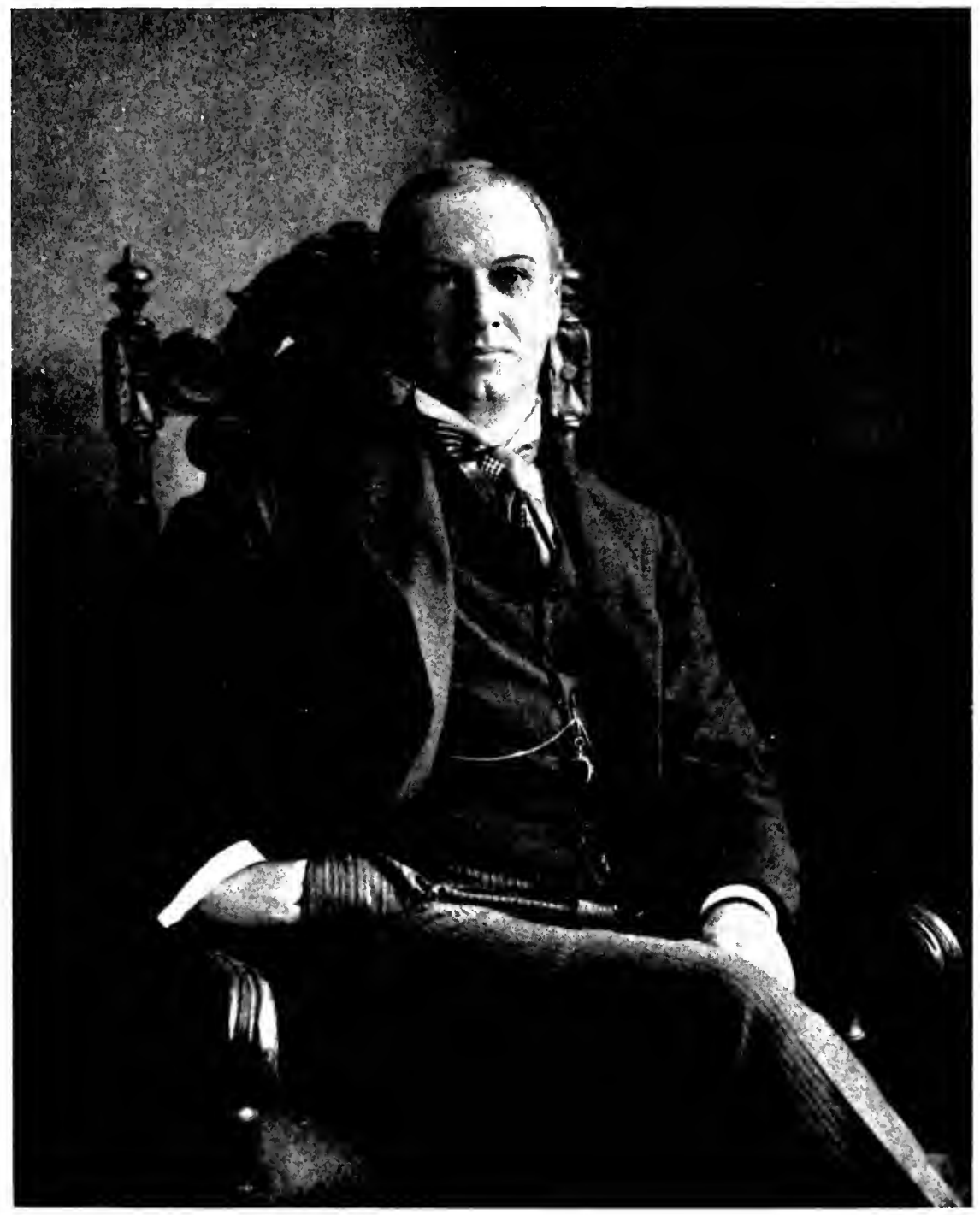

An Unsung Hero of the Spanish-American War

Alfred I. duPont in 1898. Hostilitics caught the United States with magazines empty and only the obsolescent Brandywine works capable of making the brown prismatic powder required for heavy guns. A. I. duPont, yard superintendent, performed a feat unsurpassed in the history of the explosives industry by raising his yard's production from 3,000 pounds daily to 20,000 pounds in sixty days. 
$=$ 
an executive, acting as general manager of all the DuPont interests; a yard superintendent, running Carney's Point and building a smokeless-powder plant there for quantity production; a scientist, spending hours over test tubes, working out improvements in smokeless powder. His scientific work was so much more important than his other duties that in a well-run organization he would have been free to devote all his time to it. Into the laboratory at Carney's Point Frank duPont had brought his sons, Francis Irénée, twenty-six, and Alexis Felix, twenty, and his nephew, Alexis Irénée, twenty-nine, a son of Ruling Partner Eugene. They worked beside their cousin Pierre.

In 1898 two explosions had occurred at Carney's Point with one fatality. In March, I899, three were killed and young Francis I. and Alexis I. duPont suffered painful injuries. In April a thirteen-inch shell was being loaded in the presence of Captain Sidney Stuart, United States Army. Frank duPont and his nephew, Alexis, whose wounds of a month before were scarcely healed, started to watch the operation but were called away. A few minutes after they left the shell exploded, killing five workmen and wounding Captain Stuart so badly that he died. ${ }^{8}$

Cousin Pierre severed his connection with the Carney's Point plant in the following September. The explosions had nothing to do with his resignation. The pressure of war had brought long hours and exacting responsibilities to this quiet and capable chemist. After nine years with the company, Pierre yearned to advance in its service, to reap rewards in some way commensurate with his important contributions to the development of smokeless powder. Neither chance nor rewards were forthcoming. His patience near the breaking point, Pierre felt more strongly than ever before the justice of Alfred's rebellion against the elders' policy of keeping down the young men who must carry the company through the next generation, if it were to remain in family hands. Opportunity to rise on merit in association with the large affairs of the diverse estate of the late Fred duPont of Kentucky still beckoned to Pierre, as, indeed, to Alfred. His wartime duties discharged, Pierre, who was twenty-nine years old, waited no longer for recognition from the family firm. He joined his cousin Coleman in Louisville. 
During the war Alfred's deafness had increased, further diminishing the enjoyment he was able to take from music. This may have accounted in some degree for the zest with which he threw himself into the pursuit of a new hobby: the automobile. In I899 he purchased one of the first Locomobiles on the market. It ran by steam. Alfred drove the machine into his carriage house, took it apart and learned how it worked. In a week's time he had evolved some improvements. The result was that when a breakdown came on the road he could ignore the derisive injunction of passers-by to "get a horse." Alfred prided himself on his ability to bring the machine home under its own power.

Through an advertisement in a magazine, Alfred sold the Locomobile to a man in Massachusetts and bought a Columbia electric. Presently a letter came from the purchaser of the steamer:

"I just want to report on the Locomobile I bought of you. It is loco all right, but not so mobile."

"There's a good sport," said Alfred to Frank Mathewson. "I'm going to return the amount of his check."

The electric was quieter than the steamer and there were fewer breakdowns, but it could not go fast enough to suit Mr. duPont. After making his own adjustments to the engine, Alfred had been able to get the steamer up to thirty miles an hour on level stretches on the Kennett Pike. Taking his cousin Frank on one such wild ride, Alfred cured him forever of a desire to own a horseless carriage.

The next purchase was a chain-driven, gasoline-propelled Haynes-Apperson. A Frenchman named La Roche, an agent in Philadelphia for French cars, had tried to get duPont for a customer. Alfred proposed a race from Philadelphia to Wilmington. If the Frenchman won duPont would buy one of his machines. Though French cars of that day were generally superior to American, Alfred won the race.

The gasoline engine in the Haynes-Apperson made an ungodly 
noise, often frightening horses. Minor accidents to vehicles and to harness resulted. Alfred would mollify the victims with orders for complete repairs on Frist \& Almond, Wilmington's bon ton carriage and harness makers. Sometimes he would receive a bill for a new set of harness, replacing a set with one strap broken. He did not complain.

"That," he would say, "might be cheaper than a damage suit.",

In the fall of 1899 Alfred, his brother Maurice, and Frank Mathewson went hunting in Balls Neck, Northumberland County, Virginia. They had a wonderful time, not so much on account of the hunting as on account of the friendships Alfred struck up among two families in the Neck.

At the confluence of the Potomac River and Chesapeake Bay, Northumberland County was virtually inaccessible except to boats. Balls Neck sticks into the Chesapeake, bounded on three sides by navigable water-the Bay, Dividing Creek and Balls Creek. The Neck takes its name from the Ball family which settled there in early Colonial times and which has contributed to history Mary Ball, the mother of George Washington. In I899 Balls Neck contained one church, one school and about ten plantations in varying states of genteel impoverishment. Most of the families were descendants or connections of descendants of the original Balls.

Alfred's party disembarked from a Baltimore steamer at Harding's Landing on Dividing Creek. The Landing was on the farm of Fannie Ball Harding who consented to put up the hunters at her house; in fact, was very glad to do so. The widow of a Confederate officer, Mrs. Harding had five children to bring up. A mile and a quarter from Harding place was Cressfield, the plantation home of the Neck's most distinguished citizen, Captain Thomas Ball. Captain Ball's title derived from the army of General Lee. He had practiced law in Texas, been a State Senator there, and also Assistant Attorney General of the United States. A rare storyteller and a comfortable companion all-round, Captain Ball proved a man after Alfred duPont's own heart. And not the least in the Captain's favor was his children, to the number of five. They were about the same ages as their young Harding cousins, that is, from twelve to twenty. ${ }^{10}$ 
Seeing how little money these people had and how happy they were, Alfred resolved to pay the Neck another visit. That Christmas he sent Floride, the youngest of the Harding brood, a bicycle. This brought from mother and daughter letters of thanks to which Mr. duPont replied on January I4, I900:

"I have had so many things crowded on me since the first of the year that I have really not had time to decently acknowledge the receipt of your nice letter, or that of little Flo. On the first day of the year we celebrated the one hundredth anniversary of the landing of our ancestors in this country, and it was made the occasion of a family dinner at which congregated over a hundred. ... As there was no room large enough, one had to be built, decorated, lighted and heated. . . . It is over thank goodness and it was altogether a success but I am glad I won't be alive to see the next one....

"As you had your house full [on Christmas] I presume you all had jolly times. ... Your baby's letter was a delight to me and to all to whom I showed it. You may well be proud of a child who can write a letter so well worded."11

Alfred wrote in high spirits, knowing that the time was near for a joyous time at Swamp Hall, which he hoped might melt away the differences that had come between him and his wife. After eleven years, and after Alfred had almost abandoned hope for such an event, Bessie was going to have another baby.

The infant arrived on St. Patrick's Day, and it was a boy. The Irish contingent in the yards always celebrated St. Patrick's Day, and this time there was the whoopingest celebration ever. Powdermen trooped up to The Swamp until Alfred's cellar was nearly empty.

He was christened Alfred Victor, and in all probability no infant born on the Brandywine had started life attended by more good wishes. 


\title{
CHAPTER IX
}

\author{
The Debacle
}

I

THE Spanish-American War had interrupted an earnest controversy among the DuPont partners. The decentralizing measures introduced by Eugene had not been sufficient to keep the company abreast of the times. Though still the dominant factor in the explosive field, DuPont no longer ruled with the ease and sureness of Boss Henry's day. Independent and semi-independent concerns, particularly Laflin \& Rand, grew stronger. Young, vigorous men were coming up in these companies, and this new blood made itself felt.

Of the four partners who shaped the destinies of DuPont, Francis G. and Doctor Alexis I. were ill from overwork and old beyond their years. Frank, forty-nine and a capital scientific man, had worn himself out with managerial responsibilities for which he was unfitted. His brother, 'Lex, fifty-six, who knew nothing of the technical end of the powder business, was a fair executive in a place where a first-rate one was needed. The head of the firm and third brother, Eugene, fifty-nine, was another example of an A number I practical powderman in an executive job over his head. The fourth of the older partners, Colonel Henry Algernon, the best executive of the lot, was weary of powder and expending most of his energies in the bizarre battle with "Gas" Addicks for the senatorship.

That left the two junior partners Charles I. and Alfred, neither of whom had the slightest say in the general affairs of the company. Charley did not mind. In poor health, he was satisfied to drum along as a yard superintendent, which, indeed, represented the level of his capacity. Alfred did mind, and continued to butt 
his head against a stone wall of conservatism represented in the main by two tired men, Eugene and Frank. Having been properly thanked for his wartime services, the stormy petrel was thrust back into a yard superintendency to catch up on black-powder orders while his elders ran the firm.

Colonel Henry Algernon perceived, though dimly, the defects and probable consequences of this scheme of things. Before the war he had suggested a remedy: the incorporation of the company. Eugene, Frank and Alexis were shocked. E. I. duPont de Nemours \& Company had been founded as a partnership; it had grown great and grown rich as a partnership; it would continue as a partnership. The dissenters prided themselves as the proprietors of the largest unincorporated business in the United States. The war over, Henry renewed his agitation nevertheless. Sound judgment was on his side. A business international in scope could be more advantageously conducted with a more flexible corporate structure.

This was not the argument which finally won over Eugene, however. The settlement of company affairs after the death of Boss Henry had been a difficult and delicate procedure, in which only the tact and fairness of the dead man's sons had averted a family rift. Boss Henry had autocratically mingled his own and company property. Titles to property which everyone thought had been purchased for the company were found to be in his name. Luckily for peace, the heirs surrendered them. Now that private and company properties were distinct, just what each partner owned of the firm's possessions was still vaguely defined. To make the firm a stock company would remove this possibility of friction and render a settlement simpler should another partner die. With the explicit understanding that his powers should not be curtailed, Eugene gave in; and on October 23, 1899, the family firm became a corporation under the laws of Delaware. The capitalization, $\$ 2,000,000$, was a symbol merely, having no reference to the actual worth of the property.

Thus as far as management went the difference between partnership and corporation proved to be that between nip and tuck. Partners, and partners only, became stockholders-the four seniors each owning one-fifth of the shares, as they had done under the 
partnership, and the juniors each one-tenth. Eugene was, of course, elected president and the three other elder partners became vicepresidents. That left the offices of secretary and of treasurer. They were combined and given to a figurehead, Charles Irénée. Thus an office for every stockholder-except Alfred. He was made a director, with nothing to direct.

What Colonel Henry Algernon saw, Alfred also saw, with much more clarity: the company dying on its feet, of dry rot within. Great oaks in the Brandywine woods sometimes went the same way, looking magnificent to the last. Colonel Henry, whose efforts at reinvigoration had failed, had political aspirations to divert him. Dragooned into its service, the Colonel had never acquired the emotional attachment for the firm which was the younger man's heritage.

Alfred's chief diversion, music, growing deafness threatened to take away. Threshing about for something to fill a world shrinking under his eyes, he had hit on automobiles. After Pierre had deserted the company, Alfred, too, entertained passing thoughts about throwing up the sponge and going to France to learn to make automobiles. He was sure he could build a better car than any produced in America. Then he thought of his son. There must be something to pass on to him; that had always been the DuPont way. Money would not be enough. An automobile factory would not be enough-as long as a chance remained to save the old company. Was not this infant, Alfred Victor, the eldest son of the eldest son of the eldest son of the eldest son of the founder?

The ambition to save the company for coming generations of the clan must have received fresh impetus when Alfred saw one hundred DuPonts gathered about the great table he had built for the family's centennial anniversary dinner. How had the company been kept in the family so long? How had it gained and held leadership of the industry? Simply by training, in a hard school, young DuPonts to fill old DuPonts' shoes. Alfred had no objection 
to requiring the young men to serve stiff apprenticeships. He himself had served a stiff one, and had profited by it. What he did object to was keeping the young men mere apprentices until their natural powers of expansion had been stunted; or until those too alert to endure the stunting process had been driven away. Seated about him Alfred could have counted ten young cousins, including Pierre and four other sons of the brilliant Lammot duPont, who were making or planning careers outside the company. ${ }^{1}$

To convict them of an error of judgment would have been difficult. What DuPont in his thirties could match the material progress in life of Alfred's old roommate, Coleman, who had spent not a day in the service of the company?

The attractive Coly had come up under different auspices entirely. Leaving M.I.T. he had placed himself in the hands of his uncle, Fred duPont, of Louisville, famous for encouraging young men without pampering them. Coly's first job had been driving a mule underground in a coal mine which the Louisville DuPonts owned at Central City, Kentucky. The six-foot-four beginner was popular among his fellow-workmen. He joined their Saturday night drinking bouts and signed with the Knights of Labor, the contemporary union. Step by step Coly rose to be general superintendent, then vice-president of the Kentucky family's Central City Coal \& Iron Company. Under his administration Central City grew from a squalid mining hamlet to a brisk little city of seventyfive hundred people, its miners the best-housed and most contented in the region.

Coly kept up his Delaware associations, and, like so many other DuPont men, contributed to the cohesion of the clan by marrying a cousin. She was Charles I.'s sister, Alice (always called Elsie), for whose favorable notice Alfred had figured mildly as a rival during his and Coly's college days. When death suddenly took Fred duPont in 1893, the widespread holdings he had created for the Kentucky family might have been thrown in confusion save for three men. Two of them were Tom L. Johnson and Arthur Moxham, whom Fred duPont had befriended as poverty-stricken boys and given opportunities to prove their worth. The third was Thomas Coleman duPont, then twenty-eight years old. Johnson 
and Moxham were happy to pay their debt to Fred duPont by acting as preceptors to Coly.

Under the guidance of the older men, Coleman gradually assumed charge of mining companies, steel mills and street railways. Unusual opportunities were opened to Coleman by the fact that Johnson wished to retire from active business to devote his time and money to the furtherance of the ideals of the liberal wing of the Democratic party. With the backing of Fred duPont, Johnson had started a street-railway line in Cleveland, Ohio, in opposition to the lines of the conservative Republican boss, Mark Hanna. He had served a term in Congress from Cleveland and later he was to overthrow the Hanna machine and be elected Cleveland's mayor. Though the social and political views of his patron made no impression on Coleman, the younger man proved a quick learner in the fields of industrial management, promotion and finance. Johnson and Moxham made him general manager of their Johnson Steel Company of Johnstown, Pennsylvania, and Lorain, Ohio. When the Johnson Steel Company was absorbed by the United States Steel Corporation, Coleman was ready to go it on his own as a promoter and industrialist.

Street railways, which were enjoying a boom, were his specialty. This kept him from home much of the time, and in Igoo Coleman removed his family to Wilmington, renting an unpretentious though roomy brick house at 2023 Delaware Avenue. But he talked pretty big and seemed out to impress his Delaware connections. Pierre's brother Bill had got hold of a patent for a high-grade sporting rifle. Coly organized a company to manufacture the rifle. Some local men had an idea for the making of buttons. They spoke to Coly who-presto!-conjured up a corporation and started to build a button factory.

Meantime Coleman and his fatherly mentor, Tom Johnson, had taken Pierre under their wings, giving him no cause to regret his decision to leave the powder company. Pierre proved very able, particularly in matters of corporate financing. Johnson made him president of his steel company to liquidate certain valuable holdings, principally real estate, which had not been taken over by the United States Steel Corporation. Pierre also began to learn the 
street-railway business and was a partner of Coleman in several ventures in that field. The two worked well together, Pierre's caution acting as a counterweight to Coleman's boldness. ${ }^{2}$

The crisis on the Brandywine for which Alfred had so long prepared fell suddenly.

On January 21, 1902, President Eugene duPont failed to appear at his office. He sent word that he was remaining at home to doctor a cold. In three days he had pneumonia. On January 28 he died.

Consternation took the surviving stockholders of the corporation-excepting Alfred. There were hurried, flustered, futile meetings-Alfred, as usual, not in attendance and probably not invited.

Who should succeed to the presidency of the firm?

By seniority the post belonged to Frank duPont, who was ill; "desperately" ill, according to Hamilton Barksdale who knew him well. ${ }^{3}$ Frank regretfully said that his health demanded that he "give up active business," rather than assume new burdens.

Doctor Alexis duPont offered, and truthfully, a similar excuse.

Colonel Henry Algernon eliminated himself on other grounds. The management of his large fortune and politics consumed his energies. A few months off was another election, in which the Colonel hoped to smash "Gas" Addicks and carry off the senatorship.

It is improbable that Secretary-Treasurer Charles I. was ever seriously considered. His health, too, was poor; which made it unnecessary to examine his other qualifications.

It is certain that Alfred was not seriously considered; "too young," said Cousin Frank. " Of course the objections to Alfred went deeper than the question of age, as Alfred himself later attested. "[I was] young, aggressive, and not popular. I suppose I was impulsive-and not always polite."

Thus the prediction impulsive Alfred often had made came to pass: the company adrift, its old leader dead without a new one in sight.

Secretly the beaten men came to the painful resolution to sell the 
company. It fell to Frank duPont to communicate this star-chamber decision to Alfred. Despite years of friction Frank duPont, at bottom, respected the integrity of his strong-willed and tactless younger cousin. For his part Alfred regarded Frank duPont as possessing one of the ablest scientific brains in the history of the family, a brain which he thought had been worse than wasted fumbling with matters of management.

Cousin Frank was brief. There was no one, he said, to carry on. The other stockholders felt it would be best to dispose of the business while a respectable price could be obtained. Laflin \& Rand was suggested as a likely purchaser. What did Alfred think about the matter?

For once Alfred curbed his ready tongue, though his brain was reeling. Confess to the world the utter defeat and humiliation of the first industrial family of the United States! Sell the company! Transform a heritage of five generations in the making into a chattel to be exchanged for money! Though for years he had been steeling himself to face this very debacle, with difficulty Alfred kept his thoughts to himself. Knowing his only hope to balk the proposed sacrilege lay in curbing his old fault of antagonizing his elders too directly, Alfred replied briefly that in the circumstances "a disposal of the assets of the company seemed advisable." $\mathrm{He}$ could trust himself to say no more. But he acted-quietly slipping away to New York to see bankers about a loan for refinancing the company in case cash were needed to block the proposed sale to Laflin \& Rand. ${ }^{6}$

When the conversation with Cousin Frank took place Eugene duPont had been ten days with his ancestors in Sand Hole Woods.

Another doleful week dragged by-the company drifting without a rudder. Swallowing hard, the three senior officers and Charles I. did their best to reconcile themselves to the fate they had pronounced on the company. In private they talked much, by way of self-justification. Frank duPont, who had to unburden himself to someone, had long, distressed conversations with his son, Fran- 
cis I., the young chemist at Carney's Point. The father excused himself on grounds of health. To accept the presidency and try to carry on would be his death sentence. He said the same applied to Alexis. They were all trapped. To sell was the only way out. ${ }^{7}$

Alfred, too, talked. He had to do something to conceal what was going on in his mind-for Alfred, ordinarily, was not good at the arts of dissimulation. He talked about going to France to learn to. manufacture automobiles, and would wax warm as he sketched a glowing future for the motorcar. With everyone screening himself behind an excuse for not taking over the company someone put Alfred on record:

"You certainly couldn't run it, could you?"

"No," said Alfred. "Maybe I can push a wheelbarrow; but that's all the sense I have."s

When the stockholders met to write the formal obituary of the company, they may or may not have been surprised at the presence of Alfred. It was the first stockholders' meeting he had attended in years. He had come up from the yards in his working clothes, his hands grimy with powder. He sat with his eyes closed, perhaps in order to hear better. He said not a word while Secretary Charles I., in a husky voice, read the minutes of an earlier meeting embodying the decision to sell. One by one the stockholders repeated apologies for the necessity of their course. Twelve million dollars was mentioned as a minimum price. At length Colonel Henry Algernon moved, for the record, that the assets of the company be offered for sale to Laflin \& Rand and that Hamilton M. Barksdale be appointed agent to conduct the negotiations.

Opening his eyes, Alfred offered an amendment providing that the business be sold to the highest responsible bidder. Alfred's contribution occasioned some surprise. Who, indeed, could outbid Laflin \& Rand? Nevertheless, Colonel Henry accepted the amendment. The question put, and all voting "Aye," the meeting was declared adjourned.

Except for Alfred's seemingly innocuous amendment, a cut-anddried program had gone through-much to the relief of those who had feared that, despite his assurance to Frank duPont, Alfred might make a scene. 
The meeting officially over, Alfred was the first one on his feet. "Gentlemen," he said, "I'll buy the business."”

The five others present may have suspected that they, as well as Alfred, were losing their hearing. The yard superintendent set them right:

"Yes, I'll buy the business."

Cousin Frank was the first to find his voice. He told Alfred he could not have the business, adding: "Besides, it's cash, you know."

The bald refusal snapped the taut cords holding Alfred's emotions in check. He forgot to be polite.

"Why not?" he demanded. "If you can't run the company, sell it to someone who can!"10

When Alfred was excited his voice grew shrill. For three weeks he had been restraining feelings which all but consumed a passionate and outraged nature. Backing away from the conference table, Alfred took his stand against the door, as if to say that no one should leave the room without hearing him. He made an arresting figure: soiled working clothes; muscular form, hard as nails; flashing blue eyes; firm chin with the telltale family cleft; big, imperious DuPont nose dominating a strong, sensitive face, which was flushed and defiant. For an instant he stood there, his eyes searching those of first one cousin, then another. Then words burst forth in a torrent.

Unfortunately the only authentically recorded version of Alfred's speech is the far too prosy one which years later Alfred himself gave on the witness stand in a Federal court suit. This follows:

"I pointed out to him [Cousin Frank] the fact that the business was mine by all rights of heritage; that it was my birthright. I told him that I would pay as much for the business as anybody else; that furthermore I proposed to have it. I told him I would require one week in which to perfect the necessary arrangements looking toward the purchase of the business, and asked for that length of time."11

In the lore of the family, more arresting versions of Alfred's 
speech survive. Undoubtedly they give a truer picture of the scene than Alfred's own account. Alfred's references to the occasion were always modest. The year before he died he discussed the incident with Charles Wertenbaker of the staff of Fortune magazine. All he added to the foregoing record was that he had opened his remarks by reminding his elders that the plight of the company was due to its policy of ignoring the younger men of the family. This state of affairs Alfred demanded the right to correct, and demanded to know who was better qualified than he to take over the company. ${ }^{12}$

By the time Alfred ceased speaking, the blood was returning to the face of one of his five auditors-Colonel Henry. Alfred's fighting words were taking hold of the old soldier. Rising from his chair he put a hand on Alfred's shoulder.

"All right," he said, "I'm with you."13

And then to the others:

"Gentlemen, I think I understand Alfred's sentiment in desiring to purchase the business. I wish to say that it has my hearty approval. I shall insist that he be given the first opportunity to acquire the property."

Alfred opened the door and slipped out. ${ }^{14}$

Behind him he left not much agreement with Colonel Henry's highhearted stand. The impression was that Alfred had just made another of his scenes, rendering a hard thing harder all round. Leaving the meeting, Doctor Alexis duPont put in a telephone call for Hamilton M. Barksdale.

A charming Virginian, H. M. Barksdale was perhaps the ablest man, outside the family, ever associated with a DuPont enterprise. Nor was he now outside the family entirely, having married a sister of Secretary-Treasurer Charles I. duPont. An engineering career in South America cut short by malaria, Barksdale had entered the Repauno Chemical Company, advancing to the general managership. This had happened under a scheme of independent administration set up by the enlightened Lammot duPont. Under the canons obtaining on the Brandywine, the rise of Barksdale would have been impossible, for he was only four years older than Alfred. 


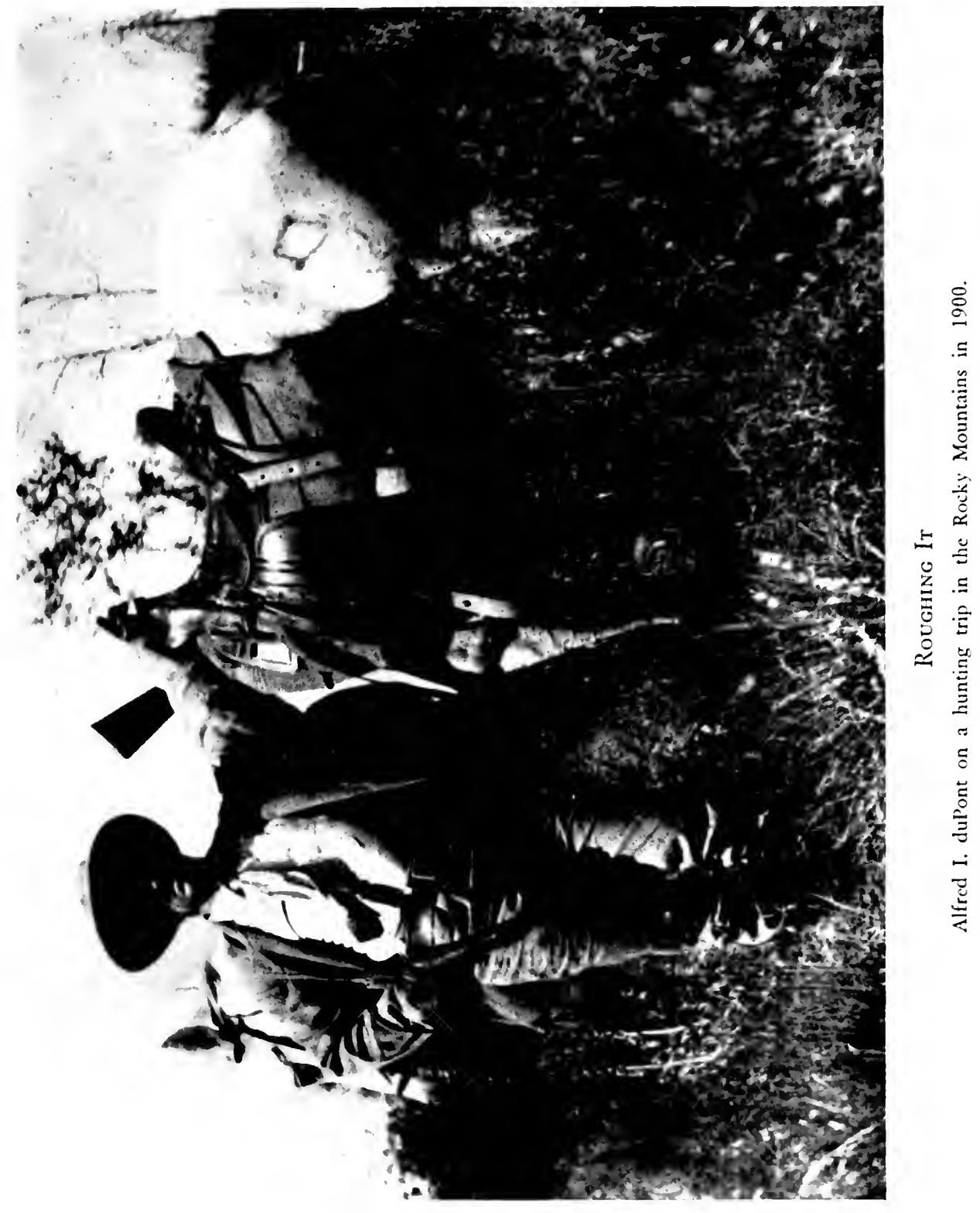



Hastening to the residence of Alexis duPont, the Virginian heard from the lips of that ill and upset man the decision to sell the company. Barksdale was asked to assume the presidency for the purpose of conducting the negotiations. If an acceptable price$\$ 12,000,000-$ could not be obtained, Barksdale was asked to run the business.

Alexis said that in the opinion of the majority stockholders, Laflin \& Rand appeared to be the likeliest prospect as a purchaser. As a sort of afterthought he mentioned that Alfred "desires an opportunity to present a proposition" which "has, of course, been granted." It was obvious that Doctor Alexis did not intend that Alfred's proposal be taken very seriously. He renewed his request that Barksdale take the presidency and make it his first duty to deal with prospective purchasers, whether Alfred or someone else.

Lord Cornwallis had done something of this sort when Washington penned him up at Yorktown. He had designated a subordinate, General O'Hara, to make the formal surrender. O'Hara had no choice but to obey. Barksdale's situation was different. He declined the doubtful honor proposed by Alexis.

"In my opinion," the Virginian told the Doctor, "it would be a great misfortune for the company to place anyone at the head of the concern until you have exhausted all efforts to secure a man of your name to take the helm."

What Alexis had been trying to say all along was that such efforts had already been exhausted. Barksdale was courteous but firm. He could not, he said, "at this time" accept the presidency under the conditions imposed. ${ }^{15}$

This was a real disappointment. Unless Barksdale could be prevailed on to reconsider, or someone else be found, the dispirited old officers themselves would have to deal with the determined Alfred. Moreover, the time was short. Alfred had asked for only a week.

On leaving the dramatic meeting of stockholders Alfred, too, used the telephone. Finding his cousin Coleman at home, he got in his automobile and drove to 2023 Delaware Avenue. 
The masterful Coly was a hard man to bowl over. He was used to bowling over the other fellow-and settling on his own terms. He talked in round figures- "never mind the pennies"-and in big figures. He immobilized opposition by the bold, swift, decisive strokes of a financial soldier of fortune enjoying the prestige of victory. Dash, competence and confidence were his weapons. To tear apart and rebuild a rickety corporation, taking for his pay a block of stock on the gamble that the reorganization would be profitable, was all in a day's work for Coly. When a thing failed he dropped it like a hot potato, turning, without repinings, to something else; he had lost his time, the others their money. This had been the history of the button factory and of the sporting rifle factory, Coly's only local adventures since taking up residence in Delaware two years before. The button factory had expired without making a button; the rifle factory after the disclosure that its product was so expensive to make that it could not be sold at a profit.

On the other hand, when a thing succeeded, Coly often made a lot of money, which he might or might not risk in the next piece of promotion to catch his eye. Like all successful speculators, he possessed an instinct which told him when to cut a loss and when to let a profit ride.

Report had it that Coly was currently short of ready cash; that he had told Alfred that he was $\$ 250,000$ in debt. That may have been. It does not seem that a man who cared as much as Coleman duPont for the external appearances of success would have lived in a \$50-a-month rented house could he have afforded a better one. Yet any money stringency that Coleman may have been laboring under at the time, represented simply a temporary vicissitude in the life of a financial adventurer. He owned valuable holdings in valuable properties, and, more important than all those, a brain of the first order for matters of corporate reorganization and management. Of all who bore the DuPont name, and none other had been considered, Coly was Alfred's first choice as an associate in what might prove a desperate throw to save the company for the family. The second choice was quiet, even-tempered, inconspicuous Pierre. Alfred really hoped to get them both. His reasons were 
characteristic, being both practical and sentimental. Alfred regarded Coleman and Pierre as the ablest of the family's young men. Moreover each was the oldest son of a brother of Alfred's father.

After hearing his old chum's audacious proposal-that the three of them buy the company-Coleman, for once, had nothing to say beyond:

"Al, it's a big thing. I'll have to talk to Elsie."

The idea of the strapping, irresistible Coleman taking counsel with his meek little wife on a question of business hazard would have been incongruous beyond belief to one who did not know that couple very intimately indeed. Elsie duPont could walk under her husband's outstretched arm. Most of her time seemed taken up with her five children. Her intellectual attainments were modest. Yet within her placid being was some resource which supplied her towering husband with strength when he most needed it. Few persons knew that Coleman was given to seizures of nervous indigestion, which frightened him badly. The person who could bring him out of those spells quickest was Elsie. When Coly was away from home Elsie kept a bag packed, never knowing when or whence a telegram would come summoning her to her husband's side by the next train.

After Alfred had gone, Coleman spoke to Elsie, whose comment was brief:

"You know what it is to be in business with your relatives."

Coleman did know. One of the never-solved problems inherited from his Uncle Fred had been to handle the kinfolk who owned part of some of the enterprises with which he had to do. And, of course, he knew the state of affairs on the Brandywine. Coleman announced a decision:

"I won't go in unless I get a free hand."16

That, indeed, had always been for him a sine qua non in ordinary business matters.

Coleman rang up Pierre in Lorain, Ohio. He said he would go in with Alfred if Pierre would go in. Pierre promised to come to Wilmington the next day to talk about it.

The three cousins met in the billiard room at Swamp Hall. The 
conversation lasted until late and resulted in an alliance for the purpose of buying the company. Tactfully Coleman asked for a free hand in the corporate management and for the lion's share of the stock that should be divided among the three purchasers. Alfred offered no objections; Pierre none. Coleman could be a very persuasive asker.

After the business part of the meeting was over, Coleman, who could never sit idle for a moment, took an envelope from his pocket and began covering it with figures. Alfred's wife watched him add them up. The total was over a million.

"What is that?" she asked.

"The money I made last year," said Coleman.

Bessie was astonished.

"Oh, that's just paper money," she said. "It isn't real."

"Yes, but it will be real," said Coleman.

"How did you make this money?"

"Suppose a town has a sick street railway. It's losing money. I find out what's wrong and what's needed to make it right: whether to ginger up the management; modernize the equipment; lay new lines; put an amusement park at one end of the track; or what. I say I'll put the company on a paying basis, they footing the bill. My pay is a bundle of stock. If I succeed the stock becomes valuable. Last year I did right well." ${ }^{\text {17 }}$

It may be that Coleman duPont did make a million dollars on paper in I90I, but more likely he was talking to impress his cousins, particularly Alfred, whom he had lately told of being in debt.

\section{7}

In later years Pierre S. duPont was asked on a witness stand why he and his cousins had been willing to pay, at lowest, $\$ 12,000,000$ for a property of which they had no inventory. What was their assurance that it was worth that much, sight unseen? Pierre replied:

"The character of the sellers."

Whatever managerial sins of omission or of commission might be laid at the doors of the elder DuPonts, their integrity was un- 
impeachable. If they had put a minimum price of $\$ 12,000,000$ on their property, it was worth in cold cash on any market every dollar of it.

Because of his exclusion from the inner councils Alfred had only an imperfect idea of what the company owned. There were, of course, the Brandywine and the Carney yards; the Pennsylvania, Iowa and Tennessee mills; some ownership of stock in the California Powder Works; total ownership of Hazard; certain dynamite interests; varying stockholdings in a great many other explosive concerns-how many or how much Alfred would not even venture a guess. Never in his life had he seen the inside of one of the company's ledgers. Of course he could compute the amount of profits segregated for dividends-being in receipt of one-tenth of them.

Poring over such sketchy data as Alfred provided, Coleman and Pierre could scarcely believe their eyes. To let this property go out of the family for $\$ 12,000,000$, or for twice that, would be a crime against DuPonts unborn. Just one hundred years before, Eleuthère Irénée duPont de Nemours had begun the erection of the original brace of wheel mills on the edge of the Brandywine. In all the ups and downs of fortune the company had experienced since that time, it seemed certain that no one DuPont's single act had counted for more than that of Eleuthère's great-grandson, Alfred, when his burning protest had halted the irreparable sale to Laflin \& Rand. In doing this, Alfred had scarcely thought of the company in terms of money at all but as a perpetual trust for one generation to protect and hand to the next.

The cousins used only three or four days of the week Alfred had asked for in which to submit a definite proposal. Coleman was selected to present the would-be purchasers' proposition to the family elders. This was a wise choice. Despite the failure of his button and his arms factory promotions in Wilmington, Coleman enjoyed a considerable prestige in the family for his successes in the West. Like all successful promoters he knew how to create such prestige. His casual remark about a million in profits the year before had not gone unrepeated. Moreover, Coleman was at home dealing with the baffled officers of corporations in distress. $\mathrm{He}$ 
knew the calm, assured line to take to make them willing, yes, eager, to shift their onerous burdens to his towering shoulders.

In the names of his two cousins and himself, Coleman offered to buy the company. He offered to pay not the minimum of $\$ 12,000$,ooo, but more-just how much more he could not at the moment say until an opportunity presented to survey the assets in detail.

A good promoter uses as little cash, especially his own cash, as possible. Coleman proposed that the sellers accept notes, bearing 4 per cent, for their stock, plus a bonus of stock in the new corporation to be chartered to run the business.

"You wouldn't want to cripple our plans by tying up all our cash," said Coleman. ${ }^{19}$

A few days before Alfred duPont had faced these same five men. His stinging words, pouring from an outraged nature, had suited the occasion. In the nick of time the sheer force of their impact had blocked the sale to Laflin \& Rand. No less impressive now was the gigantic Coleman. For so large a man Coleman had a small head but his countenance was impressive: square, clefted chin; big nose dominating a vital face. His easy gestures, rich, warm voice and confident words were a tonic for the nerves Alfred had shattered.

The elders thanked their Kentucky cousin. They promised to consider his proposal carefully. Coleman departed knowing that he had made his usual happy impression on a distressed corporation directorate.

The next day Eugene duPont, Jr., confidentially told Pierre that the elders, excepting Doctor Alexis who was too ill, had met and decided to accept the proposition presented by Coleman. Eugene was sure that Alexis, too, would assent. Pierre dashed off jubilant letters to his brothers, Irénée and Bill.

"The wheel of fortune has been revolving at a pretty high speed on the Brandywine during the last week or two. . . . Just after Cousin Eugene's death the stockholders of E. I. duPont \& Co. had a meeting and decided to sell out the business to Laflin \& Rand. Alfred made a request that he be permitted to take the property. He came to Coleman and me and we decided to make an offer to 
the old stockholders to buy them out.... I have received today verbal acceptance of the proposition. ... It is now only necessary to reduce it to writing....

"There is going to be some tall hustling to get everything reorganized. We have not the slightest idea of what we are buying, but in that we are probably not at a disadvantage as I think the old company has a very slim idea of the property they possess.... We are taking up a pretty big load; the prospects, however, are bright for making it a success....

"You may talk with Irene [Irénée duPont's wife] but do not mention it outside until I advise you as the duPonts are cranky and may not like to have the news announced until they do it themselves."”o

Bill duPont worked for his brother in Lorain, Ohio. Irénée was in the employ of a firm of construction engineers in Newark, New Jersey. Pierre asked them to take over work in the West and South which he must drop to give all his time to the Brandywine's wheel of fortune.

The cousins had to hustle faster than they expected. Pierre dropped around at the company's office, thinking to have a talk with some of his elders and if possible to obtain an inventory of the firm's assets. Cousin Frank, who had acted as president since the death of Eugene, was preparing to open the morning's mail. He handed the letters to Pierre and began to mention other matters that needed attention at once. The astonished younger man protested that he and his cousins were not prepared to take over; that nothing had been put in writing; that even the amount of the purchase price had not been definitely settled. Frank duPont replied that those were details. The elders had decided to sell. If the younger men were serious in their intention to buy and run the business they might as well begin running it now. After a few words to indicate immediately pressing matters, Cousin Frank took his hat and coat and left. ${ }^{21}$ 

PART THREE

The Three Cousins 


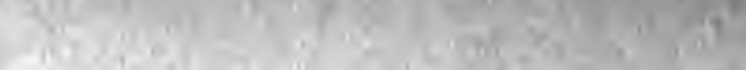

1.20

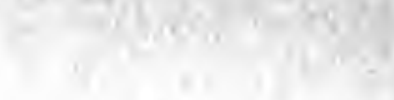

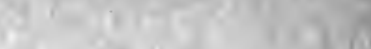

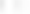

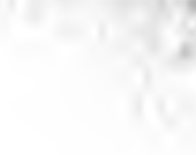

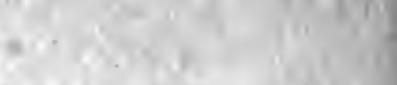<smiles>C=CCC1CC2CCCC2C1</smiles>

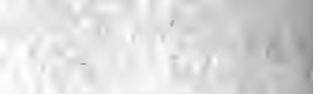
7. $(5+1,-20+2$ $(5)=\frac{1}{2}+2$

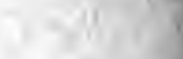
$\ln ^{2}+1+1$ (n)
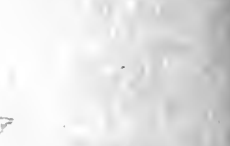

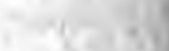

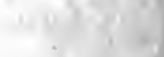
1

$+1$ $+2$

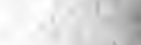
en

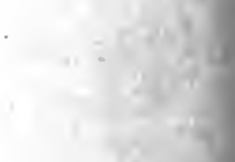
if 1.

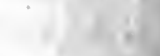

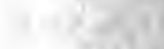
(1018)

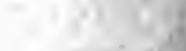

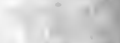
$1+\frac{1}{2}+2$ $+2$ $\because$

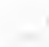

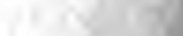

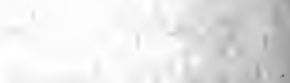
1).

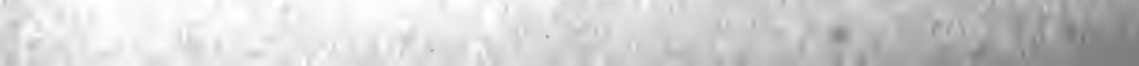

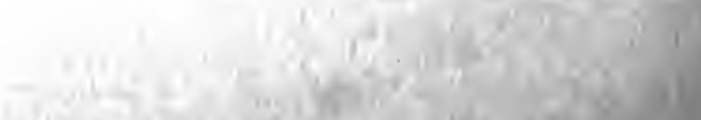

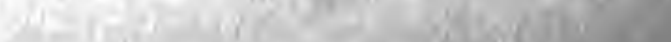




\section{CHAPTER X}

\section{DuPont Back in the SAddLe}

ON March I, I902, a week after Cousin Frank had unceremoniously turned over his desk to Pierre duPont, the three cousins formally took charge of the company. The financial arrangements represented a masterpiece of promotion, not one dollar changing hands from purchasers to sellers. Everything was on the cuff, excepting \$2roo Alfred, Coleman and Pierre put up for twenty-one incorporators' shares in the new corporation to acquire the assets of the old one which was dissolved.

The mechanics of the deal were these. A rough survey of assets showed the old company to be worth $\$ 24,000$,000 plus, or double what it might have been sold for had not Alfred taken the bull by the horns. There was $\$ 1,500,000$ in cash in banks; another $\$ 1$,500,000 in accounts receivable, material and supplies; $\$ 3,000$,000 on standard securities listed in the New York Stock Exchange, exclusive of holdings in rival powder companies DuPont had bought to cushion the impact of competition. Plants stood around \$IO,000,000 . Patents, trademarks, goodwill and miscellaneous assets easily ran the total to $\$ 24,000,000$. In a later reference to the transaction Pierre duPont has said that he voted to pay that much. ${ }^{1}$

This proved unnecessary, the old-company stockholders agreeing to a price of $\$ 15,360,000$. Payment was made as follows in the securities of the new company which the three cousins had incorporated: $\$ 12,000,000$ in 4 per cent purchase-money notes; $\$ 3,360$,000 in stock.

The new company issued, in all, $\$ 12,000,000$ worth of 4 per cent notes and 120,000 shares of stock with a par value of $\$ 12,000,000$. 
All the notes and 33,600 shares of stock, worth $\$ 3,360$,000, went to the old-company stockholders and to the estate of the late Eugene duPont. This left 86,400 shares, worth $\$ 8,640,000$, which Coleman, Alfred and Pierre split among themselves as promoters' profits.

Unlike Coleman and Pierre, who had no stake in the old company, Alfred figured in the transaction both as a buyer and a seller. As a seller, i.e., old-company stockholder, he received his proportionate cut of the sales price. This came to $\$ 1,200,000$ in 4 per cent notes plus 3,000 shares of stock. As a buyer he received his allotment of the bonus the promoters set aside for themselves. This golden egg was not divided equally, however, Coleman getting the lion's share which from the beginning he had insisted on. When all was done the voting stock of the new corporation stood as follows:

Coleman, 43,200 shares, all of them promoter's bonus.

Alfred, 24,600 shares, of which 21,600 were promoter's bonus and 3,000 his allotment of the purchase price as an old-company stockholder.

Pierre, 21,600 shares, all bonus.

Four additional old-company stockholders, the heirs of Eugene duPont and certain other DuPont minors, a total of 33,600 shares, all being their allotments of the purchase price. ${ }^{2}$

The bargain signed and sealed, Thomas Coleman duPont had hung up a record which few promoters have exceeded. On an investment of $\$ 700$ (assuming that the three cousins split the incorporating costs equally), in four weeks' time he had emerged the president and by far the largest stockholder of a great corporation, with shares valued at $\$ 4,320,000$ to his name. That was several times better than doctoring street railways, granting the truth of every word of the $\$ \mathrm{x}, 000,000$-in-a-year profits story.

Nor had Pierre any cause for complaint.

And Alfred had none, which seems generous of him. His first object had been to save the firm. This attained, he was willing that his collaborators, Coleman and Pierre, should be rewarded handsomely. The reward Alfred accepted seems modest by comparison when one reflects that he had served the company for 
eighteen years, the last few years mainly with the design of preserving it for the family.

The new company was organized without a hitch. All along Alfred's idea had been that Coleman should take the presidency. He knew the importance Coleman attached to titles; knew his cousin's qualifications in the field of corporate management, a subject in which Alfred had had no experience or shown little interest. In the days when he was complaining about the oldfashioned management of the old company Alfred, himself, had never aspired to the presidency. Office work seemed thin and bloodless beside labor in the throbbing yards. Alfred simply wanted his Cousin Eugene to change his ways or give over the job to another who would keep DuPont abreast of the times. Alfred knew that the prestige of the presidency would minister to Coly's self-esteem and bring out the best in him for the prodigious task of reorganization ahead.

Pierre was made treasurer, a post which his talents for the mysteries of corporate finance, as revealed in the West, eminently fitted him. Moreover, the post would facilitate his work of acting as a brake on some of Coly's Olympian impulses.

To Alfred himself offices and titles were not very important. Many stories are told of visitors to the yards mistaking him for a foreman, at best. A machinery salesman, or some such person, once inquired discourteously of a man in a leather jacket and smeared knickers where Alfred I. duPont could be found. The person addressed said he thought Mr. duPont would be at his residence at such-and-such time.

When the salesman appeared at Swamp Hall Alfred stopped his apology.

"All I came to the door to say is that I'm glad you spoke to me as you did and not to one of my old powdermen. DuPont employees are respectable workingmen who form an important part of the firm whose business you solicit. Good day, sir."

Coleman knew nothing about the making of powder, but was 
enough of an engineer to understand engineering problems and leave them to men who knew how to handle them. Pierre knew something about black powder and a great deal about smokeless powder. This understanding insured a sympathetic ear in the office to the problems of the yards.

Alfred selected the job for which the Spanish War had demonstrated him to be as well fitted as any man in America, and the job he liked above all others: powder-making. He became vice-president and general manager, directly responsible for the production of the powder lines. He would make the powder, Coleman and Pierre would sell it. The three working together would bring DuPont back to mastery of the industry it had enjoyed in Boss Henry's time. That was the immediate goal.

The owners of the old company, though reduced to the status of minority stockholders in the new company, were considerately handled. Frank, Doctor Alexis, and Colonel Henry were made directors and Charles I. was continued as secretary. Thus at a full board meeting the old-company men, aside from Alfred, could have outvoted the majority owners by four to three. It was understood, however, that Coleman, Alfred and Pierre, having assumed full financial responsibility for the company, should have unfettered hands in its management. As a matter of fact the representatives of the old regime seldom attended the board meetings. A year after the reorganization, the new management had worked such startling changes that the old directors probably understood little of what went on when they did attend.

On the first day of March, I902, Alfred walked into the yards, buoyed by a feeling he had known only for a brief spell during the wartime emergency in 1898 . The fruits of a lifetime ambition were his at last. To Alfred these yards, these sweaty men and clanking machines, represented the heart and soul of the best the name DuPont stood for. And they were his: to run as he had dreamed powder yards should be run; to hold in trust until some younger 


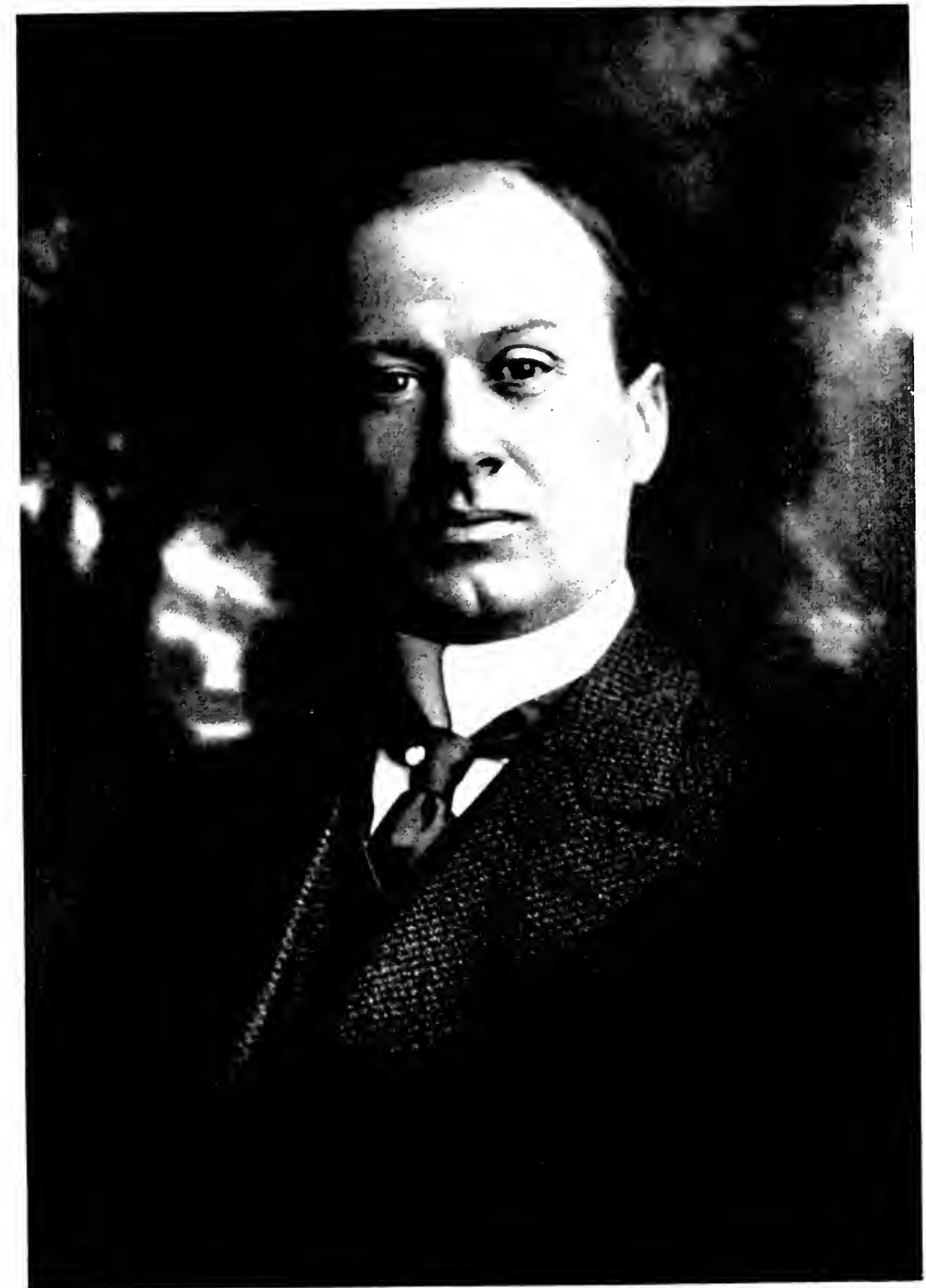

Savior of the DePont Compaxi

Alfred I. duPont in 1902. Hitherto a studiously ignored junior partner, by a dramatic coup he seized the reins and prevented the century-old family firm from passing from DuPont ownership. 

DuPont, growing in years and in experience, should prove himself worthy to succeed to the trusteeship.

Nor did Alfred's authority end at the banks of the Brandywine. $\mathrm{He}$ was boss of all the operating property DuPont owned: the smokeless-powder works at Carney's Point; the Pennsylvania mills acquired in the anthracite regions before the Civil War; the Sycamore mills near Nashville, Tennessee; the Mooar; Iowa, plant which was the largest black-powder works in the world; the Hazard Powder Company plant in Connecticut which DuPont owned by virtue of its ownership of all the Hazard Company stock.

Problem number one was to mold these plants into a smooth operating whole-with due attention to the operations of eighteen other explosive companies in which DuPont owned minority interests, and to still other companies which these eighteen concerns owned in whole or in part.

This brought up the question of what to do about the Brandywine yards. In point of continuous service they comprised the oldest powder works in North America. The plant was obsolete, and only by extraordinarily skillful supervision could it produce powder at a cost which would allow any profit. It was badly located with reference to points of consumption, an important consideration because of the high tariffs railroads charged to transport powder. The small amount of level ground put definite limits on any scheme of modernization without dangerous overcrowding. The growth of the city of Wilmington, increasing the value of the real estate, provided another argument against its continued use for industrial purposes.

Coleman surveyed these facts with the critical eye of a doctor to ailing industrial entities. He said he saw nothing to do but to abandon the Brandywine yards and distribute their production among more modern and more advantageously situated plants. In his usual abrupt way Alfred demurred. He admitted every item in the economic indictment against the Brandywine. Against these he opposed a sentiment. The Brandywine yards were the cradle of that which sustained the DuPont family and enabled it to serve society. The aesthetic sense of Alfred, the musician and lover of 
poetry, was not offended by the sight of men at work with grimy hands. He liked to have them near his home and took pride in the fact that his daughters played with workingmen's children. $\mathrm{He}$ said he would no more think of razing those granite mills, with the consequent uprooting and scattering of the Brandywine's laboring population, than a patriotic Bostonian would think of pulling down Faneuil Hall. Moreover, he offered his guarantee as a powder maker that the cost in dollars and cents of preserving the Brandywine yards would not embarrass the firm. ${ }^{4}$

Pierre sided with Alfred, and Coleman did not press his point.

With devastating energy Alfred fell to the work of making over, not the actual powder yards, but the whole Brandywine community.

As a basis for further operations he began the erection of a machine shop. The old company's machine shop, little more than a country smithy, employed seven men. Adjoining was the millwright's shop, employing about eighteen. Alfred started to raise a building which would house three hundred wood and iron workers, all to be provided with the most modern tools. Here Alfred intended to fabricate, according to his own designs, all the new machinery he planned to put in the renovated mills.

An inter-works telephone system was installed and a new dam thrown across the creek to increase the water power.

As much was done for the men as for the yards they worked in. All the real estate belonging to the firm was surveyed and valued. This comprised about three hundred properties, the majority of which were inhabited by employees. In most of the cottages and tenements, baths and toilets and electricity were installed. Roads were regraded and graveled. Residences occupied by the DuPont family, lighted by the company plant, had contained no meters. As a result few bothered to turn out the light. Alfred installed meters. Company farms were put on a business basis, even DuPonts being charged for the pasturage of cows on company lands.

This reorganization revived the old question of the titles to DuPont residences being held by the company. In Alfred's youth the younger men of the family had opposed this, Alfred probably 
sympathizing with them. Now he saw a certain essential wisdom in the old arrangement. These houses were so close to the powder yards that it would be inadvisable ever to let them pass into the hands of anyone not connected with the company. Nevertheless a few members of the family were permitted to purchase the homes in which they lived. Alfred bought Swamp Hall and some adjoining property; in all, fifty-nine acres. The consideration was "\$5 and more."

In the general sprucing up there was no overlooking the powdermen's church, St. Joseph's. St. Joe's got a fresh coat of paint of the same shade of yellow used on Swamp Hall and a new roof, Alfred meeting the cost of these improvements from his own pocket."

This renaissance was scarcely under way when July 4, I902, brought the hundredth anniversary of the founding of the family business on the Brandywine. Alfred got up a mammoth celebration with tugs-of-war, shooting matches, dancing, feasting and, of course, fireworks. All the DuPont families and all the workingmen's families were there. It was Coleman's first free-and-easy meeting with the Brandywine powdermen. The ex-coal miner could be at home in such a gathering. Coleman was a master of card tricks and of other feats of sleight-of-hand. Since his college days his talent had been one of Coly's passports to popularity. The powdermen cheered him as a worthy coadjutor of their Mr. Alfred.

In Boss Henry's old office, preserved to candles and quills as he had left it, a delegation of powder veterans, a trifle awkward in their Sunday suits, gathered to greet the new and to say farewell to the old regimes. Their spokesman, white-haired Pierre Gentieu, unrolled a scroll and began to read:

"We, the employees of the E. I. duPont de Nemours \& Company, at the home yards on the Brandywine, in meeting assembled have hereby

"Resolved: That the record of one hundred years in the manufacture of gun powder made by the DuPont Company as a family is also shared with pride by many of the employees whose fathers and grandfathers have been identified with the history of the works. 
"Resolved: That as one generation after another passes away the record left by them has always been honesty, bravery and kindness from the DuPont family and loyalty and love from their employees.

"Resolved: That we, the employees of the firm in 1902, wish to record the fact that we appreciate the kindness shown to us by the present officials and members of the DuPont family ... and as we have loved and been faithful to their fathers we mean to do the same for the present generation."

On one side of Pierre Gentieu stood the representatives of the old order: Mr. Frank, Doctor Alexis, Colonel Henry and Mr. Charley. Aging, ill and bewildered by the swift changes five short months had brought, they looked the pictures of men wistfully. awaiting the sunset. On Gentieu's other hand were their successors, the authors of the new order, vibrant, smiling, creative, confident: Coleman, thirty-eight years old; Alfred, thirty-eight; Pierre, thirtytwo.

His reading finished, the veteran turned to the first group.

"Gentlemen of the old firm," said he, "you have been our leaders and friends for many years. We are sorry that you are leaving us, for we shall miss you."

Then to the three cousins, one of whom he had seen grow up:

"What the new company will do, of course, we do not know; but let us hope that after one hundred years more as much good can be said of them as is said today of the DuPonts for the past century.",

Bred into those old Brandywiners was an integrity which made bootlicking a rare art among them.

The gargantuan Coleman duPont was a primitive exhibitionist. The urge to show off, to be the center of popeyed attention, seldom left him. He never tired of astonishing colleagues by demonstrating the facility with which he could turn from horseplay to serious matters, or vice versa. Powder executives, summoned to a meeting at which large issues were at stake, might find him, coat off and 
sleeves rolled, riffling a pack of playing cards with the dexterity of a professional blackjack dealer. Extending the deck to a conferee Coleman would boom:

"Take a card!"

Or he might make a half dollar vanish into the air, and then extract it from the ear of someone.

"Blank, have you the time?" he would ask.

Blank would reach for his watch, fumble and slap his pocket. "Here," Coleman would say, handing over the timepiece. "Keep a closer eye on your department than you do on your watch."

On his desk was a box of matches which looked like any other matches until one was struck. Then it would flame up and sputter like a Fourth-of-July "sparkler." In a drawer Coleman kept a box of loaded cigars. When one went off in the face of a victim, the president of E. I. duPont de Nemours \& Company would shake the walls with laughter.

"I never thought the powder business would be such fun!"7

It would be a mistake, however, to confuse the tumultuous democracy of Coly's manners with the feudal autocracy of his ideals. He practiced legerdemain not alone with playing cards and with fifty-cent pieces. He extracted not only watches from the pockets of rival powder barons. He took their companies.

The old company had been bought with the use of $\$ 2$ roo in cash. This Coleman regarded as a just prologue, a mere curtain raiser to the main show his vigorous imagination was contriving.

One thing about that imagination of Coly's sometimes troubled Alfred. At college Coleman, who was a good storyteller, had a habit of embroidering his tales a little too fancifully to suit his roommate. "Why, that isn't the way it happened," Al would say when the two were alone. "I know it," Coly would chuckle, "but fool 'em, $\mathrm{Al}$; fool 'em! It's fun!"8

Alfred hoped this fool 'em streak would be confined to horseplay, where it belonged. The task confronting the cousins, under Coly's titular leadership, was not a fitting subject for horseplay.

Through the Gunpowder Trade Association, red-bearded old Boss Henry had created the Powder Trust and made DuPont its master. From Nova Scotia to Mexico City the man who wrote 
with a quill by the light of three candles had his finger in every powder pie. No important move could be made in the industry without his consent. Henry DuPont had achieved this one-man control by making forceful use of the instruments known to his industrial age. The stronger of the powder firms were banded together in an association so as not to dissipate their strength in fighting each other. Instead they fought together. DuPont confirmed its position of leadership by acquiring stock in some of its fellow-association-members. Jointly with these members it acquired stock in lesser concerns, and through them, in turn, still smaller firms. Thus was knit together an alliance which dominated the industry, DuPont dominating the alliance. The combine spread itself out laterally over the continent. A hundred puppets danced when the Red Fellow pulled the strings. That such a sprawling, loose-knit organization should have worked as well as it did-and it worked very well-was a tribute to the remarkable qualities of a remarkable man. Seated in his bare little office, pen in hand, Henry duPont could attend to a thousand details without losing sight of basic principles.

Then had come the thirteen-year reign of Eugene. The strings got tangled. The puppets performed badly. The vast spread-out machine creaked and parts ceased to function. Squabbling succeeded harmony. Independent and quasi-independent companies grew stronger and bolder. DuPont slipped back; Laflin \& Rand, always the healthiest competitor, came up. In 1896 an effort was made to check the trend by re-energizing the authority of the Gunpowder Trade Association. Colonel Henry Algernon had acted for DuPont in this matter. But already the Colonel was immersed in politics and Eugene shortly had to take over his duties.

The finest machine may perform badly in the hands of an unskilled operator. By comparison with Boss Henry, Eugene was an unskilled operator. He failed to arrest the decline of the Powder Trust. In the Nineties a novel corporation technique was developing. Instead of falling in step, Eugene had set his face harder than ever against newfangled ideas. Alfred put his finger on the cause of Eugene's ineptitude when he said the company was languishing from anemia for the want of young blood. 
And now, after years of being treated as a faultfinder and troublemaker, Alfred had seized the tiller on the brink of disaster and quickly turned it over to Coleman to restore the ascendency of the days of Boss Henry. The dexterous new helmsman had an earnest respect for the ability of Henry, but was under no delusion that the powerful organization could be restored merely by patching up the old machine. As corporate structures went in 1902, Henry's machine was obsolete. Coleman meant to scrap it completely and build in its place a new one in tune with the Twentieth Century.

It was the habit in the industry to recognize the personal leadership of DuPont by referring to the company by the name of its chief. Thus in the Seventies and Eighties one spoke with awe of "Mr. Henry's Company." Then followed "Eugene's Company"and the period of slow decay. Eugene's successor had not been in charge very long before people were speaking of "Coleman's Company."

This tickled the ears of the Kentuckian, fed his vanity and his native lust for power. It drove the big, roistering, Rabelaisian showman to exert every sinew to regain and surpass the high-water mark of Boss Henry. Vanity and lust for power could drive him to do this, but they could not make him succeed. Coleman would succeed in the field of corporate legerdemain only by demonstrating a superlative degree of orginality and daring in an age which saw the flowering of a half-dozen other trusts.

Starting with a surrender to sentiment in the matter of keeping the Brandywine yards, Coleman did not reveal the inflexible qualities required for his role.

The next thing was a compromise on the matter of moving the general offices of the company. Coleman wanted to take them to New York-where the big fish swam. The old-company men were horrified. Alfred, also, objected. Had not generations of DuPonts prided themselves on the aloofness of the family business from Wall Street and Wall-Street methods? Moreover, the commodious new 
offices, built on the wooded Brandywine bluff by Eugene and electrically lighted by Alfred, were not overcrowded.

Coleman must have smiled to himself. The commodious new offices (vintage I89I) would not be big enough for the corporation he had in mind to hang its corporate hat in. Yet tactfully he agreed to move headquarters no farther away than Wilmington. Taking three floors in the little city's only skyscraper, the eight-story Equitable Building, he announced that the transfer would take place on December I5, I902.

This ended the half measures, after which Coleman behaved more like a traditional DuPont head-of-firm. Sharing his plans only with those it pleased him to confide in, he acted first and talked afterward. A series of mysterious shuttlings between Wilmington and New York began. Often he was accompanied by keen young Lewis L. Dunham, the confidential clerk Coleman had brought from the West. That wise old corporation fox Arthur J. Moxham, Coly's preceptor in the West after the death of Fred duPont, also turned up in Wilmington. Short, stout, gray-haired and with a kink in his neck, "Old Man" Moxham did not look very impressive; but those who judged him by appearances were apt to be deceived. Patron and protégé put their heads together, and Lew Dunham got more confidential errands to run. Pierre was admitted to the tight-lipped circle-taking with him his own confidential importation from Ohio, named John J. Raskob. The extent of this alert, darting little man's acquaintance with the old DuPont stamping ground may be glimpsed from the fact that on his arrival he had written the revered name as if it were two words: Brandy Wine.

Another man Coleman saw much of was Robert S. Waddell, DuPont's aggressive sales manager, who liked the way the new president went at things. Waddell outlined some of his problems. The salient obstacle to DuPont progress was Laflin \& Rand, which, in the framing of the Trade Association compact of 1896 , had outmaneuvered the larger firm. Waddell had tried to mitigate these advantages by negotiation, but Laflin \& Rand's energetic president, J. Amory Haskell, could not be budged. An irony of the situation was that Haskell had begun his career in explosives under William 
duPont in the Repauno Chemical Company, and, like certain other good men, had been permitted to escape into the ranks of the opposition.

One day Waddell said to his chief:

"Why not buy up Laflin \& Rand?"

Coleman seems to have avoided direct answer. The fact is, however, that he had been reconnoitering that very project for a matter of weeks. This was what he and Moxham and Pierre had been so furtively busy about. The middle of September, I902, Coleman told Waddell he was going to New York, adding casually:

"I've decided to take up the matter of the purchase of Laflin \& Rand and may be gone some time."

Two weeks later Waddell received a wire from his chief asking him to remain at the office until Coleman should arrive that evening. This was two months before the removal to the the Equitable Building. Coleman strode in and slapped a bundle on Waddell's desk.

"There it is," he said.

"Laflin \& Rand?" asked the sales manager.

"Yes," said Coleman.

"What did you pay for it?"

"Didn't pay anything!" boomed Coleman. "It's a matter of bonds to be worked out later."9

Coleman exaggerated, characteristically forgetting the pennies. Actually the purchase of Laflin \& Rand had called for a cash outlay of $\$ 2000$. Two thousand more had been spent to take over the Moosic Powder Company which certain Laflin \& Rand stockholders insisted on unloading: making $\$ 4000$ in all.

Otherwise the tremendous news was literally true. Coleman had gobbled, hide and hair, his company's most formidable rival, a rival which eight months before had been rubbing its hands over the prospect of gobbling DuPont. The table-turning coup rocked the industry from top to bottom.

It had come about in this way. On taking office Coleman and 
Pierre had explored the stockholdings in other powder concerns which appeared amoung the assets taken over from the old company. First there was the roo per cent interest in the Hazard Powder Company, making Hazard simply another name for DuPont where it was convenient to use another name, as had been the case in certain bribery operations in the powder wars of the Nineties. ${ }^{10}$ Taking Hazard's holdings and its own together, DuPont owned a majority of the stock in two supposedly competing companies; 50 per cent in one; minority interest in fourteen others. Among the minority interests was 34.8 per cent of the stock in Laflin \& Rand, so that a little over I5 per cent more would give DuPont control. The situation speaks for the weakness of the old management. With DuPont owning one-third of its stock, Laflin \& Rand had remained a thorn in the Delaware company's side.

Yet despite the vigorous management of Haskell, the majority stockholders in Laflin \& Rand were three old men who had no stomach for industrial conflict. What persuasions Coleman, coached by old Moxham, brought to bear are not known. Only the result is known. The elderly stockholders agreed to sell provided Coleman also would buy, at a fancy price, their holdings in the small Moosic Powder Company and get them out of business altogether. The Laflin \& Rand shares were offered dirt-cheap, considering what Coleman had in view. The Moosic proposition seemed a transparent device for rewarding the majority stockholders for the moderate price to which they had assented for L. \& R. stock. In any event Coleman did not haggle long. He got options on the necessary shares in both companies and triumphantly returned to Wilmington to startle Waddell.

The deal was quickly closed. During his absence Coleman had unobtrusively formed, through three dummies, two corporations: the Delaware Securities Company and the Delaware Investment Company. The former was capitalized at $\$ 4,000,000$, of which $\$ 2000$ was paid in; the latter at $\$ 2,500,000$ of which $\$ 2000$ was paid in. His options in hand, these corporations came to life with identical officers: Arthur J. Moxham, president; T. Coleman duPont, vice-president; L. L. Dunham, secretary; P. S. duPont, treasurer. The Delaware Securities Company issued $\$ 4,000,000$ worth of bonds 
and $\$ 4,000$,ooo worth of stock. All the bonds and some of the stock were exchanged for the stock of Laflin \& Rand. The rest of the stock, about $\$ 3,500$,000 worth, went into the till of E. I. duPont de Nemours \& Company as promoter's profit for Coleman's work. Thus DuPont controlled Delaware Securities which in its turn owned Laflin \& Rand.

The Moosic stock was acquired in exchange for $\$ 2,000,000$ worth of bonds and some stock in the Delaware Investment Company. The rest of the Investment Company stock went to the DuPont Company as promoter's rake-off. ${ }^{11}$

In this way had been repeated the formula by which Coleman, Alfred and Pierre had bought the old DuPont Company with the use of \$2,100 in cash; except that in that operation the bonus, instead of going to the company, had gone into the pockets of the three individual promoters.

Moral and material results of the Laflin \& Rand stroke were enormous. It made Coleman duPont the most watched and feared man in powderdom. Before the deal DuPont had made 36 per cent of the powder sold in the United States and Laflin \& Rand 20 per cent. United under one management, however, the two companies were able to control more than $5^{6}$ per cent of the national production. This sounds like the statement of a mathematical fantasy wherein a whole is greater than the sum of its parts. Nevertheless, here is how it worked out: among the assets of Laflin \& Rand was stock in many competing companies; the same was true of the assets of DuPont; a merger of these assets gave DuPont control not only of L. \& R. but also of eight additional competitors.

Moreover, it gave DuPont the whip hand over the dynamite situation. In 1895 a number of dynamite outfits had been drawn together under the wing of a holding concern called the Eastern Dynamite Company. Among the constituents was the Repauno Chemical Company, which comprised DuPont's main interest in the dynamite field. The Laflin \& Rand purchase afforded DuPont stock control of the Eastern Dynamite Company, which dominated 
the high-explosive market east of the Mississippi. This was an important acquisition, as already many were proclaiming dynamite the coming commercial explosive. Certainly its sales were eating into those of black blasting powder.

Finally, the merger restored DuPont to the position of top dog in the Gunpowder Trade Association, the governing body of the industry. Of the seventeen companies constituting the Association by the terms of the reorganization of 1896 , DuPont now owned nine. Of the eight remaining it owned 49 per cent of the stock in one; had a contract for the total output of another; had contractual strings on two others. This left four "free" concerns. Not even Boss Henry, the Association's founder, had so completely ruled the roost. $^{12}$

These widespread acquisitions created their own problems. Counting subsidiaries of the concerns captured through the Laflin \& Rand purchase, DuPont found itself with forty or fifty corporations on its hands. The situation was like that of Germany before the advent of Bismarck. DuPont's new empire lay in fragments all over the country, excluding the Pacific Coast. Nearly every company operated as a separate concern, with separate manufacturing, marketing and administrative organizations. The setup was wasteful and unwieldy. To bind the fragments together Coleman and his associates decided on one great corporation which, as they said, "would own all plants and tangible assets, make all sales, do all business." "13

Before the corporate existences of the scattered companies could be extinguished, minority stockholders in them would have to be bought out. This would require time and money. The Lord provided the time; Coleman and Pierre the wherewithal, by the alchemical process which had served so splendidly three times before.

This time the steps were a little more intricate. For a layman to understand the matter the following bare outline of procedure should be read with care.

With an expenditure of $\$ 1500$ Coleman set up, in May, 1903, the E. I. duPont de Nemours Powder Company. Capital of $\$ 50,000,000$ was authorized, of which $\$ 30,200,000$ was issued in common and preferred stocks. The large end of this stock, carrying control, was 
handed over to E. I. duPont de Nemours \& Company, the parent company which the three cousins had formed in I 902 to buy out the predecessor of the same name. The small end of the $\$ 30,200,000$ in stock was kept on hand to use in lieu of cash to make the necessary purchases of minority holdings in the scattered forty or fifty companies. Before any purchases were attempted, however, the parent DuPont Company took a step calculated to give the Powder Company stock immediate value. The parent company transferred all its security holdings in other explosive concerns (such as Laflin \& Rand, etc.) to the Powder Company.

It was the eventual aim of the parent company to become a holding company solely and to make the Powder Company its operating concern. It did not, however, immediately transfer plants and other operating property to the Powder Company, because the process would have been expensive. An operating company must take out licenses to do business in various states. The fees in connection therewith are based on the capitalization of the company. To provide sufficient purchasing power it had been necessary to give the Powder Company a large capitalization. Therefore Coleman and his associates decided to wait and see how the Powder Company succeeded with its mission of mopping up minority holdings before saddling it with the operating load.

Consequently another company, called the E. I. duPont Company, capitalized at $\$ 10,000$, was formed. To this the parent company transferred all plants. With its small capitalization the new concern obtained operating licenses at bargain rates. ${ }^{14}$

The Powder Company's mopping-up campaign turned out a brilliant achievement. Not only did it bag the necessary minorities, but engineered several other acquisitions, making DuPont's monopoly a reality of proportions which three years before would have seemed fantastic. Taken into camp to polish off the high-explosive situation were the Judson Dynamite \& Powder Company and the California Vigorit Powder Company. Purchase of the International Smokeless Powder \& Chemical Company and the American E. C. \& Schultz Gunpowder Company, owner of valuable secret processes, sewed up the military powder market. Acquisition of the California Powder Works opened up the Pacific Coast to 
DuPont black powder. This last was a real triumph. The California Powder Works had proved a Tartar for old Boss Henry, keeping the Pacific Coast inviolate from the encroachments of his Gunpowder Trade Association. Henry had been able to acquire $4^{\circ}$ per cent of the capital stock, but not control. When Coleman took over in I902, the DuPont stockholding in the California company had been little more than 20 per cent of the total. ${ }^{15}$

The success of the mopping-up process reduced the authority of the Gunpowder Trade Association to that of a high-school debating society. Authority rested with DuPont. The Association was worse than a hollow shell. It was a source of potential embarrassment, some of its restrictive provisions being clearly in contravention of the Sherman Anti-Trust Law. In 1904 DuPont pulled out of the Association, abrogating the agreements on prices and trade territories made under its aegis. In one instance DuPont paid \$100,000 and in another $\$ 140,000$ to get rid of such agreements. The Association collapsed.

In its place stood DuPont, which in 1905 manufactured 64.6 per cent of all soda blasting sold in the United States; 80 per cent of all saltpeter blasting powder; 72.5 per cent of all dynamite; 75 per cent of all black sporting powder; 70.5 per cent of all smokeless sporting powder; roo per cent of all military (smokeless) powder, excepting a small quantity manufactured by the Government. ${ }^{16}$ These statistics reflect the beanstalk nature of DuPont growth since the three cousins had taken over less than three years before when DuPont was selling 36 per cent of the country's powder.

The time had come to execute the final stroke in the Grand Plan: simplification of the corporate structure by making the E. I. duPont de Nemours Powder Company the one big operating concern owning all plants, making all sales, doing all business. This involved a wholesale dissolution of acquired corporations and the transfer of their tangible assets to the Powder Company. DuPont's own stopgap operating concern of \$10,000 capitalization-the E. I. duPont Company-was suppressed, and the assets turned over to the Powder Company which could now well afford the higher fees greater capitalization required it to pay for operating licenses. 


\section{CHAPTER XI}

\section{A Dream Fulfilled}

\section{I}

THE feat of the three cousins in cornering three-quarters of the United States' explosive market was accomplished by a systematic division of individual endeavor. In its broad outlines, the architecture of the corporate structure fell to Coleman. Less conspicuous but no less important was the management of a mass of interior detail by Pierre. Indeed, this quiet man had a considerable hand in the financial wizardry with which the showy Coleman so often impressed his public. Together they had accomplished their job of purchase and amalgamation with an expenditure of $\$ 8500$. $^{1}$ This was all the new capital that had gone into the business. It was spent in the physical creation of securities used to purchase $\$ 35,955$,ooo of new assets. Add these to the $\$ 24,000,000$ of assets with which they started on March I, I902, and one has $\$ 59,955,000$. This is what Treasurer Pierre certified the E. I. duPont de Nemours Powder Company to be worth on December 31, 1905. True to DuPont tradition, the figure is conservative.

How does it come that in exchanging its paper, by the million dollars' worth, for the securities, plants, patents, trademarks and goodwill of fifty corporations DuPont was exchanging fair value for fair value? In other words why is it that the three cousins were not blue-sky artists?

The simple answer is that right along they made and sold explosives at a profit sufficient to give their securities value as fast as printing presses turned them out.

This was the work of the trio's practical powderman, Vice-President and General Manager Alfred. His achievement provided the 
rock of solvency upon which the operations of Coleman and of Pierre rested.

At the close of 1905 DuPont owed $\$ 6,377,000$ to the holders of its bonds. Preferred stock with a par value of $\$ 24,151,870$ had been issued, and common stock to the par value of $\$ 24,230,352$. Interest on bonds had been punctually met, and the required 5 per cent dividend paid on preferred shares. The first common stock dividend, 50 cents a share, was paid in December, r904. Since that time no quarterly dividend on DuPont common has been passed. In I905 these amounted to $\$ 3.50$ a share, or $3^{1 / 2}$ per cent of par; in I906, $\$ 6.50$; in $1908, \$ 7$.

Spectacular as was the feat of pumping DuPont into the shoes of the old Powder Trust, no suggestion of unsound financing had been tolerated to that end. A showier, or less cautious, financier than Pierre might have yielded to the temptation to advocate faster stepping up of common dividends. The money was at hand, but it went into surplus until, at the end of 1907 , this amounted to \$ro,300,000-a stout backlog against the unpredictable. ${ }^{2}$

During the feverish early stages when by seven-league strides DuPont was spreading itself over the map, Alfred had been obliged to keep his conspicuous Roman nose close to the grindstone of his own vital problems. In one instance, at least, this had left him in surprising ignorance of what Coleman and Pierre were doing. Alfred did not know of the existence of the Delaware Securities Company until after its stock had been used to purchase that of Laflin \& Rand. ${ }^{3}$ Secrecy in this stratagem was, of course, desirable. Still, with such underlings as Dunham and Raskob in on it, Coleman or Pierre might have confided also in Alfred-who, after all, had opened their paths to this golden opportunity only five months before.

Be that as it may, the happening seems an unusual, rather than a typical, example of close relationship existing among the cousinsduring the formative period. Ten months after the Laflin \& Rand deal, the gigantic E. I. duPont de Nemours Powder Company was launched. Certainly in this company and its important early works Alfred had a considerable say, being a vice-president, a director, a member of the executive and of the finance committees. 
With plant after plant-black powder, smokeless powder, dynamite-tumbling into DuPont's lap, Alfred quickly systematized their work of production. Fortunately with plants had come good men-some of the best in the business. H. M. Barksdale, who had played his own part in blocking the contemplated sell-out to Laflin \& Rand, was general manager of the Eastern Dynamite Company. To him Alfred delegated the direction of all highexplosive manufacture. Henry F. Baldwin, brought into the fold with International Smokeless, took charge of smokeless-powder production.

Down the generations, it is almost uncanny the brains that DuPont has been able to pluck from its own family tree. A DuPont by birth not being available, one by marriage was usually on hand with the qualifications required. This happened now. Baldwin was a brother-in-law of Coleman duPont and Barksdale a brother-inlaw of Mrs. Coleman duPont. Thus DuPont daughters as well as DuPont sons have done their stint to keep entrenched the family control of this oldest of American family institutions in the industrial field; and the largest excepting a comparative parvenu, the Ford Motor Company. Since the first generation in America, marriages with young men who could be of use to the firm have kept the family vital, and consanguinate marriages have kept it tightly knit. Rigorously edited down to bare names and dates printed in type smaller than that on this page, the DuPont genealogical chart from 1800 to 1936 fills a sheet 36 by 38 inches. ${ }^{4}$ It is as criss-crossed by matings of cousins as that of a European reigning house. Of the offspring of the two sons of the original immigrant, Pierre Samuel duPont de Nemours, one daughter married the son of a financial backer of the Brandywine experiment, another a young man who became superintendent of the works, another an employee who, though a valuable mechanic, turned out a bad egg with a wife in England.

Alfred, who had married a distant cousin, approved of this way of things. The impact of dynasty more than anything else had im- 
pelled the rebellion which saved the firm for the family in $\mathbf{I} 902$. The phenomenal expansion between 1902 and ig05, creating a dozen new posts of high responsibility, posed a question as to whether alien blood should gain ascendency over DuPont blood. The family tree, put to its severest test, seemed equal to it. In addition to Barksdale and Baldwin, Alfred found work for four brothers of Pierre: Irénée in the construction department; Henry Belin, William K. and Lammot in the powder yards to learn the business from scratch. As Pierre's four sisters married, places for their husbands were made in the treasury department. Egbert Moxham, a son of old Arthur J., had inherited his father's executive ability. Alfred gave him charge of a plant for the fabrication of kegs from wood pulp, in which explosives could be shipped with less danger than in the old metal containers.

The nub of Alfred's policy was to erase the disastrous effects of Eugene duPont's error of holding young men of the family back and not risking responsibility in their hands. Nor did the hard feelings engendered by Alfred's long-futile fight against this policy govern him now. Cousin Frank duPont had gone into retirement nursing bitterness, particularly against Alfred. This did not deter Alfred from giving Frank's brilliant son, Francis I., the superintendency of the Carney's Point smokeless powder yard.

In the wholesale distribution of places, naturally some kinsmen and in-laws were the beneficiaries of pure benevolence. The expression "drag job," still current in DuPont idiom, came into being. A drag job of the first water was found for Victor duPont, son of the distinguished attorney and banker of the same name. Fat, amiable and lazy, Victor stepped into the first ornamental vicepresidency created in the DuPont corporate hierarchy. Alfred had higher hopes, however, for the future of the vice-president's son, Vic, junior, who was started in overalls to learn powder-making in Hagley Yard. George Amory Maddox was a big, handsome ladykiller, employed as a sort of rule-of-thumb chemist in Hagley. Marrying the surpassingly beautiful Alicia Bradford, one of Alfred's favorite cousins, he achieved at one swoop a promotion to superintendent of the Hagley and the Lower Yards, which Alfred 
had combined as a single operating unit. Fortunately, under Mr. Maddox were competent foremen.

With Barksdale and Baldwin in command of high-explosives and of smokeless-powder production, Alfred personally took black powder in charge. This was the big end of DuPont's output, the one upon which dividends largely depended. For the first time in his life he had a regular office. In the beginning this was in a little edifice near Hagley Yard which had been used as a Sunday school. A verse from the Bible was painted on the wall above Mr. duPont's desk. The school building was chosen because it was handy to the Brandywine yards which Alfred was making over with his left hand while co-ordinating DuPont's other farflung operations with his right. For his secretary he hired Jimmy Dashiell, leader of Alfred's old orchestra and music teacher to his daughters, Madie and Bep. As business piled up, Dashiell hired two assistants. All worked in one cluttered room, Alfred usually wearing his accustomed powder-stained knickers. Among the new hands who had come in with the new order these garments gave the boss a new nickname-The Count.

When Coleman was ready to move the general offices into the Equitable Building in Wilmington, Alfred had his Brandywine yards pretty well revamped. The Sunday-school office was abandoned, and Alfred and staff established themselves on the eighth floor of the Equitable in quarters more commensurate with the station of the general manager of the world's largest explosive business.

By this time he was terrifically busy. The purchase of Laflin \& Rand, carrying with it control of eight other companies, had brought some thirty black-powder mills under Alfred. Subsequent acquisitions increased the number considerably. These plants were distributed from one coast to the other. They included works of all kinds, from large, modern plants to primitive little wheel mills run by water power. They were manned by personnel good, bad 
and indifferent. Outputs differed correspondingly in quality. Some of the mills were safe, some unsafe. Three were wrecked by explosions before Alfred could get around to them. One of these was rebuilt, the others abandoned.

To knead these scattered and disparate elements into a harmonious operating unit, uniform as to output, efficiency and safety, was an enormous task. Alfred created a crack traveling staff and himself lived much on trains, often taking Dashiell to keep administrative details running while en route. Frank Mathewson, Alfred's boyhood chum, became a traveling inspector of blackpowder machinery. Output had to be regulated in different sections of the country according to the needs of industry, thus avoiding expensive freight hauls. Every mill was surveyed. Not even the most up-to-date escaped without some changes. Other mills were turned upside down, reorganized completely. Several were junked. Two large new mills were built—one on a virgin site named Nemours, West Virginia; the other on the site of a plant Alfred had dismantled near Birmingham, Alabama.

The Connable Mill, as the new Alabama works were called, for years stood as a model for black-powder plants. Alfred laid it out in a mile-wide semicircle along a spur of the Louisville \& Nashville Railroad. Having unloaded raw materials at one end of the curved operations line, a train could pull down to the other end and load finished powder. The operations line was on a 2 per cent grade, the different mills far enough apart for safety. All materials in the process of fabrication moved straight down this grade, with no crosshauling, as in the Brandywine yards. ${ }^{5}$

Results of Alfred's reorganization were quickly apparent. In October, I903, a year after Laflin \& Rand was taken over, he produced, with twenty-nine mills operating, the most black powder ever made by DuPont in one month in peacetime. In August, 1905, this figure was equaled with twenty-two mills. ${ }^{6}$

A significant factor in the increase was a glazing barrel which Alfred had found time to perfect in his new Hagley Yard machine shop. This revolutionized the process, reducing the time involved from about eighteen hours to about eight.

Glazing is a finishing operation, by which the powder grains are 
dried and polished with graphite to plug the pores against moisture and so keep powder from caking in the kegs. Formerly this had been done by friction in wooden tumbling barrels. Mr. duPont's invention consisted of a tumbling double-walled cylinder. Friction took care of the polishing as before, but the introduction of steam between the walls of the jacket cut the drying time by half.

The invention in which Alfred took the greatest satisfaction, however, was a new type of graining mill which represented no saving of time but which has saved many lives. The graining process, by which the presscake was broken up, was exceedingly dangerous. A minute foreign particle in the cake might cause an explosion. In the new mill a foreign particle would automatically stop the wheels.

The new machine shop was Alfred's pride: a noisy sanctuary from the cares of management and from other cares more personal-its perpetual din music to ears grown so deaf they could hardly distinguish any other music. In this shop was designed and constructed practically all the modern gear with which Alfred refurnished his plants. He spent hours there-coat off, sleeves rolled, hands dirty-never happier than when tinkering with a new model or going over an experimental plan with George Sykes, the boss patternmaker.

Among the machinists he made lifetime friends. One of them, Edward L. Bader, has told this writer:

"Alfred duPont did for powder machinery what the automobile did for transportation."

The retired machinist's exaggeration contains more than a grain of truth, and it reflects the admiration Alfred I. duPont seemed almost invariably to instill in workingmen with whom he came in contact.

In 1904 he designed and Ed Bader built a gasoline-propelled locomotive to replace horses in hauling heavy loads up the steep grades of the Brandywine yards railway.

Most visitors to the yards used the lower entrance to Hagley, protected by old wooden gates to which was joined a shack for the gateman.

"Buchanan," Alfred said to the Yaba of childhood days, "those 
gates are a disgrace to the firm. I'm going to put in a pair that'll be here when we aren't."

He designed and Bader made them of wrought iron. Though installed in 1904, they have become known as the Centennial Gates because they bear the legend:

"I802 DUPONT DE NEMOURS I902""

Such were some of the relaxations of the man who was changing the panorama of powder manufacturing in the United States. Though by the end of 1905 the transformation was almost complete, only one of the old-company men who had given way to the three cousins lived to see it. Charles I. had not lasted out the eventful year of 1902. In 1904, within three weeks of each other, Frank duPont and his brother Doctor Alexis were laid to rest beneath the oaks of Sand Hole Woods. The survivor was Colonel Henry A. who in 1906 stepped gleefully out of the company and into the United States Senate.

After eleven years he had defeated "Gas" Addicks. Colonel duPont had entered the contest in 1895 from good motives, though any successful opposition to Addicks was bound to be expensive. Actual credit for the victory in 1906 was due to the practical work of Coleman duPont who made his bow to public life as his cousin's campaign manager. In any event the Colonel's triumph was received with a national sigh of relief, President Theodore Roosevelt sending a telegram of congratulation to the people of Delaware. Thus the last of the old guard disappeared from the directors' table of the E. I. duPont de Nemours Powder Company.

In their stead was a gallery of new faces. J. Amory Haskell, late president of Laflin \& Rand, took his place as vice-president in charge of sales, filling that important post with distinction. Old A. J. Moxham also was made a vice-president. From the swarm of officers of dismantled corporations only two-James G. B. Reilly and L. R. Beardslee-gained directorships. These were all the outsiders, if Moxham could be fairly called an outsider, at the long table. The eight other new faces were those of DuPonts or DuPont 


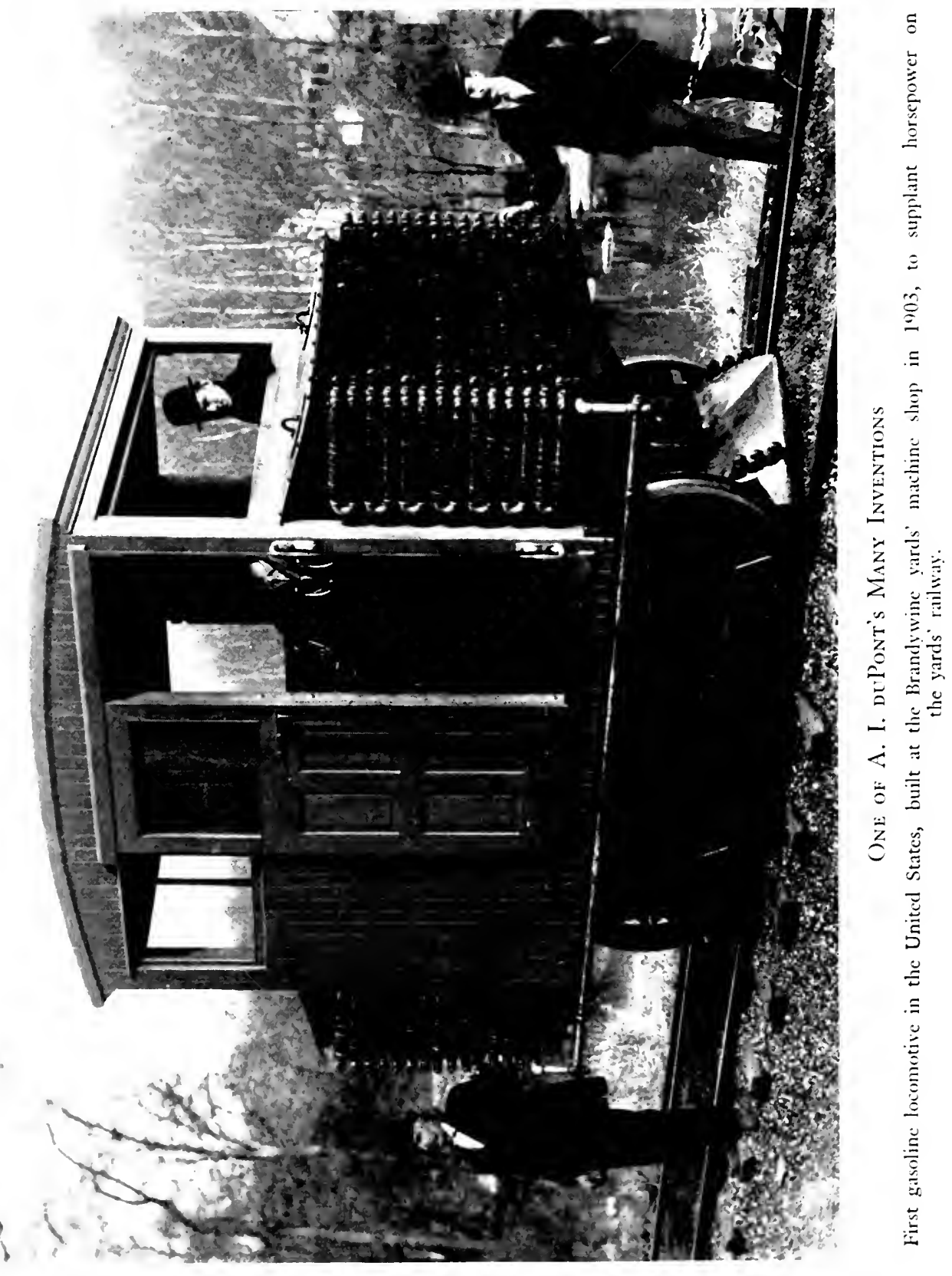



in-laws: Francis I., son of the late Frank, vice-president; Victor, son of the late Victor, vice-president; H. M. Barksdale, brother-inlaw of Coleman's wife, vice-president; Alexis I., son of the late Eugene, secretary; Irénée, brother of Pierre, assistant treasurer; Eugene II, son of the late Eugene, director; Henry Francis, son of Colonèl Henry A., director; H. F. Baldwin, brother-in-law of Coleman, director.

Not having performed to Alfred's satisfaction in the blackpowder construction department, Irénée had transferred to the treasury where Pierre advanced him rapidly-though apparently no more so than his capacity warranted. Alfred himself promoted another of Pierre's brothers almost as fast. "That boy has something back of his ears," he had remarked of Lammot, starting as an inexperienced hand in the Upper Yard refinery. In two years Lammot was general superintendent of black-powder production.

Alfred came to board meetings carrying a black box two by eight inches in dimensions. Placing it on the table before him, he would plug in a cord attached to something that looked a little like a telephone receiver. The receiver he held to his ear. This instrument, called an acousticon by its inventor, was the device Alfred used for hearing at meetings where there were several voices to catch. For ordinary conversation he used a simpler and less conspicuous aid, whose visible parts consisted of an earpiece and a transmitter pinned to the vest. About Swamp Hall, where the voices were familiar, he sometimes carried an old-fashioned ear trumpet which he called his saxophone. But whatever the difficulties with hearing, the sight which met Alfred's eyes at board meetings was what he had been working for: new blood in the company, predominantly DuPont blood, and young. The average age of the eight family newcomers on their accession to the directorate was thirty-five.

Three years had witnessed the virtual fulfillment of the aspirations Alfred had held for the company when he kept it from passing out of the family. 


\section{CHAPTER XII}

\section{A Surprise for the FAMily}

As ofTEN happens to persons growing deaf, Alfred lost the consonant sounds first. Talk became a jumble of vowels. $\mathrm{He}$ was able to enjoy instrumental music, however, for some time after a conversation, particularly a conversation with several voices participating, had become hard to catch.

By Igor Mr. duPont's affliction had reached the point where music came to him so distorted that he could no longer bear to hear it. Pious communicants burned candles before the altar of St. Joseph's Church for the return of Mr. Alfred's hearing. These prayers and the ministrations of physicians alike failing to arrest the progress of the ailment, Alfred turned to artificial aids to hearing. On the theory that one good turn deserved another, likable Jimmy Hackett, the actor, whom Alfred was still trying to wean from the whisky bottle, introduced duPont to Doctor Miller Reese Hutchison in New York.

Although he had had two years of medicine in college, Doctor Hutchison's title derived from a Ph.D. and not an M.D. degree. He was an inventor whose adaptations of electricity had attracted the favorable notice of Edison. Combining his knowledge of electricity with his understanding of the functional anatomy of the ear, Hutchison had produced the akouphone, which amplified consonant but not vowel sounds. England's Queen Alexandria was using one of the instruments so successfully that in the following year Edward VII gave the scientist a gold medal. Alfred accompanied Hutchison to a meeting at the New York Academy of Medicine where the device was demonstrated before a gathering of aurists. A deaf girl was made to hear, among other sounds, the notes of a guitar. 
That clinched it with Alfred. He ordered an akouphone made to his requirements. When it was finished he went to New York and took Hutchison to a concert. For the first time in a year Alfred heard music as it was played. He walked back to his hotel feeling like a new man.

Yet he knew that music was his again only temporarily. Hutchison had dealt honestly with his client, telling Alfred that an incurable condition afflicted his ears. Deafness would gradually grow and the day come when the akouphone would be of little use. This happened in 1904. By that time, however, Hutchison had developed his acousticon, the instrument with the box, which enabled Alfred to carry on at directors' meetings but availed little with music. When again Alfred could no longer hear the music of his own violin or enjoy playing with Madie and Bep, he went to Hutchison with an idea. Why not put a microphone on the violin to trap the musical sound waves and readjust them, equalizing consonant and vowel sounds, and transmit them by wire to his ears? Hutchison equipped one of Alfred's violins in this way. It did not work. The scraping of the bow was magnified along with the consonant tones. For Alfred music was over. ${ }^{1}$

Though he took it stoically, an occasional word dropped revealed the extent of the loss.

"If I had my ears for three hours a day," he told Jimmy Dashiell, "I would spend two of them playing a violin."

Dashiell still led the old orchestra, which without Alfred's engaging personality was no longer the spirited organization of yore. Alfred used his old musicians as intermediaries for the distribution of money to buy lessons for promising beginners, the only stipulation being that the source of the funds should remain confidential. Learning that the orchestra still played numbers of his own composition, Mr. duPont directed Dashiell to collect the scores.

"They're no good," he said. "I was just beginning to learn a little about composition."

Suspecting something was up, Dashiell withheld a few copies. This he never regretted, for Mr. duPont burned those which came to his hands.

Thomas A. Edison, who was not a musician, endeavored to lighten the burden of Alfred's affliction. 
"It's a boon, deafness," said he. "Like me, you'll miss a lot of things not worth hearing. Just think of not having to go to church."

DuPont laughed at Edison's quips. He always affected to make a jest of his bad ears; but he did not mean it. ${ }^{2}$

More than failing hearing afflicted Alfred. His domestic life was falling apart. The birth of Alfred Victor, in I900, had given rise to hope for a restoration of harmony. Every seventeenth of March, which was little Alf's birthday, the boy shared honors with St. Patrick in the Brandywine powdermen's noisy observances. Hope for peace flared again in 1903 when the third daughter, christened Victorine, was born. It proved a vain hope. Vicky was less than a year old when Mrs. duPont took the four children to Europe, settling in Brussels as if for a long stay. The older girls, Madie, seventeen, and Bep, fifteen, were placed in school there.

The pressure of rebuilding DuPont left Alfred little time for recreation. But when he could take off a week or a week end he would slip away with a few cronies to his hunting shack at Cherry Island, or to Balls Neck in Virginia. As on his first visit there, the society of the Harding and the Ball families in the Neck, with their ten children between them, appealed to Alfred more than the hunting. Frank Mathewson says that a trip to Virginia always made a different man of the boss. One day Mrs. Harding told Mr. duPont of the loss of a widow's home by fire. Alfred began to ask questions, with the result that he obtained quite a list of Neck people who had met misfortunes. Back in Wilmington, Mr. duPont sent Mrs. Harding a check, the proceeds of which he asked her to divide, according to her judgment, among the needy. Each month for many years a check arrived for Fanny Harding to disburse.

The comings of Mr. duPont became great events in the Harding and the Ball households. Usually he could not give very long advance notice, which threw both families into a bustle of preparation. Six of the ten young ones were girls, and their needles flew 


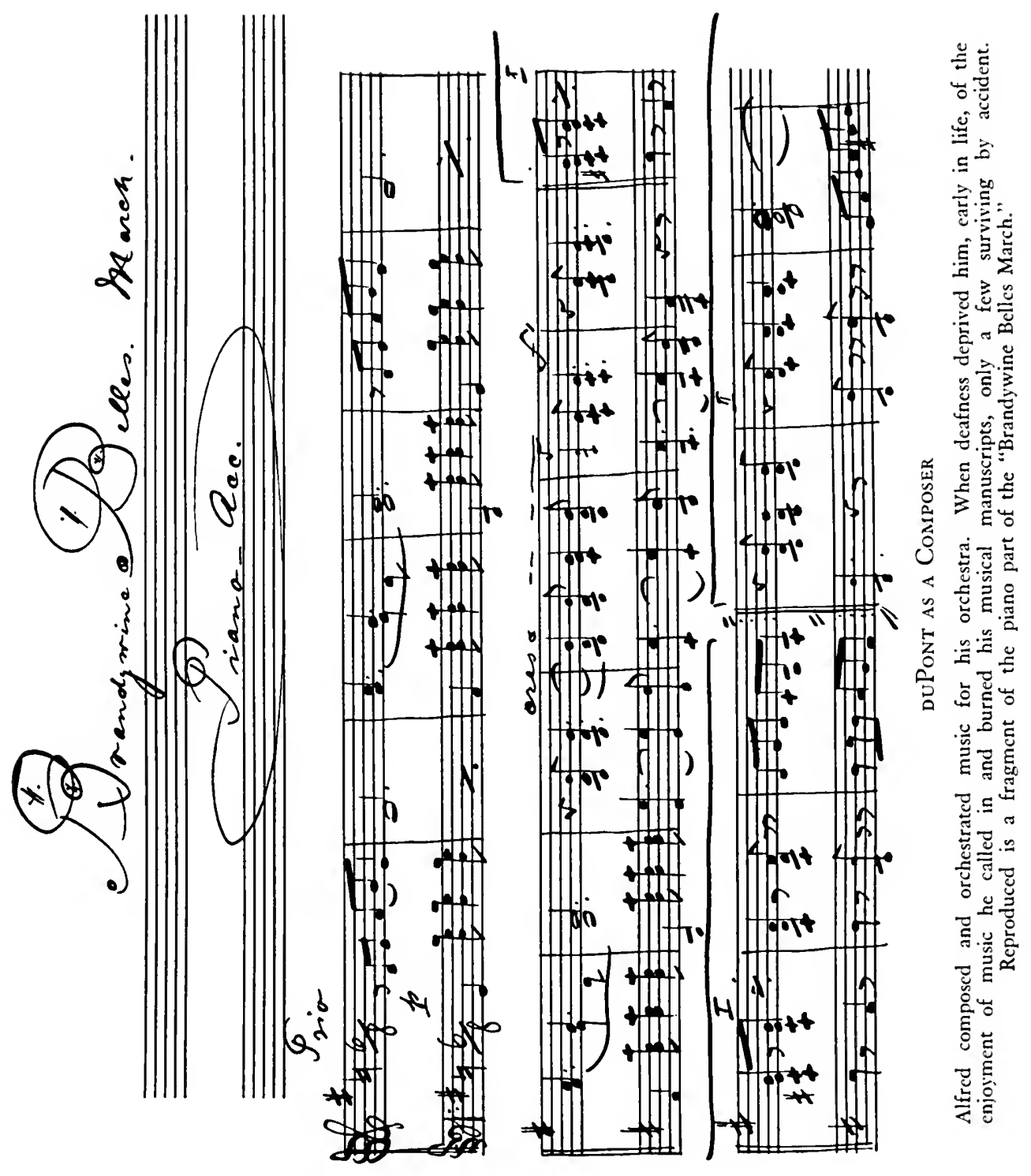



to make new dresses or to furbish up old ones. Bess was tne most skilled seamstress among the Hardings, and Jessie among the Balls. Poor Bess was an invalid who could do little except sew, but Jessie taught a country school. Tall, brown-haired, vivacious and sixteen, she was, in the considered estimate of some of the young men, the belle of the Neck. A stay of Alfred's always wound up with a big dance: waltzes, two-steps, Virginia reels to the music of fiddle, accordion and banjo. Alfred would dance every number and when the festivities were over help the girls clear away the dishes.

One night, when everyone else was in bed, Rebecca Harding saw Mr. duPont walking up and down under a row of locust trees in the back yard. She said to her mother:

"I wonder why he is so sad."

When Mrs. Harding replied that she did not know she was telling Rebecca the truth. The conviction that their visitor's gaiety was a mask for a secret sorrow rendered the rich Mr. duPont more than ever a creature of romance in the eyes of these Virginia country maidens.

The darky who carried Alfred's bag aboard the Baltimore steamer at Hardings Landing caught another side of the visitor's character. Gazing at the silver dollar in his palm, the colored man shook his head, muttering oracularly:

"A fool an' his money is soon parted."3

Between visits Alfred carried on quite a correspondence with his Virginia friends, young and old. To Miss Jessie Ball:

"You see I can keep my promise about writing to you although I am quite sure you have forgotten all about it (the promise) and its author. It matters little however, as I write so badly as to make my letters, to all but experts on chirography, absolutely unintelligible. My little visit was most delightful, and I was very blue at having to leave. I had hoped that you and your sister would be in at the finish, or in other words stay with us until the boat left, and as it was nearly an hour late we could all have seen just that much more of you. Did we not have a fine time the night of the dance? I'll never forgive you for preferring the orchestra to me. I always knew I danced poorly, but never had it rubbed in like that. However, my revenge will come some day." 
Mr. duPont's family left for Europe in the summer of ig04. The ensuing November he was at Balls Neck with Frank Mathewson, Bill Scott, divisional superintendent of the DuPont mills in Pennsylvania, and a jovial character named Weldy whose chief claim to distinction was as a volunteer fireman in Wilmington. The boat docked before breakfast was ready at the Hardings' and Alfred proposed a little gunning to whet the appetites. On the trail of game the party spread out. DuPont and Mathewson were walking beside a hedge which separated two fields. Scott was on the opposite side of the hedge thirty yards away. Suddenly he wheeled and fired straight into the hedge. Throwing himself on the ground, Mathewson saw Alfred's hat carried away by Scott's charge. DuPont dropped his gun, reeled and fell. When Mathewson reached him blood was pouring from Alfred's face. Mathewson thought Scott had killed him.

Mr. duPont was only stunned, however. The charge had struck his left eye. In a few minutes Mathewson and Weldy were able to walk the wounded man toward the house. The horrified Scott needed assistance almost as badly.

"Buck up, Scott," said Alfred. "You couldn't help it."

Mrs. Harding prepared hot compresses while one of her boys rode for a doctor. ${ }^{5}$

Emerging from a darkened room in Philadelphia's University of Pennsylvania Hospital, Doctor G. E. de Schweinitz approached the silent little group which awaited his verdict: Mr. duPont's sister, Marguerite Lee; his cousins, Alicia Maddox and Ellen LaMotte; his friends, Wallis Huidekoper and Father W. J. Scott of St. Joseph's Church.

There was a chance, the surgeon said, to save the eye. What the patient needed most was rest, quiet, freedom from the slightest emotional irritation. Mr. duPont's family and his friends could best promote his recovery by sparing him from all excitement. ${ }^{6}$

The presence of Huidekoper in the East was a coincidence. This former Philadelphia bon vivant had been a charter member of the 


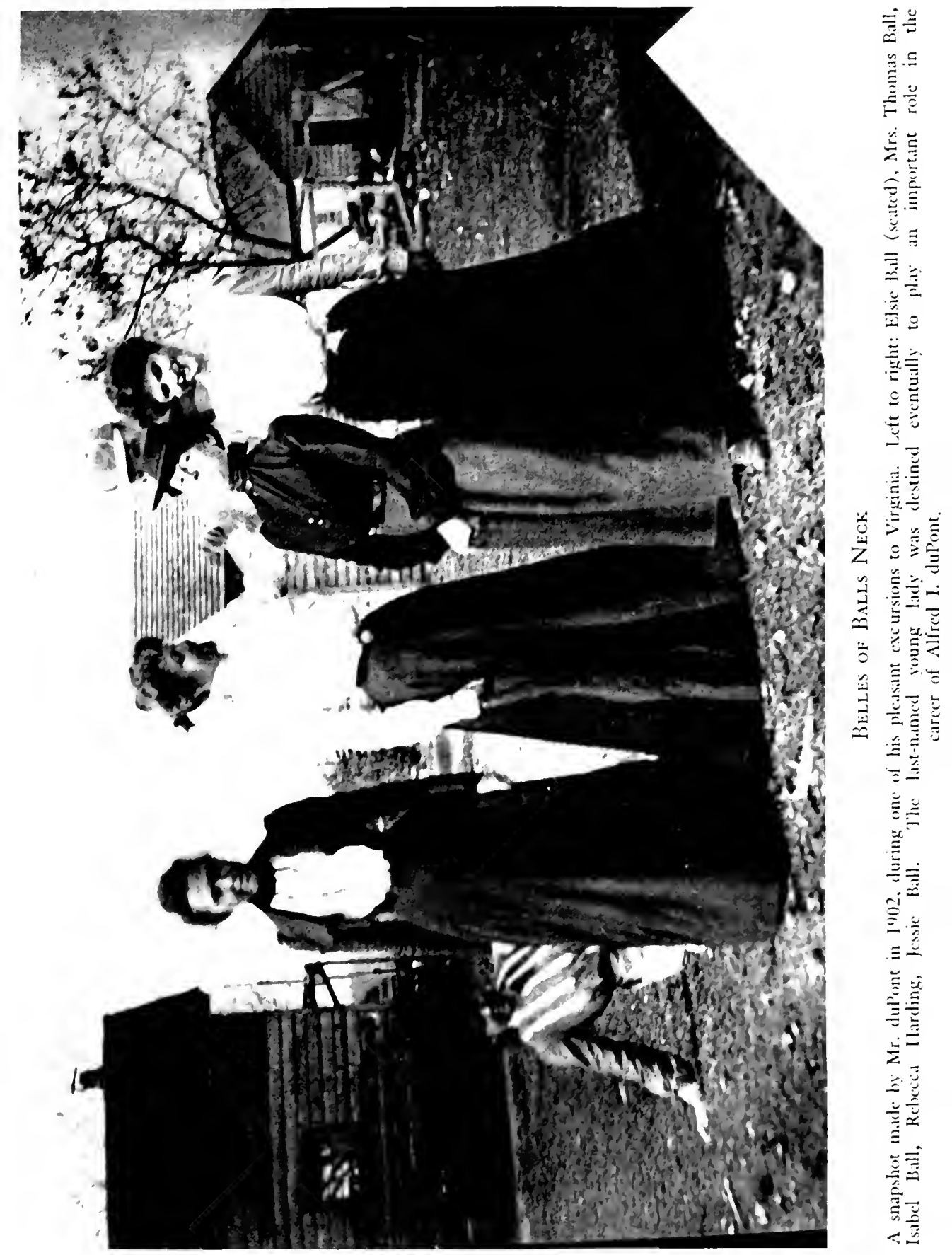


웅

$=$ 
small company of good fellows Alfred had begun taking to Cherry Island fifteen years before. Alfred had backed him in a ranching enterprise in South Dakota at which, to the surprise of many who knew him, Huidekoper was making good and repaying the money duPont had advanced. A pretty well naturalized plainsman by 1904, Huidekoper's visits to his old haunts were becoming fewer and shorter.

At Alfred's request Huidekoper wrote Mrs. duPont, in Brussels, a reassuring account of the accident. He said that though the sight of an eye had been permanently impaired, the doctor hoped that Alfred might leave the hospital within a few weeks. Should these expectations fail, Huidekoper promised to communicate at once. This intelligence was sent by mail, rather than by cable, because Alfred said that he did not wish to alarm his children.

The patient improved encouragingly. The façade of cheerfulness put on at the time of the accident to spare the feelings of Scott and of Alfred's Virginia friends was replaced by genuine good humor. On Thanksgiving he ordered a feast for all the children in the hospital who were able to eat. Though hospital authorities were sworn to secrecy, in the course of a few days the identity of the provider leaked out.

The first word from Mrs. duPont was a cablegram addressed to Doctor de Schweinitz:

"Wire me Alfred duPont's condition."7

Ten days later Mrs. duPont and Madeleine arrived in New York. She wired that they were departing at once for Philadelphia. According to Mr. duPont's nurse, the news "frightfully distressed [him] both mentally and physically."s

Weeping, Madie rushed to her father's side and embraced him. According to Madeleine, Mrs. duPont's greeting was cold. "She never once showed any pity, never once said: 'Alfred, I am sorry this has happened to you.' Not a kiss; nothing."”

The effect of this interview on the patient was serious. ${ }^{10}$ Though Mrs. duPont returned to Brussels, Alfred's depression of spirits continued. Before Christmas he suddenly returned to Swamp Hall, saying he wanted to spend the holidays with his own people. $\mathrm{He}$ ordered the usual Christmas party given for the workingmen's 
children. Two days later Mr. duPont suffered another relapse, and Doctor de Schweinitz removed the injured eye.

In March Mrs. duPont unexpectedly announced that she was returning with the children. Alfred, who had been slowly recuperating in Florida, met the boat and patched up a truce. It lasted only a few weeks, whereupon Alfred packed his trunks and left Swamp Hall for good. Until August he was very ill. On September 26, 1905, Alfred and Bessie duPont met to put their names to a document which, in all but law, ended their married life together.

By this instrument Alfred set up a trust fund consisting of 4 per cent DuPont bonds valued at $\$ 600,000$ and yielding $\$ 24,000$ a year. This income was guaranteed to Bessie Gardner duPont as long as she should remain unmarried. With it she was to support herself and the four children and to defray the cost of educating the children. Should she die or remarry the income reverted to Alfred. Should Alfred also die the income was to be paid to the children, share and share alike, until the youngest one reached the age of twenty-five. Then the principal was to be divided equally among them. The income of $\$ 24,000$ a year was guaranteed by Alfred. Should the securities ever yield more than that, however, the difference would go to Alfred and not to his family. In other words, $\$ 24,000$ a year was all wife or children could receive from the trust fund.

In consideration of the above, Bessie surrendered her dower rights and pledged herself not to contest any will he might make disposing of any property of which he was possessed or might become possessed.

It was stipulated that the children should divide their time between their estranged parents. Alfred and Bessie were to agree to the details; and failing to agree, the trustees of the $\$ 600,000$ fund were to decide "with whom or for how long a period each child shall live or dwell" during each year.

The trustees upon whom this and other responsibilities should devolve were two in number: one acting at the request of Bessie duPont and designated as "her trustee"; one acting at the request of Alfred and designated as "his trustee." 


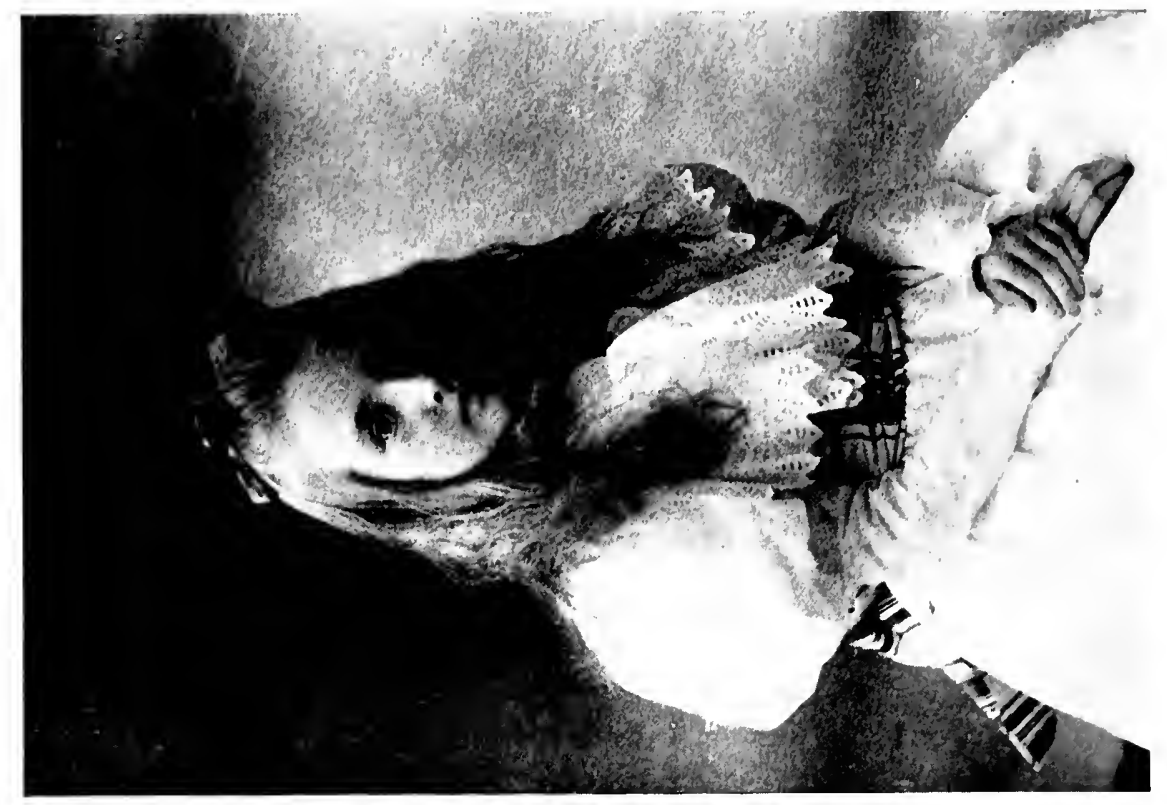

อิ

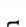

范

.



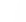

$\stackrel{\dot{\Xi}}{\Xi}$
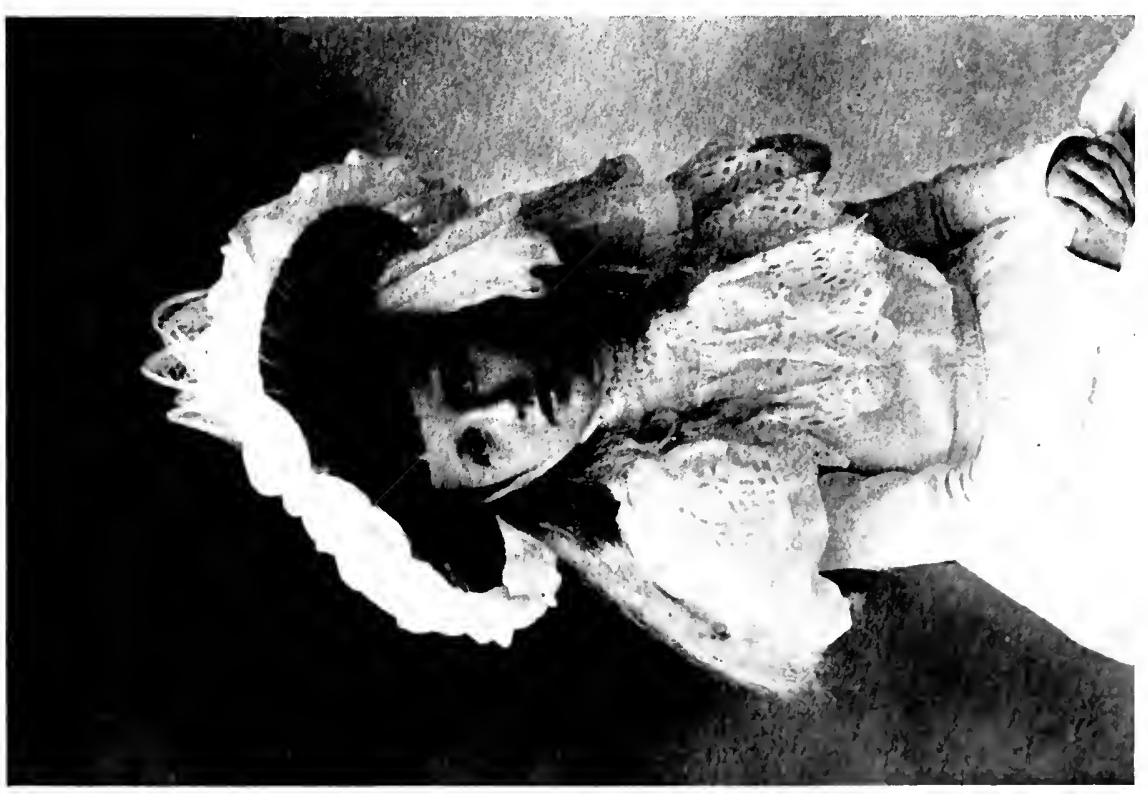
$=$ 
Alfred named as his trustee George Quintard Horwitz, a Philadelphia attorney. Bessie named as her trustee Pierre S. duPont. ${ }^{11}$

Mrs. duPont and the children remained at Swamp Hall. Alfred took up his residence in a comfortable abode on the other side of the Brandywine called Rock Farms. This was one of the properties he had looked over with the New York engineer when contemplating building a new home.

The financial settlement was not an equal division of either Mr. duPont's income or his fortune. He owned \$1,200,000 in company bonds representing his share of the 1902 purchase money notes which had been converted into bonds-and \$2,460,000 in common stock at par value. During 1905 the income from these holdings was $\$$ 134,100, to which should be added Alfred's salary of \$25,000. Thereafter this income greatly increased.

The intent was to provide his wife with funds to maintain The Swamp about as it had been maintained before the separation, but no more. This also was the effect of the settlement as it applied to the children. By its terms $\$ 600,000$ would be the most they could receive from their father's estate. Friends of Mr. duPont say this was not his ultimate aim, however. The settlement, they say, was to provide merely for the children's younger years when he did not wish them spoiled by too much money. This seems plausible. Mr. duPont was a generous man and devoted to his children. Every week end that he was at home they visited Rock Farms and had good times they were never to forget. Little Alfred was especially fascinated by his father's glass eye, which was, in truth, a remarkable counterfeit of nature. When traveling Alfred wrote the youngsters long, affectionate letters.

Eye accident, increasing deafness and domestic turmoil had kept Alfred in a low state of health for nine months. Friends described his condition as bordering on nervous prostration. ${ }^{12}$ This reflected itself sharply in Mr. duPont's work. The Brandywine yards, where he was something of a god, caught glimpses of an Alfred duPont they had never known before. One week he raised the pay of 
the boss of his prized machine shop, the next week he fired the man, neither action having apparent justification. Similar contradictions in behavior led one of the yard superintendents to refuse to accept Alfred's orders unless in writing. This superintendent was a sincere admirer of Alfred. He blamed his superior's frame of mind on his domestic difficulties and thought it would pass when they were smoothed out. ${ }^{13}$

The keeper of Centennial Gate was an Italian who had lost an arm. One day someone asked the Italian where Mr. duPont was. The man replied that he was visiting Mrs. Maddox.

When Alfred learned this he flew into a rage, firing the Italian on the spot.

The gatekeeper's foreman, however, continued him on the pay roll under an assumed name and gave him a remote post in the yard where he thought that Mr. duPont would never see him. But Alfred did see him and threatened the foreman and the yard superintendent with discharge. They appealed to duPont's fairness: this Italian, crippled in the service of the company, had done no more than to give an honest answer to a simple question.

Alfred's manner changed.

"I have done wrong," he said. "That man has a lifetime job."14

To make sure of this Mr. duPont later took the Italian into his personal employ. As this is written he tends a gate at Nemours, the Delaware residence of Mr. duPont's widow.

That was more like the old Alfred.

The death of Sam Buchanan in an explosion upset Mr. duPont for days.

There was sickness in a workingman's family on Rising Sun Hill. They were Episcopalians and, learning that the rector had not included them in his parochial calls, Mr. duPont visited this clergyman.

"Do you expect to go to heaven when you die?" asked duPont.

The astonished minister said that he did.

"Well," said duPont, "I'd suggest that you stop at Rising Sun Hill on your way."15

DuPont made a fast friend of Father Scott who had succeeded Father Berminham at St. Joseph's. The only clergyman who had 
visited Mr. duPont at the University Hospital in Philadelphia, the priest became a frequent guest at Rock Farms. Soliciting donations for St. Joe's, a powderman's daughter called at Alfred's office. Mr. duPont had known Lizzie Dorman as a little girl with red pigtails. Miss Dorman expected ten dollars. She got five hundred.

"Lizzie," said Alfred, "your church is the true church."16

The Italian gatekeeper had spoken the truth when he said Mr. duPont was visiting Alicia Maddox. Alfred had long taken an interest in this talented cousin whose life had been an unhappy one. Her father, Judge Edward Green Bradford of the United States Circuit Court, was looked up to by many DuPonts because of his position. A household tyrant, he held in subjection his gentle wife, a daughter of the late Doctor Alexis duPont. Adoring her mother and despising her father, Alicia was not the kind to submit to suppression. In the last years of her life she confided to one of her few friends in the family:

"As a child I was frightened all the time-terrified of everything. Suddenly it came to me that my father was the cause of this. He had wanted me to be a boy. I saw it all and made up my mind to get even." 17

Growing up, Alicia had disdained the attractive little stratagems by which a girl courts popularity. She found most women dull, and they found her irritating. Preferring the company of men, she kept all except brilliant and witty men afraid of her superiority of mind: a mind deficient, however, in common sense, just as her rigid temperament was wanting in ability to effect those saving compromises which smooth the way of life.

As a thing foreordained, the chivalrous Alfred, with his reputation for espousing unpopular family causes, became Alicia's champion. When Judge Bradford forbade Maddox's suit, Alfred encouraged it, arranging clandestine meetings. As the young woman was twenty-six, her father could not legally prevent a marriage. He did, however, practically disown his daughter; announce that he would not attend the wedding; browbeat his wife into staying away; and influence many of the powerful DuPonts to do the same. But he could not coerce Alfred, who stage-managed the ceremony, making quite an affair of it and, by his popularity 
with his family and his courage, bringing a good-sized gathering of the younger element of the clan to Christ Church. ${ }^{18}$

Then Alfred settled the couple in the pleasant estate of Louviers, which had once been the residence of Admiral duPont. Judge Bradford was furious. He appealed to Coleman, as president of the company, to oust his daughter from Louviers. Coleman consulted Pierre and wrote the Judge that such "radical" action would only make matters worse. ${ }^{19}$ Though he failed to make Coleman an instrument for removing his daughter from Louviers, the vindictive father did succeed in prejudicing Coleman against her-a circumstance which was to bear bitter fruit later on.

Alfred promoted Alicia's husband, Maddox, into drag jobs, at length advancing him over more experienced men to the regional superintendency of the black-powder plants in the Middle West. This kept Maddox away a good deal, which was just as well, for the match had not turned out a success. The Judge said, "I told you so"; vilified Alfred for his part in the business; and never went near his daughter. Alicia and her mother exchanged furtive visits, and almost daily they wrote each other touching letters. ${ }^{20}$ In April, I906, Alicia lost an infant son. Two months later death struck again, depriving the young woman of her mother and her only anchor, saving Alfred. More and more the proud and miserable young woman absented herself from the Brandywine, spending much time in Europe. When she did come home it was to exhibit an attitude which repelled rather than attracted sympathy. Her flashing intelligence took such a caustic turn, her biting wit waxed so devastating that kinfolk who might have helped threw up the sponge.

With Alfred steadfastly on her side she did not appear to need them. In this way it was that two unhappy persons were thrown together. They seemed to do each other good. Alfred's spirits improved.

Another portentous circumstance in the changing mosaic of events had been Pierre duPont's quiet espousal of the cause of Bessie Gardner duPont. Prior to her separation from Alfred, Bessie had not been what one would call popular with her DuPont in-laws. 
Having her own circle of friends, she had evinced no particular desire for their favor. Now this situation seemed slowly to change. Her trustee, Pierre, became her closest counselor concerning matters of money. She seemed to see more of her other in-laws than before-and the particular coterie in which Pierre and Coleman were influential. Alfred had always been popular in the family. Some of his friends thought his estranged wife maneuvering to counteract this. ${ }^{21}$

Nor was this situation the only evidence of ripples on the waters of harmony as far as the three cousins were concerned. In a world filling with discords, the syllables "Coleman's Company" fell on the dulling ears of Alfred and he did not like the sound. Moreover, borrowing another leaf from Boss Henry, Coly had begun to act as if it were his company. He grew less tolerant of opposition but would listen to the suave Pierre, who was a good compromiser, more sympathetically than to Alfred, who was a poor one. Alfred regretted his generosity in having given Coleman the lion's share of the company's stock in 1902. ${ }^{22}$

Coleman showed impatience over Alfred's long convalescence from his eye wound. A hitch had occurred in the building of a trolley line from Wilmington to Rising Sun Lane, near the Brandywine yards.

"Where's Alfred?" demanded Coleman.

Jimmy Dashiell, who had been promoted to office manager of the black-powder department, said that Mr. duPont was out of town.

"When I put a man on a job I want him to attend to it," exclaimed Coleman.

On Alfred's return Dashiell repeated Coleman's words. Though Mr. duPont seldom swore, Dashiell thought he was going to do it then. Instead he clenched his fists and replied:

"So he said that, did he?"23

In May, 1906, the newspapers printed an item saying that Alfred I. duPont, vice-president and general manager of the great powder company, had gone to South Dakota to inspect sites for a new 
plant. The fact was that he had gone to sue for a divorce. A sixmonths' residence was necessary, and Alfred took with him Ira M. Williamson to help while away the time. A trained nurse, Williamson had been employed during Mr. duPont's convalescence from the eye accident. By the time he had recovered, Alfred had taken a fancy to Williamson and retained him as secretary and all-round confidential man. Alfred bought a small house in Sioux Falls and on his departure gave it to the man he had bought it from. $\mathrm{He}$ and Williamson hunted, fished, roughed it on horseback and generally enjoyed their stay, Alfred forming local friendships, some of which endured the remainder of his life.

The divorce complaint, filed by Alfred's attorney, William G. Porter, alleged "barbarous and inhuman treatment." The principal testimony was in the form of depositions by Marguerite duPont Lee, Wallis Huidekoper and Rebecca V. Abbott, Mr. duPont's nurse in the University of Pennsylvania Hospital. Though Charles W. Brown, attorney, put in a perfunctory appearance for her, Mrs. duPont made no real contest of the suit, and the divorce was granted, for mental cruelty, on December 5 , $1906 .^{24}$

Alfred returned to Rock Farms with a new zest for his work and for life generally. His bachelor retreat became a much-frequented place. It was a rendezvous for young engineers employed at the company's research station in which Alfred was deeply interested. Library shelves were filled with technical books and the table covered with periodicals the youngsters could not afford to buy. Over the kitchen presided George, a colored man whose cooking became famous. Alfred said George's ambition was to get half of Wilmington down with gout. Glad to escape boardinghouse fare for an evening, the engineers were willing to run the risk. After supper they would sit around and drink beer while Alfred quizzed them on what they had learned at school and how they were applying it to their jobs. He told them that the age of chemistry was merely dawning, that the time would come when DuPont would be as widely known for its non-explosive byproducts as for its powder and dynamite. ${ }^{25}$

Week ends were given over to the children. Alfred thrilled his son with automobile rides. Occasionally they stopped by Louviers 
to see Alicia Maddox. The father and two older daughters took in shows in Philadelphia and once made a trip to Florida. Bep was the first to return, and her father wrote to her:

"I have been kindly expecting to hear from you, but I suppose you have been busy since your arrival in Wilmington, and have been following out my instructions and have been to see the Pill Dispenser in regard to your eyes.

"I have just sent the Boy a telegram, wishing him a Happy Birthday, which I hope he will receive in good time. Let me know what present you bought him, for me. If you bought him an air gun I suggested, he must be instructed most carefully not to use it when his little sister [Victorine, aged five] is about. It is all very well that he should start to use arms, but he must be taught the necessity of exercising the greatest possible care in handling them. By the time he is ten he ought to have a little shot gun....

"My attack of 'brown kitties' [bronchitis], which seem to savor of the pole-cat variety, showing a desire to hang on to the inside of my chest, I decided to stay in my room yesterday. Today I am decidedly better, and there is considerably less caterwaul going on in my wind pipes. Madeleine was very good and attentive, as usual stayed with me most of the day, and we read aloud and played Cribbage, and sewed. She did most of the sewing. ...

"I am sorry that you had to leave when you did, but I think it was best that your eyes should receive attention. I should like to take the Ocklawaha River trip with you, as it is unique, and you would enjoy it. I do not know whether Miss Brereton [Mr. duPont's secretary], Madeleine and I will take it or not, but Miss Brereton is going to pray for light when she goes to church today, and she will probably know more about it this evening.

"I sent the Boy, in my telegram, seven fat hugs and kisses, and these I want you to deliver to him for me. Let me know how he is, and how he has been this winter-whether he has suffered much from colds; also, is he fat?...

"With much love, and many kisses for my Dear Little Bep, "As ever, your devoted "DAD"

The river trip was taken. Alfred described it to his son: 
"My dear little Man,

"When I got back from a little two day trip up a funny river with a funny name, called Ocklawaha, I found your nice letter awaiting me here at the Hotel.

"I want to tell you that I think your hand writing is very much improved, and I only wish I could write as well myself. I am especially taken with your question marks, which are nothing more or less than wonderful. I wish as you grow older, and perhaps have a little more time, that you would make your letters a little bit longer-telling me how you are, and also how Pat Casey, John Flannigan [servants at Swamp Hall] and all the rest of my friends are.

"I sent you a card with a picture on it, which shows the river we went up in a funny looking steamboat, which had two smoke stacks and burned pine wood instead of coal. It made so much smoke that it got in my hair and made by head black....

"The river is very crooked, and winds like a snake in between two rows of tall trees for nearly 100 miles. The water is very clear, and the bottom of the river is white, so you can see the fishes, turtles and snakes when they are swimming around. There were some very funny looking fishes with long noses, and a good many snakes, but only a few alligators. I took some photographs, and I think they will be ready to show you when I come home.

"I expect to get home on Sunday, and I want you to call me up on the telephone and talk to me.

"Tell Pat Casey I am sorry I did not see him Christmas Day to wish him a Merry Christmas, but will wish him a Merry Christmas on the $4^{\text {th }}$ of July.

"Kiss yourself in the glass for me and see how it tastes.

"With lots of love,

"Your old

"DAD"27

Not long after his return Alfred and his son dropped in at Louviers.

"How would you like to have me for a mother?" Mrs. Maddox asked the seven-year-old.

"Why, Cousin Alicia, I wouldn't like it at all," replied the amazed little boy. 

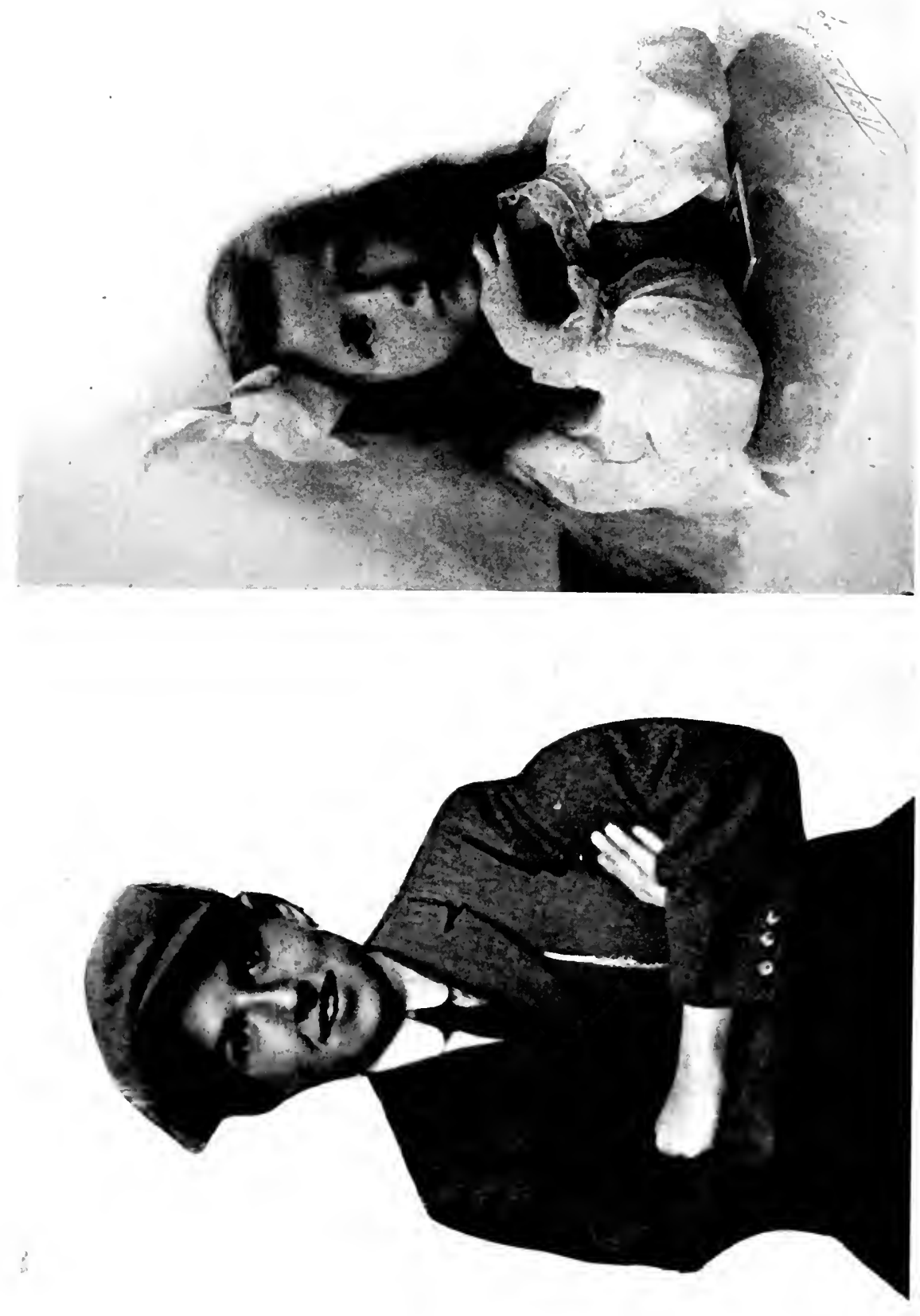

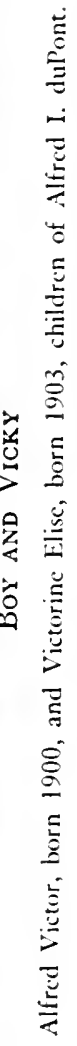


So far as he remembers, that was the last time Alfred Victor ever saw Alicia Maddox. ${ }^{28}$

The episode probably puzzled little Alfred no more than the happenings of the next few months puzzled the populace of Wilmington. Alicia was absent from Louviers: some said in Europe; others Nantucket; others elsewhere. Maddox, quietly quitting his profitable employment with the company, likewise sank from view. The Philadelphia Public Ledger revealed that Mrs. Maddox had filed in Wilmington a suit for divorce, alleging desertion, and had withdrawn it just before the convening of the trial term of court. Then the Ledger went on to say that Wilmington was buzzing with a rumor that Alfred I. duPont and his former wife, Bessie Gardner, would remarry. ${ }^{29}$

The Philadelphia Press published that George Amory Maddox had brought a suit against Alfred I. duPont but had withdrawn it before filing a declaration of particulars. Consequently the nature of his grievance was not known. ${ }^{30}$ That was as far as the newspaper went. Wilmington gossip supplied the omission by declaring the suit to have been for alienation of Alicia's affections.

The only point Alfred took public notice of was the reported reconciliation which he denied to a Ledger reporter.

The Wilmington papers printed none of this. They had not, in fact, mentioned that Alfred had divorced Bessie Gardner. As far as the name DuPont was concerned, the last vestige of a free press had disappeared from Wilmington. This cost a lot of money without fooling anyone. Wilmington people read the Philadelphia papers for the real news of Delaware's most numerous and most conspicuous family.

On October 15, 1907, Alfred gave Jimmy Dashiell a sealed envelope addressed to the editor of the Wilmington News. Mr. duPont said that he was going up to New York and would inform Dashiell from there what to do with the envelope. At nine-thirty that night he telephoned Dashiell to deliver it to the editor.

Next morning the following appeared on page one of the News: 
"Alfred I. duPont de Nemours, vice president of E. I. duPont de Nemours and Company, and Mrs. Alicia Maddox, his cousin, were married at the Plaza Hotel in New York City yesterday. Only their immediate families were present. Immediately after the ceremony Mr. and Mrs. duPont left on an extended motor trip in Mr. duPont's jo horsepower French car. On their return Mr. and Mrs. duPont will make their home at Rock Farms, near Wilmington, one of several estates owned by Mr. duPont.

"Mrs. duPont is a daughter of Judge Bradford of the United States Circuit Court, and her mother was Mrs. Eleuthéra duPont. Upon leaving Wilmington over a year ago Mrs. duPont went to Paris where she had a home on the Avenue du Bois de Boulogne. Last spring she instituted a suit for divorce from her former husband on statutory grounds and was awarded the custody of their only child."

This bombshell stood the DuPont family and the town generally on their heads. For once the family knew only what it read in the papers. Compared with the magnitude of the event, this was precious little. Wilmington's evening papers rewrote the item of their morning contemporary, one adding that Mrs. Maddox had obtained her divorce in France-an understandable deduction from the statement that had appeared in the News.

The Philadelphia papers were three days grubbing out a correction. While most of Wilmington had thought her abroad, Alicia had been living in cloistered luxury in an old mansion in Carlisle, Pennsylvania, little better than a hundred miles away. There, thanks to the discretion of lawyers and to the amiability of a judge, a divorce had been secretly granted on October 8. The complaint was abandonment. This disclosure kicked up a dust in Carlisle. Impeachment of Judg ' 'V. F. Sadler was suggested on the ground that the proceedings had been irregular. The jurist defended himself in a public statement which appeared to be unassailable, and his critics subsided. ${ }^{31}$ 


\section{CHAPTER XIII}

\section{The Wars of the Roses}

\section{I}

ALFRED and his bride had no honeymoon in the 70 horsepower French automobile. When the couple stood up for the ceremony, newsboys outside the Hotel Plaza were crying extras in which staring type announced the destruction by explosion of the DuPont plant at Fontanet, Indiana:

"20 TO 70 DEAD!"

Maurice duPont, his brother's best man, kept the news from Alfred until after the exchange of vows.

Telegraphing $\$ 5000$ to the Governor of Indiana for the relief of sufferers, Alfred with Alicia boarded the first train for the West. While Philadelphia papers were ferreting out the story of her romance, the Wilmington press emphasized Mrs. duPont's works in hospitals where the wounded lay. The death list totaled 27. The plant had been almost wiped out. Acquired during the campaign of whirlwind expansion, the works had been rebuilt by Alfred, increasing the capacity from 350 to 1800 kegs a day. Emotionally Alfred duPont never accustomed himself to the familiar spectacle of death in a powder yard. Surveying the ruins of Fontanet, destroyed on his wedding day, he ordered the site abandoned.

Alfred and Alicia were the only DuPonts to appear at the scene of disaster. Alfred returned to Wilmington irritated because the family tradition of visiting the injured had not been more substantially upheld. He meant to say something about it to Coleman but did not get the chance because Coly spoke first. He referred to the nuptials of his powder-trust partner and boyhood chum:

"Al, now you've done it. The family will never stand for this. Don't you think you'd better sell out to me and get away from here?" 
Al said that he would see the family in hell first. ${ }^{1}$

Surely Coleman was not so poor a judge of character as to have expected a different reply. But whether or not he intended deliberately to invite trouble, he got it. The whole family got it-in the form of a family row for which row is too puny a name. It was Delaware's Wars of the Roses.

Every family as numerous or as rich as the DuPonts has its factions and its frictions. Marriages and money are at the bottom of most of them. The struggle springing from the marriage of Alicia and Alfred was by no means the first to divide the Brandywine clan. It was merely the biggest, taking its stature from that of the opposing chieftains. ${ }^{2}$

On the death of acquisitive old Boss Henry a first-rate property dispute had been averted by the compromising dispositions of his heirs, notably William and Colonel (now Senator) Henry A. The first marriage to threaten an open split had been that of the affable and talented Lammot. In 1865 he married Mary Belin. The objection to Mary was not that her father was a book-keeper in Boss Henry's office. It was that she possessed a quartering of Jewish blood. A conspiracy was formed to ignore the bride. Hearing of this, old Henry ostentatiously called on her. The conspiracy died and Mary Belin duPont was taken into the fold. Born and reared on the Brandywine, she made Lammot a fine wife and their five sons and six daughters a fine mother.

DuPont-Belin ties were strengthened when Mary's brother married a connection of Lammot duPont's mother and took competent charge of the company's interests in the Pennsylvania anthracite district. Boss Henry's heavy hand drove underground, but did not quite extinguish, family antagonisms based on racial prejudice. Behind thick doors in certain houses in Pontiana-on-the-Brandywine, one could still hear allusions to "those Jews"-meaning the numerous and energetic progeny of Lammot duPont and Mary Belin. 
In 1902 Alfred had shown his contempt for such tongue-wagging by bringing Pierre and all his brothers into the firm. Nor was this the first time Alfred had behaved thus. Defending his own brother Maurice's right to take the wife of his choice, he had opposed a family phalanx composed, as he said, of "good women in the worst sense of the word." He had defended the courses of every one of the four principal parties to the famous "Cousin Willie scandal." May duPont had been in love with young Willard Saulsbury who had studied law in the late eminent Victor duPont's office. The family had forced her into a match with her Cousin William, a son of Boss Henry. This did not change the feelings of her heart and presently William himself developed a sentimental interest in a dazzling divorcee named Annie Rogers Zinn. When William went to South Dakota and quietly divorced May the family was shocked. When he married Mrs. Zinn it was outraged, and probably the only thing that kept the intramural feud from becoming public property was William's discreet retirement from the firm and from the Brandywine. Resigning his offices, he had gone to Virginia to restore Montpelier, the plantation which had belonged to James Madison, and fill its pastures with blooded horses. There Alfred often visited him, being one of the few DuPonts to do so. Alfred's only criticism of his Cousin Willie was for running away. Otherwise Alfred thought William had acted sensibly and the family ridiculously.

Next, May had upset the clan by declining the role of a martyr. She married Saulsbury, whom she had loved all along, and the family threw fits. Again Alfred said he thought this behavior silly.

May duPont and Willard Saulsbury were not married in the "DuPont church"-Christ Church on the Brandywine, with a whisky bottle sealed in its gray walls; but in Trinity Church, Wilmington. Promptly the arm of the family stretched out toward the Reverend Ashton Henry, Trinity's rector. The Right Reverend Leighton Coleman, Episcopal Bishop of Delaware, was a patriarch with a beard that made him look a little like pictures of Moses. His wife was a sister of the late Eugene duPont and also of Alicia 
duPont's mother, Eleuthéra Bradford: Bishop Coleman made life so unpleasant for Ashton Henry that Trinity's shepherd chucked his pastorate and fled to Switzerland to live.

Willard Saulsbury turned out to be unique among DuPont in-laws in that he neither asked nor received a favor from the family. His own family had left its impress on Delaware. Saulsbury's father and his uncle had sat in the United States Senate. Willard himself had similar ambitions. Though no partisan of Addicks, he had not, unlike many decent Democrats, lifted a finger to send Colonel Henry to Washington. On the contrary, he had invariably received the votes of the Democratic minority in the Addicks-duPont contests. In I906 when Coleman's management won the victory for Colonel Henry, Saulsbury remarked that the difference between Addicks' and Coleman's campaign methods was that Addicks did not know how to buy votes like a gentleman. This caused a certain coolness between the new statesman and his campaign manager on one side, and Mr. Saulsbury on the other, Senator duPont making it a rule of his life not to enter a house to which the Saulsburys were invited. Coleman duPont and Saulsbury, married to sisters, did not speak. Nor were the sisters themselves on sisterly terms. Even cautious Pierre was distant to Saulsbury, who from the proceeds of a profitable law practice sent remittances to the exiled Reverend Henry and referred to his wife's family, succinctly, as "that God-damned tribe."

The second and next divorce in the family had been that of Alfred, who, emulating Cousin Willie, had gone to South Dakota and got over the business as quickly and quietly as the law allowed. On the Brandywine there were no repercussions of note. In a family already so divided, Alfred was about as near a universal favorite as was possible. Although independent and headstrong, his sincerity commanded respect, and at a social gathering he was very good company. Moreover, since 1902 he had awakened a sense of family gratitude for saving the tribe's bread and butter or, more accurately, substituting cake for the same. 
"The fact is, we loved him," said one, presently to become an open adversary.

On the other hand Bessie Gardner had no particularly sympathetic family following of her own. Some of the older women still recalled her early standoffish ways and fashionable airs-calling dinner, luncheon, and luncheon, dinner.

When Alfred and Bessie separated, Bessie needed family allies. Finding one in Pierre, her relations with the family began to mend. Alfred's correspondingly deteriorated. He had divorced his wife, leaving her and the children with a financial settlement that was ungenerous, considering his wealth and prospects. So ran the indictment, and it was true on its face. His championship of Alicia Bradford, before and after the marriage to Maddox, was another black mark; for Alicia had been unpopular to begin with, and her father, the vindictive and clever old Judge, knew how to present a case against his daughter.

Yet nothing much had happened until the startling announcement of the marriage with Alicia. This bombshell was the first intimation the family had that Alicia was free to marry anyonethat she had divorced Maddox, giving the family its second divorce in ten months and its third in the one hundred and seven years the DuPonts had been in America. On the heels of this had come the Philadelphia papers' disclosures of the elaborately secret nature of the divorce proceedings with which Alfred, unquestionably, had been concerned.

This was more than the family could stand. It had been cheated. To get family news first in the newspapers! The enormity of Alfred's offenses was quickly apparent. Not only had he divorced one wife; he had taken another-and an unpopular woman at that-without taking the family grandes dames and seigneurs into his confidence. If anything, Coleman duPont's terse, "Al,-nowyou've-done-it!" understated the case.

This was brought home to Alfred and Alicia in dramatic fashion on the day of their return from Indiana. Alicia's brother, Edward G. Bradford, Jr., exhibited an eighteen-word telegram addressed to him and signed by one "Leighton Coleman"-the Bishop, no less! 
The telegram demanded to know whether Edward, Jr., had attended the "so-called" wedding of Alicia and Alfred.

The wire had been followed by a letter revealing the motive of the churchman's inquiry. This letter quoted the newspaper reports to the effect that only the immediate members of the families of the contracting parties had attended the ceremony. The Bishop had been in touch with Alicia's father, and the two of them were preparing to prove the newspaper report false in so far as the bride's family was concerned. Therefore the demand upon young Edward to state whether he had been present. Telegram and letter had been sent from Richmond, Virginia, where Bishop Coleman was attending a General Convention of the Episcopal Church. Their tone was bitterly hostile. ${ }^{3}$

Eddie Bradford, to whom these peremptory communications were addressed, was twenty-nine years old, or three years the junior of his sister, and a lawyer practicing in Wilmington. Good nature and conviviality, rather than strength, were the distinguishing marks of his character. Moreover, the angry old Bishop was his uncle-in-law and godfather. Yet thus far Eddie had shown independence and courage in standing with his sister against the machinations of their father. More resolute personalities than Eddie Bradford had quailed before the frown of the bearded old Bishop who, joined with the malignant Judge, made a formidable pair of foemen. Though frightened, Eddie stuck to his guns. He wrote his uncle that he had attended and "countenanced" the wedding because he believed it was right he should do so. The young man admitted, however, that he might have made a mistake. ${ }^{4}$ After that momentary show of weakness Eddie got hold of himself and, in the long struggle that lay ahead, unflinchingly upheld his sister's part.

Defeated in an attempt to denounce the marriage publicly, the Bishop and the Judge turned to undercover warfare at which the latter, at any rate, was a practiced hand. Alfred was in the same fix as Cousin Willie had been in 1892; Alicia in the same boat as May duPont Saulsbury. The same cries descended upon their heads. It was the same fight over again on a grander and more malicious scale. 

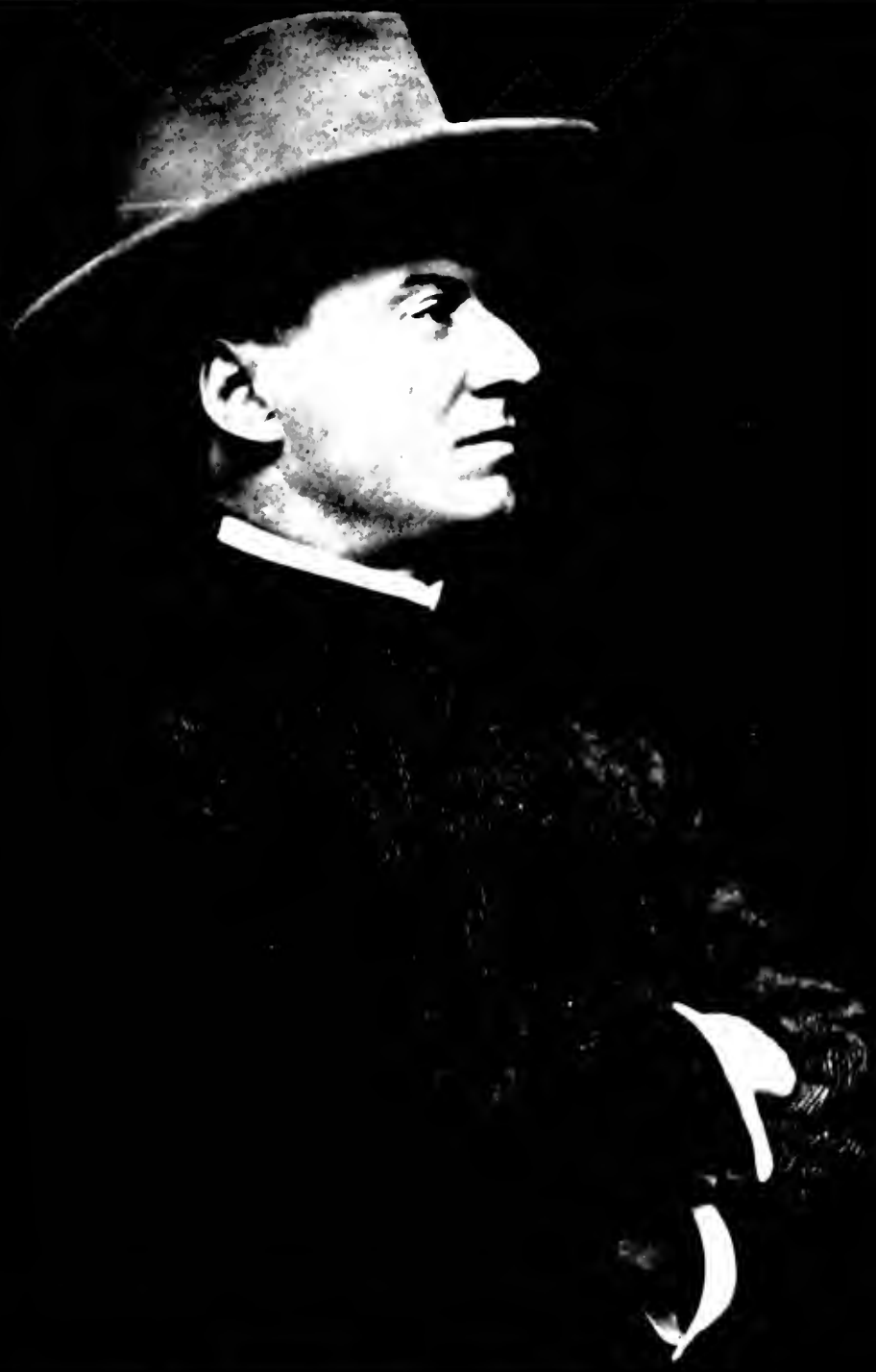

In South Dakota, 1906

Alfred I. dupont spent six months in that State in order to establish a resilence and obtain a divorce. 

"Had Alfred taken his cue from Cousin Willie," one of his supporters has told this writer, "that is, had he and Alicia slipped away and made a home for themselves in Philadelphia, say, the whole row would have petered out eventually.

"I am sure of this because, at the start of things, Alfred had too many friends in the family. We knew about the troubles that had made his first marriage no go. Alfred was the salt of the earth; I could prove it by citing his faults alone. He was entitled to a happy home life, and if he thought he could get it with Alicia, who also had seen one marriage go on the rocks, whose business was it but theirs? Of course this was not the idea of the family busybodies whose notions of marriage came from EighteenthCentury France. Alfred should have just stayed away and let them howl themselves out. The trouble was he was just too forthright to play such a game; too forthright and too scrappy."

This speculation overlooks a few things. One is Coleman's position. Another is the position Coleman had thrust Alfred into by suggesting that he cash in his chips and get out of town. Had it ever entered Alfred's head to take up a residence away from Delaware for a while, he could not do it now without backing down before Coleman. To leave the company would have been unthinkable in any event.

Moreover, why should Coly be so exercised over another man's choice of a wife? Coleman duPont's ideas of matrimony were not patterned after those of Eighteenth-Century France. Why, then, did he join the virtuous in taking up the war club against Alfred? One surmise is that he showed his real hand when he offered to relieve Alfred of his company holdings. Another surmise is that Judge Bradford had won Coleman over. Still another tale has it that Alicia was the person Coly desired to punish. When she was having her troubles with her father over Maddox's courtship, Coleman, who had an eye for feminine loveliness, is said to have approached Alicia with offers of friendly protection. She rejected them and turned to Alfred. Whether or not this story contains a grain of truth, the point is that Alfred believed it. In the circumstances, he could not fight Coleman, the Judge and the Bishop by running away; and he did not run. 
$\mathrm{He}$ and Alicia established themselves at Rock Farms. Carriages and motorcars appeared in the driveway, bearing DuPonts and their wives on the customary calls on a bride. In all came representatives of possibly six or eight DuPont households-a minority of the thirty-five or forty family households on the Brandywine. These consisted mainly of the Francis I. duPonts and Francis' brothers and sisters-children of the late Cousin Frank who had died estranged from Alfred. Coleman and Pierre stayed away though Pierre's sister, Mrs. Charles Copeland, called.

Some of the young engineers, one or two of them DuPonts, came, but did not find in Rock Farms the haven of Alfred's bachelor days. Gone from the library table was the rich array of scientific periodicals. In their places was Alicia's selection of journals of the worlds of fashion and of belles-lettres, from Paris and London and New York. Gone was the free and easy atmosphere and in its place something strained and apprehensive. Alicia seemed a riddle: beautiful, bitter, flashing a barbed, sophisticated wit. The young men did not warm to her. Their visits tapered off and ceased. Those not in the black-powder department, seeing how the wind blew, felt that their chances of promotion would not be impaired by giving Rock Farms a wide berth.

This is one glimpse of the sprawling homestead during the early days of the chatelaineship of Alicia. Here is another, quite different: a gay and cosmopolitan company; men of business, politics, science, diplomacy, the arts, from home and abroad; a duPont or so to diffuse dynastic color affording rebuttal to tales of ostracism by the family; matchless food, a connoisseur's wines, sparkling conversation; Alicia witty, surprising, challenging; Alfred radiantly happy. Old friends who had known the bleak hostility pervading The Swamp during Alfred's last years there felt their hearts expand.

Contradictory as it may appear, even the tension among the three cousins who carried on their shoulders the destinies of the powder trust seemed to relax. Notes and letters passed to and fro, 
directed to "Dear Al," "Dear Coleman," "Dear Pierre"-each signed, invariably, "Your affectionate cousin." From Florida Alfred sent his cousins some alligator steaks. In a jocular note Coleman announced his refusal to partake, but Pierre good-humoredly said that despite an original skepticism he had eaten his and found it good. This correspondence reflected a purely man-to-man relationship. Women were never mentioned. On the rare occasions when the cousins met socially it was at stag affairs, usually of a semi-business nature.

The struggle to maintain appearances received a setback in rgro when Alfred and Coleman got in a property dispute. Alfred wanted to buy some Brandywine acreage the title to which stood in the company's name. Alfred thought he was all set to get the land when he learned that Coleman had suddenly bought it up. This looked like a piece of underhanded dealing. ${ }^{5}$ It recalled Coly's "fool 'em, Al; fool 'em."

In rgir the breach between Coleman and Alfred widened when Coleman placed in his cousin's hands some letters dealing with Madeleine's marital troubles which, following an impulsive marriage, were providing material for gossip. Alfred replied:

"The letters which you sent to me via Cousin Ferd. [LaMotte] were delivered this morning. I immediately re-enclosed them and have re-delivered them to him.

"These letters were not addressed to me. They are private, and were intended for no one except the person to whom they are addressed. Therefore, I have no right to read them. Different people look at a matter of this kind differently. It involves purely a point of honor, which of course is of no interest to any one but the individual who must decide for himself."

This crisp note was concluded with "Very truly yours."

So, despite everything, the schism in the DuPont family reflected itself elsewhere than in drawing rooms. It could be detected at the long directors' table in the twelve-story DuPont Building at 
Tenth and Market Streets, Wilmington, opened in 1907 as the headquarters of "Coleman's Company." Nine DuPonts and two in-laws, brothers-in-law of Coleman, sat at that table. Of the eleven, all excepting spirited Francis I. and amiable Victor duPont, Sr., were counted against Alfred in the squabble over his marriage with Alicia Maddox.

Graver considerations also engrossed the attention of the directors when they came to that table. They had a vast business to run, for one thing. For another it might turn out that Coleman's swift conquest of the industry had been too complete. Theodore Roosevelt was in the full swing of his trust-busting crusade. On July 30, 1907, the United States brought suit against the DuPont Company, its principal subsidiaries and principal officers, for violation of the Sherman Anti-Trust Act. The question of opposing a successful defense to the Government's allegations posed a problem of the first order. A crew of expensive and astute lawyers was hired, and they went to work.

A few internal changes were made in the company. Alfred dropped off the Finance Committee, of which Pierre was chairman. The reason given was Alfred's deafness. Coleman fell ill. $\mathrm{He}$ took an indefinite leave of absence, the directors creating the post of acting president for Pierre. This caused a buzz of speculation in the ranks of the company. In the black-powder operating department there was a considerable feeling that Alfred was being edged aside.

Whether Alfred himself felt that way is hard to say. In 1902 he had not wished to assume the responsibilities of the presidency. It was not the kind of work he cared for. Alfred duPont liked to make powder. Things had changed since those simpler days and the president of the company was further than ever away from the actual fabrication of powder. Reese Hutchison, the inventor who made Alfred's hearing devices, got the impression that Alfred was definitely weary of squabbling with relatives and was contemplating getting out of the company. These two had become close friends. On Alfred's trips to New York they had long and rich talks about Hutchison's inventions. These conversations seemed a veritable tonic to duPont. They ranged over a fascinating order of subjects. Hutchison's office at I Madison Avenue was air- 
cooled-his own invention. The scientist foresaw the day when such equipment would be common in railroad trains, office buildings and hotels. Hutchison's automobile was furnished with a self starter of his own devising-the first in use-and its wheels with improved demountable rims. The friends discussed improvements for the telephone, the dictograph, the motion-picture camera, the talking machine; the possibilities and probabilities of an embryonic idea which has grown into the incredible thing the world knows as radio.

One day, in particular, duPont's eye fairly gleamed with enthusiam.

"Hutch," said he, "let's team up together. I have the money to develop your ideas, and I have some smattering of scientific knowledge. You are navigating uncharted oceans which I'd like to explore with you. If you're willing, just as soon as I can get my affairs straightened out so as to forget the DuPont Company and everything connected therewith, we'll take a trip on the boat and thresh out the whole matter."

This proposal was in 1908. "The boat" was duPont's new steam yacht Alicia. Perhaps Alfred spoke on the spur of impulse and on second thought became more reluctant to "forget" the company, especially since that was what Coleman wanted him to do. At any rate two years went by before he again mentioned the matter to Hutchison in such precise terms. Hutchison then was considering an offer to join Thomas A. Edison. DuPont was almost as elated as if he himself had received the offer. By all means, he said, join Edison. The experience would be priceless.

"Serve the great master," he concluded with a note of resignation. "There will still be time, in other years, for us to do the things I really want to do."

Alfred returned to his powder-making, which was no longer a family enterprise in the tradition of the Eighties. It was largelytoo largely for his temperament-a matter of impersonally directing a vast and complex machine. Alfred liked to restore his sense of reality by getting into a yard and dirtying his hands with soda and charcoal. Though the responsibilities of management made this direct touch with the vitals of the business a difficult thing to maintain, it remained Alfred's way of keeping DuPont black 
powder the best in the world and offering opposition to the relentless encroachment of dynamite.

Young Victor duPont, Jr., son of the ornamental vice-president, was superintendent of the Brandywine yards. A run of powder had not glazed well. It was not bright. Pressed for production, Vic neverthless had ordered it packed.

Alfred happened along on one of his periodical rambles through his favorite yards. As ill luck would have it, he went up to the Hagley packing house and fingered a pinch of this dull powder.

"Vic," he said, "don't pack that. It isn't bright."

"I know that, Cousin Alfred," said Vic, "but it's dry. It's good powder. It just doesn't look pretty, that's all; and I'm behind on my schedule."

"No matter, Vic. One of those kegs might be opened in Texas. It has our name on it. Our powder must not only be right, it must look right. Just reglaze that run, Vic, and put in a little more lead."

Jeff Blakely, one of the strongest men in the machine shop, was struggling to get in place a ten-horsepower motor in Hagley's new fuse mill for Navy powder. Alfred stood watching him.

"Blakely," he said, "a man like you shouldn't have trouble with that. You don't go at it right."

An old-timer used to speaking his mind, Blakely challenged the boss to a lifting contest. A length of four-by-four was brought and shoved under a line of shafting. A circle of men gathered. Alfred threw off his coat, took his stand at one end of the four-by-four and spat on his hands. Blakely took his stand at the other end. At a signal both men lifted. Blakely's end went down.

"Next time," said Alfred to Vic duPont as they walked away, "you won't make fun of an old man trying to keep in shape doing setting-up exercises in the smoking room of a Pullman."8

Over and over Alfred duPont said that he would take nothing in the world for his apprenticeship as a workingman, rubbing should- 
ers with other workingmen in the powder yards. The trouble with his present job was that it did not afford enough of that sort of stimulus. As soon as the company's expansion had outmoded the old paternalistic forms of social security, Alfred put through a series of regulations for the protection of employees. These çomprise the modern basis of DuPoni's enlightened labor policy, which is a metamorphosis of the policy informally in effect for generations on the Brandywine when an aged, ill or injured workman got a free cottage, fuel from a DuPont woods, hams from a DuPont smokehouse, milk from a DuPont cow and vegetables from a DuPont garden. Alfred's modernization of this policy began with a uniform pension system and the annual distribution of stock bonuses to employees for long or for exceptional service.

Considering the large number of employees he handled and the thoroughgoing reorganizations of personnel necessitated by the creation of the modern powder trust, Alfred duPont discharged very few workmen or subordinates. One subordinate he let go for drinking and not paying attention to business was a cousin who remained Alfred's friend in days to come when it required a certain amount of courage to do so. Another man received a letter of dismissal saying: "I regret exceedingly that my trust in you has not been justified. The fault is not with you but with me, as I should not have placed responsibility upon you without first satisfying myself as to the propriety of doing so."

Notwithstanding that an employer better-regarded by his hands would have been hard to find, Alfred duPont had definite ideas against Government interference with the time-honored prerogatives of management. In 1904 an Eight-Hour Bill was before Congress. Mr. duPont wrote the Secretary of Commerce and Labor in strong terms that he hoped the measure would be scotched in committee. A powderman's working day was ten hours. Mr. duPont argued that to change it to eight would "necessitate the reorganization of a system in operation for more than one hundred years"; bring additional men into the mills, increasing the chances of accident; raise costs and prices; prove an unreasonable abridgement of the rights of a laborer to market his labor as he desired, and by im- 
plication similarly abridge the right of an employer to offer labor such terms as he saw fit. ${ }^{10}$

Mr. duPont was leaning on arguments almost as old as the "system in operation" he sought to preserve. They had been used by New England textile mill owners opposing first a twelve and then a ten-hour day. Most employers holding the same views, they were able to forestall the Eight-Hour Law until 19r6. Meantime, however, DuPont voluntarily decreased its working day to eight hours, with none of the consequences prophesied. What Alfred actually had been so exercised about was the right of someone in Washington to tell him what he could or could not do in his own business. It was the same with his conflicting thoughts about retiring from the company. If he retired it would be his free act and not because Coleman or anyone else had suggested it.

In the face of rising labor and material costs, Alfred reduced the manufacturing cost of black powder from 84.76 cents a 25-pound keg in 1907 to 78.46 cents in 19ro, striking an average for all DuPont plants. Safety of operation was enhanced. Making roughly three times as much black powder and employing three times as many men as the independents, DuPont's casualty list from accidents was scarcely larger than theirs.

Alfred's steel glazing barrel, introduced in 1904, had been gradually installed in DuPont plants throughout the country. It had proved a factor in reducing the cost of producing powder. Alfred had also believed it would be safer than the old wooden barrel, being less likely to blow up. Yet, it began to grow apparent that, when a steel barrel did blow, the result was more serious than in the case of a wooden one. This was because of the greater force required to burst a steel barrel and because the flying fragments were more dangerous. After four glazing-mill accidents, which Alfred studied carefully, the barrel was abandoned. This had some effect on production routine, and it was a keen personal disappointment to Mr. duPont, at heart an inventor. Moreover, it gave his critics in the company a peg to hang something on. The fact is that one can find veteran powdermen today who doubt if the question of "Mr. Alfred's barrel" was decided on its merits. So much for one inci- 
dental shaft of light on the strength of the loyalties he engendered in some quarters and on the intensity of antagonisms prevailing in others at the same time.

A few years later, when Mr. duPont no longer was in charge of black-powder operations, his principle of steam heating was successfully and safely introduced in wooden barrels. This equipment is now in use. ${ }^{11}$

Another termite boring into the foundations of Alfred's indispensability to the company was the march of high explosives, principally dynamite. This product had been vastly improved as to safety and as to efficacy in blasting operations. From r902 to I9Io dynamite sales for the whole industry increased 300 per cent, against 25 per cent for black powder. Prior to I902 DuPont had made no dynamite. Its finger in the high-explosive pie took the form of a minority interest in the Eastern Dynamite Company which had absorbed Lammot duPont's pioneering Repauno Chemical Company. The purchase of Laflin \& Rand launched Dupont directly in the high-explosive business. Progress was spectacular. In I909 its dynamite sales topped by I0,000,000 pounds the sales of black powder. Indeed, the peak of DuPont black-powder sales had been attained in 1907; never again was the production of that year equaled. In I9r I DuPont's black-powder sales fell 500,000 pounds below those for 1904. Each succeeding year they continued to drop while dynamite sales climbed. The story for the whole industry is in keeping. Users preferred the new explosive. Historic black powder's dominance was at an end.

Alfred had no experience with dynamite. In I902 H. M. Barksdale assumed charge of high explosives. The strides made by dynamite is evidence of the wisdom of the choice, and when Alfred had a good man in a job he gave him broad authority and let him alone. Barksdale organized, developed and ran that branch of the business in which, unlike in black powder, new techniques were being introduced all the time. Methods five years old were out of date. Though general manager of the company, Alfred's authority over the high-explosives department was nominal. ${ }^{12}$ Moreover, Barksdale, a DuPont in-law of the Coleman branch, continued to rise in the company's directorate. About the time Alfred had left, he had 
joined the Finance Committee and presently was designated to act, in the absence of Pierre, as chairman of that powerful body.

Meanwhile the purely domestic aspects of the family fight intensified, and several things happened to mar the serenity of life at Rock Farms.

The story was abroad that Alfred had "forsaken" his children. On this head a seeker for truth was (and is today) confronted by irreconcilable accounts. The only fact that stands beyond the reach of dispute is that after his marriage with Alicia, Alfred did not again see his three younger children who remained at Swamp Hall with their mother. Up to that time he had been on affectionate terms with them. Now he saw only his oldest daughter, Madeleine, who, after a grand blow-up with her mother, had quit Swamp Hall for Rock Farms to make her home with her father and her new stepmother.

For this spectacle of a family rent asunder, some of Alfred's friends placed the blame on the children's mother and on the second daughter, Bep, eighteen. They say that Bep refused to see her father and that she and her mother kept the younger children, Alfred, seven, and Victorine, four, from seeing him. Bessie categorically denies this, and is supported by Alfred and Victorine who say they heard no word against their father spoken in their mother's house. He was simply not mentioned at all. All they remember is that he dropped out of their visible world, though not out of their thoughts. Victorine was so young that she got her father confused with "Our Father" of the Lord's Prayer. For years when she knelt at her bedside to repeat that prayer, a mental image of God in tweed knickers-as she had last seen her own father-rose before her. ${ }^{13}$

The other story is that Alicia "poisoned" Alfred's mind against his three younger children and brought on the tragic estrangement. Certainly Alicia, so far as even her friends are aware, did nothing to prevent her husband's separation from his children. And she might have done much. 
Madeleine, who was twenty years old, might have done something had she not been engrossed in a romance of her own which, incidentally, added to her father's anxieties. Two months after Alfred's marriage with Alicia, Madie and John Bancroft, Jr., a twenty-one-year-old Princeton undergraduate, eloped. They went abroad to live. A year later Alfred and Alicia crossed to Paris to be with Madie when her baby was born. Presently the runaway marriage cooled and shortly after the arrival of Alfred's second grandchild his daughter and Bancroft were divorced.

Separated from his own children, Alfred lavished the affection of a father on Alicia's daughter by Maddox, who also was named Alicia and who was almost exactly the same age as Alfred's youngest daughter, Vicky. The attention Alfred paid to little Alicia was set down as a black mark against him. The mistaken story became current that he had adopted her.

Alicia, senior, dearly wanted a child of her own by Alfred-a wish that seemed about to be gratified until a miscarriage frustrated it temporarily. This ordeal left Alicia impaired in health.

Also there was the serious comedy of the Wilmington Symphony Orchestra. This organization had been founded a few months before Alfred's second marriage. Though too deaf to enjoy its music, Alfred duPont made the largest standing contribution to the orchestra's support. Perhaps on that account Jimmy Dashiell got the post of concert-master. August Rodemann, of the Philadelphia Orchestra, another friend of Alfred, became conductor.

The usual women's committee was formed to work for the success of the new undertaking by getting behind it Wilmington Society-with a capital S. This responsibility fell to Mrs. Henry B. Thompson, who has been called the Mrs. Astor of Delaware. In the twenty-odd years since her debut Mrs. Thompson had witnessed a profound transformation of the pattern of Wilmington Society, owing principally to the infiltration of DuPonts. Before that time-during Alfred duPont's boyhood-the DuPont clan had lived its insular life on the banks of the Brandywine, men and women alike busy with their own affairs and maintaining slight contact with Wilmington's world of fashion. It was the young clansmen of Alfred's generation-Alfred himself participating to some 
small extent-who had changed this. DuPonts married into most of Wilmington's aristocratic families; DuPonts had money; DuPonts were well-bred and socially acceptable: consequently the entry of the family into Society which lost nothing in grace thereby while profiting in vitality and in revenue.

In this disposition of affairs it was natural that Mrs. Thompson's aggregation of orchestra patronesses should be studded with DuPont names, among which was that of Bessie Gardner duPont.

Thus Alicia's marriage to Alfred posed a problem for the social arbiters. As the wife of one of the outstanding DuPonts, in this instance the principal angel of the orchestra, she had a claim to a place on Mrs. Thompson's committee. Yet she did not get place there. Dashiell argued the matter with Frank G. Tallman, a vicepresident of the DuPont Company and president of the Wilmington Symphony Orchestra Association. Nothing came of his efforts.

Still Alfred maintained his contributions. In the fullness of time, the battleship Delaware anchored in the river off Wilmington, and a concert was arranged to buy a silver service for the man-of-war. Alfred contributed generously to financing the concert and capped this with a gift of a hundred dollars toward the silver set. When Dashiell learned that Alicia had been omitted from the women's committee in connection with the concert, he took the matter to Mayor Wilson of Wilmington. The result was the printing of new stationery with the name of Mrs. Alfred I. duPont on the list of patronesses. But when letters went out drumming up patronage for the battleship concert the orchestra's old stationery, on which Alicia's name did not appear, was used. One story is that the new stationery, four thousand sheets of it, was burned in the furnace of the Century Club, the high-toned women's organization of Wilmington. ${ }^{14}$

However that may have been, Alfred duPont ceased his contributions to the orchestra, which presently ran out of funds and disbanded.

Though the cultural life of Wilmington was poorer on that account, the foes of Alicia acclaimed the skirmish over the orchestra as another victory for their banner. A fresh crop of tales concerning his wife, documented as to source, reached Alfred's ears. $\mathrm{He}$ 


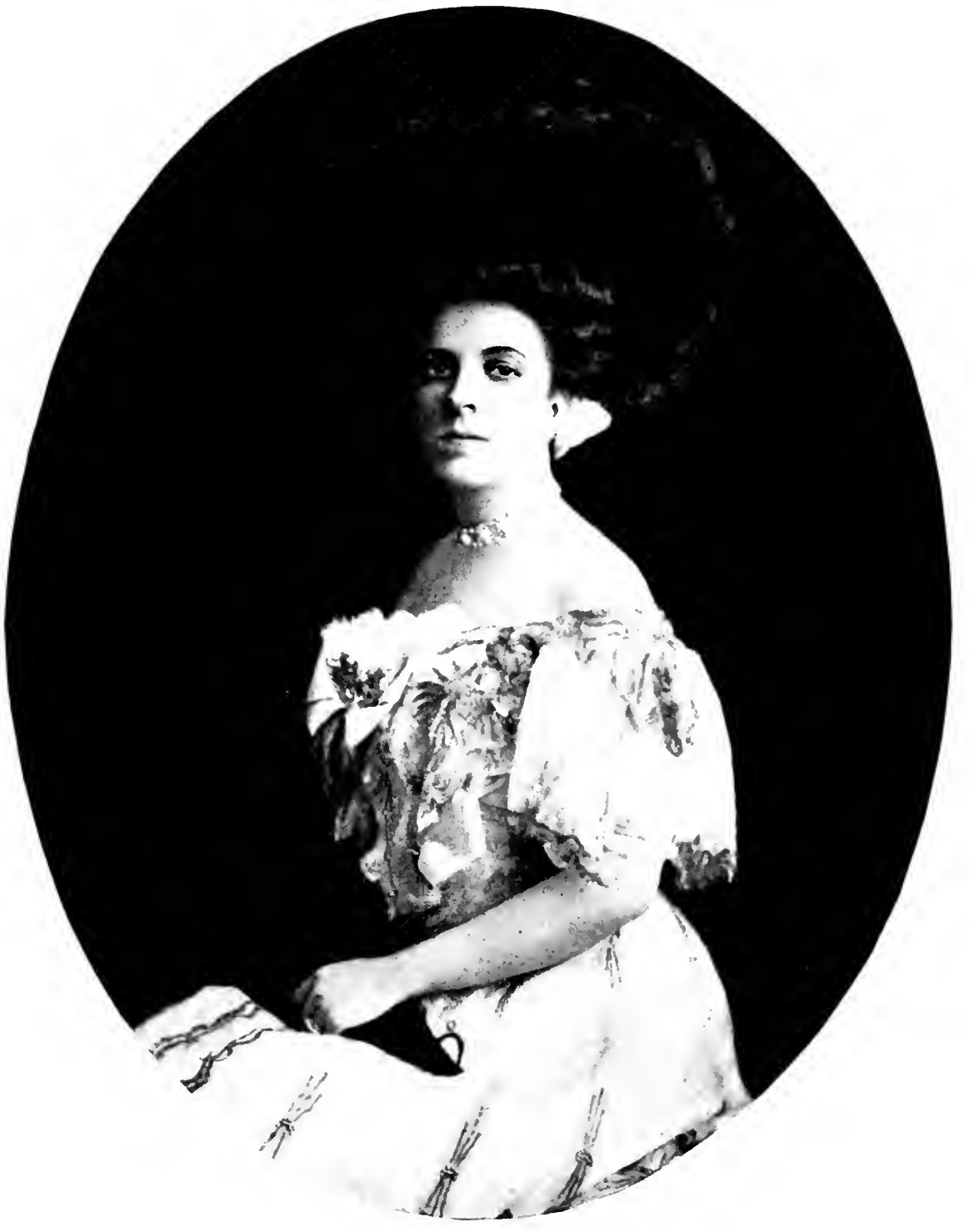

Alicia Bradford duPont

Who in 1907 divorced George Amory Maddox and married her cousin, Alfred I. duPont, starting a feud which rent the clan of DuPont asunder. She died in 1920. Photograph taken in I907. 

vowed he would stand no more. Calling in Attorney J. Harvey Whiteman on June 22, 1909, the preliminary papers of a lawsuit were filed in the Superior Court. The plaintiffs were Alfred I. and Alicia duPont; the defendant, Mary H. J. Bush, the reputed author, at any rate a reputed purveyor, of the tales.

An elderly dowager of impeccable social background, Mrs. Bush was the widow of a Wilmington manufacturer. Her adopted son had married Joanna duPont Bradford, a younger sister of Alicia who, unlike Alicia, was a favorite of her father, the old Judge.

Four weeks later the same plaintiffs filed a second suit, this time against Elizabeth Bradford duPont. This defendant, a stout, imperious lady of fifty-seven, was the widow of the late Doctor Alexis I. duPont and a half-sister of Judge Bradford; therefore an aunt of Alicia.

Under Delaware law the first papers in a legal action merely name the opposing parties and put the defendants on notice that they are to be sued. The plaintiff has a "reasonable time" in which to file a declaration of particulars outlining the cause of action. Alfred and Alicia seemed in no hurry to file such a declaration.

Mesdames Bush and duPont flew to the offices of lawyers-of good lawyers. The attorney Elizabeth Bradford duPont consulted was also her son-in-law. The Bayard family had been conspicuous in Delaware since Colonial days. Four of that name had served in the United States Senate. Attorney Thomas Francis Bayard, Jr., was a product of St. Paul's School and of Yale. Public-spirited and energetic in Democratic politics, he hoped one day to follow in the steps of his illustrious forebears. Thomas Francis listened to what his wife's mother had to say. Unquestionably Alfred intended to sue for slander. For the peace of mind of all who bore the DuPont name, Mr. Bayard's judgment was that the action must be stopped.

Mary H. J. Bush consulted Attorney Willard Saulsbury, who took her case. At first glance it seems rather strange that he should have done so. Situated as he was with reference to such powerful DuPonts as Coleman, Pierre and Senator Henry, one would have thought his sympathies with a fellow-Philistine, Alfred.

Up to this point the Wars of the Roses had been waged without the collaboration of the newspapers. Wilmington's controlled 
sheets, of course, had their instructions. Not a hint of the family split had sullied their columns.

Reporters resent working for a kept newspaper. Wilmington reporters had often tipped off Philadelphia papers to DuPont items they could not write for their own journals. For this the Philadelphia papers paid space rates, thus enabling Wilmington's representatives of a not-too-well-heeled profession to strike a blow for the freedom of the press and to put something in their pockets at one swipe. Probably the reason Philadelphia had not already broken the story of the feud over Alfred's marriage was because no convenient peg, no overt act had been discovered to hang it on. The filing of papers against Mrs. Bush and Mrs. Alexis L. duPont provided a peg. Unless Alfred could be prevailed on to withdraw the actions, their discovery by some reporter poking among the records in the prothonotary's office in the dingy old courthouse would be only a question of time.

The anxiety in the opposition camp was plain to see, and the chances are that Alfred enjoyed it. 


\title{
PART FOUR
}

\author{
Expelled From the Company
}





\section{CHAPTER XIV}

\section{A Farewell To the Brandywine}

I

IN THE days of Boss Henry a towheaded, courteous Maryland farm boy of seventeen had gone to work as an apprentice in the millwright shop in Hagley Yard, where his uncle was a head carpenter. Twenty years later James M. Smyth, a prosperous contractor on his own, had the same agreeable Maryland accent, the same polite and unpretentious manner. He had done a good deal of work for his former employers, building the smokeless powder plant at Carney's Point, remodeling Swamp Hall and, later, Rock Farms. In April, 1909, Smyth received a summons to the office of Alfred duPont.

"I want to build a new house for Mrs. duPont," said Alfred. "Look at these plans and tell me whether you can do it."

Smyth looked at the plans and his blue eyes opened wide. They called for no mere house-but a mansion, palace, such as Delaware had never seen. After a while Alfred interrupted the contractor's perusal.

"I'm not going to live forever. I want to get this place started. Can you build it?"

"Yes, Mr. Alfred," Smyth said quietly. "I can build it."

Alfred outlined terms-on a cost plus basis. As needed, funds would be placed to Smyth's credit at the Wilmington Trust Company. Smyth signified his satisfaction with the terms and asked when Mr. duPont would have them embodied in a contract.

"Since when have you and I been having contracts between us?" Alfred asked.

"But this is going to run into an immense amount of money."

"Well, I've got it," said Alfred. "You trust my word, don't you?" 
"Why, yes, Mr. Alfred."

"Well, I trust yours; and let me tell you that it's a pleasure to do business in that old-fashioned way once in a while. Not a word about what this thing'll cost. As you say, Smyth, it will run into money. Just how much money you will eventually know, the boy [Smyth's son and partner, Hugh] will know and I will know. That will be enough to know how much I spend on this place."

"They won't know from me," said Smyth.

Smyth has kept his word. For more than twenty years he directed most of the unceasing work of building and rebuilding Mr. duPont's great estate of Nemours. Other builders have estimated that $\$ 2,000,000$ passed through Smyth's hands. Whatever the sum, it all passed without a scratch of a pen between contractor and employer, or Alfred's so much as glancing at the private ledger which Smyth kept in his own hand.

Smyth once submitted his computations for an audit.

"Audit?" snorted Alfred. "Your figures are right, aren't they?" "They are, Mr. Alfred."

"All right, I believe you. Keep your books a year and then burn 'em."

A week or so after their bargain had been struck, Alfred gleefully relayed to Smyth a conversation he had had in the Fifth Avenue offices of Carrère \& Hastings, the celebrated New York architects whom Alfred had consulted for plans. The house had been months getting out of the planning stage, Alfred constantly vetoing and revising until, when blueprints were ready for a contractor, the whole conception was more Alfred's than the architects'. This stage reached, the badgered architects suggested the names of several eminent New York and Philadelphia contracting firms. They presumed that Mr. duPont would wish bids from these builders.

"Bids? I need no bids," said Alfred.

"The contract will be let without competition, then?"

"Yes," said Alfred, "I have my contractor."

"A local firm?"

"A local man," corrected Alfred. "His name's Smyth."

"Smyth?" pondered the architect. "A responsible man, I presume." 
"Damned responsible," said Alfred. "Damned good, too. Learned his trade where I learned mine--in the old Brandywine works."

Alfred leaned back and laughed. "Smyth," he said, "you should have seen the look on that architect's face. I tell you, we're going to have some fun showing them that we don't come from Hedgeville."

Hedgeville was a definitely unsophisticated suburb of Wilmington.

The site for the mansion was a rolling three-hundred-acre tract on the east side of the Brandywine, where Alfred had speculated on building a house, away from the other DuPonts, during his conversations with the Engineer "Brown" before the Spanish-American War. The mansion was to be squared with five gigantic North Carolina poplar trees planted in the form of an L. No one knew how old these trees were. Alfred remembered encountering them as a small boy on a walk with his father, during which the elder DuPont had said:

"If I could do what I wanted I'd build a house under those trees and sit down and read books and eat ice cream the rest of my life."2

As he had promised, Alfred had fun at the architects' expense. He made hash of their specifications. One day John $\mathrm{M}$. Carrère spent an afternoon on the site. Alfred ragged him all the time.

"Mr. Carrère, I brought you here to try to teach Smyth and me something. I find that we have to teach you."

When the inspection was over Carrère said to Smyth:

"I don't have to stand that kind of talk."

"It doesn't mean a thing," said Smyth. "Mr. duPont is deaf and a little bitter at the world sometimes."

There was, indeed, some cause for Alfred to be out of temper. The news of the slander suits had reached the Philadelphia press, richly embellished with names, some of the owners of which nearly had heart failure. The shrill retaliatory cries against Alfred and Alicia swelled to a new crescendo. Anything and everything furnished fuel for the flames. Alicia was the chief target, which seemed logical: otherwise certain members of the family, previously and with good cause counted as friends of Alfred, would have had difficulty justifying their flings at him. The rearing of the mansion of 
Nemours was cited as an example of her spiteful folly. A man of Alfred's simple tastes and homely ways would never care for such a "gaudy palace." No, Alicia was the real architect of Nemours; it was her idea of lording it over her relations.

Alfred had Smyth station watchmen about the building site, with instructions to keep sightseers away-and particularly members of the DuPont family. One general exception to this rule was made. Any old Brandywine powderman who had worked in the yards with Mr. Alfred was entitled to pass the line of sentries. Always interested in anything Mr. Alfred might do, they came in numbers, critically examined everything, spat tobacco juice and freely offered their comments. Particularly were they sure that Smyth was making a great mistake using dynamite instead of black powder for blasting; with all his other troubles, Mr. Alfred might have been spared that.

One day a Protestant clergyman walked past the watchman and gave the job a thorough going over. His manner suggested disapproval, as if he were standing in the presence of a temple of wickedness.

"He didn't touch you for a ten-spot, did he?" bantered Smyth when the preacher had departed.

"No," said Alfred, "and if he ever comes back I'll touch him with a brick." DuPont's face grew red with anger. "Smyth, I have told you to keep such people out of here. If God Almighty comes here you're not to let Him in."

Smyth was a religious man. On his littered desk lay a wellthumbed Bible. He laid a hand on Mr. duPont's sleeve and said in a grave tone:

"Mr. Alfred, I want you to take that back."

DuPont said nothing. Again Smyth plucked the sleeve. "Mr. Alfred, take it back."

DuPont bit his lip. "All right, Smyth, I take it back." After a pause he added: "Smyth, you get around places I don't any more. You see sights that shouldn't be: deserving people without enough to live on; bright apprentices who need a little technical schooling. Give them what they need and draw on me. Only keep my name out of it." 


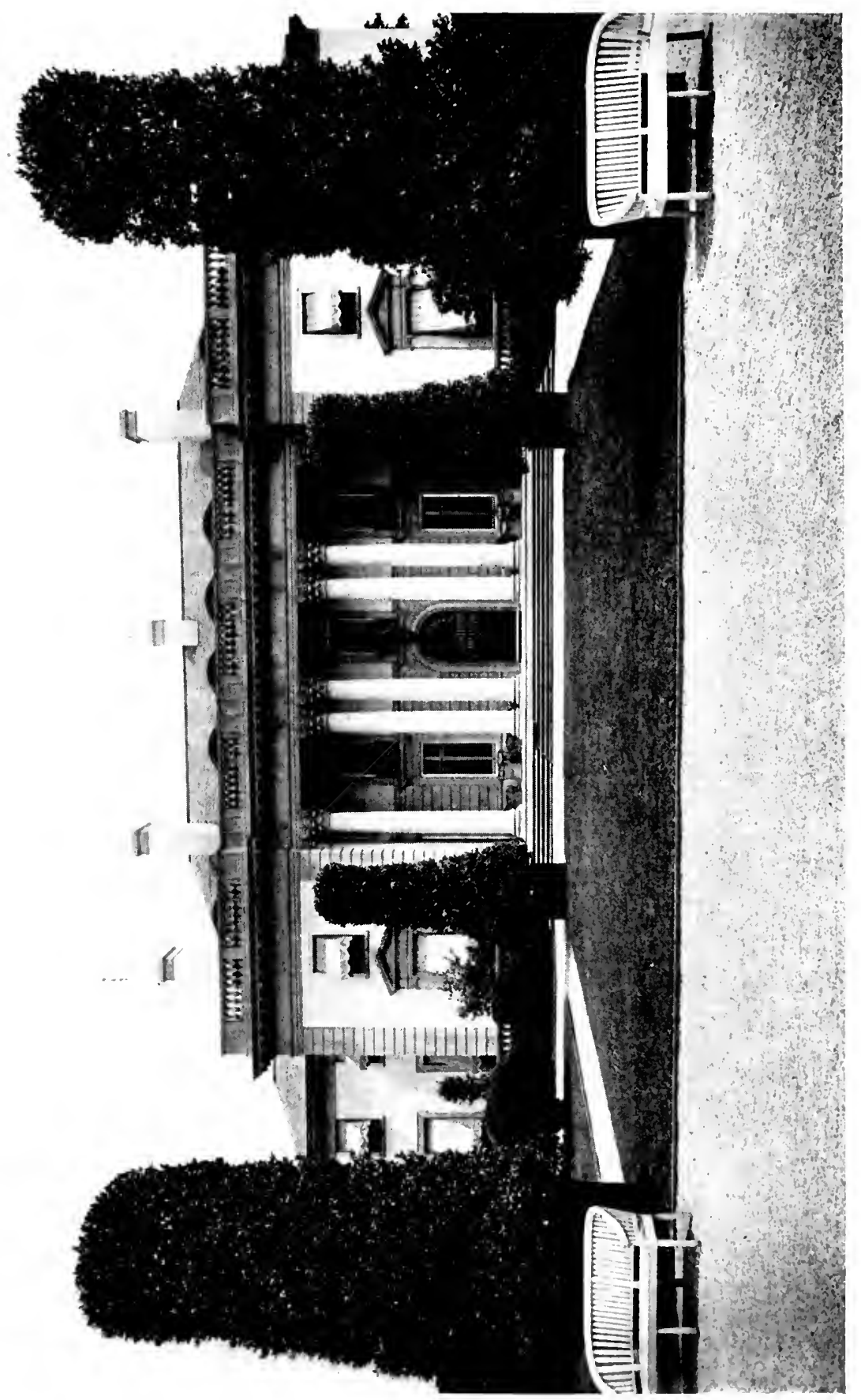

E

ํ. 멸 인 온 焉 E 号 ¿ \& 䓀 《 蛋 苛产 号恶 乙 峞㤩 世珪

岁点 :

-

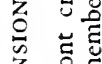

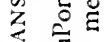
文 山 본 <焉 氮总

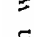

들.

焉

ㄴ.

.

岕

응

등

동

氙

氖 

The house finished in December, i9ı, Alicia and Alfred moved in. It was of limestone, three stories high, the top story being concealed behind a balustrade. In general design, for which Alfred was more responsible than the architects, it was a combination of French château and pillared Southern plantation homestead-a combination worked out with grace and dignity, making it, as it remains today, one of America's most beautiful and most distinguished residences. It contains seventy-seven rooms. Alfred's sanctum was in the basement, for coolness. It contained a drafting table, a scientific library, a large globe, ship models and an arsenal of weapons, including a small cannon and a machine gun. Also it contained five chairs which had been in the parlor of Swamp Hall when the five orphans took over in 1877 .

On the grounds work continued-and, indeed, seldom stopped in Mr. duPont's lifetime. The chief immediate thing was to build a nine-foot wall enclosing the three hundred acres. Concerning this rampart a remark, attributed to Alfred, has become an unalterable part of local legend:

"That wall's to keep out intruders, mainly of the name of DuPont."

Though Smyth, who built the wall, never heard Mr. duPont say this, he admits that it pretty well conveyed the sentiments of the master of Nemours. ${ }^{3}$

As to the slander suits, it had taken a little better than three months for the cat to get out of the bag. The New York papers did almost as spectacular a job as their Philadelphia contemporaries, which hitherto had enjoyed a corner on DuPont news unfit to print in Wilmington. In briefer and less exhilarating form, the wires of the Associated Press carried the story to the hinterlands.

Although Alfred and Alicia had not yet filed a declaration of particulars, there was no guessing as to cause of the suits. Even the conservative New York Sun said that they were for slander, adding that "Alfred I. duPont, vice-president and recognized head of the \$50,000,000 DuPont Powder Company," accused kinswomen of 
originating and circulating "untrue and vulgar statements" about his wife. Every effort, continued the Sun, had been made to head off Alfred, to persuade him to withdraw his actions. But he insisted on a trial and the case would go on the calendar of the November term of court to convene in a few days. Among the women who would eventually find themselves involved, the Sun named Victorine Elizabeth duPont Foster, a sister of Senator duPont; Alice Eugénie duPont Oritz, a daughter of Elizabeth Bradford duPont, defendant; Eugénie Roberts, young wife of an Army officer and niece of Elizabeth Bradford duPont; Amy Eugenia duPont, spinster daughter of the late Eugene, last head of the old company; and Mrs. Henry B. Thompson. ${ }^{4}$

This touched off a volcanic eruption of published rumors. For instance:

Mr. duPont would shortly drop the suits.

Mr. duPont had already dropped the suit against Mrs. Bush who "had promised to be good and refrain from ill-natured gossip."

Mr. duPont had dropped suits against no one and intended to drop none. He would prosecute both actions "to the bitter end." This was the statement of Edward G. Bradford, Jr., Alicia's brother, still a militant defender of his sister. "The people who have circulated the scandalous stories about Mrs. duPont do not even know her," said he. "She has not associated with them for years."

George Amory Maddox was returning to testify to his former wife's good character.

The Philadelphia North American spread this headline across the top of a page:

"THE WOMEN'S WAR THAT CONVULSES DELAWARE"

The New York World found "Wilmington speechless when it was announced that William Saulsbury had been employed by the defendant [Mrs. Bush] as her counsel." The World explained this statement by reciting enough DuPont domestic history to show the similarity of Saulsbury's and Alfred's offenses against the family canons.

During all this journalistic jubilee, no paper was in any way specific as to the nature of the slanderous stories alleged to have been circulated. The World touched this point more frankly than other 
newspapers, saying: "They are of such a nature that they cannot be published."

Nor did the stories touching Alicia stand alone. They were threads in a veritable tapestry of gossip reaching back for years and involving the private lives of more than one DuPont as well as others prominent in the contemporary annals of Delaware. Publication would have brought a cloud of libel suits and probably a string of convictions. Repeating backstairs talk is one thing. Swearing to facts in court is another.

This state of affairs placed Alfred on strong ground. The strong ground of the defendants was the latitude Delaware law affords the defense in slander suits. Remote circumstances surrounding or leading up to an utterance may be offered by way of mitigation or justification. But this was a mule that kicked both ways. While it might help the defendants, it might also spill family secrets right and left.

Alfred was encircled by family pressure to withdraw the suits. He declined, but neither did he file a bill of particulars. The case was put over from the November to the January term of court and then put over again. On April 4, I9ro, Messrs. Bayard and Saulsbury, attorneys for the defendants, wrote a letter to J. Harvey Whiteman, counsel for Alfred and Alicia duPont. They took a strong tone. Objecting to the "extraordinary delay" and to the exploitation of the case in "manifestly inspired" newspaper articles, the attorneys declared that unless a bill were filed within thirty days the defendants would move for a non-pros.

Four days after this letter was written Mr. Whiteman withdrew the suits. The defendants' lawyers immediately gave out their letter, which the Wilmington Journal published locally. The object was to convey the impression that Alfred had been smoked out. This Whiteman denied at once, saying that his instructions to stop the suits had come from Mr. DuPont on March 3I. Alfred himself gave the newspapers a statement saying that he had acted because of intercessions by members of his family, in particular his wife. "Mrs. duPont has never been fully in sympathy with the actions I was forced to bring to protect her good name."

To many of Alicia's acquaintances this sounded like a chivalrous 
utterance. The writer is assured by a person who should know that it was not. This informant says that Alicia, from her knowledge of court procedure, had doubted the wisdom of the suits all along.

After the suits were out of the way, Alfred called Smyth from his work on Nemours and said he wanted him to tear down Swamp Hall. Amazed, Smyth remonstrated: Swamp Hall was a Brandywine landmark; it was Mr. Alfred's birthplace. Alfred was impatient. Either Smyth would pull down the place or someone else would do it-"and not leave one stone on another." The demolition was to be as complete as the Romans' destruction of Carthage.

Smyth shook his head sadly and pulled down Swamp Hall. He knew Alfred's attachment for the old home which the five orphans had defended, weapons in hand. He wondered what fresh wound to Alfred's sensitive nature had prompted this step. Most of Wilmington wondered. Answers came on a new wave of gossip: Alicia was at the bottom of the business; she wished to assure the permanence of Alfred's alienation from his children. That was one story. Another was that Alfred was not quite responsible for what he did; it ran in his line of the family; his father had been a queer man; his mother had died in a psychopathic ward. So the gossip.

All that is known is that Alfred conveyed notice to Bessie Gardner duPont to vacate. Although not obligated by the terms of the financial settlement, he increased her annuity by $\$ 1200$ to cover the rent of a house in Wilmington. Mrs. duPont moved to a place in Red Oak Road and professed herself happier in town. Alfred Victor, ten, and Victorine, seven, made no such pretensions. Alfred missed the old swimming hole and both he and Vicky missed their playmates among the powdermen's children. ${ }^{6}$

A contributing cause to the withdrawal of the slander suits may have been the fact that the hour had come for the DuPonts responsible for the fortunes of the company to call an armistice in their private war and stand together against a common adversary. This adversary was the United States Department of Justice whose vigorous prosecution of the anti-trust litigation against the DuPonts 
had the accused in obvious distress. One Philadelphia newspaper had expressed surprise that, with the DuPont Company's future in jeopardy, "the real brains of that corporation" should be burning up his energies in a petticoat row.

Whether in the domain of church, state or private enterprise, it is pretty hard in Delaware to get away from the DuPont family circle. Filed in 1907 , in the normal course of events, the trust suit had reached the docket of the United States Circuit Court, District of Delaware, of which Judge Edward G. Bradford was one of the jurists. Judge Bradford promptly disqualified himself from acting in this suit, on the assumption that he might be suspected of favoring the defendants. At this certain DuPonts must have smiled. If Judge Bradford's relations with one defendant-his son-in-law, Alfred-were a criterion, the crusty old jurist might have been suspected of favoring the Government. Another jurist assigned to the bench of three judges detailed to hear the case, proceedings got under way in September, 1908. The array of DuPont counsel looked like a meeting of a bar association.

The last testimony was taken nearly two years later, on July 25 , I9I0. The record then filled sixteen volumes, or half the bulk of the Encyclopaedia Britannica, and more was to come. Meantime Mr. Taft had succeeded Theodore Roosevelt in the White House. He had offered the Secretaryship of State to ex-Senator John C. Spooner, of Wisconsin, one of the luminaries of the DuPont counsel table. Mr. Spooner, declining, continued his efforts in favor of the powder barons. George W. Wickersham, of New York, became Attorney General, however, thus heading the Government department in charge of the DuPont prosecution. Mr. Wickersham had acted as one of DuPont's legal advisers in years past when some of the violations charged were in the making. Surely it is nothing improper or unusual for a president to offer cabinet posts to attorneys who had had rich corporations as clients; and the public records of Senator Spooner and of Mr. Wickersham, while socially unprogressive, are above reproach. Nevertheless, it soon became apparent that Mr. Taft was indisposed to follow the vigorous example of his predecessor in making big business toe the mark. Great corporations who had been shaking in their shoes breathed easier in the tolerant atmosphere of the new administration. 
This may have afforded the DuPont lawyers some hope. Certainly the evidence before the court could have afforded them little.

The ruthless suppression of competition by dragooning rivals in the days of Boss Henry's Gunpowder Trade Association was conclusively shown. Similar tactics had been pursued under Eugene duPont, though not with the old Red Fellow's directness and skill. Then had come Coleman and Pierre. Though their methods were subtle, the subjugation of competitors was carried to ends Henry had not dared to contemplate. All this the Government made clear. Not only the anti-monopoly statutes, but probably the common law had been violated.

The main burden of upsetting the case fell to Pierre duPont.

Coleman, pleading sickness, never appeared in court.

Alfred filed a general disclaimer of participation in or knowledge of most of the illegal acts charged. As to the rest, he denied their contravention of the law. Specifically he protested that he knew nothing of the doings of the Gunpowder Trade Association prior to 1902 or of the terms by which Coleman had dissolved it in 1906. He denied knowledge of the existence of the Delaware Securities Company, of 1903, until after it had been used as the instrument for the acquisition of Laflin \& Rand; denied knowledge of the formation of certain other corporations forming part of the mechanism for bagging rival powder concerns. ${ }^{8}$ After spending portions of three days on the witness stand, giving testimony of little more than historical interest, he was excused.

Thereafter the Government virtually dropped Alfred from consideration, concentrating its fire on Coleman and on Pierre as the authors of the violations alleged after 1902. In June, I9II, four years after the filing of the suit, the court found the defendants guilty under the Sherman Act. Tranquilly DuPont's battalion of legal acumen put in motion the wheels for an appeal. Of the defendants Alfred alone objected. Surprising the lawyers by his grasp of the complex pattern of the case, he said he thought an appeal useless; that the company should make the best settlement it could get with the Government and call it a day. This heresy dumbfounded the attorneys, one of whom became so angry that for years he could not find a good word to say for Alfred I. duPont. 
It is possible that the lawyer felt freer to air his resentment because, by the time the court's decision was announced, Alfred duPont no longer was reckoned a power in the affairs of the client company. The highest ambition of his enemies in the family had been realized. In Alfred's own words he was "out"- deposed from his active posts as the company's general manager and as its superintendent of black-powder operations.

In January, I9I I, a fairly thoroughgoing plan of internal reorganization had been laid before the Executive Committee, of which Acting President Pierre was chairman. Among other things the plan called for a closer consolidation of authority in the manufacturing and in the sales departments, relieving Alfred of his operating duties and substituting as general manager, Coleman's brother-in-law, H. M. Barksdale, and as chief of the black-powder operating department, Pierre's brother, Lammot. With an appearance of prearrangement, a motion was made and quickly carried for the adoption of the plan.

Taken off guard, Alfred addressed a restrained written protest to the committee. He spoke of the plan as "prepared by the President" and known to "the other members of the Executive Committee long before it was placed before me." This was his only allusion to the secrecy with which the coup had been contrived, apparently over a considerable period of time. Except by implication there was no reference to the ethics of reconstituting the company's interior organization without consulting its second ranking officer, operating head and second largest security holder. Nor did Alfred ask the committee to rescind its action. Dominated as it was by partisans of Coleman and of Pierre, that probably would have been useless, though in no remote instance every member of that committee, including Coleman and Pierre, owed their jobs to Alfred duPont. Alfred merely asked that the changes of personnel and of method be inaugurated piecemeal, say over a period of six months. "Certain changes could be made at once, and others follow from time to time as the wisdom of each step has been made clear. If the 
plan as a whole is the right one, by this method it will finally be put into effect as it stands approved. If wrong as to detail opportunity will be given to detect errors."

No devious effort, this, of a dethroned man to cling a little longer to the scepter. Alfred's recommendations provided that "the present Heads of the Operatives and Sales Departments" surrender their seals of office at once, retaining, however, temporary advisory posts in order to help the new department heads break in. ${ }^{9}$

The suggestion was not adopted. On the part of Hamilton Barksdale this seems strange. The Virginian had never disguised his appreciation of his predecessor's genius or of the collective debt of the DuPont family to him. Alfred's protest was made on January 27, I9I I. March I the reorganization was put into effect. Alfred engaged passage for France.

Before he sailed the tremendous news spread to the outposts of the DuPont empire.

For years Ed Bader, the ironworker who made the Centennial Gates at Hagley, had kept in a pocket a penciled record of his "time." Gradually this had expanded into a sort of tabloid diary.

"Aug 7 [I909] S[aturday] Io [hours] Graining mill blew. U. G. Mott killed. ...

"Nov i T Thursday] to [hours] Blew packing house. 3 killed.... "Dec. 25 S[aturday] Xmass off. Blizzard. ...

"Aug 8 [1910]

"Aug 9

"Aug Io off. Sore foot....

"Jan II [I9II] W[ednesday] I5 [hours] L[ower] Y[ard] water wheel started....

"Feb in S[aturday] 6 [hours] A. I. duPont out!"10

The emphasis on the departure of Mr. duPont was not disproportionate to its importance in the eyes of old Brandywiners. In the home yards were men who had worked with Alfred in overalls. They were stunned. It was as if the sky had fallen about their 
ears. These workmen had watched the moves in the Wars of the Roses-on the whole well-informed of the shifting stratagems, thanks to the tradition of hiring powdermen's daughters as servants in DuPont households. To a man they were on the side of $\mathrm{Mr}$. Alfred. Almost to a man, that is. To this day pensioners confess with shame that a few "traitors" were in their midst-new men, trimmers and weaklings who, beholding the preponderance of the enemy's numbers, wanted to get on the winning side.

Of Hamilton Barksdale who took over the general managership they knew nothing; a mere dynamite man, he was outside the periphery of their consideration. Lammot duPont, the new chief of black-powder operations, they knew well. He had broken in at the Upper Yard under Mr. Alfred's old foreman, advancing to a yard superintendency. Yes, Mr. Lammot had been an all-right boss; fair to the men, though mighty distant. Y-e-s- he could pass as a powderman; a blamed good powderman, if you wanted to put a fine point on it. But he was Mr. Pierre's brother, wasn't he? And Mr. Pierre was agin Mr. Alfred. That told off Lammot. The fact is that one of the Apostles would have been at a disadvantage stepping into the shoes of Alfred.

Frank Mathewson, inspector of black-powder machinery, heard the news at Connable Mills, near Birmingham, Alabama. On his return, Alfred sent for him. The boss looked pale and calm.

"Francis, I suppose you've heard of my getting out of here."

"Yes," said Mathewson, "but I don't pay much attention to what I hear on the outside."

"Well," said duPont, "it's true. Do you want to go with me or stay with the company?"

"I don't know. I'll have to think. I can lay down on a pension any day now."

“You won't need any pension if you go with me. You and yours will be taken care of. I mention this, Francis, because if you stay with the company some of those who have it in for me may take it out on you."

Frank Mathewson sent in his resignation. ${ }^{11}$

Jimmy Dashiell, Alfred's first secretary, was office manager of the black-powder department. In the performance of a delicate 
confidential mission for Alfred, Dashiell had once incurred Pierre's displeasure. Alfred had been in Europe at the time. Pierre had written him to discharge Dashiell. Alfred had refused. When Dashiell heard of the Executive Committee resolution, he knew that his goose was cooked.

A high officer of the black-powder operating department, whom Alfred had taken over from a rival DuPont and befriended, entered Dashiell's office. He had flipped to Coleman's side of the fence just in time to save his skin.

"You're through, Jimmy," he said, "and I guess you know why." He offered Dashiell \$2000 severance pay.

Alfred told him to refuse it.

"I'll stake you," he said, reaching in his pocket and thrusting a wad of bills in Dashiell's hands.

Alfred got his subordinate a good position with John Wanamaker, the Philadelphia merchant. ${ }^{12}$

After he had taken care of a few others in this way, Alfred boarded a train for Llewellyn Park, New Jersey, and went to the home of Miller Reese Hutchison. He often visited there and at the Edison laboratories nearby. Hutchison had become Edison's chief engineer and business manager.

"Hutch," said duPont, "the time has come. Let's strike out together. I'll put a quarter of a million dollars in a laboratory and furnish all the capital needed to exploit the things we work out. What do you say?"

Hutchison hated to say it. For months he had watched Alfred's unhappiness grow as the hostile ring closed about him and his wife.

"I can't leave Mr. Edison. I'm making $\$ 300,000$ a year; but that isn't it. Carnegie has offered me a million a year to go with him; but I just can't leave the Old Man."

The Hutchisons' four boys were playing baseball in the yard. Alfred joined their game. ${ }^{13} \mathrm{~A}$ few days later he and his wife and stepdaughter sailed for Europe.

The official explanation one hears today in DuPont Company circles is that the change in Alfred's status represented a promotion. 
It is said that Mr. duPont's colleagues on the Executive Committee, realizing that his talents were of too useful an order to be confined to operating matters, desired an arrangement whereby Alfred should be free to address himself to higher duties.

Mr. duPont did not regard the change as a promotion. The "higher duties" did not, in his opinion, include the ability to protect a respected employee like Frank Mathewson, representing the third generation of his family in DuPont service. To a thin-skinned and energetic nature this was a heavy punishment.

Privately one hears another explanation. This holds that sound practical reasons existed for the reorganization. The explosives picture was changing, dynamite coming up, black powder going down. Alfred was primarily a black-powderman. After black powder had passed its peak, he continued to expand facilities, in rgro erecting a $\$ 350,000$ plant at Wilpen, Minnesota, which never paid for itself. Alfred was a scientist rather than a Class A executive; the black-powder department contained too much dead wood in the way of incompetent staff personnel. Moreover, the eye accident and domestic turmoil for considerable periods impaired or unfitted a man of Alfred's high-strung disposition for the exacting demands of his duties.

While all this seems to be true, I do not feel that it expresses the whole truth of the situation. Though Alfred cracked black-powdermen's jokes at the expense of dynamite, he had admiringly watched dynamite blast out rock for the basement of Nemours. Criticism of his inability to see the rising graph of dynamite sales as we see it now has the benefit of hindsight. After assuming the general managership, Barksdale spent $\$ 400,000$ on a black-powder plant in Colorado which was obsolescent when finished in 1912. My opinion is that Alfred was a better technical man than an executive. Nevertheless, Alfred was distinctly no failure as an executive and the dead-wood charge fails to impress. The most conspicuous example-Maddox-was got rid of in I907. Other departments had their favorites and their stuffed shirts taken over for diplomatic reasons in the course of consolidations. Coleman lost much more time from his desk through illness than Alfred, granting that the indisposition which enabled Coleman to escape testifying in the trust suit was entirely genuine. 
About the best approximation of the verities of the case I can offer is contained in the words of a member of the family:

"Alfred stuck his leg out and Coleman and Pierre pulled it. The talk about promotion is eyewash. The talk about Alfred not knowing how to run his department is flimflam. The family row was at the bottom of it. We'd had our rows before, God knows, but never such a knock-down-and-drag-out one. Alfred, stubborn as hell, shared the blame for this. He had a knack of putting his worst foot forward." ${ }^{14}$

On the day of Alfred's retirement, the home-yards men had assembled in the machine shop at Hagley and voted to give him a silver cup. The presentation took place in that shop when Mr. duPont returned from abroad in June. The committee in charge comprised fourteen veterans-white-haired, gnarled, explosion-scarred. Some of them were working in the yards when Alfred was born. There was Pierre Gentieu, who had taught Alfred photography; Gilly Mathewson, electrician, late member of the Down-the-Creek gang; Mike Maloney, blacksmith, late second violinist in "Al's band"; Joe Haley, with whom Alfred had broken in on the powder line. In a voice usually reserved for addressing his lodge brothers, Frank Pyle read a resolution:

"Whereas, our Vice-President, Mr. Alfred I. duPont, has left as executive in charge of the black powder operating department for some higher office . . . we have hereby resolved that we feel keenly the loss of our leader and chief ... [whom] we have always found a friend ...."

\section{Alfred's tones were husky when he began to reply:}

"I presume that the time comes in the life of every man when he asks himself, "Have I made a success of life, or has it been a failure?' In order to answer that question he must have clearly defined in his mind what in his opinion indicates success in life.

"He has had his ambitions; he has had a goal which he has been endeavoring to attain. Some men measure their success with the wealth they have attained; others have political ambitions; and so on. I, myself, have always believed that the man most to be envied 


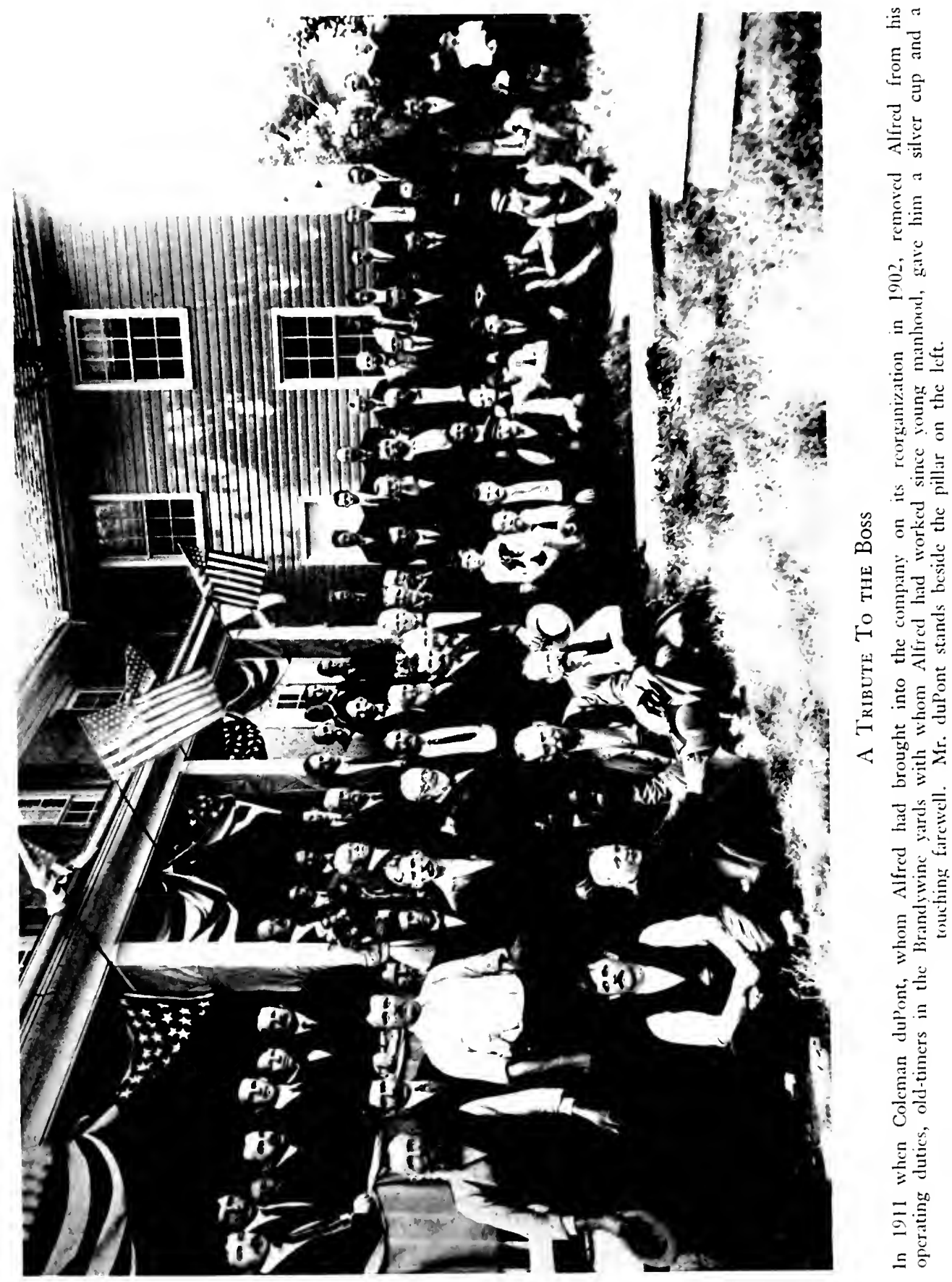


was he who, through life, had won the love and esteem of the greatest number of his fellow men. Wealth in the abstract cannot bring happiness to the owner. But he who is esteemed and beloved of his fellow beings carries with him through life a jewel which becomes brighter as time passes. Men on the Brandywine have always held the highest place in my affection. With them I began my life work and for years we have toiled as brothers, through days of sunshine and days of shadow. You may therefore feel assured that no gift of the past or of the future will be as greatly cherished as this exquisite token that you give to my keeping."15

Tears were in Alfred's eyes when the men crowded around to press his hand. He could not trust himself to try to speak again.

With Maloney, the blacksmith, he walked up the slope of Breck's Lane, past the ruins of Swamp Hall.

"I won't be here much any more," he said. "I won't feel like coming. But I intend to keep track of the Brandywine people. Maloney, if I ever hear of one of them being in need and neglected I'll hold you responsible. When anyone needs help come and see me, and if I'm away see Miss Brereton."16 


\section{CHAPTER XV}

\section{An Important Meeting at the White House}

BEFORE long it began to look as if Alfred had been mistaken in his judgment of Cousins Coleman and Pierre when they had reorganized him out of control of black-powder operations. The new setup seemed a success for the business as a whole; costs went down and profits up. It seemed a success as it touched Alfred personally, who became no thumb-twiddling vice-president. Free of the routine work of running the black-powder department, Alfred's restless mind ranged over the whole spacious map of DuPont concerns, getting into a few odd corners no other major DuPont mind had searched very well before.

Back on the Finance Committee, he gave close attention to its affairs and his advice was sometimes solicited by Acting President Pierre. Scientific things interested him most, of course. Superintending a standardization of black-powder plant machinery, Alfred singled out for especial commendation Lammot duPont's suggestions for improving the corning mills. Recognizing them as the coming thing, he began an extensive study of high explosives about which two years before he had testified in the trust suit that he knew nothing. He examined a dozen new inventions which might have been useful to the company. Chilean nitrate explorations and the possibility of extracting nitrates from the air-an old idea of Alfred's-came in for attention. Francis I. duPont, in charge of the experimental station which Alfred had helped to establish in 1904 at the old Lower Yard on the Brandywine, actually succeeded in taking nitrates from the air, though not in commercial quantity.

Alfred was proud of this experimental station and fond of the 
man in charge of it. Francis duPont was a medium-sized, shy man who looked as if he got his clothes secondhand and then slept in them. Able DuPonts there had been down through the generations, and three of these were touched with genius-Lammot, the elder, Alfred I., and now Francis I. In his younger days Francis had delivered single-tax stump speeches. Caring little for money or for titles, he had resigned a vice-presidency to head up the experimental station and direct the work of an ever-increasing corps of young chemists. The hostess at a formal dinner might look. around in vain for Francis, who had been present only a moment before.

"I expect you will find him at the laboratory," his wife would apologize. ${ }^{1}$

The scientist might return home at five in the morning or he might stay on through all the next day.

The experimental station's work concerned only explosives. Alfred was still for branching out and trying to find what could be done with the chemicals wasted in the making of powder and dynamite, but he got nowhere with that particular idea.

For one reason, as new vistas for high explosives constantly opened up, the company was making money hand over fist. Through I9Io, I9I I and I9I2 common stock dividends ran twelve dollars a share, with plenty left over to add to surplus. In I9I I an addition doubling the area of the twelve-story DuPont building in Wilmington was completed. In I9I3 the area was nearly doubled again by the addition of the spiffy Hotel DuPont and the Playhouse, a theater. In a letter to a friend, Alfred commented rather extravagantly on some of these establishments:

"The Hotel is rapidly turning into a first class saloon. No guests are allowed to remain more than a certain time unless they become drunk. In order to make the Hotel pay it is necessary that the bar distribute sufficient liquor on a basis of $100 \%$ profit. I do not know whether you received an accurate account of the opening evening of the Hotel. The tables had been engaged several months in advance, consequently nothing but the crême de la crême could gain admission. If the City's Tatler, Bill Scott, is to be accredited, the scene in the Rathskellar placed Le Rat Mort at a serious dis- 
advantage. After each incumbent had surrounded a quart of champagne, tables were pushed against the wall and the various participants in this Saturnalia started to turkey trot in a way which caused Mr. Scott to rush across the room to poor old Aunt Mary: 'Mrs. duPont, are we in Berlin or Paris?' This surely is not Wilmington.'"

Alfred's income from the company alone mounted to the neighborhood of $\$ 400,000$ a year. The possession of so much wealth started his mind to work on the evolution of a social philosophy, the germ of which he had been born with. The basis of this philosophy rejected the idea of absolute and perpetual individual ownership of great fortunes. The larger share of such wealth should be held in trust for redistribution for the benefit of society. He believed that this would inevitably bring about a new relationship between capital and labor. On this point Mr. duPont wrote Professor Irving Fisher, the economist, of Yale University:

"In my opinion the solution of the problem of industrial discontent, if so it can be termed, lies in the proper distribution of wealth between capital and labor in years to come, based on some economic principle which will be satisfactory, and which can be defended on the grounds of science and fairness. There can be no other possible solution. This will gradually result in the elimination of the line between capital and labor, and each laboring man will become a capitalist to a certain extent. When this condition arrives, all interests will be common."3

In 1902 Alfred had regarded the DuPont Company as a trust in the hands of the DuPont family and its employees. Alfred began now to think less of the family and more of the employees whose share in the earnings of the company he believed should be greatly enlarged. Thoughts for a more liberal pension and bonus plan began to take shape. Though he seldom visited the old Brandywine yards, he knew what was going on there in the lives of the workmen and their families. The pledge to Maloney had been kept. Seldom a day passed when Alfred did not consider some little domestic or financial problem of company employees or members 
of their families. He would turn from a company finance matter involving millions, or a scientific discovery which might alter the future of an industry, to start painstaking negotiations with the firm's Real Estate Department, supporting the application of Pat Casey, retired powderman, to buy the little company house in which he lived. From his own pocket, in many instances, he paid pensions and gave bonuses, when he felt that in reality it was the company who owed these men.

The following letter is taken at random from a file containing twenty such:

\section{"E. I. duPont de Nemours Powder Co.,}

"Hagley Office,

"Wilmington, Del.

"Gentlemen:

"I understand that Mary Buchanan is indebted to you for rent, in amount of $\$ 17.00$.

"I am enclosing check for this amount, and will ask you to credit the same to her account.

"Yours truly,

"LeILA Brereton

"Secretary [to Alfred I. duPont]"4

Mary Buchanan, daughter and widow of powdermen, had fallen behind in her rent for the company-owned house which had been her home most of her life.

Yet the social philosopher, contemplating a new economic order, could strike vigorous blows for the old order, as witness his part in the settlement of the Sherman Law case.

By the unanimous decision of June 2I, I9II, a bench of three Circuit judges had found the principal corporate and individual defendants guilty of nearly everything the Government had charged. The opinion of the court, written by Judge William M. Lanning, was couched, however, in temperate language. The opinion cited and leaned heavily on the "rule of reason" recently 
enunciated by the United States Supreme Court in the celebrated suits against the Standard Oil Company and the American Tobacco Company. Taking advantage of the loose wording of the law prohibiting "combinations in restraint of trade," the high court under Mr. Taft's benevolent administration had declared that this really meant "unreasonable combinations in restraint of trade." Little that was unreasonable, in the court's view, was found against the oil and tobacco trusts which, although convicted, got off virtually free. Thus was the Sherman Law emasculated and a harpoon thrown into the trust-busting started by Theodore Roosevelt.

The Circuit Court directed that the DuPont monopoly be dissolved, and that the DuPont Company and the Government jointly submit a plan to this end. In effect, the guilty corporation was invited to help write its own sentence. ${ }^{5}$

In the circumstances Alfred was perfectly right in standing out against an appeal and arguing that the company make the best possible settlement with the Government, for, indeed, it looked as if a very good settlement, from the company's point of view, were possible. Coleman and Pierre won to this view, Alfred wrote former United States Senator J. Frank Allee, of Delaware, to arrange an audience at the White House.

According to Allee's story, President Taft received him very bluntly, denouncing Coleman duPont as "slippery as an eel and crooked as a ram's horn." But he consented to see Alfred. ${ }^{6}$

Mr. duPont appeared at the White House wearing a silk hat and morning coat and carrying his acousticon. With the President were Attorney General Wickersham and Assistant Attorney General William A. Glasgow, Jr., who had participated in the prosecution of the DuPont suit.

The time was March, I9r2. After three years in office the failure of Mr. Taft as president was apparent. Men of sharp minds who had observed him closely knew the reason. Through a combination of laziness and timidity, the Executive avoided a fight wherever possible, though sometimes he would bluff a bit. But too often he yielded to the other fellow's bluff and, on occasions, to plain effrontery. The situation was not relieved by the President's 
baffled, angry state of mind, and his determination to force a renomination at the hands of a party the majority of whose rank and file preferred the return of Theodore Roosevelt.

He opened the interview by taking a strong tone with duPont. His caller took a strong tone back. When the President said something about the possibility of throwing the company into receivership if it did not prove amenable, Alfred said:

"Mr. President, if the Government does that, the DuPont Company will throw a million people out of work."

"Do you mean to threaten the United States Government?" demanded Mr. Taft.

Mr. duPont said he threatened no one; only stated a fact. DuPont would close its plants, and soon the country would run short of commercial explosives.

Nothing seems to have been said about the ability of the Government to open the plants at once by court order.

Mr. Wickersham broke into the conversation, pointing out the position of the DuPont Company as a transgressor of the Sherman Law. Alfred observed that Mr. Wickersham had been an attorney for the DuPont Company. If the law had been violated it was because the company had received faulty legal advice.

This seems to have ended the bickering and the conversation got down to a constructive level. It was broken off by the President who rose saying:

"Mr. duPont, I'm glad you came down. You have presented facts we did not know before. You will hear from us later."

Mr. duPont heard from the Government sooner than he expected. Taking a train back to Wilmington that afternoon, he was surprised to find on board Assistant Attorney General Glasgow. They took up the talk where it had been broken off. ${ }^{7}$

Wheels were set in motion in a series of supplemental hearings in which Army and Navy people urged that, in the forthcoming split-up, DuPont be permitted to retain its monopoly of military explosives intended for the United States forces.

In June, I9r2, the court handed down its final decree. Eight key corporations in the DuPont empire were dissolved and two new ones, the Hercules Powder Company and the Atlas Powder 
Company, were created. To the new companies DuPont assigned about a third of its dynamite and commercial powder plants. In payment for the facilities thus assigned, DuPont accepted bonds and stock of the new companies, which it distributed among its stockholders. Alfred's holding of Hercules 6 per cent bonds was $\$ 757,000$. In this way DuPont could have wormed back into indirect but nonetheless actual control of Hercules and Atlas had it wanted to. Events made this unnecessary. The start of the European War in I9I4 gave DuPont all it could handle without bothering about Atlas and Hercules. After the war DuPont at last went into by-products and other lines-Cellophane, Rayon, paint, General Motors, etc.-until explosives formed only 7 per cent of its business. Meantime outside capital had flowed into Hercules and Atlas making them independent in fact. Thus circumstances accomplished what the court decision set out to do.

Alicia duPont loved babies and dearly wanted one of her own. The earlier miscarriage, leaving her in shaken health, had in no way abated the determination to have another child.

Little Alicia Maddox, who was eight years old in I9rI, joined in this wish. She wrote letters to the stork to bring her a little brother.

The time came when it seemed that this hope might be realized. On January 9, I9I2, Alicia was delivered of a baby girl. The infant lived only long enough to be christened-Eleuthéra Paulina, for Alicia's mother-and was buried on the grounds of Nemours.

Alicia rallied slowly from the emotional and physical shock. She never recovered entirely. Her eyesight was so impaired that she could read only with thick-lensed glasses-which she did not wear on the street. Consequently she passed acquaintances without recognizing them, and this led to misunderstandings. She kept the little grave covered with flowers, the culture of acres of which was one of her occupations. She had to give up riding, a sore deprivation. But the stable of thoroughbreds Alfred had provided was maintained. Alicia would go down and stroke her 
favorite mounts and feed them carrots. She still exhibited them at the New York and Philadelphia horse shows. She was also a patron of the rustic Delaware State Fair, liberally posting prizes for farm animals, garden and field products, and for jellies and jams put up by farmers' wives.

Alfred did everything he could to divert his ailing wife. He showered her with jewels. One of his hobbies, of which few were aware, was the collection, in a desultory way, of precious stones. He owned a ruby, said to be worth $\$ 150,000$, which became the envy of a more ostentatious and avid collector, former Senator William Andrews Clark, the Montana mining magnate. After carrying a stone around with him until an idea occurred for its use, Mr. duPont would repair to the drafting board in his basement study and design a setting-pin, ring, earring, brooch-and take the drawing to Tiffany or to Theodore B. Starr to be executed.

Though Alicia never loaded herself with these presents, one piece of jewelry she was never without. This was a plain, inexpensive little pin. If it did not harmonize with her costume, she would wear it concealed. This ornament had belonged to Alicia's mother, her only friend of a misunderstood and miserable childhood. ${ }^{9}$

Because Alicia liked it there, Alfred replaced the shack on his shooting lodge at Cherry Island, Maryland, with a comfortable cottage and built a dock for the yacht. Frank Mathewson, who had retired from the DuPont Company when Alfred was relieved of his operating duties in I9I I, became factotum in charge of the Maryland property. Frank's brother Gilly, Alfred's colleague in electrical pioneering, was electrician of the Nemours estate. When Jim Cook, the ex-slave who was Frank Mathewson's predecessor at Cherry Island, fell ill, Alfred hastened to his bedside. The old Negro died in the arms of his employer. His children and grandchilden continued to live on the place and every year they sent a brace of fat turkeys to grace Nemours' Thanksgiving table. ${ }^{10}$

Alfred was elected commodore of the near-by Cambridge Yacht Club, which proved a good thing for the club because he gave it a new clubhouse. Governor Phillips L. Goldsborough of Maryland, a club member, approached the generous commodore on the sub- 
ject of improving the Cambridge Hospital, most of whose patients were poor people from the Eastern Shore of the Chesapeake. Alicia looked into this matter, and, seeing the primitive conditions under which babies were brought into the world in those parts, she got her husband to build a modern maternity hospital. Governor Goldsborough wanted to call it the DuPont Hospital, but neither Alfred nor Alicia would allow it. ${ }^{11}$

While Alfred was showering affection on his pretty little stepdaughter and in a charitable way expressing constant concern for the welfare of other children, the estrangement of his own children became complete. Lost to him was Madeleine, the daughter who had taken her father's side in the separation between Alfred and his first wife. After the divorce from Bancroft, Madeleine had lived in Wilmington until February, 1912, when she had a fuss with Alicia. In a huff she went to Germany to live, Mrs. Coleman duPont paying her passage. ${ }^{12}$ She supported herself on her share of the $\$ 24,000$ income from the trust fund Alfred had set up. Incidentally, Pierre duPont had retired as Bessie G. duPont's trustee of this fund and its administration had been placed in the hands of a bank, thus removing one chance for friction in the family. Yet friction, trivial and otherwise, continued from other sources. Under the Delaware law, Alfred was the guardian of his son, Alfred Victor, while the boy was between the ages of seven and fourteen. Alfred stipulated that the boy attend the Hallock School in Great Barrington, Massachusetts, which Alfred I. and Charles S. Mellen, president of the New Haven Railroad, had enabled Gerard Hallock, a mathematics teacher, to found. The boy's mother did not care for the school and Alfred Victor-perhaps on that account-did not like it either.

On February 3, 1913, the House of Representatives of the Delaware Legislature was drowsing through a dull session of little chicken-feed bills. Representative Swan, Democrat, of Delaware City, rose in his place to introduce a bill to prohibit shad fishing in the Delaware on Sundays. It was referred to the proper com- 


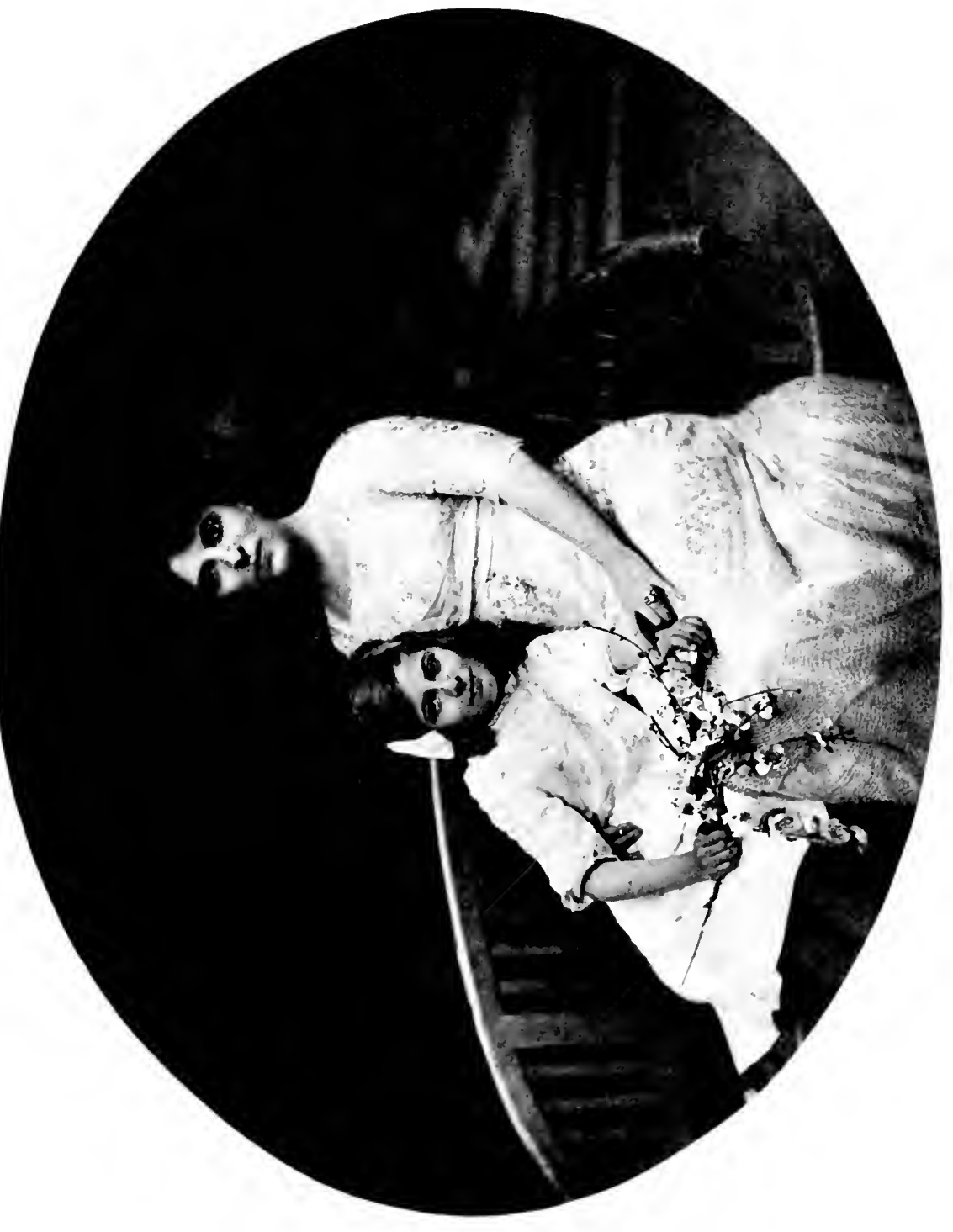

$\stackrel{0}{=}$

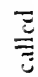

$\frac{\Xi}{3}$

눈

$\Xi$

$\stackrel{5}{\Xi}$

․ㅡㄹ

恶

菏苞苞

คُ

을

글

는

를

产

焉

递

$=\bar{a}$

焉

$\because \frac{}{0}$

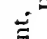

$\vdots$

$\Xi$

$-$

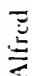

눈 

mittee. Then Mr. Swan introduced another bill, entitled: "An Act to change the name of Alfred Victor duPont to Dorsey Cazenove duPont." The name DuPont, in any connection, is sufficient to awaken the soundest-sleeping Delaware legislator. But Swan had taken care of that, privately assuring his colleagues that this bill represented a private agreement between the boy's parents. $\mathrm{He}$ said that it had been handed to him by Attorney Thomas Bayard Heisel, one of the Democratic bosses of the State. The Delaware Legislature was Democratic and more than one of its members, like Swan, owed his election to Heisel. On their side of the house, the Republican members looked to their leader, Edward Bradford, Jr. Representative Bradford was Alfred I. duPont's brother-in-law and always vigilant in the defense of his interests. Bradford said nothing.

So everything seemed all right, and the bill was referred to the Miscellaneous Committee of the House. Returning approved four hours later, it was passed and sent to the Senate. ${ }^{13}$

Wilmington's three newspapers scrupulously minimized the item, giving more prominence, indeed, to Mr. Swan's shad-fishing bill. Philadelphia and New York papers displayed no such inhibitions. When a ranking member of the country's Number One industrial family slips into a state legislature with a bill to change the name of his son, it is news.

More news was made next day. Bright and early Bessie Gardner duPont's attorney, Andrew C. Gray, appeared in Dover to say that the boy's mother had not agreed to the bill, knew nothing of it and opposed it. The House convened amid a buzz of excitement. Representative Mooney, chairman of the Miscellaneous Committee, was on his feet.

"I rise," he said, "to a question of personal privilege. Yesterday the House passed House Bill Number 97. The Miscellaneous Committee considered this bill." Mr. Mooney went on to say that because Thomas Bayard Heisel had told the committeemen that there would be no opposition to the measure the committee had reported it favorably. Now, continued Mooney, opposition had appeared, making it evident that the committee had "railroaded" the bill under a misapprehension of the facts. 
A motion to recall the bill from the Senate was carried unanimously, Swan not voting. ${ }^{14}$

Alfred I. duPont made a public statement blaming the newspapers for creating the impression that young Alfred V.'s mother had sponsored the bill. "I wish to say that this bill was introduced by me and not by the boy's mother, Mrs. B. G. duPont, as certain papers have erroneously stated. This change [of name] was requested by me for reasons to me sufficient and at the moment not of public concern."15

Heisel demanded a rehearing of the bill by the Miscellaneous Committee, saying that Mr. duPont could lay documents before that body which the lawyer intimated would create a sensation. Three weeks later the rehearing was held-in private, though out-of-town newspapermen had no difficulty reporting what is supposed to have taken place. Mr. duPont himself appeared to urge passage of the bill. The only document produced was a copy of the trust agreement under which Alfred had set up an income of $\$ 24,000$ a year to support his wife and children. Mr. duPont spoke guardedly. He said that he had not seen his son for four years. At first declining to disclose the reasons for wishing the boy's name changed, when pressed by Chairman Mooney, Mr. duPont said that he felt the lad would "bring disgrace" on his father. Pressed to be more specific Alfred would offer no details. He said that the names "Dorsey Cazenove," from his former wife's family, were suggested "through courtesy" to her.

In rebuttal Andrew Gray exhibited statements from the boy's schoolmasters as evidence of his good character and transcripts of his marks as evidence of his intelligence. Gray produced a letter which young Alfred had written his mother from Hallock School, asking why his father should wish to change his name. ${ }^{16}$

The New York Times correspondent wrote that Mr. duPont had not made a happy impression on the committee. The journalist estimated that, should it reach the floor again, not to of the 35 members of the House would vote for the bill. ${ }^{17}$

Mr. duPont was determined to force a vote, nevertheless. Four lawyers and a professional lobbyist went to work on the Democratic members, exploiting their resentment against the Repub- 
lican machine which kept Colonel Henry A. duPont in the United States Senate. On March 13-four days before young Alfred's thirteenth birthday - the bill was pried out of committee. On the floor it was beaten by the close vote of 17 to 15 . Edward Bradford was the only Republican to vote for the bill, the defeat of which was accomplished by five Democrats who declined to follow party leadership..$^{18}$

Repercussions of this unseemly affair exceeded in intensity and depth the spectacular family outcry which had greeted Alfred's marriage with Alicia Maddox. Friends who had sympathized with Alfred in that episode could offer little in his defense now. Too many of them felt as did one who has said to this writer:

"It was the greatest mistake of Cousin Alfred's life."19

The DuPont Company split-up necessitated by the Sherman Law case reduced common stock dividends from $\$ 12$ to $\$ 8$ in 1913 , but in 1914 the war in Europe banished worries on that score. Allied orders on the books as of December 22, 1914, totaled 21,621,300 pounds of death material. On February I, 1915, they stood at $43,398,300$ pounds. The money value of war orders, as of February 18 , I915, was $\$ 59,374,725$. The golden flood was on.

Amid the multiplicity of duties this avalanche threw on DuPont officials, Alfred found time to consider the question of distributing a part of these vast earnings among the working personnel of the company. Years later he wrote with specific reference to the problem under review: "Surpluses are created to take care of stockholders' interests. Why not create them to look after the interest of the creative values represented by salaried and wage employees?" 20

DuPont's original bonus plan, adopted in 1905, made the company a pioneer in profit sharing. After the required 5 per cent on preferred shares and after 5 per cent on common had been paid, 7 per cent of the annual earnings was invested in common shares for distribution as bonuses to worthy employees. Under this arrangement, by 1915, I122 of DuPont's 3840 stockholders 
were employees-owning, of course, a very small fraction of the total stock. Irénée and Lammot duPont, brothers of Pierre and now powers in the company, had each received his first block of stock (fifty shares apiece) on the personal recommendation of Alfred, their chief in the black-powder department. ${ }^{21}$ In 1909 Alfred had sold, from his own holdings, I000 shares to Pierre's right-hand man, John Raskob, because he wanted Raskob to have a bigger stake in the firm. The price was $\$ 120$ a share, which Raskob admitted a bargain. Raskob paid in installments, Pierre endorsing his notes. ${ }^{22}$

But Alfred's particular concern was the little people. Repeatedly he gave from his own holdings shares to wage or small-salary workers who had been passed over in the regular bonus distributions. Mike Maloney, Hagley Yard blacksmith, received \$5000 in bonds. ${ }^{23}$

All agreed that the hitherto undreamed-of profits the war was bringing in called for a restudy of the bonus setup. In view of the enormous amounts which would become available for bonuses, the great and rapid expansion of personnel, and the lack of opportunity, in the rush of war production, to single out impartially those deserving of recognition, Alfred advocated that bonus payments be suspended during the emergency. This was opposed by Pierre and his following which comprised a majority of the Executive Committee. They held that bonuses should be paid, and, moreover, that members of the Executive Committee be declared eligible to share in them. Heretofore Executive Committee members had been ineligible, as the primary object of the bonus policy was to benefit the lower order of company workers.

Alfred objected, contending that the Executive Committee members were getting rich fast enough. William duPont stood with him. William, who had left the company in 1893 during the storm over the first divorce in the DuPont family, had lately returned from his Virginia exile to a place on the Board of Directors. Alfred and William were brushed aside, and the bonus continued under amended regulations including Executive Committeemen among the permitted beneficiaries. This would make available an estimated $\$ 5,000,000$ to be passed out in bonuses for 1915. Alfred 
called it a pocket-lining grab and other things which pained some of his cousins greatly. ${ }^{24}$

The greatest concern the first weeks of the war had brought to Alfred was, however, a personal one. In April, I9I4, Alicia and her eleven-year-old daughter had gone to France in the company of Alicia's brother, Eddie Bradford. Her letters told of delightful pilgrimages through the wine-growing regions where Eddie made pages of notes. Eddie Bradford, attorney and Republican leader of the lower house of the Delaware Legislature, maintained about himself fewer illusions than most men. He said that his effort to be a lawyer (dictated by his old czar of a father) had resulted only in spoiling what might have been a good chef and gentleman vintner.

Alfred was delighted to hear of his wife in such excellent spirits, but she was pregnant again and must be very careful. His plan was to sail in the middle of the summer and bring her home.

The fateful first week of August caught Alicia in France separated from her brother. With the German army rolling toward Paris, Alfred could not get over, and Alicia could not get back. Nearly frantic, Alfred kept the cables hot. Eddie rejoined his sister, however, and they returned safely in September.

On October 2r a son, christened Samuel, was born to Alicia at Nemours. On October 22 the baby died and was buried beside his little sister. 


\section{CHAPTER XVI}

\section{Coleman Sells Out}

Coleman liked titles and retained that of president although Pierre had been the active head of the DuPont Company since 1908. In that year Coleman had excused himself, on grounds of illness, from appearing in the Sherman Law suit. The following year he was operated on for gallstones. The first decision in the trust case was handed down in I9I. This found Coleman sufficiently restored in health to spring into the limelight in Delaware with the startling proposal to build his adopted state "a monument a hundred miles high and lay it down on the ground."

This was Coly's large way of saying he meant to construct a road- "the straightest, widest and best in the world"-from one end of the little commonwealth to the other. Cynical persons assumed it to indicate that Coleman had political aspirations. His was the brain which had built and kept in order the costly Republican organization to maintain Colonel Henry duPont in the Senate and to keep the State generally amenable to the wishes of the DuPont Company. Coly's only visible reward for this had been the title of General annexed to his name. It derived from an appointment to the Governor's "military staff." The road project was taken to mean, however, that General duPont meant to garner for himself some of the larger rewards of politics.

In Delaware the practice had been, since Addicks' day, that when a man wanted anything in Republican politics he should pay handsomely. When Coleman went to buy his two-hundred-foot strip of right-of-way, he found that land prices had jumped three or four times. This disgusted Delaware's benefactor and after a year construction on the road was stopped.

Meanwhile, tender as the Government had been in carrying 
out the dissolution decree against the DuPont Company, Coleman's cherished explosive monopoly had been more or less pulled apart. Its creator exhibited little interest in putting the pieces together. His active mind was at work in other pastures. Of late years Coleman had spent much time in New York City, rubbing elbows with giants of industry and of finance. He felt himself a match for any of them. In 1912 when colleagues in Wilmington were sweating over the task of dismembering the DuPont Company, Coly was having the time of his life in New York building the McAlpin Hotel. His principal partner was Charles P. Taft, the President's brother. On the twenty-first floor of the McAlpin, Coleman established his New York residence. It was a gay place. Forty people, including half the chorus of a Broadway show, were not unusual at an after-theater party.

In 1913 Coleman took it into his head to write his name on the New York sky line which he loved to contemplate at all hours of day and night from his windows high in the McAlpin. On Broadway below Wall Street, he began blasting a hole in Manhattan's bedrock for the erection of the Equitable Building, which was to be the largest office structure in the world-forty stories high; 2300 rooms; cost, $\$ 30,000,000$.

With this enterprise only fairly started, Coleman underwent an intestinal operation. He recovered slowly. Next, the European war burst upon the world. Security prices coilapsed and the New York Stock Exchange was closed to avert a panic. Money was hard to get, and Coleman needed millions. He was the largest holder of DuPont stock, Alfred being second. As the war orders began to roll in, the price of this stock revived. The latter part of November common was quoted at 143 bid, 148 asked. Coleman decided to sell a block of it to satisfy the voracious demands of the Equitable Building.

In December, 1914, Pierre duPont walked into Alfred's office and said that Coleman wished to dispose of 20,00o shares, and had suggested that the company buy them for resale to important em- 
ployees on whom the burden of war orders was getting heavy. Pierre said Coleman suggested a price of $\$ 160$ a share.

Pierre's idea was to open the offer to employees earning $\$ 500$ a month or more, permitting each to buy stock worth up to three times his yearly pay. Alfred said he thought it a good thing. The conversation lasted only a few minutes.

Distributions of stock among key employees Alfred always had favored, as when personally he had sold those thousand shares to Raskob. These distributions were distinct from bonuses, though they had a bonus feature because the prices asked had always been lower than the stock could be bought outside. Yet Coleman was offering his stock at 16o, which was the current over-thecounter asking-price in Wall Street. (DuPont shares were not listed in the New York Stock Exchange until after the war.) Alfred knew Coly to be in need of money and knew him to be a sharp trader. ${ }^{1}$ In as diverse instances as the Brandywine land deal and a boat race off Cambridge, Maryland, Alfred believed he had been unfairly used by Coleman. ${ }^{2}$ Although the events under review took place before the bonus rumpus, related a few pages back, Alfred felt that any proposal of Coly's warranted careful examination. So thinking over the stock offer, Alfred dictated a note to Pierre saying he believed Coleman's price too high.

On December 23 the Finance Committee of the DuPont Company met. Those were busy days for that all-important body. New plant construction alone, to take care of war business, was running into multiple millions. The company's pool of working capital was growing at the rate of $\$ 300,000$ a day. Money was everywhere-coming in and going out. The personnel of the Finance Committee-Coleman, Pierre, Alfred, William-was evidence of the continuing dominance of DuPont blood in the affairs of the DuPont Company. Present on December 23 were Pierre, Alfred and William; absent, Coleman, who had been suddenly taken from New York to the Mayo Hospital in Rochester, Minnesota, a very sick man from complications following his abdominal operation.

Pierre laid Coleman's offer before his two cousins. Alfred objected to the price. He said 125 was as much as employees should 
be asked to pay. On an $\$ 8$ dividend basis, Alfred pointed out that this was little better than a 6 per cent investment. He did not think a smaller yield sufficiently attractive to offer the men. This statement ignored the prevailing impression that dividends in 1915 would go above I9II's $\$ 8$. Though military orders were piling up, Alfred contended that the duration of the war was too uncertain to warrant counting the profits already. On the market the stock had been at a standstill for a month-155 bid, 160 asked. William agreed with Alfred. Their point was that the offer was all right except as to price. Pierre thought the price proper, but was outvoted.

The next thing that happened eventually developed into a point of irreconcilable dispute between Alfred and William on one hand and Pierre on the other. Alfred and William's understanding of it was that Coleman was to be informed that the price of 160 seemed unjustifiable "at this time" and Pierre instructed to submit a counter-proposal of $\mathbf{1 2 5}$. In their minds this formed the beginning of a negotiation over the matter of price, and not a blanket rejection of Coleman's proposal, with the objects of which, indeed, they agreed. Pierre later said that he had regarded the committee's action as something different altogether, namely, "a definite turndown" of Coleman's offer. At the moment, however, neither Alfred nor William seemed aware of Pierre's divergent point of view. Hence no visible disagreement except over price.

Pierre later pointed to the minutes of the Finance Committee meeting to support his contention as to the action taken. These minutes read:

"Mr. P. S. duPont presented a letter from Mr. T. C. duPont, offering to sell 20,70o shares of Common Stock of this company at \$16o per share. After discussion it was voted and carried (Mr. P. S. duPont voting in the negative) that Mr. P. S. duPont be instructed to advise Mr. L. L. Dunham, attorney for Mr. T. C. duPont, that we do not feel justified in paying more than $\$ 125.00$ per share for this stock."

Although they had signed the minute book as correct, Alfred and William later claimed that, in the last sentence, the words "at 
the present time" should have followed the word "paying," making the meaning clearer. ${ }^{3}$

But if Alfred and William bobbled when they O.K.'d the Finance Committee minutes which did not express their understanding explicitly, Pierre committed an oversight a week later when he approved this report on the matter from the Finance Committee to the Board of Directors:

"The committee expressed the feeling that we were not justified in paying more than \$I25 per share and asked Mr. P. S. duPont to take the matter up with Mr. T. C. duPont further."

Alfred, for one, was never able to see how that language could be construed as "a definite turn-down."

And so began the eventful year of I9I5, with each feverish day bringing its budget of problems to the twelve-story building at Tenth and Market Streets, Wilmington. Until the second week in January, however, buyers continued to ignore DuPont common stock. The price dropped to 153 bid, 158 asked. Then it started up.

The last week in January Pierre received a cable to meet in New York a Mr. Kraftmeier, of the British Nobel Company, who was arriving on the Lusitania. Thinking this a matter of more orders, Pierre took along Colonel Edmund G. Buckner, DuPont's wizard salesman in charge of military explosives. But Kraftmeier said nothing of new business and finally managed to draw Mr. duPont aside. Then he whispered that England had a report that, owing to the embarrassment of one of DuPont's large stockholders, Germany's American financial representatives, Kuhn, Loeb \& Company, had gained control of the company. England feared that orders already given might not be delivered. ${ }^{4 a}$

Pierre set Kraftmeier straight on this wild version of Coleman's Equitable involvement and reported the matter to his cousins of the Finance Committee. As an assurance to the Allies, it was proposed that the four largest stockowners pool their holdings under an agreement that none of them should sell or should use his stock as collateral unless all four were informed. Alfred further 
proposed that any loans then out against stock owned by the Big Four be taken up by the company. As Alfred, Pierre and William had no loans against their stock, Alfred's motion became a device to try to smoke out Coleman's financial position about which rumors were piling up. It was, indeed, of grave concern to the company. In a tactful letter Pierre relayed the gist of this conference to Coly at Rochester. ${ }^{5}$

One busy day blended into another until the afternoon of February ro when Pierre, Alfred and William held one of their frequent Finance Committee meetings. The regular business attended to, the meeting was about to break up when Alfred casually asked of Pierre:

"How are the negotiations for the Coleman duPont stock progressing?"

"Why, they are all off," was the reply.

"Since when?" demanded Alfred incredulously.

"They were called off shortly after you and Willie [William duPont] turned down the offer in December."

This news nearly floored Alfred. "But the offer was not turned down," he protested. "There was merely a difference of opinion as to price, and it was my understanding that you were to convey to $\mathrm{T}$. C. through Mr. Dunham that we believe the price of $\$ 160$ a share excessive, and we suggested $\$ 125$ as a proper price at that time."

"That was not my understanding," said Pierre. "My understanding was that you turned down T. C.'s offer definitely."

William, an easygoing oldster of 59 with the negligent air of a country squire, was seated across the table from Alfred. Readjusting his hearing apparatus, Alfred asked Willie, as they called him, for his idea of the matter. Willie was a good deal keener man than he looked, and the reverse of long-winded. He said that Alfred's understanding was consistent with his own.

Alfred turned to Pierre again. "There seems to have been some misunderstanding as to the position taken by Willie and myself 
at the meeting in December, and I desire to have this matter cleared up. You have unintentionally misinformed T. C., and I suggest that Willie and I write T. C. setting forth our views."

Pierre said politely that that would be an excellent course. To inform himself as to just what misapprehension Coly was laboring under, Alfred asked Pierre for copies of his letters to Coleman bearing on the matter.

In response, Alfred received a copy of the letter Pierre had written Coleman about the pooling proposal growing out of the Kraftmeier rumor; also Coly's evasive reply. ${ }^{6}$

Alfred dropped Pierre a note explaining that the wrong letters had been sent and asking for the right ones. He did not receive them.

After waiting four days, Alfred wrote Coleman stating that his only objection had been to the price which should be on the basis of a $6 \frac{1}{2}$ per cent yield. For that reason Alfred said he had suggested $125^{7}$

Alfred's computation assumed no increase in the $\$ 8$ dividend. Although his letter did not say specifically that he still clung to the I25 figure, it did not set a higher one, though on the day he wrote traders were bidding 198 for DuPont common, and the asking price was 203. For Coleman to let 20,700 shares go at 125 would mean a sacrifice of $\$ 1,5$ II, I00.

A reply came promptly.

\section{"Dear Alfred:}

"I am in receipt of your letter of February I6th, and have read it several times. I cannot, however, make out why you wrote it.

"To reiterate, the offer I made in December ... a at what I then considered, and now know, was a sacrifice to myself.

"In that proposition, I stated the stock would go to $\$ 200.00$ early in 1915. Having made up my mind that it was wise to get the young men of the company interested, I took the question up with Pierre, who agreed with me that it was a good thing for the younger men .... and, therefore, a good thing for the company. Pierre told me that you too had agreed it was a good thing. That it was a good thing, subsequent events have proven.

"A few days after my operation, Pierre advised me there was 
some misunderstanding in regard to this proposition, and that you were not prepared to accept it. . . .

"I immediately wired Pierre to withdraw the proposition, unless he was, in some way, committed....

"You say, 'The one point on which there seemed to be a difference of opinion was the question of price.'

"If you will have the date of my proposition to the Finance Committee looked up, you will find that the then accepted orders, and the money in our hands, was sufficient to make the stock have a book value beyond the price at which I offered it, and the earnings, by reason of the accepted orders, would make the $61 / 2 \%$ you mention ... look like a drink of water. ...

"You say-'I believe it an excellent time to make an offer of this character to the employees at as low a figure, etc.-'

"To guide me, won't you please advise how much of your common stock you are willing to let go at this time to the important employees, at price suggested by you, $\$ 125$ per share. Probably I can join with you in an offer. ...

"Yours sincerely,

"Coleman DuPont"s

Coleman's letter arrived on February 23. Five days later Alfred opened his Sunday paper at Nemours on the biggest surprise of his life:

\section{GENERAL DU PONT \\ SELLS HIS ENTIRE POWDER HOLDINGS}

His Stock Bought by Pierre

S. DUPONT ANd OTHERS

Active in Company

Half a column of type added few facts not covered in these headlines. Pierre's copurchasers were unnamed. Speaking from Longwood, his country place over the Pennsylvania line, Pierre had declined to identify them, except to say that they were active in the company. This obviously was to allay fears of outside interests hav- 
ing bought in. The price paid was "understood" to be $\$ 20,000,000$. Negotiations had been in progress "several weeks." There would be no change in the company's management. ${ }^{9}$

Questions and speculations whirled through Alfred's mind.

Who could Pierre's associates be? Excluding himself and William, Alfred knew of no possible combination of men "active in the company" who possessed personal assets of anything like \$20,ooo,ooo. What credit, then, had been used without involving outside interests? The company's credit? Even so, outside interests must have played a part. Where else could the money have come from? "No change in the company's management." What of control, which lies back of management? No banker in his right mind would lend one-tenth of $\$ 20,000,000$ on anything as speculative as a powder stock in wartime without the most exacting guarantees. Was the price really $\$ 20,000,000$, or had the figure been inflated for benefit of Coleman's credit in New York?

Negotiations in progress "several weeks." ... So Pierre had been bargaining for himself at the very time when Alfred had supposed him under mandate of the Finance Committee to bargain for the company. Did this explain Pierre's failure to turn over to Alfred the letters dealing with his negotiations with Coleman? Was this part of the deliberate plan, so successfully carried out, to keep Alfred in the dark until Pierre's private bargain was an accomplished fact?

So ran Alfred's troubled meditations.

Had Pierre sent the letters Alfred had requested on February Io, this is what Alfred would have read:

"T. C. duPont, President,

"January 4, I9I5.

"Rochester,

"Minnesota.

"Dear Coleman:

"I have been intending to write you about the reception of your proposition by the Finance Committee. Unfortunately, Alfred, 
who had approved the plan before you went away, got somewhat crosswise in the meeting and I think it wise to let the matter rest for the moment; preferably until I can see you, before taking another step. I am sorry and provoked that the proposition did not go through, for I feel that your offer was a generous one and should have had more considerate treatment; but, like many other things, the result cannot be obtained quickly."

Three paragraphs followed on the booming character of war business. The letter concluded:

"Lou Dunham gives me the good news that you have been up from bed already..... All are interested in hearing from you. I have daily inquiries.

"Your affectionate cousin, "Pierre S. DuPont"10

This letter does not appear to confirm Pierre's assertion that the action of December 23 constituted a "definite turndown." It is more in keeping with the Finance Committee's report to the Board of Directors that Pierre was "to take the matter up with T. C. duPont further." Moreover, Pierre made no mention to Coleman that Alfred's (and also William's) only objection was as to price. Laying aside the provocative criticism of Alfred's behavior, the letter gives an incomplete picture of the stand of Alfred and of William-though only Alfred, already at outs with Coleman, was mentioned.

From his hospital bed, Coleman replied in shaky longhand:

\section{"Dear Pierre: ...}

"I am sorry that Alfred has taken the position that you indicate and too that it has passed the Ist day of Jany, as to have made the announcement [of a stock distribution among the men] at Xmas seems to me would have been much more valuable from the human nature standpoint. ...

"Perhaps it would be well for me to withdraw the proposition; if you think so do it.... I of course know that Alfred has some ulterior motive in mind, as he has tried to do what he could agin me on every opportunity." 
The writer went on to say that now he would have to make other arrangements for money, and expressed the opinion that the war would not last as long as some explosive-makers thought.

$$
\begin{aligned}
& \text { "Love to family. } \\
& \text { "Your aff. Cousin } \\
& \text { "CoLemaN"11 }
\end{aligned}
$$

From this it does not appear that Coleman thought his offer had been definitely turned down. One does not propose to withdraw a rejected offer. Nor did Pierre exercise his authorization from Coleman to withdraw the offer:

"I feel you must be much disappointed in the question of the stock subscription. I used my best judgment in not trying to force the situation. Possibly I could have put it through by insisting, but at the risk of having the other side pitted against me; that would have complicated the whole plan for good and all. As it remains now, I feel that the proposition is open for reconsideration, at your option, of course. Willie is away at present but will be back in a couple of weeks; at which time I will take up the work again, unless I have word from you to the contrary; my judgment is that it will go through."12

Weary of delay, Coleman answered:

"If you think it a good thing for the Co. talk to Willie and do it; if not, don't."13

Pierre still held back. First he must talk to Willie and see if the question of price was all that he and Alfred objected to. This was Pierre's first mention, in his letters, of the price factor. Then, "if not finally accepted," he continued, "would you approve of making an offer direct to the men?" Suitable financing could be arranged, Pierre said, mentioning a point important to Coleman. "I am quite sure they would like to take the stock, but do not feel in a position to say anything while you are negotiating with the Company."14

This letter, especially, seems to fail to support the thesis that Pierre understood Coleman already had been definitely turned 
down by the company. On its way West this missive passed one from Coleman:

"In view of Alfred's position I think it best to withdraw ... [the offer unless] you have talked to Willie or are in any way committed."15

Pierre wrote that he had not talked to Willie and was uncommitted. There would be disappointment over the withdrawal, he added, as some of the important employees were anxious to take the stock. ${ }^{16}$

Thereupon Coleman modified his withdrawal saying the matter could be reopened on his return East "when I am sure we can work out some plan ... that will accomplish what we want. I cannot understand why the other two [Alfred and William] should not ... let the Co. help the men on whom the success must depend." 17

Coleman's original withdrawal came on January I8. On the twenty-third the Finance Committee met. Pierre's later recollection was that he told Alfred about it on that day. Alfred said that he was not informed until February io, as has been related. The documentary evidence favors Alfred's contention as to the date. ${ }^{18}$ And even on February to he was not told of Coly's readiness to reopen.

Alfred's request of February II for the correspondence on the Pierre-Coleman negotiations availing nothing, Alfred wrote his letter to Coleman on the sixteenth. When one understands the ignorance in which Alfred wrote, Coleman's sarcastic rejoinder becomes less obscure.

Add another fact, which Alfred did not know at the time, and it becomes clearer still. When Coly wrote that warm communication, a deal was on to sell all his stock to Pierre. His money troubles thus taken care of, Coleman could afford to be upstage with Alfred.

The Pierre-Coleman deal had begun in this way.

In 1902 the two cousins had each brought into the company a 
sort of man Friday. Through all intervening vicissitudes these understrappers had stuck to their patrons, serving them loyally and confidentially, and being, in return, well rewarded. Though Coly's man, Lew Dunham, had not done quite as well as Pierre's man, John Raskob, now treasurer of the DuPont Company, he had not done badly. On the sixteenth or the seventeenth of February, Dunham dropped off a train with the whispered word to Pierre that Coleman would sell 20,000 to 40,000 shares of common. But not for I6o. Coleman's price was now Wall Street's asking price, $\$ 200$ a share. At the same time a letter arrived from Coleman confirming this.

Pierre showed Coleman's letter to Raskob. The beady-eyed little treasurer was thrilled. The main chance that comes once in a lifetime seemed within his grasp. A hurried meetingseveral meetings-followed. Present were Pierre; his brothers, Irénée and Lammot; his brother-in-law, Robert Ruliph Morgan ("Ruly") Carpenter; Alexis Felix duPont; and Raskob. The bold plan of action that followed is said to have sprung from the fertile mind of Raskob. First was a proposal by wire to buy all Coly's holdings, common and preferred. That would be about a \$14,000,000 deal-exceeding the combined assets of the six men.

Raskob reminded his colleagues that J. P. Morgan \& Company were in the moneylending business. In the firm's name Raskob was doing business, big business, every day with Morgan, the Allies' fiscal agents in America. Only the day before (possibly it was the same day the main chance came his way, for participants are hazy as to whether their talks were on February I6 or I7), Mr. Raskob had recommended to the Finance Committee that "as a matter of diplomacy ... very substantial balances" be maintained with Morgan. To the would-be purchasers Raskob proposed that he see Morgan about the required \$14,000,000. Meantime a telegram came from Coleman agreeing to sell everything. So far so good. On the morning of the eighteenth Raskob caught a train to New York.

That evening in Philadelphia he reported to Pierre. Ten millions were sure and Raskob was hopeful of the rest. ${ }^{19}$ 
This hope was speedily justified. A date was made for Pierre to run up to New York on February 23 and seal the bargain.

Meanwhile the six bargainers were collaborating on telegrams to Coleman, which Pierre signed. Yet, on the morning of Washington's birthday, no acceptance had come from the West. Pierre was to see the bankers on the morrow. At 8:55 A.M. he jogged his cousin with a wire. Coly filed his answer at $1 \mathrm{r}: 57$ :

\section{"Proposition accepted for entire holdings. ..."}

The stock was theirs: 63,214 common shares at 200 and 13,989 preferred at 85 , making a purchase price of $\$ 13,831,865$. Coleman had agreed to accept $\$ 8,000,000$ cash and the purchasers' sevenyear 6 per cent notes for $\$ 5,831,865$.

This arrangement reduced the amount needed from Morgan to $\$ 8,500,000$ - the extra half-million being for commissions and organization expenses.

Pierre went to New York and closed the deal. The six purchasers were to incorporate as the DuPont Securities Company. The $\$ 8,500,000$ loan was at 6 per cent for eighteen months. As collateral 54,59r shares of DuPont common and 14,000 shares of preferred were posted. Coleman's $\$ 5,800$,ooo note was secured by 36,900 shares of common. This collateral added up to $9 \mathrm{r}, 49 \mathrm{r}$ common shares, absorbing all the Coleman purchase and 28,177 besides, which Pierre and the others arranged to contribute from their private portfolios. Raskob's New York spadework had been well done. Only one banker asked Pierre about the financial responsibility of the purchasers. He was Seward Prosser, president of the Bankers Trust Company, whose inquiry appears to have been perfunctory. Mr. Prosser's later recollection was that Mr. duPont had given the purchasers' aggregate worth at $\$ 10,000,000$. Pierre thought he had said $\$ 11,000,000$.

A few days later Pierre duPont diminished his personal stake in the new acquisition by $\$ 1,000,000$ which he gave away. To add to their original holdings Irénée, Lammot and John Raskob each received certificates for 1250 shares of DuPont Securities stock. These gifts were worth $\$ 125,000$ apiece. Then Pierre called into 
his office Harry F. Brown, in charge of smokeless-powder manufacture; Henry G. Haskell, in charge of high-explosive manufacture; William Coyne, in charge of non-military sales. Their rewards also were $\$ 125,000$ slices, in return for promises to stay with the company a year. These three men were on the Board of $\mathrm{Di}$ rectors. Their acceptance of the Securities stock raised the number of directors in on the secret deal to eight out of twenty. Twelve hundred and fifty shares apiece also went to W. G. Ramsay and F. G. Tallman, heads, respectively, of the engineering and the purchase departments.

Word came that news of the purchase was about to leak in New York. Though he would have preferred secrecy a little longer, Pierre gave out the story from Wilmington rather than run the risk of an unauthorized "break." This was the origin of the newspaper item which shocked Alfred almost out of his shoes on Sunday morning, February $28 .^{20}$

Several other DuPonts were shocked as well. Francis I., the family's man of science, began telephoning and sending telegrams to kinsmen. He sustained another shock on learning that his brother, Felix, was one of Pierre's partners. When Felix launched into a defense of his position, Francis interrupted with a warning against revealing confidences of the syndicate. Felix said the secrecy had been largely on account of Alfred. He showed Francis a paper giving the members of the original syndicate and the extent of their participation: Pierre, 50 per cent; Irénée and Lammot, I6 each; Felix, 8; Ruly Carpenter and Raskob, 5 each.

At his winter home in secluded rural Georgia, William duPont got no Sunday newspaper until noon on Monday. Unable to reach Pierre by telephone, he drove eighteen miles to Brunswick and sent this telegram:

"Paper states you have purchased Coleman's stock. I presume. for the company. Any other action I should consider a breach of faith."21 
Alfred spent Monday at his desk, grimly awaiting word from Pierre. When none had come by four in the afternoon, he telephoned Pierre, who walked down to Alfred's office.

"Pierre duPont," Alfred implored. "Don't do this thing! . . . It is wrong!"

Pierre asked why it was wrong.

"Because you have accomplished something by virtue of the power and influence vested in you as an officer of the company.... For that reason the stock which you have acquired does not belong to you but to the company which you represent. I therefore ask you to turn this stock over to the company."

Pierre said that he was very sorry to disagree with his cousin's point of view. He had not, he said, "used the company's credit in any way."

"Pierre," resumed Alfred, "your father and my father were brothers. Neither of those men would have approved, I am confident, of what you have done. For their sake, as well as for your own, put that stock in the company's treasury. You can't afford to ... injure your business reputation. Pierre, I ask you."

Pierre said that the thing was done and could not be undone.

"Then you refuse to make this concession I ask ?"

"I do," replied Pierre duPont. ${ }^{22}$

The next two days witnessed gatherings of members of the clan who shared the views of Alfred-or went even further. Francis I. asked the largest stockholders outside the syndicate to meet at Alfred's office on the evening of March 4. The purpose was to determine, if possible, a course of action. By eight o'clock Alfred, William, Eugene E., Philip F., and Alexis I. duPont were on hand.

Then the door opened and in walked Pierre and his brother Irénée. Smiling pleasantly into the astonished faces of his five cousins, Pierre politely said, "Good evening," and asked Alfred's permission to sit down. Persons who have known Pierre duPont for thirty years have never witnessed a lapse of his meticulous courtesy. If coming to a gathering to which he had been uninvited can be construed as a lapse, Pierre tried to make amends at once. He began an amiable flow of family small talk, an inexhaustible 
conversational recourse when as many as two DuPonts get together.

Presently Francis I. came with Harry F. duPont in tow. Harry held the heavy block of shares and the director's seat which had belonged to his father before the old Colonel went to the Senate.

As composed as any individual in the room, Pierre chatted on, resolved not to be the first to bring up the question of the hour. Alfred disconnected his desk hearing box and stared at the ceiling.

Pierre's cousins outwaited him. The hands of the clock were pointing toward nine when the uninvited caller changed the subject.

As all present were aware, he said, a transaction had been completed to which certain exceptions had been taken. Cousin Willie had made an allegation of bad faith. Pierre asked Willie to explain himself.

With his usual economy of words, Willie replied that the purchase would have been impossible without use of the company's credit. Knowing Coleman willing to sell, Pierre's failure to give the company the first chance to buy constituted an act of bad faith.

Alfred seconded these remarks.

Francis I. spoke up. The DuPont Securities Company, an instrument of debtor individuals, now controlled so much of the Powder Company's stock that it controlled the power to invest the Powder Company's money. Power over the Powder Company's treasury was the real collateral back of the Securities Company's notes.

Pierre warmly replied that he had used the company's credit in no way. The transaction was a personal one purely. He "resented" the "accusations" expressed.

Alfred asked if Pierre would sell the stock to the company.

Pierre said he would not, and requested that if his cousins had other "charges" in mind to make them to his face. Nothing was said and, with a faint touch of drama, Pierre warned his cousins against uttering behind his back anything they had declined to say in his presence. Then he and Irénée withdrew. ${ }^{23}$

After sleeping on the matter, Pierre thought better of his bald refusal to sell. He drafted a letter to the directors offering to 

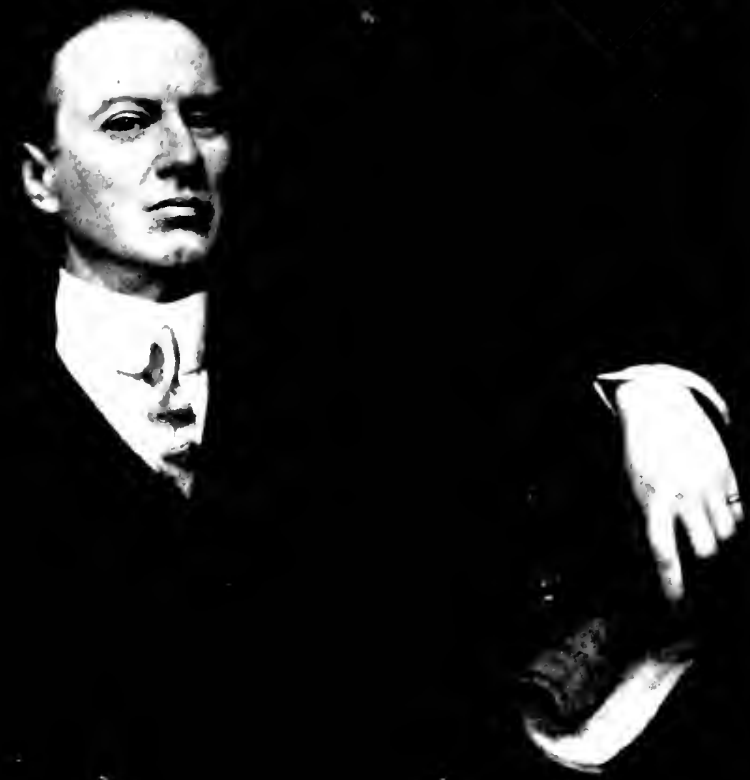

a.7.
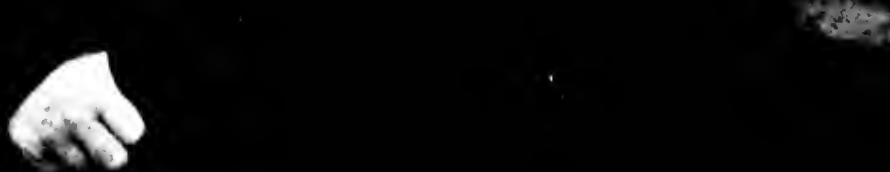

A Portrait, 1913

This likeness, exccuted by Gabricl Ferricre, was awarded a prize at an art exhibit in I'aris, and has been honored by a place in the Great Hall of the mansion house at Nemours. It would have recived no prize from the hands of some of Mr. duPont's old-time fric nds on the Brandywine. "Mr. Alfred," said Tom Montgomery", powder-mill stonemason, "you coulden't look thit mean if you trick." 

"consider" a proposition to let the company have the stock at cost to him, plus $\$ 250,000$ to cover expenses. The letter repeated the denial of having used the company's credit, or of any breach of faith or of ethics. John P. Laffey, the corporation's general counsel, looking over the communication before Pierre sent it out, said he believed the company could not legally purchase the stock. He thought such a purchase could only be made from surplus, which (owing to expenditures for plant extension) at the moment was down to $\$ 6,000,000$. Pierre told Laffey to look up the law on that. Then he sent out the letter for quick delivery as the Board was to meet next day. ${ }^{24}$

Of eighteen members who attended, nine held stock in the DuPont Securities Company. From the chair, Pierre asked that the issue of bad faith be cleared up. Willie started the kettle bubbling by saying he had made the accusation and that he stuck to it. Francis I. injected the question of financing:

"I believe Morgan \& Company loaned the money with a full expectation that in case those notes were not paid they could force payment from the company's treasury."

"There is no question as to that," agreed Alfred.

After Irénée had spoken in his brother's defense, John Raskob broke in with this remarkable statement:

"I do not understand on what Mr. William duPont bases his opinion that this loan could not be placed without the prestige of the Powder Company back of it. It happens that Mr. P. S. duPont never saw nor was he in communication with any of our bankers in any way until this deal was closed. I saw the bankers. They told me if the Powder Company could handle this, they could get the money for 4 per cent. We had to pay 6."

Pierre's choler was rising. Without pausing to correct the assertion that he had seen no bankers until all was settled, the chairman called for a showdown:

"I consider it intolerable to be in a position where an official has not the confidence of the Board. If not ... [ [here apparently the stenographer missed a few words] I do not care to remain with the company." 
The effect was somewhat electrical. First to speak was the veteran Bill Coyne, recent object of Pierre's generosity to the tune of $\$ 125,000$ :

"I move that this Board give a vote of confidence to Vice-President P. S. duPont and Treasurer J. J. Raskob."

Francis I. and Frank Connable, an old-time black-powderman whom Alfred had brought into the company, chorused objections on the ground that confidence had not been questioned. To this Alfred also subscribed, with an amplifying clause: “. . . except by Mr. Raskob and Mr. P. S. duPont; nobody else."

Irénée insisted on Coyne's motion. After much wrangling, during which Alfred left the room in disgust, it was carried unanimously, Alfred and Francis I. not voting.

Alfred was back a minute later when Pierre's guarded offer to sell the Coleman stock came up. Lawyer Laffey also entered the room with a marked lawbook under his arm. Pierre asked Laffey for his opinion concerning the legality of such a sale. The attorney opened his book and read a passage. He said that this meant that the company could buy the stock only from surplus, which was insufficient.

The matter was sidetracked to the Finance Committee with instructions to report to the directors four days later.

After all the nerveracking hubbub, what in ordinary times would have been the feature of any directors' meeting came as stale anticlimax. The resignation of $\mathrm{T}$. Coleman duPont as president of the company, chairman of the Finance Committee and a director, was accepted. "Mr. P. S. duPont was nominated for the presidency," read the minutes. They do not say who nominated him. They do say, however, that "at this point Mr. P. S. duPont left the meeting."

This amenity was without bearing on the result. Pierre received the vote of every director present. Then he was appointed chairman of the Finance Committee, after which the absent one returned and "thanked the board for the honor conferred upon him.",25

So it was that Pierre S. duPont attained, in name as well as fact, the goal which is the ultimate of nearly every businessman's 
ambition: to head his company. On the record of his long regency over the firm's affairs, he deserved the distinction. Yet, when his hour had come, it was not possible to leave out of the reckoning the effect of this stock deal on the emotions and judgment of those present. Viewed in the light of the imperfect knowledge of its critics, the transaction had established a precedent for business dealing in the history of the DuPont family. It was not so much that control had been taken from one branch and lodged with another. Alfred, himself, had done that in 1902; and hard feelings had resulted. But Alfred had worked in the open; Pierre in the dark. Thus was something wanting from the élan of the little ceremony attending the coronation of the seventh of the DuPont name to head the firm over an unbroken span of II 3 years.

Before the meeting adjourned, Irénée was put on the Finance Committee and Francis I.'s brother, Felix, became a director, making the tenth man on the Board with a financial interest in the questioned purchase.

At the Finance Committee meeting of March 8, 1915, it devel. oped that Alfred and William took no stock in Laffey's legal opinion. They voted to recommend that the Board of Directors buy the Securities Company's holdings at cost plus $\$ 250,000$. Irénée voted nay. Pierre did not vote. It was unnecessary. Irénée's vote had killed the motion, which, to pass, required the support of a majority present.

On this same day, or on the day before or the day after, Pierre gave Lawyer Laffey a $\$ 50,000$ interest in the DuPont Securities Company. ${ }^{26}$

March Io the Board met to consider the Finance Committee's action. Alfred renewed his appeal for a purchase, not because he would be pleased to see the company invest $\$$ I $4,000,000$ in its stock at the price in question, but because "I do not think the company has any alternative. I advocate the selection of the lesser evil.... From my point of view the investment already has been made by the DuPont Company." He meant that the company's credit rather than the private credit of the syndicate members was behind the loans. He thought the situation should be regularized by the company taking title to the stock. 
William said he looked at the matter the same way.

Frank Connable said he thought the purchase would be a boon to the company.

After some discussion Alfred sought to clear the air with a proposal.

"We have a situation here which I think is improper to a certain extent.... We have two organizations whose interests are diametrically opposed. Six of our board constitutes one interest [the number was ten, though no one knowing the facts spoke up] and I do not think it fair to them to place them in a position of expressing their opinion. Now I think and know we are all anxious to do exactly what is right ... what is best for the company. There is no question about that in my mind."

With every director concerned, one way or another, Alfred went on to say that they should seek guidance which would be uninfluenced by self-interest. He suggested that the Board put the stock question up to a body of economic and legal experts, "not in any way associated with this company. Surely that is a fair and proper step to take. I would like to offer a resolution."

The resolution was that the outside advisers be selected by the president of the company in conjunction with the Finance Committee.

Enthusiastically Francis I. seconded this enlightened proposal. Irénée opened the cold-water faucet:

"I do not see why we should delegate our duties to others or seek advice in a matter we know more about than others."

Pierre cautioned the Board to keep in mind what Mr. Laffey had said about the law.

Alfred said that point would be covered by the outside advisers. Irénée said such a body would waste a lot of the company's time. Alfred's motion was lost, I4 to 4-William, Francis I., Connable and the mover voting for it.

Raskob moved that the company make an offer to buy the stock at cost plus expenses.

This was lost, I4 to 3-the supporters being Alfred, William and Francis. Connable did not vote. Raskob voted against his own motion. 
The last action of the Board was to elect Lawyer J. P. Laffey a director, raising to eleven the members who were partners in the syndicate. $^{27}$

\section{7}

Though he had lost every round, and by no close margin, Alfred was unconvinced that Pierre and his associates had a righta legal right-to acquire that stock in the manner they had acquired it - that is, in so far as Alfred knew what the manner was.

Francis I. also was unconvinced.

On April I7 Francis received a letter from Pierre setting forth the prosperous state of the DuPont Securities Company. In seven weeks' time DuPont common bought for 200 had leaped to 300 in the open market; the preferred bought for 85 had gone to 90 . Everything the Securities Company owed to Coleman and to the banks could be paid, with $\$ 14,826,994 \cdot 39$ to spare. Seemingly incredible; but true. This gave Securities Company shares an actual value of $\$ 198.20$ each.

"Now that this whole transaction is definitely closed," wrote Cousin Pierre, "I offer you an opportunity to become a stockholder of DuPont Securities Company."

The offer was not a gift, as in the case of Laffey and three other directors. But it was liberal. If Francis would surrender 222.75 shares of DuPont stock, worth $\$ 66,825$, Pierre would issue him in exchange 500 Securities shares worth $\$ 99$, roo. ${ }^{28}$

The scientist soon learned that he was not the only object of Pierre's magnanimity. Similar offers had come to Francis' brothers, Ernest, Archibald and Paul; also his cousins, Philip, Eugene, Harry and Alexis; also his cousins by marriage, the husbands of Pierre's sisters, Charles Copeland, William Winder Laird and Hugh Rodney Sharp.

After thinking over the matter for two weeks, Francis called on Pierre. His recollection of that conversation differs from Pierre's. Francis thinks he said that to accept the offer would have been "against my convictions," and that somewhere in their talk Pierre protested that the offer was not intended as a bribe. Pierre's 
memory of the incident is that Francis declined to take the stock on account of his friendship for Alfred. ${ }^{29}$

However that may have been, five other DuPonts also refused Pierre's offer. The three in-laws and two DuPonts accepted. Accepting DuPonts were Eugene and Harry, both directors. This gave the Securities Company thirteen memberships on the Board. 


\section{CHAPTER XVII}

\section{The Case of DuPont Versus DuPont}

UNDERGROUND reverberations persisted over the coup which Pierre duPont called a transaction "definitely closed." Brothers joined opposite camps. Of the sons of the late Frank duPont, Alfred's old powder-yard boss, four had refused Pierre's offer to take Securities Company stock while a fifth, Felix, was one of the secret six who had engineered the purchase of Coleman's holdings. Eugene E. and Philip Francis were sons of the widowed Mrs. Alexis I. duPont, one of the defendants in Alfred's famous slander suits which did not come to trial. Eugene had accepted Pierre's offer of Securities stock while Philip stood with Alfred.

At Board meetings Eugene's vote counted for as much as any other director's, though Eugene knew more about trapshooting and sailing than he did about the affairs of the company. As for Philip, it was hard to say what he knew. "Fireman Phil" they had called him as a young man because of an inordinate passion for running to fires. Yes, Phil was thought an odd one. He lacked the DuPont nose, for one thing, and, in fact, looked a little like Robert Burns. He wrote poetry, which neither he nor anyone claimed to resemble that of Burns. At 37 , he lived the life of an unsocial recluse with his wife and two daughters at Merion, Pennsylvania. It was said that he dabbled in stocks-how successfully the family was astounded to learn thirteen years later when Phil died worth $\$ 20,000,000$.

Phil was just up from an attack of typhoid when the news of Pierre's deal broke. After letting the family know how he felt about it, Phil went to the shore to recuperate and did not return 
until late August. DuPont common, selling at 300 when he left, was then $\$ 700$ a share. Dividends paid so far during the year were $\$ 22$ a share, against $\$ 8$ for the whole year of i914. And still better things were in store. In September, 1915, Pierre changed the corporate setup, organizing a $\$ 240,000,000$ corporation called E. I. duPont de Nemours \& Company, which exchanged two shares of its stock for every share in the old E. I. duPont de Nemours Powder Company. This two-for-one split brought the price of new company common down to 393 , but in two weeks it was $45^{\circ}$ or the equivalent of $\$ 900$ for a share of old-company stock. A $\$ 30$ dividend on the new shares sent $\$ 60$ to each holder of an old share, or a total of $\$ 82$ per old share for the year.

The stock which Pierre and associates had bought from Coleman for $\$ 14,000,000$, having quadrupled in value, added just that much to the stake for which Alfred contended when he held that these securities should be turned over to the company. This stimulated the zeal of Alfred, who the more he pried into the details of that transaction, the less he liked it. As a director he voted against the $\$ 30$ dividend on the ground that the money was needed in the company treasury to buy the Coleman stock from the syndicate.

During the summer Alfred and Francis I. consulted lawyersWilliam A. Glasgow, Jr., and John G. Johnson, of Philadelphia. As an assistant attorney general, in I9I2 Glasgow had attended the memorable White House interview at which Alfred duPont opened the road to a convenient settlement of the Sherman Law case. John G. Johnson, Nestor of American corporation lawyers, had started life as a blacksmith's apprentice. At 74, his gigantic, carelessly-attired form, topped by a thatch of shaggy white hair, would have commanded a second glance anywhere. In the courts of the land it had commanded more than that. Johnson had argued the corporation side of the Northern Securities case; of the Standard Oil case; of the American Tobacco case. His presentations had evoked from the United States Supreme Court the "ruleof-reason" decisions which had so broken the effectiveness of the Sherman Law. Twice had John G. Johnson declined appointments to that bench. He had declined the post of Attorney General of the United States. Now virtually retired from courtroom 
practice, he devoted much time to his art collection, one of the finest in private hands in the country.

When Philip duPont returned from the shore he, too, saw the lawyers. John G. Johnson said he would take the case in the hope of establishing a precedent for the better protection of the interests of minority stockholders. This was a new line for Johnson, who had spent a lifetime defending the majority interests of corporations. At their first meeting Alfred duPont had expressed to Johnson some hesitation about taking legal action, saying he did not wish to act from motives of family prejudice. The old lawyer replied that, as a matter of principle, Alfred had no choice but to support the fight in which Philip eventually decided to take the nominal lead. ${ }^{1}$

In December, 1915, Philip filed a suit against Pierre S. duPont and his associates in the Securities Company who were DuPont Company directors, namely Irénée, Lammot, Felix, Harry F. and Eugene E. duPont; John J. Raskob, R. R. M. Carpenter, William Coyne, H. G. Haskell, H. F. Brown, and J. P. Laffey. A little later Alfred, Paul, Archibald, Ernest and Francis I. duPont, Eleanor duPont Perot and three small stockholders who were not DuPonts joined Philip in the action. Mrs. Perot was a sister of Francis, Paul, Archie and Ernest.

The bill of complaint accused Pierre duPont and colleagues of defrauding the company. When "charged with the duty of acting for the Company on the question of the purchase of said stock" from Coleman duPont, P. S. duPont had acted for himself, "in violation of his trust as an officer, director and confidential representative of the E. I. duPont de Nemours Powder Company." So the bill. The offer of Pierre to sell the stock to the company at cost plus expenses was called insincere. Having made a majority of the directors his partners, he was able to influence them to reject the offer. By these means, continued the bill, the defendant directors "neglected to perform the duties incumbent upon them, and in pursuance of the aforesaid scheme to defraud the E. I. duPont de Nemours Powder Company, fraudulently, and in breach of their duties, . . . secured themselves . . . the aforesaid stock." 
The bill further charged that Pierre duPont and his associates were without "either credit or marketable collateral" to borrow the money they had borrowed without looking to DuPont Company dividends for the wherewithal for repayment. Against the best interests of the company, it was charged that they had voted the $\$ 30$ dividend to further this scheme.

The court was asked to declare it the duty of the syndicate members to transfer the stock to the company on payment of the cost to them, expenses added; further, that the matter of the company's acceptance of the stock be referred to the directors, directors who were members of the syndicate to be enjoined from voting; and also that the same issue be submitted to the stockholders, syndicate members to be enjoined from voting syndicate stock. ${ }^{2}$

War contracts and the spectacular rise of its securities had won a conspicuous place in the news for the DuPont Company. Pierre's acquisition of control had been extolled as a masterful stroke. Now Alfred had his inning. The editors made a gala day of Philip's suit. Never had a DuPont family ruckus achieved such a wide press.

Pierre struck back quickly. On January Io, I9ı6, his Board of Directors, by a vote of 13 to I, deposed Alfred as vice-president and as a member of the Finance Committee. Francis I. cast the negative vote. Alexis I. did not vote, saying the directors had been given too short a time to make up their minds. William, Alfred and Connable were absent. ${ }^{3}$

On March I3 was severed Alfred's last official link with the company he had once saved from extinction as a DuPont property, and which he had served longer and with as little self-interest as any DuPont who was then living. The dismissal was made thus complete by striking Alfred's name from the list of directors up for re-election. William and Francis I. also were dropped. Two of their three successors-Ramsey and Tallman-were members of the syndicate via the gift route. Pierre and partners now numbered fifteen of twenty-one directors. They controlled the Finance Com- 
mittee (enlarged at this meeting), four of five; and the Executive Committee, eight of nine.

After this house cleaning came the annual meeting of stockholders. About sixty persons were present, representing 50,09I shares. P. S. duPont, Alexis I. duPont and J. J. Raskob held proxies for 364,514 more. Though Alfred's partisans stayed away, they sent a lawyer who could cast 3,62I votes. A long resolution, rumbling with whereases, was introduced, applauding the business acumen of the management's refusal to deplete the company treasury to purchase the old Coleman stock. Alfred's lawyer challenged the vote in advance, which turned out to be 410,984 for the resolution and 3,62 I against. ${ }^{4}$

The whole show was for the record. Pierre exhibited it as a ringing vindication of everything he had done; Alfred as a whitewashing travesty.

Though he bore these developments with something of his oldtime savoir faire, Alfred's dismissal cut him to the quick. At Nemours one night he said to his family physician, Doctor Charles M. Hanby:

"I don't like to acknowledge it, Doc, but this is the most humiliating thing I've ever had happen to me."

Alfred moved his office from the DuPont Building to the Odd Fellows Building at Ninth and King. Release from company duties gave him time to spend with the lawyers working up the case of DuPont versus DuPont.

"I am very busy in the trail of evil doers," he wrote a friend, "and hope with the aid of Providence to bring them to the bar of justice." 6

But before anyone reached the bar of justice Alfred's pursuit took a novel turn.

Coleman duPont had resumed construction on his Delaware road, at which political observers peeled their eyes. They had not long to wait. A fugitive news item seeped out of Washington to the effect that friends of General T. Coleman duPont were 
"quietly" mentioning him for the Republican Presidential nomination. Next day reporters found the General at his quarters in his new Equitable Building, I2o Broadway, New York. He professed surprise. No, he was not seeking the place. He had no political ambitions. Yet, come to think of it, "I have received thousands of letters from small businessmen and farmers asking that I permit my name to be used." Then Coly launched into a lecture on good roads and what they would mean to farmers and small businessmen.

Two weeks later the Business Men's Presidential League opened with lavish quarters at the Waldorf-Astoria Hotel, Ormsby McHarg in charge. Page advertisements in newspapers from coast to coast announced the formation of branches of the League. Ormsby McHarg, a high-class political organizer who had served Roosevelt and Taft, met the press at the Waldorf. Several great businessmen were available, he said, and head and shoulders above them all stood Coleman duPont. Mr. McHarg grew rhapsodic over the General's career, which he said had begun as a coal miner in Kentucky.

Delaware politicians scratched their heads: "What is Coly's game? Why is he spreading around all that money?" Not for an instant did they think him sufficiently deluded to believe he could get the Presidential nomination. But he could get a certain amount of political build-up, which might be turned to use in the coming campaign in Delaware. Senator Henry Algernon duPont's term was expiring. He was 78 years old. Should ill-health keep him from running again, who would be a more fitting successor than General Coleman? Even should the Senator run and be re-elected he might find himself too far along in years to serve. If he resigned, the Governor would have to appoint a successor. That was another way Coleman might cash in on the strength of his Presidential boom.

So speculated Delaware politicians, in particular one James Frank Allee. In the early Nineties "Gas" Addicks had taken Allee from his jewelry store in Dover and made him a politician. It proved a more profitable line than jewvelry. For ten years Allee stuck to Addicks. In I903 a wing of the Republicans, deserting Addicks, threw its strength to Allee and sent him to the United States Senate, bringing about a rupture between Addicks and his 
lieutenant. In 1906 Allee joined Coleman duPont behind Colonel Henry A. in the campaign which finally routed Addicks and placed the Colonel in the Senate. The understanding was that the Colonel's machine would support Allee for re-election the following year. But when the time rolled around, the Colonel's crowd, Coleman in charge, virtually discovered that Allee had been "too close to Addicks." They backed another man and beat Allee.

Since then J. Frank Allee had been a politician on the outs, sometimes working with the machine, sometimes with the hopeless little band of independent Republicans. In Igr6 he was with the independents, whose cause did not seem quite so hopeless. Public feeling against the arrogance of the machine was rising and a good many Delawareans wanted something more than a rubber stamp for the moneyed interests as their Senator. The time was ripe for revolution when Frank Allee called on Alfred I. duPont. ${ }^{8}$

Alfred, too, was ripe for revolution. On top of this, he possessed definite assets desirable from the point of view of Allee or any other independent: public spirit, courage, and a clean, if little known, record on prevailing issues. Moreover, he was engaged at the moment in a struggle with the DuPont interests which had always been behind the Colonel's machine. Add to this the fact that Alfred was rich and a free-spender-important items in any battle with the machine-and that he owned a newspaper in Wilmington, something the independents had always been without.

Alfred had quietly bought the Morning News for $\$$ IIr,000 in December, I9I. For years the purchase had remained much more of a secret than such purchases ordinarily do. Usually when a man surreptitiously buys a paper, he has an ax to grind. The grinding gives away his secret. When Alfred bought the News he ground no ax. Not a dollar did he put into the operation of the property, the most down-at-the-heels sheet in Wilmington. Men who worked on the paper wondered why he had bought it. Their guess was that he was preparing for some flare-up of the Alicia row, the slandersuit incident then being a vivid memory.

The guessers were merely warm in their surmises. Though the 
shares were transferred to Alfred's name, the actual purchaser of the News was Alicia duPont, who had heard that her bête noir, Coleman, entertained designs on a United States senatorship. I. M. Williamson did the actual work of rounding up the News shares, paying fancy figures for some of them, the overall price of \$I I , 000 being much more than a sensible newspaper publisher would have paid. During this work, Williamson had reported to Mrs. duPont, not to her husband, who simply paid the bills.

Alicia's intuition concerning Coleman's statesmanlike aspirations had been correct, though premature by a few years. Consequently the newspaper jogged along, no apparent effort being made to improve its condition as the sorriest specimen of journalism in Wilmington. Thus, in a way, Mr. duPont was more fortunate than most non-professional newspaper owners, being out-of-pocket nothing but the purchase price for his adventure in journalism. The News had a tightfisted business manager who squeezed every nickel, and an editor, Roy Jones, who belonged to a journalistic era that is gone. Money meant little to Jones, who loved his calling better than anything else on earth. He gathered about him a small, underpaid staff of reporters who loved him and who worked their heads off-for Roy Jones. ${ }^{9}$

When news of Pierre duPont's purchase of the Coleman stock burst upon the world, Alfred found his first real use for his paper. The News vigorously presented Alfred's view of that deal, being the only Wilmington paper to do so.

Frank Allee was brought to Nemours by Alicia's brother, Edward Bradford. Allee was a round little man with shrewd, merry eyes which beamed through pince-nez glasses. His handshake was hearty, his manner unctious and persuasive. He had known Mr. duPont more than casually for some years.

When the politician mentioned that a golden opportunity existed to put the Colonel out of the Senate and to overthrow Coleman at one stroke, Alfred was surprised and interested. The first blow, smoothly continued Allee, should be struck at the State Republican Convention, which would convene at Dover a fortnight hence. Delegates were to be selected to attend the National Convention at Chicago in June. Not even Colonel Henry's closest advisers enter- 
tained a doubt in the world but that the selection of their man by the rural New Castle County caucus would be a foregone conclusion. Coleman, busy with his Presidential fanfare, suspected nothing.

"But, my word for it," said Allee, "I have twenty of the thirtyfive delegates from rural New Castle ready to bolt the machineprovided they get the right man to run against the Colonel. This is the result of months of very careful work."

Alfred asked whom the delegates would regard as the right man, adding that he hoped that he, too, would be able to support him.

"Alfred I. duPont," said Allee.

Mr. duPont threw up his hands. He protested that the name DuPont was a stench to the nostrils in the politics of the State. Alfred would assist any decent effort to retire the Colonel to private life but would take no office himself.

Allee said the people of Delaware were able to distinguish among DuPonts. He insisted that Alfred was the man the New Castle insurgents wanted.

Bradford seconded this.

Then Alicia, who had joined the group, spoke up, and her speech carried the day for Allee. Alfred consented to permit his name to go before the county caucus for national delegate in opposition to the Colonel. ${ }^{10}$

On the night of April 9, 1916, the rumor ran around the lobby and the smoke-fogged rooms of the Richardson Hotel in Dover that the independents had something up their sleeves to spring on the convention which met on the morrow. None but the naive took stock in this. Similar reports had blossomed annually for years-yet the machine remained as firmly entrenched as ever. As a matter of routine George T. Maxwell, Dover correspondent for Mr. duPont's Wilmington News, asked Frank Allee about the rumor. Allee said to drop in on the rural New Castle caucus in the morning before the convention opened and Maxwell would get a good story. The newspaperman had heard that tale before. $\mathrm{He}$ was not impressed.

This time Allee made good. In an uproarious session the caucus voted 20 for Alfred I. duPont, 15 for Henry A. duPont, to be the county's delegate to the National Convention. 
The organization was stunned. So sure of his usual victory had been the old Colonel that he had not troubled to go to Dover. But Coleman was down from New York to see that the Delaware delegation to Chicago carried instructions to vote for him for President. The first reaction of the old guard was to take Colonel Henry's fight to the floor in an effort to upset the caucus decision. Allee countered with a mixture of threat and horse trading. Heartened by the New Castle victory, members of the other delegations who had felt the whip of the machine threatened a fight on Coleman's ambitions unless Alfred's election stood. It was not challenged. This stratagem committed Allee to the tacit support of Coleman's aspirations. A resolution was placed in his hands, declaring the Delaware delegation "instructed" to vote for T. Coleman duPont. The situation gave J. Frank Allee a few bad moments.

"Alfred I. will never vote for Coleman duPont," he wailed. "If they adopt that resolution he will refuse to go to Chicago."

With a pencil Allee hurriedly substituted the words "do hereby endorse" for "instruct." This rendered the text of the resolution vague. It endorsed Coleman's candidacy but did not direct the delegates to vote for him.

The altered resolution was rushed through before Coleman's crowd caught the significance of the change.

The dethroning of Henry A. duPont made a national political story. It encouraged revolts against boss rule in many states. Ridiculing Coleman's Presidential ambitions, the Wilmington News editorially declared the convention resolution too ambiguous to be binding on the delegates. In the first public utterance of his newly born public career, Alfred I. duPont promised to vote at Chicago for "the man who will bring honor and dignity to this country." 11 A little later, in opposition to the Republican national machine, he came out for Theodore Roosevelt.

The legal skirmishing preliminary to trial was under way in the lawsuit of DuPont versus DuPont. Another occupation for Alfred was the care of his income, which for I915 had amounted to $\$ 3,050$,o89 from dividends on company stock alone. After that the rate 

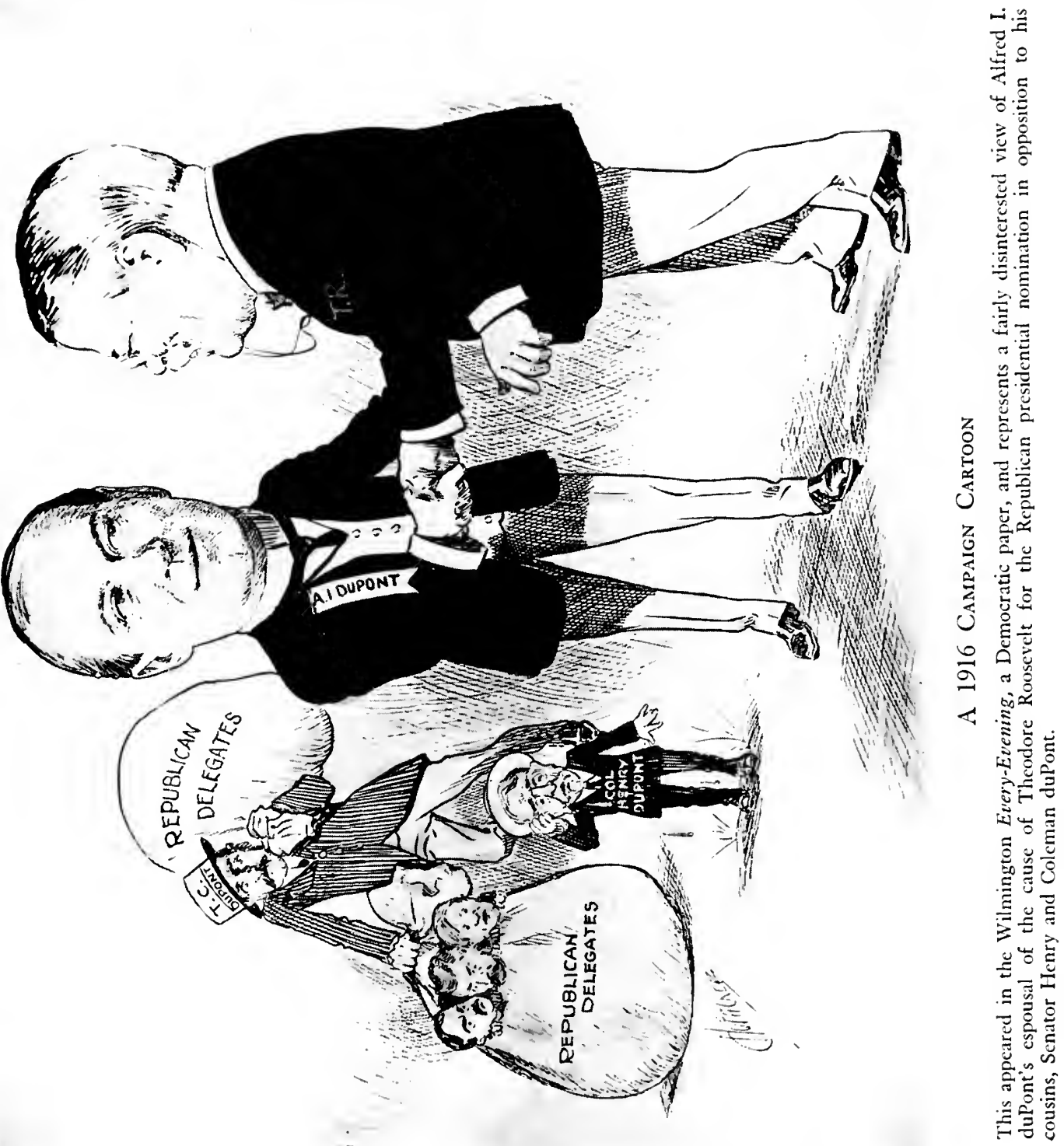
had doubled. During the first half of 1916 , Alfred was paid $\$ 3,848$,617.90 - of which $\$ 963,219.10$ was in cash and $\$ 2,885,398.80$ in Anglo-French bonds.

For many years Mr. duPont had kept a checking account in New York through which he made disbursements he did not care for Wilmington bank tellers to know about. Nearly all his charity checks cleared through that account. His local account was with the Wilmington Trust Company, which the DuPont Company controlled. Now Alfred and William duPont bought a bank of their own, the Delaware Trust Company. To Alfred one of the most pleasant features of this transaction was when Brandywine powdermen began transferring their savings.

Alfred's income also proved handy in connection with his political venture. A righteous cause is undeniably an asset, but in Delaware it stood a better chance with a backer able to match the campaign outlays of Colonel Henry's lavishly endowed organization. The immediate expenses were considerable. Without formally acknowledging ownership, Alfred pumped some money into the Morning News. He either bought or subsidized six papers downstate: the Harrington Journal, the Seaford News, the Dover Sentinel, the Laurel Leader, the Newark Ledger, the Middleton Chronicle. These organs began to parry the thrusts of Colonel Henry's Wilmington Evening Journal and three or four country presses which he owned. Alfred gave the Dover Sentinel to Allee's son and invested several thousand dollars in a sickly gas enterprise of the former Senator's. There were, of course, the multitudinous expenses of State, county and precinct headquarters and their retinues. Edward Bradford, Jr., attended to these. A stream of Alfred's checks flowed to Eddie's office. He would cash them and pass out currency. Politicians sometimes get writer's cramp when asked to endorse a check.

The Delaware habit of reading Philadelphia papers for the truth about what went on in their State where DuPonts were involved was not overlooked by those who mapped the propaganda campaign of the independents. Journalists friendly to Alfred's cause found their way into profitable on-the-side jobs as Wilmington and Dover correspondents for most of the Philadelphia dailies.

The important objective of all this effort was the August pri- 
maries to select delegates to the State convention, which would make up the Republican ticket for the autumn election. The big problem was to find an outstanding man to pit against Colonel Henry. To Allee and his corps of professional politicians the answer was simple: Alfred I. duPont. The favorable publicity expected from the stock suit, scheduled for trial in July, the insurgent spirit fermenting among the mass of independent voters-everything conspired to make him the logical man.

Allee dangled before Mr. duPont a picture of the senatorship for less than the asking. It was his if he would consent to let his friends put him in the race. Alfred's answer was No. He had entered politics pledged to seek nothing for himself; he would keep his word; another man must be found. Allee said there was no other man. Alfred said there must be. Allee tactfully dropped the subject. He had heard high-minded newcomers to politics talk that way before. ${ }^{12}$

"BANG! T. C. DUPONT's воOM BLows UP" ran the gleeful headline in Alfred's News announcing the overnight closing of the WaldorfAstoria headquarters of the Business Men's Presidential League. ${ }^{13}$

This brought two of Coly's Delaware lieutenants to Alfred's office under a flag of truce. They offered to help elect Mr. duPont Republican national committeeman, a post then held by Coleman. The condition was that Alfred take them into his organization in the place of Allee. Alfred refused the condition. On the eve of the Chicago convention, the Delaware delegation re-elected Coleman committeeman. ${ }^{14}$

It was Alfred's first national political convention, and he enjoyed the show. On the first ballot he voted for Roosevelt, Delaware's five other delegates supporting T. C. duPont. Of 987 votes cast, Coleman got $\mathrm{r} 3$ altogether. After an overnight adjournment the third ballot was taken. Alfred joined his five colleagues in the landslide to Charles E. Hughes, who won with $949 \frac{1}{2}$ votes.

Sixteen days after Alfred's return from Chicago, the case of DuPont versus DuPont went to trial in the dingy granite Federal 
Building, beneath the clock in the tower by which most of Wilmington set its watches. The proceedings lasted three weeks.

The weather was sweltering and so were the crowds which filled the courtroom to take in the sight of America's foremost industrial family hierarchy engaged in civil warfare. They saw as many DuPonts, great and small, as ever had been assembled under one roof for public exhibition; saw them surrounded by lawyers as alert as sentinels, by seconds-in-command, subalterns, satellites, camp followers and in-laws wearing anxious countenances. They saw perspiring DuPonts and many others parade in and out of the witness box, some of them not looking their especial bests. They heard witnesses dodge and stall and evade.

The lawyers alone were worth a look. Old John G. Johnson, who had fought at Gettysburg in 1863 and in the courts ever since, was a bit slow on his feet but not in his head. His cross-examinations showed that he knew backward and forward the ways of corporations and their people. A good deal of the routine work of the trial, naturally, fell to Mr. Johnson's younger colleague, Glasgow. Two local attorneys, Henry P. Brown and Robert Penington, completed the complainants' array of legal talent. Chief of counsel for the defense was the distinguished Philadelphia trial lawyer, George Scott Graham, member of Congress and former professor of criminal law at the University of Pennsylvania. The experience Mr. Graham lacked in corporation practice could be supplied by the two old-line DuPont Company attorneys at his elbow-William H. Button, of New York, and Pierre's authority on the use of the surplus, Director John P. Laffey.

The allegation on which nearly everything hinged was that Pierre had acted as a faithless corporate officer by negotiating with Coleman to acquire the stock himself when he had been directed to negotiate for 20,700 shares for the company. Continuing acts of ill service to the company were alleged in his means of financing the deal and of obtaining the directors' approval.

The gist of the complainants' evidence comprised Alfred's testimony reciting the events of the period in question essentially as given in the previous chapter of this narrative; the records of the various Finance Committee and directors' meetings; the corre- 
spondence between Pierre and Coleman duPont; the fact that fourteen banks associated with Morgan \& Company in floating the $\$ 8,500,000$ loan to Pierre, et al., were depositories of the DuPont Company and that immediately after this transaction the company's deposits in them were increased by $\$ 7,464,000$. William and Francis I. duPont corroborated Alfred where their experience had been parallel to his.

The backbone of the defense's evidence was the testimony of Pierre duPont and of John Raskob. Pierre went over the ground Alfred and William had covered, placing an entirely different construction on events. He had no agency to negotiate for the company; the deal had been called off on December 23. Pierre cited his correspondence with Coleman as proof of this, while the complainants contended the letters showed the exact opposite. It was claimed that the increase in company deposits in the loaning banks was coincidental. The company's funds had increased, and these banks were among its established depositories. A string of bigwig bankers-among them Henry P. Davison, of Morgan; George F. Baker, Jr., of the First National of New York; A. H. Wiggins, Chase National; Seward Prosser, Bankers Trust-swore that the loan was on private credit. Only Prosser, however, said he had inquired what the assets of the borrowers were. Evidence of the directors' approval of Pierre's acts was offered as the deliberate judgment of those gentlemen, uninfluenced by outside considerations.

The case seemed to boil down to the question of which side's story to believe.

Then the lawyers had their inning. This trial was not before a jury, but a Federal judge, J. Whitaker Thompson. Ordinarily lawyers reserve their emotional appeals, their courtroom oratory, for juries. John G. Johnson held to this rather strictly. From the record he hammered home the argument that P. S. duPont had violated instructions of the Finance Committee by secretly negotiating for his own benefit with Coleman. "Your Honor will remember the manner in which Pierre duPont sparred with the questions as to what he understood was meant by the statement [in the Finance Committee report] that he was to take up the mat- 
ter further [with Coleman], and finally said that what was meant was that he was to tell Coleman the whole thing was at an end. Believe it, if you may!"

Mr. Johnson closed:

"Teach these people a lesson that, higher than the mere acquisition of wealth .... it is better to do right, and that when they attempt to misuse their position and to destroy the confidence which has been put in them and which they have agreed to maintain, that such action can never be attended by any results favorable to the man who undertakes it."15

The only practiced jury lawyer in the case, Mr. Graham, after a tedious technical argument in support of the thesis of the defense, cut loose in reply to Johnson:

"My learned friend said that it is better . . . that you be right. Ah! yes; how will that apply to Alfred I. duPont? If a flash of the Eternal Light that illuminates men's souls could come into this courtroom at this moment it would show ... that Alfred I. duPont played a mean, despicable part; it would reveal him the enemy of Coleman duPont, fighting him at every turn; as the man who said, 'I will not give more than \$125 a share for this stock'; and yet who sat in the committee room afterwards and bought the stock for bonus purposes at as high as \$186 a share? What was the reason? Waiting for something to drop? He thought that $T$. Coleman duPont was in trouble and he was waiting to get his grip on that which would put him in control of this company....

"Were it not for the supreme genius of this man, Pierre S. duPont, and his associates who were welded to him like a band of brothers, this stupendous success, pouring money into the coffers of this company, could not have been achieved. And now does Alfred I. duPont come forward like a manly man and say, 'You have put your personal fortune at risk in buying this stock and you deserve to reap the profit?' No!"16

Answering Mr. Graham, Mr. Glasgow pictured the genius of P. S. duPont as employed in binding the band of brothers to him with chains of gold, in this way capturing the support of a majority 
of the Board of Directors. "He took them up on a high mountain - -an exceeding high mountain of high finance-and he showed them the world and the glory thereof." But some to whom Pierre offered shares in the transaction did not accept. "Life has not gone out of the old DuPont stock yet. William duPont said to him, 'It is a breach of faith.' Francis said to him, 'It is against my convictions and it is wrong.' Alfred said, 'Pierre, don't do this thing. Your father and my father were brothers and they would not have thought of doing a wrong like this.' He was pleading for the honor of his family, for the honor of his name."17

Gathering his black robe about him, Judge Thompson retired, with the voluminous and tangled record of the case, to decide between the conflicting points of view.

\section{7}

An earlier decision, however, would be forthcoming in Alfred's fight to strike the shackles of the DuPont political machine from Delaware. Primaries were to be held on August 19. The old guard controlled the election machinery, and it had a candidate for United States Senator-Colonel Henry Algernon duPont. Despite their spectacular victory in the April skirmish, despite a spirited and well-financed, if new, organization, and a wealth of newspaper support-all thanks to Alfred I. duPont-the independents were without a candidate to rally around. The force of the old campaign maxim that it's hard to beat somebody with nobody began to show.

The Colonel's newspapers assailed the insurgent movement as the result of the personal vindictiveness of Alfred-an extension of his court fight against the branch of the DuPont family which had made the company great and prosperous. They rehashed Allee's old association with Addicks. A whispering campaign revived the almost forgotten tales of Alfred's and Alicia's romance and marriage. One story was that she, not Alfred, was the moving spirit of this effort to "wreck" the Republican party in Delaware.

It is probable that the organization whisperers were unaware how much color of truth this statement contained. They might 
have pressed that particular pedal harder had they been able to sit in at some of the conferences in Nemours' paneled library which were attended by Allee, Bradford and the leaders from the three counties. Alicia was usually there. The vigor and the bitterness with which she expressed herself, the boldness and shrewdness of some of her ideas, amazed case-hardened veterans who still regarded politics as man's particular domain. ${ }^{18}$

The machine accused Alfred of scheming to succeed his cousin in the Senate. Most independents hoped this might be true. $\mathrm{He}$ would be their best candidate. On August 5, Alfred felt it necessary to clarify his position for friend and foe alike:

"I have both in public print and private conversation uniformly and unequivocally disavowed all personal ambition.... My desire is to advance the principles of the Republican party in Delaware through an efficient organization which is responsive to the will of the individual voter. Notwithstanding the repetition of this statement, there continues to appear in the daily press the assertion of my determination to secure at this time the nomination for United States Senator.

"I believe that no denial or disavowal is necessary to convince my acquaintances of the absurdity of the ambition attributed to me, and of the sincerity of my purpose. It is for the reason that the cause, which is now claiming the best efforts of so many worthy Republicans, may be prejudiced by this ambition wrongly charged to me, that I now state I am not a candidate for the United States Senate as the successor to the present incumbent.

"My deliberate judgment is that it would be a mistake ... to renominate for this high office Henry A. duPont. ... There are many able men in Delaware who should be considered for this nomination, and in the desire for Republican success in the State and nation, I trust that someone who is not a DuPont may be nominated."19

The last sentence was a hint to Coleman to keep off the grass.

Notwithstanding their want of a candidate, the mounting popular enthusiasm for the independent cause threw a scare into the machine. Independent rallies throughout the state drew bigger crowds than the machine meetings. Bull Moosers who had fol- 
lowed Roosevelt in 1912 came over to Alfred in droves. Two or three local machine leaders, looking to the buttered side of their bread, deserted to him. A big, bald, bluff ex-railroad brakeman named Edward M. Davis began addressing labor-union meetings in Wilmington in repayment of some favor Alfred had done him years before. Ed Davis had a crippled left arm, and he could hardly utter three grammatical sentences in a row. Yet he could hold a crowd, and, when speaking about Alfred duPont's friendship for the workingman, he had a topic on which a good deal could be said.

Hopeless of matching the independents in a popular contest, the machine relied on stealing the election on primary day. In Wilmington and in Kent County, ballot boxes were stuffed; floaters and repeaters transported from polling place to polling place; independent voters intimidated. Notwithstanding this, the results were rather surprising. In rural New Castle County, which included the Brandywine powder yards, I8 independent delegates were elected and 18 machine delegates. In Wilmington Davis' efforts were largely responsible for holding down the machine victory to 22 delegates out of 39 . Sussex County, with its strong Bull Moose element, scored a victory for the independents, 25 to I7. Kent County delivered for the machine according to specifications, 26 to I4. This gave Colonel duPont's forces control of the convention, 84 to 74 .

When the convention met at Dover on August 23, the Colonel's domination was made absolute by the machine-controlled Committee on Credentials which refused to seat the fourteen independents from Kent.

This cinched the Senatorial nomination for Colonel Henry, which the independents did not contest. The old guard's main object achieved, the independents' cup of adversity was sweetened with four excellent places on the ticket: John G. Townsend, for governor; Thomas W. Miller, for congressman; David J. Reinhardt, for attorney general; William J. Swain, for State treasurer.

Apprehensively the machine awaited the popular reception of its work. Several independent leaders at once denounced the convention slate, and Colonel Bob Houston, of Georgetown, fiery 
leader of the old Roosevelt Progressives, called for a third ticket. Of course Alfred was the man everyone was waiting to hear from. After a few days' silence, he deprecated the "railroading" of Colonel Henry's nomination and said that a third ticket "would seem to be the natural outcome." Mr. duPont was waiting to see what the Democrats did. The only way now to beat the Colonel would be to elect the Democratic nominee, either by putting up a third ticket or by open support. Therefore the importance of the outcome of the Democratic convention.

It proved disappointing. A run-of-the-mill politician, a Dover lawyer named Josiah O. Wolcott, was picked to oppose Colonel Henry, beating Thomas F. Bayard, Jr., of Wilmington, a much better man. Ironically, Alfred's cry to rid the Senate of DuPont influence probably had something to do with the rejection of Bayard, who was married to Elizabeth Bradford duPont, a double first cousin of Alicia. Notwithstanding Alfred's desire to see the seat entirely free from family ties, confined to a choice between Wolcott and Bayard, he would have taken Bayard on the ground of fitness.

Confined now to a choice between Wolcott and the Colonel, Alfred took Wolcott. A Progressive Party ticket was placed in the field. Its candidates for Presidential electors were the same as on the Republican slate, thus saving the State for Charles Evans Hughes. Of the Republican nominees the independents, Townsend, for governor, Reinhardt, for attorney general, and Swain, for auditor, were endorsed. Tom Miller, an independent whom the Republicans had nominated for congressman, was dropped because Mr. duPont had become suspicious of his devotion to the antimachine cause. Alicia's brother, Edward Bradford, took the congressional nomination on the Bull Moose ticket in an effort to insure Miller's defeat. Doctor H. R. Burton, of Lewes, was nominated for the Senate to beat Colonel Henry, and nominations were made to oppose the other old-guard candidates.

The ensuing campaign was bitter. Had a stronger man than Wolcott been put up by the Democrats there would not have been much of a contest. As things stood, a certain number of independents saw too little to choose between him and the Colonel. 
Alicia and Alfred had in a few friends to hear the returns. The first results from Wilmington foretold Colonel Henry's doom. In this stronghold he was little better than holding his own. The final tabulation showed him last in the standing of the Republican candidates, with 22,925 votes to Wolcott's 25,416, and Burton's 2,36r. All Republicans endorsed by the Progressives won; all opposed by them lost. Particularly sweet was Alfred's triumph over the Colonel who had been beaten by Republican votes alone. Had Henry received every vote cast for the Progressive, Burton, Wolcott still would have won by a majority of 130 .

While glasses were clinking in toasts to his victory, Alfred ceremoniously lighted a cigar-his special brand, costing 50 cents apiece and very popular among politicians.

"Nothing like a great occasion for turning over a new leaf," he said. "This is the last cigar I'm ever going to light."

Alfred looked around and asked where Francis was. Probably at the laboratory, someone said. Dismissed by Pierre from his post in charge of the DuPont experimental station, the family's man of science had fitted up a laboratory of his own. Presently Francis telephoned to announce the cause of his absence. He had become the father of twin daughters.

Glasses were filled again. Alfred's cigar was good for a few more puffs. Election eve of 1916 was long remembered at Nemours as a three-ply family occasion: the defeat of Colonel Henry; the birth of Anna and Francis duPont's twins; Alfred's last cigar. 


\title{
CHAPTER XVIII
}

\author{
EAGLES OF VICTORY
}

I

PROMPTLY and with vigor Alfred I. duPont put to work the personal authority gained by his spectacular defeat of the Republican machine. On November 25, 1916, less than three weeks after the election, he invited to his office leaders of the independent movement from the three counties and also several liberal Democrats and nonpartisans.

For a full generation rank-and-file taxpayers had been striving to amend the archaic revenue laws which made Delaware a congenial dwelling place for the rich. Against the opposition of the DuPont-controlled political organization, they had accomplished nothing.

This condition of affairs Alfred laid before his unofficial caucus. After several hours' deliberation the conferees issued a statement, the inspiration, the initiative and much of the language of which were Mr. duPont's:

"In view of the approaching session of the Legislature, it is well to call the attention of the public to certain considerations ... for the correction of gross abuses that exist in our commonwealth and which retard its progress and development.

"Delaware is actually living under the most obsolete laws of any state.... The most marked of these iniquitous statutes are those relative to revenue and taxation. In the main they are a century and a half old-fair and equitable enough in the day of their creation, but in view of the changed forms of wealth that exist in the present day, wholly inadequate.... The largest part of the wealth of the State bears no part of the State's expense-the old system of taxation including only land and livestock and exempting all that vast 
wealth of an interest-bearing character.... The consequence is that [though] real estate and livestock are taxed to the limit, ... the State has fallen behind in all that should make it worthy....

"Take a few of the facts:

"Education is at a low ebb, shamefully so, there being only twelve States in the Federal Union with a greater illiteracy than we have. Our whole school system is archaic and lifeless from lack of funds, and the manner of raising what we do raise is barbarous. The present system taxes the poor man's horse at its actual value, and the rich man's mansion at only its rental value.

"Take our existing institutions:

"What we have are few and inefficient, and many others are absent because of the.lack of revenue. We need a tuberculosis asylum, but there is no money; we need better provision for the deaf, dumb and blind, but there is no money; an adequate and proper provision for a general good roads system, but there is no money; the creation of a drainage bureau to reclaim one-eleventh of our entire territory, but there is no revenue.... The fourth richest State in point of per capita wealth, and the second smallest in point of territory, there seems to be no necessity for argument to prove that all we need to make the State one of the most progressive is a change in our existing laws relative to revenue and taxation....

"The agricultural stranger without our gates may and does admire our natural advantages of soil and climate, close proximity to great markets, all the riches of our creeks, rivers, bays and the ocean, but if he be intelligent he shuns a State where his property bears all the burden of taxation and all other wealth is exempted....

"Visions may be indulged in by a righteous imagination, but no progress can be had in this State without money, and the one feasible and sensible way is to pass two measures, one providing for a graduated inheritance tax for State purposes and another equalizing taxation for county purposes in which all real and all personal property shall be taxed alike, without regard to the form in which it exists."

Within twenty-four hours this pronouncement had Delaware in a ferment. Alfred's privately owned newspaper chain was not needed to spread its praises. The acclaim from agricultural Delaware, from small urban property owners and from folk of moder- 
ate means everywhere seemed nearly unanimous. Even Colonel Henry duPont's Wilmington paper, the Evening Journal, dared not openly oppose such a popular uprising as the family revolutionary had touched off. In a guarded editorial the Colonel's organ admitted a need for revision of the tax system but sparred for time, deploring precipitation in so important a matter. ${ }^{2}$ The word-ofmouth campaign of the reactionaries came to the point more clearly. Criticism ran all the way from the whispered tale that Alfred was losing his mind to the charge that he was an innocent tool of radicals and Socialists. The assertion was made that Alfred had been overridden by his extremist friends and did not personally support the decision of the meeting in his office.

This called from Mr. duPont a public statement subscribing to the program of the caucus. Existing tax laws, he said, "seem framed for the sole purpose of assisting such [wealthy] men to pay as little as possible, and it is to the minimum that they intend to stick if permitted to do so." The proposed new laws would distribute the burden equally among rich and poor. "If a man has a million to be levied upon he should object no more than the man who has only a few hundred dollars."

The statement brought a flood of acclaim, without regard to party. "We are with Alfred I. duPont," declared Peter J. Ford, whom liberal Democrats had mentioned for governor. "If Alfred I. duPont will take hold and lead the movement for a sensible, equitable tax system," said David Snellenburg, Wilmington department-store owner, "Delaware will be marked as a progressive commonwealth the world over." "We will be right with you," read a messsage from Doctor J. W. Bastian, president of the Taxpayers' League and long leader of a lonesome fight for reform. Bankers, attorneys, welfare workers, merchants, a manufacturer or two, and members of local Levy Courts (which fixed tax rates) joined the chorus. ${ }^{4} \mathrm{~A}$ few professional political henchmen hitherto attached to Colonel Henry's battered machine and now looking for more promising connections jumped the fence to Alfred's side. Yet nowhere on the lengthy and interesting list appeared the name of a person associated with the DuPont Company.

Happier than he had been in many a day, Alfred was cheered 
most by the basketfuls of letters, many scrawled on cheap paper without regard for spelling. The reformer moved swiftly. At a nonpartisan meeting in his office on December 8 four independent members of the new Legislature were chosen to outline tentative bills embodying the amendments in prospect. Under Alfred's political field marshal, Allee, permanent headquarters were retained in Dover to see the good work through.

The hard-pressed machine fought back with all the skill and energy which its real master, Coleman duPont, could bring to bear. Popular support of Alfred's program drove this opposition underground, where a political machine sometimes fights best. A factor in its favor was the vociferous support of Alfred's program, which gave many of its friends a feeling of false security. This was cunningly encouraged by the comparative silence of the machine newspapers. The game seemed to be to confuse the reformers with the heady wine of overconfidence.

The opposition made its first strategic move in the farewell message of the retiring Governor, Charles R. Miller. Miller was Wilmington's streetcar magnate and a machine adherent shelved in favor of the liberal Townsend in a futile effort to mollify Alfred's followers into accepting Colonel Henry for Senator. An able man, Miller commanded considerable popular respect despite his political affiliations. In a carefully worded message he admitted with disarming frankness the need for tax revision. But the subject was complex and Governor Miller recommended the appointment of a permanent commission to report to the Legislature in 1919, two years hence. Not every one at once saw in the Governor's plausible remarks a scheme to defer action until after another election which might see the machine back in the saddle.

Allee saw it, of course, and assured Alfred that there was no danger. The Legislature would speedily organize with the independents in charge-Harvey Hall as Speaker of the House and John A. Barnard as presiding officer of the Senate. Hall was a Democrat, and Barnard a Republican.

Within thirty minutes after the Legislature had convened on 
New Year's Day, 19I7, Allee perceived that he had miscalculated. Hall needed all the r 9 Democratic votes to elect and he got only $x 6$. The deadlock lasted until January 3 when a threat by liberal Republicans to bolt to Hall brought him the necessary Democratic votes.

The Senate also was tied in a knot, and there the situation looked dark. Six of the ten Republican Senators were machine men who cast their votes for Senator Hoffecker. The seven Democrats stood pat for their own candidate, Senator Gormley. Nine votes were required to elect. Day after day, ballot after ballot, the tally stood the same: Barnard, 4; Hoffecker, 6; Gormley, 7. The provocative words, the bitter feelings, the deals, threats and intrigues recalled the stirring days of "Gas" Addicks. From the beginning Gormley had said he would never join the machine. On January 16 he served notice on the machine men that unless they elected Barnard within a week he, Gormley, would do so. On January 22 on the forty-first ballot, Gormley made good his warning, throwing six votes to Barnard, which was one more than enough.

The Democratic members had yielded not so much to the persuasions of Allee as to pressure from home. Alfred duPont was learning the political ropes. In addition to a drumfire of editorials which he furnished to every newspaper in Delaware that would print them, he organized mass meetings from one end of the little State to the other calling for tax reform.

The victorious breaking of the deadlock took the fight out of the machine. The inheritance-tax bill moved smoothly to unanimous passage. Alfred's proposal to tax interest-bearing investments did not fare so well because of a disagreement among the liberals. Two measures were introduced and Mr. duPont's supporters were obliged to accept a compromise between them.

Still, the victory was a great one. Alfred's Morning News called it merely a curtain raiser to the great work of making Delaware a better place to live in. ${ }^{5}$

These triumphs were somewhat clouded, however, by anxiety over the delay of Judge Thompson's opinion in the stock suit. Dip- 
lomatic relations with Germany had been broken and the nation was headed for war. Alfred heard fantastic rumors of roundabout efforts to persuade the Department of Justice that a decision adverse to the DuPont Company management would hamper our efforts to prepare for battle. ${ }^{6}$

On April 6 we declared war. On April i2 Judge Thompson announced his decision. It was a sweeping victory for Alfred.

The text of the jurist's opinion would fill seventy-five pages in this volume. Near the outset he stated that "a fundamental fact to be determined" was whether the action of the Finance Committee on December 23, 1914, constituted a rejection of Coleman's offer to sell or an instruction to Pierre to submit a counterproposal with reference to price. Pierre claimed it constituted a rejection, Alfred a counterproposal.

Judge Thompson found squarely for Alfred's contention, describing Pierre's course as one colored by trickery and concealment. Citing records of the Finance Committee, correspondence between Pierre and Coleman and trial testimony by Alfred and by Pierre, the jurist set forth that Pierre duPont had been explicitly directed "to take the matter up with Mr. T. C. duPont further," and that he had done so. Nevertheless, Judge Thompson found that Pierre had concealed important details: withholding from Coleman the fact that Alfred and William duPont had based their objection to the purchase merely on the matter of price, and withholding from Alfred and William the full particulars of Coleman's original offer which contained statements in justification of his request for $\$ 160$ a share, which Alfred and William had thought too high. ${ }^{7}$

On January I7, I9I5, Coleman tentatively had withdrawn his offer to the company. Summing up Pierre's moves to this juncture, Judge Thompson wrote:

"It is impossible to reconcile Pierre's insistence that the offer was rejected on December 23rd with his own declaration in his correspondence with Coleman. ... The only construction which can be put upon his conduct ... which harmonizes with the ... [ evidence] is that he had ... the intention of concealing from the Finance Committee the fact that he was negotiating with Coleman and of taking the position with them [the Finance Committee] 


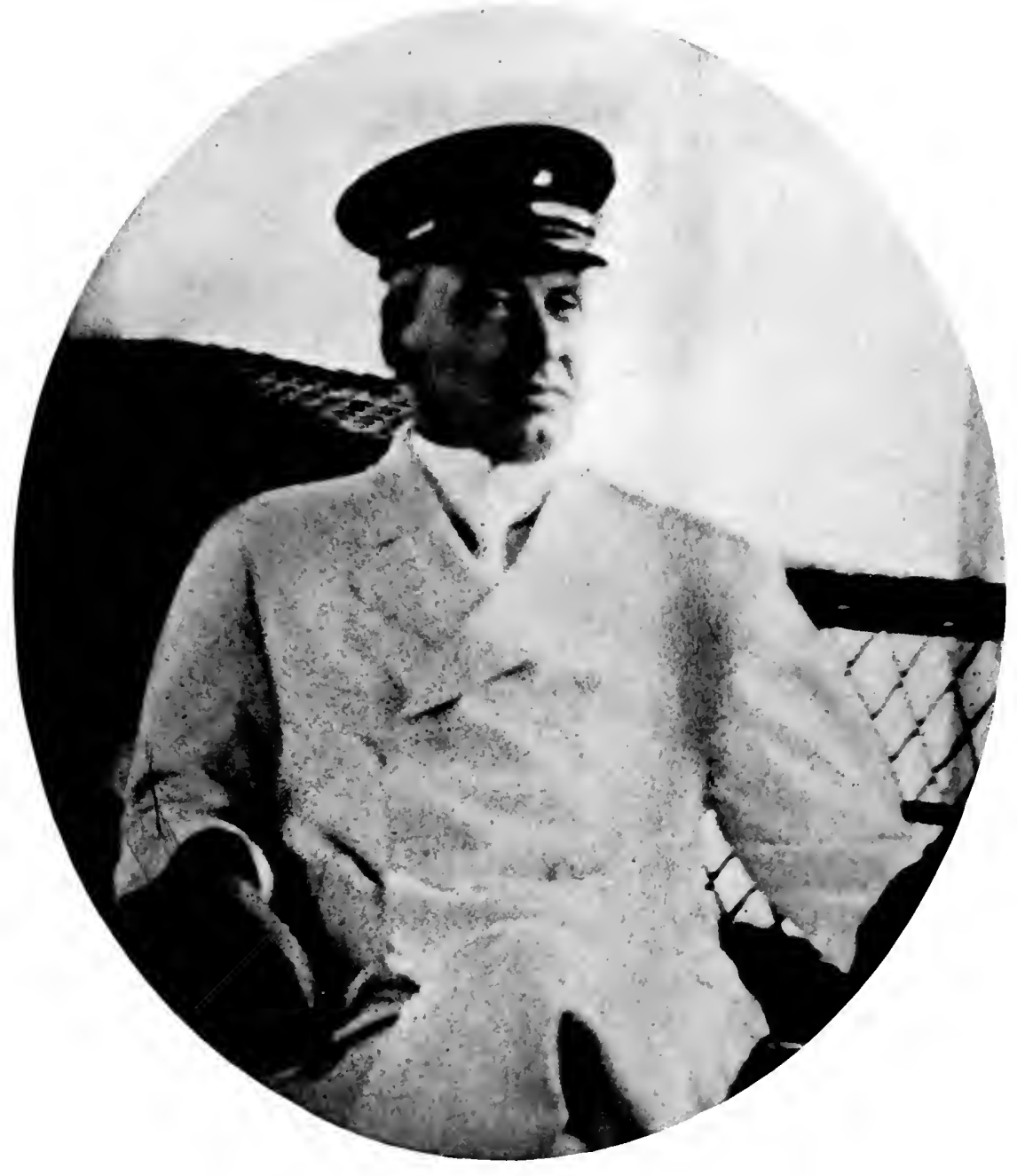

Commodore duPont

Alfred as commander of the fleet of the Cambridge (Maryland) Yacht Club. Photograph taken about 1913. 
, 
that he understood that the offer had been rejected on December 23rd; of keeping Coleman in ignorance of the attitude of the Finance Committee and at the same time keeping the negotiations . open with Coleman and the matter in such position that ... he [Pierre] might ... [act] for his own benefit rather than that of the company. ${ }^{s}$...

"It is asserted by counsel for the defendants that when Coleman withdrew his offer, the duty on Pierre's part of acting for the Company was at an end and he was free to act for his individual interests. It must be assumed that Coleman's conclusion to withdraw the offer, qualified as it was, ... was effected by Pierre's breach of fidelity he owed to the company in misinforming and misleading Coleman as to the real action of the Finance Committee."

On February to when Pierre told Alfred that the negotiations were off, Alfred's request for correspondence bearing on the subject was evaded.

"The evidence irresistibly forces the conclusion," declared Judge Thompson, "that there was a deliberate intention on Pierre's part to conceal from Alfred ... correspondence which would have ... disproved Pierre's statement that the offer had been 'turned down' on December 23rd." 10

After Pierre had purchased Coleman's holdings on his own account and the account of a few associates he explained his act to the Board of Directors in a letter, dated March 5, 1915, which Judge Thompson said "contained false statements."11

As to the meetings at which the directors refused to make an offer to take the stock off Pierre's hands, the court found:

"That action was obtained by the votes of nine directors who ... were interested in preventing the Company from acquiring the stock, and of six others who were kept in ignorance through wilful misrepresentation and suppression of facts. . . . To uphold the action of the Board meetings of March 6th and roth [1915]... would be contrary to conscience and good morals." ${ }^{.12}$

The court further held that the company possessed ample funds with which to purchase the stock, contrary to the opinion submitted to the directors by the company's general counsel, Laffey. ${ }^{13}$ 
The one important point on which the court declined to find for the plaintiffs concerned the defendants' alleged use of the company's credit to obtain the loans to swing their deal. Here the judge merely intimated that the purchasers' connection with a firm having millions to deposit with bankers probably made those loans easier to get than otherwise. ${ }^{14}$

The court found misrepresentation in the circular letter to stockholders sent prior to the stockholders' meeting of March 13, 1916, at which Pierre's purchase was formally ratified. Judge Thompson declared the action of that meeting invalid. ${ }^{15}$

Thus, reasoned Judge Thompson, there had been no proper expression of opinion as to whether the company should acquire the stock. As a majority of the Board of Directors was personally interested, that body was unfit to pass on the matter. There remained, then, the stockholders. Judge Thompson ordered that they should decide the question, and that the old Coleman shares be restrained from voting. The court concluded its opinion by saying that a special master would be appointed to supervise such an election. ${ }^{16}$

Alfred wrote his attorney, Glasgow:

"By ordering this matter to be referred to the stockholders ... Judge Thompson has badly muddled what otherwise would have been a perfect opinion.... A vote of stockholders of any Corporation is taken usually for the purpose of getting the opinion of the stockholders upon any policy or act which may affect the interests of the said company. In this instance, we have a matter referred to the stockholders which questions no past or future act, which might work to the disadvantage of the Company, but purely the question as to whether the Company shall accept the return of $\$ 43,000$,ooo in values, which the United States Court determines have been taken from it illegally. [On the face of current quotations the stock Pierre had bought for $\$ 13,000,000$ plus was then worth $\$ 43,000$,ooo.] The Court, itself, has determined that the interests of the Company have been violated. This is not a point left for the stockholders to vote upon. We have the unheard of situation where a 
matter is presented to the stockholders to vote on wherein one portion of the stockholders will vote for it, because it is to their personal interests and the interests of the Corporation to do so, and the other portion will vote against it ... [ for similar reasons]."

Here Alfred touched the crux of the situation: "Already, the stockholders who are employees are stating they will have no alternative but to vote in the interests of the defendants against their own and the Company's interests, as they naturally do not care to vote themselves out of their positions."17

True as this criticism was, it overlooked the fact that in submitting the question to the stockholders the court was doing one of the things the plaintiffs themselves had asked for in their bill of complaint. The bill had requested the court to award the stock to the company and then to order the stockholders to vote on its retention. ${ }^{18}$ Judge Thompson had simplified this by instructing the stockholders (syndicate members excluded) to vote directly on the question of transfer to the company.

Nevertheless, the court's findings constituted a tremendous victory, which nowhere gladdened more hearts than in the houses of the black-powdermen along the Brandywine. The night of April I2 was one of spontaneous celebration. Bedridden old Charley Deery, at whose side Alfred had risked his life putting out a fire in Hagley Yard, received the news from another Brandywine pensioner named LeFashion. LeFashion also brought a bottle to enable his ailing friend to celebrate the tidings suitably. As the evening wore on, LeFashion's version of events grew in stature until he declared that Pierre, Irénée and Lammot were in jail. It was months before Charley's family disabused him of this idea, and the old man talked daily of getting well so he could go to the workhouse and see Mr. Alfred's adversaries behind the bars. ${ }^{19}$

There has also passed into legend an account of a big DuPont family garden party held about the same time, though not in honor of Judge Thompson's opinion. Present was one of the family's problem children-a likeable, talented scapegrace whom Alfred had discharged from the company's employ for drinking. At the party the scapegrace took too much wine. Cold-shouldered by his rela- 
tives, he sought out one of the DuPont chauffeurs for companionship. From behind a hedge their conversation was clearly audible. The scapegrace was saying:

"Just look at all these rich DuPonts. Look at 'em in their fine clothes eating caviar and drinking champagne. But they aren't all here. Cousin Alfred isn't here. Wouldn't invite him. Yet you know as well as I do that if it weren't for Cousin Alfred most of us DuPonts wouldn't have seats in our pants."

To the stockholders Pierre S. duPont put the best face on matters he could. A circular letter cited the unprecedented prosperity of the company. This was due, Mr. duPont said, to "the Executive Committee of the Board of Directors, consisting of Irénée duPont, H. F. Brown, R. R. M. Carpenter, F. L. Connable, William Coyne, Lammot duPont, H. G. Haskell, J. J. Raskob, and F. G. Tallman. ... Against these men the decision makes no finding of bad faith, betrayal of trust or wrong doing." This was putting up a better front than the facts would support. After an admonition by the court, a second letter was sent withdrawing the statement. ${ }^{21}$

Judge Thompson named Daniel G. Hastings as special master to conduct the stockholders' election. The date was set for October Io, I9I7, and the scramble for proxies began. Without avail Alfred protested that Hastings was "Coleman duPont's political henchman." 22 The most serious situation confronting Alfred, however, was the enormous advantages in the proxy fight possessed by Pierre and his crowd. Excluding those bought from Coleman, 461,432 common shares were eligible for voting, of which 230,717 would constitute a majority. To attain this goal the defendants started off with I00,000 shares which they owned. Blood relatives could be counted on to contribute 58,000. Directors of the company, not involved in the suit, but holding their positions at Pierre duPont's pleasure, would add I4,000 more. Fifty thousand shares were held by company employees, high and low, and by pensioners. Pressure from above might well bring 40,000 or 45,000 of those votes into Pierre's camp. This would raise his total of almost certain votes to 212,000.

Alfred could count certainly on hardly more than iro,ooo. His own holdings were 75,534. William would add 27,994. That ended 
the big blocs Alfred could rely on. Other family members who had stood by him in the long fight were small share owners, Francis I. holding I,634; Philip, for all his wealth, only I,732; Ernest, I,730; Eleanor Perot, ro8; Archibald, 68; Paul, 8.

From the pool of 139,000 shares whose alignment could not be guessed in advance, Pierre had to win only 18,000 votes to obtain a majority, whereas Alfred had to win 120,000 . Thus from the outset Alfred's was a forlorn hope, and he knew it. ${ }^{23}$

Yet Alfred meant to go down fighting and to make the best showing he could. Under a Philadelphia newspaperman, a press bureau was set up to publicize Alfred's side of the case. This was done very successfully. Judge Thompson's damning opinion made excellent material to draw on. Under cover of the word barrage, Alfred sent canvassers to interview independent stockholders.

Alfred's effort was dwarfed by Pierre who mobilized the resources of the company. To outside stockholders the statement was reiterated a hundred times that a vote for Alfred was a vote to repudiate the management, a vote to kill the goose that was laying the golden eggs. Stockholders were abjured to look to their dividends-totaling 183 per cent of par in fifteen months. The flag was waved and appeals made to patriotism which were effective in those mad days of our first summer at war. To cap the skillfully co-ordinated efforts of the DuPont propaganda machine was an informal opinion on the merits of the case by Charles Evans Hughes, former associate justice of the United States Supreme Court and late candidate for President. For this Alfred heard that Mr. Hughes received a fee of $\$ 50,000{ }^{24}$

The fact that Hughes's expression was not blazoned forth in the newspapers by Pierre's publicity staff lends credence to the report that it was obtained under a promise to keep it reasonably confidential. Certainly it would have made an excellent counterfire to Alfred's thriving publicity campaign. Printed as a booklet of ninety-two pages, ex-Justice Hughes's remarks were quietly exhibited to large independent shareholders.

Mr. Hughes devoted half of his space to a résumé of the facts of the disputed transaction with which no partisan of Alfred could have taken much issue. Then came a legal interpretation of the 
facts as they affected the good faith of P. S. duPont and associates as officers of the company.

Two transactions, said Mr. Hughes, should be considered: (I) Coleman's offer of 20,700 shares to the company for distribution among employees, and (2) the purchase of Coleman's entire holdings by Pierre. The suit was based on the second proposition and sought to recover for the company all the shares that had once belonged to Coleman. Mr. Hughes set forth that Coleman had never offered his entire holdings to the company, but only 20,700 shares; that the Company had never empowered Pierre to negotiate for all the holdings.

The 20,700-share offer had come to an end without action on the company's part, due to no breach of duty by Pierre. This done, continued Mr. Hughes, Pierre had acted perfectly within his rights in purchasing, privately, all Coleman's holdings. Mr. Hughes held that consequently the stockholders had no right to deprive Pierre and associates of this stock. Should they vote to do so, it would be the duty of a higher court to restore the stock to P. S. duPont, et al. ${ }^{25}$

Alfred's reports from the field were uniformly dismaying. Usually Pierre's agents had been on the ground first and had obtained the proxies. Coercion was applied not only to members of the DuPont family and to company employees, but, according to one affidavit Alfred received, to employees of the Hercules Powder Company who owned DuPont stock. ${ }^{26}$

Although Alfred was steeled for a beating, the extent of the reverse surprised most of his followers. The vote was: to turn the stock over to the company, I40,842; to let Pierre and associates keep it, 312,587.

\section{5}

Nevertheless Alfred felt that a moral triumph had been his, a conclusion concurred in by subsequent impartial reviewers. ${ }^{27}$ Moreover, having vanquished the DuPont political machine and installed himself at the head not only of an unfettered Republican party in Delaware but of a large body of liberal Democrats, Alfred 
looked to new horizons. One excuse for his dismissal from the DuPont Company had been that Alfred was a poor businessman; a good black-powder technician, in his day, yes, but no shining corporation executive in the modern sense of the term. The statement contained elements of plausibility. Alfred duPont disliked business as such. The average big-businessman bored him as an ignoramus outside his special field, short on culture, on ideals and on social philosophy. Yet Alfred could not forget that the dismissal fostered the impression that these bores could do something Alfred duPont could not do. He meant to remove that impression by showing the world that he could play the game of big business with the best of them.

Nor would that be all. Alfred desired to contribute something to the rehabilitation of a devastated world when the war should end. When the guns ceased firing, Europe would provide an immediate market for American goods-clothing, household things and about everything else needed to put a civilized society back on its feet. European industry, preoccupied with the production of munitions, would be months making a change-over. During that interim the market would be open to the readiest supplier. Alfred I. duPont meant to be that supplier. With more money coming in than he readily knew what to do with, he could provide the capital necessary to make his bid on a sufficiently large and attractive scale.

This ambitious conception did not come to him all at once, but by degrees over 1916, ' 17 and ' 18 . The first step was taken in 1916 , some time after Pierre had ousted Alfred from the DuPont Company. For $\$ 1,000,000$ cash Alfred had bought the Grand Central Palace in Lexington Avenue, New York City, and organized the Merchants \& Manufacturers Exchange to import for exhibition purposes articles of European and South American manufacture. Such samples, not to be sold, could come in duty free. Trade is not a one-way proposition, and Alfred meant to stimulate a demand here for foreign products. This contemplated exhibit would be in addition to the normal activities of the Palace where automobile shows and different exhibitions followed one another the year round. The only immediate change Mr. duPont made on assuming ownership was to close out a dime-a-dance hall in the place 
which was paying $\$ 40,000$ a year rent. The proprietors accepted $\$ 17,000$ for consenting to break their lease. ${ }^{28}$

Alicia wished a home nearer the scene of this unfolding drama of commerce, and in 1917 Alfred bought 250 acres on the fashionable Sound shore of Sands Point, Long Island, for $\$ 236,000$. A house, which Mrs. duPont proposed to call White Eagle, was projected on a scale only slightly less imposing than that of Nemours. 


\section{PART FIVE}

An Anxious Interlude 



\section{CHAPTER XIX}

\section{Light and Shadow}

I

THE Georgian mansion, White Eagle, which Alfred duPont began to build on Long Island, represented the gratification of a whim of his wife. The property stood in her name. For himself, Alfred regarded New York as a good place to transact businessand leave. Deafness had robbed him of the pleasure he had once found there at concerts and the theater. Old plays, notably some of Shakespeare's, which he knew almost by heart, were all that Alfred could enjoy. For friendship's sake, however, he went occasionally to see Jimmy Hackett, or John L. Sullivan in one of his thunderous melodramas. Though on the water wagon, the old prize fighter was still a law unto himself. Learning that Alfred was in the house he would step out of character, and, advancing to the footlights, with a sweeping gesture announce in a voice audible a block away:

"My greetings to Mr. Alfred I. duPont."

Alfred was glad to humor Alicia because her apt judgment had been of help to him in his political career, and because she was ill. Following the death of their second baby a stroke had deprived her, temporarily, of the good use of her legs. Nevertheless, a baby had come to Nemours at last. On a day in January, 1916, Alfred had returned home to find her in Alicia's arms-an eleven-monthsold little girl who looked like a French doll. The infant's arrival at Nemours had been Alicia's own secret. Presumably through a war charity in which she was interested, Mrs. duPont had located in France this orphan whose father, a French officer, had been killed at the front. Mrs. duPont had known both of the child's parents. She and Alfred christened their new possession Adelaide Camille Denise duPont. ${ }^{2}$ 
In I9I7 Alicia translated from the French one of the poems of François de Salignac de la Mothe Fénelon, the seventeenth-century archbishop. Mr. duPont had it published by Brentano's under the title, Ode of Fénelon. A poem of escape, it reflects a mood which must have often been that of the translator:
"Sheltered from the tempest blind,
Blasting all the Rich and Great,
Underneath these leaves I find
In all weathers a retreat.
There alone my life begins,
There alone my spirit wins
Far from books, a deeper truth."3

Alfred had little difficulty getting rid of an income of $\$ 3,000,000$ a year. His personal records, which are incomplete, indicate gifts to relatives, principally his sister Marguerite and his brother Maurice, aggregating $\$ 1,500,000$ between 1913 and 1919. No one knew, nor is there any way of ascertaining, the extent of his private pension list, which must have amounted to $\$ 200,000$ annually. A hundred thousand dollars went to his old prep school, Phillips; a farm in Massachusetts and a monthly check of \$roo to John L. Sullivan when the old champion had to give up the stage. Jimmy Hackett was a constant drain. Responding to a request for $\$ 7,500$ Alfred wrote:

"No you are wrong in stating that it takes a damn wise man to realize he is a damn fool. Any man. who looks in the glass honestly ... will very soon come to the conclusion as to pretty nearly what percentage of damn fool is looking at him: All men have a large percentage of damn fool in their make-up, just as all ladies embody a large percentage of cat. ... There is no harm in being a damn fool providing it is recognized and the proper remedy adopted. I still maintain that if you eliminate rum and tobacco and late hours, you will be much better, wiser, happier, and more useful. I know for I have tried both. The trouble is not to give up these various luxuries but in making up your mind to do so. ... Each individual must work out his own salvation or damnation, and after a man attains the age of forty advice is something that he has about as much use for as the Devil has for holy water."4 


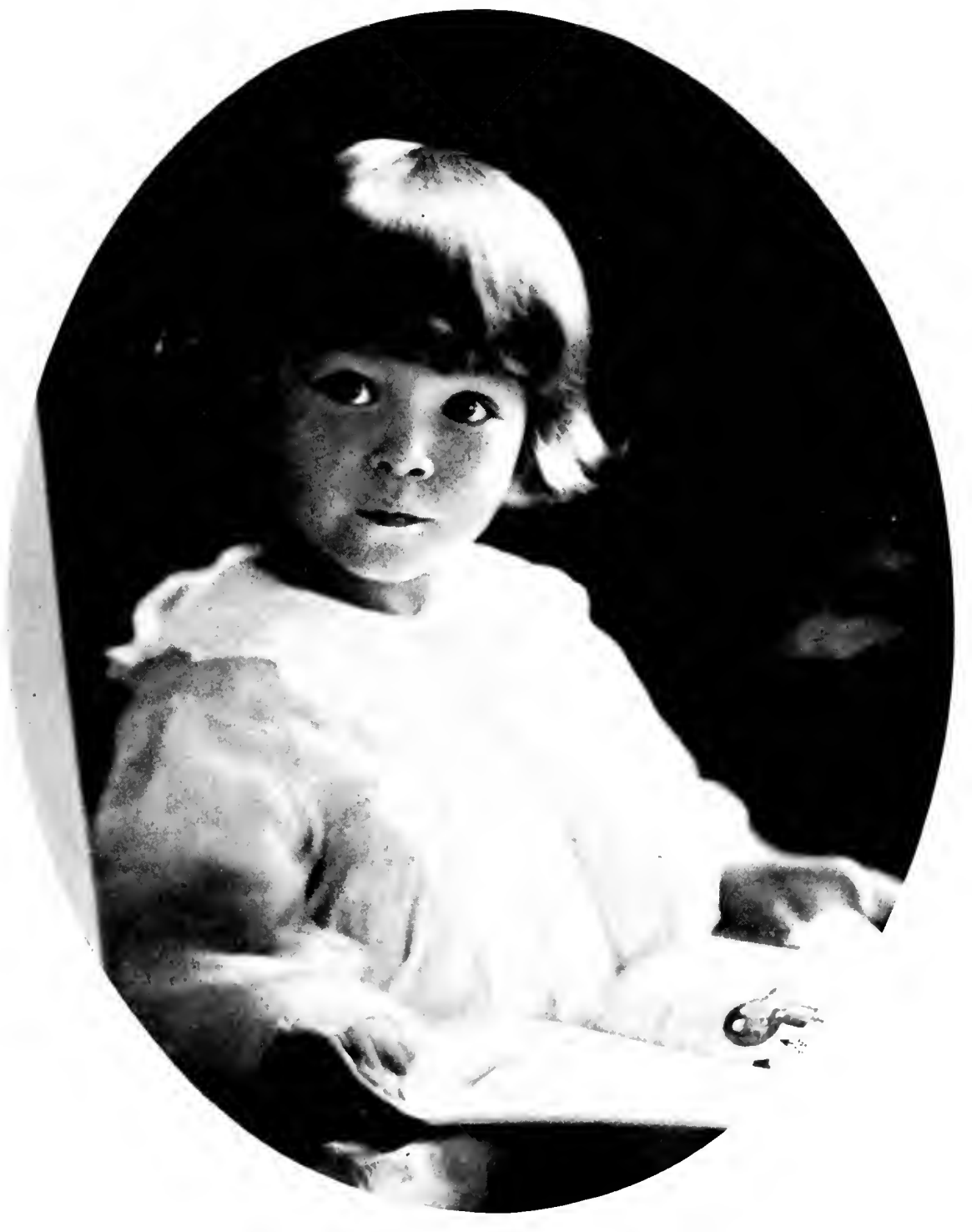

Denise duPont, Aged 3 

Alfred was a soft touch, and knew it, his apology being that he would rather comply with nine undeserving requests than to turn down one deserving one. Occasionally, however, importuners laid it on too thick, as did one who dated his letter December 25, I9I7:

"Today we celebrate the Nativity of Him who said:-_Inasmuch as ye have done it unto one of the least of these my brethren, ye have done it unto Me.' In His name and for the sake of good and of right I ask you again to cooperate with me, temporarily, to the extent of this sum of $\$ 150,000$ : letting me have $10 \%$ thereof $(\$ 15,000)$ now, and the remaining $90 \%(\$ 135,000)$ when I shall place all of the Stock of this great [Colorado copper] Mine in your hands, in trust."

An admirer wrote that Mr. duPont contributed more than any other private citizen of Delaware to the winning of the World War. Thinking this too conservative the writer changed it to read "any other individual in America." Mr. duPont's own estimate was more modest. "My war record," he wrote to his brother, "consisted in staying home and trembling in my shoes for fear I would be eaten alive by a Boche.... I believe I ... [did] less than nothing for the war."

Mr. duPont's first contribution was in 1916 when he saw war coming. After conferences with Navy officials, including Assistant Secretary Franklin D. Roosevelt, he collaborated with A. Loring Swasey, the boat designer, on plans for a speedy light craft of the type later known as submarine chasers. In December, 1916, the maritime engineering firm of Herreshoff began work on this craft, which Mr. duPont presented to the Navy. Christened the Petrel, it was the first sub chaser in commission. The check for $\$ 85,000$ which the Government sent Mr. duPont to cover the cost was returned.

Willard Saulsbury, president pro tem of the United States Senate, frequently came to Alfred with problems concerning the expansion of the Government's explosive program, as did Will Glasgow, one of Mr. duPont's lawyers in the stock suit. Though 
the right-hand man of Herbert Hoover in the Food Administration, Glasgow also served as liaison officer between Secretary of War Baker and Alfred on munitions matters. Alfred's influence was sought to obtain exemption from the draft for two young DuPont cousins. He crisply declined. Should our wars be fought, he asked, by the sons of poor men? In view of the money the family was making, Alfred thought a DuPont owed an especial obligation to the colors.

Besides buying $\$ 2,000$,000 worth of Liberty bonds, Mr. duPont subscribed to virually every known war charity. After the Armistice he provided funds for rebuilding a French village. His daughter Madeleine's second husband, a German named Max Hiebler, served in the Kaiser's army and Madeleine remained in Germany during the war. Her property here was seized by the Alien Property Custodian. In this situation Alfred forgot his differences with his oldest daughter and slipped money through the blockade.

Occasionally Alfred visited the Brandywine mills, in which during another war he had played a role that deserves to be remembered. The force of the antiquated yards trebled for the emergency, only here and there an old-timer recognized the deaf, abstracted man in knickers who strolled along the powder line, saying nothing. After the war the historic works were dismantled and the land parceled out for residential purposes among members of the. DuPont family. Alfred put in a bid for a parcel but it went to another member of the family at a lower price.

In June, 1919, a hundred Brandywine veterans, mostly pensioners, were invited to Nemours for a reunion. Sam Frizzle, John Thompson, Eben Jones, Gilly Mathewson, Frank Mathewson, Yaba Buchanan, Mike Maloney, Ed Bader, Henry Kane, Joe Corrado, Frank Bassino, George Seitz, William Horty, Benny Watson-nearly every man of them had a reminiscence to tell worthy of a place in a biography of Alfred I. duPont.

Alfred's political fortunes continued to prosper. In the spring of 1917 he addressed his attention to the municipal situation in 
Wilmington. Despite the family rebel's state-wide victories, the DuPont political machine deemed itself impregnable in Wilmington on local issues. When Alfred challenged this assumption some of his professional political advisers believed that he was overreaching himself. Nevertheless, Alfred entered William G. Taylor, an officer of Alfred's and William's Delaware Trust Company, as a reform candidate for the mayoralty nomination in opposition to the machine incumbent, Mayor Price. After a spirited primary campaign, Wilmington was amazed to discover that Price had won by only 132 votes out of 9482 - a majority for which the extraordinary competence of the machine's polling-place officials may have been responsible; at any rate the independents so claimed.

The Democrats nominated a Pennsylvania Railroad paymaster named John W. Lawson, a stratagem suggesting equally astute work on the part of Ed Davis, the ex-brakeman who had done so much to swing the union-labor vote to Alfred's banner. Mr. duPont came out for Lawson, seeking to duplicate the feat by which he had sent the Democrat, Wolcott, to the Senate in the place of Colonel Henry. This would require changing a larger percentage of the vote than in 19I6 when Colonel Henry had carried the city.

The city independents were loosely knit together in a body called the Voters Non-Partisan League, to which Ed Davis imparted a fighting spirit and Frank Allee a good grounding in practical political tactics. As a result Lawson became Wilmington's first Democratic mayor in years by a majority of $45 \mathrm{I}$ votes.

In quick succession Alfred used the Non-Partisan League as a spearhead in several fights for local reforms. The personnel of the Wilmington school board was changed, bringing in progressive men pledged to modernize the public educational system. The Wilmington Gas Company, which had long done about as it pleased, was forced to remove an arbitrary meter tax. The street railway company was defeated in an attempt to raise the fare to seven cents. Measures were taken against wartime food and rent profiteers.

Colonel Henry Algernon duPont was through as a political 
factor in Delaware. In bitterness he had withdrawn to his great estate of Winterthur on the Kennett Pike to devote himself to research on DuPont genealogy-almost too extensive and complex a subject for a man to tackle at 79. The family machine which so long had governed Delaware would have gone to pieces except for Coleman. Though his legal residence, a big old brick house at Ninth and Broom Streets, Wilmington, was usually shuttered and closed, Coly kept tab on things through Hastings and other political lieutenants. Not easily discouraged in his ambitions, Coleman still had his eyes on a seat in the United States Senate.

The next election for Senator would take place in I9I8. Shortly after the first of the year Alfred received reports that his old college chum's men were quietly active downstate. One of the Democratic incumbents, Willard Saulsbury, would be up for reelection. As a public official and as a man, Alfred had a good deal of respect for May duPont's husband. Yet Alfred wished to crown his political achievements by putting a man of his own party in the Senate to match the Democrat he had been obliged to put in, in I9I6. Moreover, he knew that to beat Saulsbury would require a united party. Coleman knew this also and prepared to demand the nomination as the price of union in the ranks.

Alfred could have defeated this move at one stroke by indicating a willingness to accept the nomination himself. For the third time, he declined to enter the race and issued one of his rare public statements:

"Any good Republican properly qualified to represent Delaware in the United States Senate will meet with my approval, but it must be clearly understood that he must not be dominated by any political machine or by any group of individuals.... The people of Delaware will in the future do the bossing. . . . Nominees must receive their nominations honorably. A repetition of the scandals of 1916 can only end again in disaster. . . This is a matter for the immediate consideration of the State Committee."

This punctured Coleman's boomlet. In great agitation the State committee called a "harmony conference" to meet in Dover. This remarkable gathering saw the persuasive genius of Frank Allee 
at its best. Rival political henchmen-the professionals who, after all the flowery tributes to high ideals have been paid, actually get out the vote and see that it is counted as cast-slapped each other on the back and strolled arm-in-arm to the Hotel Richardson bar. A State "harmony committee" was named representing all elements of the party: former Roosevelt Progressives; genuinely independent Republicans; opportunists who had joined Alfred to get on the winning side; case-hardened politicians who had done the machine's dirty work for years. A few days later, at the Young Men's Republican Club in Wilmington, Alfred addressed this diverse group.

Evincing nothing of the smooth conciliation Allee had shown at Dover, Mr. duPont spoke as an independent who conceded nothing. "The Independent Republicans stand for what is admittedly right-for clean politics and honest elections, for results expressive of the wishes of the people by the selection of officials desired by a majority of the voters." It was surrender, not compromise, for the machine. ${ }^{9}$

In the board room of the DuPont Company, ways and means of heading off Alfred were discussed. Under the name of John J. Raskob a call was sent out for a public meeting to consider a program of social reforms "on a scale never before attempted in this State." The result was the formation of an organization called Service Citizens of Delaware, calculated as an opposition to Alfred's Non-Partisan League.

Alfred's choice for the Senatorial nomination was a Wilmington attorney named William $\mathrm{H}$. Heald who had served two terms in Congress and had been brought back into active politics by $\mathrm{Mr}$. duPont's campaign for liberalism. Allee's candidate was Lewis Heisler Ball, a country doctor who had been in and out of Delaware politics for twenty years. On the eve of the State convention at Dover, Allee persuaded Mr. duPont to accept Ball. This gave Doctor Ball the nomination, and the hard work of Mr. duPont's organization, in November, I9I 8 , gave him victory at the polls by a majority of 1589 over Senator Saulsbury.

Having elected both of Delaware's Senators-one a Democrat and one a Republican-Alfred I. duPont was, in fact, the political 
boss of the State, respected and trusted by the best elements of the electorate, including those who would have preferred a bigger man than Doctor Ball in the shoes of Willard Saulsbury.

In February, I9r9, Alfred took leave of another family precedent by formally announcing his ownership of the Wilmington Morning News. For twenty-odd years the fact that DuPonts, collectively or individually, had controlled the press of Wilmington was about as much of a secret as the existence of the Delaware River. The notable feature of the current situation was not that Alfred duPont owned the News-which everyone knew-but that he admitted he owned it. Tardy as it was, this abandonment of pretense enhanced Alfred's reputation for forthrightness. Moreover, it was an excellent thing for the News and for the public causes it served.

Alfred's head filled with plans for his newly acknowledged property. A new press and linotypes were bought. Architects went to work to design a model home for a newspaper. Mr. duPont added \$1000 a month to the operating budget-not a lavish expenditure, but one which competent management could make go quite a way in a town the size of Wilmington. The News possessed competent management, which Mr. duPont let alone to a degree not always followed by non-professional newspaper proprietors. One of the few things he held out for, however, was the employment of a Washington correspondent. When the editor stuck to his contention that the money could be used to better advantage elsewhere, Mr. duPont apologetically overruled him, and, himself, paid the salary of the Washington man. At times Mr. duPont wrote editorials, some of them very pithy and to the point. He coined the masthead slogan "Right Makes Might," and, in all, changed a mediocre faction organ into a spirited, alert, crusading journal. Old-timers on the staff regretted that Roy Jones had not lived to play a part in the transformation. This beloved editor, whom Mr. duPont scarcely knew, had died in the influenza epidemic of 19r8. Though a good craftsman, his successor lacked the qualities which drape a man's memory with legend. ${ }^{10}$ 
The first signal victory in which the rejuvenated newspaper had a share was the Wilmington municipal election of I9I9 when the Independent Republicans elected William G. Taylor mayor.

An example of subordinating personality to principles was presented when the News got behind Pierre duPont's school crusade. The Service Citizens of Delaware, the social betterment organization which old-guard DuPonts launched to counteract Alfred's Non-Partisan League, had published a survey showing the backward state of education in Delaware. Then Pierre had come forward with an offer to defray half the expense of a hundred new school buildings. As Alfred also had been campaigning for improved schools, Pierre's action looked like an effort to steal the family reformer's thunder. On this assumption some of Alfred's friends in the Legislature started to oppose it. Alfred sent a note to the editor of the News to back up Pierre and to begin a campaign for legislation to modernize the State's educational code. ${ }^{11}$ Even with Alfred's support, Pierre's school program had hard sledding because many communities objected to paying their half of the cost of the new buildings. At length, however, the program went through, Pierre duPont spending, altogether, $\$ 4,000,000$.

One Philadelphia newspaper jumped at the conclusion that Alfred and Pierre had buried the hatchet. The fact was that, personally, they were farther apart than ever. The long-drawn-out conclusion of the suit over Coleman's stock promised to leave them that way.

In October, 1917, when the vote of the stockholders had left the disputed shares in the possession of Pierre and his colleagues, Colonel Henry duPont's Evening Journal offered the olive branch. Across four columns was spread an editorial in blackface type entitled:

"An Appeal to the Patriotism of Alfred I. duPont."

"There are many persons [the editorial read] who feel that you should lose no time in accepting as final the verdict of the stock- 
holders. Even men who think you have been mistaken in your views admit frankly that you have been a game fighter. They and thousands of others look to you to demonstrate quickly that you have been a game loser."

The editorial went on to say that should Alfred acknowledge the stockholders' verdict no one would be disappointed "except the lawyers," who had fared well enough already.

In the name of the DuPont Company, of Wilmington, of Delaware, of the people of the United States, of France and "the other Allied Nations," Alfred was asked to call quits and let the company devote its sole attention to winning the war. ${ }^{12}$

On the whole the plea was an admission of Alfred's moral victory, with the opposition crying for peace. Alfred was prepared to leave matters in that position and to do nothing more with the suit. His lawyers argued otherwise. An appellate court, they said, would surely invalidate the stockholders' election, and give Alfred a greater victory. John G. Johnson was dead, and Will Glasgow, for whom Alfred had developed a great liking, argued this view eloquently. At length Alfred gave in. The appeal took the form of a request to set aside the dismissal of the bill, which Judge Thompson had decreed after the stockholders' plebescite. A year later, in October, I9I8, the appeal was argued before Judges Buffington, MacPherson and Haight. One of his attorneys gave $\mathrm{Mr}$. duPont a glowing account of Glasgow's presentation. ${ }^{13}$

"I have little expectations," Alfred replied, "that the Court of Appeals will in any wise change the findings of the lower court. ... I believe that my original decision that it would be unwise to take this litigation to the Court of Appeals will be justified, though I hope to the contrary."14

On March 6, I919, the appellate bench made public its findings in an opinion written by Judge Buffington. When Alfred had said that he did not believe the higher court would change the findings of the lower, he meant that Judge Thompson's dismissal of the suit would be upheld. It did not occur to him that the Court of Appeals would concur only with that finding of Thompson's, while dissenting from practically all the others in which 
Pierre duPont's conduct had been so systematically condemned. Yet that was what happened.

Buffington differed from his contemporary on virtually every point, great or small, where Thompson had found against Pierre duPont and fellow-defendants. He acquitted Pierre duPont of any suggestion of fraudulent or undutiful conduct as an officer of the company.

On the initial question of Pierre's submission of Coleman's offer to sell 20,700 shares for bonus purposes to the Finance Committee meeting of December 23, 19I4, Judge Buffington found that Pierre had withheld no vital particulars of Coleman's offer. Being in favor of the offer, Pierre would have had no motive to conceal anything important, reasoned Buffington. Then he moved on to the crucial issue of whether the committee's action had constituted a rejection of Coleman's offer or the submission of a counterproposal with instructions to Pierre to bargain for a better price. Buffington found that it constituted a rejection, basing his opinion on the wording of the Finance Committee record even after admitting the corrections Alfred and William said should be made in that record. The court found that anything Pierre had done further to keep the general proposition alive constituted a new negotiation. Consequently Pierre's contention that the offer of December 23 had been turned down was held to be a fact. ${ }^{15}$

This was in contradiction of the understanding of Alfred and of William duPont and of the opinion of Judge Thompson who cited, as proof of nonrejection on December 23, the Finance Committee report of December 30 saying that Pierre had been asked "to take up the matter with Mr. T. C. duPont further." Judge Buffington construed this quotation as "a courteous way" of letting Coleman down easily. ${ }^{16}$

By this reasoning Judge Buffington concluded that as no agency existed for Pierre to continue negotiations, no violation of trust pertaining to such an agency could have taken place. ${ }^{17}$

Yet Pierre did keep the offer open after December 23. In Judge Buffington's view this constituted the new negotiation, indicative of Pierre's devotion to the welfare of the company. The court admitted the inexplicit nature of Pierre's letters to Coleman on the 
action of December 23. Nothing was said of rejection, but on the other hand hope was held out that the sale might yet go through. In this connection Judge Buffington took note of the affectionate personal relations existing between Pierre and Coleman. "Although Pierre regarded the offer as not accepted, it is quite evident that his effort was to keep Coleman [an ill man] from being rebuffed, and [so] induced Coleman to carry the offer along.".18

Coleman carried the offer along until January 15 when he withdrew it. In all that had preceded this act, the court found that "Pierre duPont was most earnest in his efforts and sincere in his purpose to carry out Coleman's plan.... He had done his whole duty as an officer of the Company." ${ }^{\prime \prime}$

On February ro, when Pierre told Alfred how matters stood and declined to turn over to Alfred correspondence with Coleman bearing on the subject, Pierre's act was "a matter of judgment and not a violation of duty." The correspondence was "personal" as well as "business" in character. As between intimates, Pierre had spoken of Alfred's attitude in terms which, had Alfred seen them, might have made him angry, thus affecting "the spirit of good-will which the welfare of the Company demanded should exist between its officials." ${ }^{20}$

Thus was buried Proposition Number One-Coleman's offer to sell 20,700 shares for distribution among deserving employees. Then arose Proposition Number Two-Coleman's offer to sell all his shares to any responsible purchaser. Proposition Number Two was a new thing entirely, without legal relationship to Proposition Number One. Yet the complainants sought to recover the stock involved in Proposition Number Two on the ground (in part) that P. S. duPont had acted as a faithless company officer in dealing with Proposition Number One.

The appellate court found that Coleman duPont had a right to sell his stock to whom he chose, and that Pierre duPont and the other defendants had a right to buy stock in the company from whom they chose and under such terms as they chose, so long as this did not conflict with the obligations they owed the company as officers or directors. In lengthy review of the purchase by the 
syndicate, Judge Buffington found that in no particular had such obligations been disregarded. ${ }^{21}$

In all, the opinion of Judge Buffington was more favorable to Pierre's point of view than the unofficial expression of Charles Evans Hughes.

The United States Supreme Court, denying an application for a writ of certiorari, ended the case. The fact that Alfred's confidence in lawyers was never again the same made no difference in his personal friendship with Glasgow.

Meantime Mr. duPont's ambitious commercial project, begun with the purchase of Grand Central Palace in New York City, was branching out. Considering the ultimate consequences of this adventure, the start of the story cannot be told in these pages with the fullness its importance warrants. All books and records of the corporations involved, remaining in Mr. duPont's possession after liquidation, have been destroyed. Little correspondence pertaining to the subject is to be found in his files. What follows is pieced out from fragmentary material, the controversial nature of some of which prohibits its presentation without verification, and that appears to be impossible.

Mr. duPont was not the first in the field with the idea of supplying the European market after the war. With this in view in 1918, two concerns were formed in New York-the Allied Industries Corporation and the Franco-American Constructive Corporation. Long on visions of quick profits, but short on capital to get their enterprises under way, the promoters of these corporations seem to have been a picturesque international lot. One gets glimpses of British, Canadian, French and Swedish financial soldiers of fortune, coupled with some Americans of the same stamp. Their needs were the common needs of all promoters: cash and a name which would inspire confidence. In Alfred I. duPont were both.

The steps by which Mr. duPont was persuaded to join with these speculators are not clear. But he did so early in 1918, becoming 
president of both corporations. Moreover, he induced William and Francis I. duPont to take places on the boards of directors. William P. Bonbright, a New Yorker of considerable means, and Myron T. Herrick, ambassador to France and an old friend of Mr. duPont, also were brought in. The active management, however, remained in the hands of the original promoters. With money supplied by Mr. duPont they began making contracts and buying supplies for export on a large scale. By midsummer, I918, when Mr. duPont had poured in about $\$ 2,000,000$, he felt the need of more light on how this money was being spent, as well as on the business backgrounds of some of his associates. To that end Alfred re-employed his old confidential secretary, James L. Dashiell, as auditor of the Franco-American and the Allied Industries corporations. ${ }^{22}$

Dashiell found the affairs of these concerns so chaotic that Mr. duPont decided to withdraw-at least from Allied Industrieswriting: "I have every reason to believe that the management ... . is trading on my name. ... An organization built on the name of any one person is on an insecure foundation." ${ }^{, 23}$

$\mathrm{He}$ did not withdraw, but after getting rid of some of the early promoters, consolidated everything in April, 1919, in a new company called the Nemours Trading Corporation. Meantime he had leased his Grand Central Palace to the Government as a hospital for returned wounded soldiers-a patriotic gesture which greatly interfered with his business undertakings. This involved opening offices in Fifth Avenue and hiring storage space all over the city to house the goods being bought for export.

The company was dealing in about everything under the sun. Forty separate departments were buying and selling-automobiles and accessories, shoes, ready-to-wear clothing, chemicals, food and so on. Although Mr. duPont's credit was good and his purchasing agents made full use of it, demands for cash were heavy, and it seems safe to assume that by the summer of rgrg his investment had risen to something like $\$ 4,000,000$. But money was also coming in. August showed an operating profit of $\$ 135,000$ and in September this promised to go above $\$ 200,000$. Reporting the good news to his cousin Francis, Alfred added: "It looks as if we will make a million dollars before the first of the year."24 
The good news turned out to be false, the operating profits mere optimistic accounting. Jimmy Dashiell brought this to light in October in a report revealing almost incredible stupidity and mismanagement. Reckless obligations, running into millions, had been incurred on contracts for goods. Creditors were clamoring for money and Dashiell was unable to ascertain, within a million dollars, the actual commitments of the company. On top of this Dashiell found ten trade acceptances, totaling $\$ 2,770,000$, which were due in four days. The bulk of this particular item represented the purchase of $1,000,000$ yards of obsolete cotton airplane cloth for which no market existed.

Moreover, the steady depreciation of foreign currencies was impairing the overseas market for salable goods. The result was more heavy demands on Mr. duPont whose cash reserve was exhausted, and the gusher which had supplied it during war years drying up as the DuPont Company faced the stupendous task of reorganizing its business on a peace basis. The immediate dividend outlook, however, was not as bad as might have been the case had not the company invested $\$ 50,000,000$ of its boom profits in General Motors stock. Though Alfred distrusted the investment as speculative, in 1919 the excellent performance of General Motors turned out an anchor to the windward for the DuPont Company.

Alfred was obliged to borrow to meet the needs of the Nemours Trading Corporation. Foreign money was going downhill fast. Between September and December, 1919, the German mark dropped from 4 cents to 2.08 cents, the Austrian kronen from 2 cents to 0.63. Currency of the Allied countries had begun to slide. In November Dashiell went to Wilmington with an urgent request for $\$ 300,000$. Mr. duPont handed Dashiell a check for the amount, saying:

"That will have to last."

On January 2I, I920, Dashiell received this letter from his employer:

"I have decided to liquidate the Nemours Trading Corporation. There seems to be no alternative, as its affairs are in a hopeless 
condition and the amount of additional capital required to carry it on is beyond my ability to furnish." 25

Mr. duPont conceded that if he could extricate himself with a loss of not more than $\$ 5,000,000$ he would be lucky.

The anxious summer of I9I9 had been spent at White Eagle, the Long Island estate completed the year before. Mrs. duPont's health was poor. She occupied herself with the manuscript of a book on which she had been working off and on for three years. The subject was her brother Edward's hobby-wine-making. Alicia described the process, as practiced in southwestern France, from the preparation of the soil before setting out the young vines to the proper temperature of cellars for the finished product.

In autumn the household returned to Nemours. It was a lonely, depressing time. Alicia's health did not improve and Alfred feared to leave her for more than a day at a time, despite the critical state of the affairs of the Nemours Trading Corporation. Edward Bradford assisting with the final revision, Alicia completed her manuscript, dedicating it to Myron Herrick. ${ }^{26}$ Christmas found her feeling somewhat better. On the other hand, the Nemours Trading situation went from bad to worse. Weary in body and in mind, Alfred decided to refresh himself with a vacation, before attempting to determine what to do about his costly commercial experiment. A trip to California was projected-to see the Ball family, of Balls Neck, Virginia. In the old days a visit to these happy people had always been a cordial to Alfred's spirits.

The events of the intervening years had scattered the family. Old Captain Ball was dead and his widow, two sons and a daughter were in southern California. The youngest boy, Ed, just out of the army, was a furniture salesman. Another, Tom, junior, practiced law in Los Angeles. He had repaid the \$200 Alfred had advanced to finish his education-something which had never happened to Mr. duPont before. The next-to-youngest girl, Jessie, was vice-principal of a large public school in San Diego. 
Although they had not met for fourteen years, Alfred and Jessie exchanged infrequent letters. For the most part Alfred's were couched in the old tone of jolly banter, through which shone an occasional flash of interior revelation rarely present, at this period, in his other correspondence:

"I have just returned from the Republican Convention in Chicago, which I attended more as an agent of Providence than from any desire to be there, and in this way wasted a week, caught a cold, used a good many words which should never appear in print and returned home even more disagreeable than I had hoped.... What I really am in need of, and what I have been seeking for the past half century, is a word beginning with ' $s$ ' and ending with ' $y$,' pronounced by some archeologists 'sym-pa-thy." "27

With his wife on the station platform to bid him goodbye, on January 3, 1920, Alfred left Wilmington with his stepdaughter, Alicia, wiring Jessie Ball the hour of their arrival at San Diego on the evening of January 7. Miss Ball was at the station to greet her old friend. After so many years it was a happy meeting, naturally. Mr. duPont asked Miss Ball to join him at luncheon on the day following.

Miss Ball had no more than reached the hotel at which she made her home than the telephone rang. The message was from Alfred I. duPont to the effect that his wife was dead and that he was taking the next train East.

This tragic news Alfred had received immediately on his arrival at the Hotel del Coronado where he had planned to stay. Other telegrams sent in care of the train in which he sped westward had failed to reach him. The particulars of Alicia's death could be stated with merciful brevity. The evening before she and Mrs. Francis I. duPont had taken a train for Charleston, South Carolina, to attend a debutante party for a young relative. Stricken during the night, Alicia had been carried from her stateroom and before noon she had breathed her last at a hospital in Charleston.

Alicia was buried at Nemours beside her infant son and daughter. Dean Robbins of the Cathedral of St. John the Divine, in New York, brought a choir of fourteen boys. The burial service 
was read by an Episcopal rector, Charles Bratten Dubell, formerly a powdermen's clergyman at Carney's Point, and one Protestant whom Mr. duPont rated an equal of the Catholic priests he had known on the Brandywine.

Deeply religious and a constant reader of the Bible, Mr. duPont knelt to pray beside his bed each night before retiring. These supplications were addressed to the God of no particular creed. Not until May 7, 1915, had Mr. duPont been confirmed in the Episcopal Church. He said it was done then to set an example for Alicia, junior, and little Denise. Another reason probably was his personal liking for the Right Reverend David H. Greer, the bishop of New York. Bishop Greer presided at the confirmation which took place in the Cathedral of St. John the Divine. Immediately after the death of his wife, Mr. duPont drew plans for a chapel as an addition to Nemours. He intended that the mansion should be used, after his death, for charitable purposes. He stipulated that Protestant, Catholic or Jewish services could be held in the projected place of worship. Mr. duPont's looming financial difficulties halted work on the chapel, however, and it was never finished.

Among the letters of condolence received after Alicia's death, perhaps the least expected was one from Coleman duPont which struck something like the old tone of intimacy once prevailing between these cousins. Coleman explained his delay (of three weeks) in writing by saying that he could not be sure that Alfred would care to hear from him. Yet he felt that he must chance an intrusion, so sincerely did he regret Alfred's bereavement. If there was anything whatever he could do, he hoped Alfred would say so, for in that case Coleman said he would like to come and see his cousin.

Ten days later, when Coleman duPont's youngest son was suddenly taken by death, Alfred returned a generous response to this letter. ${ }^{28}$ 


\section{CHAPTER XX}

\section{His Back to the Wall}

I

BEFore Alfred I. duPont could take steps to wind up the costly affairs of the Nemours Trading Corporation, another surprise came in the form of a bill from the Government for $\$ 1,576,015.86$ for additional tax on Mr. duPont's r915 income. This was an upshot of the change in the corporate architecture of the DuPont Company whereby the new E. I. duPont de Nemours \& Company had been formed. Each holder of a share of stock in the old company had received two shares in the new corporation. Alfred's allotment was 75,534 shares which, on advice of counsel, he had reported as a nontaxable stock dividend. Now the Government declared it taxable.

The demand caused a further reshuffling of Alfred's immediate plans. An effort to scrape together a contribution toward the endowment of the Massachusetts Institute of Technology was abandoned.

"I cannot begin to tell you how sorry I am," he wrote the president, Doctor Richard Maclaurin, "not to have been able to participate in this wonderful work but ... I am busy trying to arrange to keep out of jail."1

Mr. duPont filed with the Collector of Internal Revenue a claim in abatement of the tax, alleging the assessment improper and irregular. It was hoped that this action would, at least, prove a measure to gain time in which to make headway against the larger problem of the Nemours Trading involvement.

Here two fundamental factors presented: (I) the amount of the corporation's liabilities, and (2) the course to be taken to meet them. 
The question then was whether Mr. duPont should personally assume the liabilities, or whether the company should go into bankruptcy. Clearly the latter course would save Mr. duPont money. He would then lose only what he had put into the companysome $\$ 5,000,000$.

This situation was gone over at a conference attended by Alfred and William duPont, Charles W. Mills and Robert Penington. Mills was the active head of William's and Alfred's Delaware Trust Company; Penington, Alfred's Wilmington attorney. Mr. duPont said that as president of the corporation he was morally liable and therefore would assume the obligations.

"It was my name that gave the company its credit standing," Alfred added ruefully. "Whatever his other failings, no duPont has yet sought the protection of the bankruptcy laws. I am not going to be the first."

William applauded this sentiment but said that his cousin should bear in mind that the sum of the liabilities had not been determined. They might greatly exceed current estimates. Alfred replied that, nevertheless, he would pay the just debts of the corporation. ${ }^{2}$

Mills and Penington were instructed to round up claims, cancel contracts in process of performance, and, in every direction, make the best compromises possible.

They had no trouble rounding up claims. As the word spread that Alfred I. duPont was personally standing back of the obligations of the corporation, demands for money rained on the two agents. Some came from most unexpected sources. Former officers and employees of the Nemours Trading Corporation and its predecessors-the Franco-American Constructive and the Allied Industrial corporations-including some of the original promoters long since paid off and dismissed, came forward with bills for alleged personal services, or breach of contract. Within a few weeks the situation was so serious that Alfred took counsel with William A. Glasgow, Jr., the attorney who had brought the DuPont stock suit to its disappointing conclusion.

Notwithstanding his error of judgment in appealing that case, Will Glasgow was a very able lawyer. After a quick look at the 
tangled situation, he saw the paramount need of ascertaining a definite, or fairly definite, figure as to the aggregate of the demands which Mr. duPont had said he would regard as his personal debts. Of course this should have been done in the first place, before Mr. duPont's announced willingness to pay everything himself had offered the temptation to submit extravagant claims. At the rate claims were coming, Alfred might have to pledge every security he owned to meet them.

It was the old story of what so often happens to easy money. During the war boom Mr. duPont's income had reached a peak of more than $\$ 500,000$ a month. His prime interests and first energies preoccupied with cleansing Delaware politics and the prosecution of the stock suit against Pierre, he had started this commercial venture as a side line for the employment of idle capital. The results were almost incredible mismanagement, overextension and, with the disappearance of war-time powder profits, distress.

"I am very troubled," wrote Glasgow, who was not an alarmist. "At nearly every interview I have on the subject some additional liability of yours comes up."

Mr. Glasgow tried to compute-as of July I5, I920-the liabilities for which Mr. duPont already had put up security. There were $\$ 5,000,000$ in bank loans- $\$ 4,000,000$ of which was with J. P. Morgan \& Company on which Mr. duPont was paying 9 per cent in interest and service charges. Bonds on attachment suits totaled $\$ 1,280,000$. A guarantee of $\$ 1,000,000$ had been posted on contracts. Mr. Mills had spoken of needing $\$ 600$,00o to settle "sugar matters in France." On top of this was the 1915 income tax dun, which Glasgow put down at $\$ 1,650,000$.

These items, footing up to $\$ 10,030,000$, did not represent the full extent of Mr. duPont's financial troubles, however. Mr. Glasgow mentioned a dispute which had grown out of the setting up of the capital structure of the Nemours Trading Corporation. "And in addition suits are being constantly brought [against you] where attachment may be secured."

The lawyer said that "nothing whatever should be done in any circumstances that would add to your personal liability." Better to let the Trading Corporation go into the hands of a receiver. 
Glasgow said that he knew that Mills did not agree with this conclusion, but he asked $\mathrm{Mr}$. duPont to give it very careful thought. ${ }^{3}$

Three weeks later Glasgow's doubts had grown concerning the usefulness of Mills, either as an adviser to Mr. duPont or as a liquidator of the stranded corporation. "Something new develops every time I take this matter up. . . . Suits now pending against the corporation ... [involve] an undetermined liability, which may run high." After seven months on the job, Mills was unable to say what Mr. duPont ultimately would have to pay. The lawyer admitted his own inability to determine this. Again he brought before Mr. duPont the suggestion of throwing the company into bankruptcy. ${ }^{4}$

The strain was telling. After a sleepless night Alfred went to Philadelphia to meet Glasgow. With chin up and his eye flashing, the hard-pressed financier told the lawyer that so long as Alfred I. duPont could raise a dollar he would never enter a bankruptcy court. Mr. Glasgow was asked to shape his course accordingly.

The effort drained the last reserves of duPont's nervous strength. Nearly collapsing outside the lawyer's office, he made his way to the Broad Street Station by feeling the sides of the buildings with his fingers. ${ }^{4}$ But a fighting spirit-the spirit that had burgeoned 20,000 pounds of brown prismatic powder a day from the old Brandywine yards in 1898 -was aroused. Personally Alfred began to explore some of the claims against him and to write Glasgow in this vein:

"I will try to get up the early part of the week to see you. It is merely a question of how much or how little blackmail they will settle on."5

To meet the constant calls for money Mr. duPont hypothecated DuPont stock with a market value of $\$ 12,000,000$. This was half of what he owned. He sold all his Liberty Bonds and laid up his yacht. But the spontaneous generosities of a lifetime were not to be 
discarded like an old coat. In July, 1920, when Jimmy Dashiell, a useful man in the liquidation, was offered a better position, Alfred insisted he take it and bought Dashiell a Stradivarius violin in appreciation of his services.

"If I had my ears for two hours a day," he told his old employee, "much as I have on my mind, I'd spend one of those hours either playing a violin or listening to someone else play."

As news of his distress spread, perhaps a hundred persons came to him with offers of help. Perhaps ninety-eight of these, like the powderman's widow who brought her savings sewn in a corner of her shawl, had too little to offer to be of any use: Alfred duPont was one millionaire with comparatively few millionaire intimates. Of those who could offer something commensurate with the emergency, the first was Cousin William. Willie had put about $\$ 300$,ooo into the Nemours Corporation. Alfred consented to regard this obligation as canceled.

The other offer came from Coleman. Politely thanking his cousin, Alfred said he hoped to be able to pull through alone. Judging from what he wrote his daughter, Madeleine, in Germany, Alfred would have gone to a poorhouse before he would have accepted help from Coly or from Pierre.

Yet the story spread that Pierre had, indeed, come to the rescue of his distressed cousin-and in handsome form. This report has persisted through the years. It has appeared in print, and many of the family, including two of Alfred's estranged children, believed it implicitly. Six million dollars was the figure usually mentioned as the amount of Pierre's loan. The origin of this baseless story is obscure. $^{\text {7a }}$

Coleman's advances pointed clearly to a desire for a reconciliation. At the moment Coleman was much in the eye of New York finance. His credit was high and it is possible that he had some notion of doing his cousin an unsolicited good turn when he said to Percy H. Johnston, president of the Chemical Bank:

"Alfred is the most brilliant member of the DuPont family."s

One reason for Coleman's friendly gestures may have been concerned with the fact that Alfred had found his zeal for clean Government in Delaware too expensive a luxury to maintain during a 
period of retrenchment. With Alfred out of active politics, Coleman's long-standing aspiration to go to the United States Senate stood a chance of revival. With Alfred under obligation to Coleman, that chance would be enhanced.

On January 19, I920, just before announcing his momentous decision to close out the Nemours Trading Corporation, Alfred had written Frank Allee:

"I do not like this constant cry for money. It is against my principles to conduct campaigns along these lines. I knew it was necessary originally to spend a good deal of money to throw off the shackles of serfdom which had been thrown around the Republican voters by the old Republican machine, but it is not my intention to continually pay out money to keep them destroyed. I am rather inclined to think that the Republicans in this state do not wish to be free. If they wish to be slaves, they must be slaves of someone other than myself."

In a later reminiscence of his political career, Mr. duPont made his point more briefly:

"A buyable man has to be bought over and over again."

On January 24, Mr. duPont told Allee of his decision "to give up the political game altogether," and instructed the henchman to pass the word along. "There is nothing in ... [politics] but wear and tear, mud-slinging and an awful lot of expenditure." One example of expenditure was indicated when Mr. duPont asked Allee what he could do about repaying $\$ 100,000$ advanced by the Delaware Trust Company and $\$ 40,000$ by Alfred personally. ${ }^{11}$

Mr. duPont's decision was sad news for Republican independents, buyable and otherwise. Edward Bradford, Jr., wrote his brother-in-law in alarm that unless something were done immediately the control of the Republican organization would revert to "corrupt hands" with "Bazaza \& Co." in the saddle. "Bazaza" was a code word for Coleman duPont. Alfred replied: "I do not think your fears well founded. Bazaza and Company are just about as near dead ducks in this state as anything above ground could be."12

In June, 1920, Mr. duPont sold his Morning News for \$190,000, and began giving away his six country papers which had cost 
him about what he received for the News. ${ }^{13}$ Though the identity of the ostensible purchaser of the News does not appear in records surviving in Alfred duPont's files, control passed into the hands of Pierre. In a general about-face of editorial policy, the once liberal journal began to recommend Coleman duPont for the Senate.

Intimates like the Francis I. duPonts commented on how well Alfred bore up under the troubles which threatened his fortune. A buoyancy of spirit which in the old days had made him the life of social gatherings began to return. It was as if twenty-five years had rolled away. Attorneys and co-workers in the Nemours Trading liquidation also took notice and attributed the change to Mr. duPont's determination to assume personal command of the fight to avoid bankruptcy, a fight which he accounted as in vindication of his personal honor as well as of his business reputation.

This was putting the cart before the horse. The fact was that Mr. duPont's spirits had begun to mend in March, I920, after a trip to New York, which was not, like so many of his trips there, on the dismal affairs of the Nemours Trading Corporation. The object was to meet Jessie Ball, who had come East on six months' leave from her school duties in San Diego. This vacation, long planned, had been deferred by the illness and death of Miss Ball's mother. A couple of times during the spring Mr. duPont had Jessie and her sister Elsie (Mrs. Bayard W. Wright, of Arlington, New Jersey) at Nemours for week ends. In May he took them to Cherry Island with a family group which included Alfred's brother Maurice, Mr. and Mrs. Francis I. duPont and Edward Bradford, Jr.

After this Mr. duPont said, "Let's have a Balls Neck reunion," and sent invitations to the members of the Harding and the Ball clans who were in the East. They came to Nemours in June: Mrs. Fanny Ball Harding, the mother; "Little Flo" (Floride Harding, then Mrs. Robert Adams of Baltimore); "Miss Tom" (Rebecca Harding, then Mrs. Charles Adams of Baltimore, she and her sister having married brothers); Mrs. Wright and Jessie Ball. Little 
Flo brought a baby in arms and Elsie Wright her ten-year-old son, Tom. Everyone had a marvelous time and Miss Tripp, chaperone of young Alicia Maddox, said to Rebecca Adams:

"Why, I didn't know Mr. duPont could joke so!"14

That summer Alfred resumed a study of "speech reading," which he had attempted some years before without making a great deal of progress. This he had accorded a shortcoming of his own, rather than a defect in the system, for he had endowed a school of speech reading in Philadelphia, founded by his teacher, Cora Elsie Kinzie. Miss Kinzie's method was broader than lip reading; the pupil took his cue from expression of the entire face of a speaker. Mr. duPont did better than on his earlier trial, though he never became a facile speech reader, owing to defective eyesight. Children he could nearly always understand, however, their language being simple. With "Little Pechette," his stepdaughter Alicia, he could converse almost perfectly, though, alas, he could not hear her play or sing. This engaging girl, with a wit as quick as her mother's, was very talented in music. In September Alfred sent her to France, attended by Marie Tripp, to study under Jean de Reszke.

"Caruso tried her voice before her mother's death and pronounced it splendid," Alfred proudly wrote his daughter Madeleine. "The child was quite set on coming out in opera this Winter in New York but I decided that she was being urged to do so by her singing teacher and that she should not appear in public until properly trained."15

The old warm comradeship between Alfred and his oldest daughter was being re-established through the medium of long letters. He would write eight or nine pages. Congratulating her on keeping up her music, he asked that she encourage it among her children. By her German marriage Madeleine had three boys whom the grandfather had never seen.

In the fall of 1920, Alfred wrote Madeleine that he hoped to go to Europe that winter, business affairs permitting. Then, without giving any reason for the change of inclination, he began to speak of a trip to California and possibly Hawaii.

California it was. Shortly after the first of the year, Alfred set 


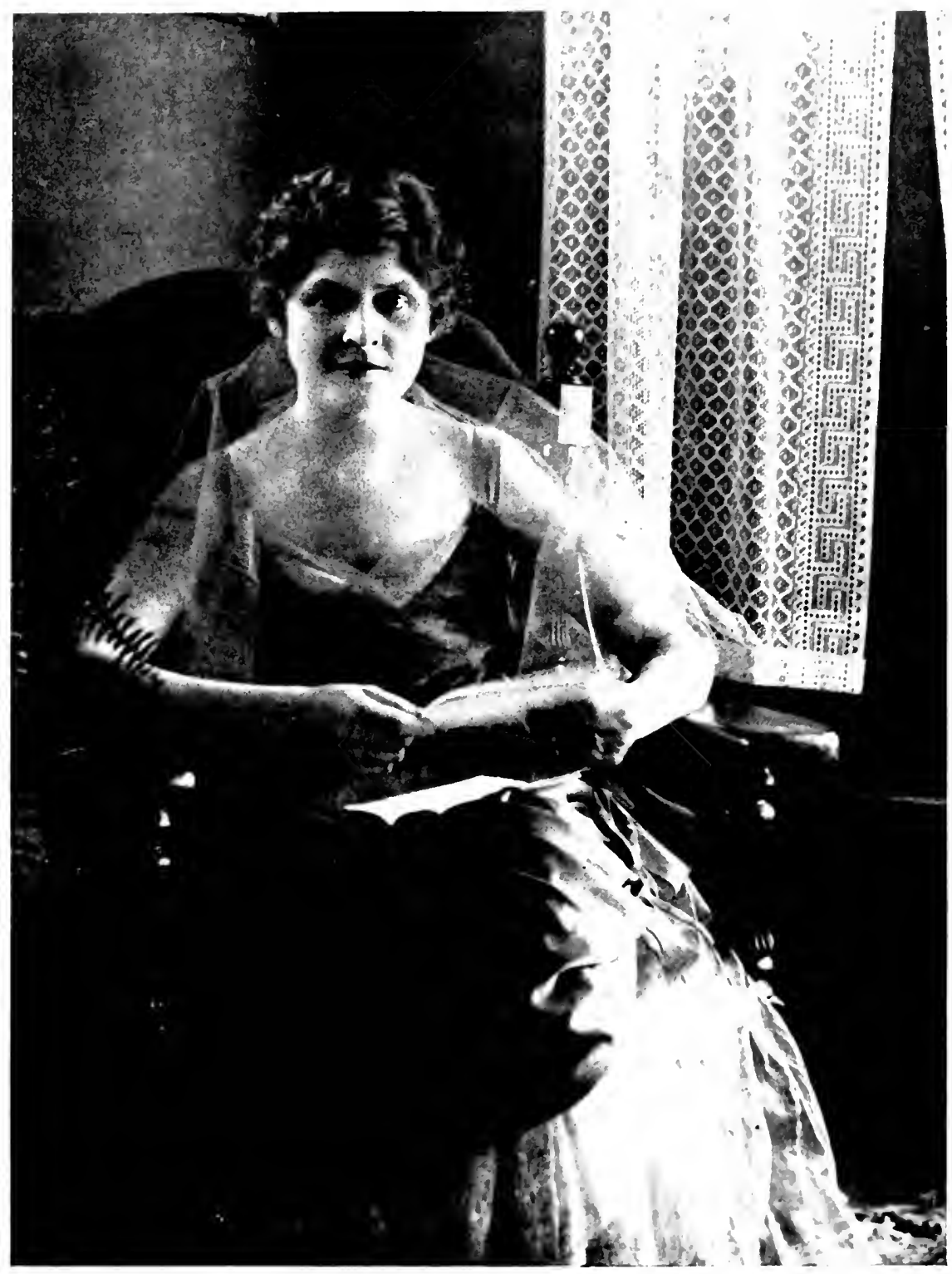

Jessie Dew B.ill

A photograph made in California, in 1919, about eighteen months bufore her marriage to Alfred I. duPont. 

out, accompanied by his valet, a portly, privileged Englishman named Thomas Horncastle, and probably the only person in Delaware aware of the object of the journey. On January 22, I921, Jessie Dew Ball and Alfred I. duPont were married in an Episcopal clergyman's study in Los Angeles.

This surprise made good newspaper copy everywhere. Most of the space was chivalrously devoted to pleasing accounts of the bride who had made such a wonderful "catch," her notable Virginia ancestry being detailed at some length. Mr. duPont, a familiar fixture with the press, was passed over cursorily as "the internationally famous financier and mechanical genius, with more than 200 patents on powder-making machinery to his credit." "There had been rumors," added one account published in Wilmington, "which coupled the name of Alfred I. duPont with that of Pauline Frederick, motion picture actress, but the wiseacres proved entirely wrong." 16

Though Miss Frederick was a friend of Coleman duPont, Alfred had never even seen her likeness on a screen. Another fact, clouding somewhat the Cinderella-like prospects held out for the bride, which the papers did not get quite straight, was that the internationally famous financier stood in danger of losing every dollar he possessed.

The "wretched affair"- to use Alfred's words ${ }^{17}$ —of the Nemours Trading Corporation had gone from bad to worse.

Only the woman Alfred I. duPont had married, and Will Glasgow, knew how near the brink he was.

"All I may be able to keep of what I now seem to own," Alfred told Jessie Ball before he had made his declaration of love, "is Cherry Island. After all I've said about wealth being a mere trust in the hands of those who possess it, I'd be a poor sport of a man not to be able to part from mine a little in advance of normal expectations and begin over again without recriminations against others or bitterness of heart."18

The cottage at the Island, which Mrs. Alfred I. duPont thought 
might become her home, consisted of seven rooms. The bride did not overlook the fact that housekeeping there would be more in line with her prior experience than at Nemours, with its seventyseven rooms.

Secrecy concerning this critical state of Mr. duPont's affairs was, however, imperative. Any other course might have spread panic among creditors-the times, themselves, were panicky-and a rush to be the first to collect. Alfred's assets could have withstood no such stampede liquidation. More than one person, knowing the facts, could have ruined Alfred duPont had he wished to do so; and Alfred was afraid that some of them did so wish. With things in this delicate balance, a stout heart and a confident air, as well as astute management, became the assets which, on Alfred's side, might turn the scale one way or another.

Practically all determined company obligations had been paid or guaranteed-amounting to some $\$ 7,000,000$. But this did not take account of undetermined claims which might run $\$ 5,000,000$ more, or several damage suits. Nor did it include the Government's demand for back income taxes of $\$ 1,500,000$. And most important it failed to draw attention to the alarming shrinkage of $\mathrm{Mr}$. duPont's available capital.

In April, 1920, Alfred's 75,534 shares of DuPont common had been worth $\$ 25,000,000$ in a strong market. In April, I92I, they were worth $\$ 9,000,000$ in a weak market. What in retrospect is called the "little" post-war depression was under way. The DuPont Company had not escaped. During the lush years of easy money, Pierre had put $\$ 50,000$,000 of the company's profits into the General Motors Corporation. Now General Motors was in the grip of hard times, coupled with complications flowing from the speculative proclivities of its picturesque founder, William C. Durant. To protect DuPont's fifty million, Pierre had relinquished the presidency of the home company to his brother Irénée and had gone to Detroit to try to get General Motors out of hot water. Pierre and his family followers were feeling none too comfortable. A continued decline in DuPont stock or the omission of a dividend might pinch them, but it would sink Alfred first.

Mr. duPont bent every effort to the task of reducing the: most 
oppressive of his loans. Nemours Trading goods were let go at distress prices. These sacrifices enabled Alfred to pay J. P. Morgan \& Company $\$ 1,000,000$, reducing his loan with them to $\$ 3,000$,ooo. "But," as he wrote Glasgow, "we are unable to get any reduction in the interest rate. They are still charging us $9 \%$... a Shylock proceeding. ... I know the DuPont Company is paying $6 \%$ and $61 / 2 \%$ for their money, $6 \%$ in Philadelphia and $61 / 2$ in New York. I borrowed $\$ 100,000.00$ a month ago in New York for $6 \%$, so it is evident that this $9 \%$ is extortionate." 19

Three months later-in September, 192I- $\$ 500,000$ went to Morgan who consented to reduce carrying charges on the $\$ 2,500$,ooo balance to 7 per cent. So happy had Alfred been since his marriage that he was apt to magnify his good fortune in other spheres. "You see," he wrote Glasgow of the Morgan situation, "I am on easy street so far as my loans for next year are concerned." fidently he launched a quiet campaign to sell 25,00o DuPont shares for 120 (they would have brought 330 eighteen months before), pay off Morgan altogether and move to the sunny side of Easy Street.

Glasgow also worked on the projected sale-without success. The depression deepening, the market had dried up. Alfred himself put out a cautious feeler, through Irénée, to see if Pierre would care to increase the holdings of the Christiana Securities Corporation, successor to the DuPont Securities Corporation of recent memory. Nothing came of this, either. ${ }^{21}$

In November the United States Supreme Court passed on a test case, instituted by a small DuPont Company stockholder, on the question of 1915 income tax. The decision was against the stockholder. This meant that the Government would be back at Mr. duPont to meet his assessment.

Easy Street had come to an abrupt dead end. "I shall have to pay $\$ 2,000,000$ more," Alfred wrote his sister, Marguerite Lee, "not a pleasant prospect with the obligations which I have already to bear. ... If I refuse to pay, they may issue a distraint warrant ... [and] grab Nemours and anything else they can lay their hands on."22

An excursion to California with his bride hastily canceled, Al- 
fred turned once more to the chore of raising money. "Sorry," he wrote his daughter Madeleine, enclosing a draft for 33,333 marks-approximately \$III, "but I am not giving any expensive Christmas presents this year. ... Do not permit anyone to send me anything but a Christmas card. That is all that is needed to bring love and affection.",33

The only bright spot on the fiscal ledger of that dark year was the fourteen-story Delaware Trust Building Alfred and William built at Ninth and Market Streets for their bank. Almost filled with tenants as soon as opened, it returned a profit even in the hard times prevailing. And for Alfred there was still another satisfaction. He could go to the roof and look down on the mere twelve-story DuPont Building a block away.

One thing which had made it easier than otherwise for Alfred to give up politics early in I920 had been the conviction, expressed to Eddie Bradford, that Coleman duPont was a dead duck. Of this Eddie was not so sure. Mr. duPont took no part in the campaign. This gave the watchful old-guard men a chance to get a few places on the State slate, among them the gubernatorial nomination which went to a young insurance broker of Dover, named William D. Denney, with no public record to speak of, one way or another.

Before many weeks Alfred began to suspect that Eddie Bradford had been correct. As time passed this grew clearer. On May 6, I92I, he wrote his sister:

"I understand there is a scheme on foot to put Coleman in the Senate by Governor appointment. The plan is to get the present Democratic Senator, Wolcott, to resign by offering him the Chancellorship of the State, which appointment is made by the Governor next month, and then to have the Governor appoint Coleman. Senator in his stead. While it is merely a rumor, it comes from a good source and I do know that Coleman was in Washington the other day and saw Wolcott. Coleman has recognized for sometime that he has no chance of being elected to the Senate by the people so long as I was alive and kicking. ... . [In I9I6] when the Colonel tried to make the grade and I threw him out, 
there was a distinct understanding, or so I am told, between the Colonel and Coleman that the Colonel would serve only one half the time and resign, and have the Governor appoint Coleman instead. That was really my chief reason for throwing the Colonel out. I do not see how to meet this new threat of having the state represented by Coleman. Possibly the rumor was invented, but it sounds too reasonable to ignore."

That such a bargain should seem reasonable to Alfred testifies to the disillusionment a comparatively brief brush with practical politics can visit on a man of sensitive instincts. Coleman duPont epitomized the influcnces from which Alfred had gone far to liberate Delaware. Josiah Wolcott owed his seat in the Senate to Alfred I. duPont. Accustomed as Delawareans were to political chicanery, many did not believe Wolcott would have the effrontery to turn over that seat to Coleman duPont. They thought Alfred's money troubles had soured his judgment.

On May 24, Governor Denney announced his judiciary appointments. Heading the list was Josiah Wolcott, to be Chancellor, the highest judicial office in the State.

So it was true, after all. A storm of protest burst. Seventy members of the New Castle bar signed a petition against Wolcott's confirmation by the Legislature. Even Henry duPont's Evening Journal came out against the deal, and Alfred and the querulous old Colonel exchanged friendly letters-their first communication in years. Much less satisfactory was the behavior of L. Heisler Ball, the other man whom Alfred had put in the United States Senate. He gave to the Morning News an interview praising T. C. duPont.

Amid the wildest scenes in the Delaware Legislature since the heyday of Addicks, Wolcott was confirmed by three votes. To a former follower who tried to explain his vote, Alfred was bitter:

"You will regret this to the end of your life.... You have chosen and there is no turning back, as you will find out."

Wolcott exchanged his Senatorial toga for the ermine of the bench. Denney appointed Coleman, innocently vacationing in Colorado, to the succession, completing what the Philadelphia Record labeled "Delaware's Shameful Deal." Some unidentified com- 
mentator, however, supplied the phrase that has survived in the argot of local politics: "Delaware's Dirty Deal."

Disgusted with both parties, Alfred said he hoped someone would start a new one. The remark brought to honest liberals hope for the return of Alfred I. duPont to politics. ${ }^{26}$ The fact that the term to which Coleman had been appointed would expire the following year gave point to this speculation.

Alfred did not appear to be tempted. Sunday mornings he liked to reserve for repairing the clocks at Nemours-and there must have been fifty of them, collected from many parts of the world. A family precedent for this hobby existed. Long before he had risen to the confidential council of the King of France, Alfred's great-great-grandfather, Pierre Samuel duPont de Nemours, had learned the watchmaker's trade.

One afternoon Mr. and Mrs. duPont were visiting the Glasgows' country place near Philadelphia. Spying a clock which was not running, Mr. duPont said:

"That's too good a timepiece to use for an ornament."

Taking out his pocketknife he went to work, oblivious to the world for an hour. When he had finished the clock was ticking. ${ }^{27}$

Another time Mr. Glasgow showed his client a pump which was not working right. With an enthusiasm which shines through four pages of dictation, Alfred narrowed down the problem to the need of a new pumping head for which he offered specifications:

" 16 " stroke, Deep Well Pumping Head, complete with flywheel, counter-weights, air compressor, gear guards, motor supports, with discharge below the base, $4^{\prime \prime}$ check valve and air chamber, one $3 / 4^{\prime \prime}$ $\mathrm{x}$ I6" brass cylinder with ball valves, $280^{\prime}$ of $21 / 4^{\prime \prime}$ sucker rod, one $3^{\prime \prime}$ suction strainer, one 3 H.P. single phase, 60 cycle, 220 volt, I200 R.P. M. motor and one pressure switch for operating the pump from the pressure in the pneumatic tank. Pump to handle I5 G.P.M. against a total head of $315^{\prime}$.

"I have used this particular deep well pumping head in several places on my property. The only weakness was the chain drive and this has been corrected by the substitution of gears." ${ }^{\text {"2s }}$

What a treat to turn from money or from politics to so clean a subject as a deep-water pump. 


\section{CHAPTER XXI}

\section{A Crisis Left Behind}

I

OF THE Christmas of I92I, when Alfred I. duPont had announced that he could give no expensive presents, he wrote, on December 27 , to his daughter Madeleine:

"I think it may well be termed the happiest [Christmas] in my life. We had only a few guests, probably eight or ten, and a lot of children, which made everything very gay and bright."1

For the most part the young ones were nieces, nephews and cousins of Jessie Ball duPont. Never forgetting that his mother was a Virginian, Alfred liked their polite Southern manners and was gratified to see Denise making especial cronies of Johnny and Jessie Gresham Baker, children of his wife's sister, Belle. Later playmates of Denise were the brood of James Dolan, the second chauffeur. And from Mrs. Dolan the child was learning to scramble eggs and mind babies.

As his old fun-loving nature returned, Alfred could not resist a little sport at the expense of the Dixie atmosphere his wife's guests brought to Nemours. One of his sayings was that he noticed how the F.F.V.'s like to fall on the v.f.f. which Jessie set before themv.f.f. meaning "very fine fodder."

The new year came, fraught with somber possibilities, which Alfred did not mention in his domestic report to Madeleine:

"Quite a large dinner Saturday night. The house was full of guests, I think sixteen or eighteen, and we had a jolly evening and all danced the New Year in.... The festivities [lasted] until the 
wee hours and as the next day was Sunday and followed by another holiday on Monday, everybody got all the sleep they wished. Fortunately I am able to get along on three or four hours sleep a night, so am always up by six or seven in the morning irregardless (as the Irishman said) of what time I retire. ...

"No, I think that your way of having supper after the theater decidedly proper and I cannot imagine anything nicer than a glass of good beer and a sausage as a nightcap, but unfortunately here there is no place to go except home for such delicacies. I was able and had sufficient foresight to put under cover all the hooch that I shall probably want in my life and which also will suffice Jessie afterwards, as neither of us consume very great quantities."3

Mr. duPont's cellar, representing the accumulations of years, had cost him about $\$ 100,000$.

Later in life Alfred often said to intimates that, looking back over the years since his marriage to Jessie, they seemed almost too happy to be real. This feeling shows in a letter to Elsie Wright on the eve of his first wedding anniversary:

"As I am somewhat maudlin today, I will simply say that after one year with The Brid [one of his names for Mrs. duPont], I must confess that she is a million times more wonderful than I had hoped. Think of spending one whole year with a girl and never a cross word or having the slightest misunderstanding or receiving anything but constant loving, thoughtful devotion! However, such is the case and at times I have to scratch my cocoamat, alias my luxuriant locks, in order to realize that I am in the world, or, as the Prohibitionists say, am living still."4

As soon as the holiday guests had departed, Mr. duPont braced himself for the blow he knew was coming from the Bureau of Internal Revenue. Paring expenses further, the mansion of $\mathrm{Ne}$ mours was closed, except for one bedroom suite, and the staff of servants reduced to Thomas Horncastle and a watchman. Mr. and Mrs. duPont took their meals at the DuPont Hotel in Wilmington.

On February 3 the Government rejected Mr. duPont's claim in 
abatement of the additional assessment on his 1915 income tax, demanding immediate payment of $\$ 1,826,158$. This was the original bill of $\$ 1,576,015$ with interest added.

"Just where the funds are coming from, at the present moment I cannot see," Alfred wrote his sister. "However, I may get some light on what seems to be a hopeless situation a little later on."

The Government issued a blanket warrant of distraint against all property of the debtor, Alfred I. duPont. This included Mr. duPont's unpledged securities, if any, his home, his automobiles, his watch-everything he owned, short of household furniture to the value of $\$ 300$ and a few other items.

The maneuver had been anticipated. Before a United States Marshal could serve the warrant, Mr. duPont obtained a Federal court injunction protecting his property until the case against him should be reheard on its merits. To this end Alfred filed a bill claiming that the statute of limitations had run. This was argued on March 3, I922. "While everybody who heard Mr. Glasgow," wrote Alfred, "is confident that I will win, my own experience with the Judicial mind makes me hesitate to hope."

However, he expected an early decision-an expectation renewed almost daily for more than three agonizing months.

In his heroic efforts to raise money, Mr. duPont came to a decision which must have cost him a greater wrench than anything he had sustained thus far. He offered for sale the whole of his common stock holdings in the DuPont Company, writing, on January I6, to Thomas Cochran, a Morgan partner:

"Do you know of anybody who would be interested in acquiring my 75,000 shares of duPont Common Stock? I have decided that if I could realize a proper price for this stock it would be not only to my best interest but to the best interest of the Company to sell it.

"As you know I have no representation on the Board of Directors and there is no possible chance of my securing any....

"My feeling is that were this block of stock in the hands of some outsider, so to speak, it would be the means of bringing a new influence on the Board of Directors, of which, as I have frankly stated to you, they are in great need. To be perfectly frank, the Company is in my opinion suffering from very bad management. 
The injury so far done is more or less superficial and can be readily corrected by the inauguration of a proper policy . . . without thought of personal friendships or relationship."

Alfred duPont's back was to the wall, fighting a fight which he could have avoided were bankruptcy compatible with his notion of honor. What changes disillusionment had brought since the winter day in 1902 when, powder-smeared and inspired, he had risen in the midst of a defeated family clan and launched the battle which kept the old firm from passing into "outside" hands.

The writer was frank to say that another reason motivated his wish to sell:

"I am anxious to clean up my obligations and go into constructive work of a kind which interests me."

Mr. duPont did not say what he thought a "proper price" for his holdings, observing only that "the present market price, which is around 75, means nothing."7

Mr. Cochran tactfully replied that to a prospective purchaser the market value would mean a great deal. ${ }^{8}$

Contending that the market had been artificially depressed, Alfred argued that the stock was worth its book value of 280 . Nevertheless, he intimated that he would take 140, remarking obliquely: "I would like nothing better than to see your Firm purchase it," because of the "splendid effect" this would have "on the destinies of the duPont Company.",

The Morgan firm was not in the market. This, said Cochran, left two courses open: to organize an outside group which might take over Alfred's block; or to try to sell to the insiders-Pierre and his brothers. ${ }^{10}$

Swallowing hard, Alfred consented to an approach to the insiders. The result was an offer, from Irénée on behalf of the Christiana Securities Corporation, at "roughly Eighty-Two or Three Dollars a share." The stock was then selling at 90 in the open market.

Alfred rejected the offer at once. No less than 150 would he take: 
The stock market had strengthened and Alfred believed the hardtimes-bargain period near its end. "In view of the better conditions of the General Motors Corporation," DuPont stock would soon be selling for 200. Even the 150 offer "does not hold indefinitely." "1

This talk did not budge Irénée who not only withdrew the 82-83 offer, but recalled somewhat extraneously, that Alfred had often spoken of his holdings as a family heritage. In view of this Irénée suggested that Alfred set aside a part of them for his son. Irénée had the discrimination to surmise that the suggestion might seem impertinent. ${ }^{12}$

Through April the market continued to improve, though it was still a question whether 20,000 or 25,000 shares of DuPont could be unloaded without depressing it; and the tax decision was due any day. Mr. Glasgow advised Alfred to have the money ready in case of an adverse ruling, for the attorney saw no hope of pulling political wires to advantage in an effort to delay or to escape payment. Secretary of the Treasury Andrew W. Mellon had begun a regime famous for handsome refunds to large income tax payers. A friend at court was always useful in such matters, however, and Alfred had none. Though Senator Coleman duPont stood close to Harding and his approachable inner clique, Alfred believed Coly would "do everything he can to prevent a revision [in my favor] and I am not sure that Ball [Mr. duPont's gift to the Senate in 1918$]$ is not working with him."'13

On May 18, 1922, Alfred sold 20,000 shares of his common at par and so got in hand \$2,000,000 for taxes. Glasgow expressed "great relief." Greater relief came on June 13 when the Federal court held for Alfred, finding that the statute of limitations barred collection of the tax.

Meanwhile the economic state of the country had continued to better. The "little" depression was passing as quickly as it had come. America was on the march toward the peaks of the too prosperous Twenties. A spurt in DuPont common, which Alfred had anticipated, caught the prophet unaware by its suddenness. Had he held his 20,000 shares only a fortnight longer they would have brought $\$ 3,000,000$ instead of $\$ 2,000,000$. A factor in this 
spurt was the fact that on May 24-six days after Alfred soldDuPont stock was listed on the New York Stock Exchange-a circumstance of which Alfred was given no advance notice by his cousins in the company.

No tears were shed over that spilled milk. Although the Government appealed the tax case, money was on hand to meet an adverse decision, as well as assets to cover all Alfred's obligations. Feeling like a free man once more, Mr. duPont and Jessie sailed for England where Alfred gave his stepdaughter, Alicia, in marriage. Two years before, on the ship which had carried her to France to put the finishing touches to her operatic studies, Alicia had met a Rhodes scholar named Harold Sanford Glendening, the son of a Connecticut mail carrier. She was seventeen, he twenty-four. Believing the girl too immature to know her mind on the subject of marriage Alfred, and then Jessie, had vainly tried to get her to wait a while.

The wedding over, Mr. and Mrs. duPont forgot their cares in a glorious holiday.

His hearty voice audible throughout the marble chamber, Thomas Coleman duPont had taken the oath as United States Senator on July 26, 1921. Though he looked his fifty-seven years, seldom had Coly's six feet four, and his masterful, big-nosed face set him off to better advantage. In ability the junior Senator from Delaware was almost the equal of his looks, which is to say considerably above the average of his colleagues. Once in his slippery climb to the eminence now attained he had laughingly remarked that he would like to be in the Senate just long enough to reorganize it into an effective legislative body. "I'd leave it in the hands of salaried persons competent to run it right." ${ }^{.14}$

Senator duPont attempted neither this nor any other reform, standing near the top of the list of absentees on roll call. Yet Coly was not idle. Inconspicuousness seemed merely a policy, and perhaps a good policy: only sixteen months remained for the smell of the Dirty Deal to die down sufficiently for Coleman to face the 
electorate of Delaware in case he wished to retain his seat. Being an appointed, rather than an elected, Senator, Coleman's term would expire the day after the next election, November 6, 1922. Then Delaware would vote to fill two Senatorial vacancies: one for the remainder of ex-Senator (now Chancellor) Wolcott's term, that is from November 7, 1922, to March 3, 1923; and one for the regular term ensuing, March 4, I923, to March 3, 1929.

Coleman meant to run for both the short and the long term. This would require considerable managing. As the Philadelphia Record remarked: "The restoration of his [Coleman's] former effective and smoothly-running party organization promises to be a laborious and intricate task. Alfred I. duPont is still in the background."15

Fortunately for Coleman this background was a distant one, where the average observer could get no more than a bare glimpse of Alfred, preoccupied as he was with his struggle to stave off financial ruin.

Coleman's machine would have to be rebuilt so as to gain a good many Democratic votes, of the type that could be machinecontrolled, to offset the independent Republican votes he would lose whether Alfred took part in the campaign or not. The foundation was laid by taking care of most of the local politicos, including Democrats, who had made possible the confirmation of Wolcott in the judiciary. They got political appointments for all except one who seems to have been put on the pay roll of the DuPont Company. ${ }^{16}$

In February, 1922, while Coleman pursued his quiet policy of affability toward everyone, Alfred and Jessie were sojourning at the Flamingo Hotel in Miami Beach. One evening they were playing cribbage in the lobby when, out of the corner of an eye, Mrs. duPont saw a tall man approach and stand beside them. In a moment Alfred glanced up.

"Hello, Coly," he said without enthusiasm, but took the proffered hand. "I want you to meet Jessie."

With all the aplomb in the world, Coleman greeted Mrs. duPont as "Cousin Jessie," and drew up a chair. Presently he reached for the pack of cards and did a few tricks. Mrs. duPont didn't 
think much of the tricks. She told Coleman she had learned most of them in her teens. ${ }^{17}$

The following May, John Raskob, who was a Democrat, sent out on his personal stationery invitations to a buffet supper at his country home. The object, he said, would be to have a good time and to meet "important people" from Delaware and elsewhere who believed T. Coleman duPont should be returned to the United States Senate. Such an invitation went to Alfred I. duPont, who declined with studied politeness, wishing Mr. Raskob and guests "a very pleasant evening."

That party touched off the campaign, the DuPont-controlled press (anti-Alfred faction) trumpeting it as a spontaneous voiceof-the-people demand for Coleman's election. Alfred wrote a woman friend:

"Personally I think he is going to have a hard fight. I am not interested in the outcome. I have presented the gentleman to the voters absolutely in an unvarnished condition and if they want that kind of representation in the United States Senate, they can have it."19

What sickened Alfred was the presence of a few of his late liberal lieutenants at Mr. Raskob's board. Caleb Rodney Layton, whom Alfred had sent to the House as a shining apostle of reform, had entertained the diners with a speech on Coly's virtues.

On Memorial Day the formal opening of the Washington Me. morial Bridge over the Brandywine in Wilmington revived pleasing memories of Alfred duPont's public career. For years the extravagant, ring-ruled State and City Governments had failed to replace the antiquated structure spanning the stream for which Alfred had an almost personal affection. When he became the power behind the throne, Alfred organized a commission to construct a new bridge, and became its chairman-the only public office he held during his political ascendancy in Delaware. The result was a beautiful bridge. Its dedication brought a heavy turnout of Alfred I. duPont independents, which seemed to bode no good for Coleman's well-chaperoned aspirations.

Late in August Mr. duPont came home from Europe rested, 


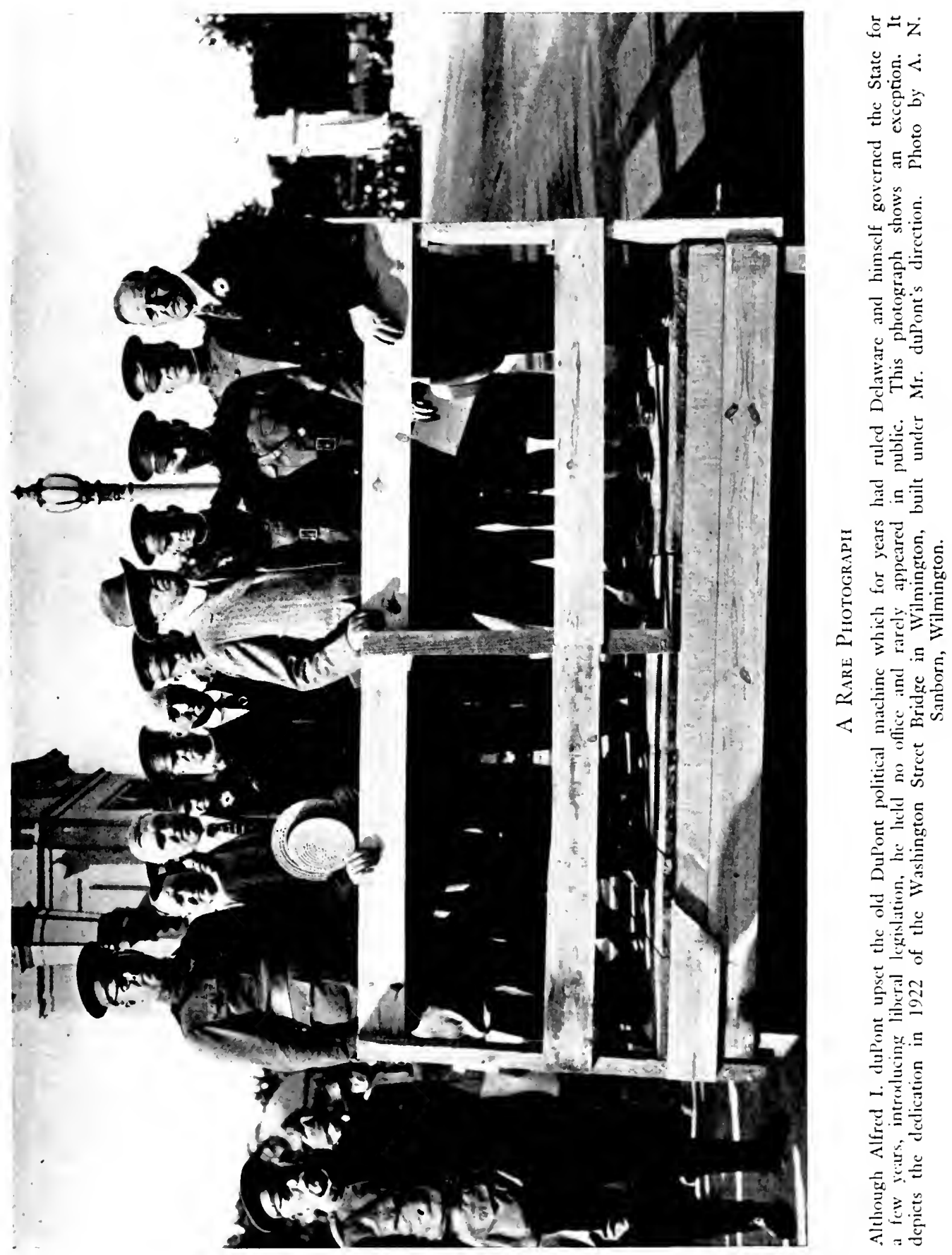


feeling fine and with the crisis of his money troubles behind him. Another reason for self-satisfaction was the political aspect: Coleman was, in truth, having a hard fight. He faced as near to a popular uprising of the citizenry as Delaware had witnessed since the Civil War. Without money, without leadership and without organization worthy of the name, enough independent Republicans resented the Senator's pretensions to keep his affluent campaign managers in a state of nervous prostration. One country newspaper which Alfred had not yet given away-the Newark Ledger, run by ex-brakeman Ed Davis-and the Dover State News which he had given to Frank Allee's son, were fighting Coleman hammer and tongs.

Alfred's return caused a flutter. He gave an interview to a reporter for the Wilmington Sunday Star:

"The people know the record of T. Coleman duPont. They know the record of Caleb R. Layton. I have nothing else to say; and I will not, through contributions or otherwise, do anything that might split the Republican Party."

But with the battle surging about him, it was more than Alfred could do to keep his hands off entirely. Within a week he had seized control of the Republican organization in rural New Castle County, throwing out all the Coleman members but one. He continued to meet the extraordinary deficits of the Newark Ledger which kept raining blows on Coleman. In return Coleman's papers unleashed upon Alfred a fusillade of hot shot which equaled anything in Alfred's active days in politics.

And still Alfred called himself a noncombatant, too deeply disgusted with politics to be anything else. That men whose support he had candidly bought should have gone back to Coleman when Alfred had closed his purse caused neither surprise nor dismay. But the sight of such a man as William G. Taylor, the banker whom Alfred had made reform mayor of Wilmington, leading a parade for Coleman, tended to confirm Alfred duPont in the conclusion that he would be happier out of politics.

Coleman's Democratic opponent was Thomas F. Bayard, Jr., of distinguished Delaware lineage. He was also a DuPont in-law. 
While not classing Bayard among the intellectual giants, Alfred said he was "decent." "I hope he will be elected."21

And this came about-by the narrowest of margins: 60 votes for the short term and 325 for the long.

Alfred did not disclaim credit for Bayard's victory; and it seems certain that had Alfred remained in Europe, Coleman would have won. "No one really thought T. C. could be unhorsed," wrote Alfred in response to a telegram of congratulation, "for the reason that he apparently had all the cards. He had all the money; he had all the [daily] papers, both Republican and Democratic because ... [they are] owned by the DuPont Company. ... His defeat ... dragged down the whole Republican ticket save three or four of my personal friends."

With the hope that sprang eternal, Alfred expressed the opinion that the "cancer" of DuPont control in Delaware "has been removed for all time."22

When Mr. duPont told Thomas Cochran of Morgan's that he wished to dispose of his company holdings and engage in "constructive" work elsewhere, opportunities were not lacking. Any rich man is deluged with applications which fall in two classes: (I) opportunities, so-called, to make more money, and (2) solicitations to give away what he has.

Mr. duPont read and personally answered every letter which was addressed to him. In 1922 he declined the following opportunities to employ his capital:

Purchase a Pennsylvania farm on which the owner had spent $\$ 100,000$; back an inventor who had an idea for a new type of storage battery; buy a shoe factory; back the inventor of a hack saw; back a grape fruit grower who promised roo per cent profits; invest \$100,000 in Los Angeles real estate-"better than 100\% profit in two years"; buy a Pennsylvania coal mine; invest $\$ 50,000$ in a Philadelphia foreign-trading house; buy a $\$ 100,000$ estate in Maryland; buy a pitchblende mine in Colorado; buy a chain of ninety grocery stores; buy an estate in Westchester County, New York; help out an artificial leather factory; buy a gold mine 
"secretly discovered" in Rhode Island; back the inventor of a device to make airplanes safer; buy a California ranch; back a theatrical stock company; come to the aid of a New Jersey bolt and die plant; manufacture a machine for mining platinum and gold; manufacture a new automobile lamp; buy an oil well in Mexico; buy a daily newspaper in Philadelphia; manufacture a new electric lighting device for airplanes, automobiles, etc.; buy a hotel in Ocean City, Maryland; buy a hotel in New York City; buy a dairy; buy a silver mine in Montana; buy a bookstore; buy a mine in Colorado, nature not stated; manufacture a hydraulic shock absorber for Ford cars; invest in a Philadelphia bank; buy a stock farm, of which the owner frankly stated: "This is no get-richquick scheme." ${ }^{23}$

These solicitations were received from strangers. Probably as many others-excluding appeals for charity-came from persons he knew. Paul duPont asked for help in manufacturing and marketing a new automobile, to be called duPont. Alfred liked the car, mechanically, but said that the automobile business of the future would be in the hands of great institutions like General Motors, Ford and Dodge-as Paul duPont was to learn to his sorrow. ${ }^{24}$ Besides, Alfred had no funds for such a large undertaking. He was still far from clear of the results of having plunged into another "constructive" enterprise with too much else on his hands and about which he had known too little.

Yet when a Virginia cousin of his wife, Robert Harding, showed up with an idea for a machine for peeling tomatoes, Alfred yielded to his weakness for inventors. Greatly enlarging the scope of the projected device and revolutionizing it mechanically, Mr. duPont spent many happy days at drafting board and bench when the financial clouds were darkest. In the fall of rg2I an experimental machine was finished at a cost of $\$ 50,000$. It would scald, peel and can tomatoes, doing the work of seventy persons. Young Harding was sure his fortune had been made and Alfred himself scarcely less enthusiastic. He wrote his daughter:

"The next consignment [of food] that I send you will include a few cases of these tomatoes for your inspection and criticism."' 
After further improving the complicated machine, Alfred formed the Clean Foods Products Company and built a plant at Laurel, Delaware, which began operation in 1922 . When it did not produce the results expected, Mr. duPont got his wife's brother, Edward Ball, to come from Los Angeles and take over the plant at a salary of $\$ 5000$ a year. Ball ran the Clean Foods Products Company during the canning season of 1923 . Then he advised his brother-in-law to close the plant and write off his $\$ 250$,ooo investment. The Harding-duPont tomato peeler and canner was a classic example of the machine age outdoing itself. Ball disclosed that thirty of these remarkable contraptions could can the country's yearly pack of tomatoes. Theoretically they could do this. Actually it would be impossible to get the tomatoes to the machines before they spoiled. Tomato canning would remain a decentralized industry, the work being done near where the tomatoes grew.

Ed Ball was glad to finish with the Clean Foods Products Company because he wanted to get back to his furniture business in California which had paid him $\$ 18$,ooo a year. He had left it because his sister asked him to; those Balls stood together. Only the fact that Ed had his fingers in other things besides the canning plant kept him from returning to the Coast right away.

One of these items was a filling station, which Mr. duPont had come to own in this way. With the financial skies clearing, Alfred had begun the construction of a new yacht, Nenemoosha. He asked Ball to buy a pier site on the Christiana River in Wilmington. Ball got the property for $\$ 15,000$. The pier would utilize only one end of the land purchased. Ball saw the other end as a marvelous fillingstation location. Ed Ball had owned or run a number of things in his time, but never a filling station-a fact which did not deter him for a moment. He sounded out the big oil companies. None would take the site. So Ed began building a station on his own-or rather Mr. duPont's own. When half done the Gulf people offered to take it over, paying a bonus of $\$ 50,000$. Ed went to Mr. duPont, thinking he had struck a pretty good bargain.

"Gulf?" queried Alfred. "No, tell 'em Andy Mellon hasn't enough money to get that site."

Ball finished the station. The first month's clear profit was $\$ 500$; the first year's $\$ 14,000$. 
To Mr. duPont this denouement had the charm of novelty, to say the least. The filling station was not, however, the most important of Ed Ball's side-line activities. Gradually the busy brother-in-law from the Pacific slope got in his mind a picture of the status of the Nemours Trading Corporation liquidation. Mr. duPont thought it a rosy picture. By comparison with the situation of a year or eighteen months before, this was true. Then Mr. duPont faced liabilities totaling millions which threatened to swallow everything he owned. These liabilities still stood; only now Mr. duPont had assets with which to work them off. Ed Ball had never dealt in such fancy figures. But he had been a trader all his life and did not see why the underlying principles of a big trade should greatly differ from those of a little one. He believed that Mr. duPont's honesty had been taken cruel advantage of. He believed settlements had been made at inflated figures all down the line, and that some of the men who had represented Mr. duPont's interests were grossly incompetent at best.

Without confiding even to his sister his real thoughts on the subject, Ed decided to pick something simple to begin on. Alfred was paying 7 per cent on the Morgan note which had been reduced to $\$ 1,000,000$. Receiving permission to try for a lower rate, the California furniture salesman took a train to New York and went to the First National Bank. He had never been inside the building before, and had never in his life exchanged a word with a New York banker, big or little. This was made up for in short order by talking to two of the biggest at the same time-Messrs. George F. Baker, Sr. and Jr. He departed with a note for $\$ \mathbf{I}, 000,000$, at 4 per cent, for Mr. duPont to sign.

Then Ed went to Boston to bargain over the White Shoe Company's claim against Mr. duPont for $\$ 1,500,000$. This affair was enormously complicated. It had dragged out for three years. First Mills, then Penington, then Glasgow had tackled it in Mr. duPont's behalf. Though Glasgow's painstaking investigations into the contracts supporting the claim afforded a good bargaining basis, the White Company, through its attorneys, a distinguished Boston firm, stood pat on the original $\$ 1,500,000$. But Ball's trading instinct told him they would not stand on that figure much longer.

In a two-day session with the lawyers, he got the claim cut in 
half-to $\$ 75^{\circ}, 000$. Rejecting this compromise, Ball reappeared in Boston a month later and got the amount down to $\$ 630,000$. This, said the attorneys, Ball could take or leave. He left it, and returned to Wilmington. Three weeks later the lawyers invited him back to Boston. This time the cut was to $\$ 490,000$, which Mr.duPont paid. ${ }^{26}$

\section{5}

When he came to Mr. duPont in 1923, Edward Ball was an apparently confirmed bachelor of thirty-five-stout, short and losing his hair. He dressed carelessly and approached any company with the easy confidence of a seasoned traveling salesman used to a different crowd at a different hotel every night. The raw edge of this breezy address to life was tempered somewhat by a trace of Virginia manners, an ability to listen as well as to talk, and a store of information which suggested considerable reading in day coaches. Still, dressing for dinner at Nemours with no one else present except his sister and Mr. duPont bothered Ed; and he never got used to a servant unpacking his satchel. On the road he ate in hotel coffee shops, continuing the practice in later years after he became an owner of hotels.

Alfred had known Ed Ball from the time he was eleven years old and liked the rough-and-tumble way he had come up in the world. The fact that Ed was the only member of the Ball tribe without what is called a good schooling weighed with Mr. duPont. Having sent more youngsters through college than he could count, Alfred had come to the conclusion that in too many cases this had been worse than a waste of a rich man's money; it had been a waste of youthful years. At thirteen Ed had quit school to work. Nights he and a cousin watched an oyster bed Captain Ball owned in the Chesapeake, with eyes peeled for oyster pirates from the Maryland shore-a Winchester ready for long-range warnings and a shotgun for short. Daytimes Ed hunted for black walnut logs, which brought a good price.

When the family moved to California, Ed clerked in a hardware store; prospected for a year in the California hills for semiprecious stones; ran a grocery in partnership with an ex-cowboy 
from Texas; became a salesman, successively, of cash registers, furniture, automobiles, and lawbooks. He starred at augmenting the libraries of lawyers, at one time or another covering most of the territory from the Mississippi River westward, including Canada and Alaska. Dissolving the sales-resistance of barristers furnished Ed with a formula for threading the complexities of the legal mind which in the future (vide White Shoe Company case) was to serve him well. The immediate reward, which Ed Ball still wore, was a pair of gold cuff links inscribed "Perfect Score Club," the gift of his firm, the Lawyers Cooperative Publishing Company, of Rochester, New York.

After his discharge from the army in I9I9 Ball went to work selling furniture for Barker Brothers of Los Angeles, the biggest house on the Coast. Within fifteen months Ball and two partners had taken over the office furniture division on a profit-sharing basis. Ball was making $\$ 1500$ a month when he left to run the canning factory for $\$ 5000$ a year.

After the settlement of the White Shoe Company claim, Alfred offered Ed $\$ 10,000$ a year to stay. He accepted and in two years was raised to $\$ 25,000$. In his flush days Alfred duPont had paid that much to men (Eddie Bradford, for instance) just because he liked to have them around. Though Ed Ball earned his salary if any employee of Mr. duPont ever did, Alfred also liked to have him around. They hit it off together.

"Had a little stag boating party down the Bay yesterday. Most of the men were in the elderly class, like myself, but Ed and I were the only ones who did justice to the rum bottle, deviled crabs, chicken salad, ice cream, etc. After we had each devoured four deviled crabs and then proceeded to superimpose upon the same several plates of ice cream, there was a unanimous vote taken that we could not possibly survive the night. This morning we both made affidavit to the effect that we never had a finer night's sleep." 27

To one who had suffered as many personal disappointments as Alfred, this budding comradeship promised much. As he wrote to Ed's brother, Tom: 
"Ed is surely a nice boy, the most livable human being, next to the Brid, that I know. Being a Ball, he is naturally a gentleman and excuse me from living with anybody less. He is a little pigheaded-another Ball feature (also a duPont feature, I being the exception) - so it is necessary to bat him over the head with a club once in a while; but he has a well-balanced cabeza and is a fine, loyal, hard worker, as tenacious as a bull dog on a tramp's pants-all qualities appealing most strongly to me.",s

Ed took over the management of Alfred's Wilmington real estate, exclusive of the Delaware Trust Building-worth about $\$ 600,000-$ converting a loss into a profit. This was done without breaking Alfred's rules which prevented the raising of rents of deserving tenants who could not pay more, and, in many cases, the collecting of any rent at all. The Nemours Trading tangle was wound up, anticipated remaining liabilities cut nearly in half. In all Alfred paid about $\$ 12,000,000$, which was $\$ 7,000,000$ more than he would have paid had he turned the company over to a receiver in bankruptcy. With the end in sight Glasgow confessed:

"I must say that at times I was almost desperate about the situation.",29

Ball wanted to put auditors on the Nemours books.

"For what purpose?" asked Alfred.

"To send some crooks to the pen."

"Don't do it, Ed. Time will take care of that. Retribution will catch up with them."

Mr. duPont was right. All three men whom Ball suspected died miserably, two of them almost penniless. ${ }^{30}$

The I9I5 income tax case went to the United States Supreme Court which gave Alfred the right to pay the assessment and sue to recover it. Alfred compromised with the Bureau of Internal Revenue which knocked off $\$ 200,000$ in interest, Alfred waiving the right to sue to recover. Accordingly, he paid $\$ 1,694,207$. Then, invoking the Supreme Court decision, he filed a claim to recover, not on the 1915 assessment, but on the assessment for 1918, involving the same principle. No lawyer thought this up for Mr. duPont. In fact Glasgow said the claim would be rejected. Cousin William also advised against it. Consulting his attorneys, he refused to join 
A CRISIS LEFT BEHIND 36I

Alfred in a claim which he said would only be turned down. Mr. duPont said that might well be, but he was so sure his interpretation of the Supreme Court opinion was right that he meant to have a test of it. For three years Alfred's claim for a refund on his I9r8 tax traversed the tedious channels of official procedure and then was allowed by the Collector of Internal Revenue. On January 22, 1926, a refund of $\$ 1,461,979$ plus $\$ 499,618$ interest was ordered. ${ }^{31}$

In high humor Alfred waved his Treasury draft for nearly $\$ 2,000,000$ under Cousin Willie's nose. Had William joined in, his check would have been for $\$ 800,000$. Now it was too late. The statute of limitations protected the Government. . 


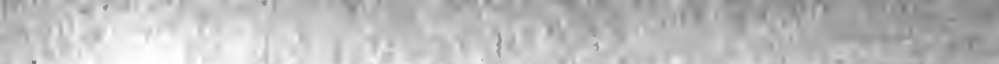

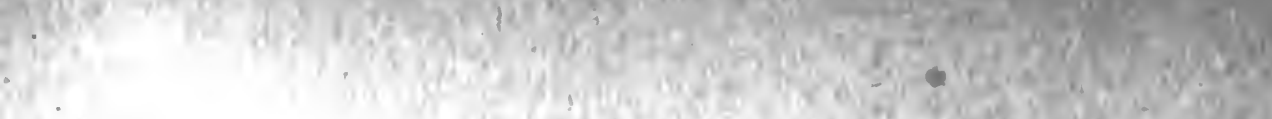

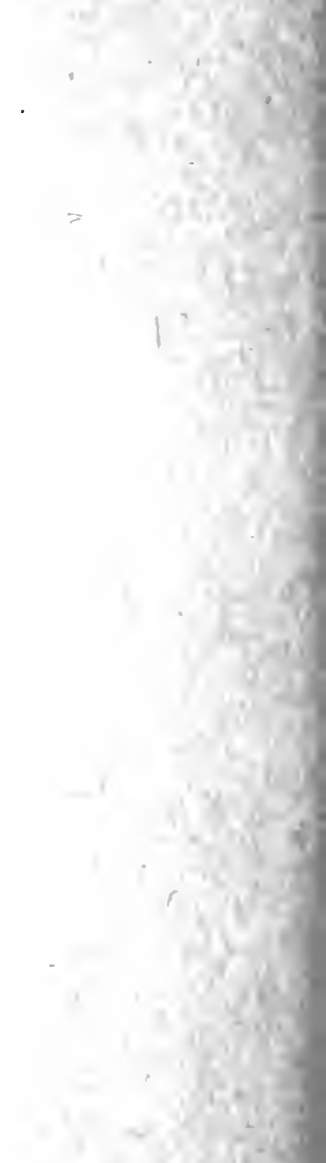

(19.5)

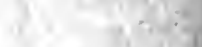

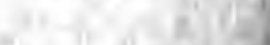




\section{PART SIX}

ClimaX OF a CAREER 


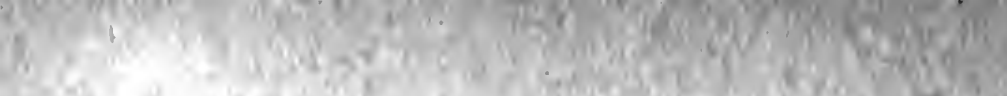

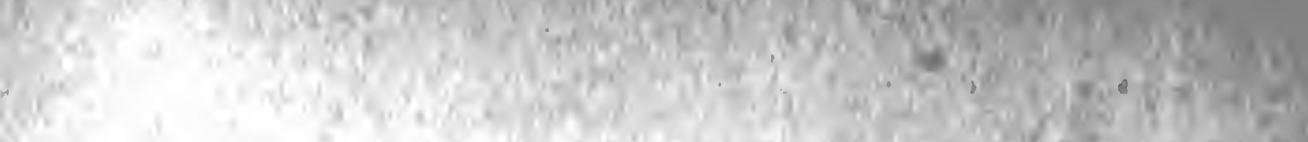

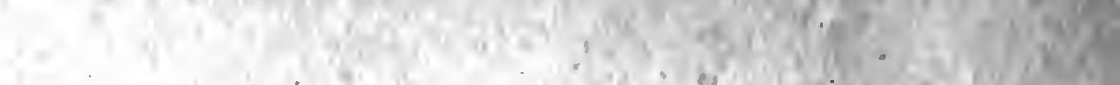

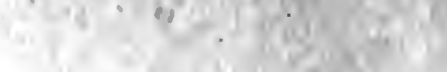

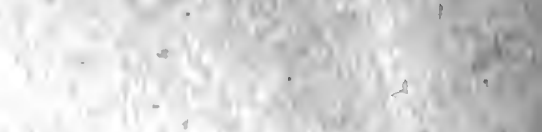

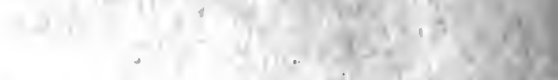

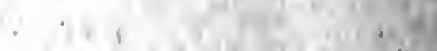

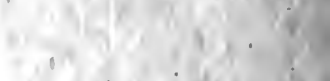

$$
\begin{aligned}
& 4 \cdot 3, \div 45 \cdot 5
\end{aligned}
$$

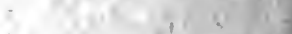

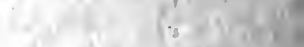

$$
\begin{aligned}
& \text { the }
\end{aligned}
$$

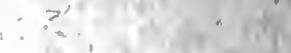

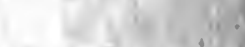

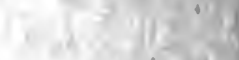

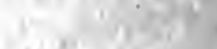

$$
\begin{aligned}
& \text { A P' . }
\end{aligned}
$$

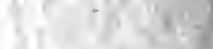

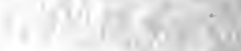

$$
\begin{aligned}
& +4+4=0
\end{aligned}
$$

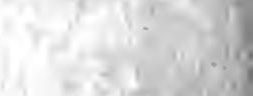

$$
\begin{aligned}
& \left(\frac{5}{1}(1,+4)\right.
\end{aligned}
$$

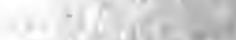

$$
\begin{aligned}
& \operatorname{lig}^{2} \mathrm{~h} / \mathrm{k}
\end{aligned}
$$

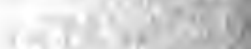

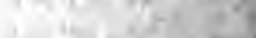

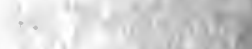

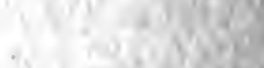

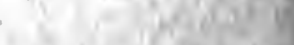

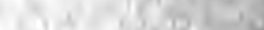

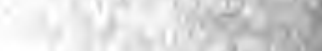

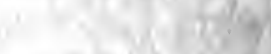

$$
\begin{aligned}
& +2 x^{2}+20
\end{aligned}
$$

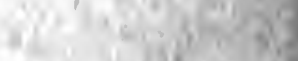

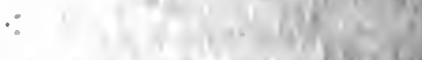

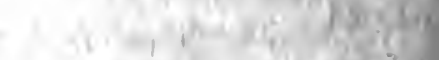

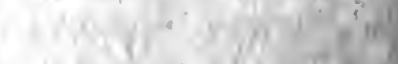

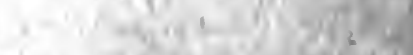

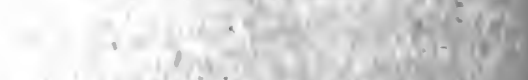

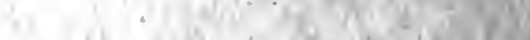

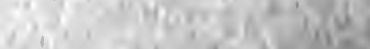

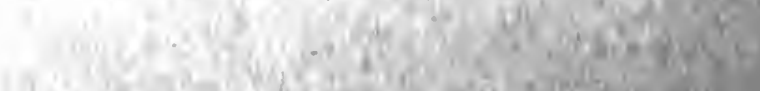
A

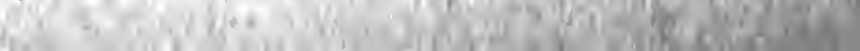




\section{CHAPTER XXII}

\section{A Life Expands}

\section{I}

Confronting the most serious material crisis of his life Alfred I. duPont had not done what was held out to him as the prudent thing. He had done the honorable thing. It took more than half his fortune, but enabled him to enjoy what was left.

"Had I made the moral mistake of going through bankruptcy I could never have taken a moment's pleasure from my money again," he told James Dashiell.

Better by far than the money Alfred duPont had been able to preserve from the Nemours Trading Corporation morass was the peace of mind and of heart which Jessie Ball brought him. When they had been married five years Alfred said to Dashiell:

"I didn't know such happiness existed."1

The truth of this showed in all sorts of ways. It illuminated the telltale small happenings of life with a species of serene conviction that, after years of frustration, things were coming his way. From a chatty letter to Madeleine:

"I have very little gossip to send beyond the fact that Miss Brereton is going to take the plunge on the and of July. She has selected the day the Carpentier-Dempsey fight is to take place, as she believes it will bring her good luck. This method of reasoning is distinctly feminine. In any event, she has chosen very wisely and is going to marry a very nice young man, and I am going to tell him that if he sasses her or finds any fault with her, I will simply take her away from him. I am awfully sorry to have to lose her, but it had to come some day and I think I have been very lucky to keep her as long as I have. Fortunately, she leaves with me one of her sisters, so I am still keeping the job in the family.". 
The lines foregoing were dictated to the bride-to-be. Mr. duPont dictated nearly all correspondence, offering to ladies the truthful excuse that his handwriting was virtually illegible. A clerk at the Touraine Hotel, in Boston, once knitted his brow over Mr. duPont's scrawl on the register. "Mr. Murphy?" he asked. "Right," replied Alfred.

Ruth Brereton, who was getting married, was the second Brereton sister to serve Mr. duPont as confidential secretary. Her predecessor, Leila, who had gone to work while Alfred headed the black-powder department, was a personage to be réckoned with. Once she told Mr. duPont that So-and-So was waiting to see him.

"Tell him to go to the Devil," snapped Alfred, who was building Nemours at the time.

The caller was straightway admitted to Alfred's presence. ${ }^{3}$

The third Brereton girl was Mary-Molly to the rest of the staff and "Titian-haired Circe" to Alfred. She served Mr. duPont until his death, having a more tranquil time of it than either of her sisters. This was because her employer had a more tranquil time.

One of the first things about Nemours to strike an observer at the time of Alfred's marriage with Jessie Ball was the chilling domestic isolation of the place. This went further than the understandable family estrangements generated by the marriage with Alicia Maddox, the stock suit and so on. Alfred's sister Marguerite had never set foot inside the walls surrounding the mansion. Alfred rarely saw Marguerite's sons, Cazenove and Maurice Lee, of whom he had been fond when they were young. He had never seen any of their five children.

For this Marguerite herself was somewhat responsible. She had not liked Alicia and caustically disapproved of the "wicked extravagance" of Nemours. Marguerite's extravagance took a different turn. Her own unhappy marriage had embittered a virile spirit. Widowed, and with her sons grown and gone, she lived in a settlement house she had built in Washington, made her own 


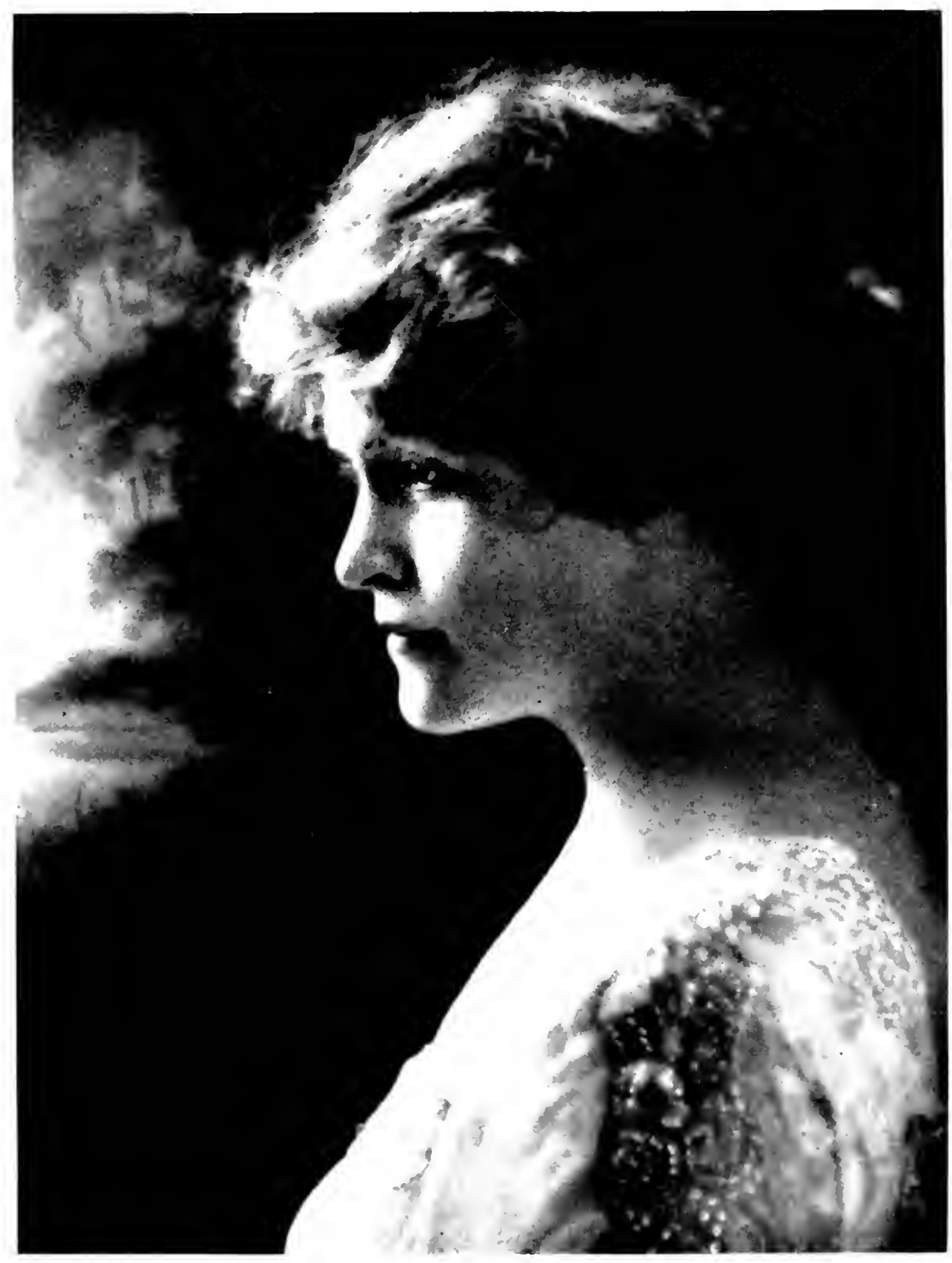

Mrs. Ilared I. dePont

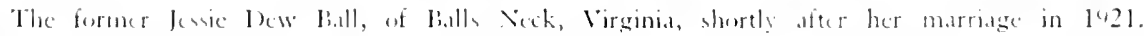



clothes and devoted her income to churches and charities. The income was never sufficient for all the good works she had in mind, and Alfred constantly sent her money though he thought most of her benefactions highly impractical. "But if they make Marguerite happy, that's the best thing one can have in life."

Jessie duPont knew it would bring more happiness into the lives of each of them if she could reunite this strong-minded sister and strong-minded brother. Alfred needed no urging. He began a campaign to entice Marguerite to Nemours. He sang the praises of the mansion's new mistress. He sent photographs, emphasizing items he thought his sister would like to see. "The marble ornament on the balustrade of the terrace is an old Italian piece I picked up a few years ago. It is of the vintage of 1650 , I believe, and is considered very fine." He threw in old Brandywine names, in an effort to re-establish the scenes of her tomboy girlhood. "You remember Pat Casey and Bill Horty. Tom Flinn you used to play with when you were a kid.... [He] lives in exactly the same house in Breck's Lane as he lived when he was a child and he looks just about the same."

Marguerite resisted these persuasions-until Christmas, I923. "Her coming," said Alfred, "was entirely due to Jessie's sweetness. Being a duPont and therefore ornery, like myself, which a lady terms firmness, I had no effect on her. But of course no one can refuse Jessie anything."

After that the sister and brother were almost inseparable. The next triumph came easily by comparison. The "Lee boys," their wives and young ones were brought into the orbit of Nemours. Alfred virtually adopted the children.

Before the captivation of Marguerite had begun, Alfred duPont received a remarkable letter from his one-time father-inlaw, Judge Edward G. Bradford. During the height of the campaign against Alfred and Alicia, no one had assailed the embattled couple more bitterly than this vindictive and unnatural father. Yet some time before Alicia's death, a reconciliation had been effected. If any testimonial to the value of Alfred I. duPont's pledged word were needed, no better could be cited than the letter Bradford com- 
posed when he fancied himself near death. It contained a remarkable request. The old Judge asked Alfred to see that he, the Judge, should be buried in the DuPont family cemetery in the same grave with his wife-to whom, poor woman, he had brought many vexations while she was on earth. If Alfred should outlive the Judge's son, Edward Bradford, Jr., Alfred was asked to see that he, the son, be interred beside his parents. It will be remembered that Edward, junior, had broken with his father, and with his uncle-in-law, the Bishop of Delaware, in espousing the cause of his sister and Alfred. In closing the old Judge begged Alfred's pardon for burdening him with a favor so unusual and asked that, "unless necessary," Alfred communicate it to no one, especially Edward, junior. ${ }^{6}$

Alfred's reply shows that relations with his ex-father-in-law, while amicable, were not of a familiar nature:

"My dear Judge Bradford:

"This in acknowledgment of your communication of September Igth.

"You may rest assured that so far as it lies within my power your instructions will be carried out.

"Very sincerely yours ..."

Except that he believed he could trust him, why did this contrite old man select Alfred as the object of such a request? Coleman and Pierre were directors of the family corporation which governed the cemetery, and, apparently, held the power to decide who should be buried there and who not. Alfred was neither a director nor on friendly terms with any director, saving the old Judge himself.

It happened that Alfred did not need the Judge's request for an excuse to attend a meeting of the directors of the cemetery. $\mathrm{He}$ believed the burying ground ill-kept and had a project for beautifying it and erecting a chapel, the improvements costing in all about $\$ 250,000$. In a letter to Ellen LaMotte, Alfred narrated the result of the meeting which he enlivened with his presence:

"The cemetery is even more dilapidated than ever and I went to the Meeting to express my opinion of it. It is supposed to be 
run by a board of directors and the said board at the present time, and for sometime past, consists of the following gentlemen:

Col. H. A. duPont

Mr. T. C. duPont

Mr. P. S. duPont

Judge Bradford

Mr. A. Felix duPont

"At the meeting, there were present:

\section{Colonel}

Eugene

myself

Felix

Francis

Ernest

and I took possession of the floor immediately on my arrival. I told the Colonel I thought all the directors, except Felix, ought to get down and out. I told them that I did not think anyone who was responsible for the present condition of the cemetery should be put back on the board and I immediately suggested a new board. Of course, I knew it would be without any avail; because, as you know, the Colonel has always been intensely bitter and is very anxious to live long enough to see that Willie [his brother, to whom the Colonel had not spoken in twenty years] is not buried in the cemetery; and the Colonel thought that if my directors went in that would be the first thing they would provide for. [Naturally, Alfred did not mention that another thing would be provision for the burial of Judge Bradford in the sacred grounds.] So he [the Colonel] stood pat, as President, and of course all the others, being afraid of him came in behind and voted for his board, and not mine. However, I had shot off my face and felt much better for doing it."

Though Alfred was unsuccessful in this encounter, old Judge Bradford got his wish by dint of longevity. When he died at eighty, in 1928 , no one was then alive to raise an objection to his taking his long sleep in the company of deceased DuPonts.

And Willie circumvented his brother Henry by outlasting him a matter of two years.

But Alfred himself, when his days on earth should be done, had 
no desire to await Judgment in proximity with so many quarrelsome relatives, dead though they might be.

Despite these bizarre happenings, Alfred's life was pleasantly expanding. Yet outside the orbit remained three of his own children-Bessie, Alfred Victor and Victorine.

Alfred's first sight in fifteen years of his son was in the fall of I922 at an amateur theatrical. Alfred Victor and a young friend imitated a currently popular vaudeville team, Gallagher and Shean. Having noticed the boy's name on the program, Mr. duPont studied him through his opera glasses. He saw a well-setup young fellow of twenty-two, with the familiar DuPont hallmark on nose and chin.

Alfred Victor and Victorine made their home with their mother in a roomy, old-fashioned brick house with a big copper beech tree in front, at Ninth and Broom Streets, Wilmington. Their sister Bessie was married and living in Washington. Her husband, Reginald Shippen Huidekoper, was a cousin of Wallis Huidekoper, Alfred's friend of the Nineties and charter member of the Cherry Island hunting set. A successful lawyer, during the war Reginald Huidekoper had served as a colonel in the Judge Advocate General's Department. Bep's wedding, in 1917 , enabled the Hearst newspapers to spread themselves with a rehash of the chronicle of the family schism which explained the absence of the bride's father from the ceremony. A long list of other DuPonts turned out, however, and, according to the Hearst article, Pierre S. duPont's gift was the most costly of all.

In the early summer of I923, Bill Scott, the old-time blackpowder-mill boss who had never ceased trying to atone for the unlucky gunshot which had taken Alfred's left eye, called at Nemours. When an opportunity presented to speak to Mrs. duPont alone, he said:

"I know how Alfred loved Bessie. She is in town now, visiting her mother in Broom Street. If Alfred will receive her I believe 
Bep will come and see him. At least I'm willing to speak to her and see what can be done."

Warmly thanking the old man, Mrs. duPont carried the word to her husband. With visible emotion Alfred said he would love to see Bep-either at Nemours or at his office, as she might prefer. Conveying this to Scott, Jessie duPont added:

"Please tell her she can see me or not as she chooses."

Bill Scott had known Bessie duPont as a child in pigtails carrying her father's dinner pail to the Brandywine yards. At Broom Street he arranged for Bep to meet her father at his office in the Delaware Trust Building.

Bessie brought her two babies, Henry Shippen Huidekoper, aged three, and Ann duPont, nine months. It was well that she did so. Alfred reveled in the sight of his grandchildren, but this ended the pleasant part of the meeting, as the words exchanged between father and daughter were formal and strained. At one point Alfred said he wished to congratulate Bep's husband on his military record: so few DuPonts had one to boast of. Bep asked how about her brother, Alfred. Alfred, senior, did not know what his daughter meant. Bep was shocked almost beyond belief to hear that her father did not know that his son had served as a private in the United States Marines.

No sooner had Bep left than Alfred sent to Broom Street an affectionate note which deeply touched the young woman. She replied, saying that it recalled the gentle parent she had known as a child. At the same time Bessie wrote a warm note to Mrs. duPont, thanking her for the message she had sent by Bill Scott and for her thoughtful agency in bringing father and daughter together. ${ }^{10}$

A year later, in August, 1924, Mr. and Mrs. duPont were taking a little rest cure at the Battle Creek Sanitarium, in Michigan, when Alfred read in a newspaper of the marriage of his son and Marcella Miller of Denver, Colorado. The young people had met while Alfred was working in the company's dynamite plant nearby.

The following summer-1925-Alfred surrounded himself with children: the Cazenove Lee young ones; Francis I.'s brood; a flock 
of Jessie's connections; and, of course, Denise. They overran Nemours, Cherry Island and the new yacht, Nenemoosha II, a longer and finer edition of the Nenemoosha I, which was christened that summer. In the Iroquois Indian tongue the name means sweetheart. On a cruise of the Chesapeake Alfred, with blood-bound oaths, turned his youthful hands into a "pirate crew" which raised the jolly Roger over the Nenemoosha.

Mr. duPont could hold the attention of children for hours with his stories-a considerable feat for an adult against the competition of radio bedtime thrillers and motion pictures. The narrator drew his tales variously from his own robust childhood, from adventures in the powder yards, from the lore of woods and streams, and from the Bible. To his sister Marguerite Lee, Alfred related a typical recital, which occurred during the freebooting cruise of the Chesapeake.

"I was telling the pirates of the advent of Moses into the life of Miss Pharaoh and her $\mathrm{Pa}$; his subsequent appointment as overseer of the Egyptian Brickyard; their escape into the wilderness; winding up with Moses' trip up to Mount Sinai and the sport that the Children of Israel had with the so-called golden calf while he was gone and how he later discovered that the calf was only an ordinary calf painted with radiator polish; and the smashing of the ten commandments." 11

That autumn Mr. and Mrs. duPont and a party of friends were visiting the Wilmington Horse Show when a bevy of laughing girls, intent on their own concerns, brushed past.

"There go some of the family spawn," observed Alfred, catching the DuPont look in the young faces.

In I925 perhaps sixty households of DuPonts were living in and about Wilmington. Naturally, not all bore, or were destined to continue to bear, the DuPont name. For instance, Pierre had six sisters, Irénée eight daughters and Lammot five daughters. Large families being the rule, the population of the clan ran well above three hundred, no one of whom knew all the others even by sight. At comparatively small family parties, say of not over thirty persons, an introduction between cousins was no unheard of thing. 

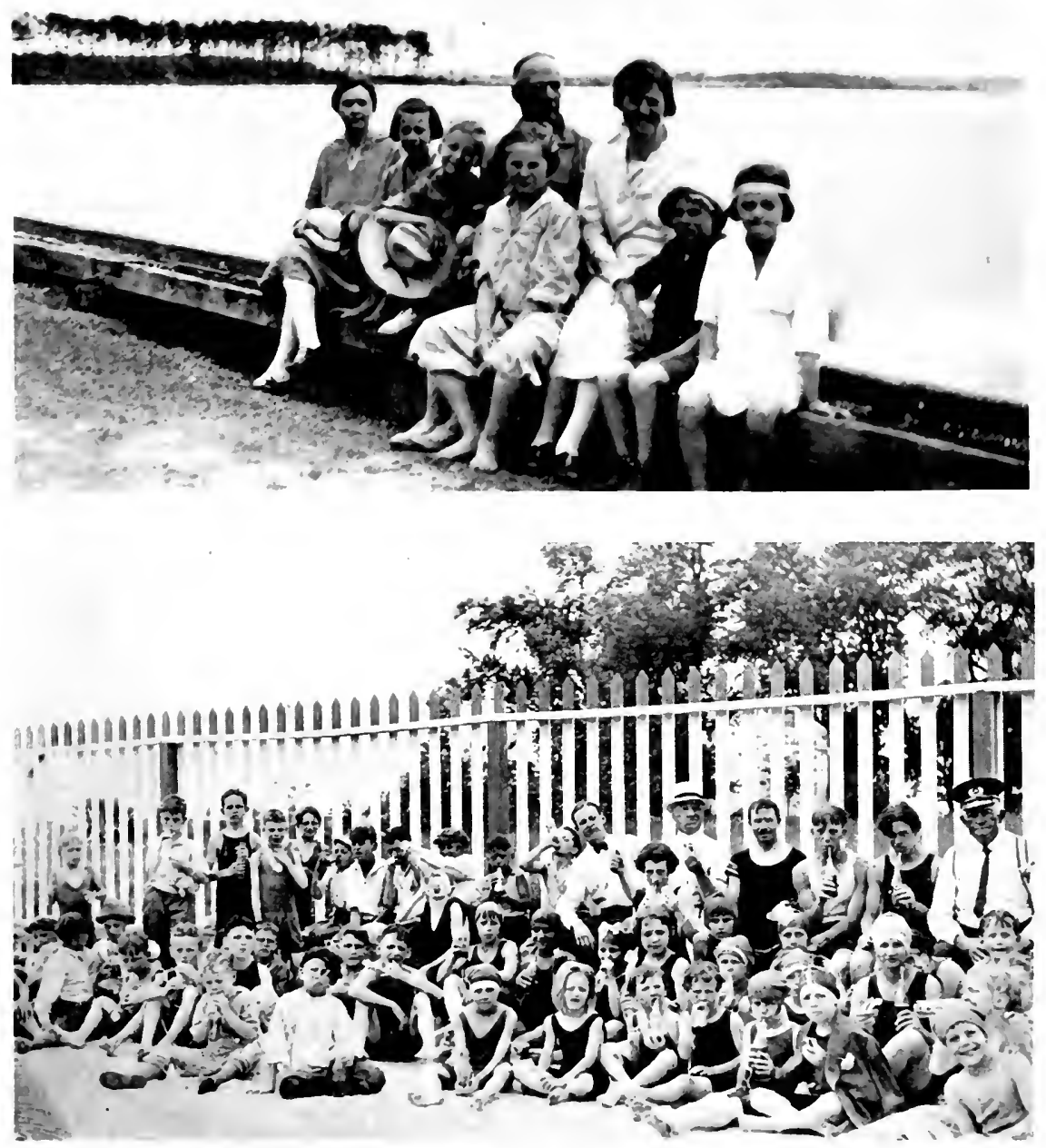

Mr. dePont and Yoc:ig Frtexds

Above: Some of the Nencmoosha pirattes at Cherry Island, about 1925. Left to right: Denisc duPont, V'andegrift Lec, Margucrite I.ec, Richard I lenry Lee, Jessic Grestiam Baker. Adults: Mrs. X. Addlison Baker (a sister of Mrs. duPone), Mr. duP'ont, Mrs. Cazcnove G. I.cc.

Below: Mr. dupent munching a hamburger sandwid while some of Wilmington's underprivileged children swig sodil pop. Fery summer dupont gave these children an outing. 

Then there were the old family rows, separating different lines and different branches of the same line. Yet these were not what they had been once upon a time. Prohibition and prosperity were the distinguishing characteristics of the new era, as far as its impact on youth was concerned. This freer generation, gayly tramping old standards, somewhat neglected to perpetuate, in the manner of the Hatfields and the McCoys, the feuds begun by their elders. The children of cousins who were socially strangers, whizzing about in bright-colored roadsters-in airplanes even-fraternized at country clubs, at the DuPont Hotel grill and smoky little "speaks" in Philadelphia and in Baltimore. The possibility of marriages was spoken of: very different from some of the family-contrived cousin matches of forty years before. Thus the pattern of the prodigious tribe was expanding and changing, so that Alfred's casual comment was one that any DuPont oldster might have made.

Drawing Mrs. duPont aside, a friend singled out one of the group of which Alfred had spoken: a tall, lithe, radiant girl with a wealth of fine blonde hair. Her countenance bore the DuPont stamp so unmistakably that almost any old resident of Wilmington would have known it.

"That's Victorine-Alfred's youngest daughter."

Mrs. duPont plucked her husband's sleeve, indicated the girl and told him who she was. Alfred duPont had last seen this child, to recognize her, in 1907-just before his marriage to Alicia Maddox. Victorine was four then. Now he had only time for a glimpse before his daughter was lost in the crowd.

"I don't like the way she's dressed," he said.

The next summer-I926-Alfred restlessly snapped on the light one morning at two o'clock.

"I have a plan," he said to Mrs. duPont. "You saw how Victorine was dressed that time. She should have better clothes. These children are grown. Bep has three babies. Huidekoper's a wealthy man, but a woman can always use some money of her own. Alfred's marricd and working his way up in the company-a steep road, I'm afraid. I think the time has come for me to let these children have some of the money that I always intended that they should have when they were on their own." 
Jessie's heart leaped. Her goal seemed immeasurably nearer.

Mr. duPont went on to speak, as he had often spoken, of his philosophy of wealth. He believed large inheritances destructive to initiative and a handicap to the development of self-reliant characters. Mrs. duPont knew that should she outlive her husband she would inherit a life-interest only in the estate of Nemours; after that the place would be converted into a home for crippled children. Alfred had declared this his choice of an ultimate disposition of the mansion since the day he had started to build it. What to do with the balance of his fortune, Mr. duPont said, was some thing he and Jessie would work out together. Meanwhile he wanted to give his children something now, while they were young enough to enjoy it. ${ }^{12}$

Papers were drawn assigning to each of the four children 2000 shares of DuPont 6 per cent debenture (usually called preferred) stock. The annual income from each gift would be $\$ 12,000$. The stock was selling for I12, making the 8000 shares disposed of worth $\$ 896,000$. Letters embodying the offers went to Madeleine in $\mathrm{Mu}$ nich; to Bessie at her summer home in Nonquitt, Massachusetts; to Alfred at Barksdale Mills, a dynamite plant in Washburn, Wisconsin; to Victorine, who was visiting her sister in Nonquitt. Each beneficiary was asked to sign a statement promising not to contest his father's will. All signed, and moreover wrote their father lovely letters. ${ }^{13}$

Responding to the communications from Bessie and her husband, Alfred alluded to the painful phases of the meeting engineered by Bill Scott three years before. "I could see that you were disappointed but it is impossible to make you understand what I have gone through." ${ }^{14}$

On her return from Nonquitt that autumn Bessie stopped by Nemours-this time with three babies and a fourth on the way. The old breach was bridged at this meeting.

Shortly after the settlement had been accepted by the children, Victorine was called to Wilmington by her mother to attend the 
funeral of a sister of Pierre duPont. The Broom Street house having been sold, mother and daughter stopped at the DuPont Hotel. The main dining room was fortunately large enough to accommodate estranged factions of the proprietary family without the embarrassment of too-close propinquity. On a certain day at dinner time were seated in different quarters of the room Mrs. Bessie Gardner duPont and Victorine; Alfred, Jessie, Ed Ball, Alfred's cousin Cap LaMotte and others. The meal ordered, Alfred excused himself to go to the lobby to buy a newspaper. Lowering his tone, LaMotte remarked to Jessie:

"Don't say anything, but that's B. G. duPont over there."

As Victorine was about to start in on a plate of soup, a tall man passed her table. She looked up-and almost dropped her spoon. The man was her father. "How proudly he carries his head," she thought, and, with brain in a whirl, tackled the soup to cover her confusion.

The meal finished, Victorine flew to her room and dashed off a note of apology which she directed to her father at his office. She feared Alfred would think that his daughter had "cut" him in public. $^{15}$

A little later Mr. and Mrs. duPont attended the annual Frolic for the Children's Hospital, a considerable social event in Wilmington. Victorine was an usher. Resplendent in a new blue dress, she made a stunning figure. Alfred's face beamed.

"That's more like it," he said. "The girl needed clothes."

About that time Victorine became engaged. The man in the case was Elbert Dent, a big, handsome chap beginning the practice of law in Philadelphia. He had finished Princeton just in time to join the armed forces at the outbreak of war and to fly a Navy airplane in France. Pride in her catch and a comprehensible impulse to show him off brought to the bursting point a desire of years on the part of this imaginative girl to recapture her father.

She tried to recall the last time he had held her in his arms, a memory all but lost in the mists of infancy. Later on, at the Broom Street house, her father's name had never been spoken. But little Vicky and her brother Alfred whispered it sometimes to one another. Once Alfred pointed out to Vicky a large automobile which 
he said was their father's. The two children would roller skate for miles on the neighboring brick walks for a glimpse of that car. Once Alfred found an old ear trumpet and innocently asked whose it was. Receiving no satisfactory answer, he knew that it had belonged to his father. And there were more confusing happenings. Growing older, Vicky learned to recognize her father by sight. Twice she boldly walked a whole block right beside him on Market Street. She was hurt because her father did not speak to her, unaware that he did not know who she was. Another time, in Philadelphia, she boarded a train for Wilmington and, having missed her lunch, brought along a cream puff to eat. Seated near him she saw her father and a young girl about her own age. (The girl was Alica, junior, who was almost exactly Victorine's age.) Too agitated to eat her cream puff, Victorine pretended to read.

However stoutly she tried to deny it to herself, Vicky felt a sense of inferiority to other girls who had fathers in their homes. Yet by word or sign Vicky asked the compassion of no one. She held her head high. What other girl, she asked herself, could have had, with her own father, the cream-puff or Market Street experiences? Why, these were romantic happenings, as in a story book. Yet, in her heart of hearts, Victorine came to know that a story-book life may not always satisfy.

Other things had been hard for the young girl to comprehend. In I9I6 during the classic struggle between her father and her Cousin Pierre, Victorine heard no word in defense of her father spoken at home. At school one day she heard a classmate vigorously defend him. It thrilled her.

Her mind conditioned by such a background of yearning, Victorine duPont at length took the simple direct course of writing her father the news of her engagement and asking permission to call with her fiancé. ${ }^{17}$

An immediate affirmative reply was received, but before a time was set Alfred Victor duPont and his wife, Marcella, arrived in town. Mr. duPont asked them to come with Victorine and Elbert Dent. The evening of April 22, I927, was named.

"That's the night of Irénée's big party," Alfred told his wife. "It will give the young people an excuse for leaving early." 
Aware that this first meeting might prove a trying affair, Alfred wished to spare the young folk as much as possible. Perhaps also he wished to spare himself.

During dinner Mr. duPont was nervous. He said he hoped the children would not stay more than fifteen minutes.

A few minutes before nine o'clock two couples stepped upon the great stones of the Nemours portico. Victorine and Alfred V. walked ahead, holding hands and trembling.

"Isn't this just like a scene in a melodrama?" Victorine said brightly to buck up her courage.

Portly Thomas Horncastle greeted the four and led them down the imposing hall-Alfred V. later said it seemed a mile long-to the formal drawing room. For what appeared an age, the four sat in silence, facing the marble corridor they had traversed. The men wanted to smoke but were afraid to-a good thing, for smoking was not allowed amid the gilded furnishings of the Louis XVI drawing room at Nemours. For the rug on the floor, a SeventeenthCentury museum piece, Alfred had refused \$100,000.

Presently, at the end of the long hall, appeared Mr. and Mrs. duPont. The four arose, bracing themselves.

Alfred walked straight to his tall daughter and took her in his arms. Then he grasped his son's hand and drew the boy to his breast. He kissed Marcella and shook hands with Dent.

As far as the participants remember, all this happened without the exchange of a word. After Jessie had greeted the four, the first words spoken which seem to have left an impression were Mr. duPont's. He turned to Dent with a quip about the responsibilities of marriage.

As Marcella recorded some hours later in her diary, the asmosphere was "strained at first but got more lively later." Alfred produced an album containing pictures of past generations of duPonts. He showed the men his collection of firearms, expatiating on the virtues and weaknesses of each weapon. Jessie duPont, her easy charm an asset to any gathering, found less obvious means of filling in the time. This was, after all, one of the proud hours of her married life. She had told herself it must succeed.

It did succeed. The callers stayed until after eleven. Relaxing 
in the car on the way to Irénée's party, they voted the visit much less of an ordeal than had been expected. ${ }^{18}$

\section{5}

Next morning Alfred Victor dutifully wrote his father a thankyou letter which went further than the requirements of etiquette. The young man mentioned an important personal decision: the resignation of his position with the company. As Alfred Victor did not attempt to sketch the steps which had led to this, after posting the letter he wondered how his father would take it.

As a boy Alfred Victor had liked to build things. Growing older he thought he would study architecture. On his graduation from Lawrenceville School in 1918, however, he joined the Marines and saw a year's service in the West Indies. Discharged at nineteen, he put in a year at Yale and, on the advice of Pierre duPont, gave up his architectural ambitions and went to work in the high-explosives division of the company. At the end of six years he was acid superintendent at the Barksdale Plant in Wisconsin, drawing $\$ 200$ a month. The job was not as important as it sounds and the pay of anyone not a DuPont would have been \$150. His father's \$12,000-a-year settlement having removed fiancial anxieties, the young man's only dissatisfaction with his pay was the fact that it was more than another man would get for the same work; but Alfred wanted larger responsibilities, a chance to rise. In April, I927, he came to Wilmington to talk over the matter with J. W. McCoy, the director of high explosives. McCoy referred Alfred to Lammot duPont, who had succeeded his brother, Irénée, as president.

Able as a technician and an executive, Lammot's potentialities had been recognized as early as 1902 by Alfred Irénée, who had given the younger man a chance to develop. Lammot's failing was a curt manner which rendered him unpopular with subordinates. "What do you come in here for?" he greeted Alfred Victor. "To get a drag job?"

"No, Cousin Lammot," said Alfred Victor, "I came for a chance 


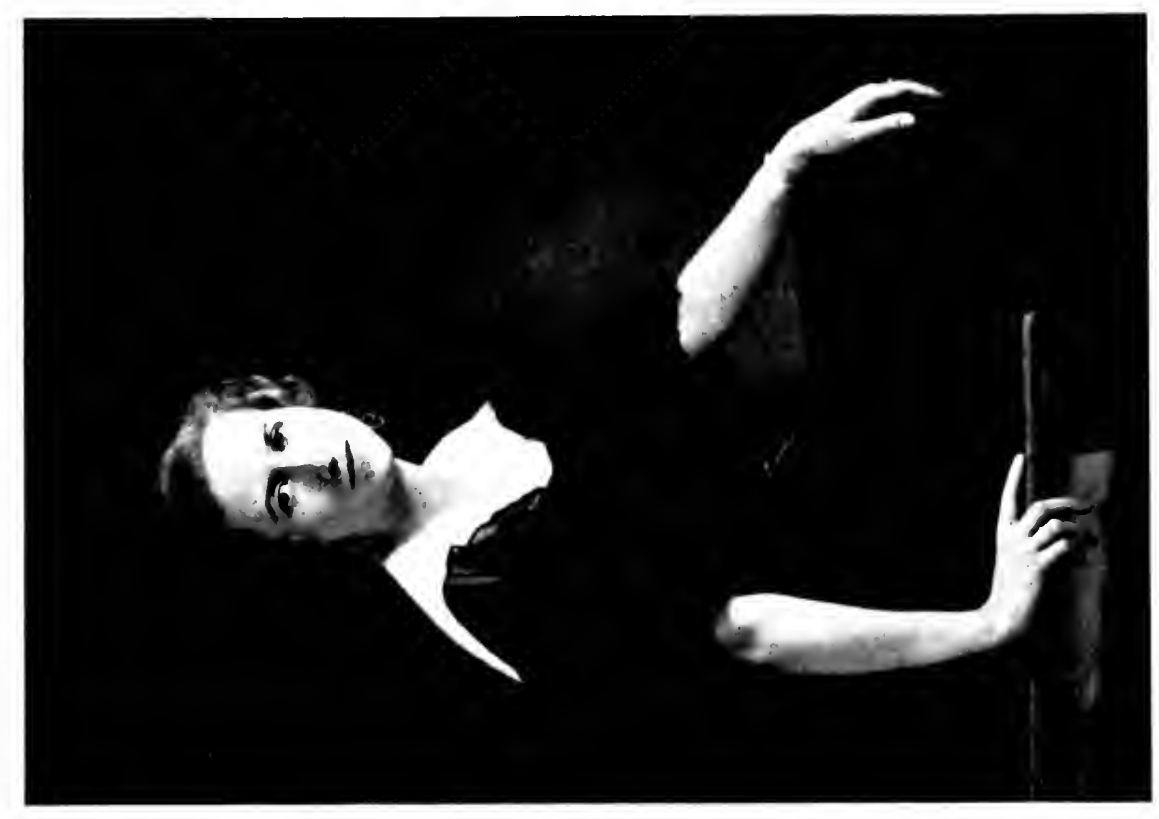

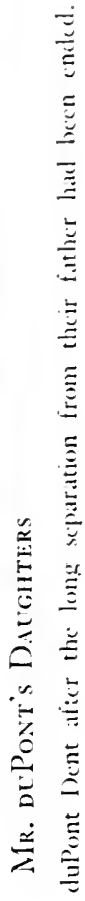

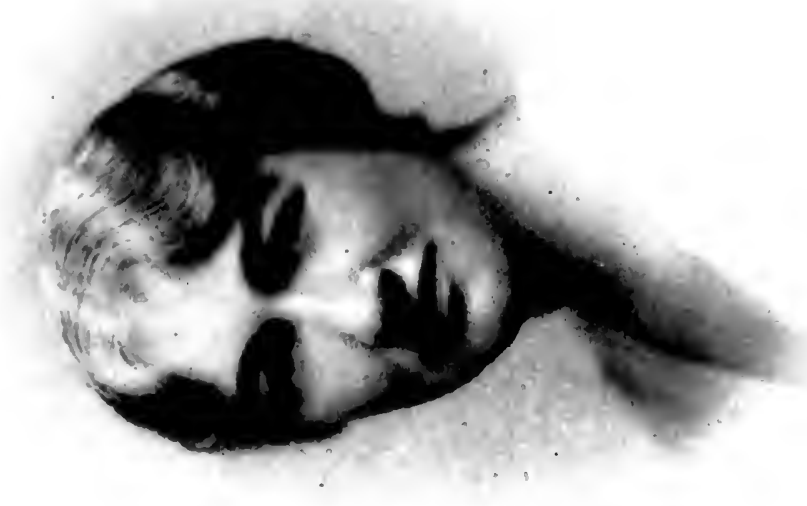

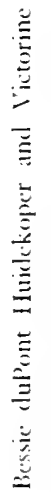



to advance myself. If it looks as if I wanted a drag job you can have my resignation."

Lammot told Alfred he'd be making a mistake to quit. But there was no promise of broader opportunities. Young Alfred did not have a DuPont nose and chin for nothing: the resignation stood. This was three days before the visit to Nemours.

The father answered his son's letter in these words:

"My dear Alfred:-

"Your letter of April 23rd has been received and most carefully considered....

"Your resigning from the duPont Company does not surprise me in the least.... I was certain it was only a question of time when you would be unwilling to accept the patronage of your cousins upon the conditions which it is usually tendered to others....

"I am very glad indeed to hear that you regarded the traditions of the duPont Company as the traditions of the duPont family, one inseparable from the other. It was for the purpose of handing down these traditions that I, in r902, took over the duPont Company and then brought here and made a party to the organization your cousins. ... But I overlooked the most important point and that was that the [former] family traditions were no longer recognized.... It was one of the greatest mistakes I ever made....

"Now you are free and can begin over again. Be sure that ... [your choice] is one which will permit you the full power of initiative .... and permit you to advance in keeping with your efforts and capabilities.

"Every man must stand or fall by virtue of the results he achieves through hard work. You should have capacity. If you have a willingness and physical strength to work hard, you are bound to succeed and I am confident that you will. Remember to always be a man in every sense of the word and thereby invite the approval of those with whom you associate. The love of one's fellow beings is the only measure of real value and that can only be acquired by living a life that will meet with the approval of all who know you. Conserve your physical strength as the most valuable asset you have. Without vitality and power to drive your brain and body to success, you are bound to fall by the wayside. 
"It is most fortunate indeed that you have married, and your sister is about to marry, separate and apart from the so-called duPont family.... Associating with people who are competent to judge impartially as to values, and living in an entirely different atmosphere, will bring illuminating results.

"Unless my judgment is sadly in the wrong, you have selected wisely in the matter of choosing your partner, and Marcella, I am sure, if accorded the consideration to which she, or any other good woman, is entitled, will stand by you through thick and thin and in addition will be a most capable adviser. It is not possible to measure by words the value of a good and intelligent wife to a young man and I only hope that you will both live long to enjoy the happiness which goes with a comradeship and love based upon mutual admiration and respect.

"I am glad to hear you expect to take a short trip to Europe and will be most interested to learn after your return of the success you are having in securing a new position. My best wishes go to you both for a most delightful vacation and a safe return."19

On their return from abroad, Alfred V. and Marcella made a sojourn at Cherry Island. Alfred, the elder, loved the Island. $\mathrm{He}$ went about in a khaki shirt, his hands usually greasy from tinkering with the innards of outboard motors. Alfred, the younger, also liked that sort of thing. The barriers of reserve fell away and father and son got to know each other.

These pleasant events, in which Jessie Ball duPont played more of a hand than met the eye, served as a balm to further disappointments Alfred had suffered in the field of politics. Mrs. duPont hoped her husband had had enough of politics. She believed he would be happier devoting his energies to matters closer home. Alfred duPont was not the first man, however, to find a resolution to abandon politics easier to make than to keep.

Seldom has a national administration taken office under conditions more auspicious than those surrounding Warren G. Harding in 1921. Yet, amid fairly general acclaim for the new Cabinet, 


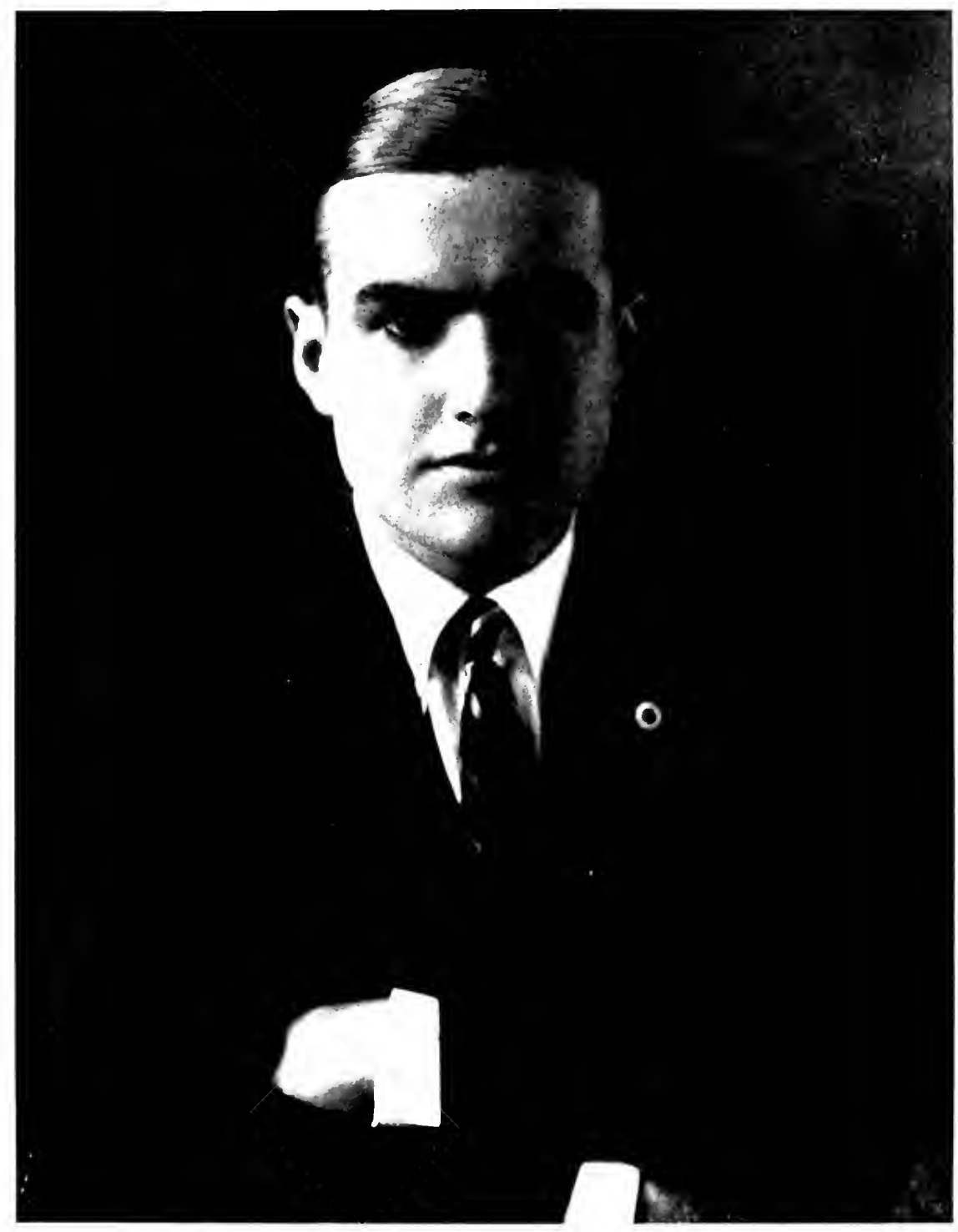

Alrked Victor de Pont

Mr. duleont's son after the reunion with his father in 1926 , ending a wparation begun when Alfred Victor was a child. 

Mr. duPont put question marks after three names: "Denby [Secretary of the Navy] is an unknown factor; Hays [Post-master General] the cheapest kind of a politician; Daugherty [Attorney General] unqualified from every point of view." ${ }^{19 a}$ When the White House clique accepted the Dirty Deal by taking Senator Coleman duPont to its bosom, Alfred was finished with Harding. In June, 1923, he declined to attend a luncheon for the President in Wilmington. "Jessie and I have other fish to fry, and of a much higher class." "

Within three months the deluded and demoralized Harding was dead, by that merciful circumstance escaping a reckoning which would have driven him from public life. Two factors saved the Republican regime: the purge by Calvin Coolidge, ridding the Administration of Harding's betrayers and eventually sending a few of them to jail; the wave of prosperity which diverted a citizenry, scrambling for the fleshpots, from the problems and scandals of government.

So chastened, however, was the Republican Party, that in the spring of 1924, with a national campaign coming on, Alfred could not believe Coleman duPont would dare to renew his Senatorial pretensions. He doubted if Coleman could continue in the post of Republican National Committeeman for Delaware, despite the intercession of old Colonel Henry duPont with President Coolidge.

"P. S., Irénée and Company," wrote Alfred, "seem to forget that their day is past and that no individual ... can dictate to the people. My work is bearing its natural fruit. Of course, the vote of Delaware is always close and they may be able to spend enough money to divide the Republican ticket, but that is about all."'11

Alfred saw his fruit sour on the vine when the Republicans not only kept Coleman as Committeeman, but gave him the senatorial nomination. Nor was this all. The Democrats put up James M. Tunnell, a friend of Chancellor Wolcott and one of the Democratic supporters of the Dirty Deal of 1921. Thus deftly was that explosive issue wafted from the campaign.

The last of Alfred's string of newspapers, the Newark Ledger, had ostensibly been transferred to the ownership of ex-brakeman Ed Davis, though Mr. duPont still met the deficits. Davis refused 
to swallow Coleman, and Alfred continued to pay the bills. A sample of Mr. Davis' editorial comment:

"T. Coleman duPont, the 'Dirty Deal' candidate for United States Senator, has opened the 'boodle bags' and is flooding the State with money to BUY the election.... Approximately two thousand workers ... are receiving from $\$ 25$ to $\$ 50$ a week, while chief lieutenants are getting as high as $\$ 500 . .$. . A big bunch of $\$ 1000$ bills have been sent downstate." 22

On election day Coleman duPont almost kept abreast of the Coolidge landslide. The national ticket won in Delaware by 19,000, Coleman by i6,700.

Irénée duPont wrote Alfred that the result showed the effect of Alfred's nonparticipation in the campaign. Irénée added that he hoped this might be a step toward the mending of old family differences. Coleman wrote that if he could ever serve Alfred in Washington, Alfred had only to say the word. ${ }^{23}$

\section{7}

"Coolidge Prosperity" were the words for it, and DuPont and General Motors led the procession. Boss Henry had used the postCivil War period of industrial transformation to take charge of the powder business in North America. Pierre S. duPont used the post-World War period to create a chemical empire built on the adaptation to peacetime uses of the ingredients of wartime explosives. The chemicals which had made high-explosive shells go off were found to be ideal for the fabrication of babies' teething rings-and some thousand other articles.

When John Raskob involved the DuPont Company with the fortunes of General Motors, Alfred had been skeptical of the move. Out of the company and at sword's point with Pierre over the stock suit, he could do nothing-failing even in an attempt to ascertain the exact extent of the involvement. The reputation of General Motors' head, the brilliant but unstable Durant, afforded a basis for Alfred's misgivings. These seemed realized in 1919 
when Durant's stock plunging so tangled Motors' finances that Pierre had to drop things in Wilmington, and, at a critical juncture on the home front, hasten to Detroit to protect DuPont's $\$ 50,000,000$ stake. In 1923 he had General Motors out of the woods and, handing the presidency to Alfred P. Sloan, Jr., returned to Wilmington. DuPont retained a 23 per cent interest in Motors, which presently was accounting for half of DuPont's profits.

"You'll have to give old Pierre credit," Alfred told Edward Ball. "The situation looked bad when he went out to Detroit. But he's put General Motors on its feet and saved the company's investment."24

In the Nineties Alfred I. duPont, a grimy young black-powder boss, used to drop into the little Brandywine laboratory where his cousin Pierre, a fledgling chemist from M.I.T., was experimenting with smokeless-powder formulas. Alfred would air his pet scheme of utilizing waste chemicals for the manufacture of byproducts-a dream Alfred never wholly abandoned as long as he was with the company. It remained for Pierre to carry that dream -something akin to it, anyway-to startling realization.

During the war a paint factory was bought. When the Armistice came, DuPont chemists were free to work their will with paint. One result was Duco, a quick-drying lacquer which revolutionized, among other things, the finishing of automobile bodies. General Motors, of course, got the inside track, but other car makers had to use it too. Rival paint makers also took it up, but found DuPont's patents so broad that the DuPont Company was able to collect six cents a gallon in royalty on nearly all quickdrying lacquers made in the United States. Ford was the only large manufacturer of automobiles to escape paying this tribute.

An artificial leather called Fabricord and shatterproof glass were other DuPont contributions to the automobile. General Motors and the Standard Oil Company of New Jersey turned over to DuPont engineers experiments they had begun on an "anti-knock" fuel for high-compression engines. The result was Ethyl gasoline, which takes its name from the chemical involved-tetraethyl lead -of which DuPont was the sole manufacturer in America. The DuPont-Rockefeller combination, holding the basic patents, again 
collected royalties as other oil companies were obliged to make the new fuel.

Toluene, a coal-tar derivative and the basis of trinitrotolueneTNT-is also the basis of synthetic dyes on which the Germans had a strangle hold until I9I4. In I9I7 the United States Government impounded German patents with the Alien Property Custodian. Francis Garvin resigned as Custodian and formed a company which bought the confiscated patents for a song. DuPont licensed from Garvin's organization enough of these patents to launch itself in that field.

Two words were given our language: Rayon and Cellophane. The products they stand for were DuPont developments and exploitations, rather than DuPont inventions. Artificial silk had been made in France since I884. A French textile chemist discovered the forerunner of Cellophane by accident in 1900. The two products are chemical cousins. The basis is cellulose, a form of which Francis G. and Pierre duPont used in perfecting the first serviceable type of American smokeless powder. Modern DuPont chemists, turning from their wartime trade, made Rayon and Cellophane parts of the American way of living.

So much for an imperfect headline to the story of the early steps only in DuPont's gigantic industrialization of chemistry.

It paid. Dividends went from $\$ 6.50$ in 1923 to $\$$ I9 in 1926 plus a two-for-one split-up of common stock. In 1927 the new stock paid $\$ 17.50$ a share, which exceeded the combined dividends for the four years ending with 1923, computed on a basis of the old capitalization.

This rebound to prosperity did much to replenish Alfred's depleted coffers. It also left him with mixed emotions. Besides a financial interest which would seem to entitle him to some participation in the management, Alfred had a scientific interest in the new trails the company was blazing. Yet the thought of doing business with his cousins chilled him.

"I would not be happy there," he said. ${ }^{25}$

The feeling was reflected in Alfred's comment on his son's resignation.

The branch of the company's manifold activities which Alfred 
was able to follow most closely concerned Rayon. His nephew, Maurice duPont Lee, was vice-president of the subsidiary DuPont Rayon Company, with offices in Buffalo, New York, seat of the pioneer Rayon plant. Alfred had given Lee his first position with the company.

Because his recommendation would not have meant very much in other quarters, Alfred confined to Lee his intercessions in behalf of young men who aspired to work for the DuPont Company. No favors were asked for the candidates beyond a chance to prove themselves. "Please remember," he wrote of the son of a close friend, "that if he does not toe the mark the print of your noble hoof should be left on that part of his anatomy which is customarily used for sitting down." ${ }^{26}$ One of Francis I. duPont's own sons was presented in these words:

"Emile duPont should make a good boy in your work. He is strong and, so far as I have been able to determine, intelligent-at least, he looks so-and is willing to work. He has had two years at Annapolis and two years at Yale. Of course, this means nothing one way or another, unless the essential requirements are there, that is, ability and fundamental principles of honesty and loyalty....

"I hope the sock factory is running full. By the way have you ever tried manufacturing ladies' lingerie?":27

Maurice Lee hired Emile, and talked to Mr. duPont about employing his son, Alfred V. The upshot was that young Alfred re-entered the service of the DuPont Company, at the Rayon plant in Buffalo.

The reconciliation between Alfred I. duPont and his children brought to his notice seven grandchildren he had not known before. Three belonged to Madeleine Hiebler and four to Bessie Huidekoper. A year after her marriage Alicia Glendening bore a son, bringing the number of grandchildren to eight; and in the fullness of time Victorine Dent became the mother of two boys. 
Then there was the Cazenove Lees' brood of three, and the Maurice Lees' three; also Alfred's brother Maurice's two.

That made eighteen who were near of kin. Other friendly DuPonts contributed, say, ten more. Add ten young in-laws from the Ball side and twenty children of friends and employees, and one gains an idea of the number of young persons with whom Alfred I. duPont was closely concerned. They ranged from cradle age to college age and beyond. With most of these old enough to read, Mr. duPont carried on an active correspondence and was usually more punctual about writing than they. Renowned for a retentive memory, Mr. duPont astonished business associates by the accuracy with which he could repeat, after an interval of months and without reference to a note, the details of a complex transaction. An equally impressive testimonial to the excellence of his memory could be adduced from the way Alfred duPont kept current track of the doings, wishes, temperaments and forming characters of forty or fifty young people.

The following letter to a girl at Ward-Belmont College in Nashville, Tennessee, is a fair sample of a kind of communication $\mathrm{Mr}$. duPont wrote over and over:

"I only returned home from my southern trip two or three days ago, and this is the first opportunity I have had to fulfill the promise to reply to your letters in which you set forth your plans for next year....

"It must be manifest to anyone who has ever studied the problems of success that in a matter of getting there, no man or woman can begin too young. ... In I884, when I had the choice of going to work when an opening was offered me in the company's powder yards, or completing my course at the Institute of Technology in Boston, I unhesitatingly took the job. The opportunity to work was of greater value to me than the sentimental value of my diploma....

"Your father told me last fall that you again wished to attend the Ward-Belmont School, that you would have completed your course this spring and that you had a position in mind of a secretarial nature, which you could fill upon your having finished your course. Your first letter presented to me an entirely different 
schedule. Careful analysis of that letter and your subsequent one forces me to a conclusion which involves several outstanding facts, among which I might enumerate:

"First: That upon graduating from the Belmont School this year, when I believe you will be twenty-one years old, you contemplate further study.

"Second: That the controlling factor in coming to such a conclusion was the fact that you desired to be with your room-mate....

"I am forced to the conclusion that you have decided to give up the position for which your work at the Ward-Belmont is supposed to have fitted you in order that you might have the pleasure of living with your friend, and that, to justify such a plan, you had put forward a line of work which, from the standpoint of achieving the goal as I originally understood it, is of no value.

"I can understand perfectly your desire to be with your roommate. Good friends are few and in associating with friends whose value has been proved, one gets the greatest possible pleasure. The matter which has given me concern is that you have set aside an opportunity to get started in your career in order that you may spend another year in the companionship of your room-mate; for surely the study which you describe-the prosecution of your music-can be carried on anywhere. The study of English literature can be achieved by reading good works....

"One cannot afford to throw away one year at your age. The path of least resistance is a pleasant one, particularly when one lives from day to day, which is an attribute of youth, but it leads nowhere in particular. I am not criticizing your ideas; I am simply giving you the benefit of the experience of a man who has profited by his mistakes.

"I am delighted to know that your surroundings are pleasant and that the springtime has brought so much that is beautiful and inspiring into your life.

"This letter has been a difficult one to write; one's duty is often unpleasant.

"With my affectionate regards, I remain,

"Very sincerely your friend ..."28

To a connection of Mrs. duPont, attending the State Teachers College at Fredericksburg, Virginia: 
"You should by all means accept the position the hotel offers you. I know lots and lots of girls who wait on tables in the Summer and don't consider it in the least demeaning. I used to do it myself when I was young."

To a cadet at the Staunton (Virginia) Military Academy:

"Now, my little man, you seem most careless in many things. When you first went to school you wrote me for some spending money, which letter I answered immediately and enclosed $\$ 2.00$ therein which you have never acknowledged. This is very, very poor policy. Don't start life thinking you can ignore obligations or good manners....

$$
\text { "Yours fondly ..." }
$$

Mr. duPont's opinion of college degrees went lower and lower. "Young H. . . . is the direct result of trying to educate a human being with no brain; for which I am largely responsible."31

Most older observers were hard on the youth of the Twenties, Mr. duPont being no exception.

"One bunch of masculine adolescence, aged 23" he wrote his sister Marguerite, "seated at my right hand at Nemours the other evening at dinner, remarked, 'Mr. duPont, where did you usually go swimming when you were a young man?" "

Mr. duPont said he usually went in the Brandywine.

"Was the Brandywine always as muddy as it is now ?" the young man asked.

Mr. duPont said that he didn't consider the Brandywine muddy.

The young man said one could not see two feet under the water.

"Whereupon," concluded Alfred, "I dryly remarked that if he wanted to look at his feet he had better take them out on the bank and look at them there. Tell me, what are you going to do with a boy of twenty-three who objects to swimming in water that is not filtered?"32

Mr. duPont to Dorothy Lee, wife of his nephew, Cazenove:

"Everybody here is well but more or less used up by virtue of entertaining sixteen to twenty youngsters. I had them on the 
yacht one day and the yacht did not quite sink, but I had practically to rebuild the boat after six hours of wear and tear. . . . How narrow are the lives of these young men and young women of today! Of the beauties of nature they know nothing; of science they know nothing; and of religion they have never heard. They can play bridge, smoke, dance and eat candy, and I presume they can suck rum, though that is one thing they had not a smell of at Nemours. They have no education and if they did they wouldn't know what to do with it. I referred to the Audubon Society to a grown boy of twenty-two. He asked me what it was."33

\section{The subject continued, in a lighter vein:}

"I have been more or less concerned on account of people parking under my stone wall in the evening and remaining there without paying for parking place, or I should say 'sparking space.' Being more or less easily influenced by the surrounding atmosphere, and trying to lead a proper life myself, I enlisted the services of one of our road cops. He has gone out around Nemours and requested the people to move on, and has also taken their license numbers. Not long ago he took the number of an automobile which, upon investigation, turned out to be the license of a parson. My cop called on the parson, whereupon the parson passed the buck to his daughter and accused her of having stolen his automobile to take a drive with her young man.

"The Parson's only daughter

Was doing what she hadn't oughter!"34

Alfred tried not to lose sight of the fact that, judged by the parental standards of the day, his own youth had not been a model invariably. "There is no harm," he counseled his daughter Madeleine for her guidance as a mother, "in a boy being high spirited and full of the devil."35

Among the voluminous mail from correspondents unknown to her, Mrs. duPont received a long letter from a resident of Baltimore, Russell A. Jones. Like Mr. duPont, Mr. Jones was 
profoundly concerned for the sake of the youth of the land. "The boy with an automobile," he wrote, "too much spending money and a flask of whisky in his pocket is a great menace to society. His very wealth and social position often protect him in his wild career. The hotels, apartment houses, road houses and dance halls have a grip on these youngsters which will have an awful bearing on future generations."

Mr. Jones had evolved a scheme for saving them. He would establish a sanitarium, patterned after the famous institution, near New York, of William Muldoon. Mr. Jones was willing to donate his country estate, valued at $\$ 150,000$. He asked Mrs. duPont to contribute $\$ 350$,00 to turn it into a resort for the redemption of youth. ${ }^{36}$

Mr. duPont himself replied to this letter. "From my point of view your plan is not practical. These boys and girls are leading the lives they do, not because they are forced to do so, but simply as a matter of personal selection." In most cases the parents were to blame. "I doubt even if many parents would bother to send their children to you for guidance and saving," Alfred continued. "And even if so they would not remain there except by being forcibly detained. ... Muldoon succeeded because patients came to him of their own free will.",37

Mr. duPont believed the prospects for remedy lay deeper in the foundations of our social structure. The emphasis was no longer sufficiently on work. Too many youths went to college to avoid work or to try to learn to make the most money with the least effort. Furthermore, elders presented poor examples to the young: witness the Florida real-estate bubble and the stock-market boom which had set millions to gambling in the hope of making fortunes without working.

Then there was prohibition. Like most Americans Mr. duPont had supported enactment of the Eighteenth Amendment. The possessor of a $\$ 100,000$ cellar, duPont would not personally be inconvenienced by the Amendment. With most others the situation was different, however. Their means being less than $\mathrm{Mr}$. duPont's, their stores of wet goods soon ran out. To replenish them the industry of bootlegging sprang up and within a few years 
was one of America's most profitable enterprises. Entirely in the hands of the criminal class, yet countenanced and supported by good citizens, this anomaly wrought havoc with respect for law and for morals. Inexperienced and impressionable youth was the most conspicuous victim.

It is one thing to see such things in retrospect and another thing to see them at the time. Mr. duPont saw them at the time. $\mathrm{He}$ decided to devote the rest of his life and as much of his fortune as need be, to an effort at making America, which, with all its imperfections he believed the greatest country on earth, a saner and more wholesome place. 


\section{CHAPTER XXIII}

\section{DAwN OF AN EXPERIMENT}

Alfred I. duPont made his first trip to Florida in the Seventies as a boy of ten when his mother had gone there for her health. In 1927 the yacht Nenemoosha, cruising in the St. Johns River, tied up for the night at Palatka. After dinner Mr. duPont and William T. Edwards, a business associate, took a stroll through the town. Presently Mr. duPont stopped, removed his hat and bowed his head for a moment.

"Bill," he said, "the old Putnam House used to be right here. That is where my mother stayed. If I ever succeed in doing anything of permanent worth in Florida it will stand, in my heart at least, as a monument to my mother."

Beginning about $1900 \mathrm{Mr}$. duPont began to visit Florida fairly regularly. He witnessed the transformations wrought by Henry Flagler-which, incidentally, were attended by considerable change in Flagler's own character. Excepting in satisfaction, the return on the Florida investments of John D. Rockefeller's once hardfisted partner were not what he could have had elsewhere.

The land boom started in 1920 and reached its zenith in 1925 . Mr. duPont, who had never before seen a boom at close range, loved to study the spectacle. Mrs. duPont and her brother Ed had seen booms in the West. From experience they knew how booms ended. By abstract reasoning Mr. duPont figured what would happen in Florida:

"They'll all go broke. No other result is possible. The aim is to get something for nothing. It never works-for long."

Mr. duPont did not gamble. While yet a young man he had abandoned playing cards for even small stakes. In South Dakota, 
in 1906, he had learned cribbage from his friend Williamson. An expert who enjoyed playing for money, Williamson found his patience tried by his pupil who insisted that the satisfaction of winning was greater if nothing else were at stake.

"Didn't you ever gamble?" asked Williamson.

"Only once to speak of," replied duPont. "On the East Coast of Florida a few years back I just thought I'd see what it felt like. I took $\$ 500$ and went to a big place. I played everything-roulette, bird cage, dice, faro. When my roll was gone I left and have never had an inclination to gamble again. Gambling is an effort to gain something for nothing. Win or lose, it's bound to prove illusory. Why try to attain a world of illusion ?"2

Mr. duPont did not urge others to follow his strict example as to gambling. In the latter years of his life he often attended the horse and dog tracks in Florida, treating his guests to two-dollar mutual tickets, though never buying one for himself. He could spend hours watching the throngs about the tables in the casino at Havana without experiencing the slightest temptation to try his luck. The fact that he was a rich man, to whom losses or winnings would mean little, does not explain it. The rich gamble as avidly as the poor.

During the seasons of $1923-24$ and $1925-26$, a quest for sleeping quarters in Miami presented a problem. A cot in a hallway might cost $\$ 5$ a night. Tent camps surrounded the city. Hundreds slept in automobiles. Workmen carried blankets and spent the night on the premises of the houses they were building. There were many of these. A view from the water front showed a horizon latticed with the steel skeletons of skyscrapers. Ever optimistic, in I9I5 Floridians had predicted 25,000 population for Miami by 1925. At the height of the season in '25, Miami claimed roo,000 permanent residents and $\mathrm{I} 77,000$ transients. These are local figures which, like vegetables, grow faster in Florida than elsewhere. Whatever the number, it was all that could be fed. An embargo was placed on precious building materials and even household goods, in order that comestibles might come through in sufficient quantity to avert famine.

A few years back people had come to Florida of winters to rest 
or to play. Their children grown and gone, elderly folk who had worked hard and saved made Florida their winter home. A good many had bought bungalows. Now the once-tranquil Elysium presented a scene of relaxation comparable to the floor of the New York Stock Exchange or the wheat pit in Chicago. Visitors came for the tense business of gambling.

Seductive tales of easy money fell on every ear. Orange groves were cut down to build subdivisions. Samuel Untermyer, the New York attorney, bought a house in Palm Beach in 1918 for $\$ 75,000$ and sold it in '25 for $\$ 800,000$. A Chicago physician's wife went to look at a tract near St. Petersburg which her father remembered having taken to settle a debt of $\$ 400$. Eventually she sold it for $\$ 450,000$ and immediately regretted the act because she could have got more. A magazine writer went down to write a piece. To get first-hand knowledge of how the mechanics of speculation worked, he bought a "binder" for $\$ 300$, sold, bought and resold until he had cleared $\$ 8300$, making it immaterial whether an editor should buy his article or not.

The retired hardware merchant and his good wife from Chillicothe, Ohio, were offered \$10,000 for the bungalow which had cost \$450o. They took it and immediately "invested" the $\$ 10,000$ with the hope of making $\$ 20,000$. That opened new areas of speculation. The bungalow was on an unfashionable street in an unfashionable inland town. Its sale doubled in value every other bungalow on the street and made the owners itch to sell. Most of them did. People who had never played more than a quiet game of penny ante in their lives presently were gambling in figures larger than their lifetime savings before they had gone to Florida.

Mr. duPont engaged his one room at the Royal Palm Hotel in Maimi months in advance. It cost $\$ 45$ a day. It was worth that much to him to sit on the old-fashioned veranda and study the money-mad faces in the crowd streaming past. Keener powers of observation compensating for his muffled ears, Mr. duPont 


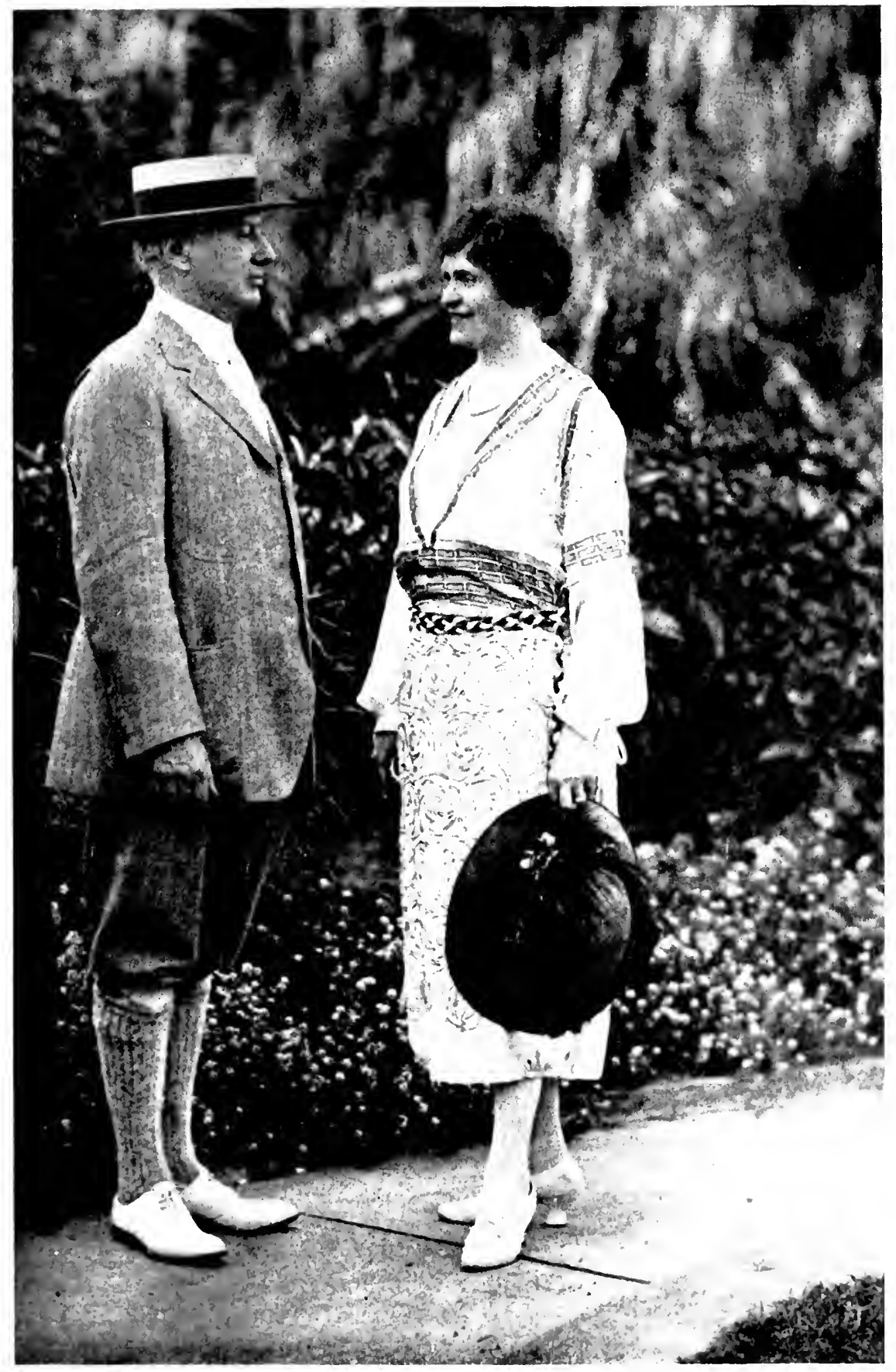

IN MHMI, 1926

Mr. and Mrs. dulont during the winters sojourn in the South when Alfred reached the decision to ant his lot with Florida in an effort to help rehubilitute the Stote from the chects of the collupse of the real-estute houm. 


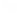


could get much out of a face. After dinner Mrs. duPont and he would sometimes change back to their street clothes and go out and drift with the crowd. Flagler Street was a blaze of light and a medley of sound. Windows of real-estate offices were plastered with pictures of swamp and subtropical jungle, done in color; not represented as swamp or jungle, of course, but as, say, glittering Peralta Terrace, the paradise of tomorrow. Canned music blared from open doors beside which stood personable young men addressing the passers-by:

"Why not buy a lot in Juanita Gardens and make your fortune?"

Coral Gables, just north of Miami, employed the best-drawing barker of all: William Jennings Bryan. The chautauquan's peerless platform English was heard every afternoon at three-thirty. Practicing what he preached, the old orator invested his lecture fees in near-by acreage.

Many were the names to conjure with. At Lake Mabel, General George W. Goethals, of Panama Canal fame, was in charge of dredging a $\$ 15,000$, 000 private harbor. Coleman duPont figured in two or three of the larger enterprises. Alfred ran onto his cousin several times, finding him as affable as could be. Knowing Coly's mode of operation in street-railway days, Alfred said that he was one Florida speculator who would stand to lose little when the bottom fell out.

Shoestring operator and big-timer alike dealt on a credit margin which grew wider until $\$ 1000$ would swing a $\$ 50,000$ deal. For $\$ 1000$, one got a binder, in effect a short-time option, on the property. Lacking any part of the $\$ 49,000-$ and only a small part would have been necessary-to effect a transfer of title, it would be up to the simon-pure binder speculator to dispose of his instrument before it expired. This was almost as easily done as said, and anything under a 25 per cent profit in a week was considered a dead loss. In the heyday a hustling "binder boy" could make $\$ 5000$ a month as a matter of course. Big operators involved the local banks; some of them, indeed, being bank officers.

The only rational basis possible for this delirium would have been the certainty that all Florida should grow during the coming ten years as Miami had in the past ten. Indeed, a dozen Goethals 
and a dozen Flaglers, working a dozen years with unlimited millions of actual dollars-as distinguished from Florida paper-at their disposal, could hardly have turned the countless miles of mango swamp, sand and jungle into the garden spots which the imaginations of promoters brought into being with one stroke.

Returning from an after-dinner stroll, Mr. duPont said to his brother-in-law:

"Ed, it is the craziest thing I ever saw. These people are on the brink of the precipice right now; and they talk about the good times only getting started."

This was the first week of January, 1925 .

It was Mrs. duPont who, possessing normal speculative instincts, had decided to ride with the boom in a small way. In I923 she had bought, for $\$ 33,000$, two adjoining strips of sand marked with unpainted stakes in Miami Beach. At the moment Alfred was manifesting an interest in a million-dollar estate at Cocoanut Grove. Having not only mastered the art of housekeeping in seventy-seven rooms, but having superintended the redecoration of them, Jessie Ball duPont wanted no more homes for a while-certainly not a million-dollar one. Consequently she evinced an active interest in a place at Miami Beach, believing it would draw her husband's attention from the grand scheme under contemplation at Cocoanut Grove. The stratagem worked. Alfred immediately began to enjoy himself drafting plans for a much simpler house for the Beach lots. Before he had gone far, however, he decided not to build in the face of a crash. This was exactly what his wife wanted. Before prices tumbled she sold one of the lots for \$100,000 and before they had tumbled very far she sold the other for $\$ 65,000-$ concluding a good deal all round.

After installing Sloan as president of General Motors, in 1923 Pierre S. duPont returned to Wilmington to watch over the home company as elder statesman, with title of chairman of the board. Though Pierre duPont had been a virtual father to his younger brothers and sisters, he did not strike one as a marrying man. 
There was considerable surprise in 1915, when, at forty-five, he married a first cousin, Alice Belin, who was a few years younger. The childless couple lived at Longwood, the estate across the Pennsylvania line which Pierre by degrees turned into a show place. His legal residence, however, was a room in the DuPont Hotel. This enabled Pierre to use his leisure for public affairs in Delaware along such divergent lines as the election of Coleman duPont to the United States Senate, and the completion of the work he had begun earlier to modernize the public educational system, defraying half of the cost.

Pierre duPont accepted the office of Tax Commissioner of Delaware and set about improving the collection of imposts. One aspect of this work represented a continuation of the labors begun by Alfred I. duPont in obtaining the enactment of legislation to bring about a greater equality in the assessments of the rich and of those of moderate means.

P. S. duPont's work as a tax-gatherer was well and fairly done, DuPonts being shown no favors regardless of what branch of the clan they belonged to. Alfred got a taste of this when a deputy of Pierre's called at his office to go over his books touching taxable property in Delaware. It is possible the deputy went of his own accord. Nevertheless, the visit riled Alfred who said he didn't like the idea of Pierre prying into his private affairs. ${ }^{4}$ To render this less likely Alfred organized under the laws of Florida the St. Johns River Development Company and the Brandywine Hundred Realty Company to take over all his landed holdings excepting Nemours.

Mr. duPont's seditious prophecy of January, I925, was not borne out by immediate events. Prices continued to climb. Nor was there a sign of the seasonal warm-weather lull in April when Alfred returned North. Activity continued all summer, with predictions that the season of '25-'26 would be the biggest yet. Italy supported a population of 40,000,000; Florida had only $\mathrm{I}, 300,000$. Verily, the golden hegira was only hitting its stride.

When Alfred returned to Miami, January, 1926, the story had been altered somewhat. A wholesome "readjustment" was under way, "values" and "prices" in a process of "stabilization" on a 
"permanent" basis. The binder boys had been cleaned out: good riddance. One heard much of the iniquities of the late binder boys, a criticism which failed to draw attention to the fact that these tin horn gamblers had simply got the most out of a process which had been nigh universal in Florida. The traffic in binders was possible only as long as the psychological atmosphere would permit a steep markup with every transaction. This ended suddenly at the close of the summer of 1925 .

The anticipated winter revival in "sound dealings" did not materialize. The crowds Mr. duPont watched pass the veranda of the Royal Palm were thinner than those of a year before, and the faces more anxious for all the brave talk about "healthy stabilization." People were not buying. Prices stalled, then began to slip. Amateur and professional speculators, stuck with property they had not intended to keep, were pressed to meet installment payments. By the end of March, 1926, Florida was scratching for cash, banks drawing on the surpluses they had laid up in Jacksonville and in Northern institutions during the plenteous years. When Mr. duPont departed for Wilmington, the reckoning was at hand.

He shuddered, he said, to contemplate the consequences. What the binder boys who had overstayed their time had lost would not be a drop in the bucket. Half of Florida was insolvent. Not individuals and corporations only, but entire communitiesmunicipalities, counties-eventually would be bankrupt and unable to meet interest on their obligations. Banks inevitably would go, one dragging down another, for those reserves would not last forever. To cushion this fall, to salvage something on which a chastened and perhaps wiser populace could rebuild would be a tremendous public service. The more he thought of it, the more the prospect appealed to Alfred's imagination, to his humanitarian impulses, to his creative instincts.

During the winter Mr. duPont kept Ed Ball busy at his favorite occupation of traveling. The trips he made were virtual voyages of discovery, attended by some of the discomforts which visit 
explorers and, incidentally, supplying a testimonial to the mudhorse qualities of General Motors' most popular-priced product, the Chevrolet automobile.

The long narrow northwestern neck of Florida, stretching from Tallahassee to the Alabama line, had hardly been touched by the boom. To feverish speculators and to casual travelers as well it was terra incognita. For one reason, it was hard to get to. Leaving Live Oak, in Suwannee County, whence runs the dark-bosomed river Stephen Foster immortalized but never saw, the next paved highway was nine miles outside of Pensacola, 320 miles distant. Ed Ball and Chevrolet traversed those 320 miles, following an old Spanish trail which in 1925 and ' 26 was about as the Spanish had left it. Not only this but Ball ventured on either side of the trail into the remotest backwoods.

As a young man Alfred duPont remembered that country as the most populous and prosperous in Florida. Lumber and cotton had been the great industries since before the Civil War. The time came when wasteful methods put an end to lumbering, saving a few antiquated mills kept going to supply near-by needs or in the hope of selling out to someone suspected of having more money than brains. The boll weevil took the cotton fields, bringing ruin to splendid plantations which had been under cultivation for seventy years. Fine old towns had decayed, the more enterprising people getting out and most of the others going to seed. From a million desolated acres, a culture representing the best traditions of the old-time South had vanished. In its place was the sorry spectacle of the local representative of the Southern poor-white class, the Florida "cracker."

All this Ball reported on. Further, he said that much timber still stood which would be valuable under modern lumbering conditions if transportation facilities existed. Much of the land was fertile, but, again, the deterioration of roads had removed it from all possible markets. On the coast stretched mile upon mile of beach equal, for resort purposes, to any in the world, except that the season would not be the same as that in southern Florida. Absence of roads made these beaches less accessible to Americans than those of Bermuda. 
Alfred mulled over Ball's reports. He pored over maps. He read technical volumes on the lumbering and wood-pulp industries. (Wood pulp is an essential ingredient of Rayon and Cellophane.) $\mathrm{He}$ boned up on Southern agriculture, with particular reference to citrus-fruit growers and the ever-increasing number of poor whites and of tenant farmers, white and black.

Without knowing what could be done or how it could be done, he came to the conclusion that northwestern Florida held possibilities as a laboratory for an experiment at bettering the lot of these unfortunate people, living amid conditions socially and economically lower than those of the peasantry of Western Europe.

Early in $1926 \mathrm{Mr}$. duPont bought, in the names of his land companies, tracts in Franklin, Bay and Walton Counties aggregating $66,08 \mathrm{I}$ acres, and 800 lots in the fishing village of Carrabelle. The cost was $\$ 808,3 \mathbf{I r} .^{5}$

During the summer of 1926 , at Nemours, Alfred duPont made up his mind to do what he could to rehabilitate Florida, and to spend the rest of his life at it. He was sixty-two years old.

"It's a challenge we can't pass up," he told his wife and her brother.

Mr. duPont rarely said "I" when speaking of his Florida concerns. The lowliest of an eventual corps of two or three hundred employees was given a feeling of partnership by his "we"-and by his "our" bank, "our" building, "our" land, "our" plans. And these words were given additional force by a distribution among the employees of a share of the profits-as soon as there were any.

"We don't want any more money," he said to Mrs. duPont and to Ed Ball, "and we shall make none for some time. But in the long run the things that we do, whatever they are, will have to pay. Profit is the water that turns the wheels of any sound economy. If what we do is to last it will have to be profitable for those who participate in it."

Mr. duPont had no thought of seeking merely to restore the status quo in Florida, with boom-time follies eliminated. $\mathrm{He}$ wanted to try to work out some of the social ideas which had been growing within him for years. Basically these had to do with a better relationship between capital and labor, a more just division 
of those essential profits. The riches soil and sun had planted in Florida he believed to have been scarcely touched. In that the boom-timers were correct. But Mr. duPont meant to go at the realization of those riches in a different way, and when realized he meant to utilize them differently. The young should have the advantages of schools, playgrounds, music, proper medical care and decent homes. In this connection Alfred had the crackers of northwestern Florida particularly in mind. Men and women in their prime should work and work hard, and there should be work for all. The old whose working days were over should be taken care of in comfort. ${ }^{6}$

Nemours was closed earlier than usual that fall. Mr. and Mrs. duPont took living quarters at the Mason Hotel in Jacksonville and Alfred opened an office in the Barnett National Bank Building. Almours Securities, Inc., was organized, to which Mr. duPont transferred everything he owned excepting his Wilmington residence. The value of these assets was $\$ 34,000,000$. From the office of Almours Securities, Inc., was dispatched a line to Tax Commissioner P. S. duPont to the effect that Alfred I. duPont was no longer a citizen of Delaware.

"You will doubtless be surprised at my taking this step," Alfred wrote a friend, "but ... I had no other course left to pursue. The golden tentacles of the wealthy class have been quietly laying hold of the whole state of Delaware. They have managed to control every office, both in the state and in the city of Wilmington."T

Among Florida communities Jacksonville is the steady member of a family of Good Time Charleys. The emphasis is on work and not play. In winter the men wear dark suits and felt hats, rather than whites and straws as in Saint Augustine, about fifty miles south. Florida's largest city and its financial capital, Jacksonville possessed three banks which for a generation had served as depositories for banks downstate and had financed much of Florida's sound industrial development. Twenty miles up the St. Johns River, Jacksonville is a busy port, manufacturing and forwarding 
center, not a resort. Though touched by the boom it had not been engulfed by it.

Mrs. duPont's enthusiasm for the new venture swept away her objections to managing another residence. Buying a few acres south of the city on St. Johns River, which is three and a quarter miles wide at that point, Mr. duPont designed a house. This was always fun. He made drawings for a fountain which consisted of groups of frogs, alligators and pelicans-all good Florida fauna, the pelicans, as Alfred said, being particularly appropriate because of the similarity between their beaks and DuPont noses. The house was to be in Spanish hacienda style, and not large-seven master bedrooms. Deeply shaded by pine and huge moss-draped oak and hickory, the grounds suggested the name which was given the new place-Epping Forest. Epping Forest is also the name of the Virginia homestead in which Mary Ball, the mother of George Washington, was born, and which had descended to a cousin of Mrs. duPont.

While the house was going up, Mr. duPont went to Miami for the winter to take the sun and study the general situation. He wished no fanfare to herald his entry into Florida, but despite his discretion news of the formation of Almours Securities, Inc., and of Mr. duPont's intention to consider further Florida investments leaked out.

"DuPont Millions to Florida!" screamed'newspaper headlines. The authorized capitalization of Almours Securities was \$40,ooo,000. Journalistic mathematicians multiplied this by five in their references to the "\$200,000,000 investment corporation" Alfred I. duPont was throwing into the breach in this interesting juncture in the history of Florida's development. Though one or two unimaginative scribes did write the figure down to $\$ 100$,000,000 , the verdict was unanimous that Mr. duPont's action supplied conclusive evidence of the soundness of Florida investments.

As drowning men clutch at straws, the victims of the collapsing boom paraded the wildest tales of Mr. duPont's "confidence" in Florida. They tried to interest Alfred in every conceivable speculation. Had duPont's fortune in truth been $\$ 200,000$,000 he could 


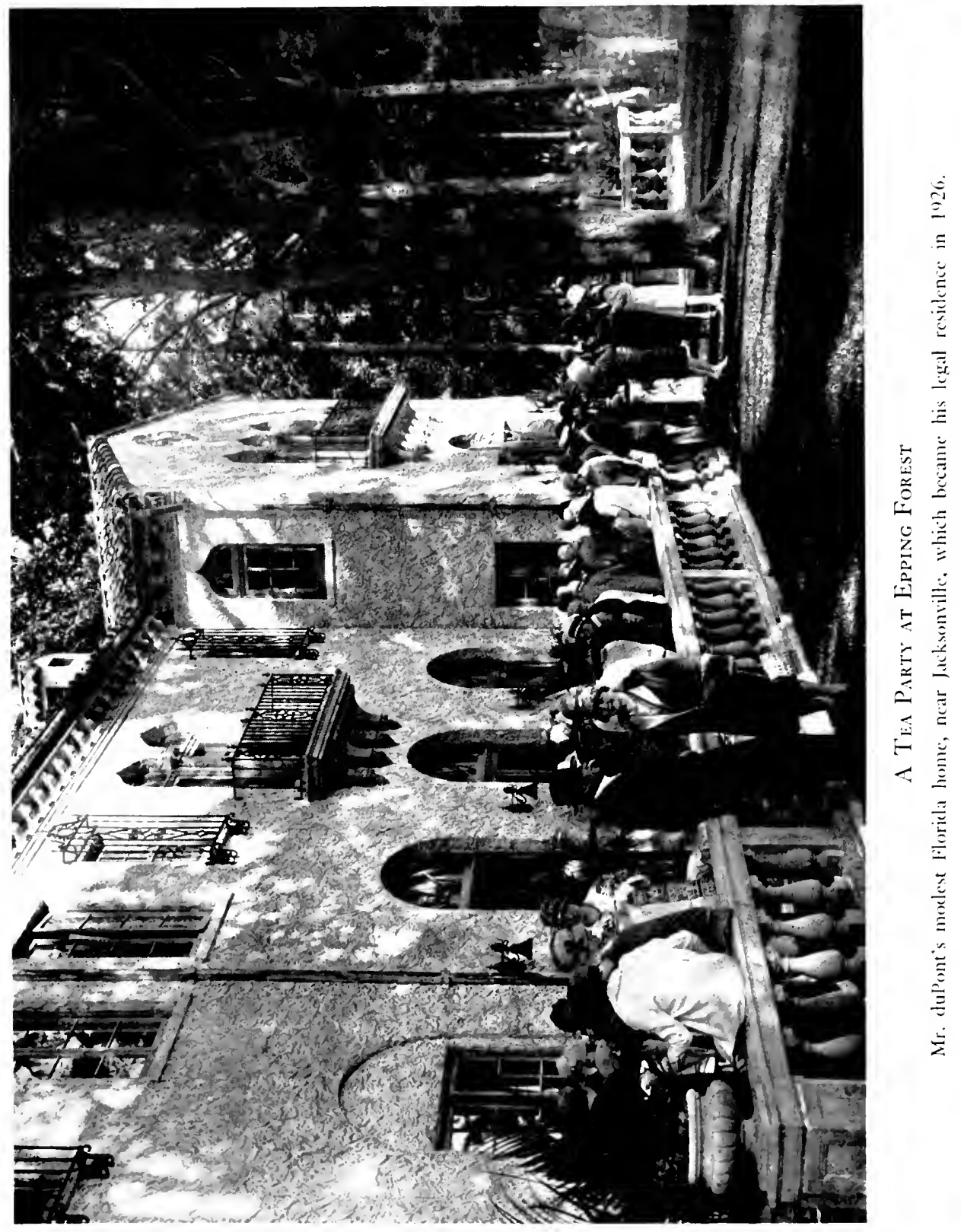



have placed it all within ninety days. Very few of these desperate manipulators saw Mr. duPont personally. Edward Ball had the job of handling them. One crowd from the west coast presented a diverse but well-integrated plan calling for an outlay of $\$ 25,000,000$.

"Gentlemen," said Ed, after listening to the project in detail, "don't you think $\$ 25,000,000$ a good many eggs to put in one basket?"

"Good Lord," exclaimed one of the promoters in astonishment. "Is that all that's wrong? We can pare down. To tell the truth we stayed awake three nights trying to get the figure that high. We know Alfred I. duPont's a big man and we thought a smaller proposition wouldn't interest him."

Such candor deserved a reward. As a part of the project outlined dealt with building a road through the inaccessible northwestern neck of Florida, Ball was able to tell his callers that Mr. duPont already was exploring the question.

This was one of the tasks assigned to William T. Edwards, a former Baltimore businessman Alfred had known in the North.

Ed Ball was asked to pick up a few shares in the three Jacksonville banks, the Atlantic National, the Barnett National and the Florida National. Already a few small downstate banks, which had made loans on fictitious real-estate valuations, had gone under. Alfred knew them to be the first of many which would have to go. He wanted to know to what extent, if any, the Jacksonville banks were involved in the punctured boom. As a stockholder he hoped to learn a few facts, from behind the cages, not available to the public.

Because of a difference of opinion on questions of management and personnel Alfred had sold his interest in the Delaware Trust Company to his partner, William duPont. This banking experience had been instructive. It had given Alfred a clearer insight into a bank's internal operation and into its role as a part of the mechanics of a well-balanced, functioning economy. With Florida's economy out of balance and ceasing to function, and with its banks in peril, Alfred knew that a few safe banks would be essential to any hope of recovery. A few safe banks, standing fast amid 
the widespread ruin which Mr. duPont was certain would come, would be anchors to tie to. By carrying people who deserved to be carried they could keep the inevitable collapse within limits, averting a general panic in which solvent and insolvent might be dragged under indiscriminately.

The largest and most powerful Jacksonville bank was the Atlantic National, dominated by Ed Lane. Edward Wood Lane was Florida's J. P. Morgan. A short, thickset man of fifty-seven, with a sharp hook of a nose protruding from his round face, Ed Lane had come down from Georgia twenty-five years before to sail the risky waters of Florida finance. Neither enjoying nor courting personal popularity, Lane knew, nevertheless, that some who cussed him loudest would continue to deposit with the Atlantic National, believing their money safe in its keeping. Long before the great boom Lane had made a fortune in Florida for himself and had enriched many of his followers.

The deposits in Lane's bank totaled $\$ 26,000,000$, or $\$ 10,000,000$ more than its nearest rival, the Barnett National. The Barnett National was the older and once had been the larger bank, just as courteous, distinguished-looking old Bion $\mathrm{H}$. Barnett, a Hoosier by birth, had once been Florida's leading financial figure. Though past seventy, spending much time in Europe and taking only a supervisory interest in the institution which bore his name, $\mathrm{Mr}$. Barnett was still a force to be reckoned with. He was known as a man to whom a fellow in trouble could turn: a virtue which lately had more than one Florida banker in difficulties.

The third Jacksonville bank, the Florida National, was just below the Barnett in point of deposits. In its management was no salient personality such as Ed Lane or Bion H. Barnett.

In each of these institutions Edward Ball acquired a few sharesenough to learn that all three were "loaded with slow notes at best," as Ball put it to Mr. duPont. In better condition than its competitors, Lane's Atlantic seemed in shape to weather the breaking storm without much trouble. The stock was closely held, as 
was that of the Barnett. Florida National stock, being more widely distributed, was easier to pick up. Ball reported the Florida definitely the weakest sister of the three. Mr. duPont said never to mind that for the present, but to keep on buying its shares. ${ }^{9}$

The middle of March, 1927, Mr. duPont returned to Jacksonville for a housewarming at Epping Forest. "You will like the joint," he wrote his old friend Cap LaMotte. "It strikes me as being about ideal as to location, size, lay-out, etc."10 Characteristically Alfred began almost at once to contemplate improvements of the ideal. "Building a new boat house," he informed Geraldine Lee, wife of Maurice, the following autumn. "The old one looked awful bum, and being more or less of a bum myself I resent the intrusion. The new boat house will be large enough to accommodate two good-sized boats and innumerable small ones. It will have quite a lovely roof garden on top, where people can sit and look out over the water and catch cat fish.... I forgot to say that on arriving home I found I was the possessor of another Two Dollar bill, to say nothing of thirteen One Dollar bills, all in a row! I hope I got rid of both before you broke your leg."11

There was a dock for the Nenemoosha. For navigating shallow inland waters Alfred bought a houseboat, the Gadfly; also a sleek and noisy speedboat which he called the Hellkat. Another source of enjoyment was a modern six-pound cannon, mounted by the water's edge beside a flagpole. Each evening at sunset the gun was fired and the flag came down. The Nenemoosha carried a fourpounder and sometimes at sea Alfred would indulge in target practice with live ammunition.

Mr. and Mrs. E. W. Lane were among the early callers at Epping Forest. Already the Lanes were Mr. and Mrs. duPont's closest social acquaintances in Florida. Lane was a rare story-teller -a sure passport to Alfred's favor. These cordial relations did not extend to the domain of business, however, Alfred remaining close-mouthed concerning his plans. Over cigars one evening another visiting 'Florida banker repeated a saying for which he was famous.

"A bank, Mr. duPont, is like a woman; something you can't talk about." 
"That's right," replied Alfred, "provided they both have shady reputations."

"The Jacksonville banks are all right," protested the banker. "Jacksonville is the sound-money center of the State. Her banks are solid."

"Yes," said Alfred. "Like cakes of ice."12

One evening Mr. duPont was seated in the library with Ed Ball and W. T. Edwards.

"Boys," he said, "we are now in Florida to live and work. We expect to spend the balance of our days here. We have all the money necessary for any reasonable effort to help Florida grow and develop. Our business undertakings should be sound, but our primary object should not be the making of more money. Through helpful works let's build up good in this State and make it a better place in which to live. In my last years I'd much rather have the people of Florida say that I had helped them and their State than to double the money I now have."13

By this time Mr. duPont had made a rough calculation of what he intended to invest without expectation of immediate return. On some of this he anticipated no return in his lifetime, and the thought of early death was not in his mind. The amount earmarked was $\$ 5,000,000$. He told his wife he would spend that and then take a bird's-eye view of the result before risking any more.

Mr. duPont heard the word "profit" so much that he got sick of it. A sure way to prejudice him against a proposition was to speak of the money to be made.

"Money, money, money," he told Edwards. "Everybody talks about money. Never in my life, I can honestly say, have I gone into anything with the sole idea of making money."14 


\title{
CHAPTER XXIV
}

\author{
The Old-Age Pension Campaign
}

AfTER a year of quiet buying, Alfred I. duPont unobtrusively obtained operating control of the Florida National Bank of Jacksonville in the fall of 1927. Ball protested that his brother-in-law paid too much for the stock. This complaint did not impress Alfred. Unlike Ball, Mr. duPont was not a close trader. When he wanted a thing badly enough and had the money to get it, price was seldom much of an obstacle. Alfred told Ball that the condition of the bank-overloaded with slow loans-added to the urgency of the case: someone who could guarantee the institution's solvency had to get in a position to take the helm if need be. It would never do, he said, for a bank in Jacksonville, seat of the little financial confidence remaining in Florida, to get in trouble. Therefore the payment of a good price for Florida National stock, when it could have been had for less, served a farsighted purpose.

Mr. duPont made no dramatic use of his newly acquired authority. Ball, who had been a director of the Delaware Trust, took a place on the Board of the bank, which enabled him to report to $\mathrm{Mr}$. duPont in detail on its condition and to give a more intimate inside picture of the general banking situation in Florida. This picture fully accorded with Mr. duPont's anticipations when the land boom was at its peak. More than fifty banks in the State had failed, and as many more were on the edge. Deflation had not run its course to a point where sound reconstruction was possible. Moreover, the national situation appeared as a possible added complication. The stock market was running away with itself, speculation on margin becoming a vogue. Mr. duPont began to fear a repetition of the Florida boom on a nationwide 
scale. All in all, the situation, locally and nationally, called for a bit of waiting.

In 1928 the Republicans nominated Herbert Hoover for the Presidency, and the Democrats Alfred E. Smith.

Alfred duPont had followed with admiration the record of Governor Smith: his grasp of the problems of public finance and taxation; his sponsorship of legislation to free natural resources from the grip of utility companies; his friendship for labor, his social reforms, his courageous opposition to the measure currently responsible for more hypocrisy in public life than any other-the Eighteenth Amendment. Moreover, Al Smith had come up by his own efforts from New York's East Side; and he was a Catholic.

Mr. duPont also thought highly of Secretary Hoover, who had no stronger supporter than Will Glasgow, Alfred's attorney and a frequent guest at Nemours and at Epping Forest. Counsel for the Food Administration during the war, Glasgow had been close to Hoover ever since. Alfred respected the Secretary of Commerce as a humanitarian and a first-class public administrator.

A Republican, Mr. duPont would have supported Hoover in any case; but what led him to renounce his retirement from politics and to take an active part in the campaign was Al Smith's choice of certain advisers. The Governor named John J. Raskob his campaign manager, and early in the canvass Pierre S. duPont came out for the Democratic nominee. There were the inevitable reports concerning the rewards these gentlemen were to receive in event of Governor Smith's election; Raskob to be Secretary of the Treasury; Pierre duPont to be Secretary of State or Ambassador to Great Britain. Though Alfred had privately defended Pierre's administration of the office of Tax Commissioner of Delaware, ${ }^{1}$ he did not relish the prospect of his cousin at the head of the State Department or in knee breeches at the Court of St. James's. On the assumption that Smith was a good man in bad company, Alfred decided to try to carry Florida for Hoover. ${ }^{2}$

After setting up a Hoover Democratic Committee in a number 
of counties, Mr. duPont sailed for Europe, leaving Ed Ball and Gilchrist Stockton in charge. Stockton, a Jacksonville real-estate man, had worked with Mr. Hoover in Europe.

Lenient tax laws had induced a good many regular winter visitors from the North to establish their legal residences in Florida. This gave the Republicans quite a scattering of bona fide partisans in the resort centers. Elsewhere two avowed appeals for the Hoover ticket were possible: the perpetuation of Coolidge Prosperity and the retention of the Eighteenth Amendment. Much was made of these issues, especially as one of their functions was to cloak the unavowed appeal which represented the Republicans' only real expectation of carrying the State. This was the appeal based on Governor Smith's religion. A similar formula was followed by the Hoover campaigners in all Southern States.

On the prosperity issue a number of impressive citizens were lined up, many Floridians being willing to forget party fences in the fervent hope that the Coolidge horn of plenty might spill something their way. On the dry issue the Anti-Saloon League joined the Hooverites. On the Catholic issue the Ku Klux Klan was used. A clergyman supposed to control the Kluxer vote was added to the speakers' bureau. Sidney J. Catts also was added to it. This darling of the Florida crackers made six speeches for the Republican ticket. Catts was a country preacher who in 1916 had been elected governor by the cracker vote. In that campaign the Reverend Catts had ignored his visible opponent and had run against the Pope. He told the crackers they had only three friends in the world: Jesus Christ, Sears Roebuck and Sidney J. Catts. A less pious man might have mentioned himself first. In 1928 exGovernor Catts was able to discover a fourth friend of the underprivileged: Herbert Hoover.

Perhaps fortunately for his peace of mind, Mr. duPont remained in Europe until a few days before the election.

"Home again," he notified his nephew Maurice Lee, "and, as usual, say, to Hell with Europe and hurrah for the United States!"3

The result of the election provided additional reasons for pride in his native land. Hoover carried Florida by 44,000 , and Mr. duPont received complimentary mention in the public prints as a 
Cabinet possibility. Alfred did not take this seriously, though he deemed the Republican victory worthy of a celebration. The youthful Nenemoosha pirates were summoned to Nemours for a reunion.

"Hurry up, P. D. Q.," the mother of three young buccaneers was instructed. "And for Heaven's sake don't make me angry for I've just licked Pierre and Raskob and made Florida Republican and I am reeking with gore!"4

The joy over being home lingered longer in Alfred's mind than gory gratification over the discomfiture of Messrs. Pierre duPont and John Raskob.

"We are very glad indeed to get back, but then I would have been glad to get back before I left. I am a poor traveler and am really an old fashioned 'stick in the mud' and would have much preferred to spend the summer in Happy-Hannock than in any portion of Europe." Happy-Hannock was Mr. duPont's way of rendering Tappahannock, Virginia, the home of an aunt of Mrs. duPont, to whom he was writing. "I am a very poor mixer, do not make friends readily and when I do I am exceedingly disagreeable. Dearest Jessie, of course, enjoyed every minute of it, as she is a wonderful traveler and gets so much pleasure out of seeing different places and meeting different people."

Mr. duPont's portrait of himself as a recluse was somewhat overdrawn. In the past seven years he had changed a good deal in that respect. Still, he enjoyed the Nenemoosha because of the opportunity it afforded to enjoy without interruption the society of a chosen group of companions.

"I find that my yacht is the only recreation which absolves me from all responsibility and worry and where I can relax. A man without ears is of necessity under a great nervous strain in connection with attending to business matters. I built the boat myself, and am constantly playing with the mechanical end of it, which makes the pastime even more interesting." 


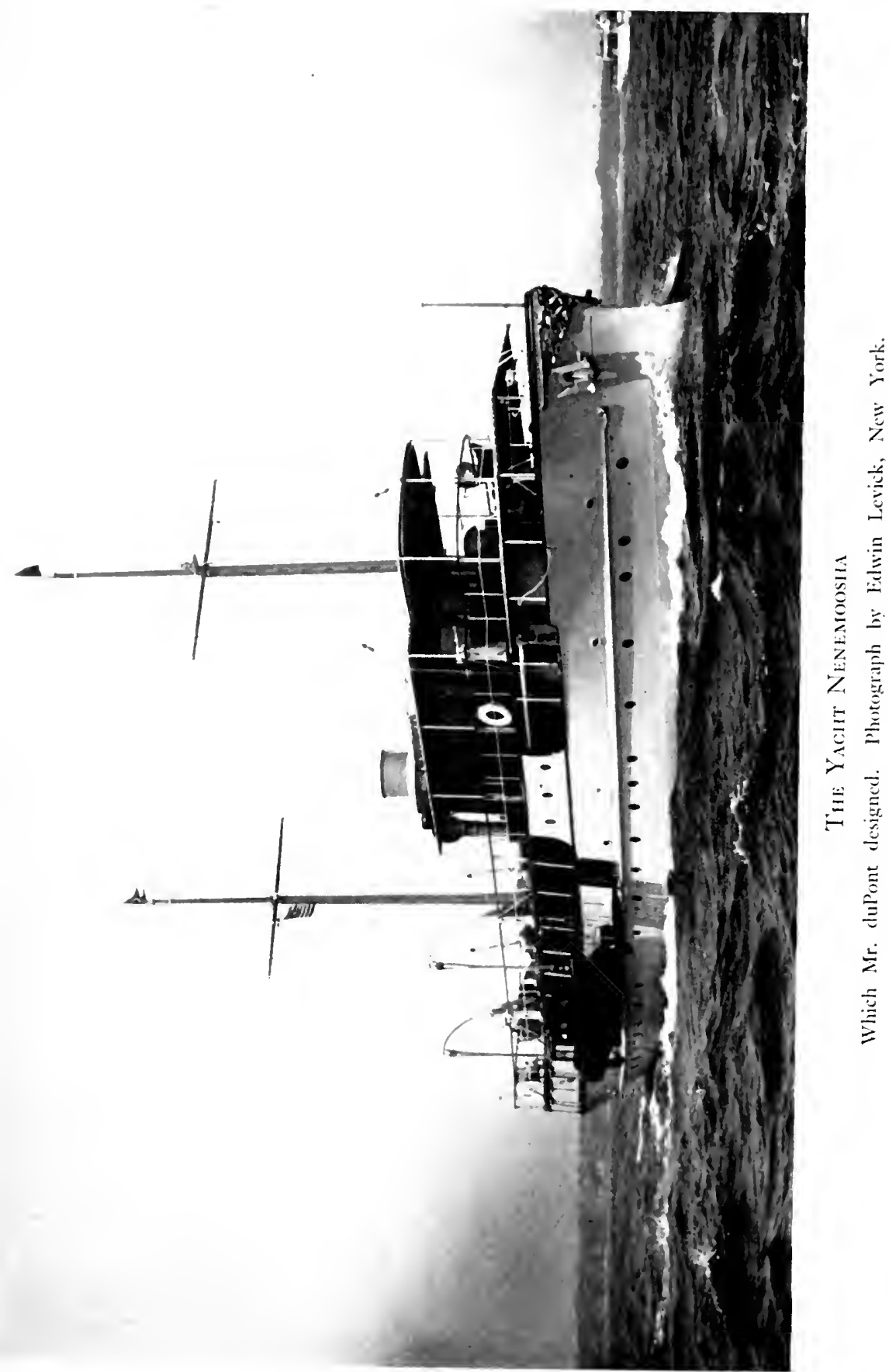



Nevertheless, the occasions on which Mr. duPont would desert his guests to spend his time in the engine room were rarer than formerly.

The smokestack of the Nenemoosha was abnormally large. The reason for this transpired when Alfred decided to put new engines in the craft. The old power units were taken apart and hoisted out through the stack and the new ones installed the same way, without tearing a hole in the deck as the shipbuilders thought they would have to do.

The pirate reunion ended too soon for the thrill of the year as far as the Nenemoosha was concerned. With only Ed Ball for company, Alfred sailed from Wilmington in order to be in Jacksonville for Christmas. Off Cape Fear they ran into a gale which, when at length a bearing could be obtained, was found to have carried them beyond the Charleston lightship.

"It was good sport for anybody who likes to see the waves thirty feet high and spray flying in all directions. I spent most of the night out on port deck or up in the pilot house with the Captain. Ed Ball was lying on his stomach in his bunk, spread out like a split buzzard, trying to hold himself from flopping out of his bunk into the mess of bureau drawers, suit cases, chairs and other furnishings that were flopping around on the floor of his cabin. When I went into his cabin in the morning after the boat had entered the [Charleston] break-water, and called out 'Jersey City,' he greeted me with a smile that would have made the high angels in Heaven turn green with envy."

Among his familiars Mr. duPont's humor could take the form of ebullient horseplay.

"Please don't write me letters with 'O. K.' in them the way you do. There is no such words as 'Okeh' or 'Okey' as some illiterate people will suppose. The two letters are of Greek origin and come from the two Greek words Okas and Karatos, meaning all right. As a student of the Bible I know practically everything concerning English, French, German, Latin, Greek and Hebrew-very, very much of the latter, due to my unfortunate associations with relatives." 
On New Year's eve he gave the recipe for the punch he said he was making.

"It consists of all the wine that has gone stale during the year. This is poured into a large punch bowl, with a few bottles of champagne and cider; two quarts of lemon ice are then added; three bottles of rum, a couple of gin and anything else that happens to be handy. I do not take this, but stick to ginger ale, the net result being that I can see the New Year in while being in bed and no one will know where I am. I will get up at six o'clock the next morning and have a lovely time all by myself, while the others will do their best to get on their feet by lunch time."9

If guests were, in truth, allowed to lie abed until noon this represented a special dispensation. Regardless of when he retired, Mr. duPont was always up at six. At Nemours, at Epping Forest and on the yacht, the breakfast hour was seven-thirty in the summer and eight in the winter; on Sundays thirty minutes later. One morning Will Glasgow overslept and crept into the dining room on his all-fours.

"Good evening, Will," said Mr. duPont. ${ }^{10}$

Habitual tardiness was recognized by a discontinuance of overnight invitations to the offenders. Perhaps some who regarded late rising as one of the essential privileges of a holiday were able to accept the sentence with equanimity. Others might slip away for naps in the afternoon.

Once at Nemours there was a disproportionate number of women guests. Alfred telegraphed his old friend Cap LaMotte in Philadelphia:

\section{“CHICKEN DINNER TONIGHT COME HELP ME OUT WIRE TRAIN."}

Alfred cared nothing for golf and poked fun at such devotees of the game as his daughter Bessie Huidekoper, her husband, his nephews Maurice and Cazenove Lee, and Will Glasgow. "Glasgow plays golf all day, talks golf all night, and his teeth look like golf balls every time he smiles. $\mathrm{He}$ and my guests come home so 
exhausted that I have to screw a bottle into their faces like a spark plug in a motor in order to give them strength to go to bed and start playing more golf next day. Now what do you think of that for a way to have fun, with all the nice boating on the river?"12

Mr. duPont's chief sport, however, was trap shooting, which he tried to encourage among some of his young men and women acquaintances by giving them shotguns.

An event with which nothing was permitted to interfere was an annual outing for veteran powdermen, their wives and families. These affairs were held in June, Mr. duPont personally arranging every detail, including the menus. The attendance ran from six to eight hundred. Alfred would charter a Delaware river steamer and take them to Riverview Beach, an amusement park below Wilmington.

Alfred duPont dearly cherished those old associations, which death and other circumstances diminished each year. One afternoon Mrs. duPont found her husband in the library at Nemours with tears in his eyes.

"Harry Smith is leaving," he said. "You can't part from a man you've worked with twenty-five years without a wrench at the old gore pump."

Harry Smith was the plumber at Nemours. Eligible for retirement, he had informed his employer that he was moving to a farm he had bought in Pennsylvania.

"I tried to get him to locate nearer here," said Alfred, "so we might see each other once in a while. You know Smith's a rare man-a fine, old-school mechanic." Alfred chuckled as he added: "And always stealing my pet tools."13

By one detail did Nemours escape being a strictly formal household. This was the presence of dogs which had the run of the place, deranging rugs which cost a fortune and sleeping on chairs which were collectors' items. Guests at Nemours sometimes longed for the privileges reserved for those dogs. On occasions when the 
company was small and intimate-Alfred's children, other near kin or old friends-it was hoped that he might waive the dress-fordinner rule. But he never did. A little after six he would stir in his favorite chair in the library and ease a dog from his lap, with: "Well, shall we reverse our cuffs?"

The library was the most homey room in the house, and, next to his sanctum in the basement, Alfred's favorite. The books on the shelves, many of them in French, attested to the catholicity of Mr. duPont's reading: European and American history, biography, science, economics, religion, drama, poetry, belles-lettres, music and yards of fiction old and new.

When Mr. and Mrs. duPont dined alone, they dressed.

"I wish we didn't have to change tonight," he would say sometimes. Then, after a moment's hesitation: "No, dress we must. If we are not going to live up to these standards"-a gesture indicated the magnificence about them-"who is?"14

Few who knew Alfred duPont well believed he would have built a place like Nemours except to gratify Alicia. His love for the simplicity of Cherry Island and his growing attachment for Epping Forest-which he called "ideal" as to size-lend some color to this view. But having Nemours on his hands, he felt that the proprieties should be observed.

For a rich man $\mathrm{Mr}$. duPont had few rich friends, and he shunned invitations to other large and formal houses. Even Cazenove Lee's wife found it difficult to lure him to their place in Washington, which was neither large nor formal.

"Too much style," he protested, "for a young country lad like me. I do not thrive on the social life." $"$

Young persons and children are not formal folk, and more and more, after the enriching episode of the reconciliation with his own children, Alfred sought their company and immersed himself in their affairs. These associations ran the gamut of youthful experience. When his niece Charlotte duPont, Maurice's daughter, had a nervous breakdown on top of tuberculosis, Alfred made a study of her case. He sent her to the Battle Creek Sanitarium, in Michigan, and wrote a series of letters of guidance. 
"A letter from your Dr. Johnny [evidently a nickname] to your Aunt recites the fact that you take all your meals in your room. Nobody but an invalid is justified in doing that and Dr. Johnny furthermore says that your health has improved remarkably, so there must be some other reason than physical inability to go to the dining room to account for this gastronomic exclusiveness on your part. Normal people do not take their meals in their room. They like to go to the 'hash-hall,' where they can look out of the windows and see anything there is to be seen and look at all the people, to say nothing of meeting with them and talking with them, which is always interesting, amusing or instructive.

"If you nurse an ill, be it fancied or real, you are going to be sick and stay sick; and again, if you don't desire to associate with your fellow beings, the condition is again abnormal. A head of cabbage is preferable to being forced to look at one's own head in the glass forever. So if you want to please me and if you want to get well, behave just as I would, did I have your ears and your strength.... "With a barrel of love, of the consistency of molasses, I remain, "Affectionately, your uncle ..."16

He wrote to the parents of the girl, trying to ease their minds. Notwithstanding their dissimilarities of character, a firm bond existed between Alfred and his younger brother; and from the day he first defended her before the Brandywine clan, Alfred had never ceased to adore his witty Irish sister-in-law, Margery. These two teased each other unmercifully. "Sister duPontificus" was one of Alfred's names for Margery-an allusion to her devout Catholicism.

The health of the youngsters within his sphere of influence was so well-worn a topic that Alfred sought to save it from tediousness, sometimes by signing his letters "Lydia P[inkham] duPont." Again to sugar-coat a point, he would lapse into verse:

"Here lies my wife Samantha Proctor

Who ketched a cold and wouldn't doctor.

She couldn't stay; she had to go;

Praise God from whom all blessings flow."17 
Mr. duPont could recite hundreds of lines of the jingles of Don Marquis and of Lewis Carroll. Gilbert and Sullivan he knew almost from end to end. Occasionally he palmed off his own compositions as the works of such writers. His letters to youngsters often contained rhymes apparently dictated on the spot. This was to his grandson, Benno Hiebler:

"Mule in a barnyard, lazy and sick,

Boy with a pin at the end of a stick, Boy jabbed the mule, the mule gave a lurchServices Monday at the M. E. Church."

Another to the same:

\section{"Little boy-pair of skates, Hole in the ice-Golden Gates!"18}

"Apropos of Shakespeare, Byron, et al.," he wrote a schoolgirl cousin of his wife, "I am sending you my latest creation entitled 'Little Willie's Golden Rule.' There is nothing personal in this creation, so you need not strain your eyes to read between the lines. It is just the imprint of one of my festive thoughts as they pass through my benighted nut. If it conveys nothing to you don't be surprised." ${ }^{\prime 9}$ Incidentally these verses had their world premier when Alfred read them to the assembled guests at the wedding of Mrs. duPont's sister, Elsie Wright:

\section{"LITTLE WILLIE'S GOLDEN RULE"}

"Then Lizzie grabbed the rolling pin

And stepped behind the door

As weary Willie wandered in

A feelin' tired and sore

A hopin' for a dainty kiss

To damp his dusty jaw;

But when the kissing it was did

Sweet William was no more.... 
"Sweet William floats among the clouds

While Angels look askance

As Willie draws his golden rule

From out his silver pants.

"To do unto the other man

As he should do to you

Sounds very well both down in Hell

And up in Heaven too,

But there upon this mundane sphere

One rule alone obtains

The one who hits the hardest blow

Is he who here remains!..."

Mr. duPont's jesting description of the origin of this jingle is probably accurate. Many of his rhymes seem to have been impulsive recordings of spontaneous thoughts. The tenor of some was quite serious. Riding on a Pennsylvania train he drew from his pocket the envelope containing his railroad tickets, scribbled a few lines without hesitating for a word and passed the paper to Mrs. duPont. He had written:

"Oh Beauty, thou flower of Unsurpassed fragrance, How brief is thy lifetime How fleeting thy breath, Today in the sunshine, Tomorrow the shadows Are casting their mantle In silence of death."20

Within the DuPont family are two or three collections of Alfred I. duPont's "poetry." Thrown together, with duplications weeded out, there would be enough to fill a small volume. The verses fall into different categories. Some of them will be shown to anyone expressing an interest in the subject. Examples of these appear on the pages preceding. Others are reserved for more limited audiences, as some understanding of family complexities and characteristics is essential to their proper appreciation. Still others are seen only by those whose discretion or whose loyalty to Alfred's con- 
nections can be relied upon. At least one of these efforts has the quality of a family saga.

In 1927 and I928 Alfred I. duPont occupied an interesting and unsatisfactory position as a stockholder in the DuPont Company. Due to the spectacular rise in the market, his holdings were worth around $\$ 70,000,000$. Yet he was without representation on the Board of Directors and practically his only light on the unannounced plans of the management, open to directors whose stakes did not represent a tithe of what Alfred owned, was obtained by roundabout means. Information thus gained was sketchy and often inaccurate. It was questionable if any other stockholder in American industry, with anything like the amount of Alfred's interest in the company which bore his name, was so greatly in the dark concerning his investment. At any rate this was the way Alfred looked at it. His private criticisms of the company management were caustic and sometimes rather sweeping. But did he mean them literally ${ }^{21}$

Not the least of Alfred's interests in the company concern the prospects it held for his son to advance. He hoped Alfred Victor would like his work in the Rayon plant at Buffalo.

"In any new industry, such as Rayon, there is greater opportunity for inventive genius and individual initiative than in an industry such as High Explosives, which in this country is over forty years old; but, even so, it is impossible to conceive of any industry wherein there is not room for yearly improvement of the mechanisms which enter into its manufacture. [This opened a favorite theme with Alfred.] I do not know why greater improvement has not been made in the past years in both the dynamite and black powder operating departments. In the latter, for instance, the various machines used are just such as I developed prior to I915. They are in the main satisfactory and a hundred percent safer than were the machines when I found them, but there was in my mind a dozen improvements which might have been made....

"The Rayon business is much more interesting from every stand- 
point, though the element of danger which entered into one's life in the powder business always gave it additional spice; but you have before you almost a clear field and, with the stimulus which independence of thought and action engenders, it is a case of matching your own brain power and thought against the field."22

Alfred Victor sent his father a model of a ship which he had made. "I used to be pretty good with tools myself," the pleased parent wrote, "but was weaned from wood working by the allurements of a machine shop, so have done more working in metals."

Alfred Victor's experience with Rayon did not turn out as anticipated. He had hoped for work in the construction department to enable him to realize his ambition to build things. Instead he was placed in the technical engineering branch for which he was poorly qualified.

"I have always felt," the father observed, "that your footing with the Rayon Co. was insecure... I worked 18 years for the old duPont Co. [prior to the 1902 reorganization] and never a thank did I get.... I hope you will be spared eating potatoes from the same barrel." 24

When Alfred V. threw up the job and went to Paris to study architecture, Alfred, senior, was delighted. He sent his son long letters displaying a knowledge of architecture which astonished the beginner. One of his letters of counsel asked the young man to remember that "there is a well worn epigram popularly misquoted which reads 'A very little knowledge is a very dangerous thing'. Of course such a statement is absurd and untrue. The correct rendering- 'A very little learning is a dangerous thing' is quite different as well as quite true." 25

\section{7}

The higher stocks went in the bull market of '27 and '28, the stronger grew Mr. duPont's distrust of Coolidge Prosperity.

"Are you making any money, Doc?" he asked Doctor Charles M. Hanby, who had been the family physican at Nemours.

"Some," replied Hanby, referring to his market operations. 
"Don't save any of it," said Alfred.

"Why?" asked the Doctor.

"Because the time is coming when they're going to take it away from you. So spend it while you've got it. Have a good time."26 Slightly different was the advice Alfred gave his son:

"In the matter of investments a young man like you should be guided, in my opinion, by the dividend return principally. Of course, the asset or book value of a stock is always to be taken into consideration, but I would not get into the habit of 'playing' the market which is only another term for gambling. No one ever made a dollar on the New York stock exchange that did not take that dollar from someone else."

By his own definition, however, Alfred, senior, was gambling, thus relaxing one of the strictest rules of his life. Ed Ball wondered what led his employer to do this, and at length came to the conclusion that he did it to teach Ball a lesson. Ed had always speculated a little in the market, though with mixed results until the advent of Coolidge Prosperity. Then he began to make money steadily. This, of course, was not difficult. The market moved consistently upward, making almost every tip good. Stenographers and elevator boys were having proportionately as great success as Ball. It was an amateur's paradise, which in market matters is another name for a fool's paradise.

Mr. duPont had opened, with Logan \& Bryan, of New York, the only margin account of his career. It was not a large account, the first purchase being Iooo shares. They were good shares: General Motors, Westinghouse, Texas Gulf Sulphur and the like. When a sudden rise yielded a profit of a few thousand dollars, he sold part of his holdings, and put in buying orders at a few points below the market to bring his account back up to Iooo shares. Thus the account ran along, Alfred buying on the dips and selling on the bulges. Though never more than Iooo shares were carried at a time, the profits began to accumulate. Alfred set them aside in a special account, using only what was necessary to restore his margin holdings to the Iooo-share maximum on the next recession. 
The profits saved continued to mount- $\$ 20,000, \$ 30,000, \$ 50,000$.

Whatever Mr. duPont's intentions, one result was to tone down Ball's style of speculating. Never before had Ed seen a speculator fail to throw the bulk of his profits back into the market which was making money for him. Ball had been operating that way. He changed and followed duPont's form of play.

In 1927 the Federal Reserve Board had inaugurated an easymoney policy, partly to stimulate business which, despite the market rise, was experiencing a slight recession, and partly to assist Europe which was losing gold to the United States. The low rates fanned the flames of speculation and the market continued to soar. In 1928 the Federal Reserve, taking account of the unhealthy nature of the situation, began to raise discount rates. From $3^{1 / 2}$ to 4 and $4 \frac{1}{2}$ per cent they went, and by the end of the year to 5 per cent at all but four Western branches. Speculation continued unabated. Pressure was brought on member banks against the increase of loans to brokers. Brokers obtained money elsewhere, at ever mount. ing rates, and the saturnalia went on.

In I928, Alfred's wealth passed $\$ 100,000,000$ on the face of current market prices. He began to toy with a suggestion of Ball's to increase the capitalization of Almours Securities by issuing preferred stock in the amount of $\$ 50,000,000$. Cassatt \& Company, of Philadelphia, offered to handle the issue at $961 / 2$, which was the price those brokers were paying for an issue of Pennsylvania Railroad securities. Mr. duPont would take no less than par and the matter subsided. In the spring of 1929 Cassatt \& Company offered par.

"No," Mr. duPont told Ball, "there is going to be no Almours preferred. I'll tell you, Ed, all hell is going to break loose. We don't know when, but it's coming. We'll have enough trouble looking after what we've got without having $\$ 50,000$,000 of other people's money."

Alfred was arranging his affairs for a lengthy sojourn abroad for ear treatment in Carlsbad. Also he expected to continue a study, begun the year before, of the operation of social legislation on the Continent, with particular reference to old-age pensions. He closed his margin account, the profits of which were more than $\$ 200,000-$ 
a remarkable sum for so small an account. It was, of course, mere pin money beside Alfred's other possessions-Almours Securities owned 582,000 shares of DuPont common, the largest single holding excepting possibly Pierre S. duPont's. The stock was selling above 200, giving Alfred's block a market value of around \$120,o00,000.

"But it isn't worth that, Ed. Everything is too high. Let's sell a little and keep the cash on hand."2s

Mr. duPont liked to have cash about. He seldom carried less than $\$ 500$ in his pocket and often several times that. On the streets of Jacksonville or of Wilmington, a stranger would not have taken him for a man with that much money on him. He usually wore knickers, though not the baggy "plus fours" which constituted a popular country-club garb of the Twenties. Mr. duPont's knickers, fitting more closely about the knees, were in the style worn by dressy cyclists and golfers in 1905. He often lunched on a stool at a drugstore soda counter.

One of the reasons Mr. duPont carried large sums of money was to meet the on-the-spot demands of charity. Not even Jessie Ball duPont knew how much her husband gave away, though during the Twenties his private pension list alone cost about $\$ 150,000$ a year. Mr. duPont's files, which do not tell half of the story, show the periodical support of more than one person from childhood to middle age. The plight of a husband or wife with a neglectful, cruel, improvident or unfaithful spouse, touched him deepest of all.

"Never be afraid of a bully," he wrote a woman-befriended since childhood-whose husband had threatened to beat her.

Alfred was often imposed upon; and he knew it.

"He'll only get drunk on that, said Doctor Hanby after Mr. duPont had given a ragged Wilmington Negro a five-dollar bill.

"Suppose he does," replied Alfred. "The poor coon doesn't get much fun out of life."

Seeing a nun soliciting funds on Market Street, Wilmington, Mr. duPont said to Doctor Hanby: 
"Here, take her this."

The gift was a hundred dollars. ${ }^{29}$

Twenty years after he had left the Brandywine yards, Alfred remained the largest benefactor of St. Joseph's Catholic Church. A pipe organ and a new roof were among his donations.

Mr. and Mrs. duPont were walking along Forty-Seventh Street, in New York, near Madison Avenue, when they saw a comely young woman, dressed in shabby mourning, pushing a baby-carriage.

Alfred thrust $\$ 500$ beneath the infant's covers.

"That's for the squab," he said and walked away before the young woman knew what had happened.

In Beauvais, France, he spied a girl, eleven or twelve years old. Her dress was in tatters, her legs like pipestems, her face white and pinched.

"Come here, my child," said Alfred.

The girl approached as if frightened. Alfred handed her a rooofranc bank note. The child looked at the note, grasped her benefactor's hand and kissed it. Then the little thing fled like a frightened rabbit. ${ }^{30}$

When Mr. duPont transferred his legal residence to Florida, he had promised not to forget the poor of Delaware. In the spirit of this pledge, he sponsored an old-age pension bill which was introduced in the State Legislature early in 1929.

This was moving with the vanguard of American public opinion. In the field of social legislation the United States lagged far behind Europe. In Germany this had been the work of no liberal, but of Bismarck who in the early Eighties instituted the first truly comprehensive scheme of social protection, of which old-age pensions were a part.

American conservatives were less farseeing than the Iron Chancellor. Conditions were different here. Many aspects of a pioneer society, with its reliance on the virtue of individualism, remained. Employers who, like the DuPonts, treated their labor decently opposed government "interference" and "dictation." In 1904 Alfred I. duPont, while perfecting in the name of his company one of the enlightened labor policies of the day, had protested against the en- 
actment of a Federal eight-hour law. Many of the early efforts for social legislation were cried down as the doing of "foreign agitators." It would be interesting to know Alfred duPont's attitude at the time toward the first old-age pension bill offered in Congress-in 1907 by Representative William B. Wilson, of Pennsylvania. Born in Scotland, Wilson had begun life as a coal miner and was an international officer of the United Mine Workers when elected to Congress. His bill got nowhere. The second oldage pension bill was futilely placed before Congress by the Socialist, Victor L. Berger, a Milwaukee editor, born in Austria-Hungary and educated in a university there. This bill died in infancy.

But the ideas of Wilson and of Berger were on the march. Under the stimulus of the liberal tide, Arizona adopted an old-age pension act in I9I4, which the State courts speedily declared unconstitutional. The war brought a check to social legislation, but in 1923 Pennsylvania, Nevada and Montana passed old-age pension bills. The Pennsylvania and the Nevada laws were thrown out by the courts.

In 1929 nearly 40 per cent of all persons over sixty-five were dependent on others for support. In a conversation with W. T. Edwards, Mr. duPont declared that simple, human justice decreed that society preserve the independence and self-respect of these old people.

"Most of them have done their work in the world just as faithfully and just as well as you and I have done ours. That they have not saved enough money to see them through their declining years is nothing against them. We all owe these old people a debt, and we should meet it." 31

In 1929 only Montana paid old-age pensions, and there the law administered at the option of the counties, was not operative throughout the State. Mr. duPont hoped that Delaware would have the honor of adopting the first State-wide law. Though bills also were before the legislatures of California and Wyoming, the speed with which the old-age measure went through the Delaware lower house by a vote of 21 to 9 , gave promise that Delaware would show the way. The Delaware House bill was not a party measure, Republicans and Democrats alike supporting it. Governor C. Doug- 


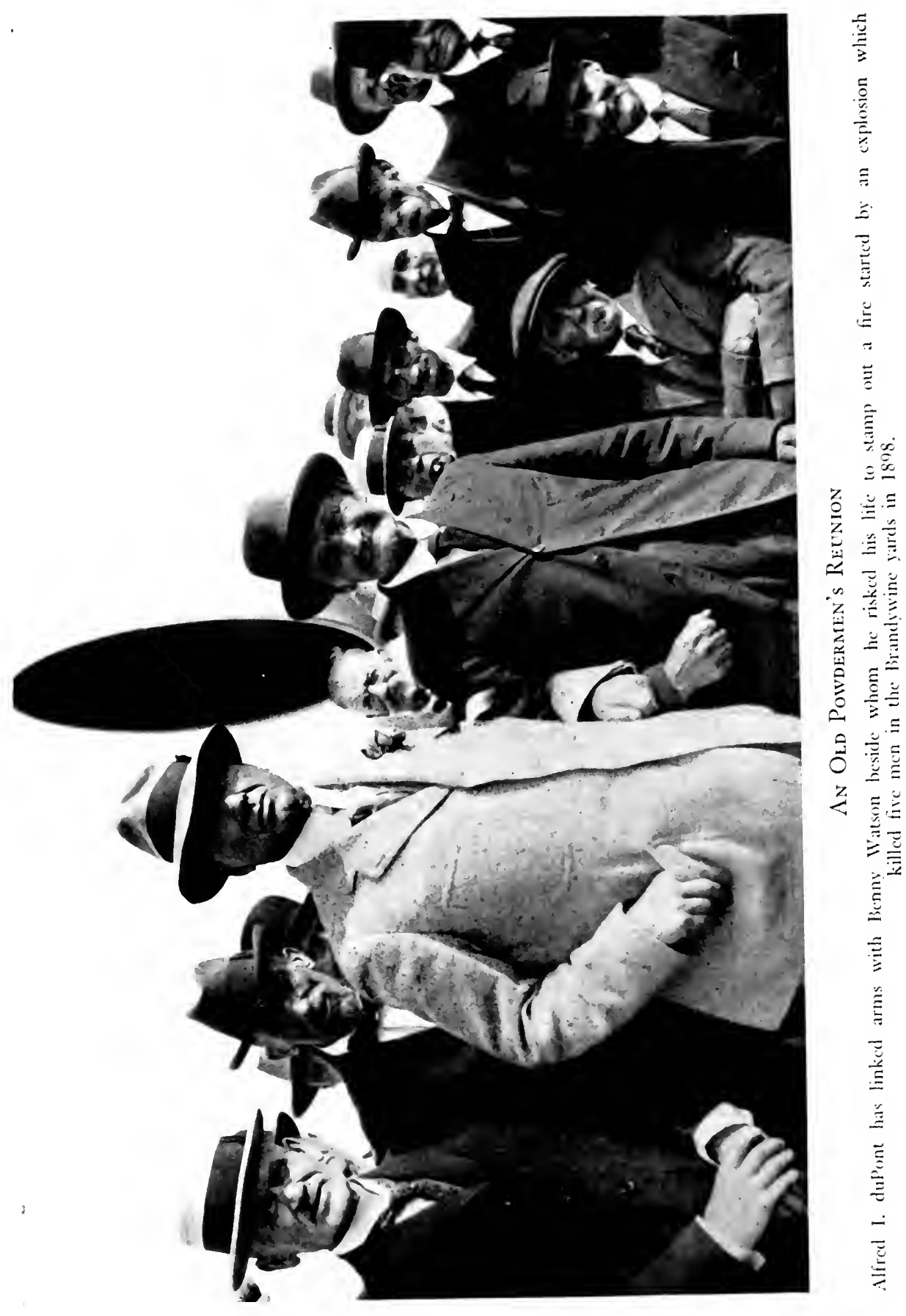


lass Buck, a son-in-law of Coleman duPont, offered no opposition. Then the unexpected happened. In the State Senate the bill was called up when several of its supporters were absent from Dover, and, on a surprise roll call, was defeated, i i to 6 . Alfred was certain that the order had come from Tenth and Market Streets, Wilmington.

The Delaware Legislature would not meet again for two years. Enactment of the old-age bills by California and Wyoming were certain. His ire aroused, Alfred decided that the old folk of Delaware should have their pensions, too. Before sailing for Europe he engaged Mrs. Laura G. Walls, a school-teacher of Lincoln City, Delaware, to open an office, create a staff, canvass the State, and prepare a list of old people who would have been eligible under the terms of the defeated measure. Mr. duPont said that he would pay the pensions until the Legislature acted. Under the terms of the bill, needy persons sixty-five or older could receive pensions in the maximum amount of $\$ 25$ a month, according to the degree of their dependency.

The arrangement with Mrs. Walls was secret. She waited until Mr. duPont was abroad, in June, to announce that "a wealthy Delawarean" had provided funds for carrying out the pension plan. This brought forth many guesses as to the identity of the anonymous benefactor, until Mrs. Walls received permission to mention Mr. duPont's name. ${ }^{32}$

Mrs. Walls spent a busy summer. Gradually an organization was set up and a system devised for investigating individually each of the claims which had flooded in at the first word of her announcement that the pensions would be paid. When Mr. duPont returned in October, about 800 cases had been approved, with fully as many more waiting investigation. Mr. duPont said that he would send checks to those approved to date, increasing his disbursements as the progress of investigations added to the list. The first 800 checks were mailed on November I, 1929. The amounts varied from $\$ 5$ to $\$ 25$, the average being about $\$ 16$.

Among the newspaper tributes was an editorial in the Wilming- 
ton Sunday Star, generally accepted as an organ of the DuPont Company. ${ }^{33}$

Governor Buck also took cognizance of the popular approval of Alfred's work. Early in 1930 he gave it a quasi-official status by appointing an Old Age Welfare Commission, with Alfred as chairman. The only authority with which Buck could invest the Commission was to make recommendations for a permanent policy on old-age relief. The action in effect put Buck behind Alfred's campaign for the adoption of a pension bill by the I93 I Legislature. This was important support. Coleman duPont's health had broken. In 1928 he had resigned from the United States Senate, turning over the remnants of his State machine to his son-in-law, Buck. Thus Alfred, a voting resident of Florida, found himself in the thick of Delaware politics again and occupying a most enviable position. "The political situation is developing along interesting lines," he wrote his cousin Ellen LaMotte, "and I have the 'gang' running around in circles trying to find out what I am going to do. My Old Age Pension activities have given me a very firm footing in the state and they fear me now more than ever. Everybody is afraid to come out for the position of senator who has not my endorsement, for fear I will jump him. They tried to get your Cousin Pierre to run. He gave one gasp and said, nit, nit, nit, securely buttoned his coat to protect his wallet and retired. If they put up Irénée, as was suggested, we shall immediately yell 'Rum.'

The last expression was an allusion to Irénée's outspoken attitude against prohibition. Alfred, too, had been eloquent on the evils of prohibition. Apparently he was able to convince himself that the presence of Irénée in the Senate would be the greater curse.

The result of these crosscurrents was a confusing campaign. For Senator the Republicans nominated a political dry, Daniel O. Hastings, the old henchman of Coleman duPont whom Alfred had fought tooth and nail for years. The Democrats put up the incumbent, Thomas F. Bayard, a wet. Pierre bolted to Bayard, and, after a severe internal struggle, Alfred came out for Hastings. In so doing he threw in a good word for Governor Buck who had two more years to serve. Praise of Buck cost Alfred no qualms. Coleman's son-in-law was a good executive, wholeheartedly behind oldage pensions. 
It was unnecessary for Alfred to take part in the campaign. His pensions worked for him and for the men he had endorsed. Mrs. Walls's list had grown to I 400 by election time, and Alfred sent out his personal checks on the first of each month. In I930 New York and Massachusetts joined the roll of states paying old-age benefits. The courts, catching up with the times, had ceased to interfere.

At his farm on the Eastern Shore of Maryland, Coleman duPont was dying by inches of cancer of the throat. But his mind was clear and he followed wistfully the Delaware campaign in which his son-in-law and Alfred were supporting Hastings-with Pierre this time on the other side. And Alfred, himself, had a kindly thought for the man on his deathbed. Believing a perusal of some genealogical tidbits just received concerning the DuPont family in France would help to pass the painful hours for Coleman, Alfred sent him a copy. The sick man responded in a note showing a trace of his old-time easy humor. On October 28 Coleman wrote again, to thank Alfred for his support of Hastings and for his evident liking for young Buck, whom Coleman forthwith recommended for re-election-in 1932. The note was concluded: "Your affectionate cousin."35

On November 4 Hastings was elected by 8000 votes. "Yes," Alfred jested to his sister, "we wiped up the floor with Bayard and your friend P.S." 36

On November in Coleman died.

"Yes, poor T. C. has cashed in at last," Alfred wrote Maurice Lee. "How long and how hard did he work for his end!"37

To his wife Alfred spoke of his schoolmate as one of the giants of the DuPont family.

"He possessed an original mind. But for his shortcomings in other directions, Coly could have been one of the great men of his time. The trouble was that you just could not trust him."38

In Alfred's estimation the other giants of the family were Pierre Samuel duPont de Nemours, Boss Henry and Lammot duPont, the elder. Ranking below these figures which stood out like mountain 
peaks on a plain, were two other DuPonts, utterly unknown to the general public, whom Alfred would accord honors for their purely technical contributions to the explosive industry: Francis Gurney (the Cousin Frank under whom Alfred had broken in at Hagley and with whose conservatism in management he had frequently clashed) and F. G.'s son, Francis I., whom Pierre had expelled from the company for his support of Alfred in the stock suit.

To this roll of the ablest of a very able line the present writer would add to the mountain-peak class the names of Alfred I. and of Pierre S. duPont.

Henry, Lammot and Coleman earned their laurels by their services to the company solely. Henry and Lammot duPont did not try to distinguish themselves otherwise, and Coleman failed to do so. Pierre's outside contributions, though commendable and noteworthy, were local in scope. Pierre Samuel duPont de Nemours failed to distinguish himself in connection with the company, with which, in point of fact, he had very little to do. DuPont de Nemours' career as a statesman, economist and social philosopher was made in Europe before setting foot on these shores on January I, I8oo. Approaching the stature of this illustrious forbear in humanitarianism, in variety of interests and talents, and in sparkling quality of mind, is only Alfred. Though his work for the company is worthy of mention with that of the other great captains of that institution, Alfred hoped to be remembered longer for what he did in other fields. 


\section{CHAPTER XXV}

\section{Building a Chain of Banks}

THough Alfred I. duPont had acquired potential control of the Florida National Bank, of Jacksonville, late in 1927, he did not exercise it until the spring of 1929. No reason for earlier action having arisen, Mr. duPont wished to avoid as long as possible the personal publicity and the flood of importunities such an announcement would provoke. Consequently the extent of his interest in the Florida National was unknown even to the majority of the hard-pressed Florida banking fraternity. There were stories, of course, which the average man in the street simply pooh-poohed. Rosy assurances that this or that Florida enterprise was safe because some gilt-edged name from Dun \& Bradstreet was behind it had proved baseless so often that reflective folk accepted all such tales with prudent reserve.

But in April, 1929, while Mr. duPont's pension bill was meeting defeat in the Delaware Legislature, the banking situation in Jacksonville took a turn which obliged him to act. So promptly and so vigorously did he move that within eighteen months Alfred I. duPont stood forth as a dominant figure in Florida's skittery realm of finance, his name and his money bulwarks of the remnants of a crumbling banking structure.

Since 1926 each season of the year had been an anxious season for Florida bankers, though the springs were the worst. Winter tourists departed, withdrawing their balances and shutting off Florida's principal source of revenue. To fend through the long, lean summers, banks had to take from their depleted reserves in Jacksonville and in the North and the East, or to borrow if they could. The standing of a bank in the spring, when the tourists had cleared out, usually told the tale of its prospects for weathering the 
summer. By April, 1929, eighty-odd, or more than one in four, of Florida's three hundred banks had closed since the bursting of the real-estate bubble. Millions of dollars in depositors' money had been lost or frozen-but mostly lost-in addition to what had gone down the drain with bankrupt land dreams.

With every sensible person who had a few dollars on deposit peering about for signs of banking weakness, the Jacksonville newspapers on April i8 carried an item to the effect that the Boards of the Florida National and of the Barnett National Banks had voted to merge those institutions. The amalgamated bank would continue to use the quarters then occupied by the two banks, which were located on Forsyth Street, with only Laura Street separating the buildings.

Regardless of the sanguine public explanations attending such affairs, when two banks consolidate something often is wrong with one of them. A suspicion of banking uncertainty in JacksonvilleFlorida's financial Rock of Gibraltar-sent a flurry through the. harassed State.

The experience of C. D. Dyal may be taken as a sample of what a hardheaded man, moved neither by unwarranted fear nor unwarranted optimism, may do in such circumstances. Dyal was a Georgian in his middle forties: six feet tall, lean of face and figure, taciturn, and so dark that many thought him part Indian. He was president of the Daytona Bank \& Trust Company of the resort town of Daytona Beach, and had brought his bank through in good shape so far. For this Dyal gave credit to an experience as a young man in a real-estate boom in New Jersey: that had cured him. In ' 24 they were saying that Dyal lacked vision, faith in Florida; in '29 that he was a smart country banker.

When Dyal read of the intended merger he took a train for Jacksonville. Browsing about the city, sniffing the financial atmosphere and comparing notes with other out-of-town bankers in Jacksonville on similar smelling-out missions, Dyal construed the proposed consolidation as a sign of weakness, the feebler bank being the Florida National. Already he heard of silent withdrawals from all three Jacksonville banks, but particularly from 
the Florida National and the Barnett: no "counter runs," merely withdrawals by checks put through for clearance in the regular way. Dyal's reserve was in the Barnett. To be on the safe side, he transferred it to Ed Lane's Atlantic National. Then he went home with the intention of moving his reserve to Atlanta, Georgia, should the merger go through.

Dyal's Daytona Beach bank had survived runs before because it had been ready for them. Fearing a merger in Jacksonville might set off another run in Daytona, he meant to be ready. Moreover, he forsaw the possibility of runs in Jacksonville itself, in St. Petersburg, Miami and Tampa-particularly Tampa where, according to the bankers' grapevine, the large Citizens Bank was facing the summer in a bad way. Runs in these places would send scores of country banks scrambling for their reserves. Dyal meant to have his where he could be sure of getting it.

These speculations were based on the assumption that the merger would be completed. In Jacksonville Dyal had heard some talk of the possibility of its being called off. He had heard Mr. duPont's name mentioned in connection with the Florida National's resources. Mr. Dyal did not know Mr. duPont, and he had been in Florida too long to take stock in all he heard. In a nutshell, Dyal took the consolidation talk as an evidence of weakness and played safe. ${ }^{1}$

The Florida National Bank having no space to rent, Mr. duPont retained offices for himself and his expanding organization on the fifteenth floor of the handsome Barnett National Bank Building, on the other side of Laura Street. From his window he could look out on the roof of the two-story home of the Florida National, as he pondered the problem of the proposed merger. One certain result of the consolidation would be to deprive Mr. duPont of his grip on a large Florida bank. The Barnett family, with its preponderance of Barnett stock, would own enough shares in the merged institution to retain control. In addition there was the possibility of unsettling the Jacksonville banking situations-as feared by C. D. Dyal.

Taking the matter all in all, Mr. duPont decided to block the 
merger. He sent Ed Ball across the street to call on Arthur F. Perry, president of the Florida National. Mr. Ball found Mr. Perry putting the finishing touches to a letter summoning the Florida stockholders to a meeting to vote on the projected consolidation. The caller drew from his pocket and passed to Mr. Perry a letter which Ball said he, himself, proposed to send to the stockholders in his capacity as a director of the bank.

"Surely Mr. duPont would not want such a letter to go to the stockholders," protested Perry.

Ball assured the banker that Mr. duPont approved of the letter, which took the ground that the proposed merger would operate to the disadvantage of Florida National stockholders and to the advantage of Barnett National stockholders. ${ }^{2}$

After some discussion it was decided that neither letter should be sent. A few days later the merger was formally called off. The reason given the public was that the Florida law prohibiting branch banking would not permit one bank to do business in two buildings, if separated only by the width of a street. ${ }^{3}$

As the true story of the blocking of the Florida National-Barnett merger began to trickle through banking circles, it was received with mixed emotions. The promoters of the consolidation were naturally disappointed. It should be said that they had been actuated by worthy motives, believing the merger would improve Jacksonville's financial position. Contrary opinion, however, was widespread, many downstate bankers feeling as Dyal had felt. They hailed Mr. duPont's action as salutary.

"I think it one of the greatest, if not the greatest single thing Alfred I. duPont ever did for Florida," said Mr. Dyal in later years. "It restored confidence when confidence, above everything, was needed. It marked the dawning of a new day in Florida."4

His hand thus forced, Mr. duPont decided to act without further postponement on a plan he had been long maturing to accept the responsibilities of a more positive role on the stage of Florida banking. For months he had been surveying the field in the search of strategic locations where sound banks might be opened to advantage. A European trip already delayed by the merger problem, he did not delay longer, but sailed leaving Ball with confidential 
instructions to open the first two of the eventual chain of banks he had in prospect. These were to be at Lakeland and at Bartow.

In Europe Mr. duPont appeared to enjoy himself, despite animadversions of his which might be cited on the subject of foreign travel. He took the cure at the Carlsbad spa. He studied the operation of legislation and inspected almshouses and low-cost residential projects in Czecho-Slovakia and Germany. He visited his daughter Madeleine and her three boys in Munich. Alfred Victor and Marcella spent two weeks with their father and Jessie in Carlsbad. He brought together the sister and brother for their first meeting since Alfred Victor was ten years old, and bought each a Buick automobile. He visited the museums and the galleries. His interest probably enhanced by young Alfred's studies, he made notes on architecture in Italy, France and Germany. He looked about for ideas for the elaboration of the formal gardens, a third of a mile long, which he was laying out at Nemours.

When Mr. duPont had said that hell was going to break loose sooner or later, he had in mind the collapse of the stockmarket boom. In preparation for eventualities, he had given Ed Ball a general power of attorney over the holdings of Almours Securities, worth, according to quotations prevailing, about $\$ 150,000,000$.

The first business communication of any moment which Alfred received from his brother-in-law did not concern the stock market, however. It was a cable announcing the failure, on July 12, 1929, of the Citizens Bank in Tampa, which had drawn down with it fifteen other banks in the Tampa area. Slow window-runs had started on the three banks in Jacksonville. Within a few days they slackened, except in the case of the Florida National. Ball asked permission to put $\$ 15,000,000$ of Mr. duPont's money behind the Florida National and to announce that fact to the public.

After sending this cable, Ball telephoned New York and Philadelphia and arranged to borrow, on the account of Almours Securities, $\$ 15,000,000$, with DuPont common as collateral. Re- 
ceiving no authorization from Mr. duPont in the matter, Ball cabled again on July 23:

ADVISED BY TELEPHONE THREE BANKS SAINT AUGUSTINE PROBABLY CLOSE TOMORROW FLORIDA NATIONAL DEPOSITS SHRUNK THREE MILLION TEN DAYS FEEL PROPOSED LOAN SAFE AND CONSERVATIVE PREVENTS POSSIBILITY OF BANK FAILURE AND INSURES CONFIDENCE OF COMMUNITY STOP IF BANK FAILS IN DEPOSITS AND INVESTMENT WE STAND TO LOSE THIRTEEN HUNDRED THOUSAND DOLLARS PLEASE CABLE APPROVAL OR DISAPPROVAL PROPOSED LOAN.

Mr. duPont replied:

YOURE ON GROUND USE OWN JÜDGMENT BUT PULL OUR BANK THROUGH. 5

When this cable was received, on July 24 , the situation for no visible reason had changed for the better. The slow run had nearly stopped, and deposits were exceeding withdrawals. Moreover, the St. Augustine banks did not close on July 24, as Ball had predicted. True, they were in a bad way, one of them closing on July 29 and the others before a year was out; but this had no effect on the immediate situation in Jacksonville. Yet it turned out that Ball had taken the right course. After two quiet days, on July 25 the run on the Florida National was resumed.

Circulating among the crowd, Ed Ball did not like what he saw and heard. It was a frightened crowd. Pushing his way into the office of the bank's president, Arthur F. Perry, Ball found Mr. Perry ill. A bank combating a run is no place for a sick banker; the ordeal can be hard enough on one who is well. Ball persuaded Mr. Perry to go to the country and take care of his health. Then Ball went to the safety box of Almours Securities and counted out $\$ 20,000,000$ in DuPont common stock certificates. They were wrapped in bundles and shipped North by express, to be in immediate readiness to borrow up to $\$ 15,000,000$ as had been arranged. This done, Ball shoved through the crowd again, and, crossing the street to his office, dictated a statement to his stenographer: 
"In an interview this forenoon on the banking situation, Mr. Edward Ball, Vice-president of Almours Securities, Inc., said:" Jacksonville is indeed fortunate and to be congratulated in having such strong financial institutions, that the public generally feels no more concern about their deposits than if they were deposited in the Federal Reserve Bank which, as everyone knows, has the entire backing of the United States Government. When the news of several bank failures in the Tampa section came over the wire, some of the banking fraternity thought that it might cause some uneasiness in Jacksonville and everyone made arrangements to secure any funds that might be needed.

" 'Right on this point, I do not mind saying that Almours Securities, Inc., the largest stockholder in the Florida National Bank, made arrangements so that they could transfer $\$ 15,000,000.00$ into the Florida National Bank if they felt it desirable to do so.

"Immediately after making arrangements for the $\$ 15,000$,000.oo, I cabled Mr. Alfred I. duPont, President of Almours Securities, Inc., advising him in detail and asking for his approval or disapproval of arrangements made.

"'Yesterday, we received a cable from Mr. duPont approving all arrangements made." ",6

Ball himself carried this to the office of the Journal, Jacksonville's only evening newspaper, and gave it to Editor Gold V. Sanders. Sanders said he would be glad to run it. But when the next edition of the Journal came out, the statement was not there. Ball telephoned for an explanation. The editor said that after consulting other Jacksonville bankers, he had come to the conclusion that publication of the statement would be inadvisable.

"How about running it as an ad?" asked Ball.

Sanders said that he did not like to run an ad that he had declined to put in his news columns. That, however, would be a decision for the business office.

Banking hours were over, and Ball crossed the street to see how matters stood. First Vice-President George J. Avent, in charge since the departure of Perry, was a big, strapping man who had worked his way up in the bank from messenger boy. Avent had nerves of iron. He seemed as fresh as when Ball had seen him at the start of the day. But the tellers were weary, and some of them 
showed it. Ball asked Avent to call together the entire staff of the bank, high and low. Ball read the statement which had been intended for publication. He asked the bank people to go out and spread the word that Alfred I. duPont had put $\$ 15,000,000$ behind the Florida National.

In a frightened community good news can travel fast, though not as fast as bad news. Consequently next morning saw a crowd on hand, waiting for the Florida National to open. Some of those present had heard the $\$ 15,000,000$ story-but they wanted to be on the safe side. The doors opened and the crowd filed before the windows. The men behind the cages showed a different spirit from the day before. "Yes, Mr. Jones, here is your money. You know, I suppose, that Mr. duPont has placed $\$ 15,000,000$ at our disposal."

By noon the run was over.

Already Ball was getting on with plans to open a bank at Lakeland, whose 18,000 population gave it second place among Florida's inland towns. Situated thirty-five miles east of Tampa, Lakeland was in the center of the rich belt where one third of Florida's citrus crop was grown.

Serving the financial needs of this community in the boom times had been four banks, three of which had failed for an aggregate of $\$ 3,750,000$. The toils of the law were closing about the president of the largest of these defunct institutions, the First National. Presently he was to go to prison for embezzlement. A typically deluded victim of the boom, this banker had not been able to resist the temptation to use other people's money in an effort to keep afloat. There is a local story that, as a last desperate resort for money, he financed a ring of bootleggers. Veteran Florida bankers who managed to weather the crises of 1926-32 hear such tales without a sign of mirth. They know, too well, the tragic extremities to which a man can be pushed in an effort to save his bank. In the summer of 1929 the sole bank holding the fort in Lakeland was backed by a wealthy Canadian, William MacDonald. 
On Mr. duPont's instructions Ball bought for $\$ 64,000$ the premises of the defunct First National. The building was worth perhaps $\$ 35,000$, but the Government had decreed that a national charter for a new bank should go to the highest bidder for the old bank building. Thus the United States was, in effect, auctioning charters. Mr. duPont's bid topped Edward Lane's by three or four thousand dollars. A new institution, called the Florida National Bank of Lakeland, was capitalized at \$150,000. Willard Hamilton was imported from the Delaware Trust Company, in Wilmington, to be president. Ball represented Mr. duPont on the Board of Directors.

The bank opened for business on September 4, 1929. For weeks the local press had been reminding its readers that the magical DuPont Millions were veritably on the scene in Lakeland. Governor Doyle E. Carlton, of Florida, had hailed the event in advance as evidence that the State had "turned the corner." The bankclosing period was over, the future roseate. Alfred I. duPont had brought a return of "the spirit of confidence and cooperation." This was laying it on a little thick. Too many Lakeland people, skeptical of such optimistic predictions, might, after all, continue to prefer to keep their money under mattresses. Consequently the premier of the new bank was awaited with considerable interest by those involved. Ball went down from Jacksonville to witness the event. Things started off auspiciously enough, with a crowd in front of the building before the doors were unlocked, and long lines in front of the tellers' windows as soon as they were openedalmost like the late Jacksonville run seen in reverse. Most of the deposits were in cash and the amount taken in during the first hour exceeded expectations.

"But there's one man we won't get-at least not right away," said Hamilton. "He's an old fruit-grower, and pretty successful, but he tells me he's through with banks."

Apparently the old fellow had merely come to see the show. He made no move toward the queues of depositors. Engaging him in conversation, at length Ball asked if he didn't intend to open an account.

"No," said the old orchardist. "I've lost money in five banks." 
Ball observed that Mr. Alfred I. duPont was behind this one.

“Don't care who you say's behind it. I wouldn't put my money in another bank if God Almighty was the president and Jesus Christ the cashier."

Later in the day the cynical fruit-grower returned and took his place in one of the lines. He deposited $\$ 2500$ and rented a safety box.

The end of the day's business showed deposits of $\$ 436,335 \cdot 33$. On the next day the lines were long as ever. The fruit-grower visited his safety box and made another deposit. A few days later he did the same. The next time he came, however, he withdrew his entire balance and put the currency in the box. The old fellow had heard something. But the effect wore off before long and he restored a sizable balance to his checking account.

The majority of Lakeland's citizenry showed greater confidence. At the end of thirty days deposits were $\$ 1,542,000$ and still going up. 8

\section{4}

Returning from Europe on October 15, 1929, Mr. duPont plunged into a pile of work at Nemours. With Ball he reviewed the condition of the two Florida banks and the plan for further acquisitions which was to be pushed vigorously. There was a roadbuilding campaign to open up northwestern Florida where Alfred had bought more land. The busy man meant to go South as soon as possible, but meanwhile Delaware had its claims. With Mrs. Walls he went over the old-age pension survey and arranged to send out the first batch of checks on November I. This enterprise was found "much more involved than I thought it would be," owing to the looming political campaign. Even Nemours required time, for, characteristically, Alfred's sunken-garden project had expanded into a man-sized undertaking.

And over everything hung the ominous cloud of the stockmarket situation. In September the boom-swollen list had broken rather badly, recovered and broken again. From the second break it had not recovered. The month ended with losses. Highly 
priced speculative favorites had naturally declined most, Auburn Automobile closing at 40r, off $\$ 97$ a share; Adams Express at 550, off 44 ; General Electric at 356, off 40. But the lower-priced issues of rock-ribbed corporations also suffered, United States Steel finishing the month at 257, off 36; DuPont, I88, off 27; General Motors, 66, off 6.

As in Florida in 1925, a word of caution was treason. The body of articulate opinion insisted the setback was only a transitory ripple. Had there not been other recessions? Better get in and buy at these bargain prices. Hundreds, yes, thousands, who had sold out at immense profits, did so. What, indeed, was one to do when such an authority as President Charles E. Mitchell of the National City Bank, the largest in the world, returning from abroad on the same day that Mr. duPont returned, told the reporters: "I know of nothing fundamentally wrong with the stock market, or with the underlying business or credit structure!"10

But prices were drifting lower on heavy European selling and, as has transpired, heavy selling by professional market-riggers on this side of the water. Short selling developed: the bears were coming out of their hollow trees. Four days after Mr. duPont's return, the market had a very bad day. It was Saturday, October I9, and a short session. Yet speculative issues lost up to 40 points. DuPont common lost 5 , touching 178 , which was 53 points under its September high of 23r. General Motors lost 2 points to 60, or 18 points under its September top. Wednesday, October 23, saw a more serious break, and Thursday brought the deluge. The bottom dropped from under the whole list and panic took the floor of the New York Stock Exchange for the first time since 1907. Fortunes built up during the five-year boom vanished in an instant as hundreds of thousands of shares were thrown on the market for anything they would bring. On October 29 these scenes were repeated. Steel sold for 166 , down 95 from its high of the year; General Electric, 210, down 190; General Motors, 33, down 45; Adams Express, a speculators' favorite, 250, down 500; Auburn Automobile, 120, down 394.

At the close of the disastrous day Alfred wrote to his son in Paris: 
"DuPont was selling at 80, and the rag man was looking for our certificates. Candidly, I think DuPont is not worth much more than par. I never did.... What will be the outcome the Lord only knows, and, due to His usual reticence, it will be impossible for me to get inside information. Of course, the pyramid house of cards could not last forever, for when one is paying Io or I2 percent interest on money he borrows to purchase securities which return only $3 \%$ or less, it is only a matter of time when the collapse must come. ... On top of the natural collapse, arriving by reason of the highly stimulated market due purely to speculation, the Bears are taking advantage of the situation to drive prices down just as far as they can, so as to cover their commitments at the lowest possible price. ... A good many people are richer in experience; also brand new Diesel yachts in New York can be had for a song."

When Alfred said that he had "never" believed DuPont worth more than par, he referred to the stock after the three-and-one-halffor-one split-up in January, I929. The remark is no contradiction of his assertion in 1922 that the stock would go, on merit, to 150 or even 200. Two separate split-ups had made one I922 share the equivalent of seven current shares.

Before turning to refresh his mind by dictating to his son three technical pages on the subject of the sunken gardens, Mr. duPont, concluded his remarks on the market:

"Altogether things are topsy turvy and it is hard to know just what to do. However, within a week or more, I shall have a better line on the situation and can act with greater comprehension and certainty."11

No such spirit of indecision characterized the words of the financial wizard of the DuPont Company, John J. Raskob, uttered at almost the same hour Alfred duPont was writing. "Prudent investors," said Mr. Raskob, "are now buying stocks in huge quantities and will profit handsomely when this hysteria is over."12

Though his paper fortune had shrunk by half, the crash had not seriously affected Mr. duPont, who fortunately had long since dis- 
counted, in his private calculations, the boom quotations. And thanks to his foresighted instructions before going abroad at the beginning of the summer, he was ready for the debacle. During July, August and September, Ball had steadily sold stock for the account of Almours Securities. Some of the sales, including one of duPont common, had been at or near the all-time highs. The result was that $\mathrm{Mr}$. duPont owed nothing and had on hand $\$ 2,000$,000 in cash. ${ }^{13}$

Already he had found use for some of it. "Personally, I was not involved," he wrote on November 12, "but, as you know, there are always lots of people who are and have to be helped out." ${ }^{14}$ At the first sign of trouble Mr. duPont volunteered protection to everyone in his organization. This proved more expensive than anticipated. During the catastrophic days of October 24 and 29, \$200,000 was required to rescue an official of one of his banks. Several other accounts cost the Samaritan from $\$ 25,000$ to $\$ 100,000$ apiece. And there was a host of smaller fry, which Alfred told Ball were the ones he cared most about. From far and near relatives, friends, friends of friends, acquaintances and strangers sent heartrending appeals. From Hawaii a cable signed "Charley" asked for $\$ 4000$. All the Charleys he could think of were queried and none found to be in Hawaii. Mr. duPont never learned who sent that cable. The October crashes did not end the stream of supplications. As the market sank lower and lower, they continued to come in. ${ }^{15}$

In the midst of these preoccupations, Mr. duPont's third bank, also called the Florida National, was opened at Bartow, a town of 5,000 near Lakeland. Both of Bartow's previous banks had failed within the past six months. The nervous state of the citizenry was attested by the fact that on the opening day, November 18, 1929, they deposited only \$1 I2,509 in a bank owned by Alfred I. duPont. Thirty days later deposits had passed the million mark, however.

Alfred remained at Nemours, frankly anxious over the financial situation and more anxious than he pretended to be over the condition of his wife who was in the Union Memorial Hospital in 
Baltimore. Mrs. duPont failing to recover from a cold, her husband had installed her in the hospital where, as he said, "they will make her take care of herself."

"The doctor tells me," he wrote Ellen LaMotte, "there is nothing to worry about, and it is only a matter of a little rest and quiet before she will be back again, as well as ever. You see, Jessie, like all well ordered women, refuses to do anything her husband advises. I can make her do nothing to keep from wearing herself out." Alfred confessed that Nemours seemed a cheerless and lonely place without Jessie. "If she were an ordinary woman that I was not particularly fond of, of course a little club life would be the most natural solution of my problem!"'16

His clubs afforded no consolation. After a day at the office Alfred would prowl about the grounds of his estate ever expanding the garden project. But his heart was not in it. In the nearly nine years since their marriage, he and Jessie had hardly been separated. When she went to Philadelphia for a few hours' shopping, he would ride with her to the railroad station, and be on the platform to greet her on her return. Such marks of devotion were a matter of common report in Wilmington-especially among wives with too-busy husbands.

Mrs. duPont lingered in the hospital until a few days before Christmas when Alfred took her to Florida, rearranging his business program in the interest of his wife's convalescence.

"I am hoping to keep her quiet here throughout January and then take her on a motoring and yachting trip through February and return to Epping Forest about March first and have our company through March and April. I do hope she learns to take care of herself. She is such a valuable woman, not only to me, but to many, many people. 'Men should train their wives during the first six months of married life, when they are open to reason and influence,' writes Dorothy Dix in some paper. Dorothy is getting funnier all the time."17

On January 20, 1930, Mrs. duPont collapsed and was taken to Baltimore on a stretcher. Physicians had difficulty agreeing on a diagnosis. They operated on the theory that internal ulcers were 
causing the trouble. This proved correct. For a week the patient hovered between life and death. The Ball family assembled in Baltimore. Dazed by grief, Alfred walked from the hospital one evening with his wife's sister, Elsie Wright.

"The one eventuality in life I am not prepared for is that Jessie should go before me."18

The patient rallied and in April she was in Florida on her way to health. The thankful husband called the narrow escape "really the worst blow that I have ever received for many reasons, but principally for the fact that it's the only thing I never anticipated could possibly happen."19

During the week of crisis in Mrs. duPont's illness, Arthur F. Perry, president of the Florida National Bank, submitted his resignation, effective in twenty-four hours, to become an officer of the rival Barnett National. Mr. duPont received the news by telephone. Ed Ball, who was at his sister's bedside, got on the wire to gather particulars. The talk in Jacksonville, as reported to Ball, was that Perry's transfer of allegiance might easily set back duPont's plans to build a strong bank chain. It was feared that $\mathrm{Mr}$. Perry would carry to the Barnett $\$ 5,000,000$, or nearly one fourth, of the Florida National's deposits. Ball was told that the only thing that could prevent this was for Mr. duPont to "throw in his name."20

Ball laid the situation before Alfred, who consented to take the presidency of the bank. The announcement was made in Jacksonville on February 8, I930. Ten days later, when Mrs. duPont was out of danger, Alfred made a flying trip to Jacksonville and gave one of his infrequent newspaper interviews:

"Florida has lacked a conservative banking system.... [Banks] are public trusteeships. Their primary object should be the safe custodianship of the money entrusted to them, not the making of money for their shareholders. If all Florida banks had had this in mind there would have been no failures." 
The new bank president closed with some words of optimism about the eventual prosperity of Florida. But there were no getrich-quick promises. The stock market was not mentioned. Only hard work and the exploitation of the resources of the soil would revive Florida, banks taking the role of handmaidens to agriculture and industry. ${ }^{21}$

Figures for the quarter in which Mr. duPont took the helm of the Florida National show that the bank gained nearly $\$ 140,000$ in deposits, notwithstanding that both the State and national aggregate of bank deposits declined during those months. On December 31, I929, the Florida National reported $\$ 20,098,378.72$ in demand and time deposits; on March 31, 1930, \$20,238,180.19.

Acceptance of the presidency of the Florida National had been no part of duPont's original plan. Circumstances forced him into it. Moreover, they gave his active entry into the banking situation in Florida a dramatic aspect which was not only personally distasteful but bound to create misunderstandings. After the establishment of the Lakeland and the Bartow banks, the story had spread that Mr. duPont was going to "save the situation" in other towns. DuPont Millions to the rescue! Every act of Mr. duPont's and every speculation concerning fancied plans were characteristically exaggerated by published and unpublished report. Considering Florida's desperate plight, this was only human nature, though the result was to raise expectations which could not be fulfilled by Alfred duPont or by anyone. Yet having set his hand to the plow he did not turn back. As inconspicuously as possible in the limelight of existing conditions, he went on to try to give Florida a sample of the conservative and unselfish banking he thought indispensable to ultimate recovery. In one series of operations, he broke the law to bolster the assets of his Jacksonville bank.

In January, I930, Mr. duPont had leased the quarters of the defunct Citizens Bank, of Tampa, which had failed the July before with such disastrous consequences. The result was a rash of publicity about the much-traveled DuPont Millions coming to Tampa. Application was made for a charter for a new national bank in which Mr. duPont was joined by Henry Waters, chair- 
man of the Atlantic Coast Line Railway, and Barron G. Collier, a New York advertising man who had heavy Florida interests. Months passed and the application was not acted upon. Ball went to Washington to see J. W. Pole, the Comptroller of Currency. Pole said that he could not grant the charter in fairness to the two Tampa banks which had survived the July holocaust.

"Those banks are making a good fight," said Pole. "A bank backed by Alfred I. duPont, Henry Waters and Barron Collier would draw off so much in deposits that they might have to suspend. I don't thing it would be right."

DuPont agreed instantly.

"It must be no part of our policy," he told Ball, "to compete with other banks when the general situation will not be helped by it. We must help the other banks who are doing a sound banking business, not hinder them."

He proved this in the town Deland by halting Ed Ball's negotiations for a bank site, after the Barnett National had already opened up in the town.

"There is no room for two banks there," said duPont. "Barnett will give Deland a good bank. As he has beaten us to it, let's let him have the field.",22

The fourth town Mr. duPont went into was Orlando, population 26,000 and largest of Florida's inland cities. It is a resort, more substantial than fashionable, and a citrus forwarding center. Four of Orlando's six banks had failed. Mr. duPont purchased as a going concern the suburban North Orlando State Bank and on March 3, I930, moved it to Orlando under the name of the Florida Bank. When Mr. duPont bought it, the outlying bank had deposits of a half million dollars. At the close of the first day's business under the new name and at the new location, they stood at $\$ 862,338$.

The fifth bank Mr. duPont added to his string was C. D. Dyal's Daytona Beach Bank \& Trust Company. A resort purely, whose magnificence dates from Flagler's activities in the Nineties, Daytona Beach is on the East Coast a hundred miles south of Jackson- 
ville. An early attraction in the eyes of Alfred I. duPont had been the automobile races on the hard sands of the ocean front there. In 1903 Alexander Winton broke the world's record with a speed of 68 miles an hour.

More important to Mr. duPont's present scheme of things, however, was the fact that at one stroke he acquired not only Dyal's bank but the services of Dyal himself. Three months before, Mr. Dyal had had no thought of selling and no thought of working for anyone else. Dyal was an individualist who did things his own way. During the boom he had refused to join the speculative group. At the cost of personal popularity, he had gone his own road and kept his bank liquid and sound. Four Daytona banks had failed, and each failure had brought a run on Dyal's bank. It met those runs, as also did the First National Bank of Daytona. In February, 1930, these were the only banks left in town. Dyal thought the worst of his troubles were over.

They might have been had not one of his directors gone out in a local election to buck the power of the reigning political machine. In retaliation the machine struck at Dyal's bank-the consequence being the fiercest run yet. For two and one-half days, crowds stormed the windows and Dyal paid out $\$ 650,000$ of the $\$ 1,650,000$ deposited with him. For a small-town banker, standing alone, that was a notable feat.

The run was over and the withdrawn funds were coming back when Mr. duPont sounded out Dyal about acquiring control of the bank. Since the vital blocking of the Jacksonville merger, Dyal had been watching with growing enthusiasm Mr. duPont's moves in the realm of Florida banking. "Here is a man," he thought, "I can work for and with"-quite an exceptional thought for the independent Dyal. He sold a controlling interest in his Daytona bank and joined the duPont organization. Rechristened the Florida Bank \& Trust Company of Daytona, the institution opened under the new aegis on May 13, 1930.

Greater responsibilities awaited Dyal when, five months later, he opened Mr. duPont's Florida National Bank at St. Petersburg. Situated on a point of land across Tampa Bay from the city of that name, "St. Pete" was founded by a resident of Detroit and called 
for the birthplace of a Russian exile who built the first railroad there in the Eighties. The largest of several typically Midwestern communities transplanted in Florida, St. Petersburg is an oldster's paradise where they have a saying that life begins at seventy, not forty. Though it rates less newspaper notoriety, its annual tourist business is second only to that of the Miami area.

With the deflation of the boom, the aggregate of bank deposits in St. Petersburg had declined from $\$ 27,410,713$ on December 3I, 1926, to $\$ 15,506,317$ at the end of 1929 . Elsewhere in the boom belt, the story was about the same, the distinction in St. Petersburg's favor being that it had experienced only one bank failure. St. Petersburg's six banks weathered the storm of July, 1929, when the collapse of the Citizens Bank and fifteen others in the Tampa area had convulsed the State, and only Ed Ball's and Alfred duPont's prompt action had ended a run on the Florida National in Jacksonville. Though weathering that storm, the St. Petersburg banks were shaken and a profitable winter season was needed to put them on their feet. Instead of raising the curtain on the profitable season, October, 1929, brought the stock-market panic. When the crucial spring season arrived the St. Petersburg situation was known to be desperate. Loans from the North to tide over the lean summer were the only hope. With the stock market still sinking, business stagnating, factories closing, and unemployment growing, Northerners faced troubles at home. Four of the five St. Petersburg banks failed to obtain loans.

First to go was the American Bank \& Trust Company, deposits $\$ 2,500,000$, which failed to open on April 25. On May 23 the Ninth Street Bank \& Trust, deposits \$1,200,000, and the Fidelity Bank \& Trust, deposits $\$ 250,000$, closed. June I the First National Bank, with deposits of $\$ 4,500,000$, followed. The only bank left, the Central National, survived by virtue of a $\$ 750,000$ loan placed in New York.

In this situation Mr. duPont applied for a national bank charter, which the Comptroller of Currency consented to grant on condition that Mr. duPont purchase the eight-story premises of the late First National Bank for $\$ 425,000$. As St. Petersburg was overbuilt, the First National receiver could hardly have got that price else- 
where. But as the money went for the relief of the First National depositors, Mr. duPont paid it, surmising that he would have to carry the building for years at a loss-a surmise which proved to be correct.

A good story-teller and a friendly soul in his intimate personal circle, C. D. Dyal did not carry those qualities into his professional life as a banker. He had seen them pave the way to trouble for too many Florida bankers. On his arrival in St. Petersburg, he shocked the affable residents who gathered around in true, sociable, Middle Western fashion. No, he said, he didn't belong to any lodges, home-state societies, civic, or booster clubs, and didn't intend to join: he had come to town to run a bank. The impression left could not have been adverse on the whole. On October 27, 1930, the Florida National of St. Petersburg opened, with Dyal as president. The first day's deposits were $\$ 514,241$. Within sixty days they passed the two million mark. ${ }^{23}$

Eighteen months after his intervention had prevented the Florida National-Barnett merger, Alfred I. duPont had established or taken over five other banks. They were separate corporations and distinct administrative entities, as required by the Florida law. On December 31, 1930, the deposits in the six banks aggregated $\$ 27,573,198.64$. This signal mark of confidence was merited. The duPont banks had come into being during times studded by one financial crisis after another. They represented a splendid conception of a banker's obligation to a community and already had performed services difficult to measure. ${ }^{24}$ 


\section{CHAPTER XXVI}

\section{FLoRida's "STrong MaN"}

Aside from his underdeveloped lands in northwestern Florida, Alfred I. duPont had invested about $\$ 1,000,000$ in urban property, though his holdings were popularly believed to be much greater. "DUPONT BARGAINING FOR BUSINESS CORNER" was a headline Florida newspaper readers saw many times when the capitalist had no more than cast a passing glance in the direction of a property. Desperate Florida "realtors" thought such publicity a prop to sagging prices. Apparently because they thought it looked more impressive, newspapers often referred to Alfred's enterprises, actual or fancied, as sponsored by "the DuPonts" or "DuPont interests." This irritated the master of Epping Forest only when someone assumed that the "company" branch of the family was identified with his Florida concerns. After Alfred began to open up northwestern Florida with roads, A. Felix duPont made a large purchase of timberland adjacent to one of his cousin's holdings. The implied compliment to his judgment rather amused Alfred, especially since relations between him and Felix had been nonexistent since the family division over the stock suit in $1915 .{ }^{1}$

Mr. duPont's largest investment in city realty was the bankrupt office building in St. Petersburg, which the Government had obliged him to buy for $\$ 425,000$ in return for a national bank charter. Though some of his purchases represented genuine hardtimes bargains, on the whole they were acquired with a view to future, rather than present, profits. One thing which bore heavily on owners of urban real estate was the ad valorem system of taxation. This taxed a structure on its recorded value-generally in- 
flated-and not on the revenue produced. When Mr. duPont's St. Petersburg building was two-thirds empty, he paid taxes on a valuation of $\$ 425,000$ and would have paid no more had it been filled with tenants. In the case of hard-up landlords such taxes had amounted to confiscation. Mr. duPont opposed the ad valorem method on principle, suggesting the substitution of a sales tax which would levy only on the income derived from business property.

Opposition to the ad valorem tax mounted, particularly among large property holders, until early in I930 a call for a meeting in Jacksonville was sent to the State's heaviest payers of real-estate taxes. As time for the meeting approached, sentiment for a radical program crystallized. A resolution was in circulation calling for a taxpayers' strike until the Legislature should grant relief from the ad valorem levy. Mr. duPont was in Baltimore at his wife's bedside. By telephone he relayed to W. T. Edwards a definition of his position, which Edwards later stated in these words:

"He would join with them [the sponsors of the proposed strike] or any other representative group in working for a revision of the tax structure by proper legislative action, but he could not and would not lend himself to a taxpayers' strike. As long as he was financially able, he would pay taxes that had been legally levied. If taxes were not paid as levied, how could the children be educated, the sick, the poor, the blind and the insane cared for? In short he would not be a party to imposing suffering and injustice on others to remedy a particular condition which financially affected himno matter how unfair."

Two hundred persons attended the meeting in the George Washington Hotel, Jacksonville. The votes to pass the strike resolution seemed in hand when Edwards read a statement embodying the views of Mr. duPont. Robert A. Henderson, attorney, of Fort Meyers, representing Barron G. Collier, supported the statement of Edwards. This led to a long discussion, after which it was decided to continue less violent forms of pressure on the Legislature to amend the law. The meeting disbanded without the strike resolution being put to a vote. ${ }^{2}$ 
In this way did the ad valorem tax question take its place on the agenda of Mr. duPont's lobby at Tallahassee. This long-remembered institution was in charge of Edwards and the ubiquitous Ed Ball, whose ingratiating personalities already had made it as popular and as effective a lobby as Florida's capital had seen in years-which is saying a good deal. Headquarters were a sixteenroom residence, known variously as the Highwayman's Hideout and the House of Lords. Presided over by a white-jacketed Negro skilled in the arts of managing a kitchen and tending bar, this pleasant establishment became the likeliest place in town to meet some of Florida's most august public personages.

The Highwayman's Hideout lived up to its name. The first effort of its genial hosts was to build roads, and until this was realized other considerations, including tax reform, took a back seat. The object of the "highwaymen's" road-building program was the inaccessible and godforsaken northwestern neck of Florida-the narrow panhandle extending from Tallahassee to the Alabama line beyond Pensacola. The fact that many Florida counties already were in default on their improvement obligations raised difficulties at the outset. Moreover, in the beginning it was said that the scheme was destined to benefit Mr. duPont personally. Had he not bought up vast domains of wild land in that section? Was he not negotiating for more? Yes, these things were true. Also true was the statement that for every dollar Mr. duPont's land should be enhanced in value, the property of others would likewise benefit; and large as they were, Mr. duPont's holdings constituted a minute fraction of the total area.

The Gulf Coast Highway Association, fostering an apparently hopeless project to build a road from Pensacola to Tallahassee and thence south to Tampa, connecting with the Tamiami Trail to Miami, was formed with Alfred I. duPont as president. Paying a large share of the expenses himself, Mr. duPont made the Gulf Coast Highway Association the most energetic road-building organization in the South. In a poverty-ridden region he raised local 
funds, matched them with State funds and, on the advent of $\mathrm{Mr}$. Roosevelt's New Deal, with Federal funds. Thus, one by one, obstacles believed insuperable were swept away, and surveys for the road began.

The strength of Mr. duPont's position rested on the local enthusiasm for road-building he engendered, though enthusiasm is not the word to apply to the results of his first efforts. Agents of the Association whom he scattered throughout the neglected region encountered frank hostility at first. Taxes were high enough. But in country schoolhouses, churches and courthouses-wherever they could get a crowd of taxpayers together-Mr. duPont's emissaries preached the gospel of roads. They worked on boards of county commissioners and on local chambers of commerce where there were such. What guarantee had these cracker counties that any bonds they might issue for road-building would command a fair price? Considering the figures to which county and municipal improvement bonds had fallen in the "rich" sections of the State the question was pertinent. Mr. duPont allayed these fears by having his agents make bids for new issues at prices which confounded the machinations of a coterie of bond sharps to bear the market as they had done so successfully in regions farther south, which had been distressed by the disintegration of real-estate values and by bank failures.

Three trunk highways ultimately were built-U.S. 90 from Pensacola to Tallahassee by the inland route; U.S. 98 connecting the same points via the coast line; and U.S. I9 connecting Tallahassee with Tampa and the south. The name of the builder is perpetuated in the Alfred I. duPont Bridge, spanning St. Andrews Bay at Panama City on U.S. 98. On their own initiative local communities improved byroads leading into the main arteries, thus beginning a network of communications in what had been a virtually roadless region. ${ }^{3}$

Mr. duPont also had an active part in the development of inland waterways in Florida and leading to Florida. J. Hampton Moore, former mayor of Philadelphia and head of the Atlantic Deeper Inland Waterways Association, said that the achievements of that organization would have been impossible without the assistance 
of Mr. duPont. In 1935, the year of Mr. duPont's death, one could travel by protected waterways from Boston to Miami, saving for a small stretch along the New Jersey coast.

His road and waterways programs on the way to realization, Mr. duPont's lobby, operating on a less sumptuous scale, paid more attention to tax reform. The fight against the ad valorem levy was not successful in his lifetime, however. His estate kept up the battle and five years after Mr. duPont's death a constitutional amendment was ratified abolishing the tax for State purposes. Counties and cities could still levy it, though.

Mr. duPont successfully supported several measures designed to keep banks liquid, though diminishing their opportunities for profit. In this he was opposed by a number of bankers. Moreover, against the opposition of a number of large bankers, Mr. duPont worked for a constitutional amendment exempting from taxation homes assessed at $\$ 5000$ or less. The amendment was adopted. Mr. duPont's argument was that the encouragement of home-building by persons of moderate means would be the best possible thing for the State. The opposed argument was that it diminished tax revenues at a critical time.

On the other hand Mr. duPont had a part in defeating proposals for a State income tax. His action favored the wealthy, but Mr. duPont thought it a good way to attract capital to Florida. In Delaware he had not opposed a State income tax when it was instituted in the early Twenties, and in 193r he wrote a letter advocating its continuance. As for Florida, he believed there were better ways of collecting from the rich. One was high inheritance taxes. Reduced as his fortune had been by the collapse of security prices, Mr. duPont knew that approximately half of it would eventually go to the Federal and State Governments in inheritance taxes. Of this he never complained, because of his fundamental disbelief in a person's having money he did not earn. Inheritance taxes, he said, should be as high as possible without impairment to the economic fabric. He believed this would be a problem in the case of closely held corporations like the Ford Motor Company. Should Edsel Ford die, would not the Ford Company have to be sold to pay the taxes-for the Government accepts only cash? Would not 
the breaking up of so great an industrial organism throw thousands out of work and disturb things generally ? $^{*}$

Mr. duPont's attorneys wrote and his legislative agents at Tallahassee successfully strove for the enactment of a bill permitting political subdivisions of Florida to accept local bonds at par and accrued interest in payment of delinquent taxes. This measure accomplished much toward the financial rehabilitation of the State. It encouraged the cleaning up of delinquent taxes, a major problem. It reduced outstanding bonded indebtedness. It supported the prices of bonds and improved the credit of communities, defeating the efforts of bond sharps who were buying local securities for next to nothing to hold for eventual redemption at par.

Events confounded the prophecy of Governor Carlton, who had saluted the opening of Alfred I. duPont's Florida National Bank of Lakeland, September 4, 1929, with the cheerful assertion that this marked the end of the bank-closing era. Three more Florida banks closed before Christmas, bringing to IIg the aggregate since January I, I926. Nor did the failures end there. In I930 thirtyone banks closed and in I93I nineteen. The total in deposits lost or tied up-mostly lost-since September, '29, was $\$ 30,000,000$; and this during the period of the stock-market panic and subsequent depression when cash was at a premium.

The Governor was correct, however, in the assumption that Mr. duPont's entry into the banking situation was a salutary thing. But for that fact there can be no question that the failures would have been more numerous than they were. In October, 1930, Winthrop W. Aldrich, president of the Chase National Bank of New York, made the statement: "I consider Mr. Alfred I. duPont's banking activities in Florida one of the finest phases of banking organization I have ever known." testimony. Barron G. Collier exclaimed: “Alfred duPont's banks are liquid as the lakes!"6

It is doubtful if a bank in Florida escaped a run during that unnerving period. C. D. Dyal witnessed a run on postal savings 
deposits in West Palm Beach. Many in the line were colored. A Negro preacher, carrying a box, appeared. Mounting the box he began to exhort the crowd, saying their money was as safe as if it were in their pockets, because Uncle Sam himself stood back of the postal savings. Failing to turn away a single depositor, the speaker tucked his box under his arm and fell in at the end of the line.

One or two runs on duPont banks assumed fairly exciting proportions, but money was on hand to pay all comers. Mr. duPont's institutions kept in their vaults cash from 20 to 30 per cent in excess of normal requirements. In the vaults of the parent bank in Jacksonville and of the Federal Reserve Bank branch there, were always two or three million more. Mr. duPont's office would receive a telephone call from Hamilton in Orlando (he had been transferred from Lakeland), or Harold Day in Bartow: "Expect an increase in business. Can you send us roo extra?" One hundred thousand dollars in currency would go forward by express. If the urgency were immediate, the money would go by automobile with an armed guard.

It will be recalled that in October, 1930, when Dyal opened the duPont bank in St. Petersburg, only one other institution in the city had survived the disasters of the preceding spring and early summer. This was the Central National which had tided itself over with a $\$ 750,000$ loan from New York. The note was paid off with money deposited by winter visitors during the season of 1930-3r. The bank's only hope of pulling through another summer was an improvement in business which would thaw some of its frozen assets, or another loan.

Instead of improving over the winter, business got worse. Spring came-normally a season for new plans and buoyant hopes, but in Florida a grim time of reckoning. Visitors began to depart from St. Petersburg and to withdraw their bank balances. For the Central National a new loan was imperative. When Dyal heard by the bankers' grapevine that it had been refused, he knew the jig was up.

Though vastly preferable to that of his colleagues at the Central National, the position of Mr. Dyal was an unenviable one. During 
the vicissitudes of the recent years, he and every other surviving banker in Florida at one time or another had known when a neighboring bank was in desperate straits. Yet the ethics of the situation demanded that they say nothing-even to a friend who might have the savings of a lifetime in the threatened institution-on the theory that a miracle might happen and the distressed bank pull through; and these ethics were generally observed-generally, though not always.

Dyal estimated that the Central National would have to close in May, owing its depositors $\$ 2,500,000$. He planned to have his own bank ready to withstand the shock.

On the night of the sixteenth of April, Mr. Dyal received a visit, at his home, from one of his bank directors.

"It's time to get your wood in," he told Mr. Dyal.

Both banks opened at the usual hour of nine the next morning. A few minutes later a representative of an out-of-town bank appeared at a paying teller's window of the Central National with a bundle of checks totaling $\$ 40,000$. There was a conference of officers, and the Central National closed its doors.

Such news spreads with the speed of light. Within thirty minutes the lobby of the Florida National was jammed. The run was on. Dyal's deposits stood at $\$ 1,761,995.95$. His cash on hand was $\$ 152,146.12-$ less than usual because of withdrawals by homewardbound winter people. In the ordinary course his cash would last until about noon. The worst that could happen would be a temporary delay in payment until cash could be got in from outside. Tellers can always slow a run by taking their time verifying balances and counting money three or four times, instead of the usual two times. This stratagem, however, increases apprehension. So Dyal decided he would have to get more money quickly.

Already a director, Dixie M. Hollins, had reached Ed Ball by telephone in Miami

"Can't you get some money in a plane and fly over here?" he was saying.

Ball said he would make other arrangements, and presently word came that $\$ 85,000$ was en route by automobile from Lakeland and $\$ 43,750$ from Bartow. 
By noon it had not arrived and the cash on hand was running low. Hollins suggested an expedient for relaxing the pressure on the windows which Dyal decided to try. Walking into the lobby the bank president said:

"It is lunch time but I know you don't want to lose your places in line. We have sent for sandwiches and coffee, which will be served here in the lobby."

The device was a new one and it worked. The pay-out rate slacked off, and before the food was consumed the Lakeland and Bartow money arrived. Later $\$ 350$,000 came from Tampa, across the bay, and $\$ 650,000$ was started on the way from Jacksonville. At three o'clock the doors were closed and those inside paid off while bank employees began ostentatiously stacking the Tampa money in the cages. The sight had a soothing effect.

Next morning a crowd was on hand early. It was not so frantic a crowd as had stormed the place the day before. The story of those stacks of currency had circulated during the night. When the doors were opened the people converged on the windows, but inside an hour all had been paid and the lobby was empty.

The visible side of a run is only one side. For the most part the smaller depositors line up before the windows, but the big fellows write checks in their offices and put them through other banks for clearance. The second day was spent clearing checks. When it was over the withdrawals for the two days stood at $\$ 455,503.51 .^{7}$

\section{4}

On August I7, 1931, four months after the St. Petersburg run, Mr. duPont opened his seventh and last bank, the Florida National of Miami. Two other banks only were open in Miami at the time; one, the Third National, in such condition that the Comptroller of Currency was looking for a way to liquidate it. When Mr. duPont applied for a national charter, the Comptroller said it would be granted if duPont would supply enough cash to pay off the Third National depositors. The amount needed was $\$ 652,000$.

"You will lose more than $\$ 250$,ooo if you make that loan," observed a member of the Comptroller's staff. 
Nevertheless, Mr. duPont made the loan and undertook the liquidation of the Third National.

The summer of I931 saw Miami in a state of blue funk, and the appearance of Mr. duPont was hailed with joy. Edward C. Rompf, president of the First National and the most influential banker in southern Florida, placed advertisements in the newspapers welcoming the newcomer. The first day's deposits in the Florida National of Miami established a record for the State-\$882,892.6r.

Mr. duPont devoted more personal attention to his Miami bank than to any other he owned excepting the one in Jacksonville. $\mathrm{He}$ took the chairmanship of the board, the only bank office he held excepting the presidency of the Florida National of Jacksonville. And the latter office he resigned in January, 1933, promoting George J. Avent to the place. In his initial organization of personnel for the Miami bank, Mr. duPont entrusted the important task of liquidating the Third National to Leonard A. Usina. Back of that appointment is a story of a man's comeback without precedent in Florida.

Leonard Usina was born in Saint Augustine, where his family had settled when Florida was a colony of the Spanish crown. His father, Domingo Benedict Usina, merchant, local political figure and onetime postmaster, was a pioneer supporter of Henry Flagler. In this the senior Usina encountered serious opposition from the easygoing and insular natives of Saint Augustine who resented Flagler as an alien intruder. Usina retorted that he would live to see monuments erected in Florida to Henry Flagler.

In 1925 Leonard Usina was president of the small Bank of South Jacksonville, across the St. Johns River from Jacksonville. The first he heard of Alfred I. duPont was when the Delawarean advocated a new bridge across the St. Johns and was cried down as an extravagant innovator. It recalled some of the things he'd heard his father say of Flagler's early trials. When Usina learned that Mr. duPont was buying bank stock in Jacksonville, he thought it a good sign. Not everyone, including bankers, agreed. Mr. duPont was not putting out any easy money. Boom investments did not tempt him. He was a tightwad.

Usina had indulged in few real-estate fliers, though the same 
could not be said for some of his directors. When the directors began to feel the pinch, they came to Usina for loans which the bank president had the poor judgment to grant. The effect was swift and disastrous. Real-estate values continued to drop. The loans were unpaid and in January, 1927, the Bank of South Jacksonville failed.

The prospects of a bankrupt banker are dark. In Florida less than one in fifty managed to re-establish himself, even modestly, in the banking world. At thirty-five Usina turned his home into apartments, and in a Model T Ford took to the road buying Florida bonds on commission for a Northern house. Presently he found himself waging little campaigns to stop the needless repudiation of local bonds. Mr. duPont's organization was doing the same thing, and in this way it happened that Usina met Ed Ball. In the fullness of time Usina was engaged as Director of Finance of Sebring, Florida, where bonds were in default. He undertook the collection of taxes, the re-establishment of public credit and the gradual redemption of the bonds. This was what Mr. duPont also wanted. Usina succeeded so well that other towns engaged him. In the fall of 1929 he joined the bond department of the duPont organization.

Still traveling about the State, Usina was in a good position to hear curbstone opinions of the man he was working for. They were not always favorable. The main criticism was Mr. duPont's stringent loan policy. "Damn that man duPont; comes here with all that money and won't loan a nickel." Other bankers, bankers whose financial lives Usina thought Mr. duPont had saved, spread such criticism. Usina repeated the stories to Ball and Ball relayed them to Mr. duPont.

The bond buyer noted rules Mr. duPont laid down for his banks. No officer or director could borrow from the bank. ("Ah," thought Usina, "if I had had such a rule!") Concerning loans was a set of regulations, boiling down to what was, in fact, a tight policy. For some years duPont banks would accept real estate as security only in exceptional circumstances. The banks Mr. duPont had taken over were, of course, loaded with slow real-estate loans. Yet, if Mr. duPont was hesitant about making loans, once he made one he rarely foreclosed. 
From top to bottom the salaries of duPont bank personnel were above the going scale. Moreover, after 8 per cent on the capital had been set aside, ro per cent of the remaining profits of a bank were distributed annually as a bonus to employees. Every person who worked for $\mathrm{Mr}$. duPont received life insurance protection in amounts ranging from $\$ 1000$ to $\$ 10,000$, according to the worker's salary. The organization paid 40 per cent of the premiums and the individual 60 per cent.

"If I ever get in a bank again," mused Usina, "that's the kind of banker I'll be."

In the summer of 1930 when Mr. duPont was picking a staff for the St. Petersburg bank, Ball told Usina that he was to be a member of the staff of the new institution.

"Frankly, it was a dream come true," Mr. Usina later said. "I tried to express my gratitude for Mr. duPont's confidence in me. I knew, of course, that he was familiar with the record of my bank failure. I should have known that he had been over the rest of my record with a fine-tooth comb. But all I could think of to say at the moment was: 'Mr. duPont knows, I suppose, that I'm a Catholic, an active Knight of Columbus and that I campaigned for Alfred E. Smith.'

Alfred I. duPont continued to observe the record of Usina and, on the strength of his performance at St. Petersburg, put him in charge of winding up the Third National Bank at Miami. Instead of losing $\$ 250,000$ in that operation Mr. duPont lost nothing. Usina's eventual reward was the presidency of the Florida National of Miami. ${ }^{8}$

In the columns of the Wall Street Journal and of the Commercial and Financial Chronicle, America's world of business and of finance had been able to follow the outlines of Mr. duPont's Florida activities from their outset. At length the lay press began to carry the news to a larger audience. An article in Time on the Miami bank opening led off: 
"When about two and a half years ago Florida's banking structure was toppling a Strong Man came to save it. He was Alfred Irénée duPont, stormiest of the great Wilmington family. . . . To Florida he brought new, sound banks, all with the name Florida National. Last week in Miami the newest of these began business...."

Aware of the scrutiny his banks were under, Mr. duPont tried to make them models. To his associates he was fond of quoting Frank A. Vanderlip, former president of the National City Bank, to the effect that no well-managed bank could fail.

In the purchase of the First National Bank Building in St. Petersburg at a fairly fancy price and in the liquidation of the Third National Bank in Miami, we have seen how the United States Government used to the general advantage Mr. duPont's ambition to own a string of Florida banks. Mr. duPont did not object to these exactions. The motive behind his banking career was set forth in a letter to a friend: "I have been endeavoring to restore the banking system in the state and insure its integrity and permanency. So far, I have been quite successful. Naturally, it has not been an easy job nor one that will prove remunerative for many years to come."10 Actually the financial rewards came sooner than expected, and by the time of his death, in 1935, the duPont chain-or "Florida National group" as he preferred that it be called-was earning a good profit.

Mr. duPont's cautious management sometimes brought questions from the Federal bank examiners. One criticized his excessive reserves of cash, saying that some of this money should be loaned. One applicant for a large loan, which Mr. duPont had declined to grant, appealed to the authorities. The chief examiner from the Atlanta office came down to investigate. He upheld the bank's judgment in refusing the loan. When the banks in Knoxville, Tennessee, went out, this examiner called Mr. duPont on the telephone to urge that he visit the distressed city with a view to establishing a bank there, along Florida National lines.

No more revealing commentary on the Federal authorities' opinion of duPont as a banker can be cited than the story of certain 
bond transactions which he engineered to improve the position of the Florida National in Jacksonville.

When Mr. duPont took over the management of the Jacksonville bank, he found on hand a heavy holding of low-grade bonds -'Frisco Railroad, Cuban Northern Railroad, Imperial Russian Government, Seaboard Air Line, etc.-which the bank had purchased at from 93 to par. They represented an outlay of $\$ 5,500,000$. In I93I the best of these securities were quoted in the forties, representing a loss of $\$ 3,000,000$ with little chance of recovery that Mr. duPont could see.

At that time the duPont organization was actively in the market for Florida county and municipal bonds, many of which were selling in the forties and the fifties. This buying was part of Mr. duPont's program to provide a market and sustain the price of these bonds; also, the chance of making a profit was not overlooked, because Mr. duPont considered many of the bonds underpriced.

DuPont began a series of bond-swapping deals, which worked out in this way. He would have his broker buy, say, $\$ 200,000$ (face value) of Orange County Road and Bridge 51/2's at $45^{\text {-that is, }}$ at a cost of $\$ 90,000$. The broker would take the bonds to the bank and exchange them for, say, 'Frisco Railroad bonds which had originally cost the bank $\$ 200,000$ but which were then worth only $\$ 90,000$. The broker would sell the 'Frisco bonds, and in this way reimburse himself for the purchase price of the Orange County $5 \frac{1}{2}$ 's. Thus one bundle of bonds worth $\$ 90,000$ had been substituted for another worth $\$ 90,000$ : an even-Stephen proposition, but according to duPont's theory the bank stood to gain because a bond with recuperative powers had been substituted for a dead fish. Here was the illegality of it, though. The Orange County bonds, costing $\$ 90,000$, would be put on the books at $\$ 200,000$, which the 'Friscos had cost originally. This was necessary to make the ledgers balance.

For two years the bank examiners winked at it. Then, one day in 1933 , an examiner said:

"We know what you've been doing. It has been a good thing, though against the law. Now it will have to stop." 
By this time Mr. duPont had replaced about 80 per cent of the low-grade corporate bonds with Florida municipals purchased at approximately the price the corporates had sold for. The Florida bonds were steadily improving, and when Mr. duPont died most of them were at par. The corporates had not improved materially. The gain to the bank had been about $\$ 2,500$,000.

An unscrupulous banker might wreck a bank by these means. An honest banker, whose judgment of bonds turned out to be bad, might wreck one. But an honest banker of good judgment might save a bank by the extra-legal manipulation. In the eyes of the Federal bank examiners and of their superiors in Washington, the character and judgment of Mr. duPont were such that the bond-switching performance was permitted to go on for two years.

DuPont was not always so fortunate in his Florida bond operations, however. In 1928, when bond repudiations began, he chartered the duPont-Ball Corporation, as a subsidiary of Almours Securities, to trade in local bonds. Alfred personally selected the bonds purchased for the bank's account. 'The duPont-Ball purchases were made on the recommendation of a municipal bond buyer acquired from a Toledo, Ohio, house. He proved to be not so good a picker. DuPont-Ball discontinued operations in 1929, and when Mr. duPont died its holdings represented a loss of $\$ 400,000 .^{11}$

Though the courts never passed on the question, it is possible that Mr. duPont's legal corner-cutting did not end with his bond swapping. While a voter in Florida, he held a State office under the authority of Delaware-that of Chairman of the Old-Age Welfare Commission. In that post he did much, his support probably the deciding factor in the re-election of Coleman duPont's son-in-law, Douglass Buck, as Governor in 1932. Buck was a friend of Alfred's pension scheme, and, in 1931, a bill drafted under the Welfare Chairman's supervision was passed by the Legislature. On July I of that year, Mr. duPont sent his last consignment of personal checks to the old people he had vowed 
to stand by until the State should take up the burden. The list had grown to more than I60o names, and Mr. duPont's disbursements since November, 1929, aggregated $\$ 350$,000.

The State took over not only his list but the organization Alfred had got together at his expense. The chairmanship of the Welfare Commission passed to Doctor Charles L. Candee, a clergyman whom Mr. duPont had brought into the work.

Though Alfred had tried to confine his list to cases which would be eligible to benefits under the law, Doctor Candee struck off $\mathrm{I} 44$ names. Mr. duPont requested and received a detailed report on each individual. Nearly all were found to have had outside resources. In borderline cases Alfred gave the pensioners the benefit of the doubt and resumed sending his personal checks to them.

At the same time the Welfare Commission, spurred by $\mathrm{Mr}$. duPont, sponsored a bill to erect a State home for the indigent, doing away with county poorhouses. The bill was enacted and ground broken at Smyrna, Delaware. The architects of the building were Masséna \& duPont-Alfred V. and partner. Completing his schooling in Paris, the junior duPont had joined a firm of architects there. Next he formed a partnership with a brilliant young Frenchman, Gabriel Masséna, and returned to Wilmington in 1930. Aside from the gardens at Nemours their first big job was the welfare home, their next an addition to a $\$ 150,000$ public school building Mr. duPont had erected near Nemours. At the dedication of the \$500,000 State Welfare Home at Smyrna in October, 1933, Mr. duPont made one of his infrequent public appearances, but begged off from addressing the 2000 persons assembled. As a parting gift he ordered radios installed for the old people. ${ }^{12}$

The very first work in this country of the firm of Masséna \& duPont was on the sunken gardens at Nemours.

This magnificent estate, begun in 1909, was a work of art which the artist never finished. Too many persons who knew Mr. duPont well believe he built Nemours only to please his second wife, 


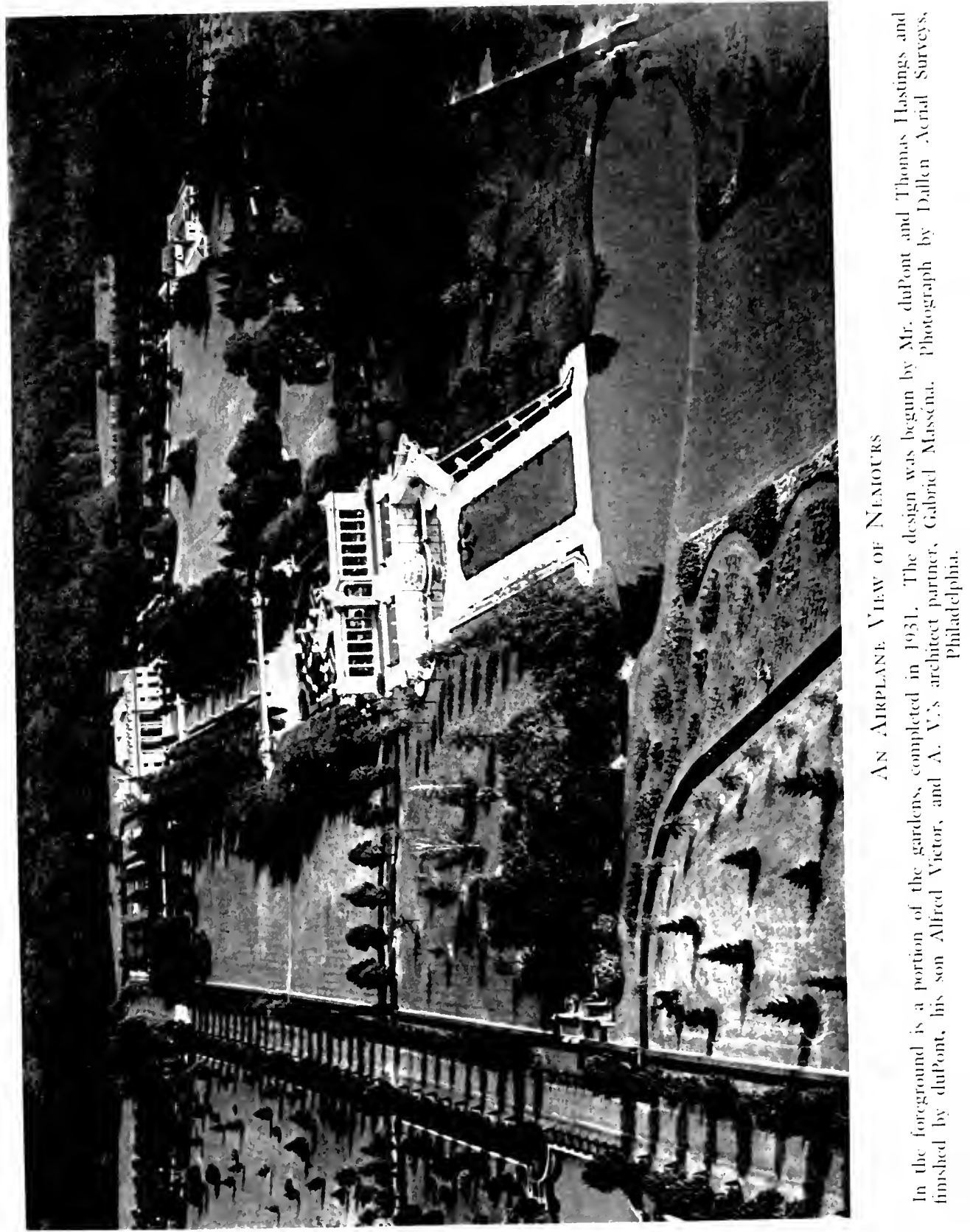


. 
Alicia, for that supposition to be ignored. Yet this can hardly be the whole story. Nemours became too genuinely a part of his own life-which Alfred I. duPont could no more finish than can any true artist be done with the work of creation until death closes his eyes. He did this for his own pleasure, to satisfy an inner urge to bring beauty into being; and also, in the dark days, as a means of release and escape. So many who create beauty, and are truly sincere about it, derive the larger part of their pleasure from exhibiting the creation. Particularly is this true of the builders of great estates. Unless others admire their possessions they are supremely unhappy.

Not Alfred I. duPont. A number of private estates in America are more costly than Nemours, but few are so delicately and consistently beautiful in the face of rather overpowering splendor. Fewer still are so much an expression of their owner-or of one side of their owner, for the "shack" at Cherry Island is also a valid expression of Alfred I. duPont. And probably no great estate is so much the physical offspring of the brain and the hands of the proprietor-setting it apart from the type of estate which the owner orders served up by architect and builder, and goes away until he can move in. Such homes are bought by their owners, but not built by them. Certainly half of Alfred's pleasure derived from the actual labor of building-the sweaty, shirt-sleeve part of the creation of beauty. In that respect Alfred duPont's relation to Nemours was similar to Thomas Jefferson's relation to Monticello. Had Jefferson done nothing else in life, his influence on American architecture would preserve his name for posterity. Any problem of construction interested Mr. duPont-whether a steam fitter's problem or a sculptor's. It was the problems they had solved together, wrenches in hand, that made it so hard for Alfred to part from his veteran plumber, Harry Smith. And when a thing was done and the rubbish of building cleared away, Alfred had no desire to show it off. Despite the gaiety, the comradeship and the laughter of children with which Jessie Ball duPont warmed and enlivened Nemours, probably no country house of its class in America was seen by so few people.

The three hundred acres inside the forbidding nine-foot wall 
contained no natural running water aside from a nameless little rill. This circumstance added to the enjoyment which Alfred, who liked water about him, was able to take from the place. To get water posed a problem he never tired of solving. Starting with two small lakes or ponds on the property he wound up with eight. The water was brought from outside by a subterranean man-made river. The gardens and the last pond to be dug, in I932, afforded an excuse for devising a more abundant water supply. Across a ridge a mile beyond the walls on a farm Mr. duPont owned, a tributary of the Brandywine called Husbands Run was dammed and enough water backed up to serve a good-sized town. This was siphoned over the hill and taken into Nemours via the buried aqueduct. To fill new lakes, which were in the draftingtable stage when he died, Mr. duPont was working on a revolutionary scheme to raise water from the Brandywine itself by means of its own power developed by an enormous overshot wheel. $^{13}$

For two or three summers in the middle Twenties, Alfred would sit on the front terrace, gaze off toward the wall a third of a mile away and dream up his garden. John M. Carrère of Carrère \& Hastings, co-designer with Mr. duPont of the original Nemours, was dead, but Thomas Hastings carried on under the firm name. In I929 plans were sufficiently crystallized to begin work with Hastings in charge. During his long stay in Europe that summer, Mr. duPont got more ideas, which he used to talk over with his son who was studying in Paris. Returning home in the midst of a tinsel world falling in ruin, he would dictate to young Alfred letters devoting five lines to the stock-market panic and five pages to the gardens. When Alfred Victor finished his studies, the father retained him as a European consultant on the project-which was convenient as many of the materials came from abroad. Hastings died. Alfred V. and Masséna came to Wilmington and took up the work.

Following the onerous demands on his funds brought by the depression, Alfred I. reversed himself and began scaling down the gardens. As early as January 9, I930, he wrote from Epping Forest to Andrew Fullarton, superintendent of Nemours: "I notice 
that your pay roll is roughly $\$ 5,000.00$ a month. Please tell me how many men you are employing and the average rate per man. It seems to me this pay roll has been going up instead of coming down." When Fullarton replied that the pay roll had been reduced to $\$ 4,000, \mathrm{Mr}$. duPont apologized and said to lay off no more men. Also he asked his superintendent "to put aside any personal prejudice" and investigate the case of a laborer discharged for drunkenness. "He never made any pretense that he did not drink occasionally, but always claimed that it did not interfere with his work."

On April II, I930, he wrote to his son, still abroad: "I think now we can get the garden down to about $\$ 300,000.00$ completed and I am arranging my finances accordingly." 15

It was finished in I931, costing $\$ 350,000$, exclusive of several costly extras.

Versailles comes to the minds of most persons who see the gardens. From almost any point of vantage, the vista is exhilarating. Generally preferred are the views from either end-the terrace of the mansion house, or the Temple of Love against the boundary walls. In lay language the mansion-house terrace is merely a stonefloored, uncovered front porch, where the family usually sat on summer evenings when the sun was down. A few steps below this porch is a graveled terrace, where automobiles may debouch guests in bad weather. Entrance to the graveled terrace is by two pairs of great iron gates, which are among the things a visitor to Nemours is likely to remember. One pair which Alfred called "Kate's gates" had been made for Catherine II of Russia by the great French ironworker, Tijon. The others originally adorned Wimbledon Manor, in England; later Henry VIII had given them to Catherine Parr, the last of his half-dozen wives.

From this terrace a wide formal avenue, lined with horse-chestnut trees and rows of sculptured marble urns filled with flowers, leads to a fountain which is surrounded by four sculptured groups, the work of Henri Crenier. Beyond this fountain are vivid beds of blossoms laid out in geometrical patterns. Next is the Terrace Colonnade, a memorial to his great-great-grandfather, Pierre Samuel duPont de Nemours, and to De Nemours' son, Eleuthère 
Irénée duPont, the founder of the Brandywine power works. Their busts appear in bas-relief. This impressive monument overlooks a second fountain, or more correctly, group of fountains. On these Alfred expended no end of ingenuity. From this fountain group the gardens sweep up a slope to the Temple of Love, similar to the one at Versailles and sheltering a copy of Houdon's lovely Diane.

The gardens received their real "housewarming" in September, I93I, when the Terrace Colonnade was the scene of the wedding of Mrs. duPont's sister and Alfred's favorite, Elsie Wright, to Major General Albert J. Bowley, United States Army.

"Even the President's military aide, who was present, said he had never seen in the White House anything comparable to Nemours or the assembly and wedding breakfast [wrote Alfred to his daughter, Madeleine]. There were probably twenty-five officers in full regalia and no less than six Generals and God knows who else. They were certainly a fine looking body of men. The groom was exceedingly handsome. His brother, about ten years younger, was best man. He was exceedingly handsome, 6 feet and 2 inches in height. We sat down seventy-eight to the wedding breakfast in the dining room at one table...."16

"[I read] a short home-made epic entitled 'Little Willie's Golden Rule.' You can imagine its reception when I tell you that the Chaplain almost slipped under the table."17

This was the time when loyal Virginians and their connections far and near were laboring to restore Stratford Hall, the birthplace of Robert E. Lee. Mr. duPont had made any number of contributions when his niece Mrs. Cazenove Lee asked for a span of strong mules. Alfred said she should have the mules if he could name them. This agreed to, they arrived at Stratford Hall labeled "Pierre" and "Irénée."1s

Mrs. duPont, naturally, was a worker for Stratford and at length she persuaded her husband to open the gates of Nemours for the benefit of the cause. On September I7 and 18, 1932, the public was to be admitted behind the walls for the first time. Almost immediately Mr. duPont regretted his decision. This invasion of 
privacy was too much for a man to bear, he complained to his sister, adding that he would either shut himself in his room with a book for the week end or leave the place altogether.

Thousands turned out, including a number of DuPonts, old and young, who were paying their first (and last) visit to their Cousin Alfred's-at the going rate of a dollar a head (fifty cents extra to enter the mansion house). And Alfred himself was therevisible to the thousands though recognized by few as he waved his arms, assisting the traffic policemen with their duties, and in general had the time of his life. ${ }^{19}$ 


\section{CHAPTER XXVII}

\section{The CRIsIs of 1933}

Alfred I. DuPont believed with Publilius Syrus, to whose writings he occasionally alluded, that one who cannot bear with the faults of a friend betrays his own. Otherwise his private pension roll would have shrunk and all branches of his charities diminished. About Alfred duPont's giving was a hearty openhandedness at which John D. Rockefeller would have been aghast. Mr. Rockefeller budgeted his charities as carefully as he budgeted a department of the Standard Oil Company. He managed his vast giving with the same cool absence of emotion. At all times he knew to the penny how his benefactions stood, whereas it is doubtful if Alfred I. duPont, at the end of a year, could have told within $\$ 50,000$ how much he had given away or "loaned." His sketchy records contain letters telling "borrowers" not to send in notes because he did not want them in his files for his executors to come across.

No more would it have occurred to Alfred duPont to tote up the sum of his benefactions for a year than to keep books on what he spent on Christmas gifts for his household. If Alfred did not know what he gave away in a year, surely no one else knewincluding the Titian-Haired Circe, who knew many confidential things. The actual giving was through so many third parties, and often in cash, that the situation would have baffled a certified public accountant with the talents of Sherlock Holmes. A truly noteworthy item under the head of charities occurs in a letter Alfred wrote Irénée duPont when Irénée was president of the company: "I must caution you about Mrs. T-, who is a beggar in comfortable circumstances." 1 To have drawn such a warning from Alfred, Mrs. T- must have been a case. 
During the prohibition era Mr. duPont was fond of making presents of cases of Scotch whisky from his famous cellar. When one thirsty beneficiary went on a ten-day spree, Alfred was sorely exercised and, accepting full blame, apologized to the celebrant's family. ${ }^{2}$ Many victims of the 1929 smash whom he assisted were persons Mr. duPont had warned to get out or to keep out of the speculative market. How costly this assistance presently was to prove appears in one of Alfred's rare references to his benefactions, in a letter, dated December 7, I93I, to Francis I. duPont: "I [have] spent about Two Million and a Half dollars in caring for the interests of others, and those accounts still stand and probably will stand for a long time to come before they can be liquidated without inviting enormous losses."

Now and then he could not resist a good-natured I-told-you-so. "At the beginning of 1929, when everything was booming, I prophesied that the duPont stock would be selling below roo inside of two years and several people were overcome by mirth and wanted me taken to a hospital. When asked for my reason I simply stated, 'The damn thing isn't worth any more." "'

In December, 1929, before echoes of the crash had died away, Mr. duPont facetiously told of a visit to his tailor. "I tried to make it a four piece suit but ran out of Kale before I could pay for the extra pair of pants." And in 1932: "I saw an advertisement of a New York tailor, stating that he was quoting a special price of $\$ 120.00$ to $\$$ r 30.00 a suit. Nobody should pay such prices these days. I think of trying the New York tailor who charges $\$ 18.75$ for everything-full dress suit, tuxedo, work suit, overcoats, and everything."

This last remark was not without a certain seriousness. "The trouble is we all have had too much prosperity to stand adversity gracefully. I think most of us will be much better off in every way when we have fought this situation to a finish. Whatever you do, don't worry and don't become despondent."'

The period from October, 1929, to March, 1933, was the darkest 
since the great panic and subsequent depression of the Seventies. At first people were either scared out of their wits or, at the other extreme, too complacent about it all. Then, in turn, they were puzzled, pinched, bitter, resentful, frightened once more, and, finally, desperate. A "hunger march" was moving on Washington; embattled farmers were encircling Western courthouses to prevent the execution of foreclosures. Not many times in our history has leadership so dismally fallen down. About all it could offer was the assurance of prosperity "just around the corner," which one newspaper, by an inspired typographical error, rendered "just around the coroner."

This page could be filled with the names of nabobs of industry, banking, commerce and economics-gods and godlings of the Coolidge era-who could say only, (I) there would be no depression; and when the facts overthrew that, (2) it wouldn't amount to much; and when this began to sound fishy, (3) it would be over before long. Mr. Hoover and his Administration did little better, first spoofing the possibility of a real spell of hard times, then denying its existence, then minimizing it.

In the face of this self-discrediting counsel, Alfred I. duPont displayed astonishing vision. One cannot but wonder what might have been the policy of the Administration had Mr. Hoover taken him into the Cabinet. From first to last, duPont, unobtrusively managing his chain of growing banks in Florida, bulwarking the shaken finances of a State and reaching out in mind toward revolutionary socio-economic experiments, saw further ahead than the body of our national leadership, political or business.

Why did he not speak out? The question strikes deeply into the psychology of Alfred I. duPont. He was a shy man, his name not even in Who's Who in America. For all his love of his fellowbeings, his fundamental democracy and instinctive preference for the lowly, in his heart of hearts he kept company with ideals so fine that few could share them. Lonely in spirit, he could love the masses as Christ loved sinners; and distrust their ability to govern.

Particularly was this true after his bold sally upon the stage of public affairs in Delaware. He had been grievously disappointed 
in most of the men he had placed or helped to place in high office -the last being Herbert Hoover.

The experience nearly finished him with speaking out to the public. His dislike for giving newspaper interviews increased, and more and more Ball and Edwards were delegated to speak for him on local Florida matters. The effect was not as if $\mathrm{Mr}$. duPont, himself, had spoken. On the national situation from '29 to ' 33 he was silent entirely. Had he spoken, and had his words been heeded, the result should have been helpful, to say the least. During this period a trained public relations counselor, such as the Rockefellers, the Wilmington DuPonts, the Mitchells, the Schwabs, the Insulls and all the Administration bigwigs kept at their elbows, might have been very useful to Alfred I. duPont, and, through him, useful to the country.

On January II, I930, when the word "depression" was called the brand of a calamity-howler, Alfred duPont wrote his nephew, Maurice Lee:

"I don't see how such a shrinkage in value, totaling, I presume, several billions of dollars, can take place, involving a proportionate shrinking of credit, without causing a period of depression."s

Mr. duPont believed the depression could be met halfway and its force broken by energetic Government action, a gesture of enormous public spending to provide work for men laid off by private industry and to keep money circulating. Early in $\mathbf{1 9 3 0}$ $\mathrm{Mr}$. duPont suggested in private that the Administration borrow $\$ 5,000,000,000$ and start vast projects of public works ${ }^{9}$ - the highways Alfred was striving to build in northwestern Florida being an example. This idea, intimated publicly by others, horrified $\mathrm{Mr}$. Hoover. It had no support from the body of Big Business, already clamoring for lower taxes.

By October things were worse. "Millions of men going around with empty dinner kettles," wrote duPont. "One can never tell what social upheaval may be imminent." In this situation, added Alfred, the gardens at Nemours would have to be finished as inexpensively as possible and other improvements dropped en- 
tirely. He wanted his money ready for other uses. "Hoover, in my opinion, is not handling the situation with the force it needs. The emergency is much more drastic than we were facing during the war." How very few of our national leaders would have agreed with that diagnosis at the time. "It is a National emergency of major importance and he should have at his disposal, by act of Congress, not less than five billion dollars to tide over the situation. ... He would not have to spend one billion, I am confident, as the mere knowledge that he had it at his disposal would inspire the necessary change of confidence to change the whole psychology of the situation."

Darker grew the picture. By June, I93I, Mr. duPont was beginning to show his exasperation. "Nothing really constructive has yet come out of the Republican administration." Democrats, on the other hand, were beginning to advocate public spending along the lines duPont had recommended. To this the Republican leadership loftily replied that they, the Republicans, were the traditional authors of American prosperity in the past and would be again. The fat Coolidge years were contrasted with the lean ones under Wilson (until war prosperity came) and under Cleveland. Solution of the hard-times riddle was emerging as a party issue. "They [the Republicans]," continued Mr. duPont, "are not willing to obligate the Government to take care of those out of employment, when it is patently their duty to do so."11

That such relief should be privately and locally administered was a cardinal principle of Mr. Hoover's doctrine of laissez faire. Rather than see men suffer, Alfred duPont did in Jacksonville what he thought the United States Government should do everywhere. He sent Henry Dew with a string of trucks to gather up jobless men, white and black, from the streets and put them to beautifying parks and other public places. At the end of a day, Dew paid each man $\$ 1.25$ for his work. This rudimentary public works administration, privately instituted by Alfred I. duPont, continued on and off for two years, until the New Deal "alphabet" took over in 1933. His relief pay roll, at times as high as $\$ 400$ a day, throws additional light on the necessity for economy at Nemours. 
William Randolph Hearst also favored Government spending on public works to give men jobs. With his newspapers he was waging his usual blatant style of campaign to that end. Like Mr. duPont, Hearst put the figure at $\$ 5,000,000,000$. They had arrived at the idea, as well as the figure, independently, for Hearst and duPont were not acquainted with each other. The publisher's crusade gained adherents for the project, particularly among Democratic politicians out of power and ordinary folk out of work. DuPont began to grow sanguine.

"I am glad to see that there is a tendency toward adopting my plan for getting the money out of the banks, namely, by the Government issuing from one to five Billions of securities which will draw the money out and put it to work. I have always maintained that this was fundamentally the cause of the present depression, the unwillingness of the people, due to loss of confidence in the stock market and industrial investments as a rule, to put their money to work, and the only way I can see to get the money out in circulation is by calling it out by Government securities of some kind." 12

These lines were written on June 13, I93I, to Maurice Lee. On June $\mathbf{I 6}$, in a speech at Indianapolis, Mr. Hoover answered the hope they expressed as explicitly as if it had been addressed to him instead. Classifying the borrowing-for-public-works agitation with "scores of theoretical panaceas which would inevitably retard recovery," the President said bluntly: "Nothing can be gained ... by detouring capital into the Treasury by taxes and loans on the assumption that the Government can create more employment than industry or commerce." Mr. Hoover went on to say that some diagnosticians had been so radical as to propose "a dole" and even "unemployment insurance."

The Indianapolis speech was not a popular success. On the trip, during which Mr. Hoover made several public appearances, Federal Secret Service men and local police took careful precautions 
to avert unfriendly demonstrations ${ }^{14}$ - a circumstance rare in the long history of presidential pilgrimages. Money remained in banks, pay rolls continued to thin, and in Jacksonville Alfred I. duPont maintained his own brand of dole and unemployment insurance which he thought our Government owed these people.

A week after the Indianapolis address, however, the hard-working and conscientious Hoover electrified this country and Europe with his war-debt moratorium proposal: the United States to forego for one year principal and interest payments from Britain, France, Italy and lesser powers, totaling $\$ 245,000,000$, provided they, collectively, would forego $\$ 385,000,000$ in reparations from Germany in that period. The stock market rose and hope breathed again. Rid, even temporarily, of this load of dead-horse payments, Europe might have some water for the wheels of commerce. What helped Europe would help us. Over the objections of a recalcitrant France, Hoover pushed this thing through in a month.

Though still criticizing the President's curt rejection of the public-works program, Mr. duPont was pleased by the moratorium. The defect, as he saw it, was that Mr. Hoover did not go far enough. On the international phase of the situation, Alfred wrote a correspondent in Germany:

"I believe that all international obligations will be canceled ultimately but it requires a man of considerable courage to step out and say so. I have always thought they should have been canceled in the beginning, purely from a business standpoint, to say nothing of the sentimental value which would have accrued by virtue of the United States taking the lead in doing the right thing. They will be canceled if for no other than for the simple reason that they will be uncollectable, and when a man owes you money, and you know he cannot pay, and he knows he doesn't have to pay, the brightest thing to do is to give him a receipted bill. By virtue of our attempting to collect reparations from Germany, France, England, et al, we have lost many times their value in trade and have created a certain amount of international enmity, which it will take generations to fully eliminate.

"In addition, we have insisted upon reparations being paid in gold instead of in commodities, with the result that this country 
and France are holding the largest amounts of gold in monetary circulation. England has been forced to abandon the gold standard and several other nations are on the verge of it. We should not only cancel all international obligation but we should pool all the gold in the world and re-distribute it among the nations needing it. This would result in permitting practically all civilized nations to place themselves on a gold basis, which would establish parity as between the currencies the world over.

"All this involves a statesmanship of the very highest order and entirely devoid of political issue, having for its ultimate goal the conservation of the interests of the human race. Where is the man to promulgate anything so drastic? Find him, and you have a real leader."15

This hit the nail on the head. We were drifting. Leadership, that heaven-sent gift which captivates imaginations and inspires a people to deeds beyond ordinary strength, was the need of the hour in America. In Mr. duPont's opinion, the present crisis had found it sorely wanting. "We have no real statesmanship among those at the head of our Government. . . . Our Government is purely an organization of political parties, in preference to the interests of the people. We lack a leader, a man of courage at the head." 16

Not that Mr. duPont was always correct in his week-to-week observations or prognostications concerning a situation which confused the most highly placed intellects of the world. In the light of hindsight several flaws may be found in views hastily expressed in private correspondence, which he did not dream should ever meet the public eye. A few times he fell into the common error that the clouds were lifting. In October, I930, "a turn upward" was expected "almost any moment."17 Eleven months later, "a turn almost any time" seemed in the offing, though this statement Mr. duPont qualified: "Not being a prophet, except on Biblical matters, I don't waste time batting a curve I can't hit." ${ }^{18}$ In November, ' $3 \mathrm{I}$, he saw "the banking situation [nationally considered] clearing" and money coming out of hoardings. ${ }^{19}$ The point is not that duPont was wrong occasionally, but that he was right so often. Instead of joining the chorus which denounced 
every critic of an outmoded and floundering economic system as a subversive radical or a crackpot-as, indeed, some of them were -he said this:

"If Capitalism is not to fall by the wayside, then it must work out some plan which will secure the laboring man against all economic conditions. This, in my opinion can readily be done, provided a fair and comprehensive plan of profit-sharing could be worked out so as to provide a surplus to be devoted to the welfare and maintenance of the working class, just as there is now a surplus devoted to the interests of invested capital."20

The banking situation did not clear in the fall of I93I, or money emerge from hiding. In nine weeks in November and December, ' $3 \mathrm{I}$, and in January, ' 32 , the country got a taste of banking experiences common to Floridians. Six hundred and fifty-five depositories failed and frightened patrons withdrew $\$ 400,000,000$ from those remaining.

Eugene Meyer, able and progressive chairman of the Federal Reserve Board, saw the need for vigorous action along new lines. In the confidence of the inner councils, he had long urged a recession from the President's Indianapolis position that private and not Government enterprise would prove the sovereign solution for our troubles. He urged in vain. Nevertheless, he privately drafted a bill calling for the creation of a body called the Reconstruction Finance Corporation, with $\$ 2,000,000$,000 in assets to loan to banks, industry, railroads, farm groups and exporters who could not get credit through ordinary channels. Not until two days before the opening of Congress in December, 193I, in the face of a revolt among some of his own party, did Mr. Hoover consent to action on the Meyer program. When the Governor of the Federal Reserve Board rushed a copy of the R. F. C. bill to Capitol Hill, neither Mr. Hoover nor Ogden Mills had read it. ${ }^{21}$ Mr. Mills was Secretary of the Treasury, having succeeded Mellon.

The House was in Democratic hands but Speaker John N. 
Garner, joining with Administration leaders, helped put through Meyer's bill, which became a law in January, 1932.

The immediate effect was salutary. In the nine weeks following the creation of the R. F. C., bank failures were only seventy-seven and $\$ 250,000,000$ in withdrawn deposits were returned.

The Democrats wanted to carry matters further. They swung behind Mr. duPont's idea of public works to relieve unemployment. The country was with them. A $\$ 2,300,000,000$ bill, sponsored by John Garner, quickly passed both houses. Hoover vetoed it, breaking the truce between the parties. A substitute bill, embodying much of the meat of the Garner measure, was quickly passed, however. This became a law.

Mr. Hoover was clearly out of step with the country-months behind with everything, giving too little and that too late. A people was crying for leadership, for bold and decisive exercise of authority. The ominous word "dictator" began to strike the ear. In a letter filled with family chitchat to Maurice Lee's wife, Geraldine, Alfred I. duPont took up the theme:

"I don't feel as though we had quite reached the bottom of our economic mire. Presidential years are always off years and I think this one is going to be more off than usual.... The absolute dearth of effective leadership depresses everybody....

"Were I a dictator of the United States today, the first thing I would do would be to cancel or repeal every bonus and every pension that might be termed as unearned, giving only to such as have suffered by injury or old age in the service.

"The next thing, I would visit every safe deposit box in the country and confiscate $5^{\circ}$ percent of all the money I found in them; notify those who got the other 50 percent that, should the next visit disclose any, it would all be confiscated; and any discovered hoard outside of the safe deposit box would result in a little shooting Bee. I would put every dollar to work in the country and in addition to that I would put every son of a gun, or daughter of a gun, back of that dollar and make them work.

"I would have an island in the center of the Pacific Ocean, called Bum Island for people like some of our cousins who either refused to work or who were unable to work. 
"I would have another island just out of reach, called Bummess Island, where all the ladies who were too fat to work or refused to work would be sent. Each would have a site where she could plant cabbages, turnips, beets and other necessities of life and keep alive if she wanted to, otherwise be thrown to the sharks.

"Anyone who smoked more than five cigarettes a day would be sent to Dope Island, where they would join other inebriates, partakers of cocaine, opium, heroin, etc. They would be given plenty of poppy seed to plant. Trained sharks would be waiting nearby.

"All the Congressmen would be sent back home to go to work!

"I would shoot any man who robbed another knowingly, and I would decide who would be shot. This refers to some persons we all know well who have speculated in the market by virtue of information which has come to them in their official capacities. I certainly would have one dandy country to live in inside of five years.

"I would tax all sales about 2 percent, probably less, and I would get 2 billion dollars annually from taxing rum and another billion from cigarettes. If people want to have fun, or rather too much fun, they would have to pay for it. I am not yet certain whether I would tax babies or not, for the reason that I have not yet decided whether they are the direct result of fun! What is your opinion?....".22

Hoover was renominated on a platform reflecting the Republican lack of initiative. On economic and social issues the document was evasive or ambiguous. Not even an issue on which the public had so unmistakably shown its mind as it had on prohibition was met with an explicit statement.

The Democratic nominee, Franklin D. Roosevelt, was everything Mr. Hoover was not: a leader, an innovator, a fighter, a smooth politician and the best campaigner on the national scene since the days of his remote cousin, Theodore. The platform promised unemployment relief, labor legislation, old-age and unemployment insurance under State laws, development of power resources in the public interest, Federal regulation of holding companies, securities exchanges and utility rates, and the repeal of the Eighteenth Amendment. Obviously many of these would be costly enterprises to realize, yet the platform promised economy 
and a balanced budget. On the stump Mr. Roosevelt compressed it all into one marvelous phrase: "New Deal."

One could comb the English language a long time for a battle cry conveying more succinctly what the American people wanted in 1932. Mr. Hoover was more forthright than his party's declaration: "This campaign is more than a contest between two men. It is more than a contest between parties. It is a contest between two philosophies of government."'?3

When Roosevelt had won hands down, Mr. duPont accepted the result with no show of regret-or of satisfaction. His only campaign activity had been in behalf of Governor Douglass Buck, of Delaware, who triumphed handsomely in the face of the Roosevelt landslide. "The Republican Party ... had gotten to think that nobody else in the world could run the country," Alfred wrote. ${ }^{2 t}$ "They ... [got] their natural good licking, which they all deserved." ${ }^{25}$ Alfred invited his friend Secretary of War Patrick J. Hurley, who had been "hoo-hooing for Hoo Hoo," i. e., campaigning for Hoover, to come to Epping Forest and rest his voice. ${ }^{26}$

\section{5}

"There is one thing certain," observed duPont, "Roosevelt can't make matters much worse than they are, and if the people think he is going to do better that is half the battle won." ${ }^{, 27}$

That was to prove true, though before matters improved they got much worse. Throughout the country, banks were losing deposits again. After the first of the year the pace accelerated, the Reconstruction Finance Corporation pumping out credit to help the depositories pay off. The closing of a small St. Louis suburban bank touched off the first series of open runs. Sixteen small banks in or near the Missouri city closed. Jumping halfway across the continent, the rash next broke out in Sacramento, California. Fear waxed and hysteria was in the making. On the night of February 13, Detroit's \$51,000,000 Union Guardian Trust Company confessed to a group of bankers and officials that it could not weather another day. The Governor of Michigan closed the banks of his 
State, freezing $\$ 1,500,000,000$ in deposits. Citizens were caught with what they had in their pockets, business concerns with what they had in their safes. Maryland followed suit and terror spread like a prairie fire. Where governors failed to act, mayors frequently took the law into their hands. On Friday morning, March 3, when Franklin D. Roosevelt left New York City for Washington to take the oath of office on the morrow, lines were in front of the windows of metropolitan banks, particularly savings institutions. Twenty-two States had invoked moratoria or some sort of restrictions. Despite closings and curbs, a quarter of a billion dollars was drawn from the nation's banks on that day - this on top of a quarter of a billion the day before and $\$ 700,000$,000 during the previous seven days.

No bank on earth could long withstand this. At midnight Governor Lehman of New York, himself a banker, signed a proclamation closing the banks of New York. As the news flashed westward the executives of Illinois, Iowa, Missouri and Minnesota followed suit before daybreak. That morning the New York and the Chicago stock exchanges did not open.

At I P. M. on this desperate day, F. D. Roosevelt became President of the United States. Fortunately it was Saturday, a half day for the banks still doing business. Sunday would afford twentyfour additional hours of grace for the new leader to prove his right to that title.

Alfred I. duPont had carefully prepared for the crisis. His outlying banks were "stacked" with currency, to use his expression. Between $\$ 3,000$,000 and $\$ 4,000$,ooo lay in the local branch of the Federal Reserve Bank of Atlanta for emergency use by the Florida National of Jacksonville. During the last two weeks in February withdrawals, while constant, aggregated just under $\$ 500,000$, or far below the national average for a bank of that size. The bank finished the month with deposits of $\$ 15,096,552$-down $\$ 5,000,000$ in two years. March I, however, was a busy day-deposits shrinking $\$ 460$,000 more. And on March 2-the first quarter-of-a-billion- 
dollar day for the country at large-the Florida National paid out $\$ 950,994$ more than it took in.

On Friday, March 3, the bank's lobby was filled as before. After eating lunch at Liggett's drugstore, on the other side of Forsyth Street, Mr. and Mrs. duPont passed through the crowd in the bank. DuPont told George Avent he saw as many people depositing money as withdrawing.

"But when a man wants his money give it to him as fast as you can and give it cheerfully. Ask no one his reason for withdrawing."

Mr. duPont's eye had not deceived him. Surprisingly, the day's deposits exceeded the withdrawals.

The morrow might bring another story, as the experienced Avent knew. That evening he sent to the Federal Reserve branch for $\$ 250,000$, so as to open with $\$ 600,000$ cash in the till. Thus Avent prepared for a brisk Saturday. It is fortunate that he did so because when morning came he was greeted by a near panic. News of the New York and Illinois moratoria sent people streaming upon the bank. Many who had deposited yesterday wanted their money back.

The Florida National still had more than $\$ 2,000,000$ in the Federal Reserve branch. To be on the safe side Avent wrote out a check for $\$ 500,000$ and sent an armored truck for the currency. The truck returned empty. On orders from Atlanta the Federal Reserve branch was closed. The Florida National's spare cash was unreachable-frozen in Government vaults. Immediate inquiry as to how the other two Jacksonville banks were faring brought information which surprised Avent. These banks were represented on the advisory board of the Reserve branch, the Florida National not. Consequently the Barnett and Atlantic had learned the night before that the Reserve branch would not open on Saturday and had got out their money-or as much of it as they thought they would need.

The $\$ 600,000$ with which Avent began the day was melting like a snowball in the sun. News of the return of the empty armored truck spread behind the cages among the bank's personnel. At ten-thirty in the morning the auditor burst into Avent's office.

"We haven't enough cash to last out the day," he said. 
Avent was talking to a nervous director at the time. "Get out of here," he told the auditor. "We have plenty of cash."

No sooner had Avent calmed the fears of this director than another appeared. He'd heard the news about the bank's spare cash being tied up in the Federal Reserve branch. "It's the end of everything. This bank and the whole country's gone to hell."

Avent asked the director to sit down. "You are wrong on two points," he said. "This bank's all right and this country's all right."

The Governor of Florida issued a proclamation permitting banks to shut their doors at eleven o'clock. The Florida National kept open until the regular Saturday closing hour of noon, and then paid off all who had been in the lobby at twelve o'clock. This took more than an hour. The last man paid was a manufacturer who drew $\$ 35,000$ for a pay roll. That left $\$ 148,302.48$ on hand. Should the bank open on Monday, checks on hand for clearance would probably take that, leaving nothing for the lines at the windows. ${ }^{28}$

\section{7}

On Sunday morning representatives of the three Jacksonville banks met in the offices of Frank P. Fleming, attorney for the Barnett, on the seventeenth floor of the Barnett Building. Appearing for the Florida National were Avent and Ed Ball. Not appearing was Alfred I. duPont, who gave his poor ears as an excuse. In his inevitable knickers he sat in his own office, two floors below, dictating replies to his mountainous mail which, as usual, embraced about every subject within the compass of the human mind. Mrs. duPont was with him. Between letters he dictated the strategy of the Florida National at the conference table above. Ed Ball bobbed back and forth keeping his brother-in-law informed of the progress of events.

The first question was whether to open on Monday. Bluff Ed Lane of the Atlantic and polished old Bion $\mathrm{H}$. Barnett of the Barnett were in agreement. They advocated opening-on a restricted basis whereby depositors could draw only a certain percentage of their balances. Having retrieved their money from the Reserve branch before it closed, the Atlantic and the Barnett 
were in a position to support an opening-of sorts. The discussion revolved about the question of the basis for such an opening. One thought a 3 per cent basis was all that could be sustained with safety, another io per cent.

At length Avent spoke up. He said that Mr. duPont was against opening at all. With a majority of the banks in the country closed, it would be idle to contend that Jacksonville could find the cash to pay its depositors. Until the panic subsided and sound banks could be set aside from unsound ones, all should close. But, if the Jacksonville banks decided to open, a 3 per cent basis would not be enough. A Io per cent basis would not be enough. Avent repeated that $\mathrm{Mr}$. duPont thought the course of greater wisdom would be no opening, but, if overruled on that point, he would suggest opening on a 25 per cent basis.

The figure made a profound impression.

"Have you got any money?" exclaimed Ed Lane.

"You're dam' right," came back Ed Ball. "We're bringing it in all day."

Ball neglected to say how much had been brought in or was on the way. That was for his hearers to guess. But he knew that they knew Mr. duPont's fancy for having cash on hand-in his pockets and in his banks.

Actually the money Ball mentioned so confidently did not amount to a great deal-certainly not when one considers the bold proposal of a 25 per cent opening. Two hundred thousand dollars had come in the night before from downstate, arriving after the time lock on the Florida National had been thrown. Ed Ball and James G. Bright had slept in a room with it at Epping Forest, firearms beside their beds. About $\$ 300$,000 more was en route from Miami and St. Petersburg where the duPont banks, in agreement with the other institutions in those cities, had decided not to open on Monday. The fact is Alfred I. duPont was playing the nearest thing to draw poker since he had foresworn that game nearly forty years before.

The conference had many other things to discuss. Similar groups of bankers were in Sunday session in every city in the land. What were they doing? What ideas had come to them? What went on 
in New York? And above all in Washington? A long-distance telephone line to the room on the seventeenth floor of the Barnett Building was open half the time. The day's bill was $\$ 1500$. The conference learned that most cities were staying shut. Some were preparing to issue scrip. The financial captains in New York City were working out a clearing-house agreement which a stenographer in the Jacksonville conference room took down verbatim over the wire.

Little could be made from the bulletins from Washington. Lights had burned late the night before in the White House and in the Treasury across the way. At ten on Sunday morning, Secretary of the Treasury Woodin reappeared, looking weary. Ogden Mills, Eugene Meyer and various Hoover Administration stand-bys were on hand to help, they, too, having worked most of the night. George W. Davison of the Central Hanover Bank of New York showed up-the significance attached to this being that Davison had fathered the great scrip issue of 1907 .

Mr. Woodin went to lunch, saying nothing, and then to the first meeting of the Roosevelt Cabinet.

Mr. and Mrs. duPont went to lunch-at Liggett's-and Mr. duPont returned to his dictation. He said to Ball:

"When the reservoir is dry it's foolish to talk of turning on the faucet. But our position is a 25 per cent opening or nothing."

At five o'clock Mr. duPont went home. John T. Walker, president of the Atlantic, W. R. McQuade, president of the Barnett, and Avent were working on an agreement to use Federal Reserve checks for settlements between banks. The question of opening or not opening was undecided.

At midnight the tired conferees were still at it when the word came from Washington that the President had signed a proclamation closing all banks. At Epping Forest, before he went to bed, duPont heard of this vindication of his position. ${ }^{29}$

"Roosevelt had the courage to handle the situation with brass knuckles," he wrote his brother Maurice. "I say Hurrah!"30

After a week banks began to resume gradually. Within three weeks 13,500 , or 75 per cent of all depositories, were doing business under Government license. Money flowed back; the reopened 
stock exchanges recorded advances in prices; the wheels of commerce turned again. Hysteria had been conquered. The purely banking phase of the crisis was past.

During these anxious weeks, as all through life, Alfred duPont refreshed his mind with the endless variety of interests which made him the versatile individual his intimates knew him to be. Set him down anywhere and he would find something of interest within reach. It might be a person. It might be a bird or an animaldog in particular. It might be a book or a painting. It might be a flower, shrub or tree. It might be a lock on a door. One of Rebecca Harding Adams' early recollections of $\mathrm{Mr}$. duPont was of his repairing door latches in her mother's house in Balls Neck, Virginia. During periods of long-sustained preoccupation with a subject such as banking, the relaxation he took from side lines toned his mind so that, at sixty-eight, he could tire out a less harmoniously adjusted individual twenty years his junior.

Despite the range of his concerns, there can be no doubt but that his main interest was in matters mechanical. Old Anthony Wagner, the head gardener at Nemours, has testified to that. The Nemours estate was beautifully planted, and many of the growing things Mr. duPont could call by their Latin names. Yet Wagner shook his head sadly in admission of the fact Mr. duPont cared more for machinery than he did for flowers. ${ }^{31}$

Mathematical and mechanical terms came naturally to his mind. "A lady's love diminishes to the square of her diversions, so I doubt that you have had much inclination to think of me during your absence or to miss my letters." 32 "She reminds me of the crosshead of a reciprocating engine, which is rather difficult to oil while in motion." 33

For a year he found wonderful diversion in the invention and construction of a contraption for negating a law of nature by raising water above its source by its own power, the specific desideratum being to elevate the water from an artesian well into the house at Epping Forest. Alfred duPont loved water power. As a child 
he had played with little wheels in Thundergust Run back of the Mathewson brothers' cottage. As a schoolboy he had made a waterpropelled mechanical fan for his Uncle Fred's office. And a few years later he was in the water-driven Brandywine powder yards. A silent electrically driven pump, costing perhaps $\$ 400$, originally forced Epping Forest's water, under proper pressure and in proper amounts, into the house. But anyone, with $\$ 400$, could have a similar electric pump. It represented no triumph of personal creation.

Alfred built a water wheel of brass, twenty feet in diameter, to multiply the energy represented by the feeble surface pressure of the well, so as to force the water through the pipes into the house. So delicately adjusted was the controlling mechanism that the wheel could be set about its business by the turning of a single faucet in the house. The device cost $\$ 100,000$, but, as Alfred gravely pointed out, the saving on electricity alone might amount to $\$ 15$ a year. What was the saving in wear and tear on a mind which daily must formulate important decisions, he left to his auditor's perception.

The next year he tackled the water situation at Nemours-meaning the supply for the house and not for his lakes which was another matter. This problem was knottier than the one at Epping Forest. The water had to be lifted higher-r 40 feet from a spring to a tower a good quarter of a mile distant. And there was no pressure to begin with, as afforded by the artesian well. Before Mr. duPont took hold, the thing was managed with commonplace simplicity. The spring flowed into a capacious underground cistern from which an electric pump boosted it, as needed, through pipes to the tower. On a level lower than the cistern Alfred set his wheel -a replica of the one in Florida, though fabricated economically of steel instead of brass. He tapped the cistern to make a race to run the wheel. The wheel actuated a pump to send the water to the tower. The spring feeding the cistern had not sufficient flow, however, to meet the double demand of turning the wheel and supplying the tower. Consequently the overflow from the wheel was trapped in a second cistern and pumped by electricity back into Cistern Number One, to be used over and over again. ${ }^{34}$ 
This electrical pump could have sent the water straight to the tower in the first instance. Indeed, it had done so before Mr. duPont interfered. Thus, from a narrow point of view, the function of the wheel represented a labor of supererogation-the whole thing a flight into the realm of pure mechanics, undefiled by utilitarianism. Wrestling with the same problem in the field of metaphysics, but with less money to spend, Immanuel Kant had written Critique of Pure Reason. This work Mr. duPont may well have known, though at the moment he was digging into the philosophy of Mahatma Gandhi, vexed because he could find nothing "authentic" on the subject. "That he is a disciple of the highest form of self-abnegation there can be no question." Alfred deprecated the fact that "so many people have set him forth as a fanatic.... Such is nearly always the fate of those who are pioneers in new ideas and thought." ${ }^{\text {"3 }}$

Perfection of concept may be possible; of execution never. The best Alfred could do with the mechanism of the automatic valve controlling the stream of water from the wheel-actuated pump to the tower was to bring it within I-Iooo of an inch of perfection. Even this rough approximation (in terms of the absolute) was achieved only after Alfred with his wife had left the house many nights in his dinner clothes to toil for hours with greasy wrenches. When the masterpiece was done, the artist affixed it to a polished metal plate a foot high reading:

\section{Made by \\ Alfred I duPont}

I93I

Mr. duPont doted on mathematical puzzles and jests. Himself something of a lightning calculator, he was fond of repeating the story of the man, who, from the window of a moving train, was asked to count the cows grazing in a field by the right of way. "Ninety-six," responded the mental marvel almost as soon as the question had been put. "How on earth did you do it?" he was asked. "Simple," came the reply. "I counted the teats and divided by four." "36

General Albert J. Bowley saw Mr. duPont work this one: You 
have $\$ 100$ to spend. Cows cost $\$$ Io apiece, sheep $\$ 3$, pigs 50 cents. How many of each can you buy to have one hundred animals for your \$roo? The answer is five cows, one sheep, and ninety-four pigs. $^{37}$

In the late Twenties and early Thirties Mr. duPont foresaw an enormous development of the airplane, both for military and civilian uses, though he was careful with whom he discussed the subject. Several young DuPonts were flying and one or two owned planes. Alfred did not think this a safe pastime and wished no one near or dear to him to try it. When his daughter-in-law, Marcella, began flying lessons, he admitted the inconsistency of such a negative attitude on the part of one who had spent twenty years in powder yards. "So here's to you, and all possible luck." Though apparently he had never made a flight, Mr. duPont had a good knowledge of aircraft. "I think I could secure a license to operate a plane within an hour and a half." 38

"Airplanes [he wrote] must be very much heavier and very much stronger in order to carry around sufficient weight to make them invulnerable against the elements. They must incorporate very much more power with very much less weight per horse power. The present internal combustion engine has been reduced to a point where they claim to be able to develop a horse power for every two pounds of motor. In order to bring this about, every possible ounce of weight has been taken out of the engines, in many instances at the sacrifice of strength and stability.

"If they ever achieve the art in driving the airplane by the Hertzian wave, and I see no reason why it ultimately will not be done, and by virtue of the power so accumulated, can drive high speed electric motors, say, at the rate of 10,000 revolutions a minute, it will be quite possible to produce a horse power with 2 ounces of motor instead of 2 pounds, possibly lighter. Then there will be some hope of developing a plane strong enough and heavy enough to put up some kind of a fight against heavy storms. ... I I can readily visualize this ultimate machine capable of 500 miles an hour...."

Alfred's reflections on this head seem to have carried him back to the days of his electrical experimentation in the Eighties, when 
the German physicist, Heinrich Hertz, discovered the propagation of electromagnetic action through space. The find was a step toward wireless telegraphy. Within ten years after the prognostications duPont uttered in 1931, problems he posed had been mastered and a speed of 500 miles an hour had been attained by airplanes on test flights, though not by the introduction of the Hertzian wave as a propellant.

After deafness, musical similes and allusions dropped almost entirely from Alfred duPont's speech and from his letters: let what was dead be buried. Consequently it is with a rather poignant sense of surprise that one meets this parenthetical phrase, thrown in to illuminate a point he was making to his niece Dorothy Lee: "... like unto the Japanese School of Music, where the very closest harmony prevails and the ordinary semi-tones are subdivided many times and it is only the cultivated ear that can recognize them." ${ }^{\text {*0 }}$

There were other evidences that the remembrance of music was still with him and that echoes of old airs haunted a mind which no musical sound could reach. Invariably he urged music-persistently at times-on the children and young people he knew. Denise was much downcast when after earnest effort she discovered that she was not cut out to master the violin. One wonders which would have been his greatest love, music or mechanics, had not his ears failed him. Had Alfred been asked, he would have said mechanics, for the last thing he wished was pity. Yet, once to his wife, he admitted that given a choice between deafness and blindness he would have chosen blindness. ${ }^{41}$ There are no blind mechanics.

Alfred duPont had only one good eye, but this he used. The beauties and whimsicalities of language may be taken in with the eye as well as the ear. From the days when he received good marks for his schoolboy compositions, Alfred had loved to play with language, as his delightful letters and his "literary" creations attest. He speckled his letters with quasi-Latin quotations. "You 
write a nice letter," Alfred wrote his son's wife, Marcella; and he was a good judge. "I like to receive nice letters from nice girls, otherwise nihil faciens damnabilis, which you may possibly interpret as "Not a damn thing doing!" "42 "I may seem unsympathetic," he observed to a friend, "but I have been up against so much in my life that is disagreeable that my classic features very seldom reflect what is going on in my 'chist.' One of my home made mottoes-Nihil mundum sub shirtum sapiens-being interpreted in good old Anglo Saxon reads, 'Of that which resideth beneath one's shirt the world knows nothing. "'43

Not always did he translate his Latin for his readers, but waited to see what they should make of it. "You are a good guesser at my rather queer Latin," he congratulated Marcella on such an occasion. "Professor Bancroft, my old Latin teacher at Andover, remarked to me: 'DuPont, you are the worst Latin scholar in the school, but I must say the most intelligible.' As language is intended solely for the purpose of conveying ideas, I thought this more of a compliment than otherwise. The word 'ducit' is rather broad in its significance and I had in mind 'to attempt, to create'; however, your translation is equally as good." ${ }^{44}$

Mr. duPont collected a number of paintings-ninety-odd, in all, by recognized artists, old and modern. Personally he would have objected to the use of the word "collected," protesting that he was no collector of art in the sense the term is usually understood. He acquired pictures, he said, to "furnish his home," buying what he liked, with no thought of establishing a reputation as a connoisseur. $^{45}$ This disarming explanation few accepted connoisseurs would question. Mr. duPont's assembly of moderns would generally be considered mediocre, and his masters spotty. There were several canvases, however, over which few would cavil: "The Choir," by Rosetti; "Muses," by Benjamin West; "Two Men on Horseback," by Albert Cuyp; "Princess Elizabeth," by Anthony Van Dyke; a LeBrun; two Woovermans; a Pieter Breughel, the younger.

But the finest canvas in the collection is a Madonna and Child, by Murillo, which Mr. duPont enjoyed almost as much for the adventure of identifying as for the picture itself. Any Murillo 


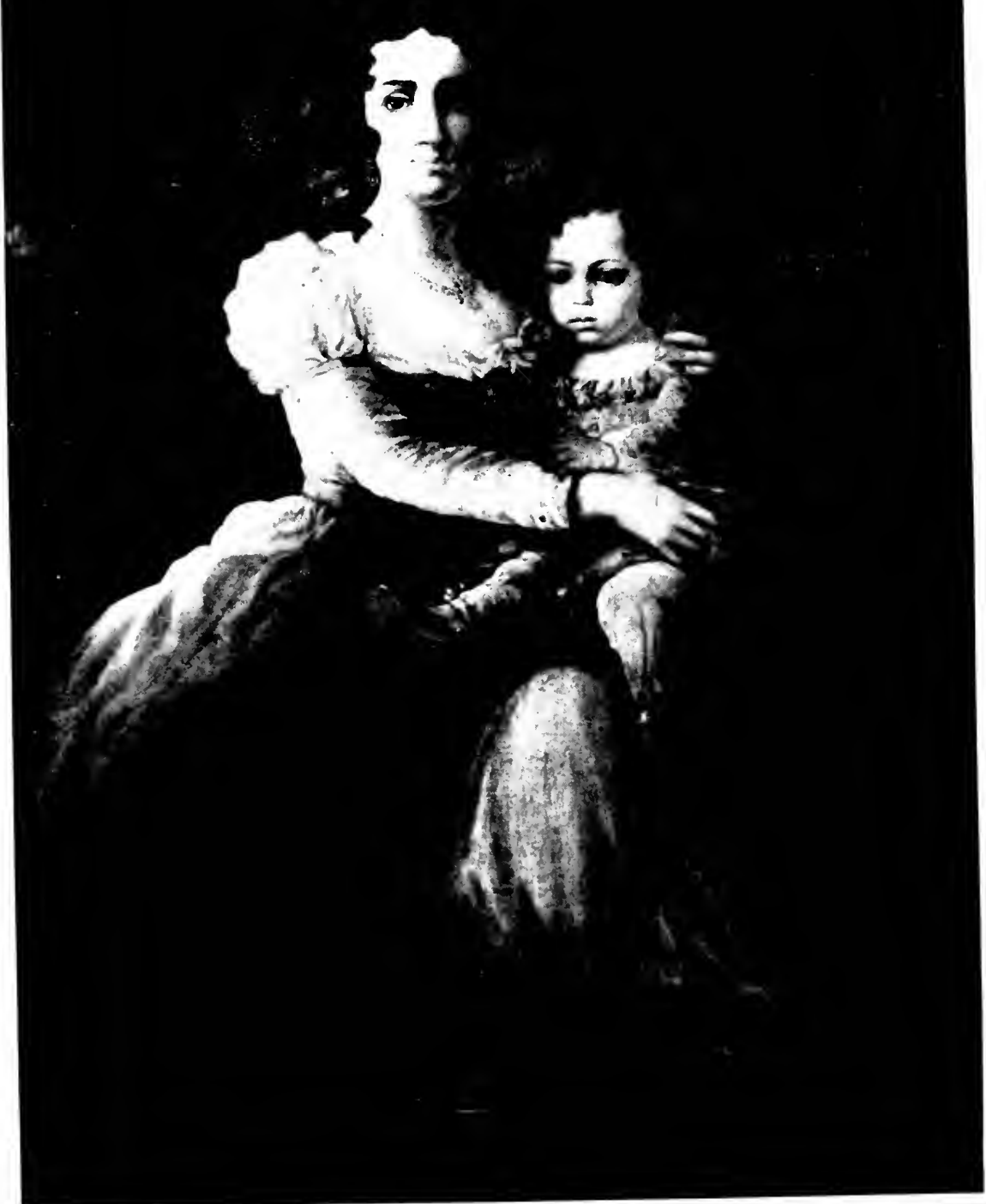

A Mystery in the World of Art

Mr. duPont bought for $\$ 1,000$ this portrait represented as a likeness of his great-great grandmother, Nichol Charlotte Marie Louise le Dée de Rencourt duPont de Nemours, and her son. Believing the work spurious, duPont set experts to work with the result that they uncoured i Murillo. Madonna and Child (reproduced opposite), valued at $\$ 150,000$. uncoreted a Murillo Mhotographs by W. C. Krown, Phitadelphia. 


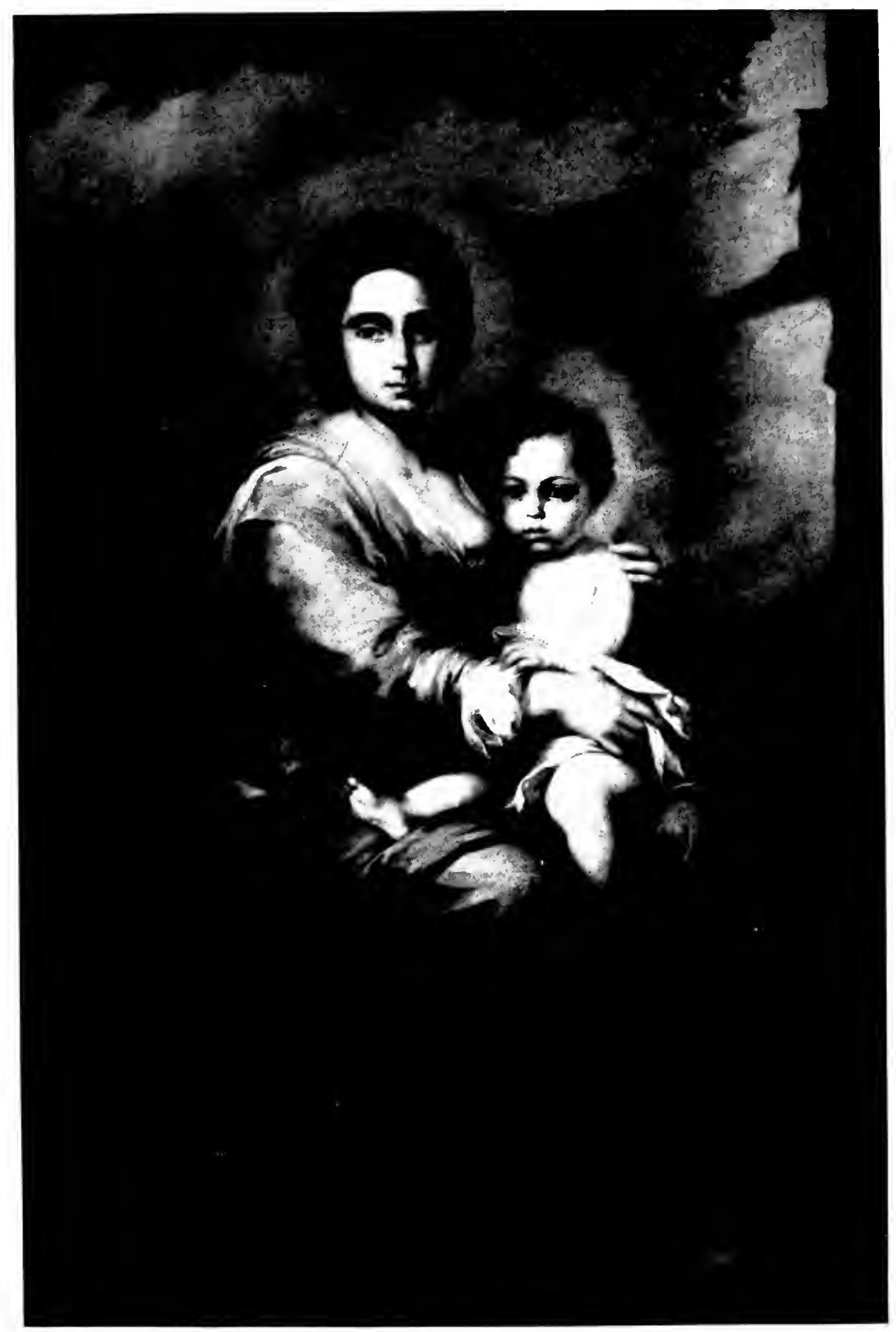


would excite the envy of any connoisseur; and this one is a beauty.

In I93I a Philadelphia dealer offered Mr. duPont a painting by an unknown artist purporting to be a portrait of Nichol Charlotte Marie Louise le Dée de Rencourt, wife of Pierre Samuel duPont de Nemours, and their infant son, Victor Marie. The lady wore a high court hair-dress, gown and jewels in keeping, and held on her lap a baby in frilly clothes. Assuming the child to have been two years old, the painting would have been made in 1769 . The dealer wanted $\$ 25,000$. To Alfred's eye, which he did not claim to be that of an expert, the painting looked old; but it seemed to be the work of more than one hand. This the dealer admitted-a repair job perhaps to cover some accident in the course of the painting's long history. Familiar with all known likenesses of Marie le Dée, Mr. duPont told the dealer he did not believe the portrait genuine. The price was cut to $\$$ ro,ooo. The father of the dealer in question, himself a dealer, had at one time owned several DuPont heirlooms which were authentic. Still, Alfred could not convince himself that the picture was a veritable representation of his greatgreat-grandmother. When the dealer came down to \$rooo, however, he bought the portrait, figuring the frame alone to be worth $\$ 400$.

Continuing his scrutiny, he noted the difference in workmanship on the woman's hands and the child's face from the entire remainder of the canvas. This suggested more than a mere job of retouching; it seemed as if the picture had been drastically made over by an artist vastly inferior to the original. Doctor Arthur Edwin Bye, formerly of the Philadelphia Museum of Art, pronounced the canvas old enough to date from 1769 and expressed the opinion that one painting had been superimposed upon another. DuPont sent the work to Bye's studio to have the later painting removed. The result was a Madonna and Child, which Bye called a Murillo, a verdict supported by other experts. The great Eighteenth-Century Spaniard painted a number of Madonnas, any authenticated one of which was said to be worth $\$ 150,000$.

The enigma of the disguised master has not been solved. Mr. duPont inclined to the theory that the Murillo had been given to DuPont de Nemours by Louis XVI or by one of his wealthy French 


\section{ALFRED I. DUPONT}

friends, and that to get it out of the country during the Consulate he had disguised it. ${ }^{46}$ This does not explain why the mask should have been retained after its arrival here, particularly when funds ran low. Murillos were valuable even then. One in family hands could have made the early financial history of the powder company much smoother than it was. 


\title{
CHAPTER XXVIII
}

\author{
Mr. duPont and the New Deal
}

I

MR. DuPonT's first land purchases amid the melancholy dilapidation of northwestern Florida, made in 1926, had been without a specific object in view, though with clear strong incentive springing from the fact that the region comprised a made-to-order laboratory for experiment in the field of economic and social regeneration.

A proprietary interest in this once-flourishing region, now a virtual waste, gave Alfred I. duPont a feeling of accepting a receivership over a bankrupt civilization, with the duty imposed on all receivers of restoring the shrunken assets in so far as possible. Should he succeed, the achievement would stand as a shining milestone in the social, cultural and economic reconstruction of the South, which is richest in resources of all the sections of our Union, yet whose people were the poorest-none being poorer than the crackers of northwestern Florida. To extend a helping hand in the form of pensions to the aged whose work in life was done was a fine and a humane act. To try to help in the form of broader opportunities to men and women in their prime and to their children coming on would be an even finer thing. And how much more reinvigorating to the life stream of the nation! Yet the problem was more complicated than that of old-age pensions.

In 1927 Mr. duPont added, in Bay County, 13,476 acres to the 66,08I purchased the year before. In 1929 he added 9,843 acres in Franklin county; in 1933, 37,710 acres in Liberty County; in 1934, 195,820 acres in Liberty and Gulf Counties. At this juncture his purchases amounted to 321,930 acres, costing $\$ 1,640,000 .{ }^{1}$ The land acquired in 1926 and ' 27 could have been had more cheaply had the purchaser waited longer or bargained harder.

Three hundred thousand apparently useless acres did not repre- 
sent the whole of what duPont had acquired in his exchange for I,640,000 good dollars. Other tangibles were thrown in, such as the Apalachicola Northern Railroad, the St. Joseph Telephone \& Telegraph Company, the town of Port St. Joe and a good share of the town of Carrabelle.

There was a time when the town of Port St. Joe alone would have been called a bargain at $\$ 1,640,000$, though that was nearly one hundred years before. In those days St. Joe was spoken of more respectfully as St. Joseph. Founded after the United States took possession of Florida in I821, the town was the scene of one of the earliest Florida booms. Two mule-power railroads brought cotton, lumber and turpentine to the wharves from which more than roo,ooo bales of cotton a year were carried away. Great warehouses lined the water front on St. Josephs Bay. Quick and easy profits paid for brick business buildings and palatial residences. The panic of 1837 , terminating the western land craze of which St. Joseph had been a part, ended this prosperity. In I84I yellow fever, carrying off about 4,000 of St. Joseph's 6,000 inhabitants, ended the town. Survivors abandoned their homes and fled. In I844 a tidal wave from the Gulf leveled the empty buildings.

From the wreckage coastal fishermen established a little settlement five miles away, which in 1905, under the name of Port St. Joe, became a scene of enterprise fostered by a group of St. Louis capitalists. A vast domain of timberland was acquired and a lumber mill built. To carry the product to the outside world, a long wooden wharf was constructed to deep water in St. Josephs Bay and the track of the Apalachicola Northern Railroad laid ninetynine miles to River Junction, Florida, where it connected with the Louisville \& Nashville. For a while the St. Louisans prospered, as did Port St. Joe. Then the boll weevil struck the cotton and wasteful lumbering methods skimmed the cream from the woods. The mill shut down. In r925 Ed Ball found at Port St. Joe four or five hundred fishermen and oystermen living a primitive amphibious life, half on land and half on board their battered boats. One fourth were Negroes. The dark skins of some of the whites suggested French and Spanish strains inherited perhaps from buccaneers who had sailed with the Laffites and with Louis Aury. 
The Apalachicola Northern Railroad was known locally as the Absolutely Nothing, and this seemed no great slander. The line possessed three locomotives, the latest built in 1906, two wooden passenger coaches, but twenty or thirty freight cars. This equipment was more than adequate for the traffic of the road, which ran one "mixed" train daily in each direction, at an average speed of fifteen miles an hour. The lines of the telephone and of the telegraph company roughly paralleled that of the railroad, representing the only connection with the outside world of an area larger than the State of Delaware though not so curious as Delaware as to what the outside world was doing.

2

Taking a view of his holdings, Mr. duPont saw that the prospects for development fell under three heads: agriculture, resort and timber. Our crushing agricultural surpluses, which Mr. Roosevelt began to combat with his plow-under program, precluded immediate action in that particular. To turn some of the miles of excellent beaches into resorts would call for an enormous outlay of money, and moreover, Florida was overbuilt on resorts for the present; so that would have to wait. This put the timber resources at the top of the list. But before anything could be done there, there must be highways. So the highway program was launched. As it progressed Mr. duPont devoted his attention to his timber, introducing fire control, scientific care and reforestation.

Meanwhile the timberland owner was studying the uses to which the products of his forests might be put. For a time the DuPont Company was regarded as a possible customer for wood pulp for the manufacture of Rayon and Cellophane, but nothing came of this. Mr. duPont read up on the manufacture of paper, accumulating a small library on the subject. Southern cutover pinelands afforded a supply of pulp for cheaper papers which would last for generations. In the river valleys and swamps, hardwoods might justify experiments in the making of finer grades. ${ }^{2}$

The efforts of an able experimental chemist, Doctor Charles $\mathrm{H}$. Herty, to perfect a formula for the manufacture of newsprint from 
Southern pine came to Mr. duPont's attention. This had long been a Southern dream, the realization of which would be a wonderful thing for the South with millions of acres of cutover pinelands, useless for lumber but good for pulp. The fiber of Southern pine differs from that of Northern spruce from which is made the stock newspapers have been printed on since the discontinuance of rag paper in the Eighties. Much of our spruce pulp was imported from Canada and from Sweden. Doctor Herty's experiments were conducted in a laboratory at Savannah under the auspices of the Georgia Legislature and the Savannah Chamber of Commerce. The fabrication of the pulp of Southern pine called for a different process and for different machinery. Nevertheless Herty produced a quantity of newsprint from the native fiber and the Atlanta Constitution printed an issue on it. Examining the result, Mr. duPont was forced to conclude that it was not up to the standard of Northern paper. The sheets were spongy, sucking up the ink like a blotter.

Nevertheless this was progress, and Mr. duPont told Herty not to be discouraged. It remained only to better the product, and this would surely come. Figuring production costs, duPont ascertained what it would stand him to produce newsprint in the South on a commercial scale. In I93 I he sent Ball and Edwards to a meeting of the Southern Newspaper Publishers Association at the Hotel Biltmore in Atlanta to see what support could be had for the idea from that quarter. The publishers were enthusiastic. Disparity in quality was overlooked for the moment and the meeting got down to the question of price. Ball said that the native paper would be $\$ 42$ a ton. Clark Howell of the Atlanta Constitution remarked that he could get Swedish newsprint laid down at his door for a good deal less. Edward K. Gaylord of the Daily Oklahoman asked: "Do you think it would be good business to pay $\$ 42$ for newsprint when I can get it delivered in Oklahoma City for $\$ 34.50$ ?"

Ball replied: "No, but what kind of businessmen do you think we would be to sell a product for less than it cost to make?"3

So ended one phase of the campaign to launch a Southern newsprint industry. Saying that the whole story had not been told, Mr. duPont urged Herty to keep plugging away. 
The staggering cascade of the New Deal had burst upon the country. The breath-taking speed and decision with which Roosevelt had broken the banking crisis, evoking an "Hurrah!" from Alfred I. duPont, smote now in a dozen directions at once. A bewildered nation had cried aloud for leadership, and had got itwith a suddenness and in a measure almost beyond ordinary comprehension. Not more than three or four times in the Republic's history had a president so firmly seized the reins, and never has one done it so promptly after taking the oath. Jefferson and Jackson affording the closest parallels to the fundamental nature of his innovations and to his sweeping use of power, in a hundred days Roosevelt had changed the course of his country's history.

At the end of six weeks Mr. duPont approved of the phenomena on the whole, appropriately employing a Jacksonian allusion: "I think the President has done splendidly since his Inauguration. He has, 'apparently, a good 'Kitchen Cabinet,' and a fairly tractable Congress which has given him a wide personal latitude in his decisions." As soon as Roosevelt closed the banks, Mr. duPont had remarked that it remained only for him to get a good banking law on the books when they were opened. The bills were in Congress when Mr. duPont wrote. "I am not altogether satisfied with... [them]," he continued. "I am utterly opposed to any form of Federal guarantee of deposits, which, even to a layman, must show that such a law would put a premium on bad banking."

Mr. duPont hoped that State banks would be placed under Federal control and "that no bank be allowed to incorporate and operate in any section of the country where its services are not needed. One of the great curses in the past has been the right of unlimited competition."

"The banking bill is bad," Alfred wrote in May, ${ }^{6}$ complaining anew of the deposit-insurance feature. When it passed and the President accepted it in that form, Mr. duPont blamed the Executive, who, indeed, personally had been lukewarm toward the insurance feature. "It is true that Franklin, with the assistance of Eleanor, is making things hum, but I have known bees to make 
things hum, too, and I fear the product of the Roosevelt family will not be altogether honey." "7 Another criticism called the law "incomplete," which would seem the best one-word characterization of duPont's attitude. Nothing was done about limiting the number of banks in a community or about placing all banks under Federal Reserve jurisdiction. But Mr. duPont approved of such extension of Federal Reserve authority as was authorized; of stricter regulation of private banks; divorcing of Federal Reserve member banks from investment affiliates; interest on demand deposits to cease; officers barred from borrowing from their own banks.

A month after Roosevelt's inauguration Mr. duPont expressed the fervent hope "that they are going to the bottom of the banking atrocities in the large cities, particularly where they are much more easily concealed." This was done, with results justifying duPont's strong language. Before the Senate Committee on Banking and Currency, Special Counsel Ferdinand Pecora smashed at more than one idol. While clamoring for wage reductions in industry and while the securities affiliate of his bank was losing hundreds of millions, Albert H. Wiggin, chairman of the Chase National Bank, of New York, admitted that he had drawn pay as follows: \$275,000 in 1929; $\$ 292,750$ in $1930 ; \$ 250,000$ in 1931; $\$ 220,300$ in 1932; and then had been retired on a life pension of $\$ 100,000$ per annum.

“ 'Pop' Wiggin certainly did have a good shaking down by Pecora, but not more than he deserved," commented Alfred. "The limited banking salary should be Fifty Thousand Dollars. Anyone receiving a canceled postage stamp in addition should be hung up at the main entrance as a warning to others who would be filchers of public funds."

Fifty thousand dollars was what Mr. duPont then paid Ed Ball.

To the basic aspirations of the New Deal, Mr. duPont fully subscribed, frequently pointing out that he had been advocating them for twenty years. He believed in a reapportionment of the natural wealth of the country, giving more to the many who had too little and less to the few who had too much. When he disagreed with 
Mr. Roosevelt, it was usually a disagreement over method and not aim. The main thing he seemed to fear was that by unscientific and headlong measures, the President and his too-enthusiastic collaborators might, in the long run, hamper the production of wealth. Thus there would be less and not more to distribute. In this situation the have-nots would suffer more than the haves, and a great social experiment primarily designed to better the condition of the common man would fail.

Watching the kaleidoscope of 1933 , in which tremendous events moved too fast for the average eye, duPont tried to see beyond the fevered moment and to calculate ultimate effects. From day to day he expressed himself freely in his intimate conversations and correspondence-praising, questioning, condemning. His own tentative estimates were subject to constant revision. What he questioned on one occasion, he might approve on another.

To broaden the young man's experience, Alfred had placed Bayard Hiebler, the oldest of his German grandsons, in the Jacksonville bank. Alert to what was going on, Bayard wrote an intelligent letter on the subject of the National Recovery Administration, with which the picturesque and dynamic General Hugh Johnson had hypnotized a large part of the popular fancy. Though Bayard had much to admire, he feared the system "Fascistic" and striking at the roots of the capitalistic structure. ${ }^{11}$

"You must be patient in the matter of any improvement we can expect from the activities of the N.R.A.," his grandfather replied. "A change from the depth of Depression to the peak of Prosperity in such time as has intervened since March"-this was written in September-"would be almost impossible, and certainly undesirable. It is not possible to predict with any accuracy as to what improvement can be achieved eventually. There is one thing certain, and that is that it is better to have someone like the President, who has the power of initiative and is anxious to do something, than to have the indifference that prevailed in the Republican Administration." 12

The stated objects of the N.R.A. were to increase production, spread employment, reduce hours, raise wages, and produce profits to pay them by diminishing cutthroat competition which experi- 
ence had shown can be as hurtful to public welfare as cutthroat monopoly. With these Mr. duPont agreed:

"I have always been very much in favor of just what has recently been done by General Johnson and the President by way of setting aside the Sherman-Clayton Act [s] and carrying on business as it should be, free from inordinate competition, which was always productive of low earnings and of course low wages, with a settled policy of fair wages to Labor and fair wages to Capital, and a proper distribution of surplus earnings after the two productive factors were properly cared for, which could not but result in industrial prosperity, and increase in the purchasing power of the masses, which after all is what spells for prosperity. This gives complete control of production, which has always been the canker worm of hard times and business depressions. And what particularly impresses me, is the fact that the people accept all this as a matter of course and natural evolution of things in general, when had it been proposed a few years ago, the one who suggested it would have been treated as an insane man.

"About twenty years ago, I worked out in the duPont Company a profit sharing plan, which would have accomplished for that Company just exactly what is being done today in all the industries, and it was with some difficulty that I escaped a padded cell."13

Mr. duPont gave his approval to the most radical of the 1933 New Deal measures, the Agricultural Adjustment Act, by which the Government undertook to reduce farm surpluses and to raise commodity prices by paying farmers to restrict their plantings. $\mathrm{He}$ approved of the steps already being taken by the Administration to assume the mortgages of homeowners and of farmers in danger of foreclosure. In this duPont would have been more liberal than the New Deal. He preferred an interest rate of $4 \frac{1}{2} 2$ per cent; the Government made it 5 per cent. "It is my idea, that the Government should lend to those who have been forced to mortgage their homes at the lowest possible rate and in this way force the Banks to follow suit."14

\section{5}

This on one hand. On the other, Mr. duPont perceived defects in the Roosevelt scheme of reform. By autumn, 1933, he was voic- 
ing serious criticism of the N.R.A. and of the A.A.A., ${ }^{15}$ which eventually was borne out by events, just as his early commendation of these agencies had been justified. As instruments of emergency, both proved helpful. Relatively soon, however, they were abandoned.

Roosevelt's monetary policy Mr. duPont followed with painstaking attention. In April the nation left the gold standard, and citizens were obliged to surrender their gold coin and gold certificates, under penalties which could include imprisonment. In May the President asked and was given power to inflate the currency by the printing of $\$ 3,000,000,000$ in Treasury notes and to reduce the gold content of the dollar as much as 50 per cent. In June he repudiated the payable-in-gold clauses in private and public contracts, gold not being legally available for such payments. In July he disrupted the London Economic Conference looking to world stabilization of currencies by refusing to tie our money to that of any other country. Instead, the President promised to tie it to American commodity prices, the object being to "maintain a dollar which will not change its purchasing and debt-paying power."

These daring moves which left old-line financiers aghast, $\mathrm{Mr}$. duPont reviewed with an open mind in a long letter to his brotherin-law, Thomas Ball:

"We are in for a complete change in our industrial and financial situation. We might as well face that fact. The upper income tax brackets will undoubtedly be eliminated in a comparatively short time and every effort made leading to a more equable distribution of national income. This on the assumption that it will increase purchases, which of course means increased production. Unquestionably, we are in for Government management of industry and a distribution of earnings along lines tending to this much desired condition; and then in the future, all surplus earnings of corporations, instead of being used to expand production unduly, will be utilized in raising wages and salaries, so as to increase the purchasing power of the masses.

"Just how far, they will carry it along the lines of stunting initiative and destroying the rugged American individuality, upon which the civilization of the past one hundred years has been constructed, it is impossible to state. Undoubtedly, they can go too far, 
and, if they do, we will simply drift into a socialistic condition, and from there on into communism: On the other hand, if the Administration realizes this danger and exercises its power to control inflation and encourages all individual values, it may work out well." 16

In October, I933, the Treasury began buying gold for $\$ 31.36$ an ounce, raising the price almost daily until the figure of $\$ 34.45$ was reached in mid-January, I934. This was inflation-a cheaper dollar bill in terms of gold. Since 1879 the dollar had represented 23.22 grains of pure gold. Inasmuch as a troy ounce contains 480 grains, an ounce of gold at this rate was worth $\$ 20.67$. When the Treasury raised the price of gold it reduced the number of ounces purchasable for a dollar and thus lowered the gold content of the dollar. Mr. Roosevelt's object was to help the farmer and the wage earner, primarily, by obliging others to pay more dollars for a hog, a load of wheat or a day's work. The main thing that happened, however, was to frighten the well-fixed. For one of the few times in our national history, Americans began shipping money abroad because they thought it would be safer there.

Still sympathizing with Roosevelt's aims, Mr. duPont grew more skeptical as to the wisdom of his methods. In one sweeping criticism he pictured the President as "wandering in the Elysian fields of finance, playing 'Alice in Wonderland' with the industries of the country, and gambling at Monte Carlo with the poor farm people."17

More detailed observations, addressed to Tom Ball:

"The financial and business situation, as I view it today, is drifting from bad to worse. The meanderings of the 'Brain Trust' in the sphere of finance are absurd, and, so far, have not produced the anticipated blessings. Nothing that is artificial can last. There is no real business being done now, outside of that created by Government financing. Sixty-four percent of all construction work today, throughout the country, is Government work, and a great deal of dissension has been produced by coddling the labor element more in one direction than in another. The farmers now, though conditions for them are much better than they were a year ago, are 
pointing to the fact that the industrialists have advanced, at the farmer's expense, and that the farmer is being left in the lurch.

"The constant changing of the value of the dollar is forcing capital out of the country. Already, Canada and England are being flooded by bank accounts, which are utterly useless to the depositories, because of the fact that it is all placed there subject to demand, for the simple reason that they consider it safer in England and Canada than they do in this country. While not altogether voicing a patriotic spirit, it is nevertheless consistent with the selfish instinct of sauve qui peut and the Devil take the hindmost. Generally when the pocket book is threatened by the wand of depletion, patriotism doesn't go very deep.

"The newspapers that have, until recently, been espousing the Administration and backing up their patent nostrums, be they 'Lydia Pinkham's' or 'Father John's', are now starting to anathematize everything that looks like Roosevelt, or sounds like Eleanor, or smells like the Democratic Party. They have tried to build up a huge political machine by buncoing the people of the country with the slogan of The New Deal. When Congress meets in January, look out-Watch the hair fly. The whole system of business and business control today is built on 'hot air,' and, in my opinion, will fall by the wayside.

"I have always espoused the cause of a much wider distribution of national wealth, and the use of gibbet and halter on men of wealth, who, by virtue of their basic acquisitions and by the power vested in their possessions, only build toward their own aggrandizement. Professor Wiggin is a good illustration of just what I mean. The handling of all funds of others, as in the case of Bankers, should be based on the acceptance of such funds as a sacred trust, and any thought of any violation of this principle should not be tolerated." 18

Though Alfred I. duPont knew more about what went on in the minds of the masses than did most millionaires, he was mistaken in his forecast of the temper of Congress which convened in January, 1934. That body was not the frightened and inarticulate instrument of the spring before, yet no hair flew. Mr. Roosevelt exercised easy control. His currency experiments having thus far 
failed to lift commodity prices or to accelerate prosperity, he asked permission to continue them, specifically requesting authority formally to put a new price tag on the dollar in terms of gold and to impound all gold in the Federal Reserve Banks, amounting to the whopping sum $\$ 3,500,000,000$. This was granted by a House vote of 360 to 40 and by a Senate vote of 66 to 33 .

Mr. Roosevelt fixed the value of the dollar at 59.06 cents in gold priced at $\$ 35$ an ounce. The object, he persisted, was "to make possible the payment of private and public debts at more nearly the price level at which they were incurred."

Economists and financiers were divided on the move, most financiers, however, opposing it. They would have made hair fly! Mr. duPont's running estimates of the New Deal, favorable and unfavorable, so far reproduced in these pages, were for private consumption. During the controversy over the President's revaluation of the dollar, he made his first public statement on the subject of currency reform in particular and the New Deal in general. Unaccustomed to public utterance, Mr. duPont's few formal papers lack the spontaneous vividness of phrase and sometimes the clarity of letters he dictated at the rate of 130 words a minute. In this statement Alfred I. duPont spoke for the masses. Also he spoke to them, seeking to give them renewed confidence in their chosen leader:

"The gold content of the dollar is not nearly as important as what that dollar will buy, nor as important as keeping the dollar at a fair purchasing level. The law of supply and demand will govern the price of any particular commodity more effectively than the amount of cash available for the purchase of that commodity, but, on the other hand, it is true that money or cash must be in the hands of potential customers before the demand can be effectuated. Customers are the people-not just a few people, but the masses.

"The world economic depression had progressed to the point where the established agencies of our country found it impossible to function in normal ways. Money ceased to flow through the ordinary and regular channels. Private industry and control of available capital found it impossible to do anything which would stem or materially retard the downward trend of general condi- 
tions, or to exercise any remedial visible influence upon future prospects. It was, therefore, apparent to the most conservative that all the people must join hands to find and apply a remedy. 'All the people' means the government; and for the leader, Franklin D. Roosevelt had been chosen. Upon assuming office, he quickly secured the passage of the National Recovery Act. The act had for its purpose three main objectives, namely, making our currency more flexible in relation to world finances; stabilizing commodity prices; and putting more money into the hands of the people-all of which are now being accomplished by the manipulation of the gold content of the dollar, control of the gold supply, regulation of commodity supplies, and public works construction....

"The President well knows that the people of our country want to hold on to the truth and well established fact that every American is rewarded in proportion to the energy, brains and ability he puts into his business and that every American believes that principle to be the mainspring of the wonderful development and greatness of these United States. He knows our citizens do not want a dole, but want to hold on to the old plan of equal opportunity to all.

"When President Roosevelt's plan shall have progressed a little further, the ultra conservative will be amazed to behold this country containing one hundred and twenty million happy, contented and prosperous people, with our wheels of domestic industry humming, our exports vastly increased and our national debt greatly reduced, so that the artificial stimulants can be withdrawn and the old Ship of State left to sail on her own power in the good oldfashioned way.

"Suppose our money now differs a little in so-called gold content from what it used to; if it buys what we need it could not be better money. Suppose government bonds are paid off with so-called 'cheap money'; if the former bond owner can take that money and buy what he wants, then he has not been hurt and should be satisfied. Suppose taxes are increased, they can be paid from increased earnings, whereas, if the depression had continued there would never have been any more earnings.

"It took courage, ability and energy of human caliber to devise, execute and carry on with a plan so new and untried as Pres. Roosevelt's National Recovery Program, but all other means have failed, and it is now the duty of every citizen, no matter what his 
training, beliefs, theories, or party may be, to stand by our President and in word and deed give him whole-hearted and active support."

A constructive critic, duPont reserved the things he did not like about the Administration for more discriminating audiences.

Farm prices rose and business improved. Friends of the Administration said Roosevelt had done it. Others said it would have happened anyhow. Reactionary die-hards said the depression had really been licked by Hoover and that the New Deal had deferred recovery. Although the earnings of General Motors had risen from I I cents a share in the first quarter of 1933 to 63 cents a share in that quarter of 1934, President Sloan, a die-hard, came out against the Administration's "interference" with business.

"I admired Sloan's stand," wrote Alfred to Maurice Lee, on May 4. "I do wish Roosevelt would let up on his experiments and scrap all his different N.R.A.'s and P.D.Q.'s and let business take care of itself once more. If he does not he will rapidly accept Socialism as part of our National system. ... The people of this country are rapidly drifting into a condition where they are willing to accept from the Government instead of living by the sweat of their brow." 20

Senator Robert Wagner's bill to establish the National Labor Relations Board to mediate labor disputes aroused Mr. duPont to the point of writing Senator Hastings of Delaware who owed his election to Alfred's support: "The Wagner Bill is adverse to the interests of both Labor and Capital and was devised solely in the interests of the American Federation of Labor. Every proper effort should be made to defeat this Bill.... I trust that your views will coincide with mine." ${ }^{21}$ Rarely did Mr. duPont so bluntly tell a public man what to do.

The Wagner Bill became a law, nevertheless, but Mr. duPont did not live to see the National Labor Relations Board in operation.

DuPont's caustic criticism of the Silver Purchase Act rested on firmer ground. "The Silver Bill will call for two or three Billions of extra currency, not needed," he declared. "[This] will only further depreciate the value of the Dollar, that standard of value, 


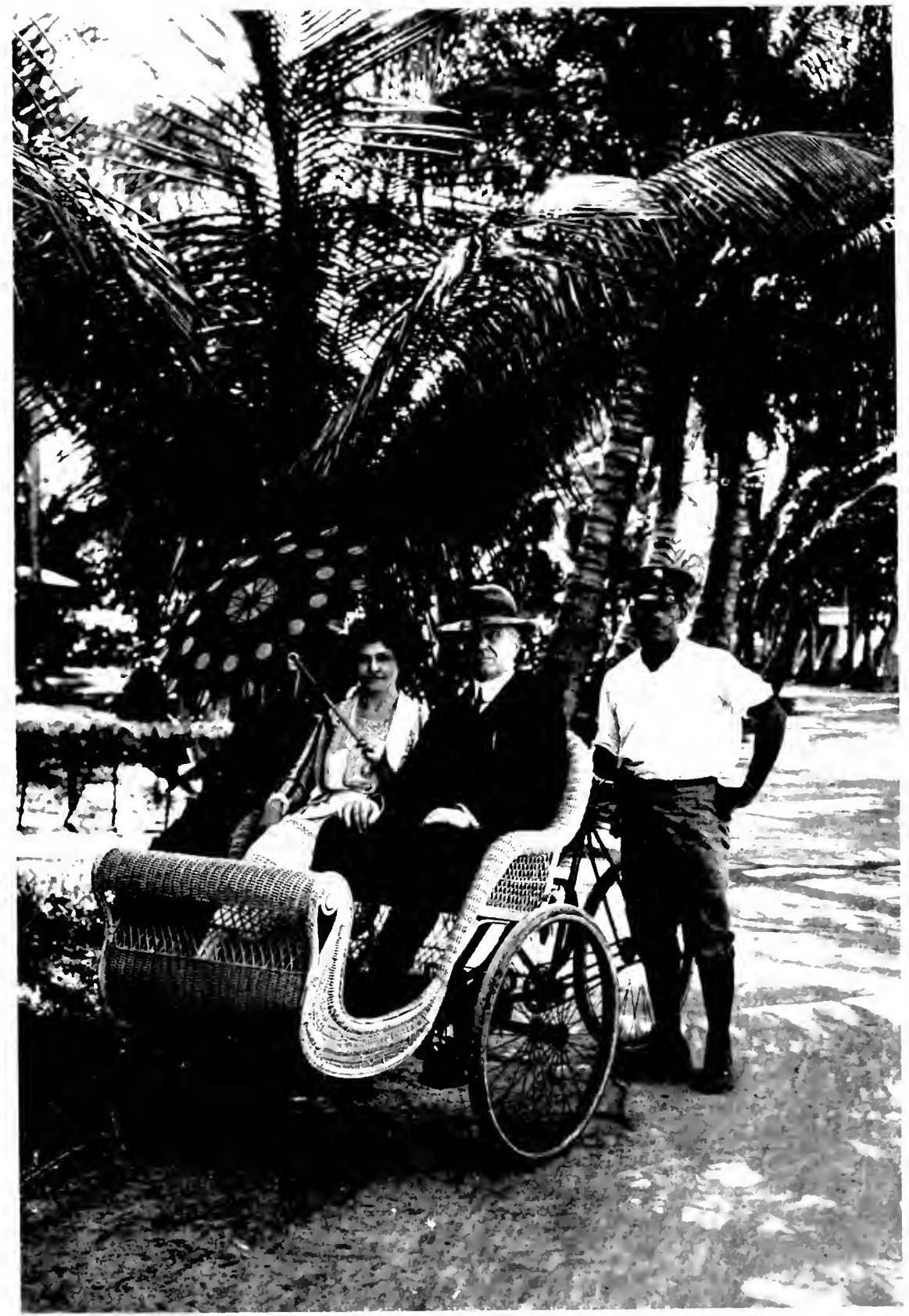

Mr. iNd Mrs. dePont, Pis.y Beich, 1928. 
honored for so many years, which now hangs its head discredited by every foreigner." 22 Senator Key Pittman and other politicians from the silver-producing states whooped up the demand for the nationalization of domestic stocks of silver and the purchase at exorbitant prices of silver by the Treasury to initiate an artificial boom in the ore. When the President surrendered to the silver bloc in June, 1934, Mr. duPont's faith in the Roosevelt methods was severely shaken.

"Every move made by the Administration now, so far as I can determine, is made for the purpose of securing more votes for the coming Fall election [he wrote]. The Democratic Administration of today reminds me of an octopus, with the head in Washington and its tentacles extending to the uttermost limits of the Nation, constituting an enormous political machine, financed by the taxpayers. Mr. Roosevelt is a good politician, but a poor business man and sadly in need of sound advisers. He has no good men to help him in administrative matters, as the men who could have helped him were unwilling to accept a position which would have placed them in a questionable political aspect. I can see nothing ahead but a period of extravagant inflation. There will be no other way to pay the bill." ${ }^{23}$

During the last month of his life he summed up his view of the situation in a personal letter dated April 3, I935:

"The present Administration certainly has been successful in making the proletariat believe that the New Deal will ultimately succeed, though it is built upon foundations which have crumbled in other countries. I don't think there ever has been an instance where a country has deliberately left the gold standard, where there was no reason for so doing [without disastrous results]."

He denounced the raising of funds by borrowing instead of by increased taxation which would make the people realize what was being spent.

"The financing attempted by the Treasury Department in April shows that the people are rapidly losing confidence in the Govern- 
ment securities, which means that they will shortly lose confidence in the purchasing power of the dollar.... The Banks already own 60 per cent or over of the outstanding Government securities, and the recent attempt to float Baby Bonds through the Post Offices has, I understand, resulted in a dismal failure....

"I considered the passage of the recent expenditures bill of nearly five billions of dollars a preliminary step toward the vote poll of 1936, just as the vote of 1934 was influenced in the same manner. Where it will all end no one can prophesy, as the power of amelioration lies entirely in the hands of the people, which power they refuse to utilize as they seemingly do not know what is before them."24

Indeed a dark picture, and a darker prospect-as he saw it. 


\section{CHAPTER XXIX}

Evening on the Brandywine

I

However gloomy the outlook in one direction, a many-sided life invariably turned up something Alfred I. duPont could enjoy. There were always his dogs. No dog has ever failed a true dog lover.

"Your Aunt Jessie is well," Alfred wrote to his German grandson, Benno Hiebler, "and so is everybody else, including Mummy, Yip and Monk."1

Mummy, Yip and Monk were the dogs.

The blueblood was Monk, a pedigreed Irish terrier. Will Glasgow had given him to Mr. duPont.

Yip, a member of the proletariat, was Alfred's own acquisition. In the autumn dusk of an evening in 1926, Mr. duPont was walking home from the laboratory Francis I. duPont had set up on his own after severing relations from the company. A half-starved little dog limped across Alfred's path, dragging a broken front leg. DuPont carried the animal home under his coat and put splints on the leg. He named the dog YP, standing for Yellow Pup. This was soon corrupted to Yip. The patrician Monk at first looked down on Yip, but this assumption of superiority was difficult to maintain in the face of Yip's demonstrable talents for chasing chipmunks, cats and squirrels-accomplishments which the master of Nemours rated highly.

Mummy belonged to the grand bourgeois. Mr. and Mrs. duPont found her in the course of an evening stroll, in r932, in a small park near Shepheard's Hotel, in Cairo, Egypt. The grimy little animal was too ill to stand. At the hotel the puppy's protectors nursed her back to health and named her Mummy. Mummy was white with black spots, and below the size of Monk and Yip. Her early life 
remained a mystery, though Mr. duPont pieced together a few plausibilities. Of uncertain ancestry, Mummy nevertheless was accustomed to soft living-someone's strayed or abandoned pet. She had been in Egypt long enough to recognize the native street cries. Mr. and Mrs. duPont had planned to return home via England. That kingdom, however, imposed a six-months' quarantine on dogs in transit. Concerning Italy's dog policy, duPont received conflicting reports. Consequently he waited three weeks to catch a ship direct from Egypt to New York.

Early in March, 1932, Mummy surveyed Nemours with a luxuryloving eye and decided the place would do.

"I am just as glad to get home as it is possible for anybody to be [wrote Alfred to Dorothy Lee]. I only wish you were here to see Mummy. Mummy has traveled over six thousand miles in her attempt to find a new home, somewhat different I think from the little mud hole she was occupying in the park at Cairo when I found her coughing her poor little head off with double pneumonia, and weighing, I judge, not over four pounds. She is about a year old, I judge-teeth as sharp as needles, and will soon be boss of the establishment, to the hopeless discomfiture of both Yip and Monk.

"She slept in our stateroom all the way over and was the pet of the boat. Two women asked Thomas [Horncastle] where in the world they could buy dogs just like that. Thomas intimated that Mummy came from a pyramid and was at least three thousand years old and was the only one of her type left. She accompanies Yip and Monk to Florida on Monday. She is a regular mascot and has proven her efficacy already by permitting Lord Reading, who was at Luxor not expected to recover from septic pneumonia, to convalesce thoroughly before we left. She also brought the Aquitania through a violent gale, estimated by one of the stewards at $2 \frac{1}{2}$ miles per hour, but in reality about 55 to 60 miles."

Epping Forest also came up to Mummy's requirements. "Yip and Monk despise her and if either of them are on the couch with me and Mummy climbs up they immediately leave. I am trying to imbue them with the Christian spirit which defines that we should love our neighbors as ourselves.", 
The aloofness of Yip and Monk could not endure forever. Not only did Mummy make herself popular as a house pet and insist on accompanying her mistress in the car, she challenged Yip and Monk at their own predatory pastimes of making things hot for skunks, cats, et cetera.

"Mummy is now becoming a seasoned hunter [Alfred proudly related]. She will hunt anything. She has her gear case in fine order and can speed up very rapidly and usually leads both of the other dogs when there is a rabbit in sight.

"I think I wrote you that Monk laid violent hands on a fox, twice his own size, and sent him on to Fox Heaven. Yip tried to climb an evergreen tree, in pursuit of the service gate cat, and what that cat did to Yip's mug was a plenty. It is true that Yip got one chew off the cat but, when I dragged Yip down the tree by the tail, his nose and face were bleeding. Everybody predicted that the cat would not survive but I saw her this morning apparently none the worse. Yip has not visited that portion of the property since."

When Denise finished her primary schooling in Baltimore and went to England to prepare for college, her father kept her posted on the dogs.

"Yip is well but thin, having chased cats so hard. Monk is also thin as he roams with Yip. Mummy looks like a stuffed bologna, set on four toothpicks.

"I wish you could have seen them this morning. As I was walking down to the pumping station, the Three Graces, running ahead down the road from the greenhouse, failed to observe the greenhouse cat, which was sunning itself in the gutter by the side of the road. They passed within six inches of the cat without seeing it. Then they all saw the cat at once and clamped brakes on, one dog rolling over the other in an attempt to stop. I reached down and scooped up the cat. I tossed the cat to a nearby gardener who tried to secrete it under his coat while the three wretched hounds tried to pull his clothes off."

\section{Again:}

"Yip and Monk got licked by a wood chuck day before yesterday. They tackled my pet chuck that lives under the wren's nest 
in the apple orchard. Yip took one blow in the solar plexus and escaped in flight; and the chuck finished off Monk in great shape. Unfortunately, they injured one leg of the chuck, of course the back leg-they would not have dared to tackle the front one-but the chuck got home all right. Both Yip and Monk looked much subdued after the skirmish-like brides who have been married about a year."

The adventures of Monk, Yip and Mummy, as chronicled by their master, would fill a book.

Alfred's allusion to the sorry spectacle of a last year's bride was a piece of fun. Yet there had been a time when he had meant that sort of thing seriously enough subtly to discourage matches he fancied he saw in the making among his friends. In the case of the young, his position was that they were not old enough to know their minds. The experience of Alicia, junior, was regarded as a confirming example. Her marriage to Glendening had resulted in divorce, and now the young woman was married to an Englishman and living abroad. The mature, Alfred contended, were apt to be too set in their ways to yield to the give-and-take necessary for a successful partnership.

This attitude had been gradually modified. When Edward Ball, forsaking the time-tried paths of bachelorhood in 1933, married Ruth Latham Price, of DeSoto, Missouri, Alfred assigned to himself a share of the credit. "Yes, Ruth is a lovely girl, but then you must not be surprised as I picked her for Ed."7

But when, in the fall of I93I, his daughter Madeleine revealed that she intended to marry again Alfred was gravely disturbed. "You are free, white and twenty-one," he wrote her, "and, while I do not say that you are fully able to judge for yourself in a matter of this kind, you ought to be." This would be Madeleine's third venture in matrimony, two earlier ones having been unhappy. "My first marriage, as you know," the father continued, "was a boy's marriage, with the outcome you also know. My second marriage was made very largely for the purpose of protecting a sick woman, who was persecuted by every human being who had every right to 
do the opposite. I failed in my first marriage and I failed in my second."

Then had come the union which had given life new meaning. Alfred only hoped that it might be the same with his daughter. ${ }^{8}$

Happily, this proved to be the case. The husband was Friedrich Hermann Ruoff, eleven years the junior of his bride, and the son of a fine old German couple who had been Madeleine's best friends in her earlier domestic difficulties.

Madeleine and Hermann made extensive visits to the United States in 1932 and '34. Fearing the ultimate consequences of the rise of Hitler, Alfred urged them to settle here. While this was being mulled over, Alfred came to know his remaining grandchild, Madeleine's first-born, John Bancroft III. After Madeleine's first divorce, the boy had been reared by his father's people, the Bancrofts of Wilmington, who were textile manufacturers.

Jessie and Alfred were lunching alone at Nemours when Thomas Horncastle announced the young man. He said he had called at the suggestion of Mrs. Victor duPont, Sr., a clan dowager always fond of Alfred and particularly happy over the reconciliation Jessie Ball duPont had wrought in his immediate family. John was twenty-three and at the University of Virginia. Alfred gave him a trip to Europe, where he visited his mother for the first time in his recollection. ${ }^{9}$

In 1934 Alfred sent the Ruoffs on a coast-to-coast tour of the United States in the hope that they would perceive the wisdom of throwing their lot and that of the boys with the land of Madeleine's birth. Ruoff was half-inclined to do so. The question in Madeleine's mind was, Will my boys come? By this time they were young Nazi zealots. ${ }^{10}$ Madeleine herself, who had lived in Germany half of her life, had begun to imbibe some of the militant optimism of her sons. In his persuasion Alfred was patient, tolerant and temperate. Hitler had done some worthwhile things, he admitted; but the main course was toward disaster. Alfred complained because Roosevelt did not do more to strengthen our Army and Navy.

In the fall of 1934 Madeleine and Hermann returned to Germany, still in a state of indecision. This did not last. The boys 
refused to desert the Fatherland. With a heavy heart Alfred accepted the fact that the fates of his daughter and of three manly grandsons were in the hands of Adolph Hitler. ${ }^{11}$

The encroaching years left their mark on Alfred I. duPont, though almost imperceptibly. He entered his seventieth year never more solid or sure in mind, or bolder or more farseeing in his projects. Some of his plans ran twenty years ahead, and, although it was understood that his wife and her brother should continue them after his death, generally he spoke as if he, himself, would be on hand to bring them to fruition. The diversity of interests continued undiminished, and his physical powers unusual. These he conserved, guarding diet and drinking almost nothing alcoholic beyond a glass of wine or beer.

The society of children stimulated him as agreeably as ever, and his talk with them was not old-man talk. "No, the kids are not a bit of nuisance," he wrote a mother. "The development of the youthful mind is a most interesting study and the viewpoint of children on different topics and their manners of expressing themselves are always refreshing." 12

Denise had grown into an extraordinarily lovely girl, thoughtful and kind, and full of spirits, too. When she was at home Jessie made Nemours hum with parties and what-all for young folk. Sometimes Alfred threw up his hands in mock protest. "Nemours is covered with ashes, cigarette butts and all kinds of trash, from one end to the other. Newman, who undertook to try to keep things in order, has broken down; Thomas, sick; footman, sick; Denise, sick; Yip, sick (tied up with a polecat last night)! They are dispersing today and I have a large bottle of Port to celebrate when the last one hits the trail."13

The Nenemoosha remained his sanctuary. Companions for a cruise were sorted out with care. "No, I don't want any Governors on my yacht," he wrote Jessie's sister, Belle Baker. "As a rule they are all swelled up like a bag of wind. I shall expect you and Victorine and possibly Ed and don't you dare bring anything 
else on my boat without permission. I am trying to get a little bit of rest and I am sure you and Victorine can entertain each other and Ed Ball and I can look on."14

"A nice two weeks on the boat in Long Island Sound," he reported at another time to Elsie Bowley, in Hawaii with her soldierhusband. "Half the time we were alone-T. G. [Thank God]; and the rest of the time entertaining, or trying to entertain, various persons, such as Gerry Lee and her husband, my brother Maurice, Mrs. Glasgow, Isabelle Crane, one of The Brid's old beaux by the name of Doctor Hardwicke, and many others too numerous to mention. Dok Hardwicke, I found to be a very nice man, and entertaining, having traveled all over the world and then having had the world travel all over him."15

Alfred was just talking. He loved these people. And it would have been difficult not to enjoy the company of the roving English surgeon, Hardwicke, as pleasant and picturesque a soldier of fortune as one would be likely to meet in half a life's journey.

With the passing of the years, the DuPont family of Delaware continued to expand-in numbers, in wealth, in power. Probably as many as a hundred households lived in or about Wilmington. Others, living elsewhere, maintained close ties with the home citadel. Alfred viewed the spectacle with detachment, most of the old rancor gone. Yet he did not fancy the example of so much power concentrated in so few hands united by blood.

"Everybody here is well, both those who are alive and dead [he wrote Madeleine]. You may perhaps remember Judge Gray who was buried today. He was eighty-five years old. I don't remember his ever having been ill and he seems to have had a grand time during the whole eighty-five years. He was a very remarkable man in some ways but, like most Wilmington people, was one of the spat-lickers, and for that class of people one can never have any great amount of respect. However, he has gone to a place now, wherever that may be, where licking duPont shoes will not bring him any chicken croquettes and cheap claret punch."16

In 1930 Professor Dumas Malone published the correspondence which had passed between duPont de Nemours and Thomas 
Jefferson. "To me," Alfred observed to his sister, "these [letters] were very enlightening, showing duPont de Nemours a man of much higher caliber and greater education and broader views on matters of political economy than I had supposed it was possible for the duPont family to produce. It is a pity he was not in Jefferson's place, as he would have made a much better President." ${ }^{\text {"7 }}$ It would hardly be fair to judge Alfred's knowledge of American statesmen by that last sentence.

Still another crop of DuPont youngsters was coming of age, its components thinking for their individual selves. The half-forgotten quarrels of their fathers were not their quarrels. Some frankly admired their Cousin Alfred, with whom more than likely they had never exchanged a word in their lives. Estimated by any standard, certainly he had achieved a place in the front rank of the family's great figures. With less inclination to acquire wealth than most of the others, and less inside opportunity, he was even the richest-or close to it, anyhow-of all DuPonts. Coleman who prided himself on his ability to make money had died in r930 supposedly worth $\$ 17,000,000$. This was a fourth of what Alfred owned at the time. The post-1929 shrinkage is supposed to have handled certain other multi-millionaire DuPonts rather badly-or such was the family gossip-bringing Pierre's fortune down to the level of Alfred's. These facts and surmises are worth mentioning only because, when Alfred was being edged out of the company, one of the excuses was that he was so impractical in matters of money.

Memories of the late family feuds of which Alfred had been the storm center were fading even from the minds of onetime participants. Pierre was frequently heard to speak well of Alfred and to dwell with evident pleasure on their friendship as young men. In certain quarters, a reconciliation was hoped for.

"I cannot think of any scandal," Alfred wrote to Madeleine, "beyond the fact that the wife of your Cousin - - [name deleted] announced that she has always liked me and would like to come over to Nemours and see me." The woman mentioned was close to Pierre. "I have announced that my heart is too weak for any such excitement. The number of such ladies who love me now and who 


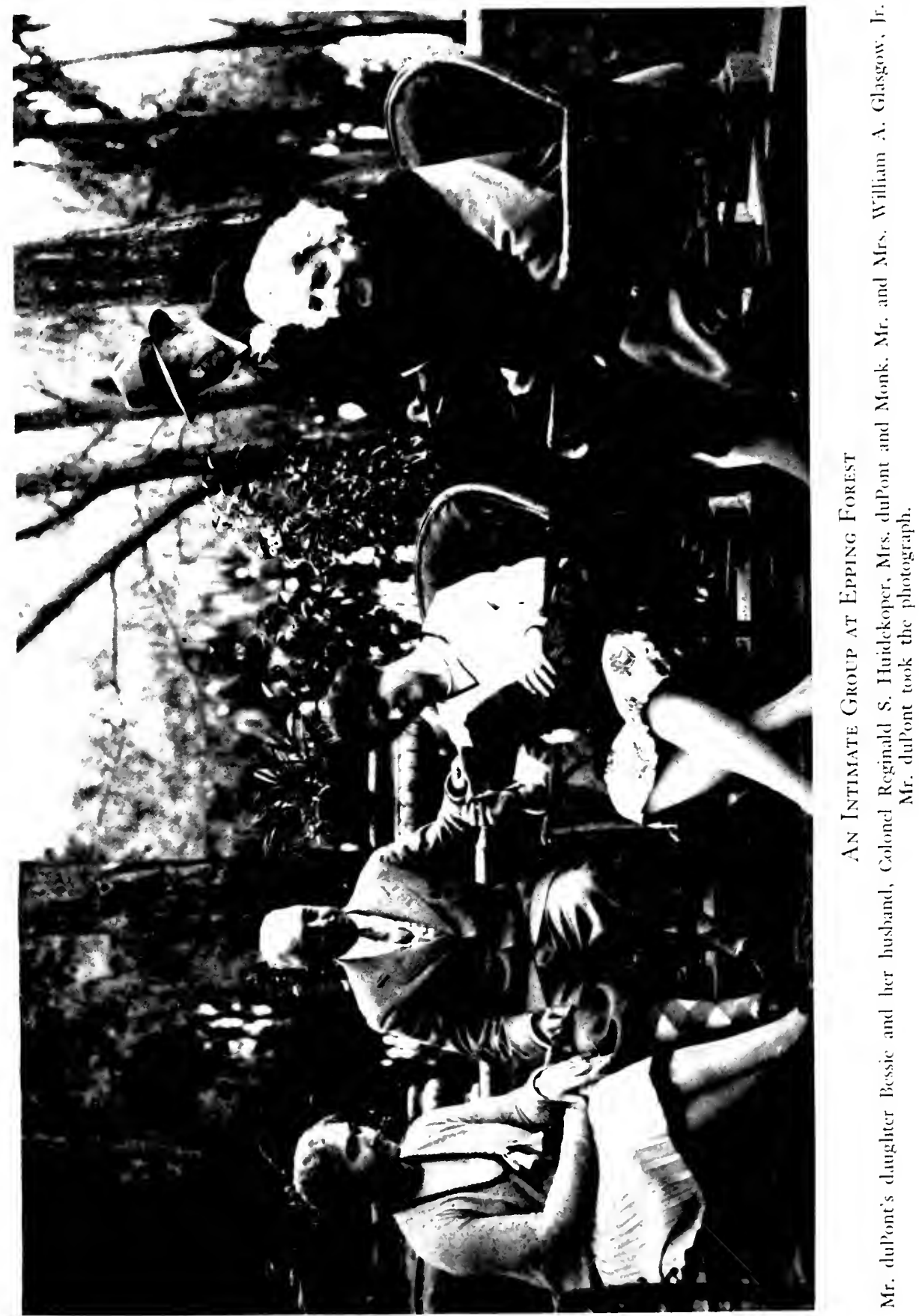


didn't use to love me is increasing at an embarrassing rate. I must resemble a Cremona violin, which becomes more beautiful and more valuable as time passes." 18

Pierre initiated a correspondence with Alfred on the subject of DuPont family heirlooms. The subject did not get beyond heirlooms, and the two men did not meet, ${ }^{19}$ except once in a long while on business or by accident.

Occasionally Alfred would walk down the hill from Nemours to the banks of the Brandywine to commune with recollections of his youth.

"Many of the old narrow twisting roads have been obliterated long ago and others have been turned into improved roads for the automobile. And the old lovely wooded fast running stream that I used to walk up as a small boy in search of sunfish, catfish and eels-how could it ever be the same, with the old wooden covered bridges replaced by modern steel and concrete?"20

He would walk to the iron Centennial Gates which he had built at the lower end of Hagley Yard. He did not go beyond those gates, though they were usually open. To have done so would have been to trespass on private property. Alfred had built a wall about Nemours to discourage trespassers, including relatives, and he did not trespass on the property of others. When the yards were dismantled after the World War, Alfred had felt keenly the fact that he had been passed over in the distribution of the land among members of the DuPont family. ${ }^{21}$ What other DuPont loved that soil more dearly or had a better sentimental right to a patch of it?

Not all the old buildings had been demolished. A row of the most venerable of the wheel mills was left in its rightful place between the race and the creek. Shrub-grown and silent, the squat granite structures in which generations of DuPonts and their colaborers had worked and in which so many had died by violence, stood as a memento to the family's black-powder past. 
Yet, in the transformation which had come to the Brandywine, Alfred had had his own part, being a silent partner in a saloon the license for which stood in the name of Elizabeth Dorman.

Mr. duPont's and Elizabeth Dorman's acquaintance dated from the time Lizzie was a redheaded child with braids, skipping a rope in front of the Hagley Yard gates, beyond which her brother and her father worked on the powder line under Mr. Alfred, as her grandfather had done under Mr. Alfred's father. With the passing years Miss Lizzie became the postmistress of the village of Henry Clay, and so an individual of renown on the Brandywine. Leaving official status aside, Miss Lizzie probably would have achieved renown on the strength of her standing as a pillar of St. Joseph's Roman Catholic Church and her tender concern with everybody's troubles. When the Henry Clay Post Office was closed, the community to be served from Wilmington, Miss Lizzie fell on ill times, from which the repeal of the Eighteenth Amendment and her friend Alfred I. duPont effected a rescue. Mr. duPont provided rent-free quarters in which Lizzie could live and set up her saloon. They were on Main Street, as they called the Creek Road now, facing the murmuring Brandywine between Breck's and Sunrise Lanes-not more than a lusty shout from where both Lizzie and her benefactor were born.

Miss Lizzie's saloon, with a crucifix above the door, might be called a tame successor to "The Lord" McCarthy's Blazing Rag or Tom Toy's William Penn which flourished as the Brandywine's places of entertainment when Alfred was a boy. Alas, the times were tame by contrast with those boisterous days; the once-teeming yards as quiet as the burying ground at St. Joe's up the hill, where so many of the men who had made them what they were slept under the white headstones. The progeny of these deceased powder pioneers was mostly scattered far and wide, the only DuPont activity surviving in the neighborhood being the trim Experimental Station, which Alfred had helped to found, on the site of the old Lower Yard. But for old-timers who remained above ground and for their families, Miss Lizzie's served as a pleasant club and forum.

There of an evening one could meet men who had worked for 
Alfred I. duPont in the yards, men who had played in his orchestra, and now and then an oracle who had known him as a Down-theCreek urchin or had worked with him in overalls. And these people knew other DuPonts, too. Among their mothers and wives and daughters, who came to Lizzie's, were former cooks and parlormaids in DuPont homes; and veteran nurses who had smacked more than one small DuPont posterior. There were men who had been gardeners, caretakers, coachmen and chauffeurs for DuPonts. Some were still in DuPont employ-company or private. They knew a side of DuPont life outsiders never see. In their casual exchanges great names were handled without self-consciousness and without reserve.

Alfred would have enjoyed the talk at Miss Lizzie's. ${ }^{22}$ 


\section{CHAPTER XXX}

\section{A Life Is Ended, Its Work Not}

When Lammot duPont became president of the DuPont Company in 1926, he decided to establish a different relationship between the concern's second-largest stockholder and the management. Anyone else holding anything like a similar stake in the firm would have had a seat at the directors' table. Yet since 19I6 Alfred duPont had been an outsider. Favorably placed owners of a hundred shares might know more about what went on in the inside councils than he who owned more than 500,000 shares, and was still buying. Might know, bear in mind. Actually Alfred sometimes knew, by the grapevine, more than he was supposed to know. This means of getting information was as unsatisfactory as it was humiliating, and the intelligence received was often out of date or inaccurate.

As was natural for a man with so heavy an investment, Alfred following as closely as he could the amazing change-over from explosives to other lines of industrial chemistry. And there must have been a further reason: Alfred's lingering emotional concern for the firm which bore the family name. Perhaps due to Maurice Lee's connection with that branch of the business, Alfred was particularly interested in Cellophane and in Rayon. As cigars began to appear in Cellophane sheaths, Alfred chose brands so wrapped when making gifts. He hailed the Cellophane jacket on Camel cigarette packages as a stroke of enterprise by the company. ${ }^{1}$

Lammot believed that Alfred should be drawn nearer the center of things. His enormous holdings constituted a claim impossible to set aside. His brains and reputation would be an asset. And such a move would make for greater harmony in the family. Now that the old enmities were dying, Lammot recalled many 
kindly things in connection with his Cousin Alfred, dating from the time Alfred had taken Lammot into the service of the company as a green hand in the black-powder department. Possibly Lammot remembered that the first share of company stock he owned was a bonus given on the personal recommendation of Alfred. In retrospect, at any rate, Lammot had a healthy regard for his Cousin Alfred's ability.

"I began my work in I902 under his direction," he said in later years. "We did not agree at all on many phases of what I might call technical management, but Alfred's far longer experience usually satisfied me that my thinking must be subject to question."2

As president, Lammot made it a point to call once or twice a year on Alfred at his Wilmington office and talk over company affairs. The object, he later said, was to answer questions, to learn Alfred's judgment on matters of policy and "to maintain or increase his confidence in the management."3

One well-placed individual in the company proposed that Lammot go further and offer Alfred a directorship. Lammot answered evasively and did not act on the suggestion. ${ }^{4}$

When Alfred heard of this it nettled him and he expressed the opinion that Lammot's visits were seldom productive of vital information. ${ }^{5}$

Nevertheless, the visits continued, and relations between the younger and the older man grew more cordial. Still, Alfred declined to sign a proxy giving the management the right to vote his shares at the annual meetings. In a firm but friendly tone, Alfred wrote Lammot a statement of his reasons:

"The proxy ... would suggest personal approval of the Management. As I had no means of judging as to the business discretion or acumen exercised by the Management, I could not honestly submit. The earnings of a Company do not always reflect the character of its management, despite the fact that most stockholders consider satisfactory earnings as a reflection of good management. You have some good men on your Board of Directors. ... There are others who, I judge, are without value from an advisory standpoint. It has, however, in the past been the policy to have large holdings of stock represented on the Board of Directors. ... 
"I assume that ... [my] holdings represent one of the largest on the stockholders' list, and it would have been, therefore, logical to presume that, ere this, personal representation on the Board of Directors would have suggested itself as a proper act. I have no time which I could allot to personal service but perhaps a representative, carefully chosen for his business ability, would be in a position to give me a clear insight into the Company's policies and management; and in addition it might be a distinct addition to the personnel of your Board. Such an arrangement would permit of my voicing my approval through the medium of an annual proxy."

Lammot was ten days in replying. During this interim it seems unlikely that he should fail to take counsel on a question so important with his brother Pierre, the chairman of the Board and by no great margin the company's largest stockholder. In a wordy rejoinder which admitted the policy of giving large stockholders representation, Lammot cited the case of one director who, living in France, was not expected to attend meetings. Therefore a confidential monthly résumé of all matters coming before the Board was sent to him. Lammot asked if this would suffice Alfred. There was no suggestion, however, that Alfred be elected to the Board.

As an alternative, continued Lammot, could not Alfred select some existing director as his personal representative?

In case neither of these suggestions suited Alfred, Lammot promised to "consider" the request that a new director be named as Alfred's personal delegate. Did Alfred have any particular person in mind? Did Lammot know him? If not, would Alfred send a statement of the individual's qualifications ? ${ }^{7}$

Alfred named Edward Ball, whom Lammot rejected on the ground that he lacked sufficient "manufacturing experience." Lammot later argued the sincerity of his desire to see Alfred represented on the Board, saying any one of several men other than Ball would have been accepted. He did not state who these men were. It is possible that Lammot labored under a genuine delusion concerning Ball's fitness. He may have heard that Ball was merely a rich man's brother-in-law, with little else to recommend him. Such stories were not hard to pick up-especially about 
Wilmington, on the whole not the first community in the land to appreciate the niche Alfred had carved for himself in Florida. Had Lammot looked in the right places, he might have convinced himself that $\mathrm{Ed}$ Ball had developed into an able and very energetic corporation executive with more achievement to his credit than some of the current DuPont directors. ${ }^{8}$

Alfred let the slight pass without comment. He had plenty else to do and plenty for Ed to do. With his banks thriving and his city real estate on the way out of the red, he concentrated on his dream of rehabilitating his portion of northwestern Florida. Arrangements were made to buy $\mathrm{I} 44,8 \mathrm{I} 7$ additional acres in Gulf and Bay Counties. When completed this brought the total of purchases in this region to a veritable dukedom of 466,747 acres. $\mathrm{Mr}$. duPont did not own all this at one time, however. In 1934 and early ' 35 he sold 186,747 acres to the United States Government for inclusion in the Apalachicola National Forest. This reduced the holdings, at the time of his death, to 280,000 representing a net investment, taking no account of improvements, of $\$ 1,087,776$. $^{9}$

Early in I934 large-scale improvements were projected, and $\$ 1,500,000$ set aside for the purpose. This activity centering about Port St. Joe, envisioned a harbor accessible to ocean-going ships; modern wharves; the making over of the Apalachicola Northern Railroad; the rehabilitation of the telephone and telegraph lines. These sweeping plans, calling for the transformation of a wilderness, were merely incidental to Alfred's prime object of transforming the slatternly fishing village of Port St. Joe into an industrial community which should serve as a model. Here duPont meant to realize the highest social aspirations of $\mathrm{Mr}$. Roosevelt-do it all himself and do it better, according to his view. He meant to bring submarginal lands, to use a New Deal expression, into profitable use. He intended that they should care for the ill-housed, ill-clothed and ill-fed-or, rather, enable such people to care for themselves and pay taxes rather than live off them. In St. Joe a class of people who needed it most should enjoy the more 
abundant life, finding work, play, health, security-and happiness, if individually constituted to compound it of those elements. Actually, Alfred duPont knew human psychology too well to accept the glib theory that material comfort ipso facto is the harbinger of contentment, though the heavy chances are it contributes greatly.

W. T. Edwards would enter Mr. duPont's office to get a decision on some matter touching the harbor, the railroad or the still unsettled project of manufacturing paper of Southern woods. $\mathrm{He}$ would find his employer, oblivious to all other earthly concerns, making and remaking sketches of his town-to-be. Under duPont's pencil would materialize representations of tree-lined avenues, modern homes for working people, schools, a playground, a beautiful park.

"Bill, for Pete's sake," Ed Ball would protest, "quit talking to Mr. duPont about St. Joe. He'll spend all his money on the town and there'll be nothing left to start a paper mill for these well-kept people to work in."10

Nevertheless, the philosopher had not lost sight of the fact that the projected paper mill, which was to support this ideal community, must be a money-making proposition. Otherwise everything would fall to the ground. Private business for private profit was the foundation stone of his socio-economic theory.

When the harbor and other improvements were begun, Mr. duPont had not decided what kind of a paper mill to build. Despite setbacks, Doctor Herty was still hard at his laboratory labors to overcome the technical obstructions in the way of perfecting a Southern newsprint which could compete with the Northern and the imported articles. As late as September I, 1934, duPont wrote: "You might be interested to know that we are seriously considering starting a newsprint mill in Florida. We believe we have practically solved the manufacture of the necessary cellulose from Southern pine, of which there is almost an unlimited quantity in the state, reproducing itself ... [in] from seven to ten years.... The first mill will cost Five Million Dollars."

A month later to the same correspondent: "The newsprint business does not look very promising at the present time.... We are now looking into the kraft situation." ${ }^{12}$ 
The fact is that Mr. duPont had been looking into the kraft situation for years, these studies paralleling those on newsprint. $\mathrm{Kraft}$ is a Swedish word for strength. In the paper business it is the trade name for a tough, heavy product used for wrapping paper, bags, cardboard boxes and the like. Kraft paper had long been made in the South on a small scale. In the Twenties scientific improvements had brought about a definite southward trek of the industry - the Southern Kraft Corporation, a subsidiary of the great International Paper Company, establishing mills in Louisiana and in Mississippi. Mr. duPont would have preferred to make newsprint because he loved to pioneer and because of the social significance of giving the South a new industry. But when at length he came to the conclusion that the time was not ripe to invest \$5,000,000 in an attempt to produce newsprint in the South, he switched to kraft with what must have appeared to outside observers as startling abruptness.

This called for a broad change of plans. Technically the manufacture of kraft paper was an undertaking quite distinct from the fabrication of newsprint. Marketing the product would have to be approached in a different way. A southern newsprint manufacturer would have had no Southern competition. A Southern kraft maker would have plenty of it. This factor bore on Alfred's scheme for an ideal industrial community, owing to the differential between Northern and Southern wages. A sine qua non in Mr. duPont's calculations was that his mill should pay wages equal to the highest in the industry-which meant paying the Northern scale.

Furthermore, Alfred intended that his mill should oppose a social theory which has some intelligent adherents. This hypothesis disposes that the millions of poverty-ridden people in America are so because, by and large, that is their natural condition, enforced by their individual capacities. It is held that they would be equally poor anywhere else because they are incompetent to advance themselves. Proponents of this line of reasoning point out that the able ones rise above their surroundings and get away. This theory Alfred I. duPont did not accept. Naturally the very exceptional individuals triumphed above adverse environments in the South as 
elsewhere-Abraham Lincoln and Andrew Johnson being monumental examples. But below the Lincolns and the thousands of others who each year in lesser degree rose above their beginnings were millions without ability or initiative to make their own opportunities, but with the capacity to use opportunity when it was placed within their reach. So duPont looked at it.

Alfred stipulated that the personnel for his great mill should be drawn from the countryside-largely populated by the race of primitives one meets in Mrs. Marjorie Kinnan Rawlings' engrossing novels of Florida cracker life. True, at first these would be fit only for common labor. It would be necessary to import all manner of technicians. What could a barefoot cracker fisherman who had never had to do with a more complicated piece of machinery than a boat anchor be expected to make of a Trimbley consistency regulator, or a sulphate digester equipped with a recording automatic gas-off controller of the reset type? What girl who could barely scrawl her name could take dictation, or operate a comptometer or a switchboard when she had never heard of one? But duPont believed the brighter of the girls could learn these things at a business college in Tallahassee, and that the brighter boys would come up through an apprentice system modeled after that in vogue in the Brandywine yards where Alfred had learned the powderman's trade.

With more cash money in their pay envelopes each month than perhaps their entire households had seen in a year theretofore, Mr. duPont believed they would learn to make sensible use of that capital, normal human frailties taken into the reckoning. On the whole he thought it would increase their sense of self-respect and dignity. Given bathrooms, a library, schools and facilities for wholesome recreation, he believed they would learn to use them. Exposed to permanent waves, nail polish and silk stockings, the girls would soon know what to do. To keep abreast the cultural tide, young men would acquire inexpensive motorcars, store clothes and go to wearing neckties after work.

With this vision before him, Alfred pushed plans for his mill and for his town, emphatically vetoing the suggestion that the latter be renamed DuPont. Accommodations for a thousand in- 


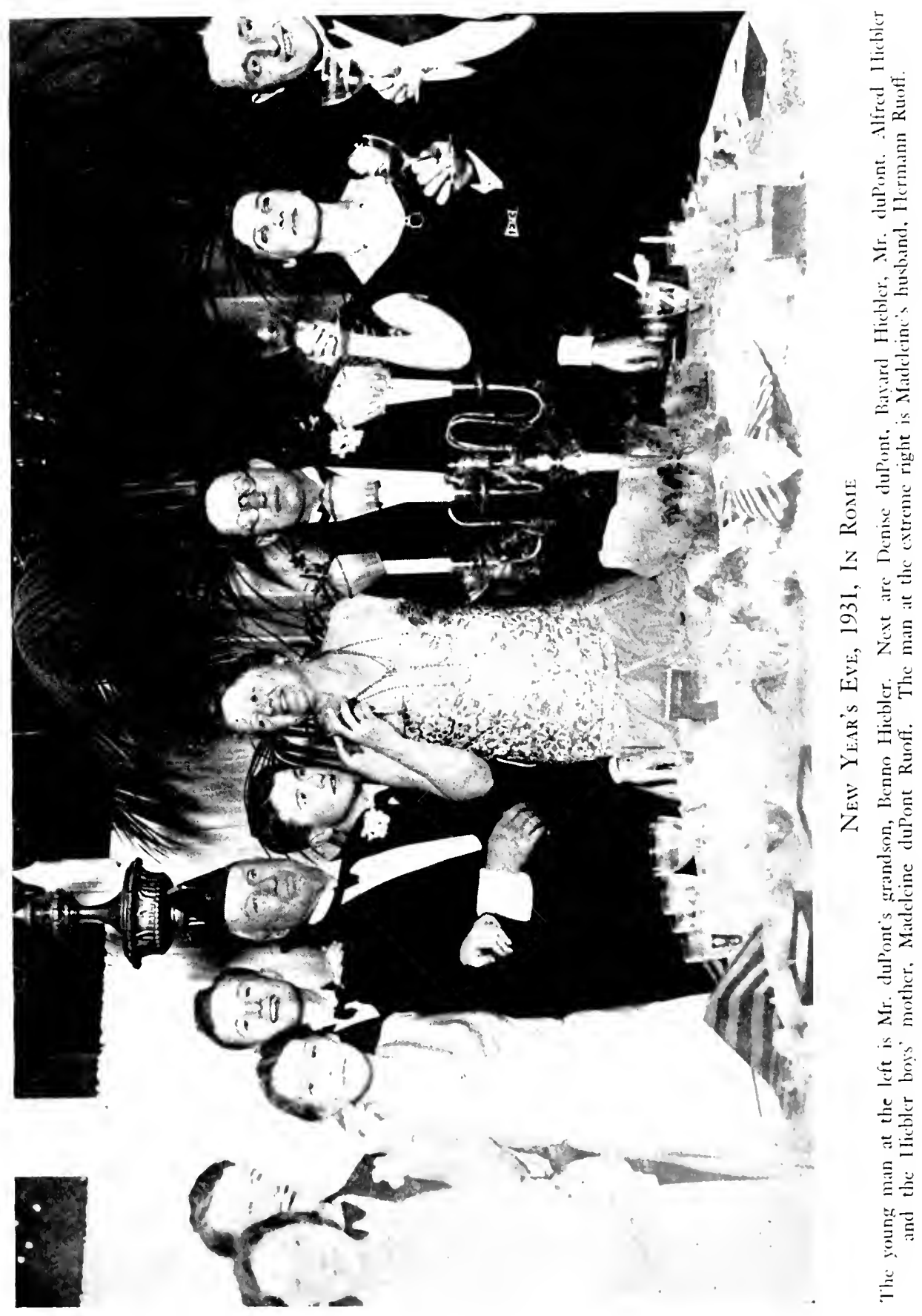


habitants must be ready by the time the mill opened. And the paper mill would be only a beginning. With such resources and facilities, such a community in which to live, other industries would gravitate to Port St. Joe. Were not outside capitalists already putting out feelers for a sawmill site ? $^{13}$

It was characteristic of Alfred I. duPont's creative nature that, once his mind was made up, he should push a project toward conclusion with all his enormous energy and skill. In the case of St. Joe still another factor intervened. In the fall of 1934 when he made the sudden switch from newsprint to kraft, Mr. duPont was ill. A few weeks later he was preparing for death. The arrangements were made with complete absence of brooding or solemnity-indeed, with flashes of casual humor one might expect to attend plans for a cruise in the familiar waters off Nantucket, rather than those of the Styx. A part of the preparation was to push St. Joe.

No illusion of personal indispensability prompted this. Mrs. duPont and Edward Ball were aware of what Alfred wanted to do. Mrs. duPont was a good businesswoman. In Wilmington and in Jacksonville she had offices which adjoined those of her husband. Through the years, dating from the Nemours Trading Corporation and income tax involvements Alfred had constantly consulted her. During the market boom of the Twenties Mrs. duPont had handled her own account, buying and selling much more heavily than her conservative husband. And, unlike him, she was caught in the 1929 crash to the extent of about $\$ 200,000$. Alfred offered to bail her out, as he was bailing others. Mrs. duPont was able to meet her own losses, however, after which she was still $\$ 1,000,000$ to the good. ${ }^{14}$

During the depression years Jessie Ball duPont more and more had assumed a role of responsibility in the management of her husband's affairs, lately taking a place on the Board of Directors of the Jacksonville bank. In her hands and in Ed Ball's, Alfred knew his dream of St. Joe to be safe. As a matter of private satis- 
faction merely, he, himself, wished to see it actually in being.

For more than ten years Mr. duPont had enjoyed robust health, suffering from nothing more serious than colds. Apropos of his tough physique he had composed an imaginary newspaper headline:

\author{
“MR. DU PONT'S YACHT BLOWN UP \\ Mr. duPont Lands Two or Three Miles Off \\ in a Tree \\ WILL BUILD NEW YACHT AT ONCE"15
}

Boasting to one of the German grandsons that he had "always been hard to kill," he continued: "A good many years ago I was experimenting with a new powder machine. They used to stand around in the offing with buckets to pick up the pieces."

Nevertheless, following the family's arrival at Epping Forest after the Christmas holidays of 1933-as usual, spent at Nemours-Alfred had come down with a cold which presented baffling involvements. But in February he wrote his sister: "I am recovering quite nicely from whatever it was that hit me. The Doc don't know, and I don't know, two negatives making an affirmative." "Downstairs again," he informed his brother Maurice, three days later, "and doing what the local paper described Mr. Rockefeller did on his arrival at Ormond-'puttering' about the place."18

In an effort to get at the seat of the trouble a number of teeth were extracted in April. Roots broke, making the operation painful. This Alfred waved aside, saying those roots were typical DuPont specimens-therefore stubborn. In May, as his seventieth birthday drew nigh, the patient seemed better all round. On the day before that event he wrote in high spirits to Ellen LaMotte: "Today I can get my new line of replacements for the upper side of my face, which has $25 \%$ of the original plantings remaining, leaving $75 \%$ to be furnished by Sears-Roebuck. As five have went from the lower side of my mug that leaves $70 \%$ of the original plantings there."19

At Nemours in June, Alfred did not feel like journeying to Troy, 
New York, to attend Denise's graduation from school-a sure indication that he was still below par. But he was not too ill to patrol the grounds of his estate and plan improvements. Two more lakes were sketched out, which would mean revising the water supply. The undertaking that lay closest to his heart, however, was a bell tower, or carillon, to be erected as a memorial to his parents, for "all lovers of music" to enjoy. ${ }^{20}$ With his architect son he fell to work on the drawings.

Although he remained consistently cheerful it was clear to those about him that Mr. duPont's health had never recovered from the stamina-sapping complications attending the cold of the winter before. The mechanics about Nemours noted a revealing sign in the way "the boss" handled tools. His hands were clumsy.

An uninterrupted correspondence had been maintained through the years with Doctor Baker P. Lee, who had joined Jessie Ball and Alfred duPont in marriage in I921. Time and again Alfred's letters alluded gratefully to "the day you made us one," as if the clergyman were somehow responsible for the happiness Alfred had found with Jessie. One such communication, dated July 25, 1934, represented duPont at his best as an intimate correspondent--simply thinking aloud and letting Mary Brereton take it down. Beginning with an account of what the members of the household were doing, he switched to the dogs, whose activities were always good for a sprightly paragraph. Then, abruptly, the subject changed again:

"My philosophy of life is exceedingly simple: be fair to every one; do as much good as you can; be honest with yourself, which means, honest with everybody; and, to put it mildly, be most disagreeable to any one who seeks to do you injury. This last, I know, is contrary to Biblical admonition, but it is the only practical way to get along in this world. Competition is so bitter, and those who succeed have such a multitude of enemies that if one would keep one's head above water, one must struggle, and use such weapons as our Creator has provided.

"As for my philosophy for the future, it is equally simple. One's proper discharge of one's duties and obligations in this world will insure proper recognition in the next-about which, of course, I 
know nothing. Everything that is given us, upon which to base conclusions, while in this world, will not permit of intelligent conclusions one way or another. That there must be a Divine Providence, as Creator of the Universe, one can hardly deny. Of this fact even a small lightning bug that alighted on my hand the other evening, while sitting in the loggia at Nemours, would convince one. As to the question of what there is for the soul in the next world, no human being has been able to evolve any conclusion that would convince any one, except those who live on faith. My definition of Faith is: belief without knowledge-a poor foundation upon which to predicate anything resembling a certainty. It is impossible to conceive of a future life of happiness without those with whom we have lived in this world-Mummy included (!) -and as everything pertaining to personality perishes at the end of this life, I am afraid Saint Peter will be busy reintroducing us in the next world.

"With my affectionate regards to you and your dear wife, as ever, your friend. ..."

Summer waned, the gay young folk surrounding Denise went their ways and that winsome girl departed for Sweet Briar College, in Virginia.

"Nemours is quite empty at the present time," Alfred notified his brother-in-law, Thomas Ball, "excepting for the quintuplets-me, Jess and the three pups. The main entrance gate is chained and the outside marked 'closed.' We are having a nice time, resting and playing backgammon in the evening, and walking about the property taking pictures in the daytime."

Plans for the carillon-2 ro feet high, with thirty-one bells-were finished and excavations begun. The interior mechanism as well as the outward form of the tower were largely of Mr. duPont's designing.

Early in January, 1935, at Epping Forest, Mr. duPont reread his will and, deciding to draw a new one, called his attorneys. He was then worth between $\$ 55,000,000$ and $\$ 65,000$,000, from which, on 
his death, Federal and State inheritance taxes would subtract upward of $\$ 30,000,000$. The preponderance of the remainder Alfred intended to leave to charity, setting up a perpetual trust for that purpose under the title of the Nemours Foundation. This was duly set forth in the text of the original will, the pages of which $\mathrm{Mr}$. duPont turned before him.

"'The Nemours Foundation' shall be created and maintained as a memorial to my great, great grandfather, Pierre Samuel duPont de Nemours, and to my father, Eleuthère Irénée duPont de Nemours ... for the purpose of maintaining ... a charitable institution for the care and treatment of crippled children, but not incurables, or the care of old men or old women, and particularly old couples, first consideration, in each instance, being given to beneficiaries who are residents of Delaware."

The site of the institution should be the estate of Nemours, where a hospital and other buildings were to be erected. The existing mansion was not to be turned into a hospital or domicile for the beneficiaries, however. "The rooms of the said Mansion shall be used for the reception of visitors and their entertainment; also for executive and administrative purposes, should my Trustees so decide, but mainly for the purpose of providing a library and exhibiting to the public interesting and valuable literature, works of art and articles of historic and artistic interest for the advancement of education."

Provision was made to insure the institution against financial embarrassment in the future. In case Mrs. duPont should-as proved to be the case-desire to erect a hospital during her lifetime, only $\$ 1,000,000$ might be taken from the principal of the Foundation's funds for that purpose. Moreover, of necessity, Mrs. duPont would have to support the institution thus built from her own money during her lifetime. Aside from the initial million, all other expenditures must come from the income earned by the principal. Under normal expectations of competent management this would be ample, in time, to turn the entire 300 acres into a vast institution for the care of the afflicted young or the needy aged. In fact surplus funds might be available. In this case Mr. duPont 
stipulated that the trustees of the Foundation should have the power to contribute to other charitable institutions caring for children or for old people. ${ }^{22}$

The concept of the Nemours Foundation embodied a philosophy of wealth held by Alfred I. duPont since he was a young man. As soon as his escape from the financial troubles of the early Twenties had insured that he would have a fortune to leave, he had begun discussing with his wife ways and means for passing on the bulk of it for charitable uses. Together they had worked out the idea for the Foundation.

The will which in January, 1935, Mr. duPont intended to recast was dated November 19, 1932, and amended by a codicil dated March 4, 1933, in the midst of the banking panic which had ushered in Mr. Roosevelt's regime. Since then conditions had improved, enhancing by millions of dollars the value of Mr. duPont's holdings. In light of this, duPont thought of making still more favorable provision for his Foundation, as well as adding a few small bequests and effecting some changes in the administrative machinery which should handle his estate. Instead of adding a second amendatory codicil, Alfred thought of taking. the simpler course of dictating a new will from scratch.

He changed his mind, however, when an attorney drew his attention to a recently-enacted Florida law rendering charitable bequests invalid in certain circumstances unless the will making them were executed more than six months prior to the death of the testator. In anticipation that he might not be alive in six months, Mr. duPont merely added a second codicil, dated January 15, 1935. These facts Mr. duPont set forth in the text of the codicil itself, adding: "It has been my firm conviction throughout life that it is the duty of every one in the world to do what is within his power to alleviate human suffering. .... It is, therefore, natural that I should desire after having made provision for the immediate members of my family and others whom I have seen fit to remember, that the remaining portion of my estate should be utilized for charitable needs." 23

This completed the last will and testament under which Alfred I. duPont disposed of his estate, in the manner following: Jessie Ball duPont should receive Epping Forest in fee simple, 
the furnishings of Nemours and all other personal possessions, and a life annuity of $\$ 200,000$ which would constitute a first claim on the earnings of the estate. After other bequests and annuities were discharged Mrs. duPont should receive the balance of the earnings of the estate during her lifetime.

The four children by Mr. duPont's first marriage-Madeleine, Bessie, Alfred Victor and Victorine-should each receive 5,000 shares of Almours Securities common stock. These bequests were worth approximately $\$ 750,000$ apiece.

No provision was made for Mr. duPont's stepdaughter, Aliciathen Mrs. Victor Llewellyn, living in England-because "she is amply provided for under the Will of her mother."

No provision was made for Mr. duPont's sister, Marguerite, or for his brother, Maurice, as they had been taken care of by a trust set up by Alfred in 1929. Under this instrument Marguerite received a life income of $\$ 18,700$ a year; Maurice, $\$ 20,400$; and Margery, the wife of Maurice, $\$ 8,160$. This instrument also provided annuities for Maurice duPont's children and numerous other relations and friends, including $\$ 12,75^{\circ}$ for Cazenove G. Lee, a nephew. From this trust Cazenove Lee's three children, Maurice Lee's three, Bessie Huidekoper's four and Victorine Dent's one were each to receive $\$ 100,000$ on attaining the age of thirty.

Denise duPont also was to receive $\$ 100,000$ from the 1929 trust at thirty. ${ }^{24}$ Meantime, under the will, she should receive an annuity beginning at $\$ 5,000$ and increasing to $\$ 30,000$ as she grew older.

Mrs. duPont's sisters, Isabel Baker and Elsie Bowley, and her brother, Thomas Ball, each were to receive Almours Securities stock worth about $\$ 150,000$. Edward Ball was left Almours shares worth $\$ 750,000$, which was to include his fees as an executor of the estate. The other executors, Jessie Ball duPont and Reginald S. Huidekoper, each were to be paid, over a period of years, $\$ 100,000$ for their services.

Maurice Lee, a nephew, was to receive a life annuity of $\$ 15,000$. His three children and Cazenove Lee's three-of the old "pirate crew"-were to receive $\$ 5000$ annuities after they were twenty-five years old.

Twenty-one additional annuities, ranging from $\$ 240$ to $\$ 2400$, 
were to go to old friends, employees and political and business associates.

One thousand dollars was to be given to each personal business or domestic employee who had been with Mr. duPont for a year or more.

Thus did Alfred I. duPont give effect to his creed concerning a rich man's responsibility to society. Always a disbeliever in great inherited fortunes, of an estate of, say, $\$ 60,000,000$, he devised outright gifts to individuals not exceeding $\$ 7,000,000$. After tax deductions, all the rest would go to the Nemours Foundation. As beneficiaries of the annuities should die, the Foundation's fund would grow and perpetuate itself, ultimately curing ailing children or caring for destitute old folk then unborn.

The amended will signed, witnessed and restored to his capacious strongbox, Alfred duPont turned to the business of enjoying what he believed would be his last little while on earth-his spirit as buoyant as ever, his mind as keen, his zeal for life as spontaneous and varied, his consideration for others as tender. With so many stimulating interests what time was there for melancholy?

Cazenove Lee's eighteen-year-old boy, Vandegrift-an ex-pirate -was in the throes of selecting a college. The ultimate outcome of this labor, observed Great-Uncle Alfred, would "depend more on the pupil than on the College. A young man can learn at any College if he really wishes to, but no College ever made a boy without his own contributive efforts." 25

"By the way, have you heard of the new explosive which the papers refer to as nitro ammonia and state to be absolutely fool proof, etc.?" he asked Maurice Lee. "Do you know anything about its costs and to what extent it is supposed to eventually replace ordinary explosives?"26

Could that be an inquiry from a man preparing for death? Or this:

"Your description of the cellulose sponge is most interesting and I am awaiting the arrival of the sample. It's been many a day 
since I washed my face with a sponge. I always considered it a dirty affair, having to be aired constantly to keep from decay. Sponges are impracticable on automobiles, due to the content of cilia which scratches the highly polished surface. If the cellulose sponge turns out practical there will be quite a demand for this product."

He was studying the engines in his river boat Gadfly and recording data on fuel consumption at different speeds. From one short trip he returned running a temperature and unable to sleep well. Pronouncing it "nervous exhaustion," a physician ordered Alfred to bed. About that time Ellen LaMotte, who in youth had been a trained nurse, arrived at Epping Forest. She diagnosed her Cousin Alfred's illness as influenza, and her treatment shortly had him up and about. $^{28}$

In March Jessie and he gave a family party at the Pancoast Hotel in Miami Beach, present being Bessie and Reginald Huidekoper, Victorine and Elbert Dent, Alfred V. and Marcella, Geraldine (Mrs. Maurice) Lee, Elsie Ball Bowley and Mrs. William A. Glasgow. Newspapers interviewed and photographed the host. The published pictures showed that he had aged since his visit the year before. His face was gaunt, emphasizing its strong and striking points: the decisive chin, firm mouth, majestic DuPont nose. Notwithstanding fairly heavy criticism of latter-day New Deal policies, on public problems Mr. duPont adopted what the Miami Herald called "a moderately liberal attitude." He praised Roosevelt for standing against political amendments to the current relief-appropriation bill. Speaking of Florida he urged legislation to encourage small farmers. ${ }^{29}$

Less serious subjects, on the whole, occupied the family party, among which Alfred led the funmaking and drew from parents the latest reports on their children.

One afternoon Elsie Bowley and Alfred were alone for a few moments. Mrs. Bowley said she was going to Europe that summer.

"Take Jessie with you," suggested Alfred.

"Why don't you take her?" asked Elsie Bowley in surprise.

"I shan't be here," said Alfred. ${ }^{30}$ 
Mr. duPont left Miami Beach a few days before the party was over, giving the pressure of business as his excuse. "We are sorely beset by people searching for mill sites and other factory locations, as their attention has recently been called to the desirability of locating many manufacturing interests in the Southern States."

This was an allusion to the fruit of Alfred's reconstruction of Port St. Joe. He pushed that work with all his strength, spending more hours at his desk in Jacksonville than a man in his condition should have spent. The business news was good news. Bank statements for the first quarter of 1935 continued their story of healthy growth. Deposits in the duPont group stood at $\$ 40,542,000$, a new high-water mark. This exceeded by $\$ 15,700,000$ the deposits in the group of banks dominated by the Barnett National of Jacksonville, and by $\$ 12,700,000$ those in the group controlled by Ed Rompf's First National of Miami. It was within $\$ 6,500,000$ of the deposits in Edward Wood Lane's Atlantic National chain, which before the coming of duPont to Florida had been without a real rival. In the creation of this vital financial force, Alfred duPont had studiously effaced himself. Finding able men like Dyal, Avent and Usina, he had stimulated their initiative and enabled them to establish their own prestige, giving the banks a solid foundation for the future.

One day Alfred would confess that "I have been driving myself like a steam locomotive for seventy years" and promise to take it easier. ${ }^{32}$ Two days later he would be at his office, calling on the last reserves of his diminishing energy. "The funniest part of my break-down, if so it might be called, is that no one seems to know what caused it." ${ }^{\prime 33}$ The doctors preached rest, rest. What did they know? How could a man rest with St. Joe to finish and the courses of a thousand lives to change? What was one life, already nearly seventy-one years gone, by contrast with a work like that?

After all, the powder business had been a second thought with the DuPont pioneers in America. Sickened of Old World injustices, Pierre Samuel duPont de Nemours had come to the New in hope of establishing in western Virginia, after the Jeffersonian 
ideal, a society where the plain man could maintain his self-respect. His dream of Pontiana and his great-great-grandson's of Port St. Joe had their points in common.

On April io Mrs. duPont enticed her husband from his labors for a two-day trip in the Gadfly up the St. Johns to Sanford. Secretary of War and Mrs. Dern and Ellen LaMotte, house guests at Epping Forest, were along. "View of St. Johns River at its best," Alfred wrote to Geraldine Lee, "that is, complete with alligators, turtles and snakes." The party returned overland, via Silver Springs, where Mrs. duPont took her guests for a ride in a sightseeing boat. "I sat on a bench," continued Alfred, "consuming one bottle of Coca-Cola and a five-cent plug of Baby Ruth while interviewed by local satellites, politicians and reporters." ${ }^{34}$

Returning home he found Yip quite sick. Putting his hand to the dog's chest he pronounced the heart action weak and asked Dolan, the chauffeur, to fetch a flask of brandy. He got Yip to swallow a sip. "Yip, we're both just a couple of has-beens. Neither of us good for long." And turning to the chauffeur: "You know, Dolan, a dog at ten and a man at seventy are about of an age." 35

Reluctantly Alfred consented to Yip's removal to an animal hospital. To Ellen LaMotte he dictated two typewritten pages about the dog's ailments. "I think it a mistake to leave him in the hospital all by himself, when he has been used to so much company and so much fondling." Concerning himself he wrote four lines. "Yes, the people here are nice and genuine. That's one reason why I like to stay here as long as possible. There are others, also, about which you know nothing."

On April I $_{7}$ Francis I. duPont dropped in for a short visit. This gentle soul, having made his peace with Pierre duPont, was anxious to expand the area of reconciliation, as was Pierre. Francis I.'s brilliant son, Emile, whom Alfred had induced Maurice Lee to give a chance in the Rayon works, was demonstrating an inheritance of scientific talents along with a capacity for administration. Looked upon as one of the outstanding family "hopes" for the coming generation, he was rising rapidly in the company. The father, naturally, was proud and grateful. In one of his talks with Pierre, Francis had worked around to the subject of Alfred, sug- 
gesting that he be made a director. Offering a number of reasons, Francis ended with the statement that it would make "for better feeling in the family." "That's an excellent reason, too," observed Pierre, nodding his head. Francis also found Lammot, who had botched the job once before, cordial to the idea. ${ }^{37}$

Francis stopped off at Jacksonville with the idea of broaching the matter to Alfred. Finding his cousin so altered in health, he spoke to Mrs. duPont instead.

"Do you think A. I. would consent to going on the Board?"

"Any offer will have to come from them," she replied. "A. I. will never hear of it from me." 38

Francis did not pursue the subject further.

Yip improved and was brought home. $\mathrm{He}$ and the master seemed to gain strength together, though it was difficult to be sure about the master because of his persistent cheerfulness whether well or ill. The family took it as a good sign, though, when he consented to go to Richmond to attend the wedding of Francis I.'s third son, Alfred, which was to be on May 4. Again, he spoke of a summer vacation in California.

On Wednesday, April 24, Mr. duPont put in a fairly heavy day at the office. That evening he was very weary but insisted on helping two plumbers to install a water softener. The next day he was quite ill. His regular physician, Doctor Herman H. Harris, being sick, Mrs. duPont called Doctor William W. Kirk and Doctor Stanley Irwin. They pronounced the patient's condition grave, but suggested that, to avoid excitement, distant members of his family should not be called. Doctor William D. Stroud, a heart specialist, of Philadelphia, was summoned.

Friday Mr. duPont was a little better. Doctor Stroud and Alfred Victor duPont arrived by plane. By physicians' orders Mr. duPont was not informed of his son's coming. The improvement continued. The doctors said every hour bettered the chances of recovery.

On Saturday Mr. duPont jested with the nurses and insisted on talking politics with Ed Ball. The Legislature was considering the abolition of the toll from Jacksonville's only bridge across the St. Johns. Alfred told Ed to work against this. "We need more 
bridges and the people who use them should pay for them." An early morning fog had cleared and the sun came out brightening the fine water view, revealed from the windows of the room in which the patient lay. And he could see the Stars and Stripes on the staff on his lawn. At sunset the ceremony of lowering the colors was performed, though the firing of the evening gun was omitted. Alfred smiled at this pampering; he could not hear the cannon. In all, the patient's condition seemed so favorable that Doctor Stroud returned to Philadelphia.

Sunday dawned cool and cloudy. In the afternoon a bleak, drizzling rain began. But the patient was all good cheer. He called for the morning papers and read them, including the funnies, with his wife. He twitted one of his nurses, a pretty Catholic girl, about skipping church, and got into quite a Bible discussion in which he astonished the young woman with his knowledge of the Roman ritual. Mrs. duPont, who had scarcely left the sickroom, prepared her husband's lunch. He ate well.

The household breathed easier. At six in the evening Doctor Irwin left, and, for the first time since the attack, there was not a physician in the house.

"Mr. duPont is out of the woods," said Irwin. "I am really confident."

When the time came for the patient's evening meal, Mrs. duPont entered the sickroom in a dinner dress which her husband had always liked. The attention delighted him and stimulated his belief in his recovery. The two chatted while Alfred ate.

A little after seven Mrs. duPont came downstairs to dine with the family: her sister Belle and husband N. Addison Baker; Mrs. William T. Edwards, who had been a schoolmate of Mrs. duPont; and Alfred V.

Before the meal was over a servant signed to Mrs. duPont and she left the table. Not until later, when Doctors Irwin and Kirk returned, did the others know that Mr. duPont's condition was critical. A second attack had come at eight o'clock. Catching sight of an oxygen tent which was wheeled in, Alfred murmured: "So, it's come to this. Too late; too late." Turning to his wife he said: "It's no use, Jessie; it's no use." At ten he lost consciousness. 
Of the family only Mrs. duPont was permitted by her husband's side. The others, with the household servants, formed a sorrowing and apprehensive company in the room adjoining. Occasionally a nurse brought them tidings.

Toward eleven o'clock Alfred opened his eyes. He was trying to speak. At length words came. "Thank you, doctors. Thank you, nurses. I'll be all right in a few days."

He did not speak again and death came at twenty-two minutes past midnight, Monday, April 29, 1935.

A life was ended, its work not. ${ }^{39}$ 
NOTES 



\section{CHAPTER I}

${ }^{1}$ George H. Kerr, DuPont Romance (1939), 64. The incident also has been described to the writer by members of the DuPont family.

2[Francis G. duPont], "History of Explosions at Brandywine Mills Compiled from Records by Francis G. duPont and Also from His Own Experiences." This is a manuscript, and includes explosions from 1815 to 1902. Several typed copies are owned by members of the family. The one used by the writer was kindly loaned by Francis I. duPont, a son of the compiler. The account of Alexis duPont's death appears on pp. 14-16.

${ }^{3}$ Thomas Jefferson to T. M. Randolph, Jan. 17, 1899. Dumas Malone, Correspondence of Thomas Jefferson and Pierre Samuel duPont de Nemours.

${ }^{4}$ John K. Winkler, The DuPont Dymasty (1935), 13-44; Kerr, 10-28.

${ }^{5} \mathrm{~S}$. Francis Mathewson to the writer.

${ }^{6}$ From various family sources, particularly conversations with Mrs. Jessie Ball duPont, widow of Alfred I.

${ }^{7}$ Mrs. J. B. duPont to the writer. The story of the orphans' defiance is quite a family legend and perhaps has grown as legends do. Mrs. duPont gives her late husband's recollection of the incident.

${ }^{8}$ Will of Eleuthère Irénée duPont, filed Nov. 8, 1877, Will Record II, 517 et. seq., New Castle County Court House, Wilmington.

${ }^{9}$ Statement of appraisers of estate, ibid.

\section{CHAPTER II}

${ }^{1}$ S. F. Mathewson, Albert Buchanan, John W. Macklem, John ("Matchie") McMahon and Mrs. Victor duPont, Sr., to the writer.

${ }^{2} \mathrm{~S}$. F. Mathewson and Albert Buchanan to the writer.

${ }^{3}$ Letters of Edward H. Farrar, W. H. Proctor, J. A. Seymour and John P. Craney, who were Mr. duPont's schoolmates, to Mrs. Jessie Ball duPont; Mrs. J. B. duPont to the writer from her husband's reminiscences; records of Phillips Academy, Andover, Mass.

${ }^{4}$ S. F. Mathewson, Albert Buchanan and John McMahon to the writer.

${ }^{5}$ Louisville (Kentucky) Courier-Journal, May 18, 19 and 20, 1893; Louisville Commercial, May 17 and 18, 1893.

${ }^{6} \mathrm{~S}$. F. Mathewson, Albert Buchanan, Mrs. Bessie Gardner duPont and Victor duPont to the writer.

\section{CHAPTER III}

1John William Macklem, "Old Black Powder Days," The DuPont Magazine, August-September, 1927, and January, 1928; also Macklem and S. F. Mathewson to the writer. Mr. Macklem was the clerks' apprentice in the office. 
${ }^{2} \mathrm{~S}$. F. Mathewson to the writer.

${ }^{3}$ Reconstruction of the powdermen's community circa 1880 derived from contemporary pay roll and other records of the DuPont Company, DuPont Museum, Wilmington; F. G. duPont manuscript; conversations with Francis I. duPont, and numerous old residents such as S. F. Mathewson, J. W. Macklem, Albert Buchanan, Elizabeth Dorman, James M. Smyth, John Thompson and Pierre H. Ferraro.

${ }^{4}$ F. G. duPont Manuscript, passim.

${ }^{5}$ Elizabeth Dorman and P. H. Ferraro to the writer.

${ }^{6}$ Mrs. J. B. duPont to the writer, repeating reminiscences of her late husband and of his sister, Marguerite.

'[Charles Wertenbaker], "DuPont," Fortune magazine, November, $1934,67$.

${ }^{8}$ Mrs. J. B. duPont to the writer, repeating reminiscences of Maurice duPont and of his sister Marguerite.

${ }^{9} \mathrm{~J}$. C. MacKinnan, Registrar of Massachusetts Institute of Technology, to the writer.

10 William M. Taylor, Indianapolis, Ind., to the writer.

${ }^{11}$ R. F. Dibble, Jobn L. Sullivan (1925).

${ }^{12}$ Mrs. J. B. duPont to the writer.

${ }^{13}$ Winkler, 128-29; Arthur P. VanGelder and Hugo Schlatter, History of the Explosive Industry in America (1927), 405, 561-70.

${ }^{14}$ Mrs. J. B. duPont and Charles M. Hanby to the writer.

${ }^{15}$ F. G. duPont Manuscript, appendix.

${ }^{16} \mathrm{~S}$. F. Mathewson to the writer.

\section{CHAPTER IV}

${ }^{1}$ Pay roll, October, 1884, DuPont Museum, Wilmington.

${ }^{2}$ Albert Buchanan and James M. Smyth to the writer who is also indebted to Francis I. duPont and to Victor duPont for assistance in reconstructing working conditions of the time in the Brandywine yards.

${ }^{3}$ Pay rolls, 1884 , DuPont Museum, Wilmington.

${ }^{4}$ Albert Buchanan, J. M. Smyth, F. I. duPont and Victor duPont to the writer; pay roll, July, 1886, DuPont Museum.

5The original ledger, covering the period from Nov. 12, 1884, to Sept. 1, 1885 , loaned to the writer by S. F. Mathewson.

'S. F. Mathewson to the writer; George B. Bryan, Edison, the Man and His Work (1926), Chapter XI, passim.

'S. F. Mathewson to the writer.

'Henry Kane, Eben Jones, S. F. Mathewson, and Albert Buchanan to the writer; Kerr, 116

"J. M. Smyth to the writer.

${ }^{10} \mathrm{Mr}$. and Mrs. Albert Buchanan to the writer.

${ }^{11} \mathrm{~J}$. W. Macklem, loc cit.

${ }^{12}$ Van Gelder and Schlatter, 126-38, 199, 200, 261-64, 294-302.

${ }^{13}$ S. F. Mathewson to the writer.

${ }^{14} \mathrm{~J}$. W. Macklem, loc cit. 
${ }^{15}$ Mrs. Bessic Gardner duPont, Mrs. Victorine duPont Dent, Mrs. J. B. duPont, Cazenove G. Lee, S. F. Mathewson to the writer.

\section{CHAPTER V}

${ }^{1}$ Mrs. B. G. duPont, S. F. Mathewson, J. M. Smyth to the writer; Pay roll, January, 1888, and January, 1889, DuPont Muscum, Wilmington.

${ }^{2}$ A. I. duPont's testimony, U. S. Circuit Court, District of Delaware, United States of America v. E. I. duPont de Nemours E Company, Defendant's Testimony, I, 556-62; Defendant's Exbibits, I, 41-57. F. I. duPont also provided the writer with a few side-lights on Alfred's mission abroad. Mr. duPont's stay at the Belgian monastery provided material for stories for his children and grandchildren. Several have mentioned it to the writer.

${ }^{3}$ B. [essie] G. [ardner] duPont, E. I. duPont de Nemours and Company, a History (1920), 129.

${ }^{4}$ Mrs. J. B. duPont to the writer.

${ }^{5}$ E. I. duPont's testimony, U. S. v. DuPont, Defendant's Record, Testimony, I, 443.

'I lid, I, 575-76.

${ }^{7} \mathrm{~S}$. F. Mathewson to the writer.

${ }^{8}$ F. G. duPont Manuscript, 47-49; F. I. duPont to the writer.

${ }^{9}$ F. G. duPont Manuscript, 50-54; F. I. duPont, S. F. Mathewson and Mrs. J. B. duPont to the writer.

\section{CHAPTER VI}

${ }^{1}$ Chicago Daily News, November 12, 1889. For the record, Margery FitzGerald and Maurice duPont were marricd October 12, 1889, in St. Peter and Paul's Church, Cork, Ireland, by the Reverend Canon Sheean.

${ }^{2}$ Mrs. B. G. duPont, Mrs. Ralph W. Seiss, Stonington, Conn., and an elderly resident of Wilmington, who prefers to remain anonymous, to the writer; Wilmington Evening Journal, December 3, 1892. Maurice duPont himself naturally would have been the best source of material on his marriage and its immediate consequences. Very courteously, however, he asked to be excused from an interview.

${ }^{3}$ Eben Jones, P. S. duPont, S. F. Mathewson, Henry Kane and P. H. Ferraro to the writer.

${ }^{4}$ S. F. Mathewson to the writer.

${ }^{5}$ Wilmington Evening Journal, December 3, 1892; James L. Dashiell to the writer.

${ }^{6}$ Winkler, 139; Mrs. Victor duPont, Sr., to the writer.

${ }^{7}$ Louisville Courier-Journal, May 17, 18, 19, 1893; Louisville Commercial, May 18; Cincinnati Enquirer, May 18, 19, 20; Mrs. Victor duPont, Sr., S. F. Mathewson to the writer.

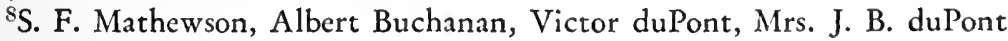
to the writer.

'A. I. duPont's testimony in U. S. v. DuPont, Defendant's Record, 
Testimony, I, 445, shows his state of mind. Mrs. J. B. duPont and P. S. duPont, in conversations with the writer, have added a few points.

\section{CHAPTER VII}

${ }^{1}$ This name is fictitious, and it is the only fictitious name used in this volume. The reason a name is used at all is for the sake of clarity and easier reading. The circumstances involving the man I call "Brown" are given as he related them to me in January, 1940, and I am sure that they are true to the best of my informant's recollection. "Mr. Brown" is in reality an accomplished engineer, now over 70 years old and in poor health. After giving me the facts set forth in the text, he sent a telegram asking me not to use his name. I attribute the desire to the state of his health and to business reasons. $\mathrm{He}$ and $\mathrm{Mr}$. duPont remained warm friends until the latter's death.

${ }^{2}$ George Kennan, "Holding up a State," The Outlook, February 7, 14 and 21,1903 ; Winkler, 285-91.

3 "J. J. Brown" to the writer.

${ }^{4}$ Depositions of Mrs. Marguerite duPont Lee and of Ellen LaMotte, Alfred I. duPont v. Bessie G. duPont, December, 1906, Circuit Court of Seventh Judicial District of South Dakota, Sioux Falls, S. D.

${ }^{5}$ John Thompson to the writer.

${ }^{6}$ Albert Buchanan to the writer.

${ }^{7} \mathrm{~J}$. W. Macklem to the writer.

sWilliam F. Lynch to the writer.

${ }^{9}$ Albert Buchanan to the writer.

${ }^{10} \mathrm{Mrs}$. Bessie Deery Gallagher to the writer.

${ }^{11}$ Elizabeth Dorman and others to the writer.

${ }^{12}$ Mrs. B. D. Gallagher to the writer.

${ }^{13}$ Mrs. Bessie duPont Huidekoper, Mrs. B. D. Gallagher, Elizabeth Dorman and others to the writer.

${ }^{14}$ Mrs. Victor duPont, Sr., and S. F. Mathewson to the writer.

${ }^{15} \mathrm{~J}$. L. Dashiell to the writer.

16 "J. J. Brown" to the writer.

\section{CHAPTER VIII}

${ }^{1}$ Mrs. J. B. duPont to the writer; Van Gelder and Schlatter, 815-16, 830,385 ; B. G. duPont, 152.

2 Mrs. Bessie duPont Huidekoper to the writer.

${ }^{3}$ John Thompson to the writer.

${ }^{4}$ Edward L. Bader to the writer.

${ }^{5}$ William S. Dutton, a manuscript history of the DuPont Company.

${ }^{6}$ Francis I. duPont to the writer.

${ }^{7}$ F. G. duPont Manuscript, 61-64; F. I. duPont and Mrs. Bessie Deery Gallagher to the writer.

${ }^{7}$ Mrs. J. B. duPont to the writer.

${ }^{8}$ F. G. duPont Manuscript, 70-71; F. I. duPont to the writer.

${ }^{9} \mathrm{~S}$. F. Mathewson to the writer. 
${ }^{10}$ Mrs. Rebecca Harding Adams to the writer.

11 lbid.

\section{CHAP'TER IX}

${ }^{1}$ A. I. duPont said that "for many years" before it came in 1902 he had been preparing for a crisis in the affairs of the company. See his testimony, U.S. v. DuPont, Defendant's Record, Testimony, I, 445. Mrs. B. G. duPont, Mrs. J. B. duPont and Victor duPont have supplied me with incidental small details of what was in Alfred's mind at the time.

${ }^{2}$ Winkler, 155-58, gives a short review of Coleman's early career; Encyclopedia of American Biograploy, new series, III, 1-14, gives a highly laudatory and uncritical one. P. S. duPont and other members of the family have also been of assistance to the writer.

${ }^{3}$ Testimony of H. M. Barksdale, op. cit., II, 625.

${ }^{4}$ Testimony of F. I. duPont, ibil., II, 964.

[Charles Wertenbaker], "DuPont," Fortune magazine, November, 1934 , p. 69.

${ }^{6}$ Testimony of A. I. duPont, op. cit., I, 446-47. The detail of the trip to New York was supplied to the writer by Mrs. J. B. duPont.

TTestimony of F. I. duPont, ibid., II, 963-64.

${ }^{8}$ Mrs. J. B. duPont to the writer.

${ }^{9}$ Testimony of A. I. duPont, op. cit., I, 446.

10 [Wertenbaker], 69; testimony of A. I. duPont, op. cit., I, 446; Mrs. J.

B. duPont to the writer.

${ }^{11}$ Testimony of A. I. duPont, ibid.

12 [Wertenbaker], 69, 180.

13 Ibid., 180.

${ }^{14}$ T'estimony of A. I. duPont, op. cit., I, 446.

${ }^{15}$ Testimony of H. M. Barksdale, ibid., II, 625. For purposes of smoothness in reproducing direct quotations from Mr. Barksdale's testimony, I have substituted the first for the third person and the present for the past tense, which he used.

${ }^{16}$ Mrs. Victor duPont, Sr., and Mrs. B. G. duPont to the writer.

${ }^{17}$ Mrs. B. G. duPont to the writer. P. S. duPont has also told the writer what he remembers of his early meetings with Alfred and Coleman.

${ }^{18}$ Testimony of P. S. duPont, op. cit., I, 482.

${ }^{19}$ Winkler, 160.

${ }^{20} \mathrm{P}$. S. duPont to Irénée and to William K. duPont (two letters), Feb. 20, 1902, U.S. v. DuPont, Defendant's Exbibits I, 38-39. The letters, identical in substance, differ somewhat in language. In the interest of compactness excerpts from the two lettcrs are presented as a single communication.

${ }^{21}$ Testimony of P. S. duPont, ibid., Defendant's Testimony, I, 479-80.

\section{CHAPTER X}

${ }^{1}$ Supreme Court of the United States, October Term, 1915, Buckeye Powder Company v. E. I. duPont de Nemours Powder Company, et. al., Testimony of P. S. duPont, I, 47, 48, 53. 
${ }^{2} U$. S. $v$. DuPont, Defendants' Testimony, P. S. duPont, I, 511-14. In this account of the details of the sale of the company Mr. duPont, speaking from memory, used round figures. I have substituted exact figures as shown by the records of the DuPont Company.

${ }^{3}$ This story, in various forms, is a part of the attractive Alfred I. duPont legend treasured by his old workmen. I have heard it from several of them.

${ }^{4}$ P. S. duPont, Victor duPont and others to the writer.

${ }^{5}$ James L. Dashiell, Mrs. Victor duPont, Sr., and others to the writer. ${ }^{6}$ Kerr, $146-47$.

7Winkler, 156, 162-63; J. L. Dashicll and others to the writer.

${ }^{8}$ Mrs. J. B. duPont to the writer.

${ }^{9}$ U.S. v. DuPont, Petitioner's Testimony, R. S. Waddell, I, 211-12. In relating his conversation with Coleman, Mr. Waddell used both the first and third persons. For smoothness I give it all in the first person.

${ }^{10}$ Ibid., F. J. Waddell, I, 257-64.

11Ibid., Petitioner's Brief, I, 72-74; Defendants' Brief, 75-81.

${ }^{12} I$ Ibid., Petitioner's Brief, I, 78-79. The Brief gives seven as the number of companies in the Gunpowder Trade Association not controlled through stock ownership by DuPont. The correct figure number appears to be eight.

${ }^{13}$ Ibid., Defendants' Brief, 82.

${ }^{14}$ Ibid., Pleadings, Answer of E. I. duPont de Nemours Powder Company, P. S. and T. Coleman duPont, 124-26; Defendants' Brief, 82-84; Petitioner's Brief, I, 77-80.

${ }^{15}$ Ibid., Defendants' Brief, 86-87; Petitioner's Brief, II, 287, 288, 328. ${ }^{16}$ Ibid., Petitioner's Brief, II, 330-33.

\section{CHAPTER XI}

${ }^{1}$ This $\$ 8500$ constituted the initial paid-up capital of the following corporations created for the following purposes: Delaware Securities Company, $\$ 2000$, whose securities were used to purchase Laflin \& Rand; Delaware Investment Company, $\$ 2000$, whose securitics were used to purchase Moosic; E. I. duPont de Nemours Powder Company, $\$ 1500$, whose securities were used to purchase minority interests in companies brought in by the Laflin \& Rand deal and to purchase a number of other concerns; E. I. duPont Company, $\$ 1000$, a stopgap operating company, maintained until the E. I. duPont de Nemours Powder Company was ready to assume the burden of operations; California Investment Company, $\$ 1000$, whose securities were used to purchase the Judson Dynamite \& Powder Company; DuPont International Powder Company, $\$ 1000$, whose securities were used to purchase the International Snokeless Powder \& Chemical Company. 2John Moody, Moody's Manual of Corporation Securities, editions of 1906 and 1908.

${ }^{3} U$. S. v. DuPont, Pleadings, Answer of A. I. duPont, 347-48.

${ }^{4}$ This chart appears on a folding sheet in each of the three volumes of the privately printed and circulated album of the DuPont family, the most ambitious project of its kind in America to come to the notice of this 
writer. The work bears the title, DuPont de Nemours. The first volume, of 348 pages, contains as many reproductions of portraits and photographs of the DuPonts in America from 1800 to 1900. It was largely the work of Louisa d'Andrelot duPont Copeland, a sister of Pierre S. duPont. She died in 1926. Then ycars later two additional volumes were issued, depicting the members of the family from 1901 to 1936 . It was copyrighted under the name of W. W. Laird, Jr., a nephew of the late Mrs. Copeland. These volumes contain 710 pages and approximately the same number of portraits, giving some idea of the population of this family.

${ }^{5}$ J. L. Dashiell, S. F. Mathewson and Victor duPont, Jr., to the writer.

${ }^{6}$ Report on black-powder operations compiled by A. I. duPont for the executive committee of the company, August, 1905. A copy loaned the writer by J. L. Dashiell.

${ }^{7}$ E. L. Bader and Albert Buchanan to the writer.

\section{CHAPTER XII}

${ }^{1} \mathrm{M}$. R. Hutchison to the writer.

${ }^{2} \mathrm{~J}$. L. Dashiell to the writer.

${ }^{3}$ Mrs. R. H. Adams to the writer.

${ }^{4}$ A. I. duPont to Jessie Ball, Dec. 3, 1903. Copy from Mrs. J. B. duPont. ${ }^{5} \mathrm{~S}$. F. Mathewson to the writer.

${ }^{6}$ Alfred I. duPont v. Bessie G. duPont, a suit for divorce, depositions of Mrs. Marguerite duPont Lee, Rebecca V. Abbott and T. W. Huidekoper. Circuit Court records, Seventh District of South Dakota, Sioux Falls.

${ }^{7}$ Ibid., depositions of Mrs. M. duP. Lee and T. W. Huidekoper.

${ }^{8}$ Ibid., deposition of R. V. Abbott.

${ }^{9}$ Statement of Mrs. Madeleine duPont Ruoff, dated September 2, 1939, in response to inquiries propounded by the writer.

${ }^{10}$ A. I. duPont v. B. G. duPont, op. cit., depositions of R. V. Abbott and Mrs. M. duP. Lee.

${ }^{11}$ A trust agreement, dated September 26, 1905, in the personal files of Alfred I. duPont, which henceforth in these notes will be designated as A. I. duPont Papers.

1"Divorce suit record. Depositions of Mrs. Marguerite duP. Lee and I. M. Williamson.

${ }^{13}$ Related to the writer by the superintendent in question.

${ }^{14}$ Ibid.

${ }^{15}$ Eben Jones to the writer.

${ }^{16}$ Elizabeth Dorman to the writer.

${ }^{17}$ Mrs. F. I. duPont to the writer.

${ }^{18}$ The characterization of Alicia and the steps leading to her marriage to Maddox were related confidentially to the writer by two elderly women members of the DuPont family who sympathized with Alicia's predicament. The marriage to Maddox took place April 30, 1902.

${ }^{19}$ The writer has been shown the original of a remarkable letter, eight manuscript pages in length, written by Judge Bradford under date of March 21, 1902, in pursuance of his campaign to have his daughter ousted 
from Louviers. The letter contains copies of an exchange of communications with Coleman duPont whom the Judge ineffectively tried to induce to bring pressure on Alfred.

${ }^{20}$ The writer has been permitted to read a number of these letters.

${ }^{21}$ The writer has confidentially discussed this phase of the family relationship with an elderly member of the DuPont family who seemed to be without prejudice against any of the parties involved.

${ }^{22} \mathrm{Mrs}$. B. G. duPont told the writer that Alfred soon regretted the generous bargain he made with Coleman.

${ }^{23} \mathrm{~J}$. L. Dashiell to the writer.

${ }^{24}$ A. I. duPont v. B. G. duPont, op. cit., Judgment Book No. 12, p. 114. ${ }^{25}$ Cazenove $G$. Lee to the writer.

${ }^{26}$ A. I. duPont to Bessie DuPont, March 17, 1907. Copy from A. V. duPont.

${ }^{27}$ A. I. duPont to A. V. duPont, March 27, 1907, ibid.

${ }^{28} \mathrm{~A}$. V. duPont to the writer.

${ }^{29}$ Philadelphia Public Ledger, Aug. 7, 1907.

30Philadelphia Press, Oct. 19, 1907.

${ }^{31}$ Ibid.

\section{CHAPTER XIII}

${ }^{1}$ Related to the writer by two members of the DuPont family who said they had it from A. I. duPont himself.

${ }^{2}$ This note must suffice for detailed documentation of Sub-chapters 2 and 3 because so much of the material therein was given the writer in confidence as to source by members of the DuPont family and by persons who were close to the family at the time. The informants represented both sides of the controversy. A search for neutrals who really knew anything was disappointing. Consequently much of the testimony is partisan and contradictory. From this I have attempted to discover where the weight of probability lay and to tell the story as it seems to me to have been.

${ }^{3}$ The writer has been shown the original copies of the telegram and the letter Bishop Coleman sent to Edward G. Bradford, Jr. Both are dated Oct. 16, 1907.

${ }^{4}$ The writer has been shown E. G. Bradford, junior's, manuscript copy of the letter he sent to Bishop Coleman. The date is Oct. 18, 1907.

${ }^{5}$ Various letters, 1907 to 1910 , between A. I. and T. C. duPont and A. I. and P. S. duPont, A. I. duPont Papers.

${ }^{6}$ A. I. duPont to T. C. duPont, Sept. 12, 1911. See also T. C. to A. I. duPont, Sept. 13, and A. I. to T. C. duPont, Sept. 18, 1911. Ibid.

${ }^{7} \mathrm{M}$. R. Hutchison to the writer.

${ }^{8}$ Victor duPont and J. L. Dashiell to the writer.

${ }^{9}$ Letter dated April 17, 1912, A. I. duPont Papers.

${ }^{10}$ A. I. duPont to Secretary of Commerce and Labor, Nov. 2, 1904. Copy from J. L. Dashiell.

${ }^{11}$ C. D. Prickett and S. F. Mathewson to the writer; Van Gelder and Schlatter, 123. S. F. Mathewson is one of the old-timers who cannot bring 
himself to believe that "Mr. Alfred's barrel" was discarded on the basis of fair scientific findings. C. D. Prickett has told the writer another story, and my text is based on what he said. Prickett, a member of a powder family in the business almost as long as the DuPonts, was one of the great black-powdermen of his day, and a warm admirer of Alfred I. duPont. Brought up in the Dulont-owned Hazard Powder Company, Prickett eventually had charge of black-powder operations for DuPont. Prickett's opinion is supported by Van Gelder \& Schlatter, 123, the standard authority on the explosive industry in America.

${ }^{12}$ U. S. v. DuPont, Testimony of A. I. duPont, Defendants' Testimony, I, 253.

${ }^{13}$ Mrs. Bessie duPont Huidekoper, Alfred V. duPont and Mrs. Victorine duPont Dent to the writer.

${ }^{14} \mathrm{~J}$. L. Dashiell and others to the writer.

\section{CHAPTER XIV}

${ }^{1} \mathrm{~J}$. M. Smyth to the writer.

${ }^{2}$ Mrs. J. B. duPont to the writer.

${ }^{3}$ J. M. Smyth, I. M. Williamson and C. M. Hanby to the writer.

${ }^{4}$ New York Sun, Oct. 31, 1909.

${ }^{5}$ New York World, Dec. 5, 1909.

${ }^{6}$ J. M. Smyth, A. V. duPont and Mrs. Victorine duPont Dent to the writer.

${ }^{7}$ Philadelphia North American, October 31, 1909.

${ }^{8}$ U. S. v. DuPont, A. I. duPont's answer, Plcadings, 347-49; his testimony, Defendants' Testimony, I, 457 and 461.

${ }^{9}$ A. I. duPont to Executive Committce, DuPont Company, Jan. 27, 1911, A. I. duPont Papers.

${ }^{10}$ From E. L. Bader's notebook, by permission of Mr. Bader.

${ }^{11}$ S. F. Mathewson to the writer.

${ }^{12} \mathrm{~J}$. L. Dashiell to the writer.

${ }^{13} \mathrm{M}$. R. Hutchison to the writer.

${ }^{14} \mathrm{~A}$ member of the DuPont family to the writer.

${ }^{15}$ Philadelphia Public Ledger, June 11, 1911.

${ }^{16}$ Elizabeth Dorman and E. L. Bader to the writer.

\section{CHAPTER XV}

${ }^{1}$ Mrs. F. I. duPont to the writer.

${ }^{2}$ A. I. duPont to Mrs. Louise B. Angell, May 8, 1913, A. I. duPont Papers.

${ }^{3}$ A. I. duPont to Irving Fisher, June 11, 1918, ibid.

${ }^{4}$ Leila Brereton to E. I. duPont de Nemours Powder Co., March 23, 1915, A. I. duPont Papers.

${ }^{5}$ U. S. v. DuPont, records of U. S. Circuit Court, Wilmington; Ernest Sutherland Bates, The Story of the Supreme Court (1936), 231, 244, 264; Winkler, 168-70. 
${ }^{6}$ J. F. Allee to A. I. duPont, July 13, 1921, A. I. duPont Papers.

${ }^{7}$ Account of White House conference given as Mr. duPont related it to Mrs. J. B. duPont and Edward Ball some ten years later. The characterization of Mr. Taft is, of course, my own.

${ }^{8}$ Alicia Maddox Kent to the writer.

${ }^{9}$ Mrs. F. I. duPont to the writer.

${ }^{10}$ S. F. Mathewson to the writer; various letters between Emma Fletcher (Jim Cook's daughter) and A. I. duPont, 1913-18, A. I. duPont Papers. ibid.

${ }^{11}$ Various letters between A. I. duPont and P. L. Goldsborough, 1913-15,

12Madeleine duPont Ruoff to the writer.

${ }^{13}$ Wilmington News, Feb. 5, 1913 ; New York Times, Feb. 6.

${ }^{14}$ New York Herald, Philadelphia Nortb American, Feb. 6, 1913.

${ }^{15}$ Wilmington News, Feb. 7, 1913.

${ }^{16}$ New York Times, Feb. 26, 1913; Philadelphia Press, Feb. 27, 1913.

${ }^{17}$ New York Times, Feb. 26, 1913.

${ }^{18}$ New York Herald, New York Times, March 14, 1913.

${ }^{19} \mathrm{~A}$ member of the DuPont family, always friendly to Alfred, to the writer.

${ }^{20}$ A. I. duPont to Margery Fitz-Gerald duPont, Sept. 18, 1931, A. I. duPont Papers.

${ }^{21}$ A. I. duPont to Executive Committee, Aug. 26, 1905, ibid. ibid.

${ }^{22}$ Various letters between A. I. duPont and J. J. Raskob, January, 1909,

${ }^{23}$ A. I. duPont to J. J. Raskob, Dec. 21, 1911, and Feb. 18, 1914, ibid.

${ }^{24}$ A. I. duPont to W. A. Glasgow, Jr., March 9, 1917; to Margery FitzGerald duPont, Sept. 18, 1931 , ibid.

\section{CHAPTER XVI}

${ }^{1}$ Pbilip F. duPont et al., v. Pierre S. duPont, et al., Testimony of P. S. duPont, VI, 88-92; testimony of A. I. duPont, II, 142-47. Hereafter citations from the record of this lawsuit will be attributed, for brevity, to DuPont $v$. DuPont. The record used by the writer is one published privately by $A$. I. duPont, none other being readily obtainable when he began work. This record comprises sixteen volumes and appears to be complete save for the omission of the brief filed at the conclusion of testimony by the defendants and for the opinion of the Court of Appeals, written by Judge Buffington. The omitted brief which the writer later consulted in the official record has no bearing on the present review of the case. Buffington's opinion was handed down two years after the original trial and decree, and was not available in 1917 when Mr. duPont published the trial record.

${ }^{2} \mathrm{~S}$. F. Mathewson to the writer.

${ }^{3}$ DuPont $v$. DuPont, Testimony of P. S. duPont, VI, 92-95 and VIII, 17; of A. I. duPont, II, 148-53; of William duPont, IV, 55-57.

${ }^{4}$ Ibid., VIII, 19.

4aP. S. duPont to T. C. duPont, Jan. 25, 1915, ibid., VI, 134.

${ }^{5}$ P. S. duPont to T. C. duPont, Jan. 28, 1915, ibid., III, 2-4. 
${ }^{6}$ Ibid., Testimony of A. I. duPont, which includes copies of letters mentioned, II, 166-68 and III, 1-7; testimony of William duPont, IV, 58-59.

${ }^{7}$ A. I. duPont to T. C. duPont, Feb. 16, 1915, ibid., III, 18.

${ }^{8}$ T. C. duPont to A. I. duPont, Feb. 19, 1915, ibid., III, 13.

'Wilmington Sunday Star, Feb. 28, 1915.

${ }^{10}$ DuPont v. DuPont, VI, 97.

${ }^{11}$ T. C. duPont to P. S. duPont, Jan. 6, 1915, ibid., VI, 100.

12P. S. duPont to T. C. duPont, Jan. 9, 1915, ibid., VI, 104.

${ }^{13}$ T. C. duPont to P. S. duPont, Jan. 11, 1915, ibid., VI, 114.

${ }^{14}$ P. S. duPont to T. C. duPont, Jan. 14, 1915, ibid., VI, 124.

${ }^{15}$ T. C. duPont to P. S. du Pont, Jan. 15, 1915, ibid., VI, 118.

${ }^{16} \mathrm{P}$. S. duPont to T. C. duPont, Jan. 18, 1915, ibid., VI, 126.

${ }^{17}$ T. C. duPont to P. S. duPont, Jan. 20, 1915, ibid., VI, 130.

18Ibid., XVI, 47-48.

${ }^{19} \mathrm{Ibid}$., Testimony of P. S. duPont, VI, 150-52; of J. J. Raskob, IX, 121-30 and X, 26-47; Raskob to Finance Committee, Feb. 16, 1915, III, 106.

${ }^{20} \mathrm{Ibid}$., Testimony of P.S. duPont, which includes telegrams, letters and other documents, VI, 153-76; VII, 5-14, 30-31 and 120-22; of S. Prosser, VIII, 136.

${ }^{21}$ Ibid., Testimony of F. I. duPont, IV, 83-86; of W. duPont, IV, 60-61. The copy of the telegram appearing in this record is dated March 2. Mr. duPont testified that he sent it on March 1, before he had received a wire from Alfred on the same subject. The copy in A. I. duPont's files of Alfred's telegram in question is dated March 1.

${ }^{22}$ Ibid., Testimony of A. I. duPont, III, 16-19; of P. S. duPont, VII, 25.

${ }^{23}$ Ibid., Testimony of P. S. duPont, VII, 26-28; of F. I. duPont, 89-92 and 134 .

${ }^{24}$ P. S. duPont to Board of Directors, March 5, 1915, ibid., III, 22; testimony of J. P. Laffey, X, 171.

${ }^{25}$ Minutes of Board of Directors, March 6, 1915, ibid., IX, 47-71; III, 33.

${ }^{26}$ Thus P. S. duPont (his testimony, ibid., VII, 32) fixed the date of his gift to Laffey. On the witness stand Laffey (ibid., X, 174) first gave the date as between March 5 and 15, 1915; then corrected himself to say that it could not have been the 5 th, and probably was about the 10 th. The 5 th was the day Laffey gave Pierre the private opinion that the company could not buy the stock.

${ }^{27}$ Minutes of Board of Directors, March 10, 1915, ibid., 72-86.

${ }^{28}$ P. S. duPont to F. I. duPont, April 16, 1915, ibid., IV, 111.

${ }^{29}$ Ibid., Testimony of F. I. duPont, IV, 114, 118; of P. S. duPont, IV, 48.

\section{CHAPTER XVII}

${ }^{1}$ DuPont $v$. DuPont, testimony of F. I. duPont, IV, 99-101; of P. F. duPont, IV, 165-67. Mr. Johnson's reasons for taking the case were stated to the writer by Mrs. J. B. duPont.

'Ibid., Bill of complaint, II, 1-40. 
${ }^{3}$ Minutes of Board of Directors, Jan. 10, 1916, ibid., III, 83.

${ }^{4}$ Minutes of stockholders' meeting, March 13, 1916, ibid., VII, 60-69.

${ }^{5} \mathrm{C}$. M. Hanby to the writer.

${ }^{6}$ A. I. duPont to Mrs. Louise B. Angell, Feb. 19, 1916, A. I. duPont papers.

${ }^{7}$ New York Times, March 16 and 31, 1916.

8Philadelphia Evening Ledger, Jan. 29, 1916, supplemented by the writer's conversation, confidential as to source, with a Delaware politician acquainted with the events described.

'Terms of A. I. duPont's purchase of the Wilmington Morning News appear in E. M. Hoopes to A. I. duPont, Dec. 11, 1911, and a receipt for $\$ 111,000$, dated Dec. 16, signed by Hoopes; A. I. duPont Papers. I. M. Williamson has described to the writer his activities in purchasing the stock. A picture of life on the News at this period furnished by one who was a member of Roy Jones's staff at the time.

10"Political Activities of Alfred I. duPont," by George T. Maxwell, I, 1-11. This is a typewritten document, in three parts, numbering about 700 pages. In $1916 \mathrm{Mr}$. Maxwell was the Dover correspondent of Mr. duPont's Morning News. Thereafter he became closely associated, in several capacities, with Mr. duPont's political career. His account is decidedly partisan, for which the present writer has made allowance. Now that the heat of battle has cooled, Mr. Maxwell himself has been sincerely helpful in this effort. From memory he has added much useful detail of incidents, such as Allee's first call at Nemours, of which Maxwell could speak either from personal knowledge or from accounts which he had firsthand from participants.

${ }^{11}$ Maxwell Manuscript, I, 12-17; Wilmington News, April 12, 1916.

${ }^{12} \mathrm{~A}$ former political associate of Mr. duPont to the writer; various letters, A. I. duPont to Edward Bradford, Jr., May-November, 1916, A. I. duPont Papers.

${ }^{13}$ Wilmington News, May 20, 1916.

${ }^{14}$ Maxwell Manuscript, I, 23.

${ }^{15}$ DuPont $v$. DuPont, Argument of John G. Johnson, XII, 45, 76.

${ }^{16} I$ bid., Argument of G. S. Graham, XII, 159-60.

${ }^{17} I$ bid., Argument of W. A. Glasgow, Jr., XIII, 122-23.

${ }^{18}$ Related to the writer by one who attended many such conferences. ${ }^{19}$ Wilmington News, Aug. 5, 1916.

${ }^{20} \mathrm{C}$. M. Hanby to the writer.

\section{CHAPTER XVIII}

${ }^{1}$ Wilmington News, Nov. 26, 1916.

2.Wilmington Evening Journal, Dec. 2, 1916.

${ }^{3}$ Wilmington News, Nov. 28, 1916.

${ }^{4}$ Ibid., Nov. 28, 29, 30; Dec. 2, 5, 1916.

${ }^{5}$ Maxwell Manuscript, II, 27-48.

${ }^{6}$ A. I. duPont to W. A. Glasgow, Jr., Feb. 7, 1917, A. I. duPont Papers.

${ }^{7}$ DuPont $v$. DuPont, Judge Thompson's Opinion, XVI, 8-29. 
$8 I$ lbid., XVI, 31.

Ilbid., XVI, 110.

${ }^{10} I$ lbid., XVI, 50.

${ }^{11}$ Ibid., XVI, 113-14; XIV, 16.

${ }^{12} I$ Ibid., XVI, 83.

${ }^{13}$ Ibid., XVI, 88-102.

${ }^{14}$ lbid., XVI, 70-71.

${ }^{15}$ Ibid., XVI, 113-14; XIV, 21 ; XVI, 106-08.

${ }^{16} I$ bid., XVI, 111-12.

${ }^{17}$ A. I. duPont to W. A. Glasgow, Jr., April 24, 1917, A. I. duPont Papers.

${ }^{18}$ DuPont v. DuPont, Bill of Complaint, II, 36-38.

${ }^{19}$ Mrs. Bessie Deery Gallagher to the writer.

${ }^{20}$ Several versions of this story are in circulation. The writer heard a young duPont tell the one given in the text.

${ }^{21}$ E. I. duPont de Nemours \& Company to Stockholders, April 13 and 27, 1917, A. I. duPont Papers; DuPont v. DuPont, Judge Thompson's Supplementary Opinion, XVI, 134-35.

${ }_{22}^{2}$ A. I. duPont to H. P. Brown, Aug. 18, 1917, A. I. duPont Papers.

${ }^{23}$ A. I. duPont to H. P Brown, Sept. 7, 1917; to H. B. Loos, Oct. 6; to H. D. Ross, Oct. 12, ibid.

${ }^{24}$ A. I. duPont to R. S. Huidekoper, Sept. 11, 1931, ibid.

${ }^{25}$ Opinion of Judge Charles E. Hughes Upon His Reviewing the Record and Opinion of the Court in the Case of Pbilip F. duPont, et al., v. Pierre S. duPont, et al. Apparently this title was supplied by the defendants who printed and circulated the document.

${ }^{26}$ Affidavit of John Hodd, Sept. 27, 1917, A. I. duPont Papers. A member of the DuPont family, not connected with the suit, has told the writer that he knew of kinsmen who believed Alfred in the right, but felt that their best interests lay in voting for Pierre and associates. The same man also said that memory of Alfred's attempt, in 1913, to change the name of his son, cost him the support of a few stockholders.

${ }^{27}$ [Charles Wertenbaker], "DuPont," Fortune magazine, November, 1934 , p. 205.

${ }^{28}$ J. L. Dashiell to the writer.

\section{CHAPTER XIX}

${ }^{1}$ C. M. Hanby to the writer.

${ }^{2}$ Mrs. J. B. duPont and Edward Ball to the writer.

${ }^{3}$ Alicia duPont, Ode to Fénelon (1917), 11.

${ }^{4}$ A. I. duPont to J. K. Hackett, June 26, 1918, A. I. duPont Papers.

${ }^{5}$ Ibid.

${ }^{6}$ Maxwell Manuscript, II, 50.

${ }^{7}$ A. I. duPont to Maurice duPont, Dec. 10, 1932, A. I. duPont Papers. ${ }^{8}$ Wilmington News, Jan. 25, 1918.

9Philadelphia Public Ledger, April 20, 1918.

${ }^{10}$ Various letters 1919 and 1920 , between A. I. duPont and E. L. Haynes, 
business manager, and Charles E. Gray, editor, Wilmington News, A. I. duPont Papers.

${ }^{11}$ A. I. duPont to C. E. Gray, Jan. 19, 1920, ibid.

${ }^{12}$ Wilmington Evening Journal, Oct. 12, 1917.

${ }^{13}$ H. P. Brown to A. I. duPont, Oct. 6, 1917, A. I. duPont Papers.

${ }^{14}$ A. I. duPont to H. P. Brown, Oct. 9, 1918, ibid.

${ }^{15}$ DuPont v. DuPont: In the United States District Court of Appeals for the Third District: Opinion of Judge Buffington, 32-36.

${ }^{16}$ Ibid., 38.

${ }^{17}$ Ibid., 39-44.

${ }^{18}$ Ibid., $48,49$.

${ }^{19}$ Ibid., 51 .

${ }^{20}$ Ibid., 49.

${ }^{21}$ Ibid., $2-20$.

${ }^{22}$ J. L. Dashiell to the writer.

${ }^{23}$ A. I. duPont to C. D. Dickson, Sept. 30, 1918. Copy from J. L. Dashiell.

${ }^{24}$ A. I. duPont to F. I. duPont, Sept. 18, 1919, A. I. duPont Papers.

${ }^{25}$ A. I. duPont to J. L. Dashiell, Jan. 21, 1920. Copy from J. L. Dashiell.

${ }^{26}$ The book was published by Brentano in 1920, after Mrs. duPont's death, under the title, The Cultivation of Vinejards in Soutbwestern France.

${ }^{27}$ A. I. duPont to Jessie Ball, June 14, 1916, from Mrs. J. B. duPont.

${ }^{28}$ T. C. duPont to A. I. duPont, Jan. 28, 1920; A. I. duPont to T. C. duPont, Feb. 2, A. I. duPont Papers. I should like to use an excerpt from the text of T. C. duPont's letter. As the text of a letter is the literary property of the sender or his heirs and not the recipient or his heirs, I requested of Francis V. duPont permission to quote his father's letter. After an exchange of correspondence the request was withdrawn. Quite understandably, the relations between A. I. and T. C. duPont form a subject on which it is unlikely that F. V. duPont and I could agree. This state of affairs is responsible for my failure to quote textually from several other letters received by A. I. duPont and referred to in this volume. In each case I have endeavored faithfully to reproduce their substance.

\section{CHAPTER XX}

${ }^{1}$ A. I. duPont to Richard Maclaurin, Jan. 20, 1920, A. I. duPont papers. ${ }^{2} \mathrm{Edward}$ Ball and J. L. Dashiell to the writer.

${ }^{3}$ W. A. Glasgow, Jr., July 15, 1920, to A. I. duPont, A. I. duPont Papers.

${ }^{4}$ W. A. Glasgow, Jr., to A. I. duPont, Aug. 5, 1920, ibid.

${ }^{4} \mathrm{E}$ Edward Ball to the writer.

${ }^{5}$ A. I. duPont to W. A. Glasgow, Jr., Sept. 10, 1920, A. I. duPont Papers. ${ }^{6} \mathrm{~J}$. L. Dashiell to the writer.

${ }^{7}$ T. C. duPont to A. I. duPont, Feb. 19, 1920, A. I.'s answer, Feb. 20, A. I. duPont Papers; A. I. duPont to Madeleine duPont Hicbler, Sept. 13, 1920, ibid. 
7awinkler, 300, mentions Pierre's supposed assistance. Alfred Victor and Victorine were the children who heard the report. Mrs. J. B. duPont is my authority for the fact that the report is baseless.

${ }^{8}$ Percy $\mathrm{H}$. Johnston to the writer.

${ }^{9}$ A. I. duPont to J. F. Allee, Jan. 19, 1920, A. I. duPont Papers.

${ }^{10}$ Mrs. J. B. duPont to the writer.

${ }^{11}$ A. I. duPont to J. F. Allee, Jan. 24 and March 2, 1920, A. I. duPont Papers.

${ }^{12}$ Edward Bradford, Jr., to A. I. duPont, April 6, 1920; Mr. duPont's reply, April 7, ibid.

${ }^{13}$ A. I. duPont to E. L. Haynes, June 16, 1920, ibid.; Edward Ball to the writer.

${ }^{14}$ Mrs. Floride Harding Adams, Mrs. Rebecca Harding Adams and Mrs. Elsie Ball Bowley to the writer.

${ }^{15}$ A. I. duPont to Madeleine duPont Hiebler, Sept. 2, 1920, A. I. duPont Papers.

${ }^{16}$ Wilmington Sunday Star, Jan. 23, 1921.

${ }^{17}$ A. I. duPont to M. R. Hutchison, April 11, 1921, A. I. duPont Papers.

${ }^{18}$ Mrs. J. B. duPont to the writer.

${ }^{19}$ A. I. duPont to W. A. Glasgow, Jr., June 23, 1921, A. I. duPont Papers.

${ }^{20}$ A. I. duPont to W. A. Glasgow, Jr., Sept. 19, 1921, ibid.

${ }^{21}$ Various letters between A. I. duPont and W. A. Glasgow, Jr., and Irénée duPont, Aug.-Oct. 1921, ibid.

${ }^{22}$ A. I. duPont to Mrs. Marguerite duPont Lee, Nov. 28, 1921, and Jan. 5,1922, ibid.

${ }^{23} \mathrm{~A}$. I. duPont to Mrs. Madeleine duPont Hiebler, Nov. 21, 1921, ibid.

${ }^{24}$ A. I. duPont to Mrs. Marguerite duPont Lee, May 6, 1921, ibid.

${ }^{25}$ A. I. duPont to Asa Bennett, July 1, 1921, ibid.

26Philadelphia Record, Aug. 21, 1921.

${ }^{27}$ Mrs. J. B. duPont to the writer.

${ }^{28}$ A. I. duPont to W. A. Glasgow, Jr., Dec. 21, 1921, A. I. duPont Papers.

\section{CHAPTER XXI}

${ }^{1}$ A. I. duPont to Mrs. Madeleine duPont Hiebler, Dec. 27, 1921, A. I. duPont Papers.

${ }^{2}$ A. I. duPont to Mrs. Marguerite duPont Lee, Oct. 18, 1921, ibid.

${ }^{3}$ A. I. duPont to Mrs. Madeleine duPont Hiebler, Jan. 6, 1922, ibid.

${ }^{4}$ A. I. duPont to Mrs. Elsie Ball Wright, Jan. 20, 1922, ibid.

${ }^{5}$ A. I. duPont to Mrs. Marguerite duPont Lee, Jan. 27, 1922, ibid.

${ }^{6}$ A. I. duPont to Thomas Ball, April 7, 1922, ibid.

${ }^{\top}$ A. I. duPont to Thomas Cochran, Jan. 16, 1922, ibid.

${ }^{8}$ Cochran to A. I. duPont, Jan. 28, 1922, ibid.

${ }^{9}$ A. I. duPont to Thomas Cochran, Jan. 31, 1922, ibill.

${ }^{10}$ Cochran to A. I. duPont, Feb. 8, 1922, ibid. 
${ }^{11}$ A. I. duPont to Thomas Cochran, April 8, 1922, ibid.

12Irénée duPont to A. I. duPont, May 5, 1922, ibid.

${ }^{13}$ A. I. duPont to W. A. Glasgow, Jr., May 11, 1922, ibid.

${ }^{14}$ Winkler, 297.

${ }^{15}$ Philadelphia Record, Oct. 9, 1921.

${ }^{16}$ Maxwell Manuscript, IV, 115.

${ }^{17}$ Mrs. J. B. duPont to the writer.

${ }^{18}$ A. I. duPont to J. J. Raskob, May 2, 1922, A. I. duPont Papers.

${ }^{19}$ A. I. duPont to Mrs. John Sebree, June 6, 1922, ibid.

${ }^{20}$ Wilmington Sunday Star, Aug. 27, 1922.

${ }^{21}$ A. I. duPont to Mrs. John Sebree, Sept. 9, 1922, A. I. duPont Papers.

${ }^{22}$ A. I. duPont to Thomas Ball, Nov. 10, 1922, ibid.

${ }^{23}$ Folder marked "Miscellaneous 1922," ibid.

${ }^{24}$ A. I. duPont to Paul duPont, April 27, 1927, ibid.

${ }^{25}$ A. I. duPont to Mrs. Madeleine duPont Hiebler, Dec. 12, 1921, ibid.

${ }^{26} \mathrm{Edward}$ Ball to the writer.

${ }^{27}$ A. I. duPont to Thomas Ball, July 19, 1923, A. I. duPont Papers.

${ }^{28}$ A. I. duPont to Thomas Ball, Oct. 15, 1924, ibid.

${ }^{29}$ W. A. Glasgow, Jr., to A. I. duPont, May 25, 1924, ibid.

${ }^{30}$ Edward Ball to the writer.

${ }^{31}$ For much of the data on the income tax cases of 1915 and of 1918 , account of which is here concluded, the writer is indebted to the valuable assistance of James G. Bright, tax expert for Mr. duPont's estate, who consulted the original documents in Mr. duPont's files.

\section{CHAPTER XXII}

${ }^{1} \mathrm{~J}$. L. Dashiell to the writer.

${ }^{2}$ Alfred I. duPont to Mrs. Madeleine duPont Hiebler, May 24, 1921, A. I. duPont Papers.

${ }^{3} \mathrm{~J}$. M. Smyth to the writer.

${ }^{4}$ A. I. duPont to Mrs. Marguerite duPont Lee, Sept. 27, 1921, A. I. duPont Papers.

${ }^{5}$ A. I. duPont to Mrs. Ella G. Haile, Dec. 28, 1923, ibid.

${ }^{6}$ E. G. Bradford to A. I. duPont, Sept. 19, 1920, ibid.

${ }^{7}$ A. I. duPont to E. G. Bradford, Sept. 23, 1920, ibid.

${ }^{8}$ A. I. duPont to Ellen LaMotte, April 19, 1923, ibid.

${ }^{9}$ Mrs. J. B. duPont to the writer.

${ }^{10} \mathrm{Mrs}$. Bessie duPont Huidekoper to the writer; Mrs. Huidekoper to her father and to Mrs. J. B. duPont, two short letters dated June 13, 1923, A. I. duPont Papers.

${ }^{11}$ A. I. duPont to Mrs. Marguerite Lee duPont, Sept. 23, 1925, ibid.

${ }^{12}$ Mrs. J. B. duPont to the writer.

${ }^{13}$ Mrs. Victorine duPont Dent and Alfred V. duPont have acquainted the writer with the terms of the settlement. The children's letters of appreciation appear in the A. I. duPont Papers.

${ }^{14}$ A. I. duPont to Mrs. B. duPont Huidekoper, Aug. 16, 1926. Copy from Mrs. Huidekoper. 
${ }^{15}$ Mrs. J. B. duPont and Mrs. V. duP. Dent to the writer.

${ }^{16}$ Mrs. J. B. duPont to the writer.

${ }^{17}$ Mrs. V. duP. Dent and A. V. duPont to the writer.

${ }^{18}$ Mrs. V. duP. Dent, Mr. and Mrs. A. V. duPont and Mrs. J. B. duPont to the writer.

${ }^{19}$ A. I. duPont to A. V. duPont, April 26, 1927, A. I. duPont Papers.

19a A. I. duPont to Mrs. Marguerite duPont Lee, March 7, 1921, ibid.

20Ibid., June 8, 1923.

${ }^{21}$ Ibid., Feb. 7, 1924.

${ }^{22}$ Newark (Delaware) Ledger, Oct. 24, 1924.

${ }^{23}$ Irénée duPont to A. I. duPont, Nov. 6, 1924; T. C. duPont to A. I. duPont, Nov. 6, 1924, A. I. duPont Papers.

${ }^{24}$ Edward Ball to the writer.

${ }^{25} \mathrm{~J}$. L. Dashiell to the writer.

${ }^{26} \mathrm{Mrs}$. J. B. duPont and Edward Ball to the writer.

${ }^{27}$ A. I. duPont to M. duPont Lee, June 26, 1925, A. I. duPont Papers.

${ }^{2 s}$ A. I. duPont to a young girl, April 23, 1925, ibil.

${ }^{29} \mathrm{~A}$. I. duPont to a young girl, April 3, 1931, ibil.

${ }^{30}$ A. I. duPont to a schoolboy, Jan. 4,1924 , ibid.

${ }^{31}$ A. I. duPont to Maurice duPont Lee, March 27, 1927, ibid.

${ }^{32}$ A. I. duPont to Mrs. Marguerite duPont Lee, Sept. 16, 1921, ibid.

${ }^{33}$ A. I. duPont to Mrs. Dorothy V. Lee, Aug. 29, 1930, ibid.

${ }^{34}$ Ibid., July 10, 1924.

${ }^{35}$ A. I. duPont to Mrs. Madeleine duPont Hiebler, May 24, 1926, ibid.

${ }^{36}$ R. A. Jones to Mrs. J. B. duPont, Oct. 1, 1924, ibid.

${ }^{37}$ A. I. duPont to R. A. Jones, Oct. 11, 1924, ibid.

\section{CHAPTER XXIII}

${ }^{1}$ W. T. Edwards to the writer.

${ }^{2}$ I. M. Williamson to the writer.

${ }^{3}$ Mrs. J. B. duPont and Edward Ball to the writer.

${ }^{4}$ Edward Ball to the writer.

${ }^{5}$ Records of A. I. duPont Estate, Jacksonville, Fla.

${ }^{6}$ Mrs. J. B. duPont, Edward Ball and W. T. Edwards to the writer.

${ }^{7}$ A. I. duPont to N. A. McArthur, Jan. 29, 1927, A. I. duPont Papers. ${ }^{8}$ Edward Ball to the writer.

${ }^{9}$ Ibid.

${ }^{10}$ A. I. duPont to T. R. LaMotte, March 18, 1929, A. I. duPont Papers.

${ }^{11}$ A. I. duPont to Mrs. Geraldine S. Lee, Oct. 17, 1927, ibid.

${ }^{12} \mathrm{Edward}$ Ball to the writer.

${ }^{13} \mathrm{~W}$. T. Edwards to the writer.

${ }^{14}$ Ibid.

\section{CHAPTER XXIV}

${ }^{1}$ A. I. duPont to C. M. Hanby, Jan. 30, 1929, A. I. duPont Papers.

${ }^{2}$ Edward Ball to the writer. 
${ }^{3}$ A. I. duPont to Maurice duPont Lee, Nov. 19, 1928, A. I. duPont Papers.

${ }^{4}$ A. I. duPont to Mrs. Dorothy V. Lee, Nov. 7, 1928, ibid.

${ }^{5}$ A. I. duPont to Mrs. Ella G. Haile, Nov. 10, 1928, ibid.

${ }^{6}$ A. I. duPont to N. A. McArthur, Oct. 29, 1925, ibid.

'A. I. duPont to Mrs. C. G. Lee, Dec. 22, 1928, ibid.

IIbid., Qct. 17, 1927.

${ }^{9}$ A. I. duPont to T. R. LaMotte, Dec. 31, 1925, ibid.

${ }^{10} \mathrm{Mrs}$. Denise duPont Zapffe to the writer.

${ }^{11}$ A. I. duPont to T. R. LaMotte, Dec. 6, 1929, A. I. duPont Papers.

${ }^{12}$ A. I. duPont to Benno Hiebler, Feb. 20, 1929, ibid.

${ }^{13}$ Mrs. J. B. duPont to the writer.

${ }^{14}$ Ibid.

${ }^{15}$ A. I. duPont to Mrs. Dorothy V. Lee, Dec. 2, 1927, A. I. duPont Papers.

${ }^{16}$ A. I. duPont to Charlotte duPont, Feb. 9, 1925, ibid.

${ }^{17}$ Copy from Mrs. Marcella Miller duPont.

${ }^{18}$ A. I. duPont to Benno Hiebler, Aug. 14, 1927, A. I. duPont Papers. Though Mr. DuPont made no such claim, these jingles are offered as original with him. In this I may be mistaken, for Mr. duPont filled his letters with the jingles of others as well as his own. In case the limericks reproduced should turn out to be composed by someone else I wish readers to understand that this inclusion here is my error and no plagiarism by $A$. I. duPont.

${ }^{19}$ A. I. duPont to Katherine Tyler, Aug. 29, 1931, A. I. duPont Papers. ${ }^{20}$ Copy from Mrs. J. B. duPont.

${ }^{21}$ A. I. duPont Papers, 1925-28. Names of correspondents withheld.

${ }^{22}$ A. I. duPont to A. V. duPont, Nov. 7, 1927. Copy from A. V. duPont. ${ }^{23}$ Ibid., Dec. 7, 1927.

${ }^{24}$ Ibid., Aug. 3, 1928.

${ }^{25}$ Ibid., May 5, 1929. Mr. duPont himself misquoted the epigram slightly, the correct rendering being: "A little learning is a dangerous thing." See Alexander Pope, Essay on Criticism.

${ }^{26} \mathrm{C}$. M. Hanby to the writer.

${ }^{27}$ A. I. duPont to A. V. duPont, Jan. 8, 1928, A. I. duPont Papers.

${ }^{2 s}$ Edward Ball and Mrs. J. B. duPont to the writer.

${ }^{29} \mathrm{C}$. M. Hanby to the writer.

${ }^{30} \mathrm{Mrs}$. J. B. duPont to the writer.

${ }^{31} \mathrm{~W}$. T. Edwards to the writer.

${ }^{32}$ Wilmington News, June 25 and July 13, 1929.

${ }^{33}$ Wilmington Sunday Star, Nov. 3, 1929.

${ }^{34}$ A. I. duPont to Ellen LaMotte, June 21, 1930, A. I. duPont Papers.

${ }^{35}$ T. C. duPont to A. I. duPont, Aug. 12 and Oct. 28, 1930, ibid.

${ }^{36}$ A. I. duPont to Mrs. Marguerite duPont Lee, Nov. 11, 1930, ibid.

${ }^{37}$ Ibid., Nov. 18, 1930.

${ }^{38}$ Mrs. J. B. duPont to the writer. Mr. duPont's correspondence corroborates Mrs. duPont's statement of her husband's estimate of Coleman. 


\section{CHAPTER XXV}

${ }^{1} \mathrm{C}$. D. Dyal to the writer.

${ }^{2}$ Edward Ball to the writer.

3acksonville Times-Union, May 5, 1929.

${ }^{4} \mathrm{C}$. D. Dyal to the writer.

${ }^{5} \mathrm{Mr}$. duPont's files fail to reveal a copy of Ball's first cable or of Mr. duPont's reply to the second cable. A copy of Ball's second cable, dated July 23, 1929, and reproduced verbatim in the text, was found. Mrs. J. B. duPont and Mr. Ball supplied the writer with their recollections of the substance of the first cable and of Mr. duPont's reply to the second.

${ }^{6}$ Edward Ball's files.

${ }^{7}$ Wilmington Every Evening, Aug. 20, 1929.

${ }^{8}$ Edward Ball to the writer who has also inspected a transcript of the bank's records.

${ }^{9}$ A. I. duPont to Mrs. Dorothy V. Lee, Nov. 12, 1929, A. I. duPont Papers.

${ }^{10}$ New York Times, Oct. 16, 1929.

${ }^{11}$ A. I. duPont to A. V. duPont, Oct. 29, 1929, A. I. duPont Papers.

${ }^{12}$ New York Times, Oct. 30, 1929. ville.

${ }^{13}$ Stock transactions, 1929, Almours Securities, Inc., records, Jackson-

${ }^{14}$ A. I. du Pont to Mrs. Dorothy V. Lee, Nov. 12, 1929, A. I. duPont Papers.

${ }^{15}$ Edward Ball to the writer. Also A. I. duPont Papers for October, November and December, 1929.

${ }^{16}$ A. I. duPont to Ellen LaMotte, Dec. 2, 1929, A. I. duPont Papers.

${ }^{17}$ A. I. duPont to Mrs. Alex Francis, Jan. 10, 1930, ibid.

${ }^{15}$ Mrs. E. B. Bowley to the writer.

${ }^{19}$ A. I. duPont to Mrs. Alex Francis, April 7, 1930, A. I. duPont Papers.

${ }^{20} \mathrm{Edward}$ Ball to the writer.

${ }^{21}$ Jacksonville Journal, Feb. 18, 1930.

22Edward Ball and Mrs. J. B. duPont to the writer.

${ }^{23}$ Edward Ball and C. D. Dyal to the writer. Figures on deposits from the official statements of the institution in question.

${ }^{24}$ In addition to the six banks mentioned, there was a widespread belief that Mr. duPont also owned the Florida Southside Bank, an outlying institution in Jacksonville. The authoritative Financial \& Commercial Cbronicle published an item to that effect. According to Edward Ball, neither Mr. duPont nor any of his companies owned a share in that institution. At the time Mr. duPont took over the Florida National of Jacksonville, the Southside Bank was largely owned by Florida National officers and directors and published its statements jointly with those of the larger bank. Finding the Southside Bank insolvent, Mr. duPont continued this practice and, in fact, indirectly took over the management of the ailing bank. After about two years the Southside was able to pay off its de- 
positors. Mr. duPont directed that the joint statements be discontinued. The Southside's officers then liquidated their institution.

\section{CHAPTER XXVI}

${ }^{1}$ Edward Ball to the writer.

${ }^{2}$ An unpublished brochure on the subject by W. T. Edwards, from which the quotation in the text is taken; Edwards to the writer.

${ }^{3}$ W. T. Edwards and Edward Ball to the writer. See also file of The Loop, official publication of the Gulf Coast Highway Association.

${ }^{4}$ Edward Ball to the writer.

${ }^{5}$ A. I. duPont to Maurice duPont Lee, Oct. 20, 1930, A. I. duPont Papers.

${ }^{6}$ Edward Ball to the writer.

${ }^{\top} \mathrm{C}$. D. Dyal and Edward Ball to the writer.

${ }^{8} \mathrm{~L}$. A. Usina and Edward Ball to the writer.

${ }^{9}$ Time, Aug. 31, 1931.

${ }^{10}$ A. I. duPont to Mrs. George Young, Nov. 27, 1931, A. I. duPont Papers.

${ }^{11}$ Edward Ball to the writer.

${ }^{12}$ Wilmington Evening Journal, Oct. 12, 1933.

${ }^{13}$ Melvin Jones, plumber at Nemours, to the writer.

${ }^{14}$ A. I. duPont to Andrew Fullarton, Jan. 9, 13 and 16, 1930; Fullarton to duPont, Jan. 14, A. I. duPont Papers.

${ }^{15}$ A. I. duPont to A. V. duPont, April 11, 1930, ibid.

${ }^{16}$ A. I. duPont to Mrs. Madeleine duPont Ruoff, Sept. 16, 1931, ibid.

${ }^{17}$ A. I. duPont to Ellen LaMotte, Oct. 1, 1931, ibid.

${ }^{18}$ Ellen LaMotte to the writer.

${ }^{19}$ Mrs. J. B. duPont and C. M. Hanby to the writer.

\section{CHAPTER XXVII}

${ }^{1}$ A. I. duPont to Irénée duPont, date obliterated, A. I. duPont papers.

${ }^{2}$ A. I. duPont Papers.

${ }^{3}$ A. I. duPont to Francis I. duPont, Dec. 7, 1931, ibid.

${ }^{4}$ A. I. duPont to Maurice duPont Lee, Dec. 17, 1930, ibid.

${ }^{5}$ Ibid., Dec. 17, 1929.

'Ibid., Oct. 3, 1932.

'A. I. duPont to Mrs. Geraldine S. Lee, June 4, 1932, ibid.

${ }^{8}$ A. I. duPont to Maurice duPont Lee, Jan. 11, 1930, ibid.

${ }^{9} \mathrm{~A}$. I. duPont to Thomas Ball, June 15, 1931, ibid. In this letter Mr. duPont says his Government-spending scheme has been in his mind eighteen months before the date of writing.

${ }^{10}$ A. I. duPont to C. G. Lee, Oct. 10,1930, ibid.

${ }^{11}$ A. I. duPont to Mrs. Alex Francis, June 1, 1931, ibid.

${ }^{12}$ A. I. duPont to Maurice duPont Lee, June 13, 1931, ibid.

${ }^{13}$ Time, June 22, 1931.

${ }^{14}$ Ibid.

${ }^{15}$ A. I. duPont to Hermann Ruoff, Nov. 3, 1931, A. I. duPont Papers. 
${ }^{16} I$ bid., Sept. 2, 1931.

${ }^{17}$ A. I. duPont to C. G. Lee, Oct. 10, 1930, ibid.

${ }^{18}$ A. I. duPont to Mrs. Marguerite duPont Lee, Aug. 28, 1931, ibid.

${ }^{19}$ A. I. duPont to Hermann Ruoff, Nov. 3, 1931, ibil.

${ }^{20}$ Ibid., Sept. 2, 1931.

${ }^{21}$ Confidential source. Papers.

${ }^{22}$ A. I. duPont to Mrs. Geraldine V. Lee, June 12, 1932, A. I. duPont

${ }^{23}$ Quoted from Samuel Eliot Morison and Henry S. Commager, The Growth of the American Republic (1930), II, 558.

${ }^{24}$ A. I. duPont to Cazenove Lee's daughter, Marguerite, of his pirate crew, then in preparatory school, Nov. 10,1932; A. I. duPont Papers.

${ }^{25}$ A. I. duPont to Ellen M. LaMotte, Nov. 10, 1932, ibid.

${ }^{26}$ Ibid.

${ }^{27}$ A. I. duPont to Mrs. Marguerite duPont Lee, Nov. 10, 1932, ibid.

${ }^{28} \mathrm{G}$. J. Avent and Edward Ball to the writer.

${ }^{29}$ Ibid.; Time, March 13 and 20, 1933.

${ }^{30} \mathrm{~A}$. I. duPont to Mr. and Mrs. Maurice duPont, May 7, 1933, A. I. duPont Papers.

${ }^{31}$ Anthony Wagner to the writer. Papers.

${ }^{32}$ A. I. duPont to Mrs. Dorothy V. Lee, July 26, 1933, A. I. duPont

${ }^{33}$ A. I. duPont to Mrs. Louise Bayard, June 29, 1927, ibid.

${ }^{34}$ Melvin Jones to the writer.

${ }^{35}$ A. I. duPont to Mrs. Madeleine duPont Hiebler, fragment of an undated letter, A. I. duPont Papers.

${ }^{36}$ A. I. duPont to Mrs. Elsie Ball Bowley, Oct. 3, 1932, ibid.

${ }^{37} \mathrm{~A}$. J. Bowley to the writer.

${ }^{38}$ A. I. duPont to Mrs. Marcella Miller duPont, Oct. 1, 1931, A. I. duPont Papers.

${ }^{39}$ A. I. duPont to Ellen LaMotte, July 10, 1931 , ibid.

${ }^{40}$ A. I. duPont to Mrs. Dorothy V. Lee, Sept. 5, 1931, ibid.

${ }^{41} \mathrm{Mrs}$. J. B. duPont to the writer.

${ }^{42}$ A. I. duPont to Mrs. Marcella Miller duPont, Dec. 30, 1927. Copy from the recipient's collection.

${ }^{43}$ A. I. duPont to Mrs. George Young, June 11, 1932, A. I. duPont Papers.

${ }^{44}$ A. I. duPont to Mrs. Marcella Miller duPont, Jan. 31, 1928. Copy from the recipient.

${ }^{45}$ Mrs. J. B. duPont to the writer.

${ }^{46}$ A. I. duPont to Mrs. Madeleine duPont Ruoff, May 18, 1932, A. I. duPont Papers. The Papers contain a lengthy history of Mr. duPont's adventure with this painting; also Mrs. J. B. duPont has furnished details to the writer.

\section{CHAPTER XXVIII}

${ }^{1}$ Records, Estate of Alfred I. duPont, Jacksonville.

${ }^{2} \mathrm{~W}$. T. Edwards to the writer. 
${ }^{3}$ Edward Ball to the writer.

${ }^{4}$ A. I. duPont to A. V. duPont, April 13, 1933, A. I. duPont Papers.

${ }^{5}$ A. I. duPont to Maurice duPont Lee, April 4, 1933, ibid.

${ }^{6}$ A. I. duPont to Mrs. Alex Francis, May 21, 1933, ibid.

${ }^{7}$ A. I. duPont to Mrs. Margery Fitz-Gerald duPont, June 1, 1933, ibid.

${ }^{8}$ To Maurice duPont Lee, April 4, 1933, ibid.

${ }^{9}$ Ibid.

10Ibid., Oct. 25, 1933.

${ }^{11}$ Bayard Hiebler to A. I. duPont, Sept. 12, 1933, ibid.

${ }^{12}$ A. I. duPont to Bayard Hiebler, Sept. 14, 1933, ibid.

${ }^{13}$ A. I. duPont to Dr. Baker P. Lee, July 18, 1933, ibid.

${ }^{14}$ Ibid.

${ }^{15}$ A. I. duPont to R. S. Huidekoper, Nov. 28, 1933, ibid.

${ }^{16} \mathrm{~A}$. I. duPont to Thomas Ball, July 6, 1933, ibid.

${ }^{17}$ A. I. duPont to Mrs. Madeleine duPont Ruoff, Nov. 14, 1933, ibid.

${ }^{18}$ A. I. duPont to Thomas Ball, Nov. 15, 1933, ibid.

${ }^{19}$ Marianna (Fla.) Floridian, Feb. 2, 1934.

${ }^{20}$ A. I. duPont to Maurice duPont Lee, May 4, 1934, A. I. duPont Papers.

${ }^{21}$ A. I. duPont to D. O. Hastings, June 1, 1934, ibid.

${ }^{22}$ A. I. duPont to Baker P. Lee, June 12, 1934, ibid.

${ }^{23}$ Ibid.

${ }^{24}$ A. I. duPont to Mrs. Alex Francis, April 3, 1935, ibid.

\section{CHAPTER XXIX}

${ }^{1}$ A. I. duPont to Benno Hiebler, Sept. 12, 1933, A. I. duPont Papers.

${ }^{2}$ A. I. duPont to Mrs. Dorothy V. Lee, March 5, 1932, ibid.

${ }^{3}$ A. I. duPont to Mrs. Geraldine S. Lee, March 16, 1932, ibid.

${ }^{4}$ A. I. duPont to Benno Hiebler, Sept. 12, 1933, ibid.

${ }^{5}$ A. I. duPont to Denise duPont, Nov. 4, 1932, ibid.

'Ibid., July 21, 1933.

${ }^{7}$ A. I. duPont to Mrs. Geraldine S. Lee, Dec. 1, 1934, ibid.

${ }^{8}$ A. I. duPont to Mrs. Madeleine duPont Hiebler, Nov. 21, 1931, ibid.

${ }^{9}$ Mrs. J. B. duPont and Mrs. Victor duPont, Sr., to the writer.

${ }^{10}$ Benno Hiebler to A. I. duPont, June 15 and Nov. 19, 1933, A. I. duPont Papers. Also various letters dated 1932 and 1933 to and from Mr. duPont, his daughter Madeleine and Hermann Ruoff, ibid.

${ }^{11}$ Mrs. J. B. duPont to the writer. Also various letters to and from A. I. duPont, his daughter Madeleine and her husband, 1933-34, A. I. duPont Papers.

${ }^{12}$ A. I. duPont to Mrs. Geraldine S. Lee, April 22, 1931, ibid.

${ }^{13}$ A. I. duPont to Mrs. Elsie Bell Bowley, Sept. 2, 1933, ibid.

${ }^{14}$ A. I. duPont to Mrs. Isabelle Ball Baker, Sept. 30, 1931, ibid.

${ }^{15}$ A. I. duPont to Mrs. Elsie Ball Bowley, Aug. 8, 1932, ibid.

${ }^{16}$ A. I. duPont to Mrs. Madeleine duPont Hiebler, Aug. 10, 1925, ibid.

${ }^{17}$ A. I. duPont to Mrs. Marguerite duPont Lee, Dec. 15, 1930, ibid. 
${ }^{18}$ A. I. duPont to Mrs. Madeleine duPont Ruoff, Sept. 28, 1933 , ibid.

${ }^{19}$ Various letters between P. S. duPont and A. I. duPont, June and July, 1930 , ibid.

${ }^{20}$ A. I. duPont to Mrs. Dorothy V. Lce, March 27, 1929, ibid.

${ }^{21}$ A. I. duPont to William duPont, May 22, 1926, ibid.

22The writer has spent many pleasant and instructive hours in Miss Lizzie's saloon. In this volume are a number of passages derived from confidential conversations with her patrons.

\section{CHAPTER XXX}

${ }^{1}$ A. I. duPont to Maurice duPont, Jan. 5, 1931; to Maurice duPont Lec, May 6, 1931, A. I. duPont Papers.

'Lammot duPont to the writer.

${ }^{3}$ Ibid.

${ }^{4}$ Confidential source.

${ }^{5} I$ bid. See also A. I. duPont to Maurice duPont Lee, March 6, 1931, A. I. duPont Papers.

${ }^{6}$ A. I. duPont to Lammot duPont, July 8, 1932, ibid.

'Lammot duPont to A. I. duPont, July 19, 1932, ibid.

${ }^{8} \mathrm{An}$ account of the rejection of Edward Ball as a director of the DuPont Company was related confidentially by a member of the DuPont family. That such a thing had occurred was confirmed, with few details, to the writer by Lammot duPont. Mr. duPont said he believed the suggestion that Alfred have representation on the Board first came from him, Lammot, and not from Alfred-though in discussing the matter Lammot admitted his memory of such remote events might be at fault. Mr. Ball, himself, declined to discuss the subject with me, or give any intimation as to whom I might apply for dependable information.

${ }^{9} \mathrm{~A}$. I. duPont estate records, Jacksonville. Though negotiated in his lifetime, the 144,817-acre purchase was not made until after Mr. duPont's death.

${ }^{10}$ W. T. Edwards to the writer.

${ }^{11}$ A. I. duPont to Maurice duPont Lee, Sept. 1, 1934, A. I. duPont Papers.

${ }^{12}$ Ibid., Oct. 4, 1934.

${ }^{13} \mathrm{~W}$. T. Edwards to the writer.

${ }^{14}$ James G. Bright to the writer.

${ }^{15}$ A. I. duPont to Alfred Hiebler, Jan. 26, 1931, A. I. duPont Papers. 16 Ibid.

${ }^{17}$ A. I. duPont to Mrs. Marguerite duPont Lee, Feb. 24, 1934, ibid.

${ }^{18}$ A. I. duPont to Maurice duPont Lee, Feb. 27, 1934, ibid.

${ }^{19}$ A. I. duPont to Ellen LaMotte, May 11, 1934, ibid.

${ }^{20} \mathrm{~A}$. I. duPont to Mrs. Marguerite duPont Lee, ibid.

${ }^{21}$ A. I. duPont to Baker P. Lee, July 25, 1934, ibid.

${ }^{22}$ Will of Alfred I. duPont, 15-19. The original of this document appears in Last Wills and Testaments Book No. 5 , beginning with page 
42, public records of Duval County, Florida, Jacksonville. The writer has used a printed copy, a duplicate of the original as to paging, supplied by the management of Mr. duPont's estate.

${ }^{23} \mathrm{Ibid}$., Second Codicil, 13.

${ }^{24}$ From the trust agreement, dated March 18, 1929, copy in the files of the Trust Department, Florida National Bank, Jacksonville.

${ }^{25}$ A. I. duPont to Mrs. Marguerite duPont Lee, Jan. 23, 1935, A. I. duPont Papers.

${ }^{26} \mathrm{~A}$. I. duPont to Maurice duPont Lee, Jan. 24, 1935, ibid.

${ }^{27}$ Ibid., Jan. 4, 1935.

${ }^{28}$ A. I. duPont to Mrs. Marguerite duPont Lee, March 8, 1935, ibid.

${ }^{29}$ Miami Herald, March 3, 1935.

${ }^{30} \mathrm{Mrs}$. Elsie Ball Bowley to the writer.

${ }^{31}$ A. I. duPont to Mrs. Geraldine S. Lee, March 16, 1935, A. I. duPont Papers.

${ }^{32}$ A. I. duPont to Maurice duPont Lee, March 29, 1935, ibid. ${ }^{33}$ Ibid.

${ }^{34}$ A. I. duPont to Mrs. Geraldine S. Lee, April 15, 1935, ibid.

${ }^{35} \mathrm{~J}$ ames Dolan to the writer.

${ }^{36}$ A. I. duPont to Ellen LaMotte, April 17, 1935, A. I. duPont Papers. ${ }^{37} \mathrm{~F}$. I. duPont to the writer.

${ }^{38} \mathrm{Mrs}$. J. B. duPont to the writer.

${ }^{39}$ The last days and hours of Alfred I. duPont have been described to the writer by Alfred V. duPont, Mr. and Mrs. N. Addison Baker, Mr. and Mrs. Edward Ball and James Dolan. 
BIBLIOGRAPHY 


\section{BIBLIOGRAPHY}

[No attempt is made here to give a full list of sources read, examined or interviewed. What follows is a recapitulation of sources, personal and documentary, which yielded something to be found quoted in the text or cited in the Notes. For further remarks on sources see "Personal Acknowledgments and Comment."]

\section{MANUSCRIPT SOURCES}

Alfred I. duPont Papers. This voluminous assemblage of Mr. duPont's personal and business correspondence and other papers formed the documentary mainstay of this book. The papers are divided between the offices of the late Mr. duPont in Wilmington and in Jacksonville. Research libraries have asked to acquire this collection but as yet Mrs. duPont has made no decision in the matter.

E. I. duPont de Nemours \& Company, Wilmington. Various DuPont Company records, running back to the early Eighties, were consulted in the DuPont Museum and in the company's Hall of Records, Wilmington.

[Francis G. duPont], "History of Explosions at Brandywine Mills Compiled from Records by Francis G. duPont and Also From His Own Experiences." This manuscript covers the period from 1815 to 1902. Copy loaned by the compiler's son, Francis I. duPont.

William S. Dutton, an unfinished manuscript history of the DuPont Company. Copy loaned by Mr. Dutton.

Duval County (Florida) records, Jacksonville.

William T. Edwards, manuscript brochures and notes on various Florida activities of Mr. duPont.

George T. Maxwell, "Political Activities of Alfred I. duPont." A manuscript of 700 pages.

Miscellaneous contemporary letters, papers, diaries or memoranda loaned by Mrs. Rebecca Harding Adams, Baltimore; Edward L. Bader, Wilmington; Edward Ball, Jacksonville; Mrs. Bessie duPont Huidekoper, Washington; Doctor Miller Reese Hutchison, New York; Reverend Doctor Baker P. Lee, Los Angeles; James L. Dashiell, Stamford, Connecticut; S. Francis Mathewson, Cambridge, Maryland; Alfred V. duPont, Greenville, Delaware; Mrs. Jessie Ball du Pont, Jacksonville; Mrs. Marcella Miller duPont, Greenville, Delaware, and two persons who wish their names withheld.

Miscellaneous papers and data from the Alfred I. duPont estate records, Jacksonville; the Florida banks founded by Mr. duPont; Almours Securities, Incorporated, Jacksonville; the Massachusetts Institute of Technology, and Phillips Academy, Andover, Massachusetts.

New Castle County (Delaware) records. 
Sioux Falls, South Dakota, Circuit Court records of divorce suit, Alfred I. v. Bessie Gardner duPont.

\section{PERSONAL SOURCES}

Mrs. Floride Harding Adams, Baltimore.

Mrs. Rebecca Harding Adams, Baltimore.

George J. Avent, Jacksonville.

Edward L. Bader, Wilmington.

Mrs. Isabel Ball Baker, Richmond.

N. Addison Baker, Richmond.

Edward Ball, Jacksonville.

Major General Albert J. Bowley, Northumberland County, Virginia. Mrs. Elsie Ball Bowley, Northumberland County, Virginia.

James G. Bright, Jacksonville.

Albert Buchanan, Wilmington.

Mrs. Elizabeth Gordon Buchanan, Wilmington.

John P. Craney, New York.

James L. Dashiell, Stamford, Connecticut.

Mrs. Victorine duPont Dent, Greenville, Delaware.

James Dolan, Wilmington.

Miss Elizabeth Dorman, Wilmington.

The Reverend Charles Bratten Dubell, Philadelphia.

Alfred V. duPont, Greenville, Delaware.

Mrs. Anna Rhett duPont, New York.

Mrs. Bessie Gardner duPont, Greenville, Delaware.

Edmond duPont, Wilmington.

Francis I. duPont, New York.

Mrs. Jessie Ball duPont, Jacksonville.

Lammot duPont, Wilmington.

Mrs. Marcella Miller duPont, Greenville, Delaware.

Pierre S. duPont, Wilmington.

Mrs. Victor duPont, Sr., Wilmington.

Victor duPont, Montchanin, Delaware.

C. D. Dyal, St. Petersburg, Florida.

William T. Edwards, Jacksonville.

Edward R. Farrar, South Lincoln, Massachusetts.

Pierre H. Ferraro, Wilmington.

Claude M. Fuess, Andover, Massachusetts.

Mrs. Bessie Deery Gallagher, Wilmington.

Frank Haley, Wilmington.

Doctor Charles M. Hanby, Wilmington.

Mrs. Bessie duPont Huidekoper, Washington.

Doctor Miller Reese Hutchison, New York.

Percy H. Johnston, New York.

Eben Jones, Wilmington.

Melvin Jones, Wilmington. 
Henry Kane, Wilmington.

Mrs. Alicia Maddox Kent, Washington's Crossing, Pennsylvania.

Miss Ellen LaMotte, Washington.

Cazenove G. Lee, Washington.

Maurice duPont Lee, Wilmington.

William F. Lynch, Wilmington.

John W. Macklem, Wilmington.

S. Francis Mathewson, Cambridge, Maryland.

George T. Maxwell, Wilmington.

J. C. MacKinnan, Boston.

John McMahon, Wilmington.

C. D. Prickett, Wilmington.

W. H. Proctor, Alderwood Manor, Washington.

Mrs. Madeleine duPont Ruoff, Munich, Germany.

Mrs. Olivia M. Seiss, Stonington, Connecticut.

Miss Mary G. Shaw, Wilmington.

James M. Smyth, Wilmington.

William M. Taylor, Indianapolis.

Mrs. Henry B. Thompson, Wilmington.

John Thompson, Wilmington.

Leonard A. Usina, Miami, Florida.

Anthony Wagner, Wilmington.

Ira M. Williamson, New York.

Mrs. Denise duPont Zapffe, Columbus, Ohio.

Several persons who asked that their names be withheld.

\section{PRINTED SOURCES}

Ernest Sutherland Bates, The Story of the Supreme Court (1936).

George B. Bryan, Edison, the Man and His Work (1926).

Buckeye Powder Company v. E. I. duPont de Nemours Powder Company, et al.

Chicago Daily News, various dates.

Cincinnati Enquirer, various dates.

R. F. Dibble, Jobn L. Sullivan (1925).

DuPont de Nemours (1937), a privately printed three-volume album of the DuPont family.

Alicia duPont, Ode to Fénelon (1917).

B. [essie] G. [ardner] duPont, E. I. duPont de Nemours and Company, a History (1920).

Philip F. duPont, et al. v. Pierre S. duPont, et al., record of the suit over the so-called Coleman duPont stock, 1915-1919.

Financial \& Commercial Chronicle (New York), various dates.

[Charles E. Hughes], Opinion of Judge Charles E. Hughes Upon His Reviewing the Record and Opinion of the Court in the Case of Philip F. duPont, et al. v. Pierre S. duPont, et al. (1917).

Jacksonville (Florida) Journal, various dates. 
Times-Union, various dates.

George Kennan, "Holding Up a State," The Outlook, February 7, 14, and $21,1903$.

George H. Kerr, DuPont Romance (1939).

The Loop, publication of the Gulf Coast Highway Association.

Louisville (Kentucky) Commercial, various dates.

- Couricr-Journal, various dates.

John W. Macklem, "Old Black Powder Days," The DuPont Magazine, August-September, 1927, and January, 1928.

Dumas Malone (editor), Correspondence Between Thomas Jefferson and Pierre Samuel duPont de Nemours, 1798-1817 (1930).

Miami (Florida) Herald, various dates.

Marianna (Florida) Floridian, February 2, 1934.

John Moody, Moody's Manual of Corporation Securities, various editions from 1906 to 1934 .

Samuel Eliot Morison and Henry Steele Commager, The Growth of the American Republic (1930).

New York Herald, various dates.

- Times, various dates.

- Sun, various dates.

-World, various dates.

Newark (Delaware) Ledger, various dates.

Philadelphia Evening Ledger, various dates.

Press, various dates.

Public Ledger, various dates.

- North American, various dates.

- Record, various dates.

Time, various dates.

United States v. E. I. duPont de Nemours \& Company, et al., record of the Sherman Law Suit, 1907-1912.

Arthur P. Van Gelder and Hugo Schlatter, History of the Explosive Industry in America (1927).

Wall Street Journal, various dates.

[Charles Wertenbaker], "DuPont," Fortune magazine, November, 1934. Wilmington Evening Journal, various dates.

Morning News, various dates. Sunday Star, various dates.

John K. Winkler, The DuPont Dynasty (1935). 
PERSONAL ACKNOWLEDGMENTS 
X0:

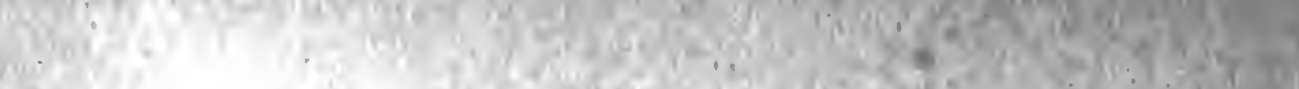

W.

1)

Siy

$+2$

$6,1-$

(10)

(1)

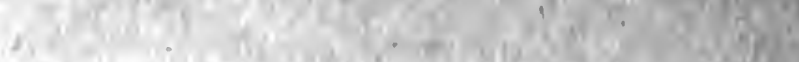

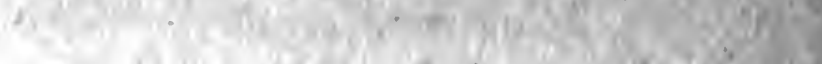

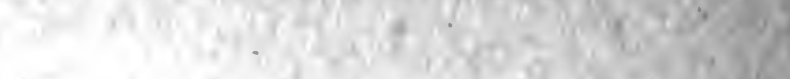

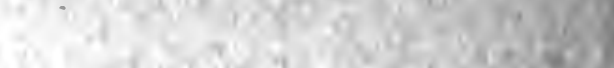

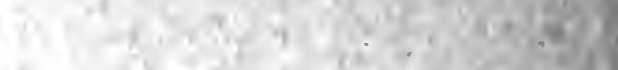

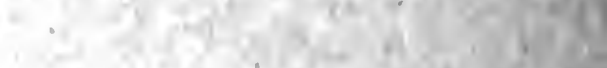

1

'3

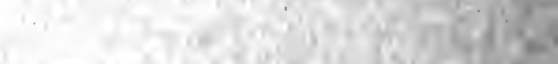

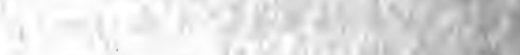

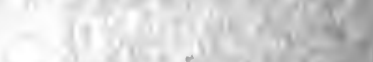

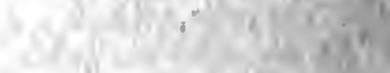

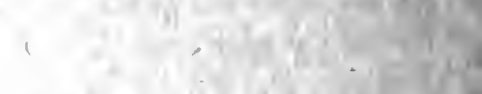

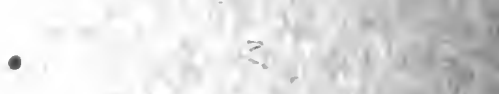

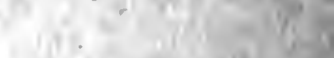

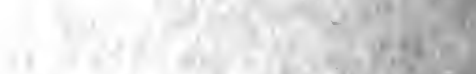

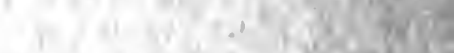

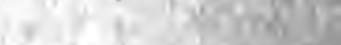

$\therefore=1+2+2=1$

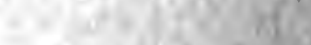

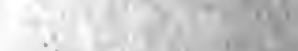

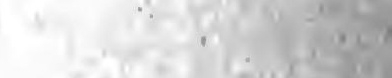

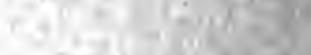

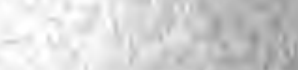

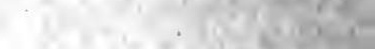

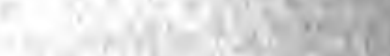

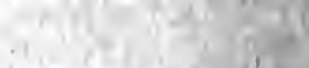

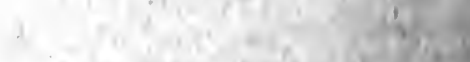

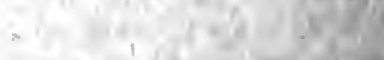

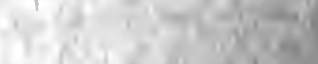
$1+1+2,0,1+20$

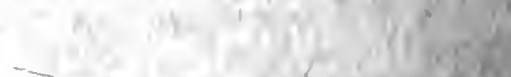

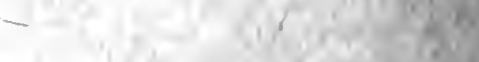

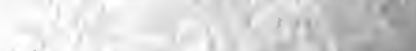

$\because+\quad+1+n=2+4=0$

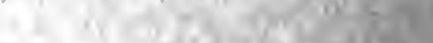

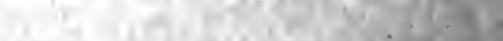

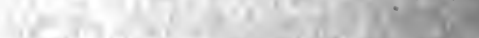

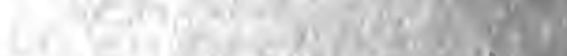

+

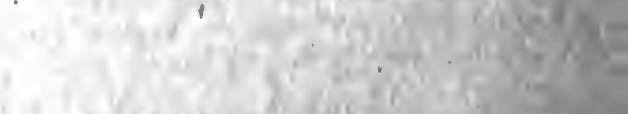

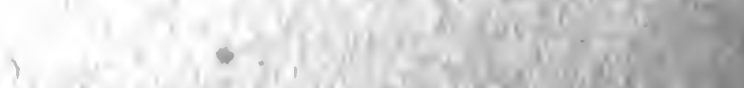
Q6.

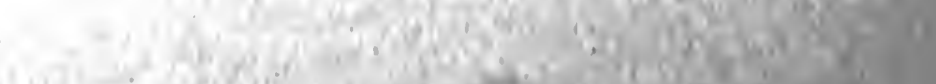

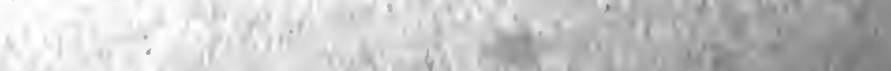




\section{PERSONAL ACKNOWLEDGMENTS AND COMMENT}

THE writer of contemporary biography enjoys certain advantages over the writer of historical biography. He also must bear with disadvantages no less distinct.

The main advantage is that the contemporary writer can find more grist for his mill. He should be able to locate and to use most of the documentary material which will constitute the sole reliance of a successor, writing, say, three-quarters of a century after the event. In addition he can draw upon the knowledge and the impressions of those who personally knew the subject of his work-knew all sides of him, at every stage of his career.

Such oral testimony will reveal conflicts and contradictions, naturally. This occurs also in the spadework for historical biography, where the researcher deals with documentary and not with word-of-mouth evidence. Here one must resolve conflicts as best he can without an opportunity of sitting down with the witnesses and trying to judge their credibility by first-hand discussion. Thus I think that there are often times when a historical biographer may be less accurate than a contemporary in the effort to determine where in the scale of contradiction the weight of probability lies. At any rate I have been up against conflicts in historical evidence which I think might have been resolved to my better satisfaction could I have had an hour or so with the opposing parties. In the present work such opportunities were open and I believe that I have profited by them.

Moreover, one can get from living sources much useful information concerning which no dispute exists. This often touches such details as personal mannerisms and all those small but very important things which tend to make the subject of a biography real. Such matters are seldom reduced to writing by a man's contemporaries. They vanish as living witnesses die.

That on the plus side. On the minus side is the want of perspective which only time can supply. One may not see the forest for the trees; and he is surrounded by others in the same fix. This diminishes the advantages flowing from association with living witnesses. With their help one may resolve fairly accurately a hundred separate details. To join these details into a proper whole-this takes perspective, hard to come by on the short view. That is one reason much history and much biography can profitably be rewritten every generation or so.

The historical biographer works free of certain restraints which affect his contemporary colleague moving on a scene so plentifully peopled by the living. One cannot write all he knows, because the sensibilities of blameless living persons must be taken into account. This point may be im- 
portant or unimportant, according to circumstances. In the present work it has not been important. While pertinent as to the detail of a few episodes, facts omitted which might be supplied without injustice to anyone seventy-five years hence would alter in no way the broad outline of this work. They would add or subtract nothing material from the portrait I have endeavored to draw of Alfred I. duPont.

And it seems advisable to say here that this portrait represents Alfred I. duPont as he seems to me to have been, and not, necessarily, as he may seem to anyone else. Any errors of judgment which may develop are mine. This statement may seem an example of keen perception of the obvious. It is made, however, because such things are not taken for granted in Delaware or by persons who know well the DuPont family and what has been written about it before. At present the tribe of DuPont lives in greater harmony than during some of the periods with which this book deals. Yet one does not have to scratch very deeply to uncover traces of old battlements, buried beneath the increments of time. During my long sojourns in Delaware, I must have been asked fifty times: "Whose side are you taking, Alfred's or the others'?" The printed word in Delaware, and much of it which has emanated therefrom, has long been so censored by this or that DuPont faction, that lack of freedom or of objectivity is assumed. I have replied that I was taking the side of no one; that I was trying to present Alfred I. duPont as my notion of the facts might reveal him. I have a feeling that this assertion was received with skepticism in more than one quarter.

Nevertheless, some of the persons with whom I have talked, and who have been courteous and helpful, will, I am sure, be very quick to disclaim responsibility for the picture I have presented-leastwise in various particulars. Indeed, I owe it to every individual whose name appears on the list of persons named in the bibliography which precedes these remarks to absolve them from responsibility for the whole work. I know of no person on this list who will agree with everything I have said.

In fairness to her I should name especially Mr. duPont's widow, Mrs. Jessie Ball duPont. In many instances her ideas differ from mine on questions involving the determination of facts and also the interpretation of them. Despite this she was as helpful to me as it would be possible to imagine one to be. She placed her late husband's correspondence at my disposal, helped to locate much other material and complied cheerfully with requests of all sorts. A biographer will go a long way before encountering as congenial and valuable a professional relationship as I enjoyed with this pleasant lady.

In other ways I have tried to adhere to the tenets of biography as I conceive them to be and have prated about at tiresome length in essays in the backs of earlier books. I make a sharp distinction between biography and history, and try to produce the former. In the present undertaking this required restraint. I was tempted to write more about the DuPont Company-under Boss Henry who made it the Prussia of the powder industry; under the Three Cousins who restored that ascendancy; under Pierre in World War-time when it performed miracles, at enormous profit to itself. 
An effort was required not to relate more of the fantastic story of Delaware politics and statecraft under the DuPont aegis; of the economic collapse and rebirth of Florida in the Twenties. I was tempted to grow expansive on these subjects because they represent history that has not as yet been objectively told. For that matter there is little good industrial history in print. Great corporations like DuPont have hired men, often first-class men, to write their annals. The usual course is to shuttle the manuscript among interested executives and department heads. One makes what seems to him a more presentable story of this, another of that. Other industrial literature of the debunking or exposé schools is no more dependable.

This book proved a larger undertaking than I had anticipated. I had hoped that it might be one job of mine from which my wife, Bessie Rowland James, could take a vacation and pursue occupations of her own election. This was not the case, and herewith I acknowledge her invaluable assistance, notably in the final stages of the work. Without it this book would present more imperfections than it does.

I am indebted to suggestions from David Laurance Chambers, the head of the publishing house whose imprint this volume bears. My thanks go also to Elisabeth Yager, Pauline Peirce and Elizabeth Frink of his staff for their assistance in correcting the proofs.

Among the names appearing in the bibliography, a few should be underlined for their especial helpfulness, and again this implies no endorsement of this book on their parts: all Alfred I. duPont's children; Marcella Miller duPont; Francis I. duPont; S. Francis Mathewson; Edward Ball. With one or two exceptions of no consequence, the officers of the DuPont Company complied with every request for information made upon them. I am obliged to Theodore G. Joslin, head of the Public Relations Department, and to members of his staff, notably William S. Dutton. William Winder Laird, Jr., a nephew of Pierre S. duPont, permitted me to reproduce certain photographs which also appear in DuPont de Nemours, 1800-1935, the three-volume privately-printed family album on which he holds the copyright.

I also am obliged to the personnels of the Wilmington Public Library, the New York Public Library, the Library of Congress, and the Free Library of Pleasantville, New York, for their patience and assistance; and to William H. Button, of New York, since 1902 an attorney for the DuPont Company, who placed his professional library at my disposal.

Pleasantville, New York

M. J.

August 6, 1941 

INDEX 


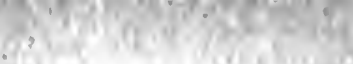

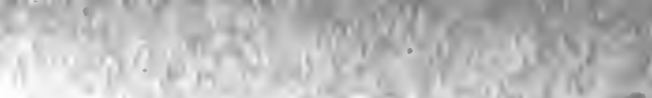

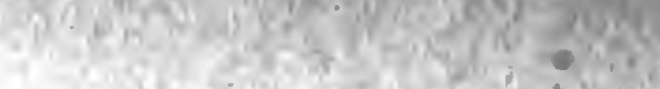

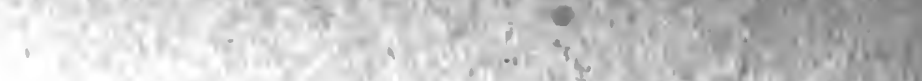

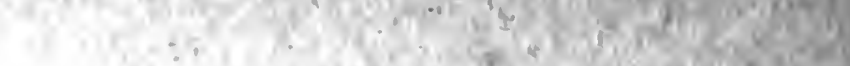

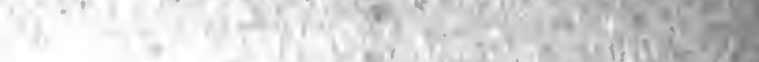
$\left(x_{1} \sin ^{2}\right)$ $x^{+1}+y_{i=8}$

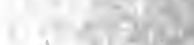

$-1+320$

13.4 istige $-x \log 3$

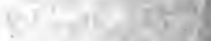

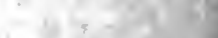

angis

4.

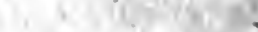

1

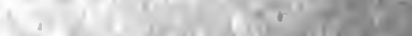




\section{INDEX}

\section{AAA, 502, 503}

Abbott, Rebecca V., 196

Addicks, John Henry O'Sullivan, and Addicks-duPont affair, 107$110,137,182,204$; and Allee, 282-283

Aldrich, Winthrop W., 454

Alfred I. duPont Bridge, 452

Alicia, 211

Allee, J. Frank, 244; early career, 282-283; and Alfred I. duPont, 300-301, 317ff.

Allied Industries Corporation, 325, 332

Almours Securities, Inc., 401, 422, $433,441,535$

American Bank \& Trust Company, St. Petersburg, 447

American E. C. \& Schultz Gunpowder Company, 173

American Tobacco Company, case, 244-278

Anti-Saloon League, 409

Apalachicola Northern Railroad, 496, 497

Associated Press, 227

Atlanta Constitution, 498

Atlantic Deeper Inland Waterways Association, 452

Atlantic National Bank, Jacksonville, 403, 404-405, 431, 483, 538

Atlas Powder Company, 245-246

Avent, George J., connected with Florida National group, 435, 458, 483

Bader, Edward L., 181, 234, 316

Baker, Isabel Ball, 535, 541

Baker, George F., Jr., 290, 357

Baker, George F., Sr., 357

Baker, Jessie Gresham, 345

Baker, Johnny, 345
Baker, N. Addison, 541

Baldwin, Henry $F$. , in charge of smokeless powder, 177, 178, 179; director, 183

Ball, Edward, early career, 328, 358; first connections with Alfred I. duPont, $356 f f$.; investigates northwest Florida, 396ff.; and Florida banks, 407, 432ff., 456, 484; works for Hoover, 409; speculation, 420-421; lobbyist, 451 ; and Usina, 459-460; in Port St. Joe project, 496ff.; salary, 500; marriage, 514; rejected as DuPont director, 524f.; in Alfred I. duPont's will, 535; carries on, 540

Ball, Elsie. See Bowley, Elsie Ball

Ball, Isabel. See Baker, Isabel Ball

Ball, Jessie Dew. See duPont, Jessie Ball

Ball, Lewis Heisler, 319

Ball, Captain Thomas, 135, 328

Ball, Thomas, Jr., 328

Bancroft, Doctor, 33

Bancroft, John, Jr., 217

Bancroft, John, III, 515

Bank of South Jacksonville, 458-459

Bankers Trust Company, New York, 267, 290

Barksdale, Hamilton, in charge of high-explosives, 102, 215; and Frank duPont, 142; refuses presidency of company, 146-147; general manager of Eastern Dynamite, 177, 178, 179; on Finance Committee of DuPont Company, 216; general manager, 233 ; builds obsolescent black-powder plant, 237

Barksdale Mills, 374, 378

Barnard, John A., 300, 301

Barnett, Bion H., 404, 484 
Barnett National Bank, Jacksonville, 403, 404, 430ff., 443; 445, 483 ff., 538

Bassino, Frank, 316

Bastian, Doctor J. W., 299

Bates, Annic, 54

Bayard, Thomas Francis, Jr., 219, 229, 295, 353

Beardslee, L. R., 182

Belin, Alice. See duPont, Alice Belin Belin, Mary. See duPont, Mary Belin Berger, Victor L., 424

Berminham, William J., 118, 132

Bird, Tom, 69

Blaine, James G., 81

Blakely, Jeff, 212

Boisson, Mrs. Pierre, 46

Bonbright, William P., 326

Bowley, General Albert J., 468, 489

Bowley, Elsie Ball, 337, 346, 416, 443, 517; marriage, 468; in Alfred's will, 535; at family party, 537

Bradford, Alicia. See duPont, Alicia Bradford

Bradford, Judge Edward Green, hostility toward daughter, 193, 206, 219; disqualifies self from $\mathrm{Du}-$ Pont trust suit, 231; makes request of Alfred, 367-369

Bradford, Mrs. Edward Green. See duPont, Eleuthéra

Bradford, Edward Green, Jr., in family row of Alfred duPont, 205-206; and slander suit, 228; and attempted change of Alfred Victor duPont's name, 249-251; frankness, 253; in politics, 284, 287, 336; assists Alicia, 328

Bradford, Joanna duPont, 219

Brandywine Fife and Drum Corps, 95

Brandywine Hundred Realty Company, 397

Brereton sisters, 366

Bright, James G., 485

Brown, Harry F., 268, 279

Brown, Henry P., 289
"Brown, John J.," 107, 110-112

Bryan, William Jennings, 395

Buchanan, Albert (Yaba), powderman, 20,29,103,114, 131, 316

Buchanan, Johnny, 29

Buchanan, Mary, 243

Buchanan, Sam, powderman, 29, 35, $69,127,192$

Buck, C. Douglass, Governor, 425, 426, 463, 481

Buckner, Colonel Edward G., 258

Buffington, Judge, gives opinion on Alfred's appeal, 322-325

Burton, Doctor H. R., 295-296

Bush, Mary H. J., defendant in duPont's slander suit, 219 ff., 227

Business Men's Presidential League, 282, 288

Button, William H., 289

Bye, Doctor Arthur Edwin, 493

California Powder Works, 73, 123, 151, 173-174

California Vigorit Powder Company, 173

Cambridge Yacht Club, 247

Candee, Doctor Charles L., 464

Carlton, Doyle E., 437

Carney's Point, smokeless-powder works, 123, 132-133, 144, 161, 178,223

Carpenter, Robert Ruliph Morgan, 266,279

Carrère, John M., 225, 466

Carrère \& Hastings, 224, 466

Casey, Pat, 243

Cassatt \& Company, 421

Cathedral of St. John the Divine, 329,330

Catts, Sidney J., 409

Cellophane, developed, 246, 384; and wood pulp, 400, 497; Alfred I. duPont's interest in, 522

Centennial Gates, 234, 519

Central City Coal \& Iron Company, 140

Central Hanover Bank of New York, 486 
Central National Bank, St. Petersburg, 447, 455; closes, 456

Chase National Bank, New York, 290,454

Chilworth Powder Company, 82

Christ Church, 13-15, 19, 20, 29, $48,70,77,89,194$

Christiana Securities Corporation, 341,348

Cincinnati Enquirer, 100

Citizens Bank, Tampa, 431, 433, 444,447

Clark, William Andrews, 247

Clean Foods Product Company, 356

Cochran, Thomas, 347-348, 354

Coleman, Leighton, Bishop of Delaware, 203-205'

Collier, Barron G., 445, 450, 454

Collison, Edward, 40

Columbia electric, 134

Commercial and Financial Chronicle, 460

Connable, Frank, 272, 274

Connable Mill, 180

Connor, Bill, 41

Cook, Jim, 247

Coolidge, Calvin, 381; Prosperity, 419

Coopal \& Company, 83

Copeland, Charles, 275

Corrado, Joe, 316

Coyne, William, 268, 272, 279

\section{Daily Oklahoman, 498}

Dashiell, James L., spells Alfred I. duPont as orchestra leader, 120; secretary to Alfred, 179; saves Alfred's music scores, 185; office manager of black powder, 195; carries Alfred I. duPont's letter to News, 199; and Wilmington Symphony Orchestra, 217; gocs to John Wanamaker, 236; auditor of Franco-American and Allied Industries, 326, 327; takes better position, 335

Davis, Edward M., 294, 317, 381382
Davis, Richard Harding, 128

Davison, George W., 486

Davison, Henry P., 290

Day, Harold, 455

Daytona Bank \& Trust Company, 430,445

Dée, Maric le, 493

Deery, Bessie, 118

Deery, Charley, powderman, 118, 132, 305

Deery, Hanna, 43

Deery, Madeleine, 118

Delaware, the U.S.S., 218

Delaware Investment Company, 170-171

Delaware Securities Company, 170171,232

Delaware Trust Building, 342

Delaware Trust Company, 287, 317 , 332, 336, 437

Denney, William D., 342

Dent, Elbert, 375, 537

Dern, Secretary and Mrs., 539

De Schweinitz, Doctor G. E., 188, 190

Dewey, Admiral, 128

Dittmar Powder Company, 123

Dolan, James, 345

Dorman, Elizabeth, 193; saloon, 520-521

Dougherty, Mick, 45

Dover Sentinel, 287

Dover State News, 353

Dubell, Charles Bratten, 330

Duco, 383

Dunham, Lewis L., confidential clerk for Coleman duPont, 168; secretary Delaware Securities and Delaware Investment, 170 ; on inside, 176, 266

duPont, Adelaide Camille Denise. See duPont, Denise

duPont, Alexis, 13-15

duPont, Alexis Felix, at Carney's Point, 133; and Pierre-Coleman deal, 266; buys Florida timberland, 449 
duPont, Doctor Alexis I., becomes partner, 85; mentioned, 88, 133; illness of, 137, 142; offers company presidency to Barksdale, 146147; director, 160 ; death, 182

duPont, Alexis Irénée, made secretary, 183

duPont, Alfred I.

Early life:

ancestors, birth and christening, 13-20; boyhood, 20-31; education, 27, 32-55; and John L. Sullivan, 50-51, 54; legacy, 66; expenditures, 66-67

DuPont Company connection: starts at powder plant, 61-65; promoted, 65; pay increases, 80, 86; powder mission, 81-83; becomes partner, 86; wires relatives' houses for electricity, 88 ff.; improves brown powder machinery, 102; concentrates on black powder, 102-105; praised by Eugene and Frank duPont, 130; during SpanishAmerican War, 122-129, 132; objects to conservatism, $138 \mathrm{ff}$.; buys company, 144ff.; vicepresident and general manager, 160-161; improves Brandywine yards, 161 ; part in reorganization, $175 f f$; in charge of black powder, 179; office, 179; regulations for employee protection, 213; and Government trust suit, 232, 244-246; relieved of operating duties, 233-239; silver cup presented to, 238239; and Finance Committee, 240,280 ; and bonuses, 252; and Pierre-Coleman deal, 255ff.; sues Pierre duPont, $279 f f ., 302 f f ., 323$; deposed as vice-president, 280 ; shares, 306 ; appeals to set aside dismissal in DuPont vs. DuPont, $322 \mathrm{ff}$.; sells 20,000 shares, 347 , 350 ; holdings in, 418,422

\section{duPont, Alfred I.-Continued}

Domestic life:

marriage to Bessie Gardner, 77; children, 80, 93; buys and visits Cherry Island, 97, 135, 189, 331, 465; builds Jim Cook, 97; and "John J. Brown," 107, 110-112; unhappiness and divorce, 112-114, 184-196, 199; hearing impaired, 120; at Balls Neck, 135, 186ff; welcomes Maurice duPont and wife, 9394; eye accident, 188-190; at Rock Farms, 191; defends and marries Mrs. Alicia Maddox, 193, 200; and family rows, 203; estrangement from three younger children, 216; and slander suits, 218ff., 227-230; builds Nemours, 223-227; estrangement from Madeleine duPont, 248; attempts to change son's name, 249-251; builds White Eagle, 310, 313; adopts Denise duPont, 313; and World War, 315-316; holds reunion for powder veterans, 316; goes to California to visit Balls, 329; confirmation, 330; reunion with Madeleine du Pont, 338; marriage to Jessie Ball, 338-339; holiday in Europe, 350; reunited with various members of family, 367; Judge Bradford's request, 367-369; gifts of stock to his children, 374; annual powdermen's outing, 413; transfers legal residence to Florida, 423; and the Depression, 438, 472ff.; at seventy, 516; wealth, 518; illness, 530; will, 532536; at family party, 537; death, 541-542

Personal business activities and associates:

interest in electricity, and Edison, 56-57, 67, 97, 185-186; 
duPont, Alfred I.-Continued

Personal business activities and associates-Continued interest in hearing devices, and Reese Hutchison, 184-185, 210-236; income, 286; buys Delaware Trust, 287; buys papers, 287; organizes Merchants \& Manufacturers Exchange, 309; organization and liquidation of Nemours Trading, 326-328, 331ff.; additional tax on 1915 income, $331,346 f f ., 360$; "opportunities," 354-355; tomato machine, 3.55; and Edward Ball, see Ball, Edward; gets 1918 tax refund, 360-361; sells interest in Delaware Trust, 403; only margin account, 420-422; transfers legal residence to Florida, 423; and the Depression, 438, 472ff.; public works, $473 f f$; wealth, 518 ; and Lizzic Dorman, 520

Political life:

dethrones Henry A. duPont, 283ff., 292-296; secures tax revision, 297; "elects" Wilmington mayor, 316-317; puts Republican in Senate, $318 \mathrm{ff}$; announces ownership of Morning News, 320; supports Pierre duPont's school crusade, 321; decides to leave politics, 336, 343; sells Morning News, 336; and Coleman duPont's campaign for re-election, $351 \mathrm{ff}$., $381-382$; and Harding, $380-$ 381 ; carries Florida for Hoover, 408; and Coolidge Prosperity, 420 ; and old age pension, 423427, 438, 463; and Hoover, 473 ; and F. D. Roosevelt, New Deal, 480-481, 486, 499ff., 537; statement on currency reform, 506-508
duPont, Alfred I.-Continued

Florida interests: during boom, $392 \mathrm{ff} . ;$ organizes Almours Securities, Inc., $401 \mathrm{ff}$.; builds Epping Forest, 402; acquires shares in Jacksonville banks, 404 ; obtains operating control of Florida $\mathrm{Na}$ tional, 407; prevents Florida National-Barnett merger, 430 432; opens Florida chain of banks, $433 \mathrm{ff}$; president of Florida National, Jacksonville, 443; urban investment, 449; tax lobby, 451, 453; president Gulf Coast Highway Association, 451; waterway development, 452-453; chairman board Florida National, Miami, 458; bank management, 461 ; bond transactions, 462-463; duPontBall Corporation, 463 ; in bank emergency, 484ff.; increased holdings, 495; experiments with newsprint, 497-498; additional land purchases, 525; improvements at Port St. Joc, 525-529, 538

Personal attributes:

36-38, 48, 99, 103-104, 116$118,196-197,365,371-372$, $385-386,388-391,424,441$ 443, 490-491, 511, 514-515, 519; characteristics, hobbies and inventions, 20, 55-57, 68, $74 \mathrm{ff} ., 79,97,134-135,139$, 180-181, 214-215, 237, 247, $487 f$., 492-493; estimate of, 428; evaluation of various $\mathrm{Du}$ Ponts, 427ff.; generosity and philanthropies, 186, 193, 217, $226,235,236,239,242-243$, 247-248, 287, 314-315, 335, $422-423,425,427,441,470-$ 471; music, 31-32, 47, 50, 69$70,95-96,120,126,217-218$, 335 , 491; social philosophy, 242 , 374, 400-401, 527-528, 
duPont, Alfred I.-Continued

Personal attributes-Continued 534ff.; stories about, 114-116 Correspondence:

Frank Allee, 336; Isabel Baker, 516-517; Thomas Ball, 503505, 532; Elsie Bowley, 346, 517; Judge Bradford, 368; Thomas Cochran, 347-348; James Dashiell, 327-328; Alfred Victor duPont, 198, 379 $380, \quad 418-419,440,467$; Bessie (Bep) duPont, 197; Coleman duPont, 209, 330 ; Denise duPont, 513; Francis I. duPont, 471; Henry Algernon duPont, 187, 329; Jessie Ball duPont, 187, 329; Lammot duPont, 523-524; Madeleine duPont, 338, 342, 345$346,355,365,514-515,517$, 518-519; Marcella duPont, 492; Marguerite duPont, 342$343,367,518,530$; Maurice duPont, 486, 530; Irving Fisher, 242; Andrew Fullarton, 466-467; James Hackett, 314; Fanny Ball Harding, 136; Daniel O. Hastings, 508; Bayard Hiebler, 501; Benno Hiebler, 511; Mr. Jones, 390; Cap. LaMotte, 405; Ellen LaMotte, 368-369, 426, 442, 530, 539; Baker P. Lee, 531-532; Dorothy Lee, 388-389, 512; Geraldine Lee, 405, 479-480, 539; Maurice Lee, 385, 427, 473, 475, 508, 536; Richard Maclaurin, 331; various, 241-242, $352,359,386-387,388,410$, $442,461,468,476-477,478$, $481,489,490,492,499,500$, 502, 508ff., 513-514, 516, 519, $526,530,538$

duPont, Alfred Victor (Uncle Fred), Kentucky career, 18, 35, $46-47,51-52$; guardian for various duPont orphans, 24-26, 32,
duPont, Alfred Victor-Continued $49,55,66,86$; benefactor to Coleman I. duPont, 140-141; death and scandal, 100

duPont, Alfred Victor, birth, 136, 139, 186; father's estrangement from, 216; and attempt to change name, 249-251; in amateur theatrical, 370; in Marines, 371; marriage, 371 ; given stock by father, 374; reunited with father, 376ff.; resigns, 378; re-enters DuPont Company, 385; quits DuPont to study architecture, 419; architecture partnership, 464; gardens at Nemours, 464ff.; in father's will, 535; at father's death, 540,541

duPont, Alice (Elsie), 36, 140, 149 duPont, Alice Belin, 397

duPont, Alice Eugénie (Mrs. Oritz), 228

duPont, Alicia, early life and characteristics, 193; and father, 205; first marriage, 178, $193 \mathrm{ff}$.; marriage to Alfred, $205 \mathrm{ff}$.; and Coleman, 207; at Rock Farms, 208; and Alfred's estrangement from children, 216; health, 217, 313, 328; and Wilmington Symphony Orchestra, 217-218; and slander suit, 219ff., 227-230; children, 246, 253; fuss with Madeleine duPont, 248; buys News, 284; political acumen of, 284, 292293; White Eagle built for, 310 , 313; adopts daughter, 313; Ode of Fénelon, 314; death, 329

duPont, Amy Eugenia, 228

duPont, Ann, 371

duPont, Anna (wife of Francis I. duPont), 296

duPont, Anna Cazenove (Annie), reports to mother, 22; runs Swamp Hall, 24, 30, 36; and Alfred I. duPont, 66; marriage, 77; and Bessie Gardner duPont, 113 duPont, Annie Rogers Zinn, 99, 203 
duPont, Archibald, 275; sues Pierre duPont, 279ff.; shares, 307

duPont, Bessie Gardner, 76; description of, 77; marriage, 77; traits and innovations, 79-80; children, 80, 93; treatment of Alfred $I$. duPont, 112-114; children, 136; estrangement and divorce from Alfred, 184-196; finds allies in duPont family, 205; and estrangement of children, 216; and Wilmington Symphony Orchestra, 218; leaves Swamp Hall, 230; and attempted change of son's name, 249-251

duPont, Bessie (daughter "Bep"), birth, 93, 113; interest in music, $120,125,126$; trip to Florida, 197; estrangement from father, 216; marriage, 370; reunited with father, $370 \mathrm{ff}$.; given stock by father, 374; children, 385; in Alfred I. duPont's will, 535; at family party, 537

duPont, Bidermann, 25, 35, 46, 100 duPont, Bill, 141, 152, 153

duPont, Charles I., becomes partner, 86; ability and inclination, 137 ; secretary-treasurer, 139; death of, 182

duPont, Charlotte, 414

duPont, Charlotte Henderson, 21-22 duPont, Coleman, early life and career, 35, 49, 51, 53, 100, 105, 140-142, 148, 151; buys DuPont, $148 f f$.; becomes president, $\mathrm{Du}$ Pont, 159; agrees to keep Brandywine yards, 161, 167; popularity, 163; characteristics, 164, 195; compromises on moving offices, 167-168; buys Laflin \& Rand, 169-171; forms Delaware Securities Company and Delaware Investment Company, 170-171; forms E. I. duPont de Nemours Powder Company and E. I. duPont Company, 172-173; suggests Alfred sell out, 201-202,
duPont, Coleman-Continued 207; and Saulsbury, 204; joins in war against Alfred, 207ff.; illness of, 210,232, 237; and Government trust suit, 232; road project, 254; builds and lives in McAlpin Hotel, 255; erects Equitable Building, 255; operation, 255f.; sells stock, 255ff.; letter to Alfred, 260-261; letters to Pierre duPont, 263-264; political activities, 281ff., 300, $318 f f ., 351 f f$., 381-382, 426; and Pierre-Coleman deal, 322-325; writes condolence to Alfred, 330; proffer of aid to Alfred, 335-336; Florida enterprises of, 395; death, 427; wealth, 518

duPont, Denise, childhood, 313 , 345, 372; characteristics, 516; education, 531, 532; in Alfred I. duPont's will, 535

duPont, Eleanor, sues Pierre duPont, 279; shares, 307

duPont, Eleuthéra (Mrs. Bradford), 204

duPont, Eleuthéra Paulina, 246

duPont, Eleuthère Irénée, founder of business, 17; Alfred I.'s memorial to, 467-468.

duPont, Eleuthère Irénée, II, death and funeral, 15-16,18,19, 151; children, 19; characteristics, 20; marriage, 21-22; estate, 23, 25; deathbed conversation with Alfred I. duPont, 47

duPont, Elizabeth Bradford, 219; defendant in A. I. duPont's slander suit, $219 f$., 227, 295

duPont, Emile, 385, 539

duPont, Ernest, Pierre duPont's offer to, 275; sues Pierre, 279ff.; shares, 307

duPont, Eugene, and father, 15; appearance, 18; as head of company, 85, 86, 87, 178, 232; cancels Navy's order, 130 ; and Alfred, 75, 130, 138; misfit, 137; 
duPont, Eugene-Continued president of the corporation, 139 , 166; death, 142; against novel corporation technique, 166

duPont, Eugene, II, 152; director, 183, 275, 276; in Pierre-Coleman deal, 269ff., 277; sued, 279

duPont, Francis G., described, 18; kept record of explosions, 43, 44, 70 ; interest in electricity, 75; copes with firebugs, 89-91, 92; finds smokeless powder formula, 101; at Carney's Point, 102, 133; attitude toward Alfred I. duPont, $63,65,87,130,142-143,178$; strain on, 132-133; takes automobile ride with Alfred I. duPont, 134; illness, 137, 142; turns office over to Pierre duPont, 153; director of DuPont, 160; death, 182; Alfred I. duPont's estimate of, 428

duPont, Francis Irénée, bravery in fire, 90; at Carney's Point, 133, 143-144; superintendent at Carney's Point, 178; vice-president, 183 ; and family warfare, 208 , 210; takes nitrates from the air, 240; ability, 240-241; and PierreColeman deal, $268 \mathrm{ff}$.; sues Pierre duPont, 279; dropped from list of directors, 280; dismissed by Pierre duPont, 296; children, 296, 371; shares, 307; joins Alfred I. duPont's commercial enterprise, 326; Alfred I. duPont's estimate of, 428; mentioned, 539, 540

duPont, Henry, head of company, 16-17; during Civil War, 21; family power of, 23 ; attitude toward Alfred I. duPont, 36-38, 80; company policy, 40, 52-53, 76, 84-85, 232; stories about, 71; controls Powder Trust, 72ff., 165-166; illness and death, 8384, 85; and family antagonisms,
duPont, Henry-Continued 202; Alfred I. duPont's estimate of, 427

duPont, Colonel Henry Algernon, described, 18, 25; in Civil War, 21,44 ; applies for electrical service, 88; weary of powder company, 137; suggests incorporation, 138 ; attitude toward company, 139, 142; approves Alfred I. duPont's buying company, 146; director in DuPont, 160; and Gunpowder Trade. Association, 166; averts property dispute, 202; candidate for U. S. Senator, 107-110; elected, 182, 204, 251, 254; Alfred takes field against, 282-286, 287-288; defeated for reelection, 292ff., 321322; in retirement, $317-318$

duPont, Henry Francis, director, 183, 275, 276; sued, $279 \mathrm{ff}$.

duPont, Irénée, joins company, 152,

153; assistant treasurer, 183; first block of stock, 252; and PierreColeman deal, 266ff.; sued, 279ff.; becomes president, 340; makes Alfred I. duPont offer for stock, 348-349; and prohibition, 426

duPont, Jessie Ball, friendship with Alfred I. duPont, 187, 337; marriage, 339; helps reunite Alfred I. duPont and family, 367ff; in Florida boom, 396; illness, $441 \mathrm{ff}$; Stratford Hall benefit, 468-469; business acumen, 529; in Alfred I. duPont's will, 533, 534-535

duPont, Lammot, described, 17-18; makes dynamite, 52; death of, 54-55; president of Powder Trust, 72, 88; Alfred I. duPont's estimate of, 427

duPont, Lammot (brother of Pierre), early rise, 183; row over marriage, 202; chief of black-powder department, 233; training, 235; improves corning mills, 240; first block of stock, 252; and Pierre- 
duPont, Lammot-Continued

Coleman deal, $266 f f$.; sued, 279ff.; president, DuPont, 378; and Alfred Victor duPont, 378-379; conciliatory attitude toward Alfred I., 522; declines to seat Alfred's representative on Board, 524

duPont, Louis, childhood, 24; at Yale, 76; and Bessie Gardner, 7677; brought friends home, 79; death of, 98-99

duPont, Louisa, 88

duPont, Madeleine, interest in music, 120,126; visits father in hospital, 189; Florida trip, 197; marital troubles, 209; goes to live with father, 216; marriage and divorce, 217; sent money, 316; children, 338, 385, 515; given stock by father, 374; visited by father and brother, 433; marrics Hermann Ruoff, 515; stays in Germany, 515-516; in Alfred I. duPont's will, 535

duPont, Marcella Miller, marriage, 371; first call on father-in-law, 376-377; at Cherry Island, 380; in Carlsbad, 433; flying lessons, 490 ; at family party, 537

duPont, Margery May Fitz-Gerald, row over marriage, 94-95; and Bessie Gardner duPont, 113; Alfred I. duPont's attitude toward, 415, 535

duPont, Marguerite, early life, 24, 28-29, 36; marriage, 48; and Bessie Gardner duPont, 113 ; visits brother in hospital, 188; deposition in Alfred I. duPont's divorce, 196; gifts from Alfred I. duPont, 314; reunited with Alfred I. duPont, 366ff.; in Alfred I. duPont's will, 535

duPont, Mary, 88

duPont, Mary Belin, 202

duPont, Maurice, childhood, 24; and

Bessie Gardner duPont, 76, 79,
duPont, Maurice-Continued

113; marriage of, 93-94, 203; refuses to enter company, 94-95; at Balls Neck and Cherry Island, 135, 337; best man at Alfred I. duPont's second wedding, 201; gifts from Alfred I. duPont, 314; children, 386; bond with Alfred I. duPont, 415; in Alfred I. duPont's will, 535

duPont, May, 99, 203

duPont, Paul, offer from Pierre duPont, 275; sues Pierre duPont, 279 ff.; shares, 307 ; automobile project, 355

duPont, Philip, offer from Pierre duPont, 275; and Pierre-Coleman deal, 277; career, 277; sues Pierre, 279; shares, 307

duPont, Pierre S., childhood, 55; musician, 95; collaborates with Frank duPont, 101; tact, 105; early career, 133, 141-142; buys company, 148 ff.; letters to brothers, 152-153; treasurer, DuPont, 159; in inner circle, 168; treasurer Delaware Securities and Delaware Investment, 170 ; and Bessie Gardner duPont, 191, 194195, 205, 248; and Saulsbury, 204; president of company, 210 , 272-273; and government trust suit, 232; and stock-buying deal, 255ff.; letters to Coleman duPont, 262-263, 264; organizes E. I. duPont de Nemours \& Company, 278; sued, $279 \mathrm{ff}$., $302 \mathrm{ff}$; shares, 306; keeps stock, 306308; school crusade, 321; upheld by Judge Buffington in DuPont vs. DuPont, 322-325; story of aid to Alfred I. duPont, 335; relinquishes presidency, 340; gift to Bessie duPont Huidekoper, 370; builds chemical empire, $382 f f$; and General Motors, 382-383; chairman of board, 396; marriage and tax administrator, 397; sup- 
duPont, Pierre S.-Continued

ports Al Smith, 408; stock in DuPont, 422; estimate of, 428; wealth of, 518 ; attempts at reconciliation with Alfred I. duPont, 519, 540

duPont, Samuel, 253

duPont, Rear Admiral Samuel Francis, 21, 194

duPont, Victor, 17; executor and trustee, 25-26, 42

duPont, Victor, 120; in "war" with Alfred, 210; vice-president, 178, 183

duPont, Mrs. Victor (wife of the vice-president), 515

duPont, Victor, 212

duPont, Victorine, birth of, 186; father's estrangement from, 216; described, 373; given stock by father, 374; reunited with father, 374 ff.; marriage, 375; children, 385; in Alfred I. duPont's will, 535; at family party, 537

duPont, Victorine Elizabeth (Mrs. Foster), 228

duPont, William, resigns partnership, 86; divorces wife, 99; retirement from firm, 102, 203; remarriage, 203; returns to company, 252; and Pierre-Coleman stock-buying deal, 256ff., 302, 323 ; dropped from list of directors, 280; buys Delaware Trust Company, 287; shares, 306 ; joins Alfred I. duPont's commercial enterprise, 326, $332 \mathrm{ff}$.; declines to join Alfred I. duPont on 1918 tax refund, 360-361; buys Alfred I. duPont's interest in Delaware Trust Company, 403

duPont de Nemours, Pierre Samuel, career and ideals, 15-16, 344, 538; children, 17, 177; Alfred I. duPont's estimate of, 427; Terrace Colonnade, 467; Murillo, 493; correspondence of, 517
duPont de Nemours, Victor Marie, 45, 493

DuPont Company, founding, 1617; partnership, 26; during Spanish-American War, 129-130; incorporated, 138; proposed sale, $142 f$; outstanding position, $172-$ 174; Government suit against, 210, 231, 243-246; labor policy, 214,251 ; internal reorganization, 233-239; in World War I, 251ff.; corporate setup changed, 278, 331 ; in post-war depression, 340 , 349; Coolidge Prosperity, 382; and General Motors, 327, 382383; peacetime products, $383 \mathrm{ff}$.; in stock-market crash, $439 \mathrm{ff}$;; see also duPont, Alfred I., DuPont connection

DuPont Securities Company, 267ff., 341

DuPont versus DuPont, 279ff., $288 f f ., 302 f f ., 322 f f$.

duPont-Ball Corporation, 463

DuPont Club Brass Band, 95

Durant, Mrs. Paulina, 53

Durant, William C., 340

Dyal, C. D., president of Daytona Bank \& Trust Company, 430, 445-446; runs Florida National Bank, St. Petersburg, 446, 448, 455-456

Dynamite, introduction, 52; controlled by DuPont, $171 \mathrm{ff}$.; Alfred I. duPont's attitude toward, 212, 237; increased importance of, 212,215

Eagle Brand powder, 16

Eastern Dynamite Company, DuPont interest in, 171, 215; Barksdale general manager, 177

Edison, Thomas A., 56-57, 67, 97, 185-186; and Reese Hutchison, 211

Edwards, William T., business associate of Alfred I. duPont, 392; and Florida experiment, 403, 406, 
Edwards, William T.-Continued 526, 573; and old age pension, 424; lobbyist, 450, 451

Edwards, Mrs. W. T., 541

E. I. duPont Company, 173-174; see also DuPont Company

E. I. duPont de Nemours \& Company, see DuPont Company

E. I. duPont de Nemours Powder Company, see DuPont Company

Eighteenth Amendment, 390, 409, 480

Eight-Hour Law, 213-214

El Caney, 128

Eleutherian Mills, 16, 39

Epping Forest, 481, 485, 486, 487 $488,512,530,534,537,539$

Equitable Building, 255, 258, 282

Ethyl gasoline, 383

Explosions, 43, 44-45, 54, 90, 132, 201; Great Explosion, 91-92

Fabricord, 383

Fidelity Bank \& Trust, St. Petersburg, 447

First National Bank, Daytona, 446

First National Bank, Miami, 458, 538

First National Bank, New York, 290, 357

First National Bank, St. Petersburg, 447

Fisher, Professor Irving, 242

Fitz-Gerald, Margery May. See duPont, Margery May Fitz-Gerald

Flagler, Henry, 392

Flamingo Hotel, 351

Fleming, Frank P., 484

Florida Bank, Orlando, 445

Florida Bank \& Trust Company of Daytona, 446

Florida National Bank, Bartow, 441

Florida National Bank, Jacksonville, 403, 404, 405, 430ff., 443; in banking emergency, $482 f f$.

Florida National Bank, Lakeland, 437-438, 454

Florida National Bank, Miami, 457
Florida National Bank, St. Petersburg, 446, 448; run on, 455-456

Ford, Henry, 383

Ford, Peter J., 299

Ford Motor Company, 177, 453

Foster, Mrs. Antoine L., 88

Foster, Mike, 29, 31, 35

Franco-American Constructive Corporation, 325, 332

Frist \& Almond, 135

Frizzle, Sam, 131, 316

Fullarton, Andrew, 466

Gadfly, 405, 537, 539

Gardner, "Caz" (Cazenove), 97, 98

Gardner, Dorsey, 76

Garner, John N., 478-479

Garvin, Francis, 384

Gaylord, Edward K., 498

General Motors, 246, 327, 340, 382, 508

Gentieu, Pierre, powderman, 44, 163-164, 238

George Washington Hotel, 450

Glasgow, William A., Jr., counsel for Alfred I. duPont in DuPont versus DuPont, 244, 278, 289 ff., $304,322-325$; counsel on $\mathrm{Ne}-$ mours Trading, $332 f f ., 339$; and Hoover, 408; golf devotee, 412

Glasgow, Mrs., 537

Glass, shatterproof, 383

Glendening, Harold Sanford, 350

Goethals, George W., 395

Goldsborough, Phillips L., 247-248

Gordon, Michael, 70

Gormley, Senator, 301

Graham, George Scott, 289, 291

Grand Central Palace, 309, 325, 326

Gray, Andrew C., 249-250

Greenleaf, Louis, 69

Greer, Right Reverend David H., 330

Grouchy, Marquis de, 45

Gulf Coast Highway Association, 451-452 
Gunpowder Trade Association, formation, 72 ; revamped, 84 ; strength, 165f., 232; DuPont restored to leadership in, 172; collapse of, 174

Gunpowder Trust. See Gunpowder Trade Association

Hackett, James K., 79, 96, 184, 314

Haight, Judge, 322

Haley, Frank, 76

Haley, Joe, 238

Haley, Patrick, 51

Hall, Harvey, 300-301

Hallock, Gerard, 248

Hamilton, Willard, 437, 455

Hanby, Doctor Charles M., 281, 419,422

Hanna, Mark, 141

Harding, Bess, 187

Harding, Fannie Ball, 135, 186, 337

Harding, Floride (Mrs. Robert Adams) , 136, 337

Harding, Rebecca (Mrs. Charles Adams), 187, 337-338, 487

Harding, Robert, 355

Harding, Warren G., 380-381

Hardwicke, Doctor, 517

Harrington Journal, 287

Harris, Doctor Herman H., 540

Haskell, H. G., in charge of high explosives, 268 ; sued, 279

Haskell, J. Amory, in charge of high explosives, 102; president of Laflin \& Rand, 168, 170; vicepresident of Powder Company, 182

Hastings, Daniel. O., 306, 426-427

Hastings, Thomas, 466

Haynes-Apperson, 134

Hazard Powder Company, 72, 151, 161,170

Heald, William H., 319

Hearst, William Randolph, part in Spanish-American War, 121; favored government spending, 475

Hecla Powder Company, 84

Heisel, Thomas Bayard, 249-250
Hellkat, 405

Henderson, Charlotte Shepard. See duPont, Charlotte Henderson

Henderson, Robert A., 450

Henry, Reverend Ashton, 203

Hercules Powder Company, 84, 245-246

Hercules Torpedo Company, 84

Hern, Jack, 69

Herreshoff, 315

Herrick, Myron T., 326, 328

Herty, Doctor Charles H., 497-498, 526

Hiebler, Bayard, 501

Hiebler, Benno, 511

Hiebler, Max, 316

Higgins, Anthony, 108-109

Highwayman's Hideout, 451

Hille, Gustav, 69

Hitler, 515

Hobson, 128

Hoffecker, Senator, 301

Hollins, Dixie M., 456-457

Hoover, Herbert, in 1928 campaign, 408-410; and the Great Depression, $473 \mathrm{ff}$.; contrasted to Roosevelt, 480

Horncastle, Thomas, 339, 346, 377, 515

Horty, James, 89

Horty, William, 316

Horwitz, George Quintard, trustee for Alfred I. duPont, 191

Hotel Biltmore, 498

Hotel del Coronado, 329

Hotel DuPont, 241, 346

Hotel Richardson, 319

Houston, Colonel Bob, 294

Howell, Clark, 498

Hughes, Charles Evans, nominated by Chicago convention, 288; opinion in DuPont versus $\mathrm{Du}$ Pont, 307-308

Huidekoper, Bessie duPont. See duPont, Bessie

Huidekoper, Henry Shippen, 371

Huidekoper, Reginald, husband of Bessie duPont, 370; executor of 
Huidekoper, Reginald-Continued Alfred I. duPont's estate, 535; at family party, 537

Huidekoper, Wallis, 97, 188-189, 196, 370

Hurley, Patrick J., 481

Hutchison, Doctor Miller Reese, and Alfred I. duPont, 184-185; 210211; inventions, 211 ; with Edison, 236

International Smokeless Powder \& Chemical Company, 173

Irwin, Doctor Stanley, 540, 541

Jacksonville Journal, 435

Johns Hopkins, 79

Johnson, General Hugh, 501

Johnson, John G., 278; counsel for Alfred in DuPont versus DuPont, 278, 289

Johnson, Tom L., 140-141

Johnson Steel Company, 141

Johnston, Percy H., 335

Jones, Eben, 316

Jones, Roy, editor of the News, 284, 320

Jones, Russell A., 389-390

Judson Dynamite \& Powder Company, 173

Kane, Henry, 69, 316

Kane, Thomas, 71

Kelly, Father, 42

Kidder, Kathryn, 79

Kinzie, Cora Elsie, 338

Kirk, Doctor William W., 540

Knox, Tom, 131

Kraft paper, 527

Kraftmeier, Mr., 258, 260

Kuhn, Loeb \& Company, 258

Ku Klux Klan, 409

Laffey, John P., 271, 289, 303

Laflin \& Rand, 72ff., 84, 123, 137, $143,147,151,152,166,168$; bought by DuPont, 169-171; $176,177,179,182,215,232$
Laird, William Winder, 275

LaMotte, "Cap" (Theodore), 97, $375,405,412$

LaMotte, Ellen, 96, 113, 368, 426, $530,537,539$

Lane, Edward Wood, president Atlantic National Bank, 404, 405, 484,538

Lanning, Judge William M., 243

La Roche, 134

Las Guasimas, 128

Laurel Leader, 287

Lawson, John W., 317

Lawyers Co-operative Publishing Company, 359

Layton, Caleb Rodney, 352

Lecarpentier, Alfred, 41, 61

Lee, Doctor Baker P., 531

Lee, Cazenove, 366, 414; children, 371,386 ; golf devotee, 412; in Alfred I. duPont's will, 535

Lee, Dorothy, 388

Lee, Geraldine, 405, 479-480, 537, 539

Lee, Maurice, 366, 405, 409, 414

Lee, Maurice duPont, vice-president DuPont Rayon, 385, 522; children, 386; golf devotee, 412; in Alfred I. duPont's will, 535

Lee, Vandegrift, 536

Le Fashion, 305

Lehman, Governor, 482

Locomobile, 134

Logan \& Bryan, 420

London Economic Congress, 503

Longwood, 261, 397

Louisville \& Nashville Railroad, 180

Louisville Courier-Journal, 47, 100

Louviers, 194, 196

Lynch, William F., 116

MacDonald, William, 436

Macklem, John W. (Willie), 71, 76, 115

Maclaurin, Doctor Richard, 331

MacPherson, Judge, 322

Maddox, Alicia, Alfred I. duPont's attitude toward, 217,338; wanted 
Maddox, Alicia-Continued

little brother, 246; musical ability, 338; marriage and divorce, 350, 514; as Mrs. Victor Llewellyn, 535

Maddox, George Amory, 178, 193194, 199, 228

Malone, Professor Dumas, 517

Maloney, Mike, blacksmith and musician, 69, 114, 238, 252, 316

Mannering, Mary, 79

Marcellus Powder Company, 84

Massachusetts Institute of Technology, 48f., 55, 56, 76, 79, 331

Masséna, Gabriel, 464, 466

Masséna \& duPont, 464

Mathewson, Francis, early association with Alfred I. duPont, 20, 29, 57; electrical work, 68-69, 77-78, 88; at Cherry Island, 97, 135,188 ; resigns from the $\mathrm{Du}-$ Pont Company, 235; in charge of Alfred I. duPont's Maryland property, 247; at Nemours reunion, 316

Mathewson, George, 29, 35; early association with Alfred I. duPont, 29, 35; in band, 69; in orchestra, 95

Mathewson, Walker (Gilly), early association with Alfred I. duPont, $29,44,57$; electrical work, 68$69,77,78,88-89$; in band, 69 ; at Cherry Island, 97; and presentation to Alfred I. duPont, 238; electrician at Nemours, 247; at Nemours reunion, 316

Maxwell, George T., 285

McAlpin Hotel, 255

McCann, Thomas, 131-132

McCarthy, Tim, 42, 520

McCoy, J. W., 378

McHarg, Ormsby, 282

McIlhenny, Robert, 131-132

McMahon, Matchie, 29, 31, 35, 115

McQuade, W. R., 486

Mellen, Charles S., 248

Mellon, Andrew W., 349, 478
Merchants \& Manufacturers Exchange, 309

Merrill, "Papa," 32

Merrimac, 128

Meyer, Eugene, 478-479, 486

Miami Herald, 537

Middleton Cbronicle, 287

Miller, Charles R., 300

Miller, Jonas, 44-45

Miller, Marcella. See duPont; Marcella Miller

Miller, Thomas W., 294, 295

Mills, Charles W., $332 \mathrm{ff}$.

Mills, Ogden, 478, 486

Mitchell, Charles E., 439

Monk, 511 ff.

Montpelier, 203

Mooar Mills, 84, 161

Mooney, Representative, 249

Moore, John, 131-132

Moore, J. Hampton, 452

Moosic Powder Company, 169-170

Morgan, J. P., \& Company, 266, 290, 333, 341

Morris, Mr., 120

Moxham, Arthur J., 140-141, 168; president of Delaware Securities and Delaware Investment, 170; vice-president of DuPont, 182

Moxham, Egbert, 178

Muldoon, William, 390

Mulhearn, John, 131-132

Mullin, Mickey, 46

Mummy, $511 \mathrm{ff}$.

Murphy, John, 131

National City Bank, New York, 439, 461

National Labor Relations Board, 508

Nemours, building of, 223-227, $310,316,337,346,397,400$, $401,408,410,412,413,438$, 441; sunken gardens, 464-468, 474; Stratford Hall benefit, 468469; water situation, 488; mentioned, 515, 530, 532, 533, 534, 535

Nemours Foundation, 533-534, 536 
Nemours Trading Corporation, 326-328, 331 ff.; Ed Ball's efforts, $357-360 ; 529$

Nenemoosha I and II, 356, 372, 392, 405, 410-411, 516

New Haven Railroad, 248

Newark Ledger, 287, 353, 381

New York Sun, 227-228

New York Times, 250

New York World, 228-229

Ninth Street Bank \& Trust, St. Petersburg, 447

Nitroglycerin, 52

Nobel, Alfred, 52

Non-Partisan League, 317, 319

North Orlando State Bank, 445

Northern Securities case, 278

N.R.A., 501-502, 503

Old-Age Welfare Commission, 463464

Oriental Powder Mills, 72, 73

Oritz, Mrs. See duPont, Alice Eugénie, 228

Pancoast Hotel, 537

Parr, Samuel, 69

Payne, Maggie, 100

Pearl, Thomas, 51

Pecora, Ferdinand, 500

Penington, Robert, 289, 332

Perot, Mrs. See duPont, Eleanor

Perry, Arthur F., banker, 432, 434, 443

Petrel, 315

Philadelphia North American, 228

Philadelphia Public Ledger, 199

Philadelphia Record, 343, 351

Phillips Academy, 32, 48, 314

Phillips, Captain Jack, 128

Pittman, Senator Key, 509

Playhouse, 241

Pole, J. W., 445

Pontiana, 16

Porter, President of Yale, 76

Porter, William G., Alfred I. duPont's attorney, 196
Powder, black, 174, 212-215, 237; brown, 80, 82, 83, 87, 123-129; manufacture, 63-65

Powder, smokeless, 81, 82, 83, 87, $101,122-123,128,132,161$, $174,177,179$

Price, Mayor, 317

Price, Ruth Latham (Mrs. Edward Ball), 514

Prosser, Seward, banker, 267, 290

Pulitzer, Joseph, 121

Putnam House, 392

Pyle, Frank, 238

Ramsay, W. G., 268, 280

Rayon, 246, 384, 385, 400, 418419, 497, 522

Raskob, John J., early career, 168; on inside, 176; Alfred sells shares to, 252, 256; treasurer of $\mathrm{Du}-$ Pont Company, 266; and PierreColeman duPont deal, 266ff.; sued, 279; in politics, 319, 408; dinner for Coleman duPont, 352; and stock market crash, 440

Rawlings, Marjorie Kinnan, 528

Reilly, James G. B., 182

Reinhardt, David J., 294, 295

Repauno Chemical Company, 53, $54,99,102,146,169,171,215$

RFC, 478-479, 481

Rhenish Westphalian Powder Company, 82

Richardson Hotel, 285

Robbins, Dean, 329

Roberts, Eugènie, 228

Rock Farms, 191, 196, 208, 223

Rockefeller, John D., 74, 392, 470

Rodemann, August, 217

Rompf, Edward C., 458, 538

Roosevelt, Franklin D., 315; contrasted to Hoover, 480; election and banking crisis, 481; New Deal, $499 \mathrm{ff}$.

Roosevelt, Theodore, 128, 286; trust-busting crusade, 210,480

Rowan, Lieutenant, 128

Royal Palm Hotel, 394 
Ruoff, Hermann, 515

Ryan, Paddy, 50

Sadler, Judge W. F., 200

Saltpeter, 52, 63, 174

Sanders, Gold V., 435

Saulsbury, Willard, marriage to May duPont, 203, 204; takes case of Mary H. J. Bush, 219, 228, 229; consults Alfred I. duPont, 315; defeated for Senatorial re-election, 318-320

Saulsbury, Mrs. See duPont, May

Scott, Bill, 188, 370-371

Scott, Father W. J., 188, 192

Seaford News, 287

Seitz, George, 125, 316

Service Citizens of Delaware, 319, 321

Sharp, Hugh Rodney, 275

Shepheard's Hotel, 511

Sherman Anti-Trust Act, 210, 232, 243, 251, 254, 278

Shinn, Reverend James G., 27

Sigbee, Captain, 122

Sigma Chi, 49

Silver Purchase Act, 508

Skimmerhorn, "Professor," 69

Sloan, Jr., Alfred P., 383, 508

Smith, Alfred E., 408-410

Smith, Harry, 413

Smith \& Rand, 72

Smyth, James M., builds Nemours, 223-227; tears down Swamp Hall, 230

Snellenburg, David, 299

"Soda powder," 52, 63, 174

Southern Kraft Corporation, 527

Spooner, John C., 231

St. Johns River Development Company, 397

St. Joseph's-on-the-Brandywine, 42, $46,70,89,163,184,188,192$, 423

Standard Oil Case, 278

Stewart, Hamilton, 69

Stewart, Sam, 131-132

Stock Market crash, 438
Stockton, Gilchrist, 409

Stratford Hall, 468

Stroud, Doctor William D., 540, 541

Stuart, Captain Sidney, 133

Sullivan, John L., 50-51, 67, 313, 314

Swain, William J., 294, 295

Swamp Hall, 19-20, 21, 22ff., 28, $29 f f ., 44,68,75,77-78,79 f f .$, 93, $110 f f ., 136,149,189 f f ., 223$, 227 ; remodeled, 80 ; bought by Alfred I. duPont, 163; torn down, 230

Swan, Representative, 248

Swasey, A. Loring, 315

Sycamore Mills, 73, 161

Sykes, George, boss patternmaker, 181

Taft, Charles P., 255

Taft, William Howard, tolerance toward trusts, 231, 244; and DuPont, 244-245

Tallman, Frank G., 218, 268, 280

Tankopanicum Musical Club, 69, 79

Taylor, William G., 317, 321, 353

Third National Bank, Miami, 457, 461

Thompson, John, powderman, 114, $126-127,316$

Thompson, Judge J. Whitaker, 290; opinion in favor of Alfred, 302

Thompson, Mrs. Henry B., 217

Time, $460-461$

TNT, 384

Townsend, John G., 294, 295, 300

Toy, Tom, 42, 520

Trinity Church, 203

Tripp, Marie, 338

Tunnell, James M., 381

Union Guardian Trust Company, 481

United States Steel Corporation, 141

Usina, Domingo Benedict, 458 
Usina, Leonard A., liquidates Third National, 458; earlier career, 458-459; president Florida $\mathrm{Na}$ tional of Miami, 460

Vanderlip, Frank A., 461

Waddell, Robert S., 168, 169

Wagner, Anthony, 487

Wagner, Senator Robert, 508

Waldorf-Astoria Hotel, 282

Walker, John T., 486

Wall Street Journal, 460

Waller, Absalom, 77

Walls, Mrs. Laura G., 425, 438

Watson, Benny, 132, 316

Watson, William T., 109-110

Waters, Henry, 444, 445

Watterson, Henry, 47, 100

Wellesley College, 53

Wertenbaker, Charles, 146

White Eagle, 310, 313, 328

White Shoe Company, 357-358, 359

Whiteman, J. Harvey, counsel for duPont in slander suits, 219, 229

Wickersham, George W., 231, 244245

Wiggins, A. H., 290, 500

Williamson, Ira M., 196, 284, 393
Wilmington \& Northern Railroad, 127

Wilmington Club, 98

Wilmington Evening Journal, 9394, 98, 229, 287, 299, 321, 343.

Wilmington Morning News, 283, $286,287,288,301,320-321$, 336

Wilmington Nows, 199

Wilmington, Sunday Star, 353, 426

Wilmington Symphony Orchestra, $217 f$.

Wilmington Trust Company, 287

Wilson, Mayor of Wilmington, 218

Wilson, William B., 424

Winton, Alexander, 446

Wolcott, Josiah O., 295-296, 343, 351,381

Woodin, Secretary, 486

World War I, 246, 251, 255, 302, 315

Wright, John, 131-132

Yale, 76, 79, 98, 378

Yip, $511 f f ., 539,540$

Young Men's Republican Club, 319

Zinn, Annie Rogers. See duPọnt, Annie Rogers Zinn 



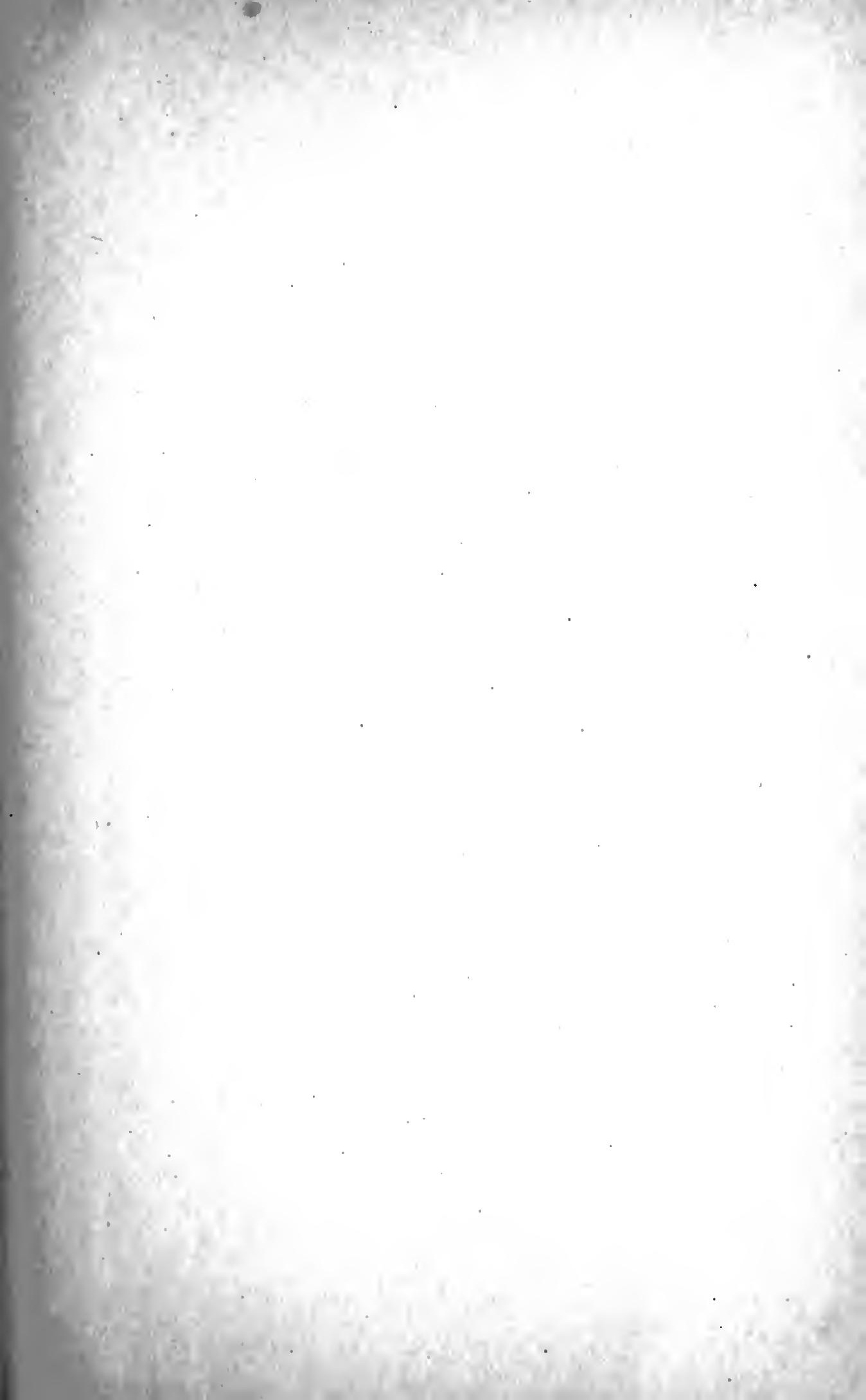







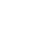





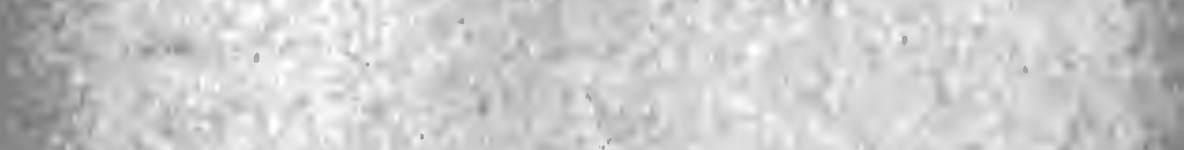

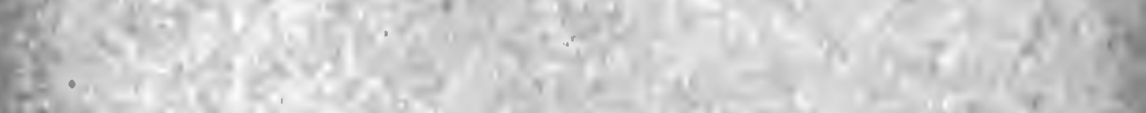
6.

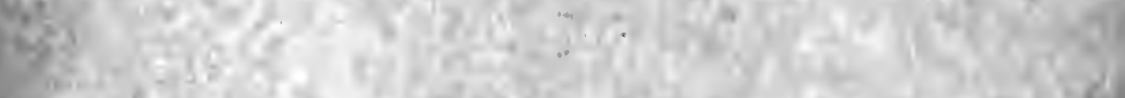

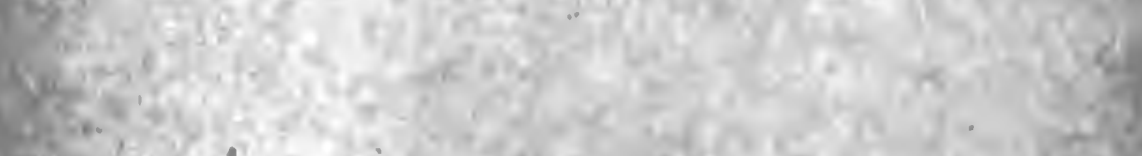

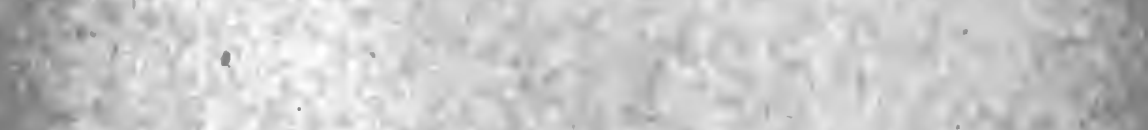

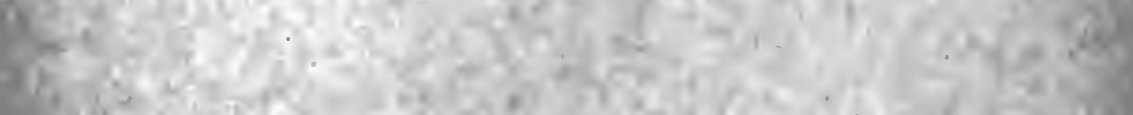

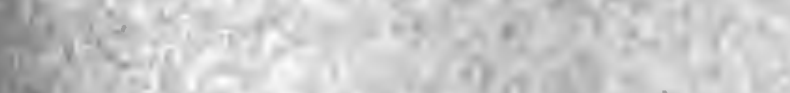

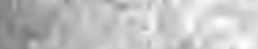

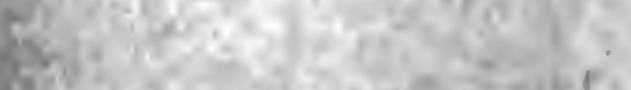

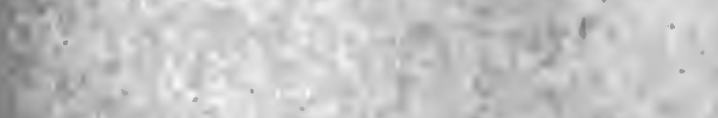
$x^{2}-y^{2}$ Sy

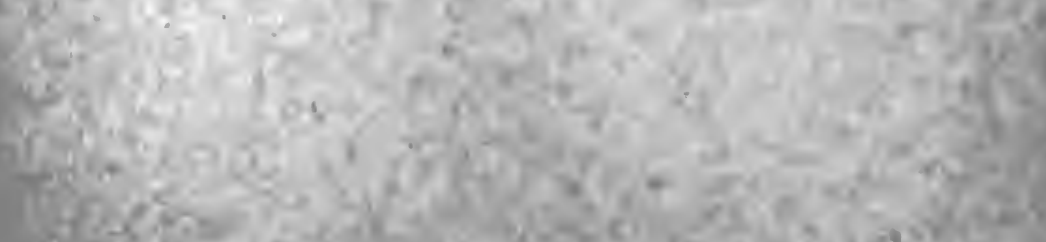

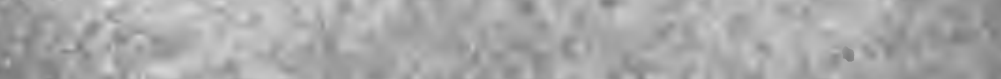

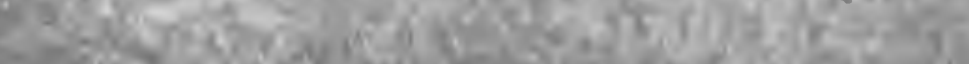

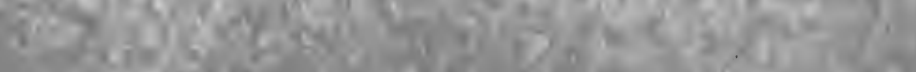

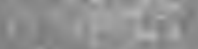

(n) 


